\author{
Universidade de São Paulo \\ Faculdade de Filosofia Letras e Ciências Humanas \\ Departamento de Geografia \\ Programa de Pós-Graduação em Geografia Humana
}

PEDRO BENETAZZO SERRER

Estudo sobre as imagens fotográficas da Chapada Diamantina

São Paulo

2018 


\author{
Universidade de São Paulo \\ Faculdade de Filosofia Letras e Ciências Humanas \\ Departamento de Geografia \\ Programa de Pós-Graduação em Geografia Humana
}

PEDRO BENETAZZO SERRER

\title{
Estudo sobre as imagens fotográficas da Chapada Diamantina
}

\author{
Versão Original
}

Dissertação de mestrado apresentada ao Programa de Pós- Graduação em Geografia Humana da Faculdade de Filosofia, Letras e Ciências Humanas da Universidade de São Paulo, sob orientação do Prof. Dr. Carlos de Almeida Toledo.

São Paulo 
Autorizo a reprodução e divulgação total ou parcial deste trabalho, por qualquer meio convencional ou eletrônico, para fins de estudo e pesquisa, desde que citada a fonte.

Catalogação na Publicação

Serviço de Biblioteca e Documentação

Faculdade de Filosofia, Letras e Ciências Humanas da Universidade de São Paulo

Serrer, Pedro Benetazzo

S488e Estudo sobre as imagens fotográficas da Chapada Diamantina / Pedro Benetazzo Serrer ; orientador Carlos de Almeida Toledo. - São Paulo, 2018.

$318 \mathrm{f}$.

Dissertação (Mestrado) - Faculdade de Filosofia, Letras e Ciências Humanas da Universidade de São Paulo. Departamento de Geografia. Área de concentração: Geografia Humana.

1. representação. 2. autonomização. 3. região. 4 . fotografia. 5. Chapada Diamantina. I. Toledo, Carlos de Almeida, orient. II. Título. 
FICHA DE APROVAÇÃO

Autor: Pedro Benetazzo Serrer

Título: Estudo sobre as imagens fotográficas da Chapada Diamantina.

Dissertação de mestrado apresentada ao Programa de Pós-Graduação em Geografia Humana da Faculdade de Filosofia, Letras e Ciências Humanas da Universidade de São Paulo, sob orientação do Prof. Dr. Carlos de Almeida Toledo, para a obtenção do título de Mestre na área de Geografia Humana.

\section{Banca Examinadora}

Prof(a). Dr(a).

Instituição: Julgamento:

Assinatura:

$\operatorname{Prof(a).~Dr(a).~}$

Instituição: Julgamento:

Assinatura:

Prof(a). Dr(a).

Instituição: Julgamento:

Assinatura:

Aprovado em: 


\section{AGRADECIMENTOS}

Tem um bocado de pessoas queridas que foram companhias fundamentais nesses últimos três anos e pouco. Não apenas ajudando na produção dessa dissertação, mas sobretudo para tocar a vida nesse nosso mundo cão. A importância que elas tiveram não cabe na precariedade desses agradecimentos, o que já pode valer de desculpa para minhas comidas de bola e mal agradecimentos. De qualquer forma, quero dizer que:

Certamente teria sido muito mais complicado fazer essa pesquisa sem o acolhimento de minha tia Nô, que além da atenção e dos confortos domésticos todos, me ajudou na revisão do projeto e na tradução do relatório de Babinski.

Minha mãe e meu pai sempre me deram apoio incondicional. Minha mãe agradeço pelos carinhos, pelos diálogos francos e interessados, que apesar das diferenças, como mãe que é, acabam sempre no desejo daquela tal felicidade para esse seu filho com tendências ao acabrunhamento. Meu pai, no convívio silencioso dos homens da família, pelas forças todas na vida, e na pesquisa particularmente com as soluções para as imagens.

O Mateus esteve em Lençóis em 2017 e foi ótima companhia nas andanças pela serra, para o que o tamanho das pernas ajuda certamente! Depois me recebeu em João Pessoa, onde tive a tranquilidade pra empurrar um bocado dessas letrinhas aqui e partilhar os perrengues dos primeiros de muitos voos. A Isa esteve distante nos últimos tempos, mas perto pelos caminhos da internet, sempre disposta pruma conversinha.

Essa pesquisa é muito mais coletiva do que pode parecer. Grande parte, senão a totalidade, das formulações teóricas desse trabalho são desdobramentos da prática dos estudos coletivos nos grupos de crítica do valor e da dissociação do Labur-USP e nos grupelhos paralelos desde o tempo da graduação. Certamente não teria encarado a árida solidão da pesquisa acadêmia não fossem os esforços de todo pessoal que fez e faz os grupos acontecerem, e para além dos grupos, nas camaradagens no mundão afora.

O Carlão foi bem mais que orientador, abriu as portas da “arapuca pós-moderna” e de relações importantes para o trabalho de campo em Lençóis. Me mostrou uns caminhos pra essa coisa difícil que é juntar desencanto e generosidade.

O Dieter, o Allan e o Chico, leram os esboços do projeto de pesquisa e deram bons pitacos naquele momento.

A Rachel, encontro inesperado entre as críticas da educação e os estudos para o processo de exclusão, foi intensa companhia nos ótimos, bons e maus momentos partilhados. 
Vou sempre carregar em mim aquele denso agosto de 2015, mês em que “envelheci” uns bons anos.

O Xavito, parceria desde a graduação, além da camaradagem de sempre e uns bons rolês por Minas, abriu a casa de São Bento onde rolaram os primeiros avanços de escrita da qualificação e saudáveis horas de jardinagem. O Necas é outro dos amigos que me fizeram sentir saudades de São Paulo enquanto estava em Lençóis, parceria nos rolês desde a graduação foi companhia numa viagem pelo sul da Chapada. À Mahara, também parceira há tempos e de voltas, devo um agradecimento especial por ter topado a tarefa ingrata de revisar o texto. O Marchinha, bandeou pros lados de Minas e deixou a gente aqui na tristeza, mas antes disso encarou ir de carro para a Chapada em 2016 comigo e a Lígia reclamando no pé do ouvido, e no meio do caminho me deu umas aulas de trabalho de campo em Itaju do Colônia. O Peres e o Paçoca, ainda que a gente já saiba, nunca me deixam esquecer que "é foda mano...”.

Do convívio com o Vitão, Rafa, Zen, Andy e Dió, tenho boas saudades, que a gente mata em intervalos de tempo estendidos demais pro meu gosto. Agora, no apagar das luzes dessa fase de mestrando, voltei a sentir esse gostinho bom de compartilhar o dia a dia doméstico com o Rafa, e com a Cami.

Bruno, o Passarinho, amigo dos primeiros tempos de São Paulo, provavelmente porque gente ranzinza se reconhece, também foi pra Lençóis por uns tempos, além de me acompanhar no Lapa N834-11 um punhado de vezes nos últimos anos.

Em 2016 a Olivia armou um trabalho de campo em grupo (ela, Mari, Ceci, Carlão, Marcha e eu) lá em Mirangaba. No ano seguinte voltamos nós dois e fomos novamente muito bem recebidos pela Celma e todo povo de Mangabeiras. As duas idas foram ótimas oportunidades para dividir a prática de campo e conhecer um pouquinho mais da Bahia. Em 2017 a Ceci também chamou para um campo no Vale, foi uma passagem curtíssima, mas assim como os campos em Mirangaba, foi uma boa chance de se aproximar de pesquisas que tocamos paralelas e afins.

O Fabião sempre esteve na disposição para trocar ideia desde que comecei a frequentar o "grupo do Colapso”. Fez parte da banca de qualificação, bateu perna e papo na serra em Lençóis. E agora, estou escrevendo as últimas linhas da dissertação no conforto da casa que ele e a Ceci nos emprestaram.

A Liziane também se dispôs a participar da banca de qualificação e me ajudou cedendo farto material de sua pesquisa em Lençóis. 
A Vivi, a Mari, a Ceci, o Caio e o Daniel arranjaram tempo de ler o texto em um momento que estava meio travado e me ajudaram a encontrar caminhos para ajambrar os problemas da forma de apresentação.

Teve um tanto de gente que foi pra Chapada e ficou na casa do Carlão nos períodos em que eu estive por lá. Foi muito bom estar lá no convívio doméstico, ainda que breve, com todas essas pessoas "de fora”, cada uma se relacionando com a cidade de forma diferente. Certamente meu olhar estrangeiro para o campo foi se compondo por esse caleidoscópio de outros olhares estrangeiros.

Devo agradecer aos fotógrafos que registraram a Chapada Diamantina e se dispuseram a conversar comigo: Iêda Marques, Aristides Alves, Rui Rezende, Rino Marconi e Açony Santos, foram solícitos e atenciosos.

Em Lençóis ganhei umas boas saudades das quais sofrer em São Paulo. O Neto foi grande amigo nesses três anos, sem dúvida foi quem mais me ajudou em Lençóis e quem me deu mais oportunidades de entrar no trabalho de campo e entender um pouco mais o universo do garimpo. Elias também esteve presente, sobretudo nesta última temporada, e me tirou uns pares de dúvidas pelo celular durante a escrita aqui em São Paulo.

A Val me mostrou suas fotos e contou sobre a Lençóis de quando era jovem, me fez repensar o lugar social da mulher naquele tempo/espaço, e foi sempre muito acolhedora. Assim como Seu Chiquinho e Dona Rai, que sempre me receberam bem. Seu Chiquinho contou da experiência de migração para São Paulo e do trabalho na construção civil. Foi ele também quem me apresentou Vanginho, que se dispôs a me levar para conhecer o quilombo da Iúna, apesar da tristeza ainda muito presente.

Seu Milton e Mara, também me receberam sempre muito bem. Seu Milton, além de não deixar de fazer uma zoadinha no cavaquinho, contou do tempo que viveu no Pau de Colher e quando eu quis conhecer o povoado foi ele quem sugeriu que Ró me levasse. A visita ao Pau de Colher e a conversa com Ró me colocaram atento para questão da metropolização de um jeito que até então não tinha estado.

O Ude foi quem me fez aproximar um pouquinho da consciência prática do que é a vida na serra. O Tonho, principalmente nas primeiras temporadas, esteve bastante presente, contou do tempo da draga e ensinou que na Chapada Diamantina "tem que saber pisar”. O Marcão abriu sua oficina e cozinha, com o que salvamos algumas facas e jogamos fora boa conversa.

Devo agradecer Delmar que me recebeu uns pares de vezes na UEFS, apesar da sobrecarga de trabalho, e me forneceu farto material iconográfico de Lençóis. Assim como o 
Heraldo, que me contou sobre o processo de patrimonialização de Lençóis e que indiretamente forneceu as fotografias de Steve Horman que compuseram o material do MCC.

Por fim, a Paula, que além de aguentar uma montanha de piada ruim, nessa última temporada foi a companhia de vários momentos especiais, da lida com os perrengues do dia a dia e das incertezas com o mundo do trabalho. Já tenho saudades de nossas conversas e das noites de Lençóis entrando pela janela entreaberta.

Esta pesquisa foi financiada por bolsa de estudos da Fundação de Amparo à Pesquisa do Estado de São Paulo (FAPESP), Processo 2015/19088-0. 
Esta dissertação pretendeu interpretar as representações fotográficas da área que hoje é compreendida como Chapada Diamantina, localizada no estado da Bahia. Para tanto, está sugerida a necessidade de considerar os limites objetivos da paisagem como categoria de análise do processo social do qual resulta e, consequentemente, de sua representação em fotografias. Na interpretação aqui empreendida, a paisagem e a fotografia que fazem aparecer tal processo, ao mesmo tempo escondem aquilo que lhe é substancial enquanto forma social. Característica própria da sociabilidade mediada pela mercadoria. Por isso, durante o processo de estudo, por um lado buscou-se montar um panorama interpretativo lógico e histórico da área estudada e dos nexos que estabelece enquanto particularidade com a totalidade da reprodução social capitalista em escala nacional e global. Em paralelo correlato, buscou-se estabelecer um quadro das relações que possibilitaram a produção de cada um dos grupos de imagens selecionados para a realização dessa pesquisa. A análise crítica desses processos é a intenção dessa dissertação.

Palavras-chave: representação, autonomização, região, fotografia, Chapada Diamantina. 


\begin{abstract}
This dissertation intended to interpret the photographic representations of the area that today is understood as Chapada Diamantina, located in the state of Bahia. Therefore, it is suggested the need to consider the objective limits of the landscape as a category of analysis of the social process from which it results and, consequently, of its representation in photographs. In the interpretation made here, the landscape and the photograph that make this process appear, at the same time hide what is substantial as a social form. Characteristic of sociability mediated by the commodity. For this reason, during the study process, on the one hand we sought to create a logical and historical interpretive panorama of the area studied and the nexus that establishes as a particularity with the totality of capitalist social reproduction on a national and global scale. In parallel correlate, it was tried to establish a framework of the relations that enabled the production of each of the groups of images selected for the accomplishment of this research. The critical analysis of these processes is the intention of this dissertation.
\end{abstract}

Keywords: representation, autonomization, region, photography, Chapada Diamantina. 
2. Um início a partir do conceito de região.

3. Os antecedentes da formação da região das Lavras Baianas................................. 21

4. A formação e o auge da região das Lavras Baianas........................................... 26

5. Crise: novas relações e uma outra região............................................... 34

6. Postais da série “Lavras Diamantíferas Baianas” de Rodolphe Lindemann..................... 43

7. Fotografias do cônsul estadunidense Henry Watson Furniss.................................. 49

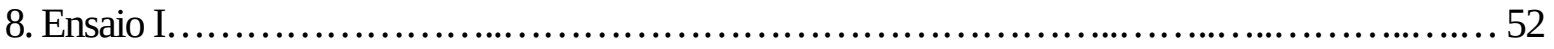

9. Crise: regressão econômica e abertura da região......................................... 64

10. Fotografias do jornal “O Sertão”.................................................... 68

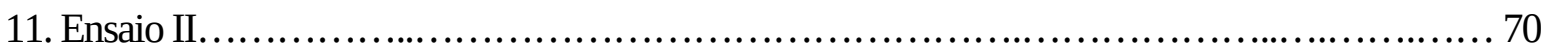

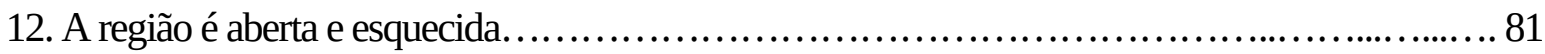

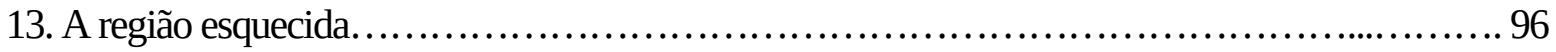

14. A descoberta da Chapada Diamantina e sua incorporação ao Estado nacional.................... 104

15. Fotografias do voluntário do Peace Corps Steve Hormann................................. 122

16. Fotografias do arquiteto Fernando M. Leal em pesquisa para o IPHAN.........................126

17. Fotografias de Aristides Alves para a BAHIATURSA ..................................... 132

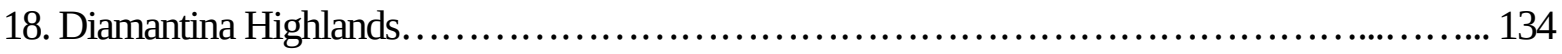

19. As fotografias autorais no tempo da circulação impressa................................. 147

20. A Chapada Diamantina mais que duplicada na internet................................. 154

21. Ensaio III................................................................. 166

22. Conclusão: paisagem, fotografia e fetichismo.......................................... 187 
Referências.

Anexos:

Anexo A - Postais da série “Lavras Diamantíferas Baianas” de Rodolphe Lindemann.................. 203

Anexo B - Fotografias do cônsul estadunidense Henry Watson Furniss........................ 216

Anexo C - Fotografias do jornal “O Sertão”................................................ 222

Anexo D - Fotografias do voluntário do Peace Corps Steve Hormann (coloridas).................. 243

Anexo E - Fotografias do voluntário do Peace Corps Steve Hormann (P\&B) . . . . . . . . . . . . . .... 259

Anexo F - Fotografias do arquiteto Fernando M. Leal em pesquisa para o IPHAN................. 292

Anexo G - Fotógrafos do pôr do sol no Morro do Pai Inácio................................. 305 


\section{APRESENTAÇÃO}

O leitor se apropriará melhor dessa dissertação sabendo o que foi planejado a princípio como projeto de pesquisa, como esta de desdobrou e o que foi possível realizar ao final. O texto ora apresentado como sequência de itens singulares foi escrito em quatro partes separadas, ainda que o processo de estudo e pesquisa tenha sido feito de forma mais ou menos unitária. Por isso a intenção desta apresentação é revelar como se construí a estrutura do texto.

O projeto de pesquisa inicial previa uma investigação sobre as transformações da forma de consciência sobre a paisagem da Chapada Diamantina a partir dos anos 1970, quando começaram a se dar as primeiras transformações que apontavam para formação da atividade turística na área. A intenção era cotejar os elementos apreendidos dessa transformação com a forma da reprodução social própria do colapso da modernização (Kurz, 1992), buscando identificar as particularidades do processo na Chapada Diamantina. Para tanto, foi proposto um estudo comparativo das representações fotográficas da área, de modo a contrapor imagens produzidas em momentos distintos de sua história socioeconômica, bem como imagens produzidas com intenções distintas entre si. Dessa fricção surgiriam os elementos que particularizariam o momento histórico marcado pelo desenvolvimento do turismo.

Ao mesmo tempo, se construiu uma leitura teórica sobre a fotografia e a paisagem, que inqueriu até que ponto elas poderiam ser tomadas como elementos de análise para interpretação do processo social. A partir da consideração do fetichismo da mercadoria (Marx, 1996) como elemento central da crítica pretendida, verificou-se o limite da paisagem como categoria de análise e da fotografia como documento e linguagem para esse objetivo. Para traçar, ainda que como grande esboço, uma interpretação do processo social na área estudada foi preciso empreender uma revisão de sua história e submetê-la à análise teórica crítica. Portanto, olhando bem para o quadro imposto, a pesquisa pode ser compreendida a partir de uma organização em três níveis: o primeiro correspondeu àquele da paisagem e da fotografia; o segundo a revisão da história, lida em planos escalares como se verá; e o terceiro aquele da teoria crítica radical do capitalismo. Certamente essa divisão não passa de um artifício analítico, os níveis se mesclaram durante o processo de pesquisa, que buscou realizar sua síntese justamente no terceiro nível, aquele da crítica radical.

Logo se percebeu que não seria possível utilizar as imagens da época que antecedeu a formação do turismo, fortemente identificada com a atividade do garimpo, sem a revisão bibliográfica da formação e reprodução das relações sociais próprias da comunidade lavrista. 
A primeira das quatro partes mencionadas acima foi resultado dessa necessidade e ficou identificada como Síntese de Estudos I: elementos para o estudo da formação e reprodução da região das Lavras Baianas. Ela corresponde à revisão do período entre a década de 1840, momento da formação da região, até 1930, a partir de quando se dá a abertura das regiões e a formação do Estado nacional brasileiro propriamente dito (Oliveira, 2008, 2013). Vale dar destaque para a referência da tese de Carlos de Almeida Toledo, $A$ região das Lavras Baianas (2008), que serviu de pano de fundo para esta parte, a qual era composta pelos itens: 2. Um início a partir do conceito de região; 3. Os antecedentes da formação da região das Lavras Baianas; 4. A formação e o auge da região das Lavras Baianas; 5. Crise: novas relações e uma outra região; 9. Crise: regressão econômica e abertura da região.

A segunda parte entre as quatro mencionadas era a continuação da revisão histórico teórica, e partia de 1930 para chegar a atualidade, ficou identificada como Síntese de Estudos II: da Região das Lavras Baianas à Chapada Diamantina: elementos para o estudo da área a partir da formação do Estado nacional brasileiro. Vale destacar que toda esta parte foi elaborada em diálogo com as formulações de Francisco de Oliveira constantes em cinco de seus textos: Elegia para uma re(li)gião: Sudene, Nordeste. Planejamento e conflitos de classes (2008); Crítica da Razão Dualista (2013); O elo perdido: classe e identidade de classe na Bahia (2003); O Surgimento do Antivalor - Capital, Força de Trabalho e Fundo Público (1988) e O Ornitorrinco (2013). A leitura crítica de Oliveira se deu a partir da releitura de Marx proposta por Moishe Postone (2014) e Robert Kurz (1992, 2002, 2014). Essa parte era composta pelos itens: 12. A região é aberta e esquecida; 13. A região esquecida; 14. A descoberta da Chapada Diamantina e sua incorporação ao Estado nacional; 18. Diamantina Highlands.

A terceira parte, enquanto processo de pesquisa e estudo, foi produzida simultaneamente as duas anteriormente apresentadas. Diz respeito a coleta de material fotográfico, coleta de informações sobre este material, seleção de um conjunto representativo e sua interpretação. Como a pesquisa acabou retrocedendo temporalmente, ampliando o arco histórico de análise, a seleção dos conjuntos de imagens foi feito tentando dar conta desse alargamento. Os conjuntos de fotografias selecionados tentam cobrir o século XX e XXI. Mais que a apresentação das imagens propriamente ditas, intencionou-se apreender o contexto da produção dos conjuntos. Essa parte era composta pelos itens: 6. Postais da série "Lavras Diamantíferas Baianas" de Rodolphe Lindemann; 7. Fotografias do cônsul estadunidense Henry Watson Furniss; 10. Fotografias do jornal "O Sertão"; 15. Fotografias do voluntário do Peace Corps Steve Hormann; 16. Fotografias do arquiteto Fernando M. Leal em pesquisa para o IPHAN; 17. 
Fotografias de Aristides Alves para a BAHIATURSA; 19. As fotografias autorais no tempo da circulação impressa; 20. A Chapada Diamantina mais que duplicada na internet.

A princípio essas três partes não comporiam o texto final da dissertação. A intenção era acessar esses elementos acumulados pelo processo de estudo e produzir textos na forma de ensaios que partissem do conteúdo de algumas das imagens selecionadas. Esse projeto se mostrou inviável dadas as condições objetivas impostas à execução dessa dissertação, sobretudo os limites de prazo. A partir dessas condições se optou por escrever três ensaios que já se encontravam esboçados, nos quais tratou-se de algumas questões que as três outras partes não puderam abarcar. Pode-se dizer que esta quarta parte era um registro da forma de apresentação dos conteúdos acumulados que se desejava executar e permaneceu no plano das intenções não realizadas.

A dissertação seria então formada por essas quatro partes separadas. Mas, a partir da leitura e sugestão de colegas de estudo e do orientador, essas partes foram desmembradas e seus itens reorganizados na sequência histórica. Daí o leitor compreenderá a estrutura desta dissertação, as variações que o texto apresenta e os saltos temporais que os três ensaios acabam fazendo, pois neles o arco histórico da pesquisa encontra-se sintetizado. 


\section{UM INÍCIO A PARTIR DO CONCEITO}

DE REGIÃO

A caracterização de uma região poderia ser estabelecida a partir dos conteúdos que a faz emergir aos olhos de um determinado observador (Hartshorne, 1969, apud Toledo \& Boechat, 2008). Assim entendida, como realidade singular aparente a um observador, a definição de uma região resguarda uma tensão reveladora, que passa pela designação de quem observa daquilo que vale ser observado. Isso porque o que vale para alguém pode não valer para outrem. Desta maneira, pode-se dizer que as regiões nada têm de absoluto. A região pode ser definida então a partir de características variadas, a depender das escolhas de um observador. Como resultado incontornável da definição, abarcar a totalidade concreta mostrase uma impossibilidade, apesar de nossos pretensiosos esforços.

A geografia constituiu-se disciplinarmente enquanto aquilo que pode ser definido como ciência de síntese, em outras palavras, ciência de contato entre ciências naturais e ciências sociais - do que importa salientar, ainda que brevemente, os limites dessas definições ao abstraírem o processo de formação dos campos disciplinares e a própria constituição histórica da separação entre natureza e sociedade, isso para não dizer a constituição histórica da natureza e da sociedade como separadas. Grosso modo, a dita geografia regional entende como aquilo que vale ser observado as distintas relações entre sociedade e natureza, das quais o observador/pesquisador derivaria gêneros de vida e regiões distinguíveis, ou seja, uma região seria o produto particular da forma como uma determinada sociedade se reproduz em seu meio.

Como se verá, o esboço de definição aqui proposto não está plenamente de acordo com a primazia do observador na definição da região, tampouco que esta possa ser definida como limite espacial de um determinado gênero de vida. Ainda assim, tais formulações ensejam questões importantes para o debate. Do ponto de vista aqui assumido, o caráter da região está posto como particularidade de uma totalidade. Tal totalidade, por sua vez, não é entendida como simples somatória das partes que a compõem, mas como uma forma social específica de mediação que dá sentido às formas particulares vinculadas e que é constituída em processo, tanto historicamente como lógica ${ }^{1}$. Mais diretamente: são como particularidades

1 "A crítica marxiana da totalidade é uma crítica historicamente específica que não confunde o que é com o que deveria ser. Ela não aborda a questão da totalidade em termos ontológicos; ou seja; ela não afirma ontologicamente a existência trans-histórica da totalidade nem nega que a totalidade exista (o que, dada a existência do capital, só poderia ser uma mistificação)." (Postone, 2014:102) 
históricas da formação social capitalista que as regiões se constituem. Mas a questão está longe de se encerrar neste enunciado, a definição dos fundamentos do capitalismo é envolta por sérias controvérsias, do que decorre a necessidade de acuidade para sua definição. Ela pode começar a ser tratada a partir de uma primeira aproximação ao objeto:

Se tomarmos o caso daquela área que viria se tornar o Brasil, o processo genitivo de sua formação social se faz marcado por um determinado sentido, o "sentido da colonização" de que nos alerta Caio Prado Júnior em Formação do Brasil Contemporâneo: Colônia (1977), quer dizer:

\begin{abstract}
"No seu conjunto, e vista no plano mundial e internacional, a colonização dos trópicos toma o aspecto de uma vasta empresa comercial, mais completa que a antiga feitoria, mas sempre com o mesmo caráter que ela, destinada a explorar os recursos naturais de um território virgem em proveito do comércio europeu. É este o verdadeiro sentido da colonização tropical, de que o Brasil é uma das resultantes; e ele explicará os elementos fundamentais, tanto no econômico como no social, da formação e evolução histórica dos trópicos americanos.” (Prado Júnior, 1977:31-32)
\end{abstract}

Para Caio Prado Júnior as relações mercantis mantidas entre metrópole e colônia possuem valor central para a compreensão das regiões que se constituiriam após a colonização portuguesa da América. Em outros termos, o autor não abstrai o fato de haver um processo histórico de formação da relação de submissão das colônias às metrópoles, e para tanto coloca em evidência que as coisas produzidas na colônia destinam-se ao mercado europeu:

\footnotetext{
"Se vamos à essência da nossa formação, veremos que na realidade nos constituímos para fornecer açúcar, tabaco, alguns outros gêneros; mais tarde ouro e diamantes; depois algodão, e em seguida café para o comércio europeu.” (Prado Júnior, 1977:31-32)
}

Trata-se, portanto, da desnaturalização da relação entre metrópole e colônia, de modo que o sentido da colonização é submetido a um ponto de vista crítico, assim como as relações que se formam na colônia, sobretudo o trabalho escravo. Isso é o que vale resgatar na caracterização geral do colonial para Caio Prado Júnior. No entanto, parece que a formação de outra relação, que não aquela entre metrópole e colônia, mas relacionada a ela, fica apagada na interpretação do autor acerca da dinâmica colonial. Se não completamente abstraída, de certa forma é naturalizada a descoberta que jocosamente Marx atribui à Wakefield, aquele que 
“[...] descobriu nas colônias que a propriedade de dinheiro, meios de subsistência, máquinas e outros meios de produção ainda não faz de uma pessoa um capitalista se falta o complemento, o trabalhador assalariado, a outra pessoa, que é obrigada a vender a si mesma voluntariamente. Ele descobriu que o capital não é uma coisa, mas uma relação social entre pessoas intermediada por coisas.” (Marx, 1996:384 [L. 1, T. 2])

Quer dizer, o segredo descoberto na colônia de que “a riqueza nacional é, por natureza, idêntica à miséria do povo” (Marx, 1996:390 [L. 1, T. 2]), não tem relevância para a forma como Caio Prado Júnior pensa a dinâmica do nacional formado. A formação da relação capitalista na metrópole parece não se vincular àquela não-formação de um "caráter mais estável, permanente, orgânico, de uma sociedade própria e definida” (Prado Jr., 1977:31), fato que é apresentado, tão somente, como resultado do sentido dado a tais coisas. A crítica de Prado Júnior é a do sentido dado às mercadorias produzidas no processo social colonial, não o sentido que a produção de mercadorias dá ao processo social colonial. Mais que isso, o desejo subjacente na formulação do autor é o da própria formação da Nação, quer dizer, de um mercado de trabalho internalizado na ex-colônia.

Como desdobramento das proposições dos capítulos da teoria moderna da colonização e da fórmula trinitária de O Capital (Marx, 1996) deve-se considerar que as regiões, como particularidades referidas à totalidade capitalista, não são definidas simplesmente pela relação que uma sociedade estabelece com seu meio, mas sim como forma particular e sociohistoricamente constituída de relação entre as pessoas em uma área econômico-política posta pela produção de mais-produto. Área na qual a autonomização das formas de rendimento e seus agentes personificadores estão em processo de constituição, assim como a autonomização da violência da figura do capital e do proprietário fundiário. Na interpretação aqui esboçada as relações entre sociedade e natureza estão postas pelos arranjos produtivos derivados do processo de formação socio-histórica capitalista. Se o que qualifica fundamentalmente a relação capitalista que se forma na Europa a partir da revolução industrial inglesa é a exploração de tempo abstrato de trabalho ou produção abstrata de coisas, o processo de formação da relação teria o mercantilismo como espécie de antessala, enquanto circulação abstrata de coisas. Ainda que não especificamente capitalista, nos termos da valorização do valor (Marx, 1996) já se tem na colônia produção de mercadorias que comportam, desde então, seu duplo caráter, ou seja, comporta valor de uso e valor de troca, este último entendido como forma de manifestação do valor que o precede historicamente, ao menos para os agentes mercantis no âmbito da circulação. Neste sentido parece importante destacar que 


\begin{abstract}
"Quando Marx discute a produção baseada no valor, ele a descreve como um modo de produção cujo "pressuposto é e continua sendo a massa do tempo de trabalho imediato, o quantum de trabalho empregado como o fator decisivo da produção da riqueza”. O que caracteriza o valor como forma de riqueza, de acordo com Marx, é ele ser constituído pelo dispêndio de trabalho humano imediato no processo de produção, permanecer preso a esse dispêndio como o fator determinante na produção de riqueza e possuir dimensão temporal. Valor é uma forma social que expressa e é baseada no dispêndio de tempo de trabalho imediato. Para Marx, essa forma está no cerne da sociedade capitalista. Como categoria das relações sociais fundamentais que constituem o capitalismo, o valor expressa o que é e continua a ser a fundação básica da produção capitalista.” (Postone, 2014: 40)
\end{abstract}

Para ser rigoroso com a definição do conceito de valor, não é possível afirmar que os produtos do trabalho cativo colonial possam ser interpretados como riquezas constituídas enquanto dispêndio de trabalho humano mensurado em tempo abstrato voluntariamente mobilizado. Mas, ainda assim, também não eram resultantes de qualquer ocasionalidade, e sim, desde o início, produzidos para o mercado. Do ponto de vista da dessa pesquisa interessa trazer o excerto citado acima, no qual Moishe Postone retoma a definição do valor como fundamento da mediação social historicamente constituído, para perto do debate do conceito de região proposto por Francisco de Oliveira em Elegia para uma Re(li)gião (2008). Seu conceito de "região econômico política" aponta para os elementos que fazem as regiões distinguíveis naquilo que para ele seria o cerne da relação capitalista:

“[...] um conceito de região que se fundamente na especificidade da reprodução do capital, nas formas que o processo de acumulação assume, na estrutura de classes peculiar a essas formas e, portanto, também nas formas da luta de classes e do conflito social em escala mais geral.” (Oliveira, 2008:145)

Para Francisco de Oliveira as relações fundamentais do capitalismo estão situadas na dimensão política imbricada às relações de produção e à forma de reprodução do capital, determinando assim as formas particulares das relações de classe pelas quais se reproduzem as regiões. Nos seus termos, “[...] a elaboração mais cuidadosa do conceito de "região” que se queria introduzir seja a da dimensão política, isto é, de como o controle de certas classes dominantes “fecha” a região” (Oliveira, 2008:151). 
Interessa reter dessa definição a formulação da região como formação particular e, ao mesmo tempo, relacionada à reprodução do capital em geral. Essa relação é fundamental e tem sua gênese posta pelo sentido da colonização. No entanto, o autor entende a relação de capital fundamentada nas desigualdades da distribuição da riqueza social, por isso traz para o centro de suas atenções a dimensão política da luta de classes. Sem desconsiderar a problemática da luta de classes e da propriedade privada, é fundamentalmente importante para esta pesquisa abordar a questão a partir de uma leitura crítica da própria forma da riqueza social, não apenas de sua distribuição. Desdobrada a posição teórica aqui proposta, verificarse-á que a compreensão da região exclusiva ou fundamentalmente como domínio de uma classe que a fecha constitui-se como interpretação fetichista do processo, porque abstrai o caráter histórico da forma de riqueza do valor, assim como o núcleo contraditório interno da sociabilidade baseada nessa forma de riqueza.

Resta então situar a região como particularidade no marco teórico redefinido. O que se sugere, tendo em vista o caráter histórico da forma de riqueza especificamente capitalista, é a impossibilidade da interpretação da região nos termos de uma comparação da composição orgânica (Marx, 1996) entre áreas. Isso porque o que define a região é justamente a não formação interna da superpopulação relativa (Marx, 1996) como base fundamental para existência do mercado de trabalho e do próprio tempo abstrato como forma de riqueza a ser explorada. Em outros termos, a região é caracterizada por nela encontrar-se ainda em processo a autonomização das formas de rendimento que caracterizam a produção capitalista ${ }^{2}$, assim como não está completamente autonomizada a violência na figura do Estado como ente político que detém seu monopólio (Leite, 2014).

No entanto, isso não exclui certa determinação da dinâmica da mercadoria no processo social regional. Tal questão demanda resposta contraditória: se por um lado não é a dinâmica da produção da mercadoria (valorização do valor) que medeia fundamentalmente as relações na região, por outro, a “contradição em processo” (Scholz, 2016) da sociabilidade da mercadoria externa à região forma e transforma profundamente as relações regionais, ao ponto de determinar sua própria dissolução. Isso porque na região não deixa de se dar acumulação, ainda que como acumulação de relações regionais.

A caracterização da região aqui sugerida deve ser melhor compreendida se operada a inversão do ponto de vista do qual normalmente se pratica a análise. Quer dizer, fazer a leitura da formação do tempo abstrato não apenas do ponto de vista do capital, ou seja, da exploração

2 Portanto, também suas personificações (Marx,1996) enquanto capitalista, proprietário fundiário e trabalhador. 
do tempo como valorização do valor, mas considerando também o ponto de vista do trabalho3 ${ }^{3}$. Isso implica em se perguntar sobre o lugar das mercadorias na reprodução do trabalhador regional, da família e da própria comunidade. Essa inversão não pode se dar como simples prática teórica, os conteúdos específicos do processo que se analisa somente se evidenciarão como realidade concreta, daí a importância do trabalho de campo para a pesquisa. Do que vale ressaltar: o lugar da prática do trabalho de campo se faz como tensão constante em relação ao fetichismo que subjaz como fundamento da forma de consciência da sociabilidade mediada pela mercadoria (Marx, 1996).

É importante destacar ainda que do ponto de vista da presente pesquisa a implicação com a prática de uma teoria crítica radical consequente demanda esforço para considerar as posições teóricas divergentes não como simples erros ou acertos, sendo assim descartáveis ou não. Pelo contrário, a crítica deve levar em conta o lugar desses discursos do processo social que se analisa, considerando seus caráteres históricos e o lugar social que personificam em tal processo. O mesmo se aplica para o próprio trabalho de campo, os discursos coletados a respeito do processo social analisado são encarados aqui como pontos de vistas de determinados lugares sociais. Assim sendo, os discursos são entendidos como material fértil para a explicitação da contradição como a verdade do processo social.

O abismo entre intenções e realizações, para o que as condições objetivas da realização dos planos e o próprio fetichismo das intenções corroboram decisivamente, certamente implicará em muitas brechas nas interpretações do processo social adiante sintetizadas. De qualquer modo, a intenção é situar os discursos e posições, e por consequência os fundamentos teóricos que os sustentam, considerando suas historicidades e seus lugares de personificação. Esse esforço não estará circunscrito unicamente ao debate entorno do conceito de região, mas se pretende como constância nessa dissertação.

3 Tal formulação pode gerar certo estranhamento se considerada as repetidas referências nesta dissertação ao livro de Moishe Postone, Tempo, trabalho e dominação social (2014). O autor afirma que "enquanto nas interpretações marxistas tradicionais o trabalho constitui o ponto de vista da crítica de Marx à modernidade capitalista e a base de uma possível ordem social póscapitalista, na interpretação desenvolvida aqui, o trabalho constitui o objeto fundamental da crítica de Marx." (Postone, 2014:9). Não se trata de assumir o ponto de vista do marxismo tradicional, mas de considerar uma mirada atenta ao cotidiano do trabalhador. 


\section{OS ANTECEDENTES DA FORMAÇÃO DA REGIÃO DAS LAVRAS BAIANAS}

A área que hoje se identifica como aquela onde viria se formar a região das Lavras Baianas (Toledo, 2008) passa a ser ocupada com a finalidade da extração das pedras preciosas em meados da década de 1840. No entanto, a formação de tal região produtora de diamantes não é um processo que se deu sem precedentes, nem teve por base um "vazio territorial” (Prado Júnior, 1977), como por vezes as narrativas da história local e também da história nacional fazem parecer. Existem pressupostos à formação da região das Lavras Baianas enquanto particularidade na modernização, esta última entendida como processo de universalização da sociedade produtora de mercadorias (Kurz, 1992).

O sentido da colonização é certamente o primeiro momento dessa breve aproximação aos pressupostos enunciados. À produção de gêneros tropicais extravertida, que dá o tom da colonização portuguesa na América, soma-se o entendimento do processo colonial como momento particular da própria formação do capitalismo nas metrópoles europeias, ou seja, o processo colonial é parte da acumulação primitiva (Marx, 1996) ${ }^{4}$.

Outro pressuposto histórico é a existência dos diamantes. Mas, além de sua existência física como mineral com tais e quais características, sua existência como coisa de valor em uma sociedade produtora de mercadorias, quer dizer “Os diamantes são procurados tendo em vista o seu valor, o que possibilita
acessar outros produtos, produzidos por outros trabalhadores. A produção de
diamantes refere-se, pois, a uma totalidade social mediada por coisas.”
(Toledo \& Boechat, 2012:451)

$4 \quad$ Quer dizer, é fundamental, uma vez mais, afirmar a relação indissociável entre os processos coloniais - considerando a multiplicidades de formas como se realizaram - e a acumulação primitiva europeia. Isso implica colocar em questão a pergunta sobre a acumulação primitiva brasileira - quando se deu, e suas bases. Ou seja, a acumulação primitiva do Brasil, que ainda não o era, é a mesma da acumulação primitiva clássica - a rigor o processo único de gênese das relações capitalistas - ainda que os "legados” desse processo de caráter universalizante assuma formas múltiplas e aparentemente antagônicas. Sobre isso interessa ter claro que foi, e ainda é, justamente a interpretação dualista dessa relação - que mira o centro como ponto de chegada a ser alcançado pela periferia, como se nela faltasse modernização - que organizou o ideário desenvolvimentista do pensamento nacionalista brasileiro, o qual de fato empreendeu o planejamento como forma de superar a condição do dito subdesenvolvimento. Neste sentido seria importante estabelecer as diferenças entre o que foi a acumulação primitiva descrita por Marx e os surtos de "modernização retardatária” (Kurz, 1992) que caracterizaram a história nacional de diversos países no decorrer do século XX, a começar pela União Soviética. 
Desta forma, na colônia e depois no Brasil imperial, principal produtor mundial de diamantes durante mais de um século, uma política de restrições severas ditava as prédicas para a extração das pedras preciosas. Durante o período colonial a extração ficou proibida em todo território, exceção feita à Intendência Diamantina, cujo controle da coroa visava a regulação da oferta do bem nos mercados europeus:

"A área em que se tinha fixado a exploração de diamantes circundava o arraial do Tejuco, hoje cidade de Diamantina. Seus contornos tinham sido rigorosamente demarcados desde a criação da Intendência do diamante, órgão similar das Intendências do ouro, em 1734. [...]Nesta área ninguém podia estabelecer-se, nem ao menos penetrar ou sair sem autorização especial do Intendente. A vida dos seus 6.000 habitantes - é em quanto monta a população nos primeiros anos do séc. XIX - achava-se inteiramente nas mãos daquele pequeno régulo, que punha e dispunha dela a seu talante. Não havia juízes ou tribunais, nenhuma outra autoridade superior ou paralela; e seus poderes iam até o confisco de todos os bens e decretação da pena de morte civil sem forma de processo ou recurso algum. Tudo isso unicamente para melhor fiscalizar a extração e impedir o descaminho das pedras. 'Única na história, comenta Martius, esta ideia de isolar um território no qual todas as condições de vida civil de seus habitantes ficassem sujeitas à exploração de um bem da coroa'.” (Prado Júnior., 1977:182)

Além disso, as terras que viriam formar o território colonial estavam longe de serem vazios territoriais. A abstração do processo de incorporação e extermínio do gentio durante o povoamento colonial, além de ocultamento dessa violência particular, parece também esconder a violência imanente da imposição da relação social mediada por coisas, ainda que para a jovem Nação a generalização de tal mediação apareça apenas como devir civilizacional. A acumulação primitiva é a violência parteira do capitalismo, criadora de uma potência econômica. O sistema colonial constitui-se como uma das formas dessa violência, que já para Marx são casos particulares:

"[...] a história da expropriação da base fundiária do produtor rural, do camponês, base do processo, assume coloridos diferentes nos diferentes países e percorre as várias fases em sequência diversa em diferentes épocas históricas. Apenas na Inglaterra, que, por isso, é tomada como exemplo, mostra-se em sua forma clássica". (Marx, 1996:342, L. 1, T. 2])

$\mathrm{Na}$ formação da sesmaria do Alto Sertão, uma das bases fundiárias da região pecuarista da qual a região das Lavras Baianas viria se destacar em meados do século XIX, o colorido é aquele dado pela Guerra dos Bárbaros (Puntoni, 2002, apud Toledo, 2008), esforço 
conjunto de sesmeiros, coroa, bandeirantes paulistas e outros grupos interessados no domínio do interior. Quer dizer, luta até a morte ou aprisionamento dos indígenas habitantes daquelas paragens, fundamental para a formação da potência econômica terra ${ }^{5}$.

\begin{abstract}
"Graças a essa tremenda expansão que cada dia ocupava mais terras e semeava currais onde havia água permanente, é que os índios foram levados à revolta. Revolta que se estendeu por mais de 10 anos e que entrou para a história com o nome de Guerra dos Bárbaros. [...] Guerra que provocou muitas mortes e devastações, que atraiu os bandeirantes paulistas hábeis na luta contra os índios, que provocou o devassamento do interior e que se concluiu com o aniquilamento de poderosas tribos e com o aldeamento dos remanescentes.” (Andrade, 1964:178)
\end{abstract}

$\mathrm{Na}$ expansão das possessões dos Guedes de Brito ${ }^{6}$, certamente não se tratavam de camponeses os expropriados, e as relações particulares engendradas estão longe do assalariamento como no caso inglês, "nestes sertões desenvolveu-se uma civilização sui generis" (Andrade, 1964:180).

A área em que a exploração de diamantes viria ganhar vulto foi ocupada também por outros grupos sociais formados no decorrer do processo colonial. Em Andaraí, mais tarde um dos principais arraiais da região das Lavras Baianas, encontrava-se um importante quilombo com o mesmo nome. Documentos da época guardam registros de agressões de parte a parte entre quilombolas e forças coloniais oficiais ${ }^{7}$. Além disso, a existência de pequenos povoados

5 Do que vale destacar, a terra na colônia ainda não se apresentava como riqueza autonomizada, a sua monopolização era então condição para existência do capital agrícola colonial que não se realizava sem também lançar mão da violência extraeconômica para mobilizar trabalho.

6 “Competindo com ela [Casa da Torre de Garcia d'Ávila] pela extensão das terras que possuía, só se comparava a família do Mestre-de-Campo Antônio Guedes de Brito, uma vez que possuía propriedades que se estendiam desde o Morro do Chapéu até as nascentes do Rio das Velhas, compreendendo mais de 160 léguas de terras." (Andrade, 1964:176) e "no início do século XVIII, os currais baianos se estendiam pela margem direita do Rio São Francisco e pelas ribeiras do Rio das Velhas (hoje território mineiro), das Rãs, Verde, Rapamirim, Jacuípe, Itapicuru, Real, Vasa-Barris e Sergipe, possuindo parte de 500.000 cabeças de gado.” (Andrade, 1964:178).

7 "Dizem os moradores da Villa da Cachoeira abaixo assignados, que pela geral utilidade que lhes resulta da extincção dos Quilombos do Orobó, Tupim e Andarahy, donde diariamente sahem os foragidos nelles acoitados, em tropas armadas, acommettendo as estradas, ainda as mais publicas, a despojar os viandantes, roubando muitos gados nas fazendas por onde .passão, especialmente as circunvisinhas daquelles Quilombos, assassinando, deshonestando mulheres donzellas e cazadas com toda a impunidade e escandalo e depois disto persuadindo $e$ conduzindo os seus semelhantes aos mesmos coitos e isto muitas vezes por força e a vista dos seus mesmos senhores, são contentes que o Capitão-mór de Entradas e Assaltos SEVERINO DA SILVA PEREIRA investigue os referidos Quilombos, fazendo, como promette, as despezas a. sua custa, permittindo-se-lhe os despojos delles e ainda as proprias crias nascidas n'elles desde o 
de roceiros nas imediações da serra do Sincorá demonstra já as relações daquela área com a formação de regiões de mineração na Bahia ainda na primeira metade do século XVIII. O entorno daquela que viria a ser a região das Lavras Baianas, de início a dita Chapada Nova ${ }^{8}$, não passava de área agrícola subsidiária do sertão pecuário e garimpeiro. Além disso, a área onde se formaria a região das Lavras Baianas era cortada pela estrada real do ouro que ligava Jacobina à Rio de Contas, os dois principais centros baianos de exploração desse minério no século XVIII, que contavam inclusive com casas de fundição da coroa.

Outro importante pressuposto é o entendimento da figura do garimpeiro, sem o qual não se forma uma região de lavras. O garimpeiro é um desclassificado (Mello e Souza, 1990, apud Toledo, 2008), sua condição na colônia é resultante do monopólio das minas pela coroa. A garimpagem, ainda que como atividade clandestina na colônia, configurou-se como possibilidade para esses homens livres. A dupla liberdade, que caracteriza a figura do garimpeiro, livre dos meios de produção e livre para vender sua força de trabalho, está vinculada ao processo de mobilização do trabalho $^{9}$ (Gaudemar, 1977), relacionada à

tempo da sua subsistencia..." (Documento n. 17.957, do Arquivo de Marinha e Ultramar de Lisboa) [...] "Após o retôrno do capitão-mor Severino Pereira à vila de Cachoeira, foi levada a efeito a expedição contra os "quilombos" de Orobó e Andaraí e, conforme diz o governador Dom Fernando José de Portugal ao ministro de Estado Dom Rodrigo de Sousa Coutinho em carta datada de 6 de abril de 1797, foram "destruidos os dous Quilombos ou Mocambos denominados de Orobó e Andarahy e nelles se acharão plantaçoens de mandiocas, inhames, arroz, algumas canas de assucar, fructas e outros viveres de que se sustenta vão"." (Pedreira, 1962:84)

8 No romance de Lindolfo Rocha, "Maria Dusá” (1910), que retrata a sociedade regional das lavras por volta do ano de 1860, os personagens em trânsito se referem àquela área que viria a ser conhecida como as Lavras como Chapada Nova, em oposição a Chapada Velha, alcunha utilizada até hoje para designar a antiga área de exploração de diamantes, relativamente insignificante em termos econômicos a sua sucedânea.

9 “Assim, a mobilidade do trabalho perde, com Marx, o caráter de uma noção ao mesmo tempo vaga e contraditória que tem em Smith: adaptabilidade às exigências do capital ao mesmo tempo que expressão da liberdade natural dos homens. Marx dá-lhe os contornos e os conteúdos de um conceito muito precisamente colocado: é certo que a mobilidade do trabalho conduz a uma 'liberdade' dos homens, mas aquela que significa a sua emancipação de modos de produção anteriores. Cessa aí essa liberdade, pela mercantilização da sua capacidade de trabalho, que o novo modo de produção impõe. Com o aparecimento do capitalismo, a mobilidade do trabalho na acepção dos modos de produção anteriores, torna-se figura genérica da mobilidade da força de trabalho; é o uso da força de trabalho como mercadoria que põe fim à imobilidade do trabalho imposta pela rigidez das estruturas feudais [...] Marx exprime-se explicitamente acerca deste ponto: 'o axioma da economia política clássica é a mobilidade da força de trabalho e a fluidez do capital. É exato, por isso, que o modo de produção capitalista para aí tenda impiedosamente, a despeito de todos os obstáculos que em grande parte ele próprio cria', sublinhando assim o modo de pensar dos clássicos e o ponto em que separa deles: na recusa de fazer da mobilidade do trabalho uma determinação geral, ahistórica, do seu caráter produtivo; na vontade de dela fazer a expressão de uma lei específica do capitalismo: a que transforma força de trabalho em mercadoria." (Gaudemar, 1977:208- 
acumulação primitiva e à formação da mercadoria força de trabalho, o que na colônia ganha seus coloridos particulares: acumulação extravertida e as formas particulares de trabalho livre, existentes sempre em relação tensa com o trabalho escravo. Com a independência em relação à metrópole portuguesa o poder administrativo da terra, dado até então pela concessão das sesmarias, se transmuta com a transformação da terra em mercadoria, ou seja, a expropriação condicionante da mobilização garimpeira passa pela formação da propriedade privada da terra no Império ${ }^{10}$. A elite oligárquica então formada, para além de proprietária de terras, se caracterizou também pelo monopólio da violência oficial através dos títulos da Guarda Nacional (Toledo, 2008). Desta forma, os coronéis sintetizam as figuras do capitalista, do proprietário fundiário e do portador da violência extraeconômica em uma única persona.

Foram os garimpeiros das Minas Gerais, tangidos por sua dupla liberdade e pelas notícias de riquezas minerais, aqueles que adentraram os territórios da província baiana e realizaram o povoamento ligado ao garimpo de ouro durante o século XVIII. São figuras sob a mesma condição que, em meados da década de 1840, deixaram as lavras auríferas decadentes e as roças periclitantes do sertão, atraídos pelas notícias dos diamantes encontrados na Serra do Sincorá, entorno da qual se formou a região das Lavras Baianas. Mas a migração não retirou esse garimpeiro da condição de expropriado. Muito rapidamente a disputa entre dois grupos proprietários provenientes de outras regiões constitui a nova estrutura fundiária na região em formação, caracterizada por propriedades menores que as extensas fazendas pecuárias do Alto Sertão, das quais, até então, faziam parte as terras ricas em diamantes.

210).

10 Neste particular duas ressalvas se fazem necessárias. É certo que para a história do Brasil a Lei de Terras de 1850 é tida como marco importante da gênese do mercado de terras, no entanto não é possível assumir a juridificação como correspondente imediato de uma forma de relação social que se transforma em processo. Dessa processualidade emerge a segunda ressalva importante de se apontar, os termos concretos da expropriação estão em constante transformação. A afirmação da condição de expropriado do garimpeiro em meados do XIX certamente é, problematicamente, a abstração de uma série de elementos que dizem respeito à reprodução dessa figura arquetípica que não passam pela produção/circulação de mercadorias para o/no mercado, portanto para o que a terra não constituía meio de produção. Desta questão se desdobra a pergunta: é possível apontar com precisão um momento de virada no qual a expropriação estaria consolidada? Isso certamente não se deu de forma homogenia no território nacional e, ainda que pareça uma amarração um tanto frouxa, parece mais interessante estar atento à processualidade das transformações em curso do que fixar um momento de viragem no debate sobre a reificação. 


\section{A FORMAÇÃO E O AUGE DA REGIÃO DAS LAVRAS BAIANAS}

Existem alguns relatos sobre a descoberta de diamantes na serra do Sincorá. Um dos primeiros documentos com este teor é o "Reise en Brasilien”, publicação de Carl F. P. von Martius sobre suas viagens realizadas entre 1817 e 1820 em companhia de Johann B. von Spix na ainda colônia americana de Portugal. Segundo os expedicionários “dizem que se acharam diamantes em sua [da Serra do Sincorá] encosta leste” (Martius, 1938:42). A este, somam-se outros tantos relatos sobre descobertas de diamantes na área em questão, no entanto é difícil precisar ao certo o contexto de tais descobertas. O evidente é que, em torno do ano de 1844, uma multidão atraída pela promessa de fortuna aflui àquela área, dando início ao povoamento relacionado às lavras e à formação dos principais centros comerciais da região (Falcón \& Dutra, 1978).

O lapso de mais de duas décadas entre a passagem de Martius e Spix pela área, onde souberam haver diamantes, e a migração massiva que dará origem à região, sugere um contexto mais complexo que a simples descoberta das pedras preciosas, como algumas narrativas querem crer. Para isso concorrem uma série de fatores que extrapolam o simples conhecimento da existência de diamantes na área, dentre eles certamente a própria ilegalidade da atividade no período colonial:

\footnotetext{
"Notemos, antes de mais, que como os anteriores, ele [o sistema imposto pela coroa] só se aplica a um pequeno trecho do território de Minas Gerais, o Distrito ou a Demarcação Diamantina, onde hoje está a cidade deste nome; é esta a única área em que na colônia se exploraram legalmente jazidas diamantíferas. Noutros lugares, a extração era severamente proibida, medida que se adotara para reduzir a produção e manter os preços, bem como para facilitar a cobrança dos direitos da coroa e impedir o contrabando. [...] $\mathrm{Na}$ Bahia, cujas jazidas se descobriram em 1732, foram proibidas habitações e serviços num raio de 10 léguas ao redor dos pontos onde se achassem diamantes.” (Prado Jr., 1977:181)
}

É possível que a área em questão já fosse frequentada há tempos por faiscadores ${ }^{11}$ antes da onda migratória. Porém, a afirmação positiva sobre o contexto do qual se desdobra o processo de migração em massa deve permanecer no campo das especulações. O certo é que o

11 "Quem viaja por estes lugares, topa a cada passo com estes faiscadores, em grupos ou isolados, e que metidos nos rios ou revolvendo suas margens, fazem rodar as bateias na ânsia de uma miserável pepita que lhes garanta o pão daquele dia." (Prado Júnior, 1977:171) 
diamante era entendido como coisa valiosa o suficiente para atrair uma massa de aventureiros, fossem esses garimpeiros expropriados querendo retirar com as próprias mãos e instrumentos rudimentares as pedras da terra, ou proprietários almejando acessá-las através do trabalho desses garimpeiros e de negros cativos.

A partir de 1844 constituem-se os principais centros urbanos da região ${ }^{12}$ - vilas como Santa Isabel do Paraguassú (atual Mucugê) e Lençóis, além de arraiais como Andaraí, Igatu e Palmeiras. Em um primeiro momento as explorações se fazem em empreitadas sem qualquer política fiscal, de modo que, de certa forma, se dava também livremente o acesso às catas.

"Mas, tão logo ganhou importância o comércio de pedras no sertão baiano, o Governo Imperial instalou uma Administração Diamantina, que começou a funcionar em 1846, responsável pela cobrança dos mais diversos impostos.” (Falcón \& Dutra, 1978:123)

Para além de uma intervenção do Governo Imperial visando a fiscalização, o que logo se estabeleceu foi uma disputa pelo poder na área, o que viria a influir na forma da reprodução das relações de produção da região nascente. São dois grupos que se antagonizam: proprietários sesmeiros do Alto Sertão coligados com proprietários de escravos das Minas Gerais, e proprietários do Recôncavo e do litoral da Bahia.

\begin{abstract}
"Vindos de uma ou outra origem, os coronéis representam a imposição do capital escravista sobre a região garimpeira das serras desconhecidas. Símbolo deste domínio, a sede da administração diamantina começou a funcionar em 1847 em Mucugê, sob a inspetoria do Dr. Benedicto Acauã. [...] Já em 8/10/1847, Benedicto Marques da Silva Acauã é nomeado inspetor da Tesouraria da Fazenda da Paraíba. O sucessor de Acauã foi o Coronel Francisco da Rocha Medrado, seguindo sempre sendo ocupada por homens importantes e de prestígio (Pereira, G. A. 1910:59), ou seja, membros da Guarda Nacional e proprietários de terra na região. Ocorre nesta passagem a transferência do poder sobre a instituição de um quadro da política imperial para o que viria a ser o primeiro grande chefe regional, o dono da sesmaria onde os diamantes foram encontrados.” (Toledo, 2008:88)
\end{abstract}

Apesar do domínio estabelecido pelo grupo do Alto Sertão, encabeçado pelos Rocha Medrado, disputas em torno do poder político são uma constante na história da região. O que se estabelece, em fins da década de 1840, é a existência de um grupo de proprietários de terras

12 "[...] convergindo para Mucugê de Setembro de 1844 a 48 cerca de 30,000 almas. [...] Esse grande número de novos habitantes, de entre elles os garimpeiros espalhando-se pelas serras, valles, gargantas e rios - novos povoados se foram levantando rapida e sucessivamente. A população subiu em todos elles a 50,000 almas.” (Menezes, in Ferreira, 1885:223) 
e escravos, sejam quais forem as personas que o representam, que controlará as posições institucionais estratégicas da política regional durante as duas décadas áureas da exploração de diamantes e também nas seguintes. Tais líderes personificam a terra (seja como proprietários ou como concessionários do Império), o capital (como proprietários de escravos) e a violência de Estado (através dos títulos da Guarda Nacional e dos cargos administrativos da política local).

Se até então o trabalho encontrava-se disperso em pequenas cateações, o grande afluxo de pessoas para a área e a estruturação do poder político atrelado à propriedade da terra (via compra de concessões junto ao governo da província) e propriedade de escravos, constituíram a base material de uma nova forma de exploração dos diamantes, através de companhias ${ }^{13}$, dando novo caráter à região, ou melhor, transmutando-a em região escravista (Toledo, 2008).

Em um quadro de escassa documentação, a Memória descriptiva e estatística da riqueza mineral da província da Bahia, escrita em 1863 por Gustavo Adolpho de Menezes e constante no Diccionario Geographico das Minas do Brazil de Francisco Ignacio Ferreira (1885), é um documento relevante. Nestas memórias Menezes faz menção aos dados presentes no "relatório do inspetor geral dos terrenos diamantinos de 10 de janeiro de 1862”, do que importa lembrar que o cargo da inspetoria era ocupado normalmente pelos coronéis da região. Segundo Menezes a primeira companhia é criada em 1847 e o relatório dá conta da existência de seis companhias em funcionamento no ano fiscal de 1862-63, cada uma das quais contando com 100 trabalhadores, número mínimo exigido para a aprovação da concessão das lavras. Afora essas, outras duas encontravam-se com os contratos de criação pendentes. Ainda segundo o relatório citado por Menezes, tratavam-se de companhias nacionais, três delas com contratos de 15 anos e as outras 3 com contratos de 10 anos.

Mas, o mesmo relatório dá conta da existência de 953 faiscadores licenciados, dos quais 821 eram homens livres e 132 eram escravos, além do que, o registro de 113 lotes em execução, dos quais Menezes depreende cerca de 1130 trabalhadores em atividade, estimando 10 trabalhadores por lote. Tais números nos permitem no máximo algumas suposições, uma delas a necessidade de relativizar o trabalho escravo na região, bem como o papel das companhias na absorção do trabalho disponível, ainda que em termos de área trabalhada as

13 "Diante da falta de recursos individuais com que lutavam os mineradores empobrecidos, e as grandes obras necessárias ao prosseguimento da mineração, cogitou-se em alguns raros casos de associar esforços e organizar companhias. Mas isto, que parece evidente e deveria ter sido tentado desde o início, só veio muito tarde e em proporções insignificantes. As tentativas para a organização de companhias datam do último quartel do séc. XVIII, muito tímidas embora." (Prado Júnior, 1977:179-180) 
companhias se sobrepujassem: os supostos $600^{14}$ trabalhadores mobilizados por elas mineravam uma área quase três vezes maior que os lotes em execução pelos 1130 trabalhadores estimados por Menezes. De qualquer forma, tratam-se de suposições que devem inspirar ainda maiores reticências quando o próprio autor das memórias revela a imprecisão dos valores apresentados em relação à realidade regional. Números, segundo ele, certamente depreciados devido ao contrabando e a falta de policiamento:

"É espantoso em verdade o contrabando; o que lhes facilita a vastidão de terrenos diamantinos, e os poucos ou quasi nenhuns recursos da administração para fiscalizar tão grande extensão, sem os auxilias que diz carecer. Uma das causas, e talvez a maior de escacez de rendas, é a concessão dessas grandes extensões de terrenos concedidos ás companhias, que, invadidos pelos garimpeiros - não podem ellas evitar, não lhes valendo o direito de propriedade, dando-se constantemente o furto, resultando uma horrível desmoralisação completa, a despeito de disposições penaes, e de outras fiscaes, mui pouco aproveitando á fazenda publica as capitações estatuídas e aquellas por augmento só de faiscadores que por excepção honestos e probos compram bilhetes de licença as mesmas companhias para livremente faiscarem nos terrenos por ellas concedidas, sendo préviamente matriculado e satisfeita a fazenda.” (Menezes, in Ferreira, 1885:240-241)

Sobre o argumento de Menezes a respeito da impossibilidade de vigilância dos terrenos por parte das companhias, Carlos de Almeida Toledo (2008) coloca em questão a real inviabilidade da fiscalização. O autor lembra primeiro das manobras jurídicas realizadas pelos arrematantes de terras em concessão com claro intuito de centralizar em suas mãos áreas maiores que as permitidas pela lei, o que revela uma incongruência flagrante do argumento de Menezes: por que acumular terras se estas terão pilhadas suas riquezas minerais por garimpeiros individuais? Além disso Toledo acrescenta:

“A vigilância não é matéria desconhecida da empresa escravista, a própria forma da coerção do trabalho do escravo é exercida com a mediação da mercadoria. No pagamento do feitor, na compra das armas, dos chicotes e outros insumos da imposição violenta do trabalho, lá está o dinheiro produzindo a desigualdade na violência explícita do escravismo. Este mesmo dinheiro pode ser usado para evitar a mineração clandestina, basta que o trabalho do gerente seja pago" (Toledo, 2008:96)

14 Os números redondos instigam a desconfiança! 
A esse quadro se soma o fato desses mesmos empresários acumularem o papel do capital comercial no interior da região, o que ao certo dificultaria o salto-mortal ${ }^{15}$ da mercadoria diamante vendido em prejuízo das companhias dos próprios empresários, quer dizer, na comercialização da pedra a ilegalidade da produção tornar-se-ia evidente. Isto, é claro, não quer dizer que não existissem subterfúgios para evitar tal controle. O autor sugere que tais garimpeiros clandestinos, antes de agirem em detrimento das companhias, trabalhavam para as mesmas e em prejuízo do governo imperial.

A parte tal questão, é importante notar que na região escravista há lugar para o trabalhador livre. Isso se explica certamente por fatores que extrapolam os limites da região, e extrapolam inclusive também os limites da própria colônia. O auge da mineração na região das Lavras Baianas se dá durante pouco mais de duas décadas, de meados da década de 1840 até o início da década de 1870. O que significa que tal período coincide com a Bill Aberdeen e as subsequentes leis brasileiras que viriam a culminar na abolição do trabalho escravo no país em 1888, de modo que o preço do trabalhador escravo nesse período passou a limitar o emprego do mesmo às regiões de economia mais dinâmica do império. No entanto,

\begin{abstract}
“A presença do trabalhador livre nas Lavras, ao contrário do que poderiam pensar alguns, não indica a existência da contrapartida imediata do trabalho escravo: isto é, do trabalhador assalariado. Traduz, na verdade, o "arranjo" ao nível das relações de produção, fruto de uma economia mercantil de base escravocrata decadente, obrigada a solucionar seus problemas de acumulação nos limites de circunstâncias históricas especiais, onde encarece e se torna escasso o escravo, e onde o padrão de acumulação de capital (e, em consequência, o estatuto jurídico) não permite a legitimação do trabalho assalariado.” (Falcón \& Dutra, 1978:126)
\end{abstract}

O antagonismo simples entre a economia mercantil de base escravocrata e o assalariado, resolvido no argumento como "arranjo" herdeiro da ordem decadente, deve ser questionado, pois corre o risco de apagar a modernização, enquanto processo gradual e nãosimultâneo espacialmente de imposição da forma da riqueza capitalista, como pano de fundo da análise. A problemática a que se refere o trecho acima foi fartamente debatida pelas ciências sociais no Brasil, quer dizer, aqui o fim do trabalho escravo não coincide com a formação de relações de produção ditas especificamente capitalistas, do que se depreende a formação do trabalho livre assalariado. Apesar de certa unidade advinda da própria restrição do trabalho do cativo e do processo de formação da propriedade privada da terra no Brasil, a

15 " $M-D$. Primeira metamorfose da mercadoria ou venda. O salto do valor da mercadoria, do corpo da mercadoria para o corpo do ouro, é, como o designei em outro lugar, o salto mortal da mercadoria.” (Marx, 1996:229, [L. 1, T. 1]) 
maneira como as relações de trabalho se reestruturam nas diferentes regiões do Império e depois na República Velha guarda particularidades fundamentais. Na região das Lavras Baianas, por exemplo, o trabalho do escravo não coincidia necessariamente com o trabalho cativo, registros como o do romance de Lindolfo Rocha, Maria Dusá (1969), dão conta da existência comum de escravos de ganho trabalhando inclusive como garimpeiros. Além disso, dois outros pontos parecem importantes de serem mencionados para uma aproximação aos “coloridos” que marcam a região em estudo.

O primeiro deles diz respeito à influência da conjuntura econômica da região das Lavras Baianas em relação à província da Bahia e em relação ao restante do território econômico imperial, sobretudo à região do café, esta última em franca expansão para o interior paulista. A convivência do trabalho escravo com o trabalho livre diz respeito à crise da economia açucareira e pecuária-algodoeira no nordeste, o que possivelmente condicionou a existência de um fluxo de capital, na forma de trabalhadores cativos, em direção às lavras no contexto do mercado nordestino de escravos. Ao mesmo tempo, na escala do território imperial, o movimento desse mercado interno de escravos aquecido pela Bill Aberdeen descrevia um sentido norte-sul, ou seja, a dinamicidade do dito ciclo do café fazia afluir para a região escravos das lavouras decadentes do nordeste ${ }^{16}$. Desta maneira a região das Lavras Baianas parece se situar em um entremeio, surge como possibilidade de investimento aos proprietários de escravos das regiões adjacentes, ao que corrobora as narrativas de disputas pelo domínio político-econômico da região entre serranos e mandiocas ${ }^{17}$; mas, enquanto polo de atração de capital, sofre a concorrência da futura região hegemônica ${ }^{18}$.

16 "Ao crescer a procura de escravos no sul para as plantações de café intensifica-se o tráfico interno em prejuízo das regiões que já estavam operando com rentabilidade reduzida." (Furtado, 1979:119)

17 "Configura-se um enfrentamento entre os grupos do Alto Sertão, serranos, e grupos do litoral, mandiocas; os primeiros ligados às atividades de mineração, os últimos vindos de regiões agrícolas" (Toledo, 2008:23)

18 Segundo cálculo proposto pelo GTEP/CPE (Falcón \& Dutra, 1978) - a partir das “Propostas e Relatórios apresentados a Assembleia Geral Legislativa pelos Ministros e Secretários de Estado dos Negócios da Fazenda, Rio de Janeiro, 1852-88" e da "Falla dos Presidentes da Província da Bahia, 1851-89) - o diamante figura entre os cinco principais produtos de exportação da província da Bahia entre os anos de 1850 e 1878, entre os anos de 1850 e 1865 figura entre os três principais produtos, perdendo apenas para o açúcar e para o fumo, e ultrapassando produtos importantes da economia do sertão baiano como o algodão, couros e peles. Durante essa década e meia de fulgor os diamantes foram responsáveis por $10 \%$, em média, das exportações da província, tendo seu auge no ano fiscal de 1855/56, quando contribui com 15,20\% das receitas. Já em termos nacionais sua participação é bastante mais modesta, ainda que no mesmo período (1850-65) tenha mantido uma participação média próxima aos $3,4 \%$, com pico de $5,3 \%$. 
Por outro lado, existe um conjunto de fatores internos à região que deve corroborar para a existência paralela do trabalhador escravo com trabalhadores livres, estes últimos inclusive, submetidos a relações de trabalho também diversificadas. Parte desses fatores diz respeito à própria atividade do garimpo de diamantes, e da forma como ela foi desenvolvida na região das Lavras Baianas. Não é raro que o garimpo seja comparado com um jogo de azar devido às incertezas produtivas da atividade, o que, na região em questão, se exacerba em decorrência da exiguidade técnica da forma como a extração era realizada e das características geológicas em que lá se encontram os diamantes; tratam-se de depósitos de aluvião, resultantes da erosão da rocha matriz ao longo de milhões de anos e que se apresentam relativamente dispersos ${ }^{19}$. Mesmo os depósitos de aluvião resultam em situações muito variadas em que se encontra o cascalho, a camada de sedimentos onde estão os diamantes. Disso decorre uma série de formas a partir das quais o trabalho poderia ser desenvolvido nas lavras diamantinas. Ao que se soma uma sazonalidade relacionada ao período de chuvas, que viabilizavam certos trabalhos em áreas secas, ao mesmo tempo que impediam trabalhos em áreas alagáveis ${ }^{20}$.

Esse conjunto de fatores acabava por influir no tipo de relação de trabalho que se desenvolvia em cada caso. Por isso, de modo geral,

“[...] definiram-se dois tipos de organização para a exploração das minas. Quando as jazidas tinham alguma importância, quando a produção era abundante, surgiam as lavras, espécies de empresas onde trabalhavam uma mão-de-obra composta por escravos (mais comumente) e homens livres (excepcionalmente). Essas empresas dispunham de aparelhamento especializado e tinham uma direção central. Por outro lado, quando as

19 O outro tipo de mina de diamantes é o kimberlito, o veio vertical da rocha mãe em que os diamantes ascendem à crosta terrestre, esse tipo de depósito é muito mais rico e concentrado que o depósito de aluvião.

20 O livro de Herberto Sales, Cascalho, importante romance regionalista de 1944 que retrata a Andaraí da década de 1920, começa da seguinte forma: "Do céu escuro, com armação que houve de uma hora para outra, as águas caíram de uma vez nas cabeceiras distantes. E inundando talhados, catas e grunas, carregaram pela noite a dentro os paióis de cascalho. No povoado da Passagem, à margem do rio Paraguaçu agora de monte a monte, rajadas de vento cortavam de alto a baixo as ruas ermas, quando os garimpeiros, em lúgubre vozerio, irromperam pela praça alagada com enxurradas descendo para o areão. Vinham encharcados de chuva, transportando como destroços suas bateias, seus carumbés, suas enxadas, seus frincheiros, suas alavancas, seus ralos, suas brocas - suas ferramentas de trabalho, no ombro e na cabeça. [...] Como o ruído da chuva fosse ensurdecedor, o velho Justino teve de gritar: As águas tomaram o serviço todo!" (Sales, 1951:15). Já em seu Garimpos da Bahia, monografia do tema de 1955, o mesmo autor elenca quinze "espécies de serviço mais comuns" (grupiara, monchão, montoeira, restinga, talhado, canalão, faisqueira, cata, cata-de-barranco, cateação-derebaixo, cascalhão, barranco, gruna, mergulho, lancheio). Nesse mesmo trabalho Sales divide os garimpos em "trabalho a seco" e "trabalho com água". 
dificuldades se avolumavam, quando a produção se tornava limitada, surgiam, com mais frequência, as faiscações, isto é, as explorações individuais e nômades. Os faiscadores podiam estar reunidos no mesmo ponto, porém, cada qual trabalhando individualmente e por conta própria, com instrumentos rudimentares. Estas faiscações sempre existiam, mas se generalizavam na decadência da mineração.” (Machado Neto \& Braga, 1974: 117, apud Toledo, 2008:107)

É importante salientar que o trabalho escravo não estava nesse contexto vinculado ao arcaico, como pode parecer para a consciência contemporânea. Ao contrário disso, o trabalho escravo está relacionado as minas mais ricas e produtivas, as quais eram exploradas pelos capitais mais opulentos daquele contexto. Tanto foi assim que o fim do trabalho escravo nas lavras precede a própria abolição da escravidão e está vinculado a grave crise enfrentada pelos produtores de diamantes no Brasil, como se verá a seguir. 


\section{CRISE: NOVAS RELAÇÕES E} UMA OUTRA REGIÃO

Na teia dos interesses e relações que dizem respeito a região estudada uma questão de primeira ordem ainda não foi tratada nesta espécie de breviário, trata-se do lugar do capital comercial para fora da região. O diamante, enquanto mercadoria, somente se realizava na Europa. Isso significa dizer que, para além da região, as pedras percorriam o circuito comercial que lhes condizia, sendo neste circuito formados os preços que, depreciados a cada agente, chegavam na região como imposição externa. Desta maneira, apesar de o Brasil ocupar o lugar de principal produtor de diamantes no mundo até o final da década de 1860, os preços praticados se adequavam a uma rede que tinha como centros de decisão as praças europeias: Londres, Paris, Amsterdã, Antuérpia, Liverpool, Southamptom, Hamburgo, etc. Trata-se de uma das formas de permanência do sentido da colonização, mas também revela uma característica fundamental da produção de diamantes na região das Lavras Baianas: o capital regional se adequava com relativa facilidade as oscilações dos preços de monopólio estabelecidos no exterior pelo capital comercial porque, além do baixíssimo investimento em capital constante, a força de trabalho regional se reproduzia de maneira relativamente independente do acesso aos itens mercantis trocados por dinheiro. Quer dizer, na produção da região das Lavras Baianas não estava formado o tempo abstrato.

A condição de produtora da mercadoria diamante para o mercado estrangeiro, da mesma forma que constitui a base da riqueza da região das Lavras Baianas, foi também o chão que lhe faltou quando uma concorrente significativamente mais produtiva surgiu no mercado internacional. Por volta do ano de 1870 é descoberta a mina de Kimberley, fazendo em pouco tempo do Cabo o principal produtor mundial das pedras. Sobre os efeitos desta descoberta sobre a região temos a impressão do Coronel Durval Vieira de Aguiar:

"Até os fins de 1871 as Lavras floresceram de maneira espantosa. Uma grande affluencia de immigrantes atulhava a cidade e todos os demais pontos commerciaes espalhados no termo, especulando cada qual com bons resultados no genero de negocio que escolhia. [...] Com a descoberta dos diamantes no Cabo da Boa Esperança baixaram na Europa os preços a ponto de repentinamente quebrar o commercio inteiro das Lavras, ficando reduzidos à miseria os negociantes, quasi todos capangueiros, e que empregavam nesse gyro todo capital de que dispunham. Foi um completo desastre que affectou não só a praça da Bahia, como a todos os termos vizinhos, que mais ou menos, se alimentavam da influencia do diamante. Dez annos depois passámos nas Lavras, e em logar da riqueza, actividade e 
do grande movimento commercial encontramos a pobreza, a escassez e o desanimo. Os garimpeiros que ainda teimavam mal ganhavam para comer.” (Aguiar, 1979:136-137)

Em verdade, a exploração de diamantes estava longe de acabar na região das Lavras Baianas, o que a grave crise acabou por resultar foi a impossibilidade da manutenção das relações de produção na forma como se davam até então na região. Quer dizer, a concorrência de uma produção significativamente mais produtiva ${ }^{21}$ não leva a região à falência, e isso somente pode ocorrer justamente porque a força de trabalho existia de forma relativamente independente de ganhos monetários salariais, do contrário sucumbiria na crise. Nos termos aqui assumidos, passa a se formar uma nova região a partir deste momento. O novo contexto internacional faz da região das Lavras Baianas uma possibilidade menos atrativa ao investimento de capital, de modo que a exploração passa a se dar a partir de novos critérios de “dificuldade”, ou seja, possivelmente terrenos que antes seriam destinados a empreitadas que utilizariam trabalho escravo cada vez menos, lançavam mão dessa forma de trabalho pois

\begin{abstract}
"A partir da década de 70, o contexto é de decadência. Este fato tende a significar uma redução na atração de escravos, até a abolição. Com relação aos trabalhadores livres, garimpeiros ou faiscadores, estes buscam frentes de trabalho para explorar. Se elas não estão acessíveis por serem propriedades privadas, a produção não ocorre. Nessa situação de crise, os termos da dificuldade de trabalhar uma área, acima discutidos, têm seu parâmetro alterado. O que implicou numa mudança do caráter da restrição do acesso do garimpeiro à terra.” (Toledo, 2008:109)
\end{abstract}

Uma questão chama atenção acerca das mudanças das relações de produção nas Lavras Baianas, é difícil precisar quais eram as formas do trabalho livre no período que precede a crise, elas aparecem nas narrativas sobretudo como oposição ao trabalho escravo, mas pouco esmiuçadas nas fontes disponíveis, diferente do período que sucede a crise, especialmente já nas primeiras décadas do século XX. Sobre tal questão o depoimento de Esmeraldo José Pereira parece exemplar:

"Há muitos anos passados - não é do meu tempo - não existia essa modalidade de meia-praça. Os garimpeiros ou trabalhavam por conta, com fornecimento próprio, ou então alugados na diária, sem ter nada com a produção. Então veio praqui o Sr. João Viana, que criou essa modalidade de

21 Além da condição física da mina, um grande veio de kimberlito - daí o nome da rocha -, o uso de maquinário sofisticado, se comparado àquele empregado no Brasil, ficam evidenciados nos registros fotográficos da época. 
meia-praça. Muito garimpeiro ficava trabalhando alugado a vida toda, né? Ele então criou essa modalidade de meia-praça que tinha a finalidade de beneficiar mais o garimpeiro.” (Falcón \& Dutra, 1978:109)

Trata-se de elucubração, mas não parece exagero supor que a gênese da relação de fornecimento na região das Lavras Baianas, a qual Esmeraldo imputa ao Sr. João Viana, antes tenha relação com uma adequação empreendida pelos proprietários da região no momento que já não podiam contar com o braço escravo, mercadoria cada vez mais cara no império e em vias de extinção.

É fundamental então tratar aqui, mesmo que sumariamente, das relações de trabalho livre existentes na região. O garimpeiro, salvo nos trabalhos em terras devolutas que tendem a ser menos ricas, deveria estabelecer um acordo de trabalho com um dono da terra. Esses acordos se davam de duas maneiras, citadas por Esmeraldo na passagem acima: O garimpeiro pode trabalhar como "alugado", nesse caso tratam-se de "garimpeiros pagos pelo trabalho diário, sem direito algum sobre o produto extraído” (Falcón \& Dutra, 1978:115). Enquanto a outra possibilidade que tem o garimpeiro é ser um “meia-praça”, nessa forma de acordo ele tem participação nos ganhos da empreitada, mas fica obrigado a pagar os “onos”, ou "quinto” ao proprietário das terras, uma porcentagem do preço da venda dos diamantes encontrados. É importante destacar que a opção pelo trabalho do alugado normalmente quer dizer que o serviço é entendido pelo proprietário como mais rico, de modo que a escolha pela imobilização de capital na forma de pagamento do diarista está resguardada pela certeza do ganho futuro, o qual não interessa ao proprietário dividir com um meia-praça. Do ponto de vista dos garimpeiros o trabalho de alugado é entendido como segunda opção em relação à meia-praça, já que os rendimentos da diária praticados eram muito baixos.

Fica clara a maneira como as diferentes relações de trabalho são mobilizadas pelo proprietário também de acordo com a oferta de trabalho neste trecho do romance Cascalho, de Herberto Sales:

“[...] ao ver avolumar-se o número de garimpeiros que lhe pediam trabalho, garimpeiros que se reuniam defronte da casa, espalhados pela calçada, debruçados nas janelas, comprimindo-se num grande ajuntamento de gente necessitada, ele ia restringindo aos poucos as colocações de meias-praças, ao constituir as sociedades. Naquele ano, quando Salu lhe apareceu, foi logo dizendo ao garimpeiro:

- Você vai ganhar dois mil e quinhentos por dia, Salu. Sei que você é bom de serviço.

- Quer dizer que eu entro como alugado? - respondeu o garimpeiro. 
- Oxente! Como é que você queria entrar? Como meia-praça? Já não tem mais lugar pra meia-praça.

- Eu tenho oito filhos, coronel - alegou Salu.

- E o que é que eu tenho com isso? [...]

Salu lembrou-se da advertência da mulher: "Se arrume por lá de qualquer maneira, porque senão seus filhos vão pedir esmola.” (Sales, 1951:20)

O trecho acima revela uma situação em que o capitalista/proprietário de terras diante da oferta abundante de mão de obra, uma superpopulação relativa circunstancial, opta pelo trabalho assalariado, pois pôde rebaixar o preço da diária de forma conveniente em uma empreitada que prometia rendimentos futuros abundantes.

Além disso o trecho também pode ser um indicativo do papel da família na formação moral do trabalhador que se submete às condições de trabalho desfavoráveis. A formação do trabalho livre se faz em relação também com a formação da família, o que por vezes se entende como momentos autônomos do processo social, quando não naturalizadas cada qual enquanto instituições separadas, o que aqui se intenciona interpretar como relacionadas. A honra da família é elemento determinante na sociabilidade regional patriarcal. A família é o âmbito da responsabilidade do patriarca, se ele não dá conta da reprodução da família é sua a culpa, em outras palavras, ficam assim salvaguardadas da crítica sua condição de expropriado, bem como a própria moral do trabalho, enquanto é culpabilizado o indivíduo. Em relação, e fechando essa espécie de círculo das humilhações impostas pela instituição familiar, na esfera privada de sua existência, a mulher, como responsável pelas atividades reprodutivas da força de trabalho do marido e da família, encontra-se submetida à violência do patriarca ou a humilhação da necessidade de suprir suas faltas como provedor. Em verdade, na região os lugares estanques do homem trabalhador e da mulher dona de casa funcionam muito mais como parâmetros morais estruturantes inalcançáveis, antes justificando a violência latente e patente da relação familiar, do que propriamente uma realidade concreta. Abundam as narrativas de mulheres que sustentam suas famílias através da prestação de serviços domésticos, lavando roupa, cortando lenha, cozinhando, transportando água, cuidando de crianças, etc. a serviço das famílias proprietárias, ou ainda se reproduzindo como objeto de consumo dos homens quando portadores de dinheiro, como prostitutas.

Toledo (2008) chama atenção para a tensão característica da relação entre proprietário e garimpeiro, que de modo geral se conforma no choque entre a astúcia que marca a persona do garimpeiro, normalmente concretizada na forma do furto possível pelas particularidades da própria atividade; e a violência que normalmente caracteriza a persona do proprietário, forma pela qual garante seus privilégios na relação. Relação essa que revela sua tensão latente em 
uma terceira persona, a do gerente de serra, homem de confiança do proprietário e que garante seus interesses no decurso da produção do diamante ${ }^{22}$. A violência exercida pelo gerente é a imposição da ordem em uma relação de trabalho na qual há pouquíssimo capital adiantado e se dá como simples extração de mais produto. Trata-se de garantir o controle do dono da terra, não de uma fiscalização racional do processo de trabalho. O nexo entre violência econômica e violência extraeconômica ${ }^{23}$ assim se apresenta: o proprietário se autonomiza do processo de trabalho apenas a partir da formação da sociedade com o garimpeiro, mas não sem a tensão da desconfiança, resultado da impossibilidade de fixação prévia de uma estimativa de produção, conformando assim a forma regional da acumulação ${ }^{24}$.

Mas Esmeraldo comenta a criação de “uma nova modalidade” de relação de trabalho, a "meia-praça", que livrou o garimpeiro de ficar "trabalhando alugado a vida toda". O fornecimento ao qual se refere e que também é conhecido na região como "saco" 25 , é a cesta básica do garimpeiro, por vezes acrescida das ferramentas de trabalho. Na sociedade firmada

22 Para além do processo produtivo, o jagunço, esse homem armado a serviço dos proprietários, tem lugar central da dinâmica social dos sertões nas disputas fundiárias. A forma da sua reprodução e sua moral compõem um tema a parte.

23 Marx emprega o termo quando está tratando do caso da acumulação primitiva inglesa em " $O$ Capital": "Violência extraeconômica direta é ainda, é verdade, empregada, mas apenas excepcionalmente. Para o curso usual das coisas, o trabalhador pode ser confiado às "leis naturais da produção", isto é, à sua dependência do capital que se origina das próprias condições de produção, e por elas é garantida e perpetuada. Outro era o caso durante a gênese histórica da produção capitalista. A burguesia nascente precisa e emprega a força do Estado para "regular" o salário, isto é, para comprimi-lo dentro dos limites convenientes e manter o próprio trabalhador num grau normal de dependência. Esse é um momento essencial da assim chamada acumulação primitiva.” (Marx, 1996:359)

24 "Nas lavras o assassinato sempre foi coisa muito natural; porém o furto ou o roubo sempre foi o maior dos crimes." (Aguiar, 1979:143).

25 'Dá-se o nome de 'saco' à provisão semanal de víveres do garimpeiro, custeada ou não pelo fornecedor, pois há casos, em bora raros, em que o garimpeiro trabalha por conta própria. $O$ saco é comumente constituído do seguinte:

1 quilo de carne

1 quilo de toucinho

1 litro de feijão

1 litro de arroz

6 litros de farinha

$1 / 2$ libra de café

Rapadura

Temperos (sal, pimenta-do-reino e cominho)

Gás (querosene)

Fumo

[...] O fornecimento do saco pode ser feito mediante a entrega, ao garimpeiro, do dinheiro respectivo, ou por autorização, em vale assinado pelo fornecedor, destinada a determinada venda ou armazém. [...] realizando suas compras por meio de vales do fornecedor [...] o garimpeiro vê diminuída a capacidade aquisitiva da sua verba semanal.” (Sales, 1955:36-37) 
através do fornecimento, o garimpeiro garante metade da sua produção em troca do adiantamento do saco, do qual necessita para passar a semana de trabalho na serra, além de ser a forma de garantir a subsistência também de sua família. O saco pode ser feito na feira, sem crédito e mais barato, trata-se da opção do garimpeiro autônomo. Mas pode também ser feito no armazém, onde é mais caro, é a opção dos garimpeiros fornecidos. Vale destacar que como relação de crédito, o fornecimento não é adiantamento de dinheiro livre para o consumo, este somente surge na relação após o achamento do diamante, até então o crédito existe, na maior parte das vezes, apenas na forma de comida.

Ser dono de barracão interessa ao fornecedor. Por vezes o mesmo indivíduo é o proprietário da terra, do barracão e fornecedor, assim a manipulação da relação com o garimpeiro é mais efetiva. No caso de figuras autonomizadas na relação de fornecimento, tanto garimpeiro como fornecedor são devedores do armazém. Na região das Lavras Baianas o comércio é parte central da acumulação: forma da violência econômica a qual o garimpeiro tem que se submeter. O fornecimento é momento da manutenção do capital, é, portanto, mais um momento da expropriação do garimpeiro.

Existem ainda outras formas de relação como variações menos usuais da meia-praça, como é o caso do

\footnotetext{
“[...] 'quarto até salvar', que implicava a quase completa dependência do garimpeiro ou faiscador do seu 'sócio'. Este lhe financiava certa quantia, que só seria saldada quando um quarto do valor da pedra encontrada cobrisse totalmente o empréstimo feito; caso contrário, o 'sócio' financista teria direito ao seu quarto, sem ter a obrigação de descontar nada do débito. Existiu dentro do mesmo sistema, na região da Lavras, a figura do 'meiapraça até salvar'.” (Falcón \& Dutra, 1978:115)
}

Para além das relações entre proprietários, garimpeiros, fornecedores e gerentes, existe a relação dos pares entre si. Vale destacar que a desconfiança da relação do proprietário com o garimpeiro se estende também à relação entre garimpeiros, decorrendo também daí a violência explicita que marca a região. Dificilmente um serviço é tocado por um garimpeiro solitário, e era comum a associação do trabalho de meia-praças junto com alugados em serviços de maior vulto. Da sociedade entre garimpeiros o valor da pedra, depois de feitos os descontos do quinto e do fornecimento, é divido igualmente. Numa sociedade de garimpeiros normalmente existe um "frente de serviço", garimpeiro mais experiente do grupo. Um bom frente de serviço gozava de maior crédito no fornecimento e acessava serviços possivelmente mais ricos. 
Garimpada a pedra resta ao garimpeiro a vendagem do diamante. Não se trata de momento menos importante, ou simples realização da mercadoria, isso porque a região tem a marca da pessoalidade em todas suas relações, de modo que o comércio está longe de ser a relação entre vendedores e compradores anônimos. Por isso é na cidade, onde a vendagem se dá, em contraponto à serra como local do trabalho, que o processo da produção ganha sua feição pública, onde o bambúrrio ${ }^{26}$ de um garimpeiro torna-se notícia. Essa publicização é momento importante do controle das relações de trabalho, pois não se vende para qualquer um, não é raro que o proprietário de terras ou mesmo o fornecedor atrelem o acesso à terra ou o fornecimento do saco ao privilégio da compra dos diamantes encontrados em um determinado serviço, o que se consubstancia em mais um momento de expropriação do garimpeiro a partir da depreciação do preço da pedra. A venda é parte do controle porque, se um garimpeiro burla os acordos pré estabelecidos, escondendo uma pedra e vendendo-a para outro comprador a fim de receber melhor pagamento e "bater o quinto", o faz sabendo dos riscos que corre de ser descoberto por conta do seu consumo no comércio. Sobre tal caráter do comércio regional Toledo (2008) fornece um diálogo exemplar:

\begin{abstract}
"Certa vez, conversando com Guina, um dono de armazém em ChiqueChique do Igatú, ele me dizia que os garimpeiros ficavam devendo em seu armazém. No entanto, dizia Guina, não era motivo de preocupação, pois uma hora destas eles pegariam um diamante e ele cobraria a dívida. Ponderei que eles poderiam vender o diamante longe de seus olhos. Ele riu e disse: eu sempre sei se eles pegaram, garimpeiro bamburrado bebe cerveja, infusado, pinga.” (Toledo, 2008:132)
\end{abstract}

De qualquer forma existiam além dos “capangueiros” (os grandes compradores, por vezes também proprietários de terras) os chamados “mosquitadores"27, pequenos compradores que também abundavam nas lavras.

Outra importante característica que dá o tom da particularidade da região garimpeira de trabalho livre, é o que Sales (1955) chama de “índole do garimpeiro”, o autor aponta que

"Nada caracteriza mais o garimpeiro do que seu espírito de imprevidência. Tem ele uma verdadeira volúpia de gastar tudo o que ganha. E quanto mais tempo passar infusado (sem encontrar diamantes), mais incoercível se torna, ao bamburrar, a ânsia de esbanjamento.

26 Descoberta de pedras de maior valor, espécie de “fortuna” repentina.

27 Mosquito é o nome dado ao pequeno diamante, de pouco preço. 
[...] O garimpeiro é um tipo eminentemente citadino. Ao contrário do trabalhador da zona rural dos mesmos municípios lavristas, frequenta ele bilhares, cinema, cabarés, pratica esportes, como o futebol, integrando os times locais. Gosta de vestir-se bem, ou melhor, de ostentar luxo, sempre que possa.

[...] Essa prodigalidade do garimpeiro, como é natural, determinou sempre enorme afluxo de meretrizes às cidades lavristas.” (Sales, 1955:41-42)

Sobre tal índole Toledo (2008) argumenta que a forma do garimpeiro viver a riqueza, para além de uma certa mimese do consumo das elites, não pode ser interpretada como idêntica a forma como essas vivem a riqueza: quer dizer, é a diferença da riqueza vivida como fonte de rendimentos e a riqueza vivida como valor de uso. O dinheiro acessado no garimpo reproduzia o garimpeiro como trabalhador ao quitar suas dívidas na praça, dificilmente como poupança. O garimpeiro infusado se reproduz como trabalhador a partir de outros expedientes, muitos dos quais independem da relação monetária. A generosidade do garimpeiro bamburrado é um marco moral da sociabilidade da região, a admiração dos companheiros molda as relações regionais, assim como a violência direta ${ }^{28}$. Além disso a própria narrativa do garimpeiro imprevidente está marcada pelas lentes que filtram a desigualdade pressuposta da condição de expropriado em uma sociedade marcada pela violência direta, pela concentração da propriedade da terra e pela pessoalidade das relações.

A distinção da região lavrista em relação às regiões agropastoris, no que tange o padrão de consumo da classe trabalhadora, não deve ser tratada como banalidade. Isso porque uma análise da formação das relações de produção que abstrai o consumo, restringindo-se à produção entendida de forma estrita, perde o nexo da reprodução da força de trabalho e corre o risco de lidar com a questão como simples acesso a valores de uso, apagando as mediações da mercadoria e do dinheiro ou entendendo-as como contínuo histórico, distinguível somente do ponto de vista quantitativo ou circunscrevendo-se a uma crítica distributivista. No caso analisado, tal nexo se encontra em formação. O dinheiro e as mercadorias que o garimpeiro

28 Sobre a questão da violência Teodoro Sampaio registrou que "basta que se saiba que em dous annos de mineração deram-se para mais de cem assassinatos, pela maior parte impunes. A vida e a propriedade ficaram sem garantias." (Sampaio, 1905:200). Como fica evidente, Sampaio, ainda que revestido pela áurea da neutralidade científica, tem bem definida sua posição ao lado dos proprietários - inclusive, é nas sedes de fazendas e casas desses proprietários baianos que fica hospedado ao longo de sua pesquisa -, não tem dúvida alguma que a propriedade precede a violência, possivelmente acreditava que a propriedade também seja um dom da Providência, como os reservatórios naturais de água, que por sinal costumavam ter alguma relação com tais propriedades: "São verdadeiros dons da Providencia, e lição nem sempre aproveitada, estes reservatorios naturaes onde se occumulam as aguas do tempo de chuva, guardando-as de um anno para outro, n'uma região cujo problema economico mais grave é o abastecimento d'agua [...]" (Sampaio, 1905:152). 
acessa através da atividade que lhe identifica não correspondem, necessariamente, a sua reprodução e de sua família, como força de trabalho. Por um lado, não era raro que quando bamburrado o garimpeiro dissipasse festivamente (Toledo, 2008) o dinheiro adquirido, por outro, quando infusado, não perece completamente diante da impossibilidade de se reproduzir via mercado. Em outras palavras, tal rendimento está longe de ser trabalho necessário, nos termos de Marx (1996), o que significa dizer que o garimpeiro vive em uma condição de expropriação relativa, já que acessa meios de vida de outras maneiras. Disso decorre um fator particularizador da região: o garimpeiro bamburrado é um consumidor exemplarmente compulsivo, já quando enfusado sobrevive através do crédito do saco e de uma forma que podemos definir problematicamente, na falta de melhor expressão, como de economia natural $^{29}$, são duas faces de uma mesma persona.

29 Ainda que não se tenha folego para desdobrar a questão neste trabalho, parece importante ressaltar que o entendimento de "expedientes de sobrevivência" - os quais, como forma de consciência, estão longe de se restringirem a manutenção da vida biológica ou a uma questão de "cultura” - como "economia” merece atenção crítica. 


\section{POSTAIS DA SÉRIE “LAVRAS DIAMANTÍFERAS BAIANAS” DE RODOLPHE LINDEMANN ${ }^{30}$}

As informações sobre essa série de postais são fragmentadas e contradizentes entre si. Segundo Santana (2013), as imagens foram produzidas pelo fotógrafo francês, então residente em Salvador, Fréderic François Rodolphe Lindemann no ano de 1900. A autora afirma que este trabalho de Lindemann

“ [...] funcionava como uma verdadeira campanha de comunicação comercial, diretamente endereçada a dois grandes financistas europeus, Robert Oppenheim e Henri Samuel. Três anos antes, os dois haviam comandado, um estudo de terreno intitulado Rapport sur une visite aux Lavras Diamantinas ["Relatório sobre uma visita às Lavras Diamantinas"], que avaliava o potencial econômico da região. O texto atribui o baixo nível da produção "a abolição da escravatura, ao esgotamento dos garimpos superficiais e a extrema violência das lutas políticas internas”.” (Santana, 2013:02, tradução minha)

Segundo Santana (2013), os postais de Lindemann compunham uma campanha publicitária das Lavras Baianas a favor dos interesses de uma família proprietária de terras, com o intuito de atrair investidores para a região decadente no momento em que a concorrência inglesa no Cabo encontrava-se abalada pela guerra Anglo-Boers, que se deu entre os anos de 1899 e 1902. A relação entre os interessados na atração de capitais e Lindemann não está bem esclarecida. Já o relatório citado pela autora foi produzido pelo engenheiro civil de minas Henri Babinski em 1896, contratado por Oppenheim e Samuel para uma expedição de avaliação da região produtora de diamantes. De qualquer modo, Santana considera que

“[...] em resposta a esse quadro sombrio [da violência, precárias condições de exploração das jazidas da região, e escasseamento da força de trabalho por conta da abolição da escravidão], o homem de publicidade que é Rodolphe Lindemann se dedica, em suas imagens, a "demonstrar” que os exescravos continuam a participar da produção local de riquezas, que o emprego de um novo método de extração é exequível, e, sobretudo, que a região diamantífera está pacificada. Realiza esse intento por meio de uma reportagem fotográfica sobre a região, veiculada pelo suporte de maior visibilidade do momento: o cartão postal ilustrado.” (Santana, 2013:02) 
De fato, o cartão-postal era um dos veículos mais populares de circulação de imagens na virada do século XIX para o século XX. A grande maioria dos postais de então eram impressos na Europa, mesmo que representassem ex-colônias e colônias do além-mar. Segundo Teixeira e Linsker (2005), os postais de Lindemann sobre as Lavras Baianas foram impressos na França em 1906.

Um dos senões apontados por Babinski em seu relatório, além das limitações das técnicas empregadas nas Lavras Baianas para a extração das pedras preciosas e do esgotamento das jazidas superficiais, diz respeito justamente ao preço da "mão de obra", julgada cara pelo engenheiro francês. O registro de trabalhadores em ação ou posando em seus locais de trabalho conformam a representação da região como produtora de diamantes, bem como a indumentária reforça os lugares sociais ${ }^{31}$ dos garimpeiros e dos proprietários das terras que figuram nos postais.

Vale ainda destacar a apreciação feita por Santana dos postais de Lindemann sobre as Lavras Diamantinas em relação ao conjunto dos postais que representam o Brasil na época. Para a autora

"Ao contrário das cenas de progresso urbano com as quais o Brasil tentava se mostrar 'civilizado' para o exterior, as imagens da série Lavras Diamantíferas Baianas apostam em um idealismo bucólico e pré-industrial. Afinal, a matéria-prima que se anunciava brotava diretamente da natureza." (Santana, 2013:01)

Do ponto de vista dessa pesquisa, a ideia de que Lindemann intencionava produzir uma representação calcada no “idealismo bucólico" diz respeito à leitura feita por um olhar atual dos postais do autor sobre as Lavras Baianas. Ao que parece, seguindo a ideia de que os postais compunham uma peça publicitária, estava ali representada uma região naquilo que diz respeito a sua potencialidade econômica: as Lavras Baianas são representadas sobretudo como região produtora de diamantes, uma riqueza a ser explorada. Ainda que se possa atribuir um certo apelo ao exótico em alguns dos postais da série, estes mal se comparam, por exemplo, à série de postais de tipos negros da Bahia produzida pelo próprio fotógrafo em Salvador ${ }^{32}$. Sobre a autorrepresentação da região das Lavras Baianas vale lembrar que era justamente seu caráter de civilização que as famílias proprietárias costumavam propalar. Para ilustrar esta

31 Sobre as relações de produção que caracteriza a região das Lavras Baianas ver o item anaterior dessa dissertação, 5. Crise: novas relações e uma outra região. 
dissonância é notável o ponto de vista de Walfrido de Moraes, que em seu livro sobre o Cel. Horácio de Matos intitulado Jagunços e Heróis (1997) define as Lavras Baianas como “civilização do diamante”.

Ainda segundo Santana (2013), um homem registrado em um dos postais sem título de Lindemann seria Cezar Andrade de Sá, então prefeito de Lençóis, filho e herdeiro de Felisberto Sá, dono de uma das concessões descritas no relatório de Babinski. Seriam os Sá aqueles interessados na divulgação da Lavras Baianas como região produtora de diamantes e os contratantes dos serviços do fotógrafo? Ou o fotógrafo não foi contratado, tendo trabalhado por conta própria esperando rendimentos com a comercialização dos postais? Isso não está esclarecido e outras dúvidas podem ser levantadas sobre a produção da série.

A dificuldade de entender o contexto da produção dessa coleção de postais diz respeito às poucas informações sobre o próprio fotógrafo, seria o caso então de remontar as informações esparsas sobre Rodolphe Lindemann presentes de forma rarefeita em publicações variadas. Segundo Santos (2014) o fotógrafo francês teria nascido em Paris ${ }^{33}$, tendo chegado em Salvador em 1879, com 29 anos, ou seja, teria nascido em $1850^{34}$, onze anos depois de Louis Daguerre publicizar o daguerreótipo naquela capital. Santos menciona que muitos fotógrafos estrangeiros migraram da Europa tentando evitar a concorrência já estabelecida entre trabalhadores e empresários do ramo nas praças do velho continente, buscando a garantia de se reproduzirem como produtores de fotografias em outros locais ${ }^{35}$.

Em 1881 aparece um anúncio do estabelecimento comercial de Lindemann no “Almanak da Província da Bahia”, o estúdio estava localizado na Rua Direta do Palácio, área

33 Ainda que Santana (2013) e Santos (2014) apresentem Lindemann como francês, o trabalho do fotógrafo consta sem maiores detalhes, no livro de Pedro Karp Vasquez "Fotógrafos alemães no Brasil do século XIX” (2000), e também é apresentado como alemão no verbete de Sticker em seu "Uma pequena biblioteca particular - subsídios para o estudo da iconografia do Brasil” (2004). Já Maria Guimarães Sampaio relata que "sobre a nacionalidade/ascendência de Rodolphe Lindemann, Ricardo Mendes, baseado em registro de casamento (abril de 1888) de Lindemann, informa seu nascimento em Paris, filho de João Frederico Lindemann e Aimée Francisca Haquin. Segundo Cid Teixeira, Lindemann seria judeu austríaco. Por indicação de Lygia Sampaio, encontrei um Frederico Lindemann no Almanach de 1812 como cônsul da Gran Bretanha - uma terceira possível nacionalidade.” (Alves, 2006)

34 Para Santana (2013) Lindemann teria nascido em 1855, e aportado na Bahia no ano de 1876. Já no portal da Brasiliana Fotográfica (http://brasilianafotografica.bn.br/) consta que Lindemann teria nascido em 1852.

35 É notável que a concorrência muito provavelmente tenha também internamente mobilizado fotógrafos instalados nas principais cidades do Império e depois da República. Kossoy, por exemplo, menciona que Napoleão Bautz “manteve sua 'oficina' de daguerreotipia no Rio de Janeiro até cerca de 1853/54 quando então mudou-se para Salvador, local onde encontrou poucos retratistas como concorrentes.” (Kossoy, 1980:29, apud Alves, 2006:18) 
de comércio considerada "elegante” na Salvador de então. Por volta de 1888, firma sociedade com Guilherme Gaensly, constituindo a Photographia Gaensly \& Lindemann, antes disso Lindemann teria sido assistente de Gaensly, possivelmente desde $1882^{36}$. Lindemann, além de fotógrafo, era também pintor e possivelmente tenha sido o "habil artista francez" que retoca “esplendidamente” os retratos feitos na Photographia Gaensly, segundo anunciado no Almanach do Diário de Notícias de 1884 (Alves, 2006:33).

Lindemann foi um dos poucos fotógrafos que deixou panoramas da cidade de Salvador no final do século XIX, em 1889 uma série de seus clichês compuseram o “Album de Vues du Brésil "37.

Em 1894 Lindemann e Gaensly abrem uma filial paulistana a partir da qual Gaensly tornar-se-á o fotógrafo encarregado pela documentação imagética da The São Paulo Tramway Light and Power Company de 1899 a 1925. Segundo o portal da Brasiliana Fotográfica (http://brasilianafotografica.bn.br/?p=7260) “Gaensly foi chefiar a sede paulista e Lindemann permaneceu em Salvador.[...] Tudo indica que a crescente concorrência em Salvador e a queda do desempenho da economia baiana devido à seca foram as causas da abertura do ateliê em São Paulo.”

Em 1900 (ano em que Lindemann teria produzido os postais da série "Lavras Diamantíferas Baianas”) os fotógrafos desfazem a sociedade, ficando Lindemann como proprietário do estúdio de Salvador. Kossoy se pergunta e responde: “Até quando teria o fotógrafo se mantido em atividade? O fato é que existem fotos de autoria de seu estabelecimento datadas de 1922.” (Kossoy, 2002:209). Já Santos (2014) dá conta de que o

36 "Embora usualmente se aponte o início da associação em 1882, é difícil precisar a aproximação entre os dois colaboradores. Lindemann parece ter desenvoltura própria na divulgação de sua produção. Registra-se sua participação nas mostras organizadas pela Academia de Belas Artes da Bahia em 1880, 1883 e 1885. Quatro anos depois recebe medalha de bronze na categoria Provas e aparelhos de fotografia, na Exposition Universelle de 1889, em Paris, com fotos da Bahia e Pernambuco. No mesmo ano, tem imagens inclusas em Álbuns de Vues du Brésil, anexo à segunda edição da obra Le Brésil, de E. Levasseur.” (Mendes, 2014:27/28)

37 “O barão do Rio Branco (1845-1912) foi o responsável pelo Album de vues du Brésil, considerada a última peça para a promoção do Brasil imperial, representando um resumo iconográfico do país e de suas riquezas. Nas palavras do barão, o álbum pretendia "mostrar a fisionomia atual das principais cidades do Brasil e seus arredores. Sob esse aspecto, a presente coleção é a mais completa publicada até hoje”. Trazia fotografias produzidas por Augusto Riedel (1836 -?), Joaquim Insley Pacheco (c.1830 - 1912), Marc Ferrez (1843 - 1923) e Rodolpho Lindemann (c. 1852 - 19?), dentre outros. Foi lançado em Paris na ocasião da Exposição Universal de 1889, ocorrida entre 6 de maio e 31 de outubro e fazia parte da segunda edição de Le Brésil, extrato da Grande Enciclopédia, trabalho dirigido pelo geógrafo Émile Levasseur (1828-1911), para o qual o barão havia colaborado." (http://brasilianafotografica.bn.br/?p=7462) 
fotógrafo “'dono e possuidor’ do estúdio de fotografia, Lindemann, volta a negociá-lo em 28 de fevereiro de 1906, desta vez definitivamente com José Dias da Costa por 4:000\#000 (quatro contos de réis)” (Santos, 2014:31), após a venda frustrada em 1904 para seu então sócio. Ainda segundo Santos, em 1908 o fotógrafo e sua esposa eram residentes na Ásia Menor.

Maria Guimarães Sampaio (Alves, 2006) também se questiona sobre a permanência de Lindemann em Salvador. Até quando teria dirigido a Photographia Lindemann? Mas além disso, a pesquisadora se interroga ainda:

“Como já referido, a qualidade de Lindemann não é a mesma de antes [se refere a fotografias produzidas no século XX]. A Sociedade com Gaensly foi desfeita em 19 de fevereiro 1900. Desse ano localizei, dentre outras, uma fotografia Gaensly-Lindemann originária de Amargosa, uma carte-de-visite Lindemann de Itabuna, uma carte-postale datada de 1912 vinda de Belmonte e, com data atribuída à década de 10, a carte-postale do Theatro São João, assinada Phot. Lindemann com "alta tiragem” pelo Magasin Loureiro Bahia e impresso no verso Bilhete Postal da Bahia - Para Coleção. Ao final dos anos 10 a entrar nos anos 20, é a vez dos postais fotográficos com ampla e visível variação de qualidade e de origem.

A partir de 1909, comprovadamente, de Lindemann apenas o nome do atelier agora pertencente a José Dias da Costa. Teriam vindo à Capital (de trem ou barco ou animal) tão díspares pessoas, ido ao atelier do photographo depois de habituais visitas aos parentes e amigos, voltado à sua cidade e, com todas dificuldades inerentes ao tempo, reenviado para a capital sua photographia em sinal de amizade? Será que, já velho, em 1900, Lindemann se deslocava ao interior? Seu sucessor se deslocaria? Teriam eles "prepostos" viajantes? Ou [...] o fotógrafo do interior usaria a marca Lindemann em troca da exclusividade nas compras de equipamentos e insumos, quem sabe uma participação nos lucros?” (Alves, 2006)

Neste sentido, teriam as fotografias da série "Lavras Diamantíferas Baianas” sido feitas realmente por Rodolphe Lindemann? Essa questão fica em aberto para a pesquisa. Em 1922 o estúdio que lhe pertencera, então propriedade de Dias da Costa e Diomedes Gramacho (Santos, 2014), queimou em um incêndio, destruindo os negativos do fotógrafo.

Esse breve apanhado de informações pode revelar o lugar social ocupado por Fréderic François Rodolphe Lindemann: trata-se de um dos fotógrafos estrangeiros da capital baiana em fins do século XIX e início do XX, e que "além do trabalho fotográfico, Lindemann mantinha atividade empresarial no ramo gráfico, executando serviços especializados de 'phototypia, photogravura, photogalvanoplastia'” (Kossoy, 2002:209). Assim como boa parte daqueles que então se dedicavam à atividade no Brasil, era europeu e possuía comércio em 
uma área "elegante” de Salvador, bem como "equipamentos fotográficos e tipográficos de tecnologia avançada” (Santana, 2013:). Como fotógrafo artesão e mobilizado pelo trabalho ${ }^{38}$, provavelmente tenha migrado para o Brasil fugindo da concorrência já estabelecida nas principais cidades europeias nas últimas décadas do século XIX, assim como a possível mudança para Ásia Menor também corresponda às estratégias pessoais do fotógrafo de inserção no mercado.

38 Ver nota de rodapé 9, pág. 24 desta dissertação. 


\section{FOTOGRAFIAS DO CÔNSUL ESTADUNIDENSE HENRY WATSON FURNISS ${ }^{39}$}

Em setembro de 1906 a revista estadunidense Popular Science publicava o artigo Diamonds and Carbons in Brazil ${ }^{40}$, de autoria de Henry Watson Furniss, médico negro estadunidense e cônsul em Salvador entre os anos de 1898 e 1905. Losch, no artigo Dr. Henry W. Furniss, cônsul afro-norte-americano na Bahia, 1898-1905 (2010), faz um apanhado da trajetória de Furniss, sobretudo do período em que este esteve no Brasil, demonstrando o empenho do então cônsul em atividades vinculadas com o cargo que assumira. O artigo destaca seu entusiasmo para com a ciência, tendo colaborado com uma série de pesquisadores, principalmente em questões relativas à medicina, mas não só. Losch revela que Furniss

“ [...] também era adepto da fotografia e ele mesmo revelava as fotos que tirava. Mandou para Washington vários relatórios, com fotos anexadas, e ainda escreveu duas matérias sobre as excursões que fez pela Bahia, amplamente ilustradas com imagens feitas por ele, que saíram no Boletim do Bureau das Repúblicas Americanas.” (Losch, 2010:230)

Ainda sobre a fotografia, destaca-se que Furniss “achou que os aparelhos fotográficos dos Estados Unidos seriam uma novidade bem-vinda no mercado [baiano], e que as várias escolas de missionários norte-americanos que estavam sendo abertas na região iriam precisar de um fornecedor de material” (Losch, 2010:232). As atividades científicas desenvolvidas por Furniss estavam longe de serem separadas de sua função de cônsul,

“ [...] alguns dos informes que ele preparava resumiam as notícias econômicas e políticas, ou comunicavam dicas práticas sobre os métodos comerciais na praça. Também enviava notícias de outras oportunidades para empresas norte-americanas, como avisos de licitações traduzidos para o inglês. A maioria dos informes tratava ou da demanda por determinado produto específico, que algum fabricante norte-americano queria vender, ou da oferta de alguma matéria-prima baiana que pudesse interessar aos importadores nos Estados Unidos. Muita informação Furniss conseguia em primeira mão, às vezes viajando para o interior. Descreve em detalhes o aproveitamento de vários recursos naturais, como os carbonatos da Chapada Diamantina, o manganês de Santo Antônio de Jesus, e a areia monazita, de Prado. Também informava sobre o cultivo da "borracha de maniçoba", em

39 As imagens encontram-se no Anexo B desta dissertação.

40 Disponível em: https://en.wikisource.org/wiki/PopularScience_Monthly/Volume_69/September _ 1906/Diamonds_and_Carbons_in_Brazil. 
Jequié, sobre os engenhos de açúcar em Sergipe, e sobre os vários tipos de indústrias que se tinham instalado em Salvador.” (Losch, 2010:231)

Quer dizer, as atividades de pesquisa de Furniss não eram entendidas por ele próprio como separadas de suas atribuições como cônsul, o sentido de tais atividades estava estreitamente vinculado aos interesses comerciais estadunidenses nas oportunidades que a Bahia poderia oferecer. As fotografias produzidas pelo cônsul possuem claro caráter documental, servindo de subsídio para suas pesquisas e para os relatórios que produzia como persona que representava comercialmente os EUA na Bahia. Mas, naquele país, acabam transformando-se também em ilustração para artigos de uma revista de conteúdo científico para o grande público, a Popular Science.

Furniss certamente esteve na região das Lavras Baianas realizando estudos em loco, “o geólogo Orville Derby, no seu artigo sobre a Chapada Diamantina, agradece a Furniss por ter servido de fotógrafo na sua expedição a essa região, em 1904” (Losch, 2010:234). Já em seu próprio artigo o então cônsul traça em poucas linhas uma história sumária da mineração de diamantes no Brasil, sobretudo o desdobrar espaço-temporal da atividade no estado da Bahia. Em seguida, trata da qualidade dos diamantes baianos; do carbonato, sua raridade e seu uso; além de fornecer uma síntese da situação geomorfológica em que os diamantes são encontrados no estado. Na sequência do artigo arrola informações de interesse para possíveis futuros investidores: o acesso às Lavras (quatro dias de viagem considerada simples para quem está acostumado a viajar, sobretudo em comparação à situação das áreas de mineração em Minas Gerais); número de proprietários em atividade ("não mais que meia dúzia”); mão de obra garimpeira (o fato de ser quase totalmente composta por negros ou mestiços, seus hábitos alimentares e consumo de bebidas alcoólicas, que considera pequena para uma região de mineração); moradia (cita as tocas construídas sob bordas de pedras salientes), a prática do crédito nos armazéns e consumo de itens caros, como a cerveja e comidas enlatadas, em decorrência do acesso temporário ao dinheiro; as más condições de saúde na região, em especial o caso da malária; as condições de trabalho precárias, exiguidade de materiais e técnicas empregados, inclusive estabelecendo uma comparação com a produtividade na África do Sul; menção às máquinas instaladas em Minas Gerais, Salobro e bombas de uma "companhia inglesa no Rio São José”, que também previa instalar uma pequena usina hidroelétrica. Explica que as terras diamantíferas são propriedade do Estado e são trabalhadas por concessões. Furniss encerra o artigo afirmando a potencialidade da 
exploração de diamantes e carbonatos na Bahia e a existência de áreas ainda por serem exploradas sob a condicionante de que se empregue o maquinário adequado.

O artigo é ilustrado por seis fotografias de autoria de Furniss: uma imagem do "maior carbonato já encontrado"; outra da "casa de um rico proprietário de mina”; uma terceira “da casa de mineiro” e outras três fotografias de garimpeiros trabalhando. Além destas, dois artigos do geólogo Orville Derby contam com imagens produzidas por Furniss, no The Serra do Espinhaço, Brazil ${ }^{41}$ consta uma fotografia da “Vista de Santa Isabel do Paraguassú”. Já no The Geology of the Diamond and Carbonado Washings of Bahia, Brazil ${ }^{42}$ quatro outras imagens de Furniss: “Garimpeiros concentrando cascalho com enxadas em valas de água”, “Concentração final e lavagem em bateias” (imagem que Furniss utiliza também em seu artigo para a Popular Science); "Um mergulhador nativo nu se preparando para ir para baixo, suspenso na corda é um tubo de transporte de ar para um homem em traje de mergulho já no fundo" e "Lençóis, construído no solo de rolamento de diamante”.

41 “The Serra do Espinhaço, Brazil”, Journal of Geology vol. XIV, número 5 (1906), p. 374.

42 "The Geology of the Diamond and Carbonado Washings of Bahia, Brazil” Annual Report of the Smithsonian Institution, 1906, Washington DC: Government Printing Office, 1907, p.218. 
ENSAIO I

Duas fotografias: a primeira (Figura 1) delas retrata a região das Lavras Baianas, trata-se de um cartão-postal do fotógrafo Fréderic François Rodolphe Lindemann provavelmente produzido em 1900. Nele se vê em primeiro plano um homem de perfil, ele aparenta meia idade, está elegante, vestindo terno e chapéu. Está em pé sobre um monte de cascalho, apoiado com a mão esquerda em um guarda-chuva, enquanto a direita, suspensa, segura um fragmento de rocha que mira fixamente, a cabeça levemente inclinada para baixo. Nem todas as pessoas para as quais esta imagem foi apresentada notaram a pedra que absorve a atenção do homem registrado na fotografia. Ainda no primeiro plano pode-se constatar a erosão da encosta provocada pela garimpagem de diamantes. Ao fundo uma bela paisagem: o leito do rio Lençóis corta a imagem do centro para a esquerda, sucedido por três planos de serras, a mais distante delas uma formação tabular que caracteriza a área. O postal traz a seguinte inscrição sobre o céu nebuloso e esbranquiçado: “Um admirador da natureza. Lençóis - Bahia”.

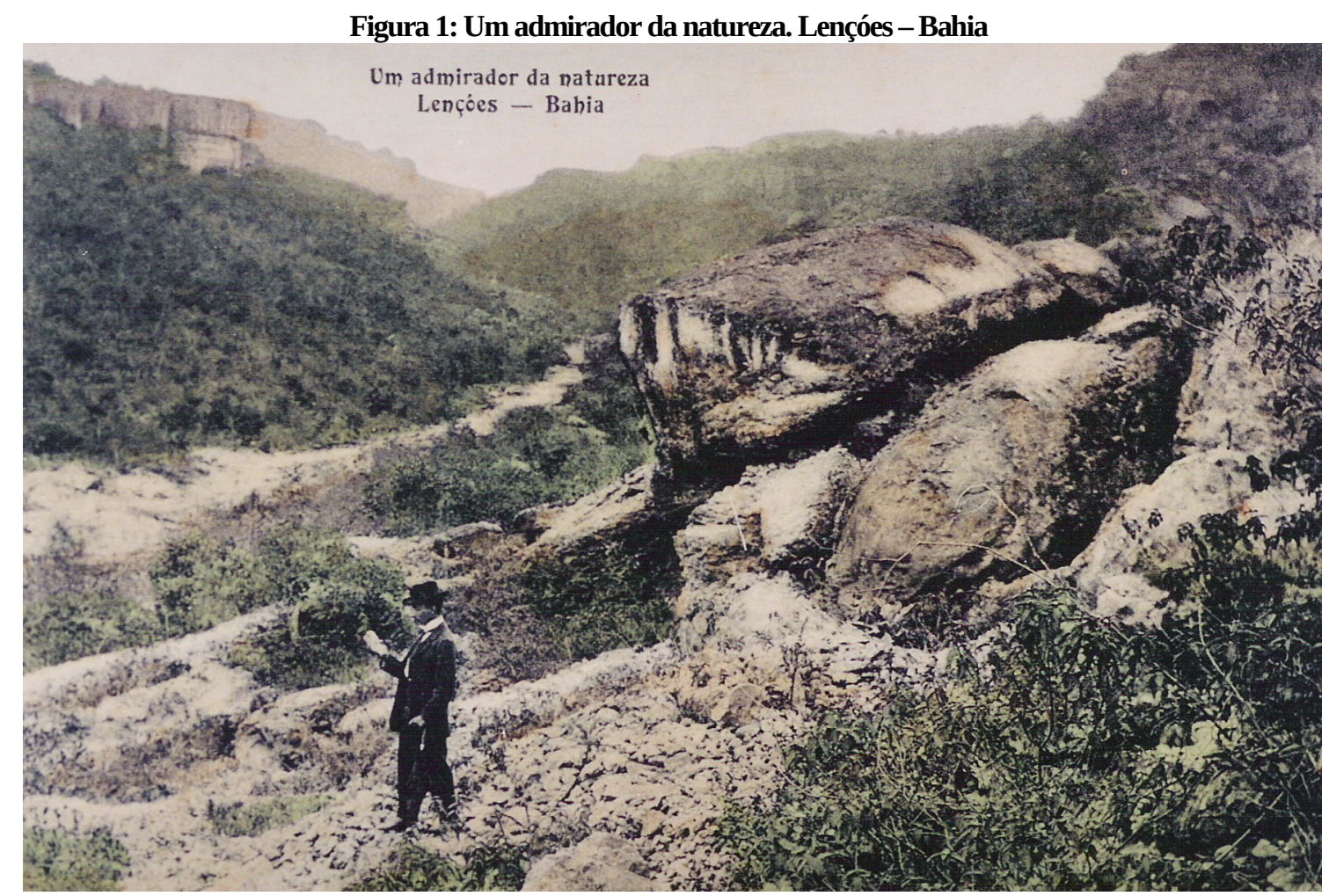

Fonte: Arquivo pessoal de Mestre Osvaldo.

A outra fotografia (Figura 2) é de autoria do fotógrafo Araquém Alcântara, capa do seu livro dedicado à Chapada Diamantina, publicado em 2007 (Alcântara, 2007). Nela se pode ver em primeiro plano a silhueta de uma pessoa, aparentemente um homem, sentado na beira do Poço Encantado localizado no município de Itaetê. A pessoa sentada observa o facho de luz 
que atravessa a água azul do poço, o reflexo da luz nas rochas submersas filtrado pelo azul e o fundo pedregoso do poço também colorido pela água.

Figura 2: Poço Encantado - Itaetê

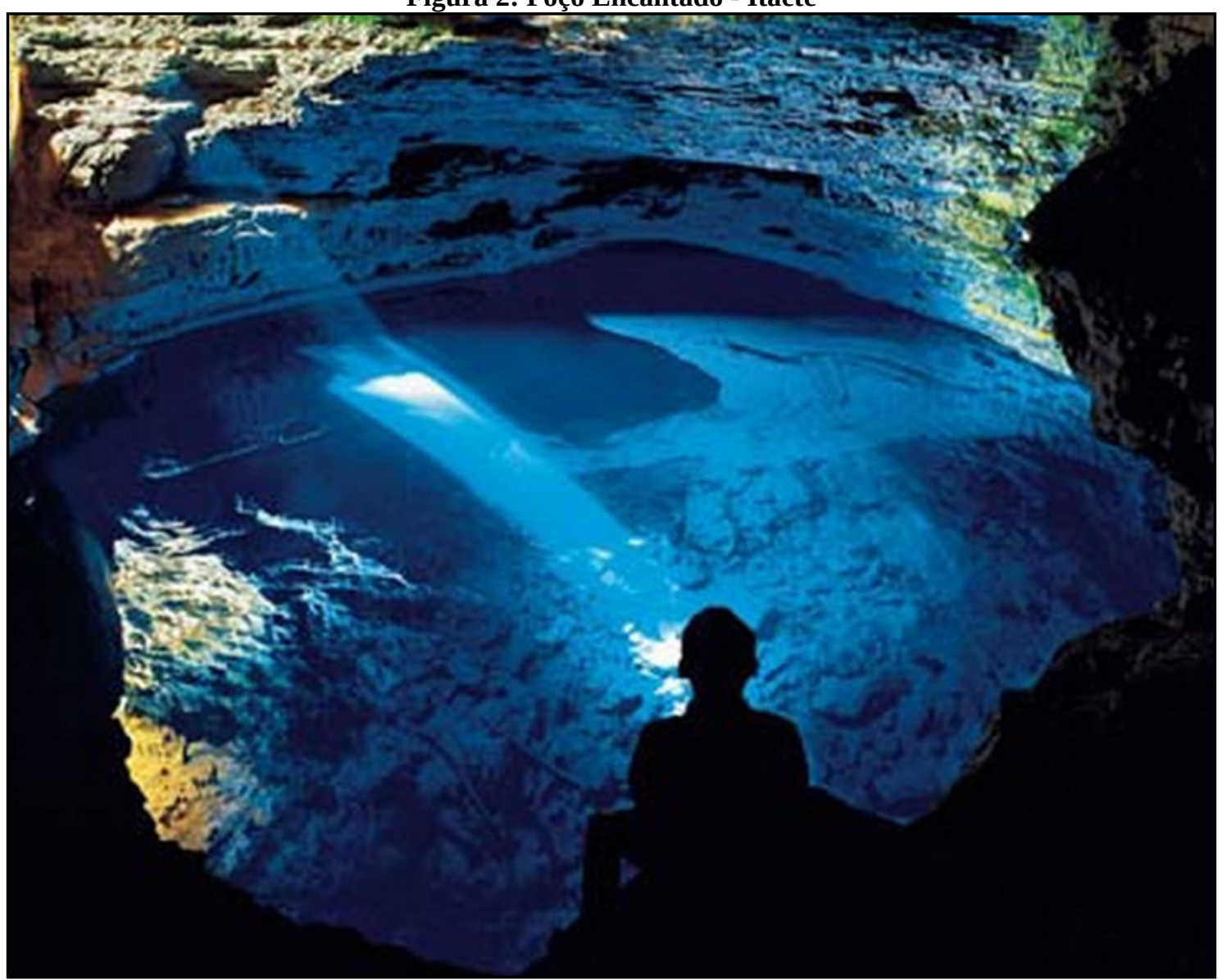

Fonte: Alcântara (2007).

Ironicamente, esta segunda fotografia também poderia ter como legenda a frase: “Um admirador da natureza”. No entanto, é de se ponderar que a comparação das duas imagens e a contextualização histórica da produção de cada uma delas revelam diferenças abissais entre aquilo que está entendido como natureza nos registros de Lindemann e de Alcântara. Quer dizer, tal comparação pode revelar a existência de formas de pensar a natureza distintas em cada um deles, o que revelaria momentos distintos da forma da mediação social. As representações de observadores da natureza tão diferentes podem ser indícios de que a natureza não é a mesma nos dois momentos registrados, sendo, portanto, também diferentes os motivos que mobilizaram os fotógrafos em cada um dos casos. Mas também, o simples enunciado de um observador que contempla a natureza diz respeito à constituição de uma forma de consciência fundamentalmente moderna, o que não significa dizer que as categorias que emanam da relação sujeito-objeto tenham sido simplesmente descobertas na 
Modernidade, mas que são sim condição e resultado da mesma, daí seu sentido sociohistórico. A aproximação das imagens a partir da existência em comum da representação da natureza e de observadores dela extrapola a condição de simples termos de aproximação, são índices que demarcam historicamente uma forma de pensamento.

Esse caráter histórico da relação aparece de forma especialmente evidente no enunciado da categoria paisagem. Para a paisagem não se produziu a hegemonia de um consenso trans-histórico da mesma maneira como para outras categorias, tais como o trabalho, por exemplo. Pelo contrário, parece ser mais ou menos acordado entre historiadores da arte e filósofos o caráter histórico da paisagem. Já entre os geógrafos esse caráter histórico da paisagem nem sempre é considerado, ou então, é posto na chave interpretativa de uma história da relação entre homem e natureza indiferente à forma histórica da mediação social. A paisagem, mais do que um objeto, é uma forma de consciência coerente à formação do indivíduo no âmbito da generalização da abstração monetária como forma de mediação social. Por isso, como forma de consciência, a paisagem acompanha as transformações internas da forma do dinheiro na história da modernização. O que implica dizer que o dinheiro não corresponde sempre à mesma relação, tanto externa, quanto internamente à história do capitalismo (Kurz, 2014). Nesse sentido, é possível afirmar também que não existia paisagem onde hoje é a Chapada Diamantina até pouco mais de cinco séculos atrás.

Retornando as imagens em questão: a natureza a ser admirada no postal de Lindemann é aquela provedora de diamantes, corresponde às relações da sociedade lavrista que passa a ser formada na área em meados do decênio de 1840 e se prolonga ao início do século XX, quando foram produzidas as fotografias. Seu admirador tem o olhar perscrutador dos indícios da existência de diamantes, cuja extração é a atividade econômica que identifica a região. Tal observador da natureza, julgando vantajosa a empreitada e possuindo as condições materiais para tanto, não titubearia em lavar um trecho de serra em busca das pedras preciosas. É possível que o observador registrado por Lindemann não tirasse, ele mesmo, os diamantes da, assim entendida, natureza, já que, a julgar pela sua vestimenta, deva se tratar de um proprietário que se vale do trabalho alheio para acessar a riqueza diamante. Sua vestimenta no postal é um indício do lugar social que ocupa, mas a possibilidade de ser aquele homem realmente um proprietário não passa de uma especulação desta pesquisa, afinal, a fotografia não passa de uma representação. Ainda assim, o olhar lançado para a natureza é, neste caso, aquele para o qual derrubar a vegetação, subtrair o solo até encontrar um veio de cascalho, desagregá-lo e selecioná-lo em busca de diamantes, são atividades reconhecidas como normais. A natureza, portanto, é aquela provedora da riqueza mineral diamante, riqueza 
mineral igualável ao dinheiro. Mas é também a natureza que impõe dificuldades e precisa ser dominada. Por isso as fotografias de Lindemann em geral, parecem sugerir a potência da sociedade lavrista no domínio de uma natureza provedora de diamantes, mas, ao mesmo tempo, ameaçadora. Neste sentido que esta natureza é admirável.

Outro cartão-postal de Lindemann (Figura 3) reforça a sugestão anterior. Nele se vêem representadas apenas duas grandes pedras e alguma vegetação no entorno, a fotografia pouco nítida foi retocada pelo fotógrafo, que deu destaque para a textura laminar da rocha de origem sedimentar da área. Poderíamos imaginar que a intenção de Lindemann ao produzir tal imagem fosse simplesmente registrar a paisagem aprazível, ou desafiadora, dada a imponência das pedras. Talvez fosse, mas o título do postal coloca em dúvida tal interpretação. Aquelas não são pedras quaisquer, são "Pedras no Garimpo Estrella do Céo. Lençóis - Bahia”, nos alerta o letreiro do postal. Ainda que não se perceba indício algum de atividade de mineração na imagem, o texto insiste na alusão ao garimpo. Afinal de contas, qual seria o sentido de produzir um postal de duas rochas formando um belo cenário?

\section{Figura 3: Pedras no Garimpo Estrella do Céo. Lençóes - Bahia}

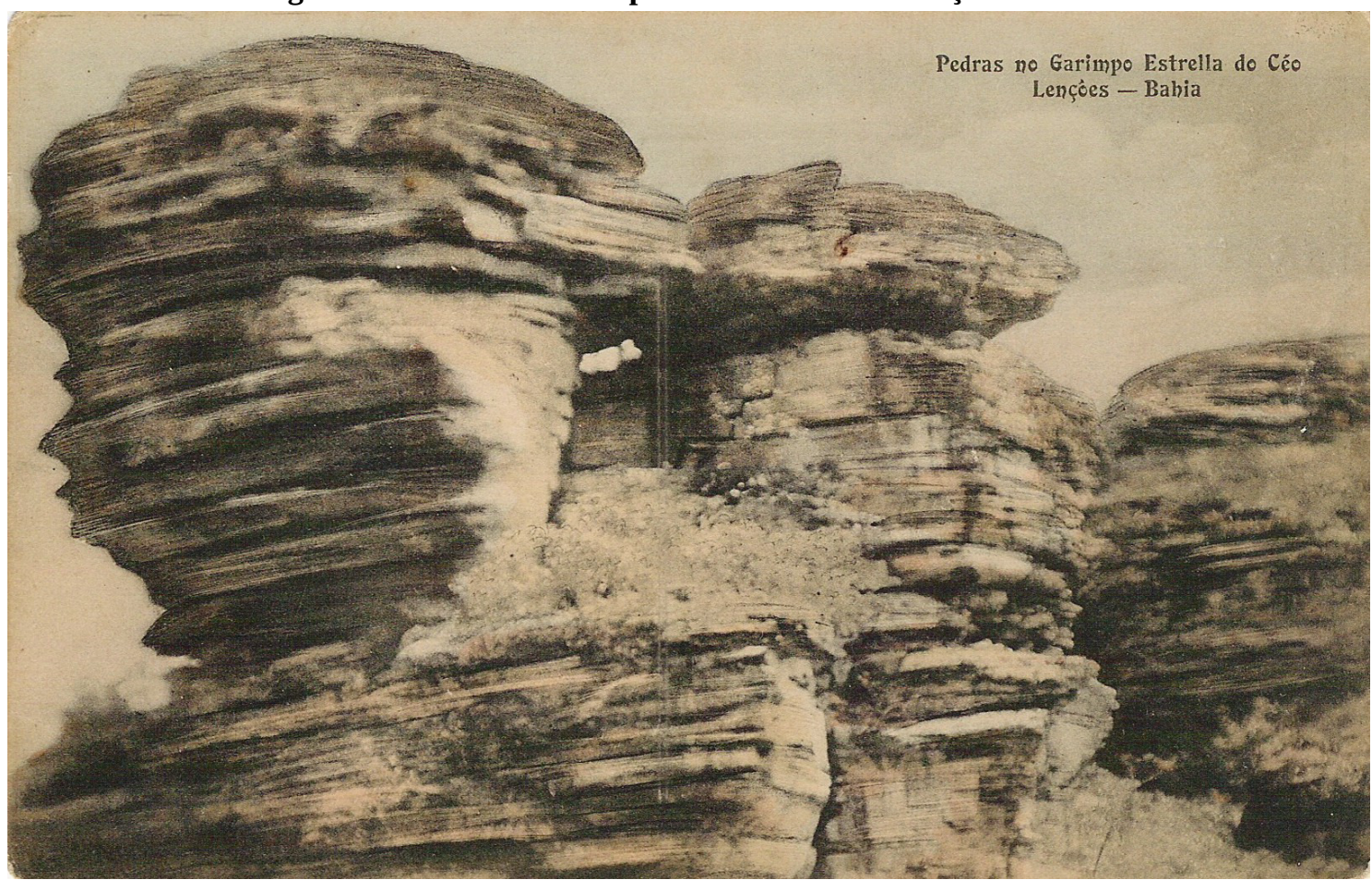

Fonte: Arquivo pessoal de Mestre Osvaldo. 
Já o observador da fotografia de Araquém Alcântara é uma silhueta sem rosto e de vestimenta oculta. Um anônimo. Um observador qualquer, colado à frente da paisagem exuberante. Talvez mesmo um observador desnecessário da natureza admirável. No caso desta imagem, a natureza interessa por si mesma, independente do engenho do sujeito, que se satisfaz com o simples deleite da visão. Talvez um outro sujeito da prática oculto possa ser identificado: o fotógrafo que produziu a imagem. Isso porque esta imagem não é encarada como um registro fotográfico simplesmente documental, trata-se de uma fotografia produzida como arte. O fotógrafo neste caso é um “observador qualificado”, aquele que apreende a realidade de forma distinta, não mais um mero operador da máquina que registra a realidade ${ }^{43}$.

Como mencionado acima, é comumente aceito que a paisagem seja uma forma de consciência do mundo cuja gênese está relacionada à modernização. O mesmo não se dá com o trabalho, dificilmente se atribui especificidade histórica ao trabalho, sendo normalmente aceito sem grandes ressalvas que ele é a relação que o homem em geral estabelece com a natureza. Do ponto de vista aqui assumido, o trabalho é a relação real e abstrata que iguala todas as atividades como mercadorias, e como relação hegemônica também é formado historicamente. Antes disso a própria igualdade entre os homens, como ideia que organiza a vida social, não era possível. Não por acaso o longo e sangrento processo de imposição do trabalho como forma da mediação social ao longo da modernização se fez, em muitos casos, tendo a desigualdade como pressuposto, o que é evidente na história de um país profundamente marcado pelo escravismo colonial como o Brasil.

As duas fotografias de Lindemann mencionadas anteriormente são registros sobre o garimpo de diamantes nas Lavras Baianas, mas não são propriamente registros sobre o trabalho nos garimpos desta região. Entre os postais de sua série, seis deles fazem referência mais direta ao processo de trabalho nas lavras, entre os quais quatro (Figuras 4, 5, 6 e 7) são panorâmicas que dão boa ideia da forma como a paisagem foi transformada pela atividade garimpeira.

43 Na abertura do livro de Araquém Alcântara, Orlando Senna afirma que o fotógrafo “[...] exerce e exercita essa função de desvendar, de acrescentar lentes aos nossos olhos, de emprenhar nosso entendimento com a beleza e a sensibilidade de seus fragmentos de natureza $e$ humanidade, revelando o invisível no visível, e também o vice-versa.

As artes e as tecnologias do olhar desenvolvidas no século passado (o avanço da fotografia, o cinema, a televisão, os jogos eletrônicos) criaram a possibilidade de uma outra forma de pensar, a possibilidade de libertar a filosofia da fala e da escrita, seus leitos naturais, para que ela também seja criada e desenvolvida em linguagens visuais e audiovisuais. [...] Araquém Alcântara também filosofa em sua extensa e densa coleção de mundos, em suas cores dramáticas, ora acariciantes, ora perturbadoras. Filosofar, ou seja, nos fazer pensar, repensar e pensar-nos." (Alcântara, 2007) 
Fig. 4: Garimpeiros em trabalho. Lençóes - Bahia

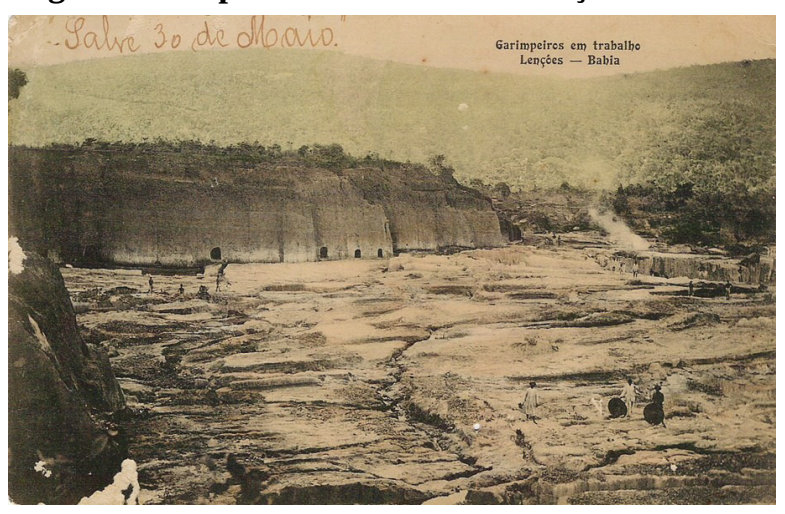

Fig. 6: Garimpeiros Trabalhando. Lençóes - Bahia

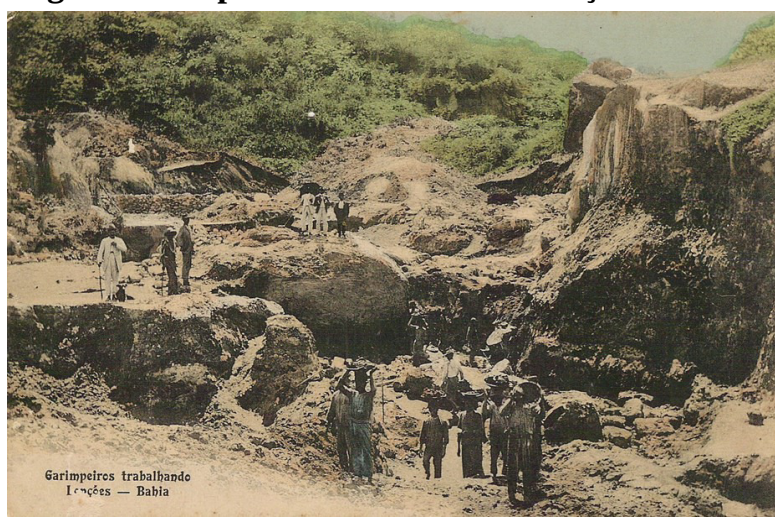

Fonte: Arquivo pessoal de Mestre Osvaldo.
Fig. 5: Em busca de Fortuna. Lençóes - Bahia

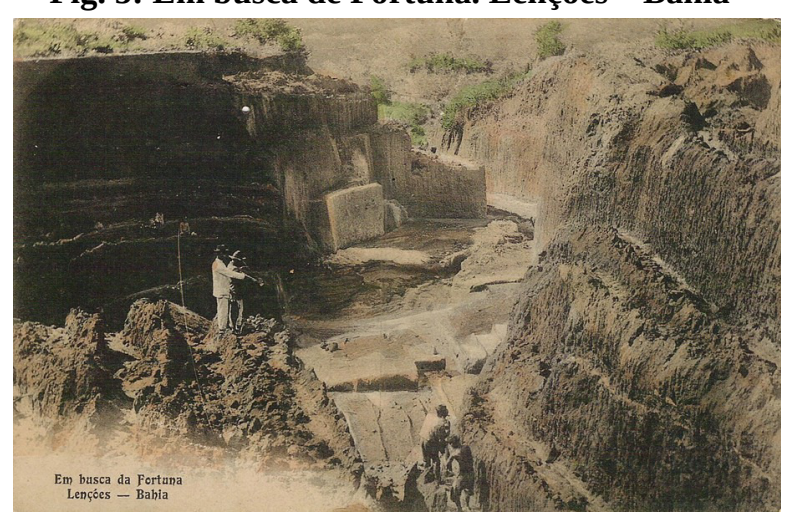

Fig. 7: Garimpeiros em trabalho. Lençóes - Bahia

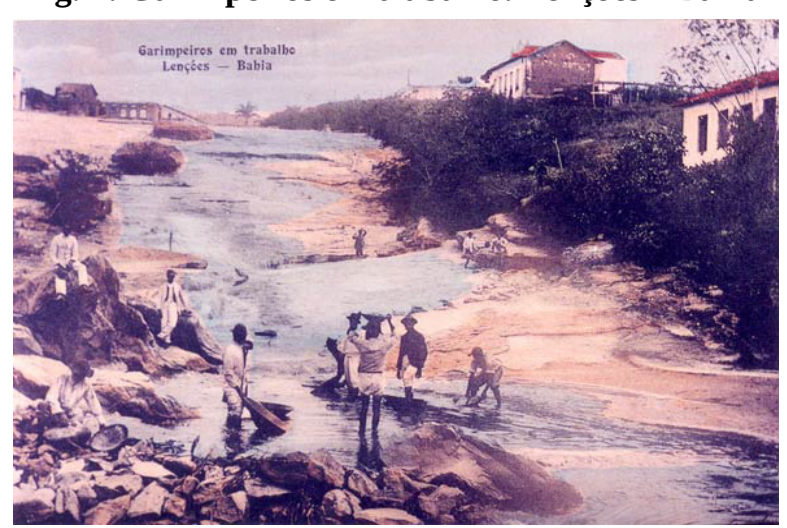

No entanto, os outros dois postais interessam mais neste momento, são registros mais detalhados e mostram os trabalhadores portando suas ferramentas nos locais de trabalho. São claramente quadros compostos pelo fotógrafo, os personagens registrados posam distribuídos de forma harmônica nas duas imagens. Em uma delas (Figura 8), cujo letreiro indica “Excursão do garimpo Brejinho. Lençóes - Bahia”, vemos dez homens que posam para a câmera. Um deles é ainda bastante jovem (talvez nem mesmo um adulto), está de pé no primeiro plano da imagem e, com exceção do homem sentado ao centro, é o único que tem as mãos livres, pendidas sobre as pernas. Além dos dez homens, um menino chama a atenção: uma criança, é o único nu da cintura para cima. Ele quebra a disposição planejada dos corpos no quadro, está retraído, colado ao homem que segura com a mão esquerda uma bateia apoiada no chão e com a direita o cabo de uma ferramenta escondida atrás da bateia. O semblante de choro do menino destoa da seriedade austera estampada no rosto dos demais. Parece um birrento intruso da imagem planejada.

Nem todos homens registrados nesta fotografia parecem ser trabalhadores, no entanto, considerando as dificuldades de estabelecer distinções raciais claras no Brasil, pode-se considerar que eram todos homens brancos. A vestimenta dos dois homens mais à direita do 
quadro sugere que sejam garimpeiros, o restante é difícil afirmar. O homem em pé no centro, com a mão esquerda apoiada na cintura não segura uma ferramenta de trabalho, está apoiado com a mão direita sobre um guarda-chuva, sugerindo certa distinção. Atrás dele à esquerda um dos três homens de roupas alvíssimas segura um pequeno instrumento de cordas, um bandolim (?). Possivelmente alguns dos homens registrados nesta imagem sejam proprietários de terras ou gerentes de garimpo.

Figura 8: Excursão do garimpo Breginho. Lençóes - Bahia

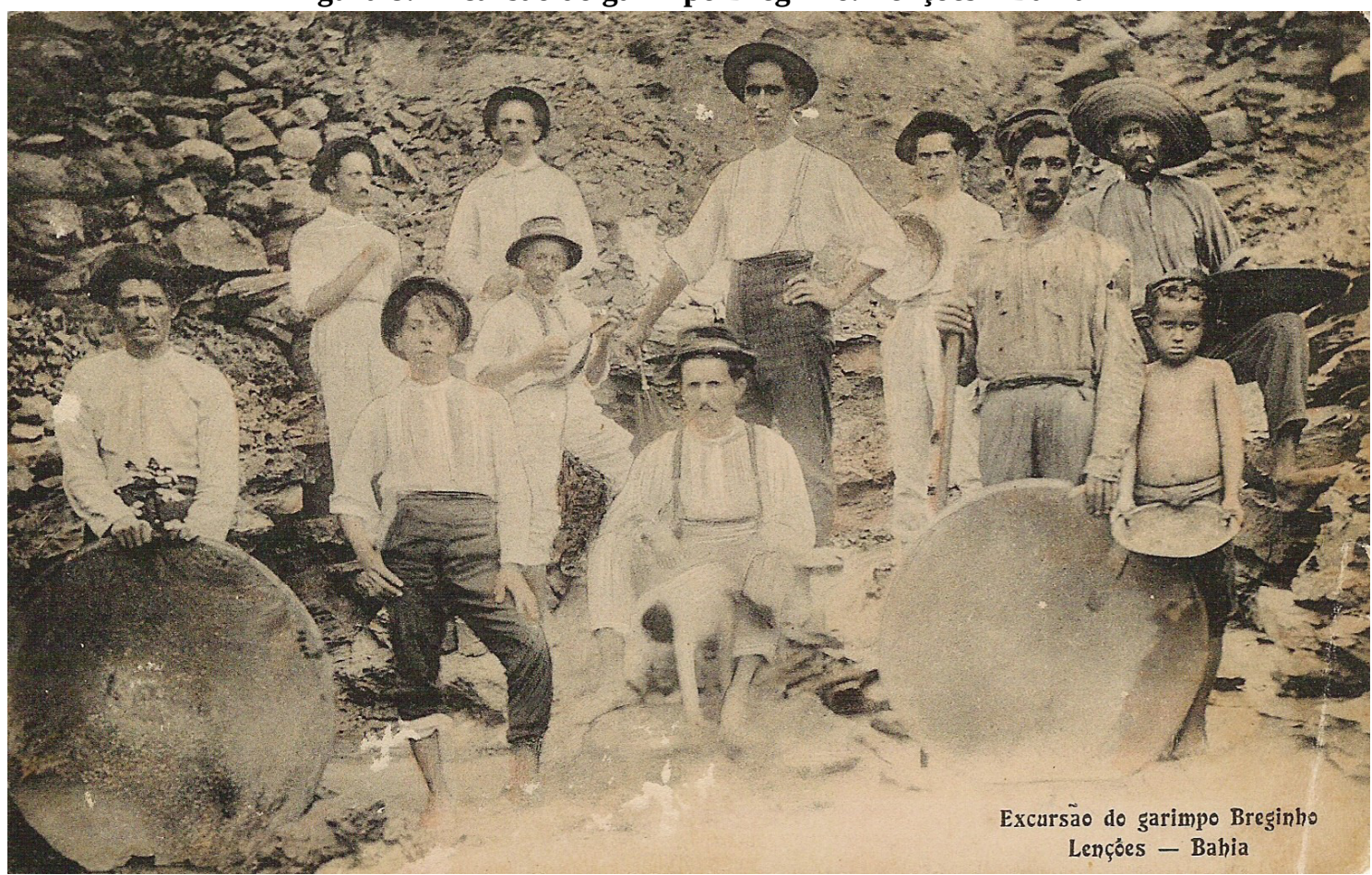

Fonte: Arquivo pessoal de Mestre Osvaldo.

Já a outra imagem (Figura 9) sugere uma distinção mais clara do lugar social dos personagens registrados. Os dois garimpeiros, um deles negro, encontram-se dentro da água e seguram com as duas mãos bateias que flutuam cheias de cascalho. Ambos têm as mangas da camisa arregaçadas e usam uma espécie de boné. Os outros três homens que compõem o quadro vestem paletó, chapéus de abas e estão calçados. Estão fora d’água e dois deles estão apoiados em guarda-chuvas, o terceiro segura um objeto com as duas mãos. Também é possível identificar ferramentas de trabalho dispostas no entorno. Os homens estão no “Garimpo Estrella do Céo. Lençóes - Bahia”, indica o letreiro do postal.

Coincidência ou não, a notável predominância de homens brancos nas duas imagens que representam mais de perto o processo de trabalho na região das Lavras Baianas corrobora a sugestão de Santana (2013) de que os postais de Lindemann tenham sido produzidos como propaganda dos garimpos de Lençóis na virada do século XIX para o XX. 
Figura 9: Garimpo Estrella do Céo. Lençóes - Bahia

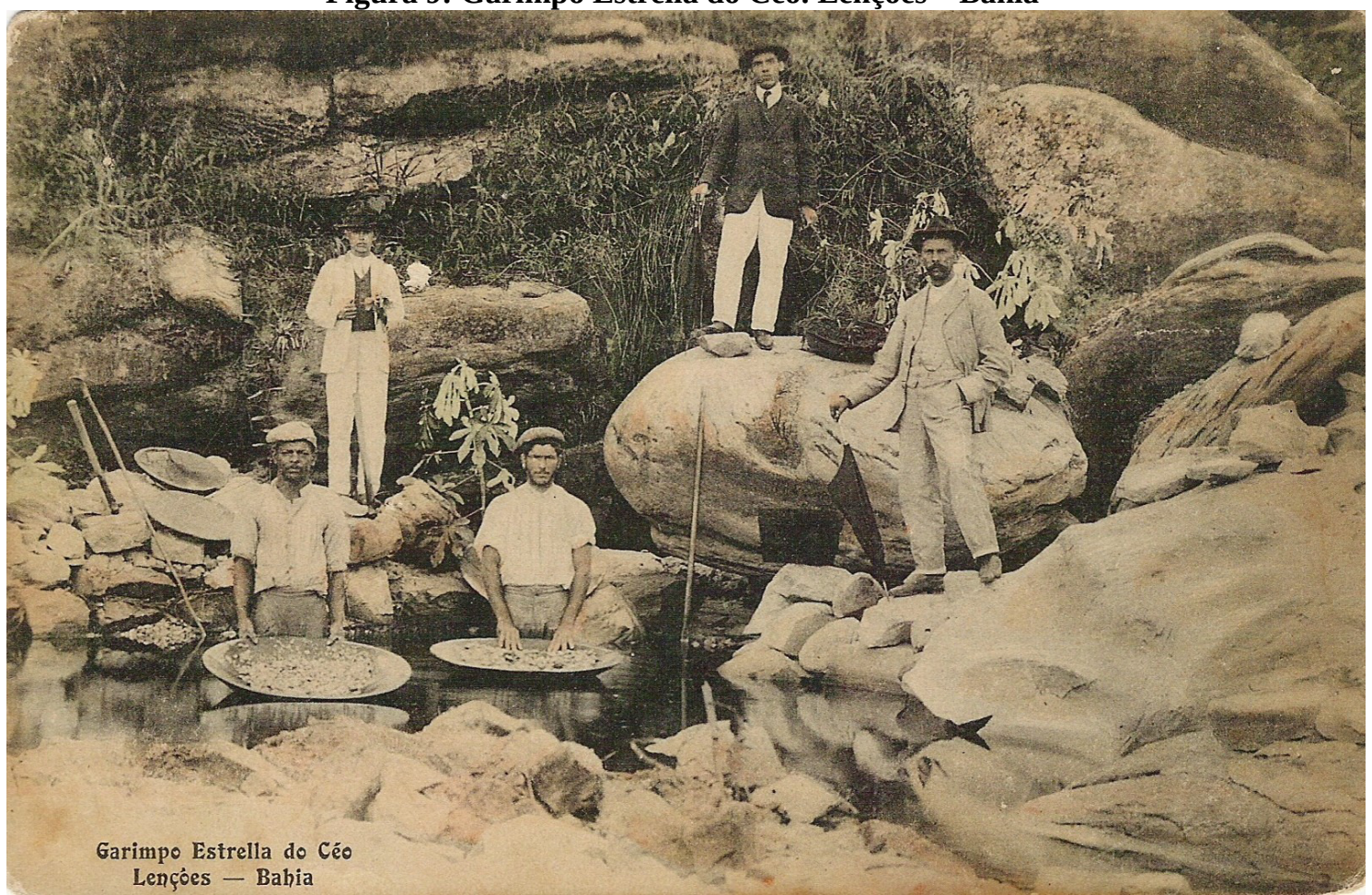

Fonte: Arquivo pessoal de Mestre Osvaldo.

Nas imagens produzidas por Furniss (Figuras 10, 11 e 12), apenas quatro anos depois de Lindemann, a maioria dos trabalhadores, que não estão posando para o fotógrafo, são homens negros:

Figura 10: Garimpeiros escoando água para coletar cascalho

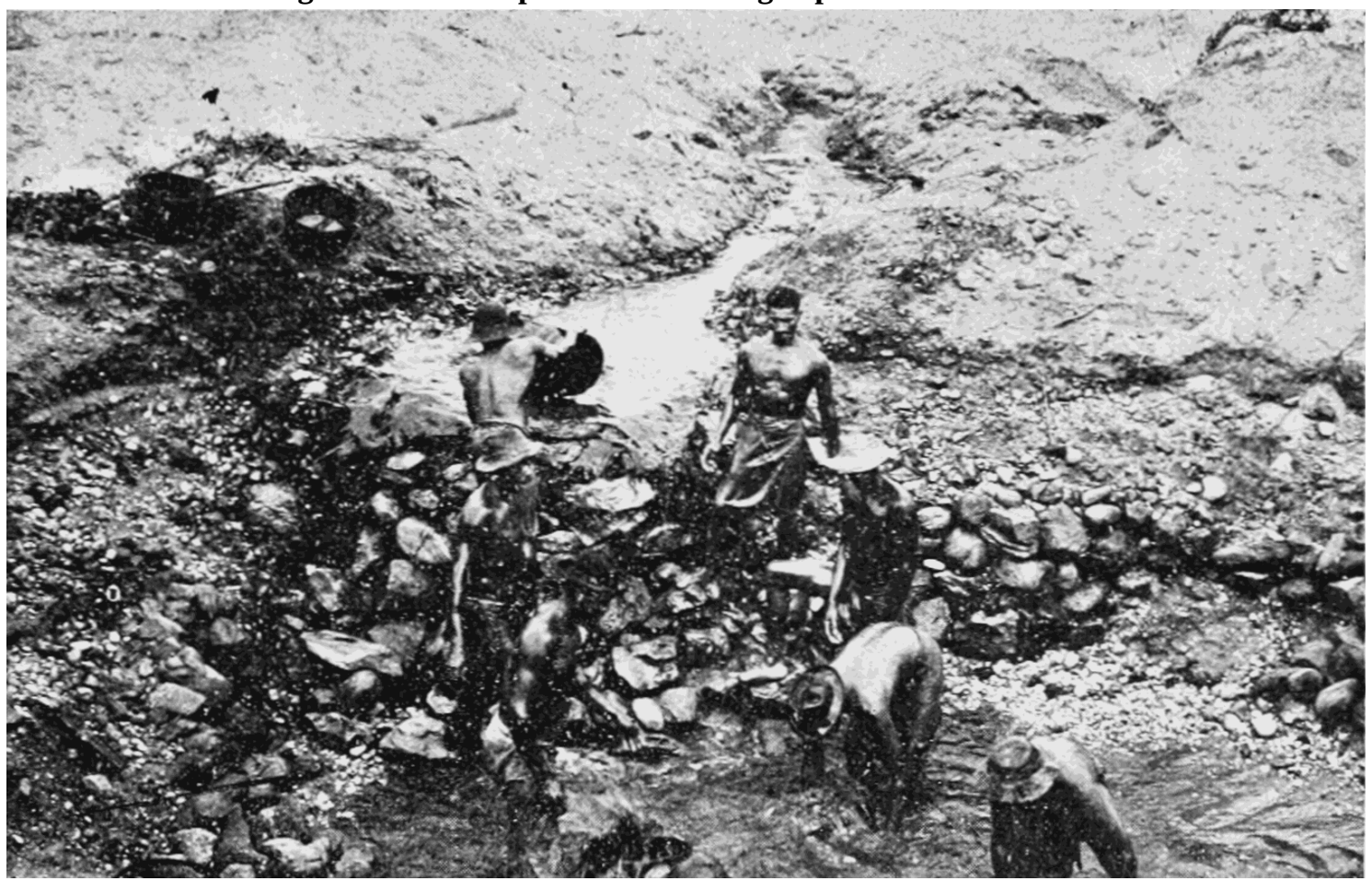

Fonte: Furniss (1906). 
Figura 11: Concentração final e lavagem em bateias

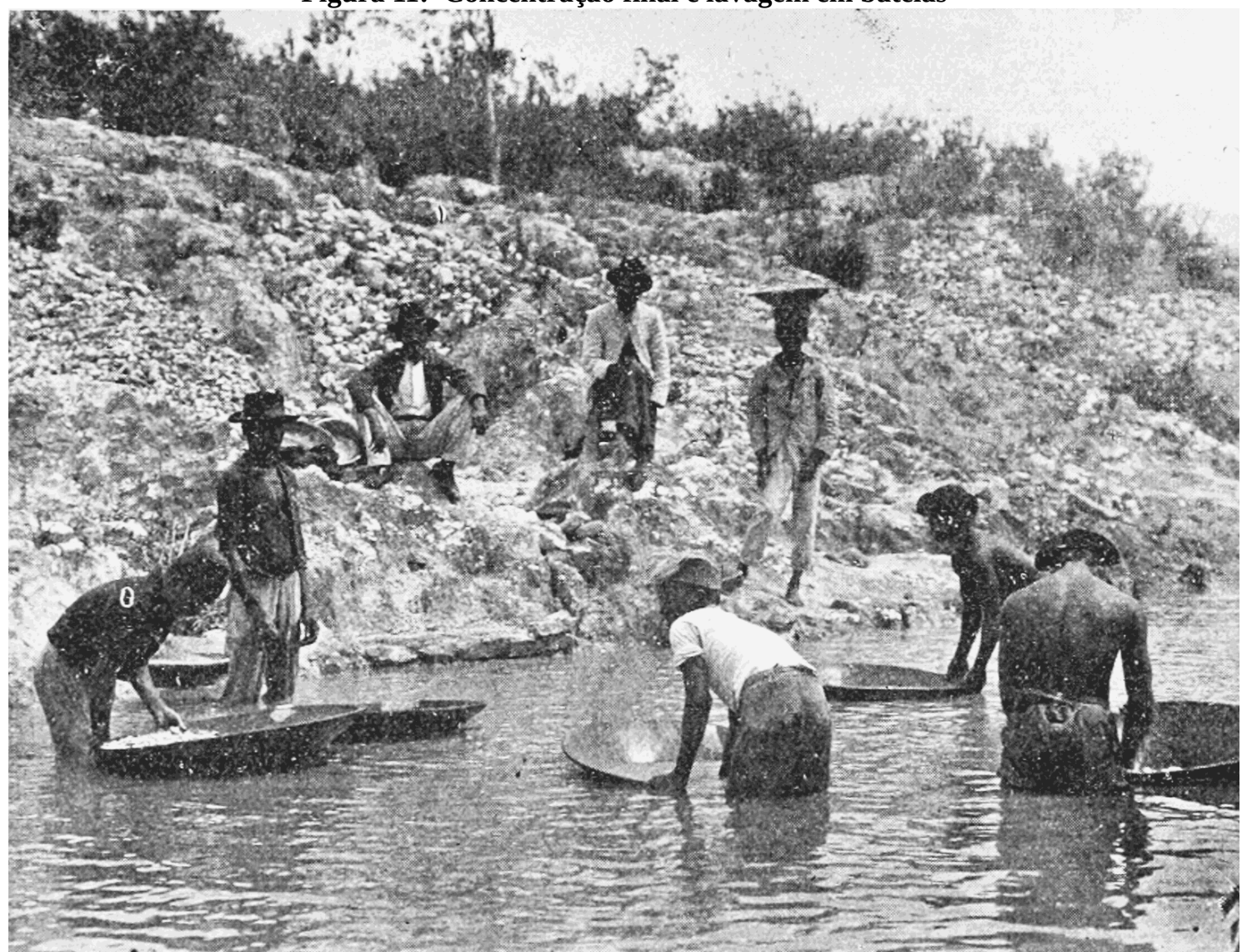

Fonte: Furniss (1906).

Figura 12: Método garimpeiro de remoção de subsolo para expor o cascalho

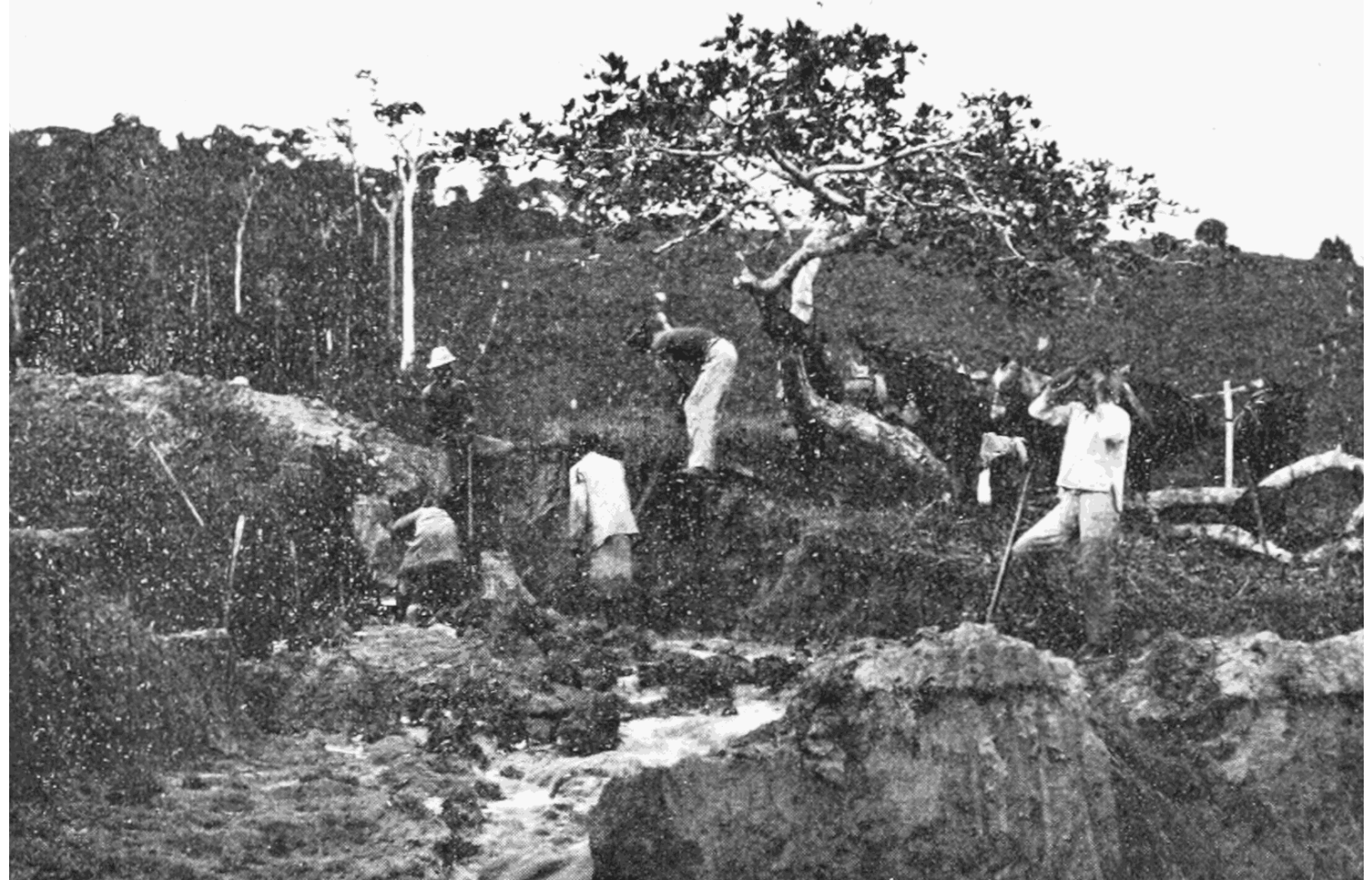

Fonte: Furniss (1906). 
Cerca de um século depois que Lindemann e Furniss produziram essas fotografias, coincidência ou não, pesquisas acadêmicas, exposições e livros produzidos nas duas primeiras décadas do século XXI têm utilizado as imagens de Lindemann como ilustrações sobre a sociedade regional das Lavras Bainas, enquanto, até onde se pôde averiguar, nenhuma publicação fez uso das fotografias de Furniss. Será um preconceito quanto à qualidade do trabalho?

Retornando à comparação inicial, do ponto de vista técnico é possível tecer outro paralelo entre Lindemann e Alcântara, ambos dispõem dos produtos e máquinas de ponta disponíveis em suas épocas. No entanto, o acesso à tecnologia é uma aproximação superficial entre os dois fotógrafos. Mais do que isso, encerrar a comparação entre os eles no aspecto técnico de suas práticas esconde distinções importantes entre as relações sociais e de produção que ambos estabelecem para se manterem profissionalmente ou não como produtores de imagens. Nesse ponto surge a questão: Por que Lindemann se deslocou para a região das Lavras Baianas? Não se tratava de um trajeto simples, eram aproximadamente quatro dias de viagem no início do século XX, feita em barco, trem e lombo de mula, para se chegar em uma região onde ainda não se contava com serviços de telégrafo (Babinski, 1897). Teria Lindemann empreendido a viagem por conta própria, imaginando poder cobrir os custos da empreitada e se remunerar com a venda dos postais? Ou teria sido contratado por algum membro da classe proprietária da região para produzir o material? Neste último caso, o que teria motivado a contratação do fotógrafo? Intenções publicitárias, como propõem Santana (2013), ou as aspirações civilizacionais que faziam os proprietários de terras da região mimetizar os costumes metropolitanos europeus? Ou ainda, não seriam os postais de autoria de Lindemann, como sugere Sampaio ${ }^{44}$ (Alves, 2006)? É quase certo que Lindemann não encontrava-se em atividade recreativa nas Lavras Baianas, ainda que gozasse de certas condições materiais. A suposição de Santos (2014) de que Lindemann tenha migrado para o Brasil fugindo do já saturado mercado de fotógrafos em Paris não parece absurda, isso significa que não se tratava de um oligarca ou burguês que contasse com dinheiro sobrando para realizar suas extravagâncias. Para Lindemann, produzir imagens era forma de ganhar a vida, de acessar dinheiro. Neste ponto Lindemann e Alcântara também se aproximariam, isto é, também para o segundo produzir imagens é forma de acessar dinheiro. Diferente de Furniss, que não dependia em nada de seus conhecimentos de fotografia para se remunerar. O que está em questão então é a forma como aqueles dois fotógrafos se remuneram, como suas

44 Ver página 47 desta dissertação. 
atividades profissionais se inserem no conjunto da economia, ou seja, de que modo acessam dinheiro.

O próprio livro de Araquém Alcântara traz inscrito no verso da folha de rosto um selo da lei de incentivo a cultura do Ministério da Cultura do Governo Federal. Ou seja, a produção de Alcântara pressupõem a estrutura econômico política de renúncia fiscal do Estado brasileiro para o incentivo à cultura, existente somente a partir de meados dos anos 1980 . Diante disso, é possível estabelecer um paralelo entre a possibilidade da produção das fotografias de natureza por Araquém Alcântara e a implantação do turismo na Chapada Diamantina através da planificação estatal. Se na escala nacional, é no bojo das mesmas transformações da estrutura econômico política do Brasil que o turismo chega na área da antiga região das Lavras Baianas, localmente determinadas práticas que correspondiam à reprodução social de tal área passam gradativamente a ser marginalizadas e/ou folclorizadas, ao mesmo tempo que outras práticas são naturalizadas, conformando um novo padrão de normalidade. No caso da formação do turismo na área da Chapada Diamantina uma das atividades que se banalizaram de maneira mais evidente a partir dos anos 1980 foi justamente a produção de imagens, sejam elas fotografias ou vídeos. Visitar a Chapada Diamantina como turista e não fazer fotografias chega a parecer um dispare. Se quando Lindemann produziu (?) as fotografias da região das Lavras Baianas o roçado, a caça, a pesca, a coleta e mineração eram atividades cotidianas não criminalizadas na Serra do Sincorá, hoje fotografar é uma das principais práticas permitidas dentro do Parque Nacional da Chapada Diamantina (PNCD). A rigor um turista só pode retirar de dentro da área de preservação fotografias. Isso porque o turismo na Chapada Diamantina, como atividade econômica pretensamente sustentável, deve se dar de modo a não agredir o meio ambiente. Desta maneira, a fotografia torna-se momento importante da nova atividade que move a economia daquela área ao mesmo tempo que parece garantir a preservação da natureza ameaçada pela modernização avassaladora. Nesse sentido as imagens dos fotógrafos profissionais como Araquém Alcântara, comercializadas como livros de arte, servem de exemplo para os fotógrafos amadores.

Não é mera coincidência que o mesmo argumento seja utilizado tanto pelos apologetas do turismo como por aqueles da fotografia. Se, por um lado, um dos dois estudos, que servem de base para as intervenções estatais no turismo baiano no início dos anos $1990^{45}$, chamava-se Salvador uma alternativa pós-industrial (Queiroz, 2002), por outro, Wagner Souza e Silva em seu livro Foto 0 / Foto 1 propõem que "sendo a fotografia uma técnica moderna, o que ela

45 Ver item 14. A descoberta da Chapada Diamantina e sua incorporação ao Estado nacional desta dissertação. 
desafia? O que ela estoca? Ela não intervém concretamente na natureza, a não ser simbolicamente, e isso constitui o seu caráter pós-industrial” (Silva, 2016:173). Quer dizer, tanto o turismo como a fotografia são entendidos como atividades pós-industriais.

Seria preciso inquerir o que exatamente se entende como industrial no argumento dos autores. De qualquer forma, este enunciado é uma verdade muito precária e o seu limite está dado pela autonomização do turismo e da fotografia como atividades que pairam independentes. Se a questão é tomada apenas do ponto de vista do uso dos ditos recursos naturais, a ideia de que o turismo seja uma atividade sustentável, uma "indústria sem chaminés”, se sustenta sob bases frágeis, ou melhor, é mesmo insustentável. Tanto para o turismo, como para a fotografia, se poderia propor uma retomada dos processos produtivos que estão por trás de um inofensivo disparo fotográfico em um das cachoeiras da Chapada Diamantina, logo se descortinariam diante de nossos olhos processos extrativistas e um parque industrial nada banais. O mesmo se dá também para toda a série de consumos que o turista realiza. A sustentabilidade ambiental do turismo ou da fotografia, se sustenta como forma de consciência pelo desconhecimento de como as mercadorias que nos cercam são produzidas. Isso para não falar do cinismo que permeia nossa sociabilidade cotidiana no calar dessas questões. Neste sentido, as mercadorias que nos cercam aparecem como natureza. 


\section{CRISE: REGRESSÃO ECONÔMICA E} ABERTURA DA REGIÃO

Se os anos 1870 marcaram a crise da região escravista e a formação de uma região caracterizada pelo trabalho livre, ainda que sob relações de trabalho particulares advindas da não formação de uma superpopulação relativa - como já ressalvado acima, em casos de empreitadas entendidas pelo proprietário como ricas, este preferia firmar a diária como forma de remuneração do trabalho. Do que se depreende que a não formação da superpopulação relativa na Região das Lavras está estreitamente relacionada com as incertezas quanto à produtividade do trabalho decorrente da imprevisibilidade da existência dos diamantes, o que se agravou ao longo do tempo com o escasseamento do cascalho superficial. Essa característica do ramo é um determinante importante para as relações de produção que se formam na região. A entrada na década 1930 marca a crise da reprodução daquela área enquanto região, senão com o fim, ao menos com sua reprodução em uma posição submissa na relação tensa com o novo ente político em formação: o Estado nacional. O processo, que se gestava há algum tempo e que em 1930 ganha forma mais clara, diz respeito ao

\footnotetext{
“[...] desenvolvimento industrial da "região" de São Paulo [que] começou a definir, do ponto de vista regional, a divisão regional do trabalho na economia brasileira, ou mais rigorosamente, começou a forjar uma divisão regional do trabalho nacional, em substituição ao "arquipélago" de economias regionais até então existentes, determinadas sobretudo pelas relações com o exterior. Derrocaram as barreiras alfandegárias existentes entre os estados, na rota das transformações operadas pela Revolução de 30, pois existiam na forma de um imposto estadual sobre as importações provenientes de quaisquer outros estados; instituindo-se o Imposto de Consumo sobre todas as mercadorias produzidas no país, e aboliu-se a capacidade que detinha cada estado de legislar sobre o comércio exterior.” (Oliveira, 2008:199-200)
}

Para Francisco de Oliveira (2008) a formação do "espaço econômico capitalista nacional unificado", além da quebra das barreiras estaduais, está vinculada à política econômica de depreciação da taxa de câmbio e de taxas alfandegárias elevadas, que por conta das taxas de lucro desiguais formou um "mecanismo de triangulação das trocas de mercadorias Nordeste-Exterior-Centro-Sul-Nordeste”, que drenava os capitais nordestinos para o Centro-Sul. Em um plano estrutural técnico esse processo é viabilizado pela expansão da rede de circulação do território nacional. Tomando a região das Lavras Baianas como referência, seria o caso de se perguntar se estamos realmente diante do choque entre taxas de 
lucro como aponta o autor. Do ponto de vista aqui adotado não estaríamos propriamente tratando de um sistema extração de mais-valia e sim de uma estrutura social baseada no tributo, do que decorre a incoerência de tratar o choque como sendo entre taxas de lucro.

As transformações do regime de acumulação na região do café, a partir da qual se formou a principal metrópole nacional, colocam em choque a reprodução das relações de produção das demais regiões do país ${ }^{46}$. Nesse contexto, enquanto o Estado acumula através do planejamento (que é a captação de parte da mais-valia e do mais-produto social que passam a serem geridos por uma racionalidade central, no caso atrelada aos intentos da "região vencedora”) a acumulação regional entra em crise.

Para Francisco de Oliveira, tal processo não se dá somente em um plano econômico político restrito aos termos da produtividade dos capitais regionais e de uma política econômica de gabinete. As elites regionais resistiram à submissão perante o Estado nacional, mantendo enquanto puderam a região "fechada”, o que se deu por subterfúgios múltiplos que iam desde a violência direta até a ocupação de posições políticas estratégicas para a "captura do Estado" - o que fazia de determinados institutos "sumidouros" de dinheiro público que garantiam a posição dessas oligarquias locais, como foi o caso do Departamento Nacional de Obras Contra a Seca (DNOCS) e do Instituto do Açúcar e do Álcool (IAA) (Oliveira, 2008).

$\mathrm{Na}$ análise aqui proposta, tomando a família como elemento significante para interpretação do processo social, a resistência das oligarquias regionais como donos do poder diante do projeto modernizador do Estado nacional comporta certa nuance contraditória: os filhos da classe dominante, via de regra, não repõem de maneira idêntica o lugar de poder de seus genitores, migravam para os centros urbanos para estudar e iriam se recolocar como classe dominante a partir também da posição de tecnocratas. Quer dizer, enquanto classe a burguesia então em formação não é exatamente a oposição ao poder oligárquico, mas o

46 Sobre tal questão vale uma nota crítica à forma como Francisco de Oliveira expõe a questão no seguinte trecho: "A diferença desse processo, quando comparado aos efeitos que a expansão capitalista do Centro-Sul exerceu sobre outras regiões, é ilustrativa: o efeito inicial destruidor sobre os "Nordestes" somente ocorre porque nestes existiam "economias regionais", com circularidades específicas do processo de reprodução. Não se nota o mesmo efeito em relação a uma região como o Centro-Oeste; aqui, a redivisão regional do trabalho comandada pela expansão capitalista do Centro-Sul tomou claramente formas de "criação" e não de “destruição"." (Oliveira, 2008:203) A afirmação de um processo de caráter criativo, e não destrutivo, soa como eco da ideia asséptica de "vazios territoriais" e de "povoamento do território" (Prado Júnior, 1977), as quais pressupõem as categorias econômicas como parâmetros positivos da análise. Se não destruiu uma "economia" propriamente dita, a abstração, no argumento, do genocídio indígena que a ocupação do Centro-Oeste ainda hoje significa parece - pedindo muito da polidez pouco afeita ao bandeirantismo - problemática. 
reposicionamento dos donos do poder diante da transformação da forma de acumulação que se operava internamente ao território nacional.

No caso da região das Lavras Baianas a figura do Cel. Horácio de Matos se destaca como exemplo do posicionamento da classe dominante local frente ao poder do Estado nacional nascente. Horácio de Matos, como líder político de Lençóis e daqueles sertões, compõem o quadro de lideranças do interior baiano nas movimentações armadas que vieram a ser conhecidas como Revoltas Sertanejas (Moraes, 1997), que na virada de 1919-20 tomaram partido da frente de oposição liderada por Rui Barbosa e se antepuseram ao então governador do estado J. J. Seabra na disputa pela sucessão do posto. Em seguida foi personagem central do Convênio de Lençóis, espécie de tratado de paz que deu fim ao conflito na região das Lavras Baianas. Em 1930, no contexto da Revolução, Horácio de Matos é preso em Salvador e, assim que liberto, assinado. Nas narrativas locais, Lençóis “morre” junto com Horácio de Matos e a população “desenganada” passa a deixar a região em crise por conta do fim de seu “chefe e protetor" (Moraes, 1997). Em verdade a história pessoal de Horácio de Matos representa os últimos suspiros do coronelato stricto sensu - personificação aglutinadora da terra, do capital e do Estado na região, posição que demandava o controle da violência direta como necessidade do coronel. Sua eliminação como ação planejada do Estado nacional representa a autonomização da lei e, em termos econômicos, é reflexo do enfraquecimento da acumulação da relação regional em oposição à acumulação da relação capital estadual e nacional, sobretudo no que isso diz respeito ao acesso às armas. Neste sentido, o Estado nacional é a forma da autonomização da violência que garante à classe dominante, na forma de burguesia, a possibilidade de acumular sem ter que ser portadora da violência direta.

Nem as transformações das relações político-econômicas impostas pela formação do Estado nacional, nem a morte de Horácio de Matos deram fim à extração de diamantes na área das Lavras Baianas. No entanto, as lideranças locais que permanecem após o início do processo migratório (do qual parte significante da classe dominante regional foi a primeira participante) estavam longe de organizar grupos de jagunços que pudessem enfrentar as forças armadas nacionais de igual para igual como antes (Chagas, 1996 e Moraes, 1997). A região se conformava então definitivamente como área do Estado nacional brasileiro pela autonomização da violência direta. Tal condição se revela também, para além da autonomização do porte da violência, de outras maneiras: é a partir de 1930 que a emigração transforma aquela em mais uma área do sertão nordestino provedora da população que viria formar a superpopulação relativa da metrópole estadual e sobretudo das metrópoles nacionais. Na reprodução da classe trabalhadora que permanece na área, ganham maior relevância as 
atividades de subsistência do tipo “economia natural” - como a caça, coleta, pesca e pequenos roçados. O que de um determinado ponto de vista atual tem a ver com o que se entende como “tradicional”. Já do ponto de vista do economista político pode-se dizer que a área sofre neste momento um processo de regressão econômica (Furtado, 1979), já que lá passa a circular menos dinheiro. Essas transformações voltarão a ser debatidas mais adiante nesta dissertação, com maior riqueza de elementos. 


\section{FOTOGRAFIAS DO JORNAL}

“O SERTÃO”47

O jornal “O Sertão” foi criado em Lençóis em 1921 pelo Cel. Horácio de Queiroz Matos, então recém-empossado Delegado Regional do centro-oeste do estado baiano, nomeação esta resultante dos desdobramentos dos conflitos que ficaram conhecidos como Revoltas Sertanejas e que redundaram no Convênio de Lençóis, o acordo político que estabeleceu a liderança do coronel ante seus inimigos na região (Moraes, 1997). Segundo Walfrido Moraes, Horácio de Matos

“Associa-se a um velho tipógrafo, Vicente Morais, no lançamento de um
jornal que está fadado a prestar grandes serviços àquele povo - O Sertão -
'hebdomadário político, noticioso, literário e independente’ [...] ” (Moraes,
1997:117)

É manifesta a afinidade do autor com seu biografado, seria o caso de questionar a que povo o jornal viria "prestar grandes serviços”. Curiosamente, ainda que evidentemente não seja o caso do sentido dado na citação acima, não é raro que a expressão “povo” seja utilizada para se referir a uma família (“o povo do Fulano de Tal” ou “o povo dos Tals”). Elucubrações à parte, fato é que o jornal representa importante testemunho do ponto vista de uma parte da classe proprietária e mandatária de Lençóis e circunvizinhanças.

Quanto à propriedade do jornal, foi possível verificar, a partir dos exemplares disponíveis, as mudanças ao longo dos quase trinta anos de sua existência. Entre 1920 e 1929 a primeira página do jornal indica que Horácio de Mattos e Vicente Moraes são seus proprietários, em 1929 a primeira página passa a indicar Franklin de Queiroz como sócio de Horácio de Mattos.

Horácio de Mattos é assassinado em 13 de maio de 1931, em Salvador, ao ser solto do cárcere imposto aos chefes sertanejos pela Revolução de 1930. Mesmo assim somente em agosto de 1934 o jornal passa a estampar o nome do novo proprietário, Archimedes de Queiroz Mattos, irmão do coronel falecido. Em julho de 1941 o jornal passa a ser propriedade

47 Esta pesquisa teve acesso a uma parte significativa dos exemplares de $O$ Sertão a partir do material digitalizado dos originais de Heraldo Barbosa Filho pela pesquisadora Liziane Peres Mangili, que gentilmente os cedeu. Vale destacar ainda que “O Sertão" passou por períodos de inoperância e que, para além desses períodos, o material digitalizado disponível não é a totalidade das publicações do jornal, tratando-se de exemplares publicados entre 1921 e 1950. Uma pequena amostra desse material encontra-se no Anexo C desta dissertação. 
de Olympio Antonio de Barbosa, para em fevereiro de 1948 passar às mãos dos irmãos João Ganem e Nadir Ganem.

Quanto às fotografias que ilustram o jornal, é possível fazer alguns apontamentos. A maior parte delas, sobretudo aquelas publicadas nas duas primeiras décadas de sua existência, são retratos de proprietários regionais e homens envolvidos na política oficial, fossem eles da própria área das Lavras Baianas ou governantes em escala estadual e nacional. Durante a década de 1940 o jornal passa a estampar outros tipos de fotografias além dos retratos, destaque às imagens de prédios públicos ou panoramas das cidades de Lençóis, Andaraí, Palmeiras e Seabra. Também na década de 1940 algumas edições possuem matérias produzidas pela "British News Service” que contam com fotos ilustrativas, tratam-se de notícias sobre a Segunda Guerra Mundial, sobre a realeza britânica e obras recentes da construção civil na Inglaterra.

Além disso, é possível fazer algumas inferências sobre tais imagens. É notável que a grande maioria das fotografias que estampam o jornal são retratos de "homens públicos”, a estrutura patriarcal caudilhesca é um marco do momento regional da história brasileira e a região das Lavras Baianas não é exceção. O jornal existiu justamente durante os últimos anos da assim chamada República Velha e as duas décadas subsequentes. Quer dizer, durante o processo de internalização da metrópole no território nacional empreendida a partir da Revolução de 1930. Por isso é também sugestivo que seja na década de 1940 que o jornal passe a utilizar outras imagens que não os referidos retratos. As fotos, com raras exceções, servem como ilustrações de textos elogiosos, seja a um político, seja a uma cidade ou local. A fotografia no caso do jornal $O$ Sertão atesta a autoridade dos representados, nunca a coloca em dúvida ou a critica. 
ENSAIO II

Aqui está mais um postal de Rodolphe Lindemann ${ }^{48}$ (Figura 13). Em primeiro plano, na esquerda do quadro vemos dois homens, um parece falar a respeito de um objeto que tem nas mãos, enquanto o outro o observa, além de também segurar algo nas mãos. Os homens estão vestidos elegantemente, com paletós e chapéus. Parecem negociar diamantes, ou simplesmente conversam sobre as pedras. Na imagem também aparecem dois trabalhadores negros, um deles, sentado ao fundo e com as mãos pousadas no joelho, parece olhar diretamente para o fotógrafo. O outro está posicionado de perfil no lado direito do quadro, segura com o braço estendido à frente do peito o que parece ser um fragmento de rocha, de modo a deixar o objeto exposto à câmera. O terreno é de rocha exposta, e também é possível identificar pequenas "montoeiras” de cascalho, sinal de que foi trabalhado garimpo no local. Ao fundo duas construções, uma delas à direita com aspecto de casa rica de dono de lavras, a outra um possível barracão, difícil afirmar. Ainda mais atrás dois planos de serras enevoadas. O letreiro no canto superior esquerdo identifica o local, "Veneno - garimpo de diamantes e carbonatos, Lençóis Bahia”.

Figura 13: Garimpo de diamantes e carbonatos. Lençóes - Bahia

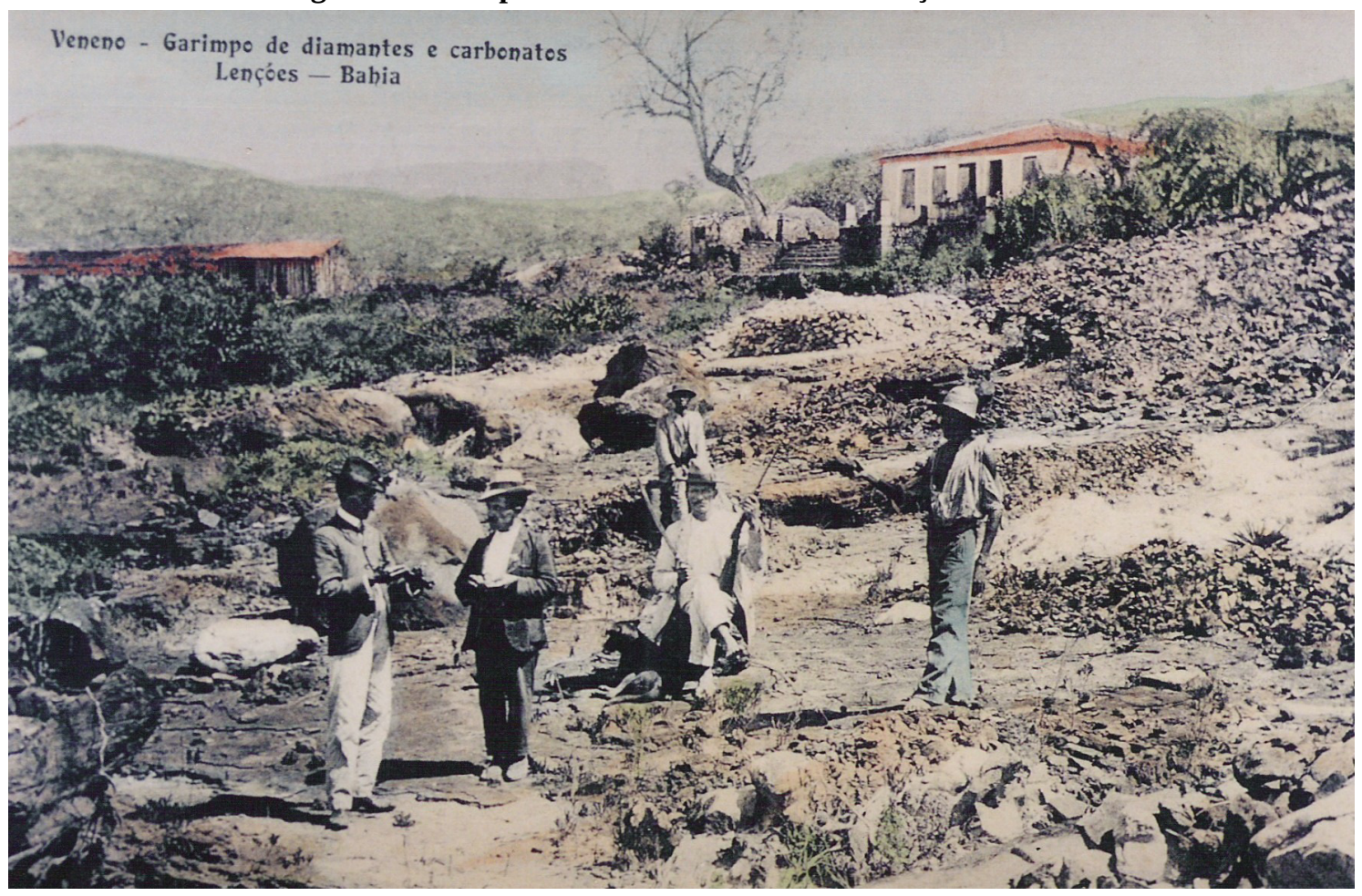

Fonte: Arquivo pessoal de Mestre Osvaldo.

48 Ver item 6. Postais da série “Lavras Diamantíferas Baianas” de Rodolphe Lindemann desta dissertação. 
Um último personagem compõem a fotografia, um homem sentado justamente no centro do quadro, está vestido todo de branco e chapéu, tem as pernas cruzadas e ao lado dos seus pés descalços um cachorro. Olhando firmemente para o fotógrafo, este homem segura uma arma em cada mão de modo a deixá-las em evidência. Possivelmente se trata de um gerente de serra, homem de confiança dos proprietários, fiscal da conduta dos garimpeiros.

A fotografia parece ter sido meticulosamente composta, todos os personagens têm os rostos voltados para o fotógrafo, estão pousando para a câmera. É possível afirmar que a cena pode ser lida como síntese das relações de produção no garimpo: proprietários (compradores) e garimpeiros aparecem em lados opostos, entre eles a figura que personifica a violência, mediação inevitável do processo produtivo dos diamantes na região das Lavras Baianas. De qualquer forma, resta a dúvida sobre as intenções exatas do fotógrafo na construção da cena em questão. Santana afirma que

"[...] o homem de publicidade que é Rodolphe Lindemann se dedica, em suas imagens, a "demonstrar" que os ex-escravos continuam a participar da produção local de riquezas, que o emprego de um novo método de extração é exequível, e, sobretudo, que a região diamantífera está pacificada.” (Santana, 2013:02)

Que a região não estava pacificada isso é certo, a bibliografia ${ }^{49}$ que trata do período não deixa dúvidas a esse respeito. Isso não impediria Lindemann de tentar transmitir certa confiança sobre o tema ao observador de seus cartões-postais, daí a função de publicidade de seu trabalho: transformar imageticamente seu objeto naquilo que ele não é. No entanto, se foi essa a intenção de Lindemann no postal em questão, a pacificação está representada aqui como forma de violência, o jagunço que a personifica é justamente o centro do quadro montado pelo fotógrafo.

Essa imagem pode chamar a atenção de forma mais acintosa para a presença do gerente/jagunço porque o personagem segura a arma ostensivamente à mostra. Mas, olhando bem, a figura desta persona está presente em outras imagens de Lindemann, bem como em fotografias de Furniss ${ }^{50}$ e de Steve Horman ${ }^{51}$. Entre os grupos de fotografias que precedem a patrimonialização de Lençóis apresentadas nessa dissertação, somente nas imagens do jornal

49 Sobre o tema da violência na região das Lavras Baianas entre o final do século XIX e o início do século XX ver Walfrido de Moraes (1997) e Américo de Chagas (1996 e 1998).

50 Ver o item 8. Ensaio I desta dissertação.

51 Mais informações sobre tais fotografias e sobre o fotógrafo serão apresentadas no item 15. Fotografias do voluntário do Peace Corps Steve Hormann desta dissertação. 
O Sertão não se encontra tal figura social representada, mesmo porque entre os volumes disponíveis do autodeclarado "órgão noticioso, litterario e defensor dos interesses da zona sertaneja” não se vê uma única imagem que represente o processo de trabalho no garimpo, a atividade que identifica a região. Esta última está representada fotograficamente sobretudo pelos homens proprietários. Além das imagens já apresentadas no Ensaio I desta dissertação, em uma fotografia de Steve Horman (Figura 14) também se identifica a figura do referido "fiscal de trabalho" do garimpo:

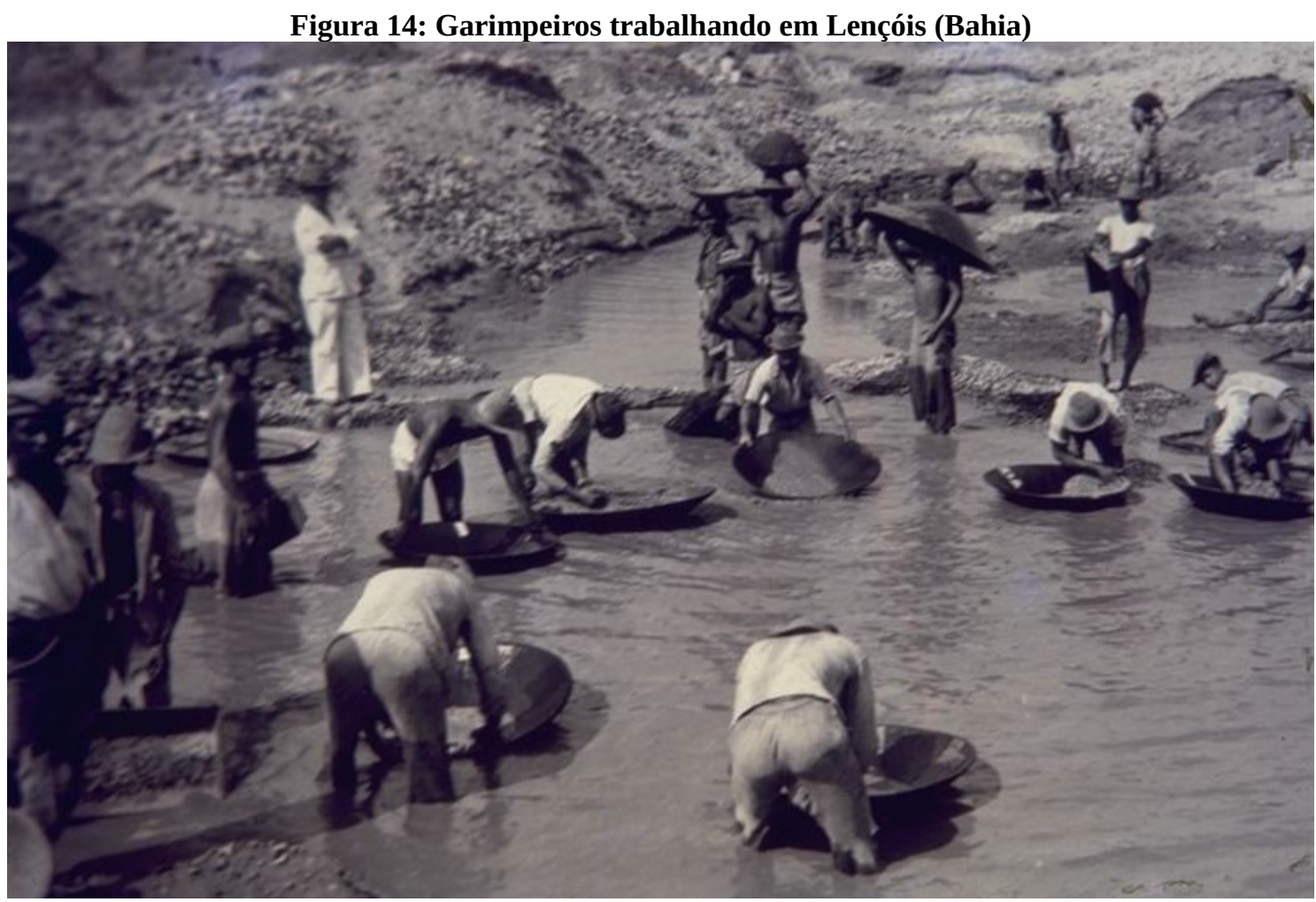

Fonte: Arquivo pessoal de Heraldo Barbosa Filho.

Esta fotografia data do início dos anos 1970, nesse período o garimpo estava em franca decadência em Lençóis. Ao fundo, do lado esquerdo da imagem se vê um homem vestido todo de branco, de braços cruzados observando os garimpeiros que lavam o cascalho “resumido” em bateias. Provavelmente está fiscalizando a lavagem para que não haja furto de diamantes.

A violência que caracteriza os conflitos territoriais entre os coronéis da região normalmente é interpretada como irracional do ponto de vista econômico, quer dizer, a sequência de sucessivas investidas violentas entre esses proprietários impedia que a região consolidasse suas atividades produtivas de forma coesa, realizando assim o potencial progresso baseado na riqueza mineral diamante. Pelo contrário, o que as imagens do processo extrativo dos diamantes podem sugerir, do ponto de vista desta pesquisa, é que a violência é 
parte constitutiva da razão econômica. No caso analisado a propriedade da terra é elemento central das relações de produção dos diamantes e é conquistada e garantida através do exercício direto da violência de forma não autonomizada da figura do capital e do proprietário de terras. O porte da violência é um atributo do proprietário/capitalista, por vezes literalmente incorporada por ele. Sobre Horácio de Matos, por exemplo, além da fama de bom estrategista de campo, se dizia ter corpo fechado (Moraes, 1997).

Na região a violência se encontrava em processo de autonomização, o que se pode averiguar a partir da figura do coronel que é seu principal portador, mas que também pode aparecer em relatos nas próprias relações de produção do ponto de vista de quem normalmente a sofre, o trabalhador. O garimpeiro regional é um sujeito econômico em formação também do ponto de vista da forma da violência à qual está sujeitado. Não se trata da sujeição à violência na forma posta pela relação da instituição escravista colonial, na qual a coação ao trabalho era exercida diretamente na forma do castigo e do aprisionamento do corpo do escravo. O garimpeiro se move por conta própria ao trabalho, está mobilizado pelo ganho monetário futuro, nesse sentido encontra-se já sob violência econômica stricto sensu, ainda que possamos questionar o papel do dinheiro na reprodução da família regional ${ }^{52}$. No entanto, como a justiça não se encontrava autonomizada, quando o contrato era quebrado, e até mesmo quando a quebra não era uma certeza absoluta, a forma da justiça normalmente era a violência extraeconômica ${ }^{53}$ aplicada por uma das partes, especialmente pela parte do proprietário.

Existem dois exemplos no romance de Herberto Sales, Cascalho (1951), que podem ser retomados aqui. O primeiro deles é o caso do personagem do jagunço Zé de Peixoto, que cuidava do barracão do Cel. Germano e, em uma noite em que estava bêbado, deu tiros para alto procurando um "homem de coragem", pois estava "com vontade de uma fecha", atalhando em seguida para o velho Justino, também jagunço do Cel. Germano: “vá escovar urubu na praia. Eu hoje não estou respeitando nem meu padrinho!”. O deslize do insulto ao padrinho foi sua sentença de morte no romance, o coronel que encontrava-se próximo, não

52 Ver item 5. Crise: novas relações e uma outra região desta dissertação.

53 Marx emprega o termo quando está tratando do caso da acumulação primitiva inglesa em " $O$ Capital": "Violência extraeconômica direta é ainda, é verdade, empregada, mas apenas excepcionalmente. Para o curso usual das coisas, o trabalhador pode ser confiado às "leis naturais da produção", isto é, à sua dependência do capital que se origina das próprias condições de produção, e por elas é garantida e perpetuada. Outro era o caso durante a gênese histórica da produção capitalista. A burguesia nascente precisa e emprega a força do Estado para "regular" o salário, isto é, para comprimi-lo dentro dos limites convenientes e manter o próprio trabalhador num grau normal de dependência. Esse é um momento essencial da assim chamada acumulação primitiva.” (Marx, 1996:359) 
tolerando desaforos, tempos depois encomendou a morte de Zé de Peixoto para o próprio delegado da cidade, o qual cumpre a ordem como um funcionário.

Mas, antes de ser morto, Zé de Peixoto protagonizou outro episódio exemplar de violência extraeconômica: deixando de ser apadrinhado pelo Cel. Germano, passou a fornecer o garimpeiro Peba e o sertanejo Silvério em uma nova frente de serviço na serra. Silvério encontrava-se na região das Lavras Baianas, na cidade de Andaraí, a fim de juntar dinheiro suficiente para voltar a ser roceiro em terra própria, fato que causava certo estranhamento aos garimpeiros da região que não entendiam a disposição de Silvério em voltar para o trabalho de lavrador, no qual mal se pega em dinheiro. No dia em que Peba e Silvério executariam a última etapa da garimpagem, a lavagem do cascalho, após um mês de serviço na serra, Zé de Peixoto subiu armado até o local de trabalho a fim de vigiar o serviço e evitar que fosse enganado. A cena é descrita por Herberto Sales como momento de forte desconfiança entre os homens, sobretudo de Peba e Zé de Peixoto com relação ao desconhecido Silvério. Num determinado momento os dois entendem que o lavrador tentara furtá-los engolindo um diamante que estava em sua bateia. Depois de ser esganado por Peba e sob a mira do parabélum de Zé de Peixoto, Silvério foi obrigado a beber meio litro de óleo de mamona. Após fazer efeito o poder laxante do óleo, o sertanejo foi obrigado a "garimpar” seus próprios excrementos, no que se verificou que era inocente da acusação dos outros. Ainda assim, Zé de Peixoto o expulsa do garimpo, impossibilitando que tome parte dos possíveis ganhos que seu trabalho ainda poderia render, e promete cobrar as quatro semanas de fornecimento que lhe havia adiantado.

Tomando esses dois exemplos fornecidos pelo romance regionalista que retrata as relações de trabalho na região das Lavras Baianas na década de 1920, é possível perceber que a separação da força de trabalho do trabalhador do próprio trabalhador não estava ainda completamente posta como realidade social. O corpo do outro era objeto da coação também pela violência direta, não imposta exclusivamente pela necessidade de se ganhar dinheiro e se adequar a um contrato prévio. Mesmo sendo o ganho monetário o fim que colocava todos em relação. Não havia instância jurídica separada à qual recorrer após a humilhação, ou na eminência do ato violento. Após o episódio na serra, Silvério vai dar queixar com Alípio, outro gerente do Cel. Germano. Se dá o seguinte diálogo:

\footnotetext{
“- Como é que se manda um pai de família lavar bosta! - exclamou [Alípio]. [...]$$
\text { - E o que é que você pensa em fazer? - continuou Alípio. }
$$ 
- Eu mesmo não sei - disse Silvério. - Eu estava pensando em dar queixa ao Cel. Germano.

[...]

- Você tem coragem de matar êle?

O sertanejo teve um sobressalto; para ocultar sua fraqueza, limitou-se a responder:

- Eu tenho quatro filhos pra criar, Seu Alípio. Não vou sujar minhas mãos com o sangue daquele negro.

Alípio tirou um cigarro do bôlso da calça:

- Bem, quer dizer que você não está disposto a matar êle, não é?

- Eu já disse ao senhor que eu tenho quatro filhos pra criar, Seu Alípio.

- Então não adianta você dar queixa ao coronel.

- Por quê?

Alípio acendeu o cigarro no candeeiro e sentou-se de novo na cadeira.

- Não adianta porque o coronel costuma fazer justiça é com as próprias mãos do queixoso - disse [...]” (Sales, 1951:141/142)

Na sequência Alípio sugere que Silvério vá dar queixa com o delegado da cidade, Esquivel, mas nenhum dos dois realmente acreditam que a questão será resolvida desta forma, o delegado age imediatamente de acordo com a vontade dos proprietários da cidade.

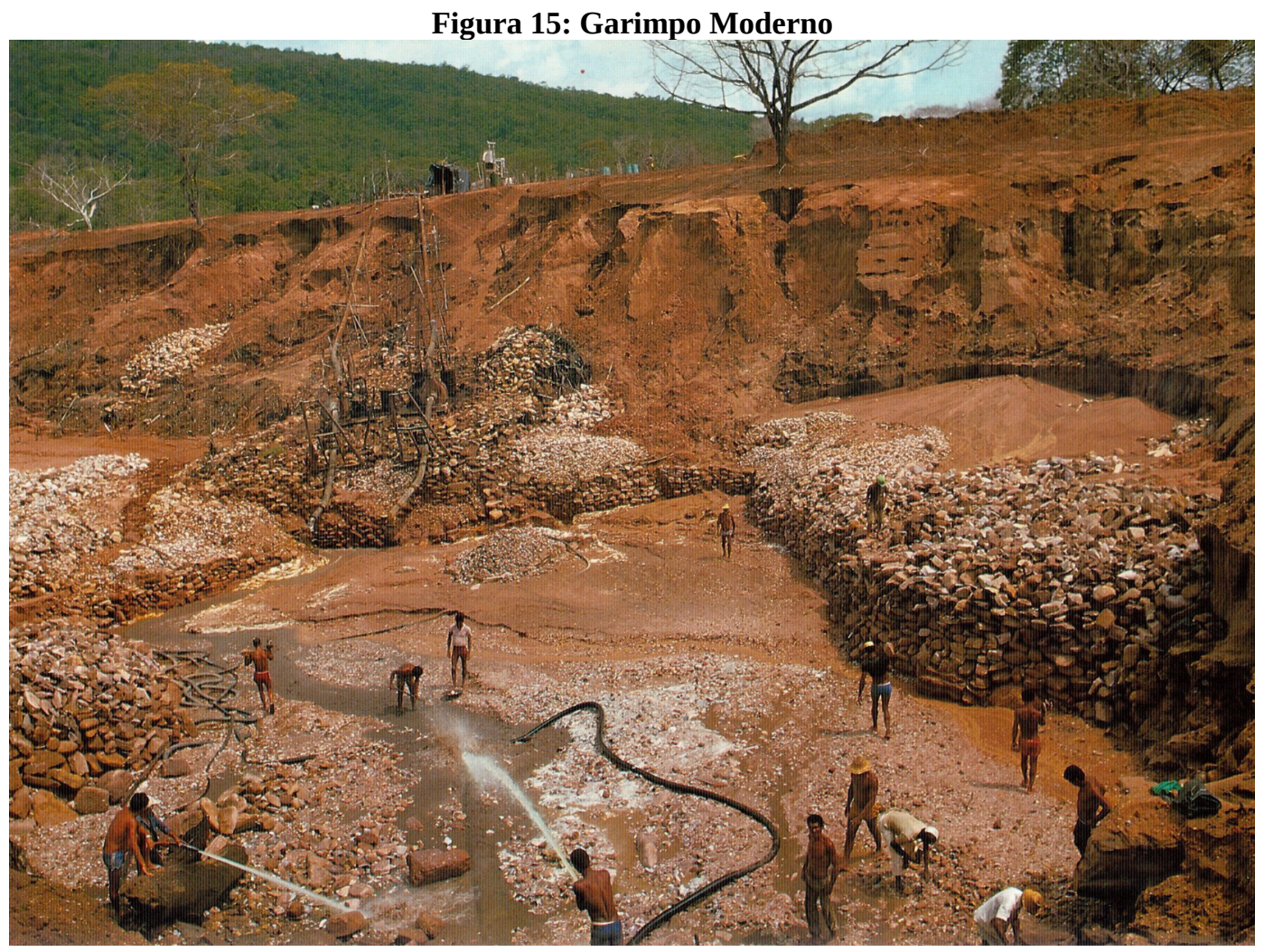

Fonte: Amado (1988)

A fotografia acima (Figura 15) é de Luiz Claudio Marigo, um dos pioneiros da fotografia de natureza no Brasil, e está presente no livro “Chapada Diamantina: Diamantina 
Highlands” de 1988. Na imagem vemos um grupo de garimpeiros trabalhando dentro de uma catra de garimpo mecanizado, conhecido também como garimpo de draga ${ }^{54}$. Na imagem, impressiona o volume de material revolvido na busca por diamantes, os garimpeiros são como miniaturas dentro do buraco. O texto de autoria de Jorge Amado, que acompanha a fotografia no livro informa que

"Hoje o garimpo não é mais artesanal, o diamante buscado e conseguido pelas mãos do homem no uso apenas de picareta e da peneira, hoje o garimpo é industrial, as dragas modernas retiram a água, escavam o leito dos rios, facilitam a vida dos garimpeiros. Tudo mudou aparentemente para melhor, apenas as jazidas estão exaustas, trabalhadas que foram durante tantos anos - o diamante é achado raro. Ainda assim os obstinados mantêmse na lavra, garimpando as derradeiras esperanças.” (Amado, 1988:14)

A pesquisa campo e outras fontes bibliográficas ${ }^{55}$ não confirmam as informações acima. Ainda que sobrepujado pelo garimpo de draga a partir dos anos 1980, o garimpo manual não deixou de existir. A permanência do dito garimpo artesanal até meados da década de 1990 se confirma de maneira significativa pelo próprio antagonismo com o garimpo mecanizado ${ }^{56}$. Além disso, a maior produtividade do garimpo mecanizado não coincide com diminuição do trabalho do garimpeiro, muitas vezes este passa a trabalhar em jornadas mais longas para dar conta das exigências que a racionalização da produção passa a exigir, o trabalho passa a ter a escala da máquina. Vale ainda destacar que a dificuldade de se achar diamantes não diz respeito à existência deles na área, na realidade os diamantes continuam existindo na Chapada Diamantina ainda hoje. De fato, a dificuldade maior estava em mobilizar capital e trabalho para empreender a prospecção. A chegada de capital na forma das dragas nos anos 1980 representou esse fôlego novo da atividade garimpeira na Chapada Diamantina, inclusive atraindo trabalhadores de áreas adjacentes.

Jorge Amado afirma também que os métodos mecanizados "facilitam a vida do garimpeiro”. As conversas com os garimpeiros colocam a afirmação em dúvida, é difícil chegar em uma posição conclusiva sobre as dragas entre eles, muitas vezes o mesmo

54 Mais informações sobre o garimpo mecanizado serão apresentadas a partir da página 116 dessa dissertação.

55 Por exemplo Brito (2005).

56 Após 1996, quando o Ibama, o Centro de Recursos Ambientais da Bahia (CRA), o Ministério de Minas e Energia, o Departamento Nacional de Produção Mineral e a Polícia Federal em ação conjunta fecham os garimpos de draga, os garimpeiros de Lençóis se organizam através da Sociedade União dos Mineiros (SUM) a fim de lutar contra a criminalização do garimpo de serra e pelo reconhecimento da importância cultural do garimpo na cidade. 
garimpeiro externa opiniões contradizentes entre si. Um fato é importante ressaltar, a mecanização do garimpo não necessariamente torna o trabalho do garimpeiro mais leve ou mais seguro, o garimpeiro não deixava de estar exposto a riscos, por vezes maiores que no garimpo de serra manual. De uma forma distinta, o garimpo mecanizado continua sendo um trabalho violento. Além dos casos de violência entre os envolvidos no processo de trabalho, assim como no garimpo manual são vários os relatos de acidentes de trabalho no garimpo “industrial”. A própria mecanização redundou no aumento de certos riscos, um dos mais comuns era o desmoronamento de terra no momento da desagregação do solo com jato d’água, acarretando por vezes o soterramento de trabalhadores que se encontram no local.

Mas os riscos que o garimpo de draga representava para os trabalhadores, quando muito, foram tratados como tema marginal nos debates envolvendo a atividade nas décadas de 1980 e 1990. Nas palavras de Carlos Ribeiro, que produziu o texto sobre a história da Chapada Diamantina que compõem o livro junto com as fotografias de Luiz Claudio Marigo e as legendas de Jorge Amado, "ao lado dos benefícios em termos de criação de empregos e revalorização da região, o que se verifica de concreto é o prosseguimento de uma prática altamente danosa ao meio ambiente" (Amado, 1988:25). O autor verifica ainda, que no final dos anos 1980

\footnotetext{
“O afluxo de aventureiros, turistas, botânicos e naturalistas, para essa região, indica o reconhecimento dos grandes atrativos que dispõem - e não são poucos os que se dedicam ao conhecimento e à preservação do seu patrimônio natural, histórico e cultural. Talvez, em breve, não seja mais necessário, aos seus habitantes, buscar em outras cidades um futuro melhor ou a viver de um passado remoto, quando o diamante ficava à flor da terra.” (Amado, 1988:25)
}

Quer dizer, nesta perspectiva, mais que as próprias pessoas envolvidas na atividade, quem sofre a violência do garimpo de draga é a natureza. Que o potencial da nova forma de mineração era realmente devastador está claro, no entanto, é de se notar como se abstrai a violência do próprio trabalho que sofrem as pessoas mobilizadas. Na linha discursiva do livro, as pessoas viviam do "passado remoto", da esperança na restituição da história gloriosa das lavras. Esse apego ao passado é tratado como um mal a ser suplantado pela esperança em um futuro diferente, viabilizado pela atividade do turismo. Curiosamente esse esperado futuro dadivoso está baseado na mobilização do passado que se quer superar. Em nome da fé neste futuro possível, a violência do passado e do presente é sistematicamente abstraída, ou melhor, autonomizada. 
Se entre a década de 1920 e 1940 são raras as notícias que pautavam diretamente a violência no jornal regional $O$ Sertão, hoje na área da Chapada Diamantina já se produz aquele que ficou conhecido como "jornalismo marrom”, especializado no tema. Isso para não falar de quando a região é tema do jornalismo nacional ${ }^{57}$. Alguém que não esteja dedicado exclusivamente a ser um consumidor dos “atrativos" da Chapada Diamantina, com pouco esforço pode se deparar com uma fotografia (Figura 16) como esta abaixo:

Figura 16: Chapada: Polícia põe fim em 'boca de fumo' na cidade de Lençóis

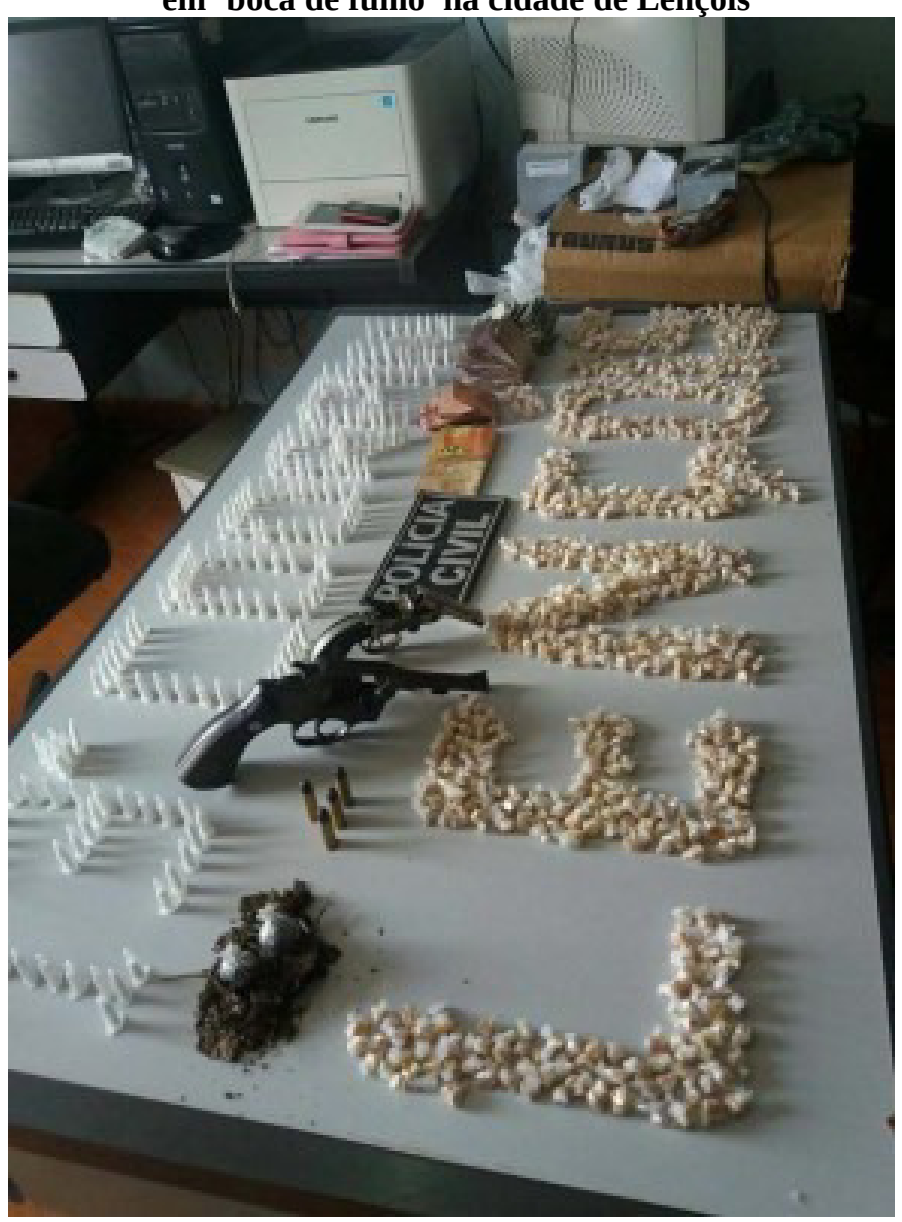

Fonte: https://jornaldachapada.com.br/2016/02/23/ chapadapolicia-poe-fim-em-boca-de-fumo-na-cidade-de-lencois/

Ela foi publicada no dia 23 de fevereiro de 2016 no portal do Jornal da Chapada na internet, ilustrando uma nota que informava a descoberta e o desmantelamento de uma "boca de fumo" pela polícia civil no bairro do Tomba Surrão em Lençóis. Na imagem, produzida de acordo com um padrão recorrente em fotografias para divulgação do resultado do trabalho

$57 \quad$ No dia 6 de agosto de 2017 seis homens foram vítimas de uma chacina no território quilombola de Iúna, em Lençóis. O ocorrido foi notícia na edição do Jornal Nacional da Rede Globo do dia 8 de agosto de 2017. 
policial, se vê escrito o nome da cidade com embalagens de pedra de crack sobre uma mesa da delegacia, além de outros materiais apreendidos na operação e a identificação da instituição.

Os trabalhos de campo realizados no âmbito desta pesquisa revelaram a frequência cotidiana de histórias de violência direta na cidade de Lençóis, a maioria delas desdobramentos da disputa entre grupos do narcotráfico, do embate destes com a polícia e da abordagem truculenta que a mesma adota com uma parcela da população local. Em 2016, nas semanas que antecederam o $18^{\circ}$ Festival de Lençóis as batidas policiais se intensificaram, senão efetivamente em números absolutos, ao menos para a percepção daqueles que de antemão são os suspeitos de sempre. Conhecidos residentes nos bairros populares da cidade, em sua maioria negros, estavam evitando andar na rua durante a noite para não sofrerem o constrangimento de uma batida policial, das quais foi possível ouvir alguns relatos.

A fotografia abaixo (Figura 17) foi feita na última noite de apresentações do referido festival, nela se vê em primeiro plano um policial militar e um fotógrafo, eles observam o público que aparece em segundo plano durante uma das apresentações, ao fundo parte de duas edificações da Praça Horácio de Matos e do palco do evento.

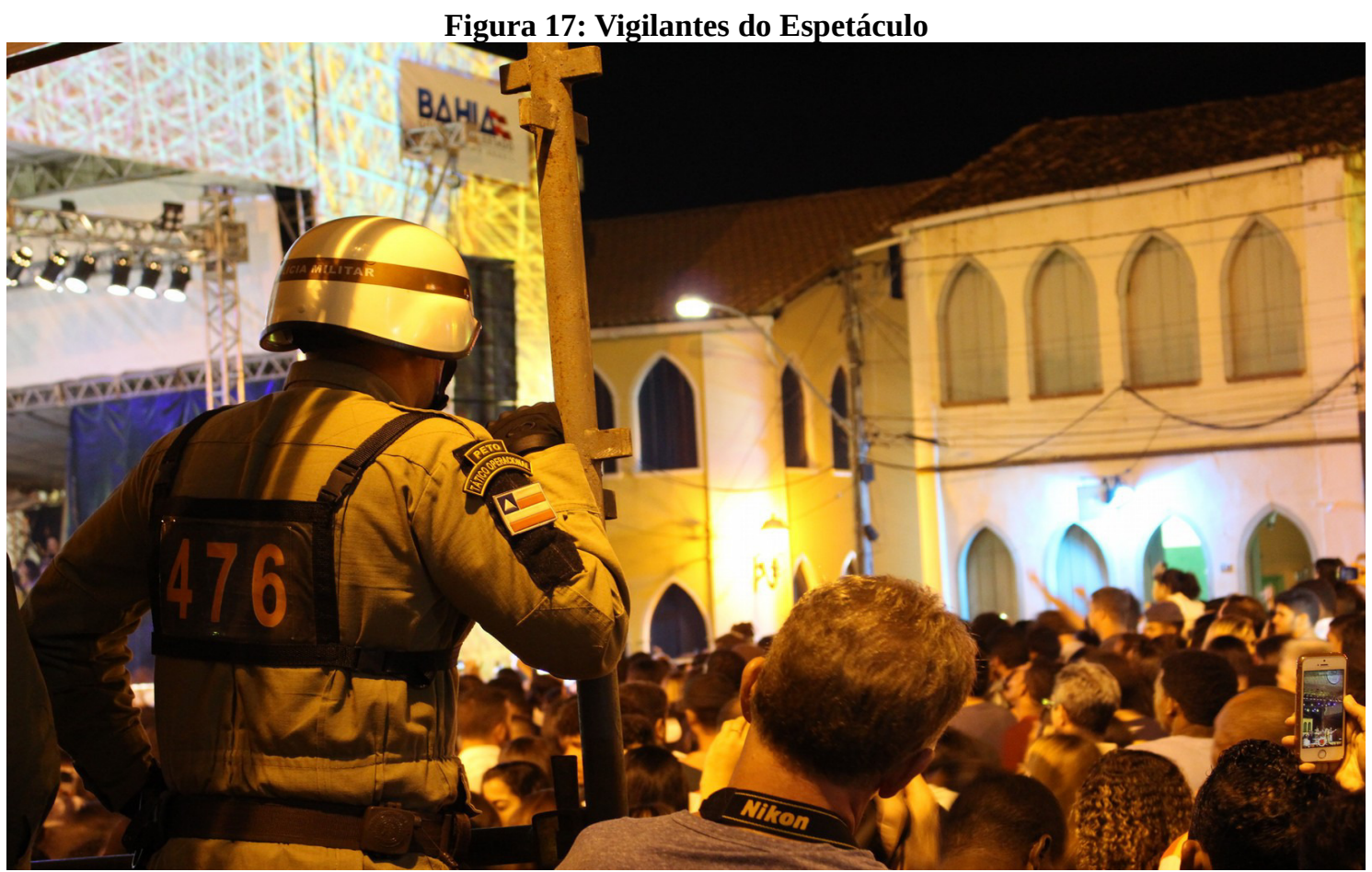

Fonte: Arquivo pessoal do Autor. 
As duas fotografias estão relacionadas às formas de violência na cidade de Lençóis, não resta dúvida, uma vinculada aos conflitos entre a polícia e o narcotráfico e outra evidenciando a naturalização da militarização que aumenta durante um grande evento como o festival. No entanto, essas imagens dificilmente seriam incorporadas na composição da identidade visual usual da cidade para o turismo, elas destoam sensivelmente das imagens utilizadas para esta finalidade. A fotografia acima deverá ser guardada como registro de pesquisa, no máximo utilizada como ilustração de um trabalho acadêmico. Já o Jornal da Chapada é um veículo de informações de circulação restrita, que tem como público os moradores da área.

Além disso, a violência autonomizada como função do Estado nacional nos parece menos chocante que o monopólio da violência pelo coronel. Numa sociedade profundamente militarizada uma fotografia em que se constate a existência massiva de policiais nos parece mais natural, ou aceitável, do que o jagunço do coronel. Isso revela que não se trata de uma simples permanência da violência, entendê-la como continuidade do passado pode fazer com que se perca de vista a compreensão da forma como os fundamentos sociais a movem atualmente.

Neste sentido, a pergunta sobre as diferenças entre a forma da violência na Lençóis dos coronéis, para a Lençóis do turismo não é uma banalidade. O postal de Lindemann explicita um elemento importante para o desdobramento desta questão: a violência direta que marcava a sociedade garimpeira estava imediatamente relacionada às relações de produção particulares do coronelismo. Em outros termos, a violência extraeconômica não havia ainda se tornado função exclusiva do Estado nacional. Na fotografia vemos o jagunço do garimpo, ele representa a violência extraeconômica e é parte do capital do proprietário. Lá o nexo entre capital e violência é evidente. Ao que parece o mesmo movimento interpretativo não se aplica à situação atual, na qual a autonomização do porte da violência pela polícia apaga esse nexo. Pelo contrário, trabalho e produção aparecem como oposto da violência, quem porta violência além da polícia é marginal. Nas representações fotográficas a autonomização se repete, turismo e violência não se misturam, e se isso ocorre, são entendidos como um par dualista. 


\section{A REGIÃO É ABERTA E ESQUECIDA}

No item 9. Crise: regressão econômica e abertura da região o tema da abertura foi abordado brevemente, a intenção agora é retomar a análise de tal processo de modo a acompanhar o desenvolvimento histórico dos nexos externos que se estabeleceram e a maneira como estes reverberaram na reprodução social da área estudada. Como foi dito, a abertura da região se dá como momento da Revolução de 1930, a qual internamente a região das Lavras Baianas é marcada politicamente pela entrega das armas do chefe sertanejo Horácio de Matos e de seus jagunços. Tal evento, antes de ser um erro estratégico do coronel ou da simples traição de que é alvo, deve ser entendido como parte das transformações das relações de produção e da estrutura de classes em escala nacional.

O quadro do período republicano do país que antecedeu as transformações que se dão a partir 1930 pode ser resumido como o de uma economia agroexportadora, que tinha a região do café no Centro-Sul como área economicamente mais dinâmica do Brasil, o que, no entanto, não representava uma ameaça significativa às outras oligarquias regionais, sobretudo às oligarquias nordestinas. No que diz respeito às relações de produção, o baixíssimo desenvolvimento técnico e o monopólio da violência pelos coronéis que "fecham” as regiões conformavam um mosaico de formas de relações consideradas não especificamente capitalistas $^{58}$, das quais foram sintetizadas aquelas que caracterizavam a região das Lavras Baianas. A industrialização e urbanização resumiam-se a experiências marginais no território naquele momento, sendo que a maioria do parco proletariado existente neste período se reproduzia sobretudo no interior da empresa ${ }^{59}$, quer dizer, ainda estavam por se formarem os pressupostos sociais que viabilizariam a existência de um mercado de trabalho nacional, ou algo com aparência de um.

58 O que a literatura costuma associar às formas não salariais de remuneração do trabalho, mas que me parece ser melhor definido pela não formação do tempo abstrato e da superpopulação relativa, o que extrapola a questão das formas de remuneração.

59 São casos exemplares desse padrão de industrialização pré-1930, no qual as fábricas mantinham vilas operárias, as iniciativas de Irineu Evangelista de Sousa, o Barão de Mauá, a cidade de Paulista em Pernambuco dependente inteiramente da fábrica de tecidos da família Ludgren; a vila ferroviária de Paranapiacaba, cujas edificações foram trazidas da Inglaterra pela São Paulo Railway Company, que chegava inclusive a planificar as atividades de lazer de seus operários; ou ainda a experiência de Delmiro Gouveia em Alagoas com sua Companhia Agro Fabril Mercantil na produção de linhas. 
O processo instaurado pelo golpe que levou Getúlio Vargas à presidência, mais do que uma simples disputa pelo poder, representou um ponto de viragem da estrutura econômica do país, consequentemente a reorganização das relações entre classes inerentes à nova estrutura e à reorganização das instituições mediadoras das relações. Trata-se, de forma sumária, da formação de uma economia urbano industrial que se hegemoniza na escala do Estado nacional, o que pode ser entendido também como processo de internalização da metrópole, e que se instala através de uma política de destituição da centralidade do plantation extravertido. Nesse particular é de se salientar que a questão escalar não está aqui entendida apenas como ponto de vista da análise do pesquisador que escolhe este ou aquele recorte espacial. Da perspectiva aqui adotada, a questão escalar diz respeito à história da imposição da modernização, ou seja, a estruturação de Estados nacionais periféricos como necessidade para a reprodução do capitalismo do século XX, o que se dá de forma particular a depender das características das sociedades onde a modernização retardatária ${ }^{60}$ (Kurz, 1992) é imposta. Neste sentido, a questão escalar está posta pela acumulação capitalista como contradição em processo (Scholz, 2016). Pode até ser considerada como uma questão de método nesta pesquisa, na medida em que o método está posto pela realidade social a ser interpretada, não como escolha do pesquisador.

A história econômica do Estado nacional brasileiro tende a interpretar a industrialização como decorrência de dois fatores. Por um lado, da acumulação proveniente da cafeicultura paulista, no que se percebe certo cariz evolucionista da teoria, que deduz a industrialização da aparente acumulação monetária interna, abstraindo o processo genitivo das novas relações de produção e o debate acerca do fundamento substantivo ${ }^{61}$ de tal processo.

60 Modernização retardatária diz respeito àqueles processos de modernização empenhados como planejamento estatal já tendo os níveis de produtividade dos países centrais como parâmetros impostos pela concorrência.

61 A substância é material, porém não coisal: "Esta força é ela própria uma substância material, não porém natural, mas social. A substância natural da abstração real moderna, como abstração da forma do princípio essencial "valor", é a matéria abstrata física $e$ mecanicisticamente reduzida; a substância social deste princípio da forma da metafísica real é - o "trabalho abstrato" (Marx). O "trabalho", como forma de atividade e ao mesmo tempo como substância do capital, constitui a força social-material e o processo, através do qual somente pode afirmar-se no mundo terreno o princípio da forma da metafísica real, com a sua pretensão de Absoluto negativa e destrutiva. O movimento mediador do trabalho abstrato é a automediação da substância e, assim sendo, um fim-em-si e uma auto-agregação na forma do valor (manifestando-se na forma do dinheiro) e como permanente "alienação [Entäusserung]" na matéria natural e nas relações sociais, enquanto sua moldagem até à respectiva destruição, a fim de as transformar na simples imagem da abstração real que se processa consigo mesma." (Kurz, 2004/2005) 
Por outro lado, identifica como fator determinante da internalização da indústria o elemento circunstancial da oferta deficitária de bens industrializados ${ }^{62}$, que já faziam parte do universo de consumo nacional, sobretudo bens de consumo não-duráveis, como os têxteis por exemplo. Francisco de Oliveira (2013) critica $^{63}$ o limite economicista desses argumentos (que, no entanto, não deixam de ser constituintes materiais da industrialização brasileira) por apagarem os elementos políticos que seriam a base de tal transformação. Em outras palavras, para o autor a industrialização se desenvolve também como projeto de uma burguesia nascente, que se realiza através de uma série de mudanças políticas institucionais e infraestruturais.

Para Francisco de Oliveira (2008), a principal forma de proceder o enfraquecimento da economia agroexportadora e fortalecer o capital industrial voltado para o mercado interno no Brasil foi o estabelecimento do controle das taxas de câmbio e importação. O que se deu de forma casada com a destituição das taxas alfandegarias entre os estados, forçando a entrada das manufaturas do Centro-Sul nas demais regiões ao mesmo tempo que inviabilizava a balança de pagamentos das mesmas através do câmbio, formando assim um comércio triangular interessante à burguesia nacional nascente. Além disso, outras estratégias foram postas em prática neste mesmo sentido:

“A destruição das regras do jogo da economia agrário-exportadora significava penalizar o custo e a rentabilidade dos fatores que eram tradicionalmente alocados para a produção com destino externo, seja confiscando lucros parciais (o caso do café, por exemplo), seja aumentando o custo relativo do dinheiro emprestado à agricultura (bastando simplesmente que o custo do dinheiro emprestado à indústria fosse mais baixo)." (Oliveira, 2013:35)

62 A economia mundial vivia os reflexos da grande crise de 1929 e viria a ser, cerca de nove anos depois, abalada pela eclosão da Segunda Guerra Mundial, a qual demandaria das grandes potências industriais envolvidas esforço ímpar para suprir as demandas decorrentes do conflito, sendo inclusive momento fulcral do salto de produtividade do capitalismo mundial.

63 "O estilo de interpretação ao qual se acostumou associar a industrialização, tanto na América Latina quanto no Brasil, e que fornece as bases para uma tímida teoria da integração latinoamericana privilegia as relações externas das economias capitalistas da América Latina e, nesse diapasão, transforma a teoria do subdesenvolvimento numa teoria da dependência (Furtado). Parece, assim, que a industrialização substitutiva de importações funda-se numa necessidade do consumo e não numa necessidade de produção [...] da acumulação; além disso, as formas de consumo impostas de fora para dentro parecem não ter nada a ver com a estrutura de classes, com a forma da distribuição da renda, e são impostas em abstrato: começa-se a produzir bens sofisticados de consumo, e essa produção é que cria as novas classes, é que conforma o padrão de distribuição de renda, é que 'perverte' a orientação do processo produtivo, levando no seu paroxismo à recriação do 'atrasado' e do 'moderno'." (Oliveira, 2013:49). 
A política intervencionista é de fato momento determinante do processo que se analisa, é a forma necessária da instalação da modernização retardatária no país. No entanto, salvaguardadas as particularidades inerentes às distintas sociedades em que tal processo se deu, parece importante destacar que como forma histórica geral o mesmo ocorreu em uma série de outros países, não se tratando, pois, de uma singularidade da subjetividade da burguesia brasileira. Por isso, e por outros motivos, é possível colocar em questão a interpretação que entende que os pressupostos da internalização da metrópole se acumularam internamente pela jovem república.

Se a história é o campo das possibilidades em disputa, a mirada da história da modernização retardatária e da instalação do Estado nacional brasileiro a partir do presente, antes de tudo, parece se revelar como limite da acumulação interna dos países centrais do capitalismo global. Pressupondo aqui o argumento desenvolvido por David Harvey (2005), é mais coerente interpretar tal processo como “ajuste espacial” imposto às então potências imperialistas pelo automovimento da acumulação capitalista como forma de mitigar as chamadas "contradições internas da sociedade civil” (mantendo o vocabulário hegeliano do qual Harvey se vale no artigo em questão), destaque dado aos EUA. Nesse sentido a insistência na escala do Estado nacional brasileiro como ponto de partida da análise do processo revela o cariz nacionalista do argumento.

Seguindo a interpretação de Francisco de Oliveira, como condição imanente da existência de uma burguesia nacional, forma-se também o operariado, para o que concorre outra política fundamental, qual seja: a das leis trabalhistas, e dentre elas destaque dado a fixação do salário-mínimo. O autor critica as teorias que julgam que o salário-mínimo fixou institucionalmente o salário a cima do custo de reprodução da força de trabalho, portanto acima do salário que uma economia de livre mercado formaria. Para ele a análise da evolução dos salários reais apontaria para um processo de estagnação, sobretudo a partir da década de 1960.

Aqui vale relembrar que a fixação do salário-mínimo é uma das formas da eliminação da necessidade da reprodução da força de trabalho no interior da empresa, ou seja, estamos diante da separação da mercadoria força de trabalho da pessoa do trabalhador, processo que se dava pela primeira vez no núcleo do setor dinâmico da economia nacional.

O debate sobre o salário posto nos termos do cálculo de sua justeza conforma, do ponto de vista aqui adotado, uma falsa questão. Isso porque, em primeiro lugar, não existiu a 
possibilidade no Brasil ${ }^{64}$ da formação de uma economia de livre mercado como gostaria um teórico de extração neoclássica, por tanto tal cálculo é por si absurdo. Ao mesmo tempo, a disputa em torno do que se pode chamar de salário justo parece questão de interesse de teóricos da modernização, não exatamente de uma teoria crítica da economia política. O que interessa destacar aqui é que a contradição em processo impôs o salário mínimo como relação neste momento histórico no Brasil. Antes de mais nada, o salário mínimo como promessa da vida urbana constitui-se como elemento da mobilização do trabalho (Gaudemar, 1977) no período de formação da superpopulação relativa nos centros metropolitanos brasileiros. Vale lembrar que o Estatuto do Trabalhador Rural data somente de 1963, cerca de trinta anos depois da CLT de Vargas, quer dizer, ainda que seja difícil avaliar quantitativamente, é inegável que a afamada carteira de trabalho influiu decisivamente nos fluxos de migração e na constituição de um mercado de trabalho no Brasil. Pensado de maneira genérica, o salário mínimo é um dos elementos ideológicos centrais para ultrapassagem de um ponto de nãoretorno da auto-expropriação a que se submeteu uma enorme massa de trabalhadores ao migrarem do campo para a cidade neste momento.

Já para Francisco de Oliveira, a legislação trabalhista

“Ao mesmo tempo que cria as condições para a acumulação necessária para a industrialização (...) é a cumeeira de um pacto de classes, no qual a nascente burguesia industrial usará o apoio das classes trabalhadoras urbanas para liquidar politicamente as antigas classes proprietárias rurais, e essa aliança é não somente uma derivação da pressão das massas, mas uma necessidade para a burguesia industrial evitar que a economia, após os anos da guerra e com o boom dos preços do café e de outras matérias-primas de origem agropecuária e extrativa, reverta à situação pré-anos 1930.” (Oliveira, 2013:64)

Como já abordado no item 9. Crise: regressão econômica e abertura da região, o antagonismo duro entre classes proprietárias rurais e burguesia nascente, enquanto agrupamentos sociais distintos, conforma certo cariz dualista da interpretação. Enquanto classe dominante, boa parte da burguesia e da tecnocracia brasileira descende das famílias proprietárias rurais, não considerando tal fator corre-se o risco de desconsiderar as estratégias

64 Rigorosamente não existiu ou existirá livre mercado em canto algum, mas o papel de mediador das contradições impostas pelo capital exercido pelo Estado nacional apresenta caráteres históricos importantes de serem distinguidos ao longo da história da modernização. Como não é o caso de desdobrar aqui tal debate, fica indicada a referência sobre o tema nos textos de Robert Kurz: "A falta de autonomia do Estado e os limites da política: quatro teses sobre a crise da regulação política" (1994) e o segundo capítulo de "O Colapso da Modernização": "Estatismo e Monetarismo no Processo Histórico da Modernidade” (1992). 
das classes dominantes para manterem-se no poder ante um processo de modernização no qual se reposicionam somente como sujeitos de suas adequações às transformações do processo de reprodução social capitalista. Este último sim, o sujeito ${ }^{65}$ automático que dita o processo social. Nesse sentido as migrações dos filhos das classes proprietárias rurais para os centros urbanos, sua formação técnica e acadêmica e sua inserção na nova estrutura social, seja como empresários, seja como quadros da burocracia ou ainda como produtores da indústria cultural nacional, representa, não o antagonismo sugerido, mas a manutenção dos donos do poder. Entre os quais, ainda assim, certamente não faltaram perdedores.

Particularmente interessado no assalariamento, Francisco de Oliveira aponta que a formação de um proletariado nacional está longe de significar a generalização dessa forma de relação, quer dizer, da instalação da mais-valia relativa (Marx, 1996) como forma de exploração generalizada. Para ele, ainda que a burguesia industrial passe a gerir a política econômica, não se dá a dissolução da estrutura agrária precedente ou mesmo uma generalização do assalariamento no espaço urbano, sobretudo no caso do terciário. Nesse sentido, o autor aponta que ainda que aparentem ser permanências da ordem ultrapassada pela industrialização, a manutenção da estrutura fundiária e das relações de produção no campo e o trabalho informal do inchado terciário urbano devem ser entendidos como partes constitutivas da modernização brasileira ${ }^{66}$. Agricultura e indústria, nesse sentido, não formariam um par dual, no qual a primeira estava atrasada em relação a segunda: as relações de trabalho do campo, tidas como atrasadas, cumprem o papel de rebaixar os custos da cesta básica e,

65 "Assim, enquanto em A sagrada família (1845) Marx critica o conceito filosófico de "substância" e, em particular, o entendimento de Hegel da "substância" como "sujeito", no início d'O Capital ele faz uso da categoria substância. Ele se refere a valor como tendo uma "substância", que ele identifica com o trabalho humano abstrato. Marx, então, já não considera "substância" uma simples hipostasia teórica; agora a entende como um atributo das relações sociais mediadas pelo trabalho, como expressão de um tipo determinado de realidade social. Em O Capital ele investiga a natureza dessa realidade social desenvolvendo logicamente as formas de mercadoria e dinheiro a partir das suas categorias de valor de uso, valor e sua "substância". Sobre essa base, Marx começa a analisar a complexa estrutura de relações sociais expressas pela sua categoria do capital. Inicialmente ele determina capital em termos de valor que se autovaloriza. Nesse ponto de sua exposição, Marx descreve o seu conceito de capital em termos que se relacionam claramente com o conceito hegeliano de Geist. [...] Marx caracteriza explicitamente o capital como a substância em processo que é o sujeito. Ao fazê-lo, Marx sugere que um sujeito histórico no sentido hegeliano existe realmente no capitalismo, mas ainda assim ele não identifica com nenhum grupo social, como o proletariado ou a humanidade. Pelo contrário, Marx o analisa em termos da estrutura de relações sociais constituídas pelas formas de prática objetivante e apreendidas pela categoria do capital (e, portanto, valor).” (Postone, 2014:96)

66 Qual o tamanho desta parte? Qual sua determinação no processo? São questões em aberto para esta pesquisa. 
consequentemente, da reprodução da força de trabalho urbana. Além disso, é através das divisas oriundas do setor agroexportador que o país amealharia, em sua instável balança comercial, parte do capital a ser invertido na adequação tecnológica de seu parque industrial.

No entanto, estão abstraídos no argumento do autor as diferenças qualitativas da reprodução da força de trabalho nos casos $\operatorname{contrapostos}^{67}$. Isso se dá porque mercadoria e trabalho são naturalizados como mediações sociais, ou seja, como forma trans-histórica da relação humana e da relação entre sociedade e natureza. Assim, não se debate a historicidade do valor como forma da riqueza na formação social capitalista ${ }^{68}$, recaindo a crítica sobre os termos da apropriação desigual da riqueza socialmente produzida nesta formação social, particularmente no Brasil, o caso analisado. Interessa nesse particular chamar atenção para o caráter da expropriação a que foram submetidas as massas de migrantes mobilizados para a formação da superpopulação relativa (esta sim a questão fulcral no debate da formação do mercado de trabalho no Brasil: a formação da superpopulação relativa) nas metrópoles do Centro-Sul: parte ${ }^{69}$ da riqueza que lhes é expropriada neste processo não corresponde em nada com a mais-valia (ou com o próprio valor), mas sim com a inviabilização da possibilidade de acesso à riqueza efetiva ${ }^{70}$ que a migração acarreta. Em outras palavras, o que se destaca é uma

67 O que não exclui a importância da crítica do dualismo subjacente nas interpretações que diferem as formas de relação comparadas em um sentido evolucionista e que perdem os nexos de suas existências simultâneas.

68 Mais tarde, em 1988, no artigo "O surgimento do antivalor", ao demonstrar que "no fundo, levado às últimas consequências, o padrão do financiamento público "implodiu" o valor como único pressuposto da reprodução ampliada do capital, desfazendo-o parcialmente enquanto medida da atividade econômica e da sociabilidade em geral”, a historicidade do valor é considerada, ainda que trabalho, como seu fundamento, permaneça intocado pela crítica.

69 Novamente, qual o tamanho dessa parte é uma questão em aberto para nesta pesquisa. De qualquer forma, o que salta aos olhos é que a supressão é tendente à totalidade.

70 "[...] muitos argumentos relativos à análise de Marx da unidade do trabalho como fonte de valor não reconhecem essa distinção entre "riqueza efetiva" (ou "riqueza material") e valor. Mas a "teoria do valor-trabalho" de Marx não é uma teoria das propriedades únicas do trabalho em geral, mas uma análise da especificidade histórica do valor como forma de riqueza e do trabalho que supostamente o constitui. Consequentemente, é irrelevante, para Marx, argumentar a favor ou contra a sua teoria do valor, como se ela fosse proposta como uma teoria da riqueza-trabalho (trans-histórica) - ou seja, como se Marx tivesse escrito uma economia política e não uma crítica da economia política." (Postone, 2014:41/42). Ainda que a diferença explicitada por Postone seja central para a análise aqui desenvolvida, a definição de riqueza efetiva pode ser apreendida em sua exposição justamente como contínuo trans-histórico, de maneira parecida com a forma que o valor é entendido pelo marxismo tradicional. Por isso, é o caso de colocar em questão também tal riqueza efetiva. Se aproxima polo do valor de uso que constitui o fetichismo da forma de consciência capitalista. Quer dizer, não seria o caso de apontar e destrinchar também sua historicidade? 
transformação qualitativa da forma da expropriação que não pode ser tomada como simples crescimento da taxa de exploração.

Para Francisco de Oliveira, uma primeira fase da industrialização nacional se fez baseada na produção de bens de consumo não-duráveis que compunham a cesta do trabalhador, sendo, portanto, também fator determinante para o rebaixamento dos custos de reprodução da força de trabalho, pois do contrário tais bens seriam importados. Apenas em uma segunda fase, e sendo resultado da necessidade da produção/acumulação do capital industrial nacional e não da demanda pelo consumo, se instalaria a produção de bens de consumo duráveis, intermediários e bens de capital. Tais bens (dos quais o automóvel talvez seja o exemplo máximo), diferente dos produtos que compõem a cesta do trabalhador, que por isso deveriam se manter com preços baixos, são realizados a preços mais altos que a média internacional, justamente alimentando a cadeia de acumulação dos chamados ramos dinâmicos. A realização dessas mercadorias só pôde ser garantida pela formação de uma classe média: trabalhadores relativamente bem remunerados composta pelos técnicos, “colarinhos brancos”, profissionais liberais e da burocracia estatal, surgidos como necessidade do novo arranjo produtivo nacional urbano industrial. Vale destacar que o discurso do nacional, ou de seu devir, é formulado justamente por este novo agrupamento social, o qual, como personificador privilegiado do espetáculo internalizado no Brasil, focaliza o nacional como escala prioritária. Nesse esquema interpretativo a região é associada com a natureza (o campo do negativo, do irracional), aquela a ser dominada pela racionalidade planificadora para uns, ou alçada como particularidade que identificaria a forma da modernidade antropofágica brasileira para outros.

Ainda que saliente que

"Era tal a carência desses serviços, que a primeira onda de industrialização
assistiu à tentativa de autarquização das unidades fabris, processo que logo
seria substituído por uma divisão do trabalho para além dos muros da
fábrica. Logo em seguida, com a continuidade da expansão industrial, esta
vai compatibilizar-se com a ausência de acumulação capitalista prévia, que
financiasse a implantação dos serviços, lançando mão dos recursos de mão-
de-obra, reproduzindo nas cidades um tipo de crescimento horizontal,
extensivo, de baixíssimos coeficientes de capitalização, em que a função de
produção sustenta-se basicamente na abundância de mão-de-obra." (Oliveira,
2013:55)

Para Francisco de Oliveira (2013), esta primeira fase da reprodução da indústria nacional se faz internamente (quer dizer os pressupostos da acumulação são constituídos por 
um processo interno ao território brasileiro), mesmo que parte de sua capitalização se faça através das divisas alcançadas no mercado externo com a venda de commodities, como o caso do café. Para ele esse quadro irá se transformar somente a partir de 1968, o que será abordado mais adiante.

Francisco de Oliveira compreende a industrialização como resultado na diferenciação inter-regional, ou melhor, no fim das regiões, entendidas como entes políticos econômicos isolados em âmbito nacional, com laços diretos com o exterior. Essas ex-regiões passam a compor um todo político-econômico, o Estado nacional, com papéis distintos entre si na nova estrutura. De certo que o centro dinâmico da indústria nacional se forma no Centro-Sul, tendo como principais polos as cidades de São Paulo e Rio de Janeiro, tornando-se assim espécie de modelo nacional a ser alcançado. Já o Nordeste, ganha a aparência de estagnação, como se não tivesse, pelos motivos que fossem, conseguido acompanhar o Centro-Sul desenvolvido, mantendo-se assim uma sociedade “tradicional”. A crítica do autor neste particular recaí coerentemente sobre a interpretação dualista da oposição entre moderno e tradicional ${ }^{71}$, a qual não corresponde a forma como o processo se deu, quer dizer, não é possível compreender Centro-Sul e Nordeste como entes autônomos na dita acumulação industrial brasileira.

Mesmo assim, a afirmação do caráter endógeno da industrialização nacional garantida pela realização interna da produção industrial é problemática. É possível interpretar essa questão retomando a afirmação do início deste subitem a respeito da questão escalar. Vinculála ao desenvolvimento histórico da reprodução capitalista fornece elementos centrais para a interpretação da problemática dos pressupostos da industrialização brasileira.

Para tanto seria interessante retomar o argumento de David Harvey em "O Ajuste Espacial” (2005). Neste artigo o geógrafo está interessado em rever o lugar da questão espacial na teoria econômica, mais especificamente nas possibilidades abertas pela dominação territorial para a estabilização do capital. O que em termos mais diretos seria uma pergunta sobre o papel do ajuste espacial para a solução das crises de superacumulação. Após apresentar como a questão foi abordada por Hegel e Von Thünen, Harvey apresenta o posicionamento de Marx no debate, este último bastante enfático na anteposição a Hegel: no argumento de Marx a distribuição de lucros (primeira solução apontada por Hegel $^{72}$ para as

71 Tendo em vista um dos temas de interesse dessa pesquisa, a turistificação da área da Chapada Diamantina, o debate sobre a oposição entre moderno e tradicional parece importante já que ganha novos contornos - sobretudo na mercantilização do exotismo -, permanecendo a interpretação dualista dessas realidades com pano de fundo nas interpretações correntes.

72 As duas soluções, segundo Harvey, são: impostos sobre os ricos para criar trabalhos para os pobres, mas isso segundo Hegel somente exacerba a contradição, pois mais riqueza será produzida numa sociedade que não tem como consumi-la. "Assim, Hegel tem de considerar um 
contradições da sociedade civil) é simples relaxamento ocasional, que afeta apenas um pequeno grupo de trabalhadores. No que diz respeito ao argumento do ajuste espacial, o trabalhador poder sair do país, fugindo da contradição da sociedade civil, poderia representar uma possível solução para o trabalho, mas certamente não para o capital, para o qual a expropriação como processo crescente é uma necessidade. Em Marx o ajuste espacial não resolve as contradições do capitalismo, seria apenas sua mitigação e a reposição da crise alhures.

Mesmo assim, Harvey relativiza o posicionamento de Marx a partir do próprio autor, apontando que o ajuste espacial é uma das contra-tendências à queda da taxa de lucro (Marx, 1996), ainda que tal argumento apareça de forma difusa na obra do autor alemão. Do contrário, a única solução para crise de acumulação, que não seja ajuste espacial, é desvalorização de capital como moeda (inflação), mercadoria, capacidade produtiva ou do trabalho. E, fechando o argumento, Harvey ressalva a partir do próprio Marx:

“Não é possível um país continuar a inundar outro país com seus produtos”, afirma Marx, "a não ser que o primeiro país seja capaz de dar ao segundo país algum proveito em troca". Portanto, "quanto mais o interesse industrial (no caso abordado trata-se dos interesses britânicos) tornava-se dependente do mercado indiano, mais sentia necessidade de criar novos recursos produtivos na Índia”.” (Harvey, 2005:116)

De qualquer forma, Harvey considera que Marx estava posicionado de modo bastante claro, muito influenciado pela anteposição a teoria hegeliana, em afirmar o ajuste espacial como expansão das contradições internas do capitalismo. O feito do pensador alemão para o geógrafo britânico teria sido explicitar a natureza destas contradições. O final do século XIX, no entanto, impôs ao marxismo o debate sobre o imperialismo, o que recolocou a questão espacial na pauta de debate novamente. Harvey considera que tais análises por vezes encaminham a interpretação para um esquema de dominação tipo centro-periferia que fazem tábula rasa das contradições internas do capitalismo. Seu intuito, portanto, seria buscar o encontro entre a teoria da acumulação capitalista de Marx com a geografia histórica do capitalismo, de Lenin.

segundo conjunto de soluções. A sociedade civil, assevera ele, move-se por sua "dialética interna", "impelindo-se para além dos seus limites e buscando mercados - portanto, meios necessários de subsistência - em outros países, deficientes nos bens que superproduziu e/ou atrasados no setor industrial”. Também deve fundar colônias e, assim, permitir que parte de sua população "retorne a uma vida sobre uma base familiar em uma nova terra", enquanto também "oferte a si mesma com uma nova demanda e um novo campo para sua indústria"." (Harvey, 2005:100) 
A partir da teoria da acumulação capitalista, das contradições internas do capitalismo como relação social, Harvey olha para sua geografia histórica a partir do centro e vê emanar dali o processo de expansão territorial de tais contradições. Assim, a periferia do capitalismo está posta pelo ajuste espacial do centro, que nada mais é que a externalização de sua crise. Interessante notar que tal externalização, a depender da forma como se dá, redunda na contradição da gestação da concorrência - o que no caso analisado pelo autor não se dá na relação entre a metrópole imperialista britânica e sua colônia indiana, mas sim na formação dos EUA, a futura nova potência imperialista.

Olhando bem para o caso da dita industrialização brasileira, tendo tais questões em mente, é difícil sustentar o argumento da internalidade de sua formação. De maneira sucinta, é possível lembrar, por exemplo, da massa de migrantes estrangeiros que compuseram a superpopulação relativa dos centros urbanos brasileiros, muitos deles mobilizados pela reestruturação produtiva dos países europeus entre o final do século XIX e a primeira metade do século XX, além dos conflitos armados que transformaram aquele continente, decorrentes do processo de modernização. Ou ainda, pelo montante nada insignificante de capital internacional, fruto da superacumulação em seus locais de origem, que compuseram os inputs da industrialização brasileira, pois já não poderiam ser reabsorvidos em novos ciclos nesses locais $^{73}$. Quer dizer, existe uma relação fundamental entre o processo de modernização retardatária brasileira e os termos da acumulação do capitalismo mundial. O que a eleição intransigente da escala do Estado nacional como ponto de vista tende a obliterar.

Mas a interpretação da chamada industrialização brasileira comporta elementos importantes para este debate. Seguindo os argumentos teóricos de Harvey, grosso modo, o capital superacumulado, sobretudo nos EUA, mas também em outras centralidades, não mais podendo se reproduzir em novos ciclos de acumulação nesses países teria se realizado aqui e assim, consequentemente, também a industrialização brasileira. No entanto, parece importante colocar em perspectiva tal industrialização nacional, de modo a considerá-la sob o prisma do fundamento capitalista da valorização do valor. De fato, essa questão extrapola os limites dos capitais individuais e deveria, se fosse possível, ser tratada como do conjunto dos capitais nacionais na relação com o capitalismo global ${ }^{74}$. Ainda assim, no desdobrar dessa dissertação será tratado o tema do limite lógico e histórico da valorização enquanto processo que se

73 O que se deu, por exemplo, na forma de exportação do Departamento I superproduzido pelas economias centrais, sobretudo os EUA.

74 Como se pretende que fique claro: também o Estado nacional não pode ser considerado como totalidade fechada a ser analisada. O caso é de superar os limites do nacionalismo, e tratar a questão de um ponto de vista fenomênico não restrito a contabilidade. 
repetiria infinitamente. Suspeitar da incapacidade de remuneração dos investimentos de capitais para industrialização brasileira neste momento seria o mínimo para uma leitura crítica do processo.

Além disso, essa questão evidencia uma importante diferença com a maneira como Harvey parece compreender a crise. A ideia de que a crise possa ser resolvida com novos expedientes de espoliação, incorporando assim excedentes como recriações de acumulação primitiva parece entender o capital estritamente como coisa, matéria. No entanto, o problema na crise não é propriamente acumular mais coisas, mas sim criar e aprofundar mais relação capital. Mais uma vez: capital é uma relação social. Neste sentido, o ajuste espacial somente efetiva sua capacidade de suspensão provisória da crise ao acumular novas relações extensivamente.

Olhando para a fisicalidade da industrialização brasileira é inegável sua realização, porém como reposição da valorização do valor que caracterizou a industrialização nos países centrais do capitalismo possivelmente não tenha realmente se dado tal processo no Brasil, tendo em conta a diferença de produtividade dos capitais nacionais em relação ao exterior. Tratar-se-ia mesmo de um fetiche de industrialização.

Ainda assim, vale ressalvar que tal formulação, ao apontar os limites da interpretação da industrialização brasileira, o faz assumindo o ponto de vista do valor como referência a ser criticada. Por outro lado, a partir do ponto de vista da vida cotidiana do trabalhador o avançar da modernização como imposição da mediação do trabalho e da mercadoria é contundente no processo em questão. Sem levar em conta este segundo momento a crítica perde potência analítica.

O Nordeste passa a ser um “problema” a ser resolvido pelo Estado nacional quando o capital superacumulado no Centro-Sul passa a demandar novas áreas de expansão. Isso porque o limite da região aberta não é a concorrência, a rigor a região não fali. Mesmo estando completamente fora da média da produtividade social a região aberta se reproduz como empreendimento porque funciona como minadouro de mais-produto, na qual a força de trabalho se reproduz marginalmente ao mercado, e o proprietário/capitalista se reproduz como capital comercial. Além disso, o fator do acirramento da luta de classes se tornou uma ameaça considerável no Nordeste, como é o caso exemplar das Ligas Camponesas. É nesse momento 
que se constitui a Superintendência do Desenvolvimento do Nordeste (Sudene), em 1959 ${ }^{75}$, sob a batuta de Celso Furtado, à autarquia era auferida a função de resolver o problema da desigualdade inter-regional ${ }^{76}$. Em verdade, a Sudene representa a instalação do EstadoProvidência ${ }^{77}$ no Nordeste, tendo como principal instrumento de ação a renúncia fiscal em benefício das empresas que lá se instalassem.

“Tratava-se, na verdade, em termos mais teóricos, de converter toda a
riqueza nacional, especialmente a parte que era captada pelo Estado, em
pressupostos da nova produção: um mecanismo típico do capitalismo
monopolista e de seu correlato, o Estado monopolista.” (Oliveira, 2008:252)
“A Sudene traz inscrita, desde sua origem, a marca da intervenção
'planejada' no seu programa, que se reflete mesmo nos textos das leis de sua
criação e de seus planos diretores, isto é, de uma tentativa de superação do
conflito de classes intra-regional e de uma expansão, pelo poder de coerção
do Estado, do capitalismo do Centro-Sul. Isso não é uma dedução que se

75 Antes disso, desde meados dos anos 1950 se formou no Recôncavo Baiano, como excepcionalidade no caso do nordeste, o enclave industrial da Petrobras que viria remediar a deficiência da base energética da industrialização nacional. Por quase três décadas o Recôncavo será o único produtor de petróleo no Brasil, suprindo um quarto do consumo nacional (Oliveira, 2003). “[...] a massa de investimentos da Petrobras não tem paralelo na história econômica do estado [Bahia]: entre 1955 e 1959, o total de investimentos corresponderá de 1\% até 7,4\% da renda total e de 8,1 a 66,9\% da renda interna industrial do estado da Bahia. A massa de salários pagos pela Petrobras despejada na economia baiana crescerá à razão anual de 18\% reais, entre 1958 e 1969, e no mesmo período se elevará de 7,64\% a 38,7\% do total da renda industrial interna do estado, tendo atingido o nível de 50\% no ano de 1967. Toda essa massa monetária, de investimentos e salários, concentrada num espaço reduzido, praticamente no Recôncavo e em Salvador, transformará a economia baiana radicalmente. A dinâmica dessa radicalidade concentrará a renda em Salvador quase como em nenhuma outra parte do Brasil.” (Oliveira, 2003:43)

76 Antes disso já havia sido criado em 1952 o Banco do Nordeste do Brasil (BNB), caracterizado por ser o banco de desenvolvimento daquela região.

77 Francisco de Oliveira se vale do termo em seu artigo "O Surgimento do Anti-valor" (1988) para se referir a transformação do Estado nacional a partir do pós-guerra nos países centrais do capitalismo e que o autor via chegar em seu limite no final dos anos 1980. O EstadoProvidência "pode ser sintetizado na sistematização de uma esfera pública onde, a partir de regras universais e pactadas, o fundo público, em suas diversas formas, passou a ser o pressuposto do financiamento da acumulação de capital, de um lado, e, de outro, do financiamento da reprodução da força de trabalho, atingindo globalmente toda a população por meio dos gastos sociais." (Oliveira, 1988:8). Para Francisco de Oliveira "o fundo público é agora um ex-ante das condições de reprodução de cada capital particular e das condições de vida, em lugar de seu caráter ex-post típico do capitalismo concorrencial. Ele é a referência pressuposta principal, que no jargão de hoje sinaliza as possibilidades da reprodução. Ele existe "em abstrato" antes de existir de fato: essa "revolução copernicana" foi antecipada por Keynes, ainda que a teorização keynesiana se dirigisse à conjuntura. A per-equação da formação da taxa de lucro passa pelo fundo público, o que o torna um componente estrutural insubstituível." (Oliveira, 1988:9). 
permite apenas por um exame a posteriori: o que não estava garantido era 0 sucesso do empreendimento, mas seus objetivos não poderiam ser mais claros." (Oliveira, 2008:251)

Afora os limites da análise que elege o Estado nacional como ponto de vista, já mencionado acima, o que está sugerido é que o empreendimento do planejamento racional da inversão do capital nacional pela Sudene está inscrito no momento ímpar da centralização do capital (Marx, 1996) no Brasil. A Sudene funcionava já como ajuste espacial interno ao Estado brasileiro. Se nas páginas acima se apontou em nota de rodapé o caso da industrialização baiana particularmente concentracionista, o contrário não pode ser tomado como verdade para o restante do país. Francisco de Oliveira frisa que a escalada da concentração de renda reverberará de forma imperativa no salário mínimo real, no que se averígua o aprofundamento do processo inflacionário. Sobre isso,

“[...] pode-se perceber claramente três fases no comportamento do saláriomínimo real: a primeira, entre os anos 1944 e 1951, reduz pela metade o poder aquisitivo do salário; a segunda, entre os anos 1952 e 1957, mostra recuperações e declínios alternando-se na medida do poder político dos trabalhadores: é a fase do segundo governo Vargas, que se prolonga até o primeiro ano do governo Kubitschek; a terceira, iniciando-se no ano 1958, é marcada pela deterioração do salário mínimo real, numa tendência que se agrava pós-anos 1964, com apenas um ano de reação, em 1961, que coincide com o início do Governo Goulart.” (Oliveira, 2013:78)

Para Francisco de Oliveira a crise que se gestava terá a partir do governo Kubitschek caráter múltiplo; para os bens de consumo da cesta do trabalhador é crise de realização, justamente em decorrência da compressão dos salários reais; já para os bens de consumo duráveis, as camadas médias acabam assegurando sua reprodução e, desta maneira, reporiam o processo concentracionista em termos elevados. Para o autor, pode-se falar do crescimento da taxa de exploração e do momento da quebra do pacto populista, do que decorreria o acirramento da luta de classes durante os primeiros anos da década de 1960 e que irá se desdobrar no golpe militar de 1964.

Sobre tal processo, vale atentar para uma mudança importante nos termos da reprodução da força de trabalho urbana, mudança esta que se realiza gradativamente ao longo dessas pouco mais de três décadas analisadas até aqui. Trata-se do crescimento relativo dos elementos mercantis que compõem a reprodução do trabalhador, do que duas consequências imediatas se desdobram. A primeira delas diz respeito ao significado da reificação como processo social experimentado pelo trabalhador, o qual, na medida que uma parcela maior de 
suas necessidades passa a ser suprida (e criada) através do mercado e que seu salário sofre rebaixamento real, irá experimentar a depreciação de suas condições de reprodução. Uma ruptura inédita até então na história do país, já que experiência de migração campo-cidade neste período, ainda que signifique a submissão desses trabalhadores a taxas de exploração muito maiores do que de seus lugares de origem (se é que podemos expor tal comparação nesses termos), via de regra são experimentadas como ascensão da dita “qualidade de vida”, tendo em vista a discrepância das condições materiais de reprodução contrapostos. Aquele que já era um trabalhador tornara-se um consumidor ao migrar.

Já do ponto de vista da reprodução capitalista nacional, a inclusão dessa massa de trabalhadores no mercado como consumidores necessários à reprodução da indústria nacional (diferente do campo brasileiro, sobretudo no Nordeste), no modelo de acumulação concentracionista, com o achatamento dos salários reais, representa a gestação a longo prazo de uma crise de superacumulação.

Os três primeiros anos de regime militar, sob o Plano de Ação Econômica do Governo (PAEG), não representam mudanças significativas do quadro econômico:

“Qual é o primeiro resultado da execução do PAEG? Uma forte recessão, que se prolongará até o ano de 1967, e que é, um tudo e por tudo, bastante semelhante à breve recessão surgida logo após a tentativa de execução do Plano Trienal sob a batuta conjunta Santiago Dantas - Celso Furtado [Governo Goulart]. A identidade do erro deriva da identidade das supostas causas: a de que se estava em presença de uma inflação de demanda; o remédio era, num como noutro caso, a contenção dos meios de pagamento, o corte nos gastos governamentais, e o resultado foi, numa como noutra experiência, a recessão, breve a primeira e prolongada a segunda. (Oliveira, 2013:93) 
A REGIÃO ESQUECIDA

Como se percebe, no item anterior o esforço foi o de esboçar um quadro interpretativo sumário do Brasil como crítica da economia política entre 1930 e os últimos anos da década de 1960. Se essa recapitulação da formação do Estado nacional no Brasil nas três décadas e meia que sucedem a dita República Velha, silenciou momentaneamente a análise particular da área das Lavras Baianas, isso não se deu por descuido, mas sim porque a crítica do dualismo é fundamental para a compreensão do que se deu internamente na área estudada. Quer dizer, se por um lado o fato das Lavras Baianas não serem mencionadas nas páginas a cima diz respeito aos limites do lugar de onde se faz a teoria, mesmo que atenta à crítica do dualismo, por outro pode ser encarado como expressão da aparência de autonomia que as áreas ganham no processo analisado, no que uma análise da área das Lavras Baianas por ela mesma também incorreria. Se a análise aqui exposta sobre o período entre 1930 e 1967, é feita separada no texto, os desdobramentos do processo social no período subsequente levam a tentar uma mescla das escalas de análise, como se verá. Mas antes disso, cabe a pergunta: o que se deu na área das Lavras Baianas neste período?

Como região mineradora, a área já vivia desde as últimas décadas do século XIX a crise resultante da concorrência das minas sul-africanas e do escasseamento do diamante encontrado nas camadas superficiais do solo, quer dizer, aquelas pedras extraíveis através do emprego quase que exclusivo de trabalho vivo, com investimento em capital constante insignificante. Em seu diário de campo na viagem pelo rio São Francisco e Chapada Diamantina Teodoro Sampaio registra suas impressões do início de 1880:

“Como se vê, foi extensissima a superfície lavrada nestes sertões á cata do diamante.

Por occasião da nossa visita, porém, a mineração estava já em franca decadência. As lavras permaneciam abandonadas, e os lucros das que ainda se mantinham já não compensavam muitas vezes os esforços dos mineiros. Os trabalhos agricolas começam a solicitar a attenção dos habitantes já agora desenganados de que não podiam esperar mais nada da mineração.” (Sampaio, 1905:202) 
É de se notar, no entanto, que foi justamente esse o momento que é identificado o início de um ciclo do carbonato ${ }^{78}$ (vinculado à segunda revolução industrial e a grandes obras ao redor do mundo nas quais essas pedras encontradas em quantidade significante exclusivamente na área das Lavras Baianas e impróprias para joalheria, mas de dureza semelhante aos diamantes e por isso utilizadas para perfuração, corte e polimento), do qual se fala como de grande relevância comercial, mas que, no entanto, aparentemente não impediu a evasão dos garimpeiros da região. A contradição fica em aberto para esta pesquisa: a região detém o monopólio da extração do carbonato (que é entendido como de grande relevância comercial) por cinquenta anos (Herold, 2011), não apresenta mudanças significativas em termos de composição orgânica do capital e, ao mesmo tempo, sua população segue diminuindo.

O relatório (1897) produzido pelo engenheiro de minas francês Henri Babinsk para dois investidores europeus interessados em negócios na área das Lavras Baianas é revelador ao narrar a exiguidade de ferramentas empregadas na extração de diamantes na Serra do Sincorá. O engenheiro, ao descrever o uso dos carumbés ${ }^{79}$ no processo de garimpagem observado na região, afirma que "as picaretas, pás e carrinhos de mão parecem completamente desconhecidos no local” (Babinsk, 1897:26), do que se depreende a escassez de capital empregado para extração das pedras.

O relatório de Babinsk é revelador também ao fornecer dados populacionais das cidades das Lavras Baianas, o que provocou a revisão da formulação assumida até então neste processo de pesquisa, formulação na qual se relacionava o esvaziamento populacional da área das Lavras Baianas com o movimento revolucionário de 1930. Essa proposição era baseada na narrativa do jornalista Walfrido Moraes (1997), sobre a história do Cel. Horácio de Matos, fonte recorrente de pesquisas sobre a Chapada Diamantina. Nela Moraes afirma que

"Quando, porém, tomaram dos elementos dessa civilização [refere-se às Lavras Baianas] os seus instrumentos essenciais de luta [refere-se a entrega

78 Sobre os carbonatos Teodoro Sampaio registrou: "Não consta terem-se encontrado jamais, nesta região, diamantes de mais de uma oitava, mas os carbonatos e as torras têm-se achado de grande volume, extrahindo-se mensalmente grandes partidas, que regulam por mil oitavas, á vista da grande procura que essas pedras, especialmente o carbonato, tem tido no mercado pela sua applicação nas industrias.

Até hoje, só na Chapada Diamantina se tem encontrado o carbonato.

Ha trinta annos não se pagava por oitava do carbonato mais que $1 \$ 280$ reis. Hoje, os preços subiram tanto, que se pode equiparar essa pedra escura e feia ao próprio diamante." (Sampaio, 1905:204)

79 Vasilha produzida artesanalmente em madeira ou metal, utilizada para transporte e lavagem do cascalho. 
das armas à Revolução de 1930] - e eliminaram o seu verdadeiro líder [refere-se ao assassinato de Horácio de Matos em 1931] [...] ficou evidente que já não restava mais nada. Estava destruído de vez, por uma revolução nacional, um sistema secular de vida regional, sem a necessária compensação, por quem de direito, em termos de implantação de outro sistema.

Então, o povo foi saindo, saindo para muito longe.

[...]

Milhares e milhares de garimpeiros e mesmo famílias e de indivíduos que exerciam atividades correlatas à garimpagem foram deixando a região.

$[\ldots]$

Para que se tenha uma ideia exata dessa fuga, basta o fato de que, daquelas trinta mil criaturas que se comprimiam, em meados do século XIX, às margens do rio Lençóis, transformando, logo mais, o sítio, numa das mais civilizadas cidades sertanejas restam, apenas, segundo estatísticas recentíssimas, 2483 pessoas [o ano de publicação da primeira edição do livro é 1963].” (Moraes, 1997:181-182)

Ainda que de forma imprecisa, a narrativa de Moraes sugere que o processo de esvaziamento populacional das Lavras Baianas passa a se dar a partir de 1930, no entanto o relatório de Babinsk, de 1897, reporta uma população aproximada para a cidade de Lençóis de apenas 3000 pessoas $^{80}$. Esta informação sugere que a regressão econômica (Furtado, 1979) mais significativa da região já havia se dado ainda no século XIX, tendo parte significativa de sua população já migrado quando ocorreu a "revolução nacional”, possivelmente a maior parte para as áreas agropastoris sertanejas do entorno ou para outras áreas garimpeiras.

Ainda assim, a entrega das armas e o assassinato de Horácio de Matos simbolizam uma mudança importante, senão o fim do fausto da região das Lavras Baianas, já que esse período parece ter se encerrado ainda durante o século XIX, mas o fim do pleno controle político da região pelos coronéis locais, que até a década de 1920 ainda conseguiam se antepor em armas de igual para igual com as forças estaduais e nacionais, como se deu durante as Revoltas Sertanejas (Chagas, 1996 e Moraes, 1997). Neste caso, se antepor em armas é a forma de aparecer da concorrência entre capitais: a entrega das armas, nesse sentido, marca a suplantação do poder das oligarquias regionais ante o novo ente gestor da economia política no assim entendido território nacional brasileiro ${ }^{81}$.

A questão populacional referente as Lavras Baianas continua em aberto. É bastante provável que os dados oferecidos pela pesquisa de Babinski se restrinjam apenas aos núcleos urbanos das referidas cidades. Relatos de moradores mais velhos de Lençóis, por exemplo,

80 Em seu relatório Babinski calcula para Palmeiras uma população de 1500 habitantes, para Andaraí 2000 habitantes e para Santa Isabel (atual Mucugê) 2500 habitantes. 
revelam a existência de pequenos núcleos de moradia vinculados ao garimpo que deixaram de existir apenas ao longo da segunda metade do século XX. De certo a população encontrava-se muito mais pulverizada pelo território do que se encontra hoje. De qualquer forma, é importante destacar as dificuldades que permeiam tal debate para além dos números absolutos. Se por um lado o levantamento documental já é bastante difícil de se fazer para o caso da área estudada ${ }^{82}$, por outro, seria importante interpretar os dados populacionais pensando as formas das relações de trabalho praticadas na área e naquilo que tais dados podem nos revelar sobre a formação de superpopulação relativa. Os números por si dizem pouco.

No capítulo da lei geral da acumulação capitalista Marx (1996 [L. 1, V. 2]) demonstra que se observada em perspectiva histórica a acumulação de capital não corresponde a uma operação meramente quantitativa, ela implica na transformação qualitativa da composição do capital, o qual entendido como processo social generalizante deve ter sua parte constante em crescimento relativo se comparada a sua parte variável. Esse movimento tem desdobramentos fundamentais para o desenvolvimento das crises, mas o que interessa salientar agora é a determinação da formação de uma superpopulação relativa para o estabelecimento do dito modo de produção capitalista,

\begin{abstract}
"Essa população excedente de trabalhadores, que funciona como alavanca da acumulação, parece ser fruto de um crescimento natural da população maior que o crescimento da oferta de empregos, mas, no entanto, o é de uma "lei populacional” própria ao capitalismo, que aparece naturalizada.” (Leite, 2014:79)
\end{abstract}

81 O caso da demonstração do poder de fogo da metralhadora em praça pública em Lençóis um dia antes da prisão de Horácio de Matos por parte do primeiro-tenente revolucionário Hamilton Pompa D’Oliveira é exemplar se tivermos em conta que armas se compram com dinheiro: "Marcada para segunda-feira a viagem de volta, no domingo à tarde, na pracinha do mercado em frente ao rio, o jovem revolucionário faz sua última encenação de valentia. Convida o Coronel Horácio de Matos e as demais autoridades, convida o povo, através de boletim, para assistir ao manejo da mais moderna arma de guerra que a revolução usou nos seus assaltos. A esta altura, milhares de pessoas, garimpeiros, bruaqueiros, capangueiros estão na terra para a feira do dia seguinte. O tenente, então, cercado por um pelotão revolucionário que o acompanha, manobra com furor uma metralhadora pesada, pondo-lhe o pente longo de cartuchos, e varre o inimigo imaginário na barranca do rio que está perto." (Moraes, 1997:175)

82 Marjorie Csekö Nolasco (2002:86) apresenta uma sistematização dos dados populacionais referentes à área das Lavras Baianas em sua tese de doutorado "Registros Geológicos gerados pelo garimpo, Lavras Diamantinas - Bahia.” 
Assim, o que determina os salários não é a população trabalhadora absoluta, mas sim a composição entre ocupados e reservas. A queda da superpopulação na produção capitalista encaminha o processo para a busca do aumento da produtividade, repondo assim seu pressuposto populacional. Superpopulação é o pano de fundo no qual opera a dita lei da oferta e procura da força de trabalho como mercadoria, quando não existe, tende-se a criar sua existência por artifícios variados. A formação da superpopulação relativa é, portanto, o processo violento de expropriação do trabalhador dos pressupostos de sua reprodução como já tratado acima. Esse mecanismo diz respeito a sociedades em que a relação capital opera sobre seus próprios pressuposto, no caso brasileiro a

“ [...] acumulação se transformou com o processo de autonomização entre o Estado metropolitano e a colônia, que se constituíra num Estado Independente, quando a acumulação passou a estabelecer internamente as bases da reprodução. No momento em que o fundamento dessas bases (a superpopulação relativa) ainda não estava estabelecido, a acumulação encontrava-se fundada na reprodução regional, ela própria processo de autonomização das categorias do capital, que viria a desembocar na formação do Estado nacional e na ascensão do moderno sistema produtor de mercadorias. Processo passado primeiramente em São Paulo, com a cafeicultura e o colonato, mas a se generalizar por outras regiões brasileiras, no longo processo de modernização retardatária que se iniciou em 1930. (Leite, 2014:84)

Seria o caso de pensar a forma dessa generalização na área estudada. O debate entorno da população da área das Lavras Baianas interessa na medida em que é neste fator que se estabelece o principal nexo daquela área decadente com o processo de industrialização e formação do Estado nacional, quer dizer, a região implodida faz parte dos “vastos sertões” de onde emigraram as massas que formaram a superpopulação relativa dos grandes centros urbanos brasileiros. Ou seja, a autonomização das categorias do capital não se dá como processo interno na área das Lavras Baianas nesse período. Detalhe a ser relembrado: não foram apenas os despossuídos que abandonaram a área, grande parte das famílias proprietárias também é mobilizada pelo processo e será desse agrupamento social, que tem acesso à educação nos centros urbanos, que parcela da classe média baiana em formação adveio.

Quanto a migração dos trabalhadores, é de se notar que estamos diante de um processo de mobilização para o trabalho que ao mesmo tempo é processo de mobilização para o consumo de mercadorias, ou seja, a formação do trabalhador urbano expropriado é ao mesmo tempo formação do consumidor que se reproduz exclusivamente, ou quase exclusivamente, através do mercado. Essa dupla formação tem importância central para a análise aqui 
empreendida, esse trabalhador/consumidor que surge efetivamente neste momento da história nacional estará sujeitado as transformações do regime de acumulação, quer dizer, sua existência como personificação do processo social comporta historicidade em nada trivial.

Agora é possível retomar a crítica do dualismo a partir de um olhar interno a área das Lavras Baianas. Se por um lado no próprio capítulo da lei geral da acumulação capitalista Marx (1996) diferencia acumulação de centralização (a segunda já é incorporação de capital por capital), e aponta a centralização como um dos sentidos do processo - atrelado ao movimento imposto pela própria acumulação, quer dizer, capitais maiores ou mais produtivos, incorporam capitais menores. O caso das famílias proprietárias da cidade de Lençóis, por outro lado, corresponde a um processo de centralização decorrente da regressão da acumulação da relação regional. Carlos de Almeida Toledo (2008) demonstra em sua tese como a referida migração dos proprietários/capitalistas da cidade implica na centralização das terras diamantíferas nas mãos do Cel. Armando Spinola Pereira, o qual permanece como sócio/gestor desses terrenos e ao longo do tempo se estabelece como principal proprietário das terras garimpáveis. Como personificação da terra, capital e Estado, Armando Spinola Pereira aparece nas narrativas locais como figura mais comedida no uso da violência direta, o que é compreensível justamente pelo desarmamento dos coronéis pela revolução de 1930 (inclusive com a destituição da Guarda Nacional enquanto instituição legitimadora de tais personas politicamente), além da inexistência de outros proprietários concorrentes na área. Mas a manutenção das atividades pelo proprietário e depois por seu filho, Isaías Pereira, só é possível porque existiram famílias que permaneceram na área sobrevivendo através de atividades que extrapolavam os parcos rendimentos do garimpo. Para tanto, além do acesso à dita riqueza efetiva, essas famílias também dominavam o conjunto de conhecimentos que tornava viável fazer dessa possibilidade também um uso efetivo dos recursos.

Mas o que move o trabalhador migrante da área das Lavras Baianas para os centros urbanos? Walfrido Moraes supõem que os moradores de Lençóis deixam a cidade por conta da morte do Cel. Horácio de Matos, ainda que se esteja longe de concordar com tal hipótese, enquanto padrão de discurso regional a versão do historiador é exemplar, a narrativa heroica da história da elite regional e o personalismo são uma marca da forma de entender o processo histórico internamente. Outra hipótese bastante difundida pelas narrativas orais sobre o processo de emigração na vila de Igatu, o imputa a uma grande seca ocorrida na década de $1940^{83}$, a qual teria forçado seus moradores a fugirem para sobreviverem. Que tenham

83 É de se notar que a data não coincide com nenhuma das grandes secas históricas registradas no nordeste brasileiro. 
existido motivos destacáveis, como a seca, que representassem um ponto limite para a tomada de decisão pela migração é evidentemente plausível, mas não pode encerrar o debate em torno da questão migratória. Os motivos da migração em massa da força de trabalho para os centros urbanos certamente não se esgota nos fatores expulsivos, a atração desses trabalhadores era elemento determinante nesse processo. Sobre tal aspecto é importante ter em mente que a constituição do Estado nacional comporta também a formação de uma indústria cultural nacional, da qual o rádio se destaca como instrumento ideológico mobilizador das massas que constituiriam os centros metropolitanos, quer dizer, a formação da superpopulação relativa de trabalhadores/consumidores.

A partir de 1950 a Bahia ${ }^{84}$ passa pelo processo de industrialização que teve a Petrobras como ponta de lança e mais tarde a Sudene, a partir de 1959. No entanto, tais ações do Estado planejador passam ao largo da área das Lavras Baianas, sua participação no processo de industrialização nacional somente pode ser entendida como negativo do mesmo. O que se dá é a retração relativa do mercado na participação da reprodução das famílias que permaneceram na área. De modo que a caça, a coleta, a pesca e a roça de subsistência passam a ter ainda maior importância. O que não quer dizer que o garimpo tenha deixado de ser praticado, mas ele parece não garantir uma circulação monetária na área tão significativa como antes, principalmente se comparada aos padrões de consumo das metrópoles nacionais em formação. Ao menos relativamente aos centros urbanos a área das Lavras Baianas se desmonetariza. Vale lembrar novamente que quem de fato movia o consumo de mercadorias na região eram as famílias proprietárias, as primeiras que passam a deixá-la nesse período.

Do ponto de vista político (e mesmo daquilo que se pode entender como “cultura”, a partir de um ponto de vista estrangeiro, já que os habitantes da área certamente não entendiam suas práticas como culturais, ao menos não no sentido espetacularizado (Debord, 1997) que o termo ganhou contemporaneamente) aparentemente se dá uma espécie de permanência das relações que diziam respeito a sociedade regional, já que não se revolucionam significativamente as condições de produção, tampouco as relações de classes ou aquelas condizentes a reprodução interna da família. Ainda assim, é importante notar que não se trata de uma simples permanência isolada, é possível identificar pontos em que as profundas transformações ocorridas na estrutura política, econômica e cultural do país naquele período reverberam na área das Lavras Baianas e ganha, ora mais ou ora menos, as tonalidades daquele colorido regional.

84 Como toponímia de uso corrente na época a "Bahia” era apenas o que hoje reconhecemos como Salvador e Recôncavo Baiano. Viajava-se das “Lavras” para a "Bahia”. 
Um dos exemplos insólitos dessa sobreposição é o cruzamento da presença da indústria cultural internacional e nacional em Lençóis - na forma do cinema pertencente ao principal proprietário de terras diamantíferas da cidade, Isaías Pereira. Sobre o Cine Rex, que no início funcionava através da energia elétrica de uma roda d’água, narram alguns moradores mais velhos, que as crianças da cidade recebiam como pagamento para fazer o transporte do cascalho em carumbés nas terras do proprietário, bilhetes de ingresso para as sessões de cinema do dia.

Além disso, vale destacar o abismo que se abre entre o que é considerado um bom rendimento na área em retração econômica e aquilo que o padrão nacional de acumulação instituía como "normalidade", o que se percebe por outra narrativa curiosa: esse mesmo grande proprietário de terras ocupava o cargo de agente dos Correios, um dos poucos postos de trabalho disponível na cidade cujo salário era estabelecido a partir da realidade metropolitana. O que indica que naquela localidade desmonetarizada o salário de um agente dos Correios era significativo para um importante proprietário local, ainda que o controle das correspondências também possa ser um fator motivador. Ao mesmo tempo, moradores mais velhos relatam também que Isaías, “o homem forte” da cidade, utilizava uma moeda produzida por ele próprio como pagamento para quem lhe prestava serviços, inclusive aos garimpeiros. Com esse dinheiro local se consumia em seus comércios na cidade. Esse relato revela a manutenção do arranjo de relações que caracteriza o período regional, ainda que com uma elite proprietária que já não personifica mais a violência de Estado e se encontra relativamente empobrecida em comparação a realidade metropolitana do país e ao seu próprio fausto no período regional. 


\section{A DESCOBERTA DA CHAPADA DIMANTINA E SUA INCORPORAÇÃO AO ESTADO NACIONAL}

Se em um primeiro momento na área das Lavras Baianas não se deu internamente as transformações da estrutura econômica e política que se operavam em âmbito nacional, tendo participado de tal processo como provedora de força de trabalho, mais tarde alguns elementos desse processo passam a chegar à área (para o que Lençóis continua sendo uma centralidade) prenunciando algumas caraterísticas das mudanças que se operaram lá a partir de então. Para além das criações de ordem institucionais e infraestruturais que o Estado passa a promover, é importante atentar para o fato de que a partir de meados dos anos 1960 passam a chegar em maior número (transformando quantidade em qualidade, pode-se dizer) na área das Lavras Baianas indivíduos que personificam lugares sociais condizentes a modernização urbano industrial em âmbito nacional e internacional. Não se trata de qualquer fortuita coincidência ou genialidade personalista aquilo que fundamenta as práticas de tais personas no momento que se passa a analisar agora, existe sim uma base social material, que diz respeito ao desenvolvimento da acumulação capitalista em escala internacional, a qual fundamenta a existência de tais práticas. De modo sintético, pode-se dizer que passam a chegar na área das Lavras Baianas indivíduos que compõem as classes médias (a superproduzida força de trabalho complexo e a "cultura” que lhe é característica) metropolitanas tanto nacionais como internacionais, os filhos da segunda revolução industrial.

Provavelmente as pessoas que ganharam maior destaque nesse processo de (trans)formação da Chapada Diamantina tenham sido os três voluntários do Peace Cops ${ }^{85}$ que

85 O Corpo da Paz é um programa de cooperação estadunidense criado no início dos anos 1960, durante o governo de John Kennedy e estava inserido no conjunto da política internacional dos EUA que ficou conhecida como Aliança para o Progresso (Brito, 2005). Sobre o tema Francisco de Oliveira diz: "A presidência Kennedy estava inaugurando, nos Estados Unidos da América do Norte, um novo estilo de relacionamento internacional, adaptado às novas condições da competição interimperialista e da competição capitalismo versus socialismo. A "New frontier" para a América Latina chamar-se-á “Aliança para o Progresso" (Oliveira, 2008:256); e sobre a ação estadunidense em Recife no período que precedeu o golpe militar: "O consulado norteamericano em Recife chegou às proporções de uma verdadeira embaixada, com mais de onze vice-cônsules e uma legião de funcionários que incluía os indefectíveis agentes da CIA, disfarçados em Corpo da Paz, pessoal técnico e pessoal diplomático.” (Oliveira, 2008:261). A polêmica sobre os voluntários do Corpos da Paz serem ou não agentes da CIA disfarçados não enfraquece o reconhecimento de que o programa de cooperação possui claras intenções de garantir a hegemonia estadunidense em áreas que as tensões sociais pudessem se desenvolver no sentido de uma "revolução de tipo cubana". Depoimentos de voluntários constantes no documentário Em Nome da América, de Fernando Weller (2017), revelam a normativa evidente dada pelo programa: os voluntários deveriam trabalhar para o "desenvolvimento local", mas não deveriam se envolver em "questões políticas". 
trabalharam em Lençóis a partir de 1965. O primeiro dos voluntários é David Blackburn, que permanece por três anos na cidade. O segundo será Steve Horman, este voluntário que chega a cidade no início dos anos 1970 terá participação decisiva no processo de patrimonialização de Lençóis, que se consuma no ano de 1973. Mas não são apenas os “gringos” que chegam a área neste momento, ela é descoberta também pela classe média brasileira, sobretudo soteropolitana e brasiliense, mas também dos grandes centros urbanos do Centro-Sul. Data, por exemplo, da década de 1970 a formação das primeiras comunidades alternativas da Chapada Diamantina (Brito, 2005). À chegada dessas personas em Lençóis concorrem algumas obras infraestruturais determinantes, a primeira delas é a construção da rodovia asfaltada BR-242, ligando Brasília, e a massa de tecnocratas que abriga, a Salvador, então principal destino turístico nacional. Lençóis passa a ser uma opção de parada para descanso dos veranistas que faziam o trajeto de automóvel ${ }^{86}$ entre as duas cidades, sobretudo depois da construção da Pousada de Lençóis no final da década de 1970. Sobre o choque entre os estrangeiros e os habitantes locais vale mencionar Brito (2005):

\begin{abstract}
"Algumas destas pessoas provocaram um estranhamento na cidade ao trazerem comportamentos considerados bastante liberais para uma sociedade profundamente conservadora como o fato de pessoas do mesmo sexo beijarem-se em público e fumarem maconha. Chocados, os moradores passaram a rotular de gays tanto estas pessoas quanto todas aquelas 'de fora' que vieram morar em Lençóis” (Brito, 2005:128)
\end{abstract}

Mas, se a "turma dos gays" e os turistas chamavam atenção pelo estranhamento aos costumes, também atraíam os lençoenses por outro motivo: significavam a possibilidade de engorda da dispensa familiar em uma localidade profundamente pauperizada. Isso aparece no relato de um guia de Lençóis sobre a época em que era criança, durante entrevista realizada em trabalho de campo esse guia comentou:

Guia: [...] Nós todos tínhamos parentes na porta do hotel. Porque também tinha uma outra coisa, o pessoal de Brasília, quando eles desciam de Brasília, eles traziam muita coisa, e também muita comida. Entendeu? Isso também levava a gente para ir pra frente do hotel.

Pesquisador: Por que eles paravam no hotel para pousar de noite?

Guia: Pra pousar e a gente ganhava muita coisa. Porque a vida de garimpeiro não era um mar de rosas. Entendeu? Tinha época que o bicho pegava. Então a gente se acostumava [...].

86 Segundo informação de Heraldo Barbosa Filho, até o final dos anos 1970 Lençóis contava com não mais que dez carros. 
Mas não são apenas os “gringos” e a classe média nacional no gozo de seu tempo livre que chegam a Lençóis nesse período. A Pousada de Lençóis, citada acima e inaugurada em fevereiro de 1979, é resultado emblemático da ação de outro ator social que entra em cena na Chapada Diamantina nos anos 1970, trata-se do Estado-Providência ${ }^{87}$ de Francisco de Oliveira (1988). A partir de meados dos anos 1960 teve início a organização institucional daquilo que Lúcia Aquino de Queiroz (2002) nomeia “Sistema de Turismo Estadual” na Bahia ${ }^{88}$, no que se destaca a criação do Departamento de Turismo vinculado a Secretaria dos Assuntos Municipais e Serviços Urbanos, cuja finalidade era elaborar o "Plano Estadual de Fomento ao Turismo”, além de supervisionar as Estâncias Hidrominerais do estado. Em 1968 foi criada a Hotéis de Turismo do Estado da Bahia S/A (BAHIATURSA), mais tarde renomeada como Empresa de Turismo da Bahia (BAHIATURSA), cujo objetivo original era o incentivo à construção de estabelecimentos de hospedagem no estado, em seguida expandido suas atribuições. Já

\begin{abstract}
“A partir de 1974, verifica-se a primeira tentativa de ação planejada do Governo do Estado na região com o objetivo de interiorizar e promover o desenvolvimento do turismo ao deslocar para a Chapada Diamantina uma equipe técnica - da Coordenação de Fomento ao Turismo, ligada à Empresa de Turismo da Bahia (Bahiatursa) - integrante do projeto "Identificação do Potencial Turístico do Estado” para a realizar um diagnóstico dos municípios de Lençóis, Andaraí e Mucugê que resultou no documento Chapada Diamantina, uma avaliação prévia para a implantação do turismo nos municípios de Lençóis, Andaraí e Mucugê que além de analisar as principais atividades econômicas dos referidos municípios também efetua o levantamento fotográfico da área urbana, do artesanato, das manifestações culturais e dos principais casarões destas cidades.” (Brito, 2005:124)
\end{abstract}

Será baseada neste projeto que a Empreendimentos Turísticos da Bahia S.A. (EMTUR), órgão subsidiário da BAHIATURSA, construirá a Pousada de Lençóis e outros quinze empreendimentos espalhados pelo interior do estado. Segundo Brito,

87 Ver nota 77 na página 93 dessa dissertação.

88 É importante mencionar que a Bahia foi uma espécie de modelo do desenvolvimento do turismo no Brasil, Salvador foi uma das primeiras cidades brasileiras a contar com uma secção na administração municipal para o assunto (em 1930 foi criada a Secção de Turismo da Diretoria do Arquivo e Divulgação), bem como colocou em prática uma lei específica para captação de fundos para reinvestimento na área em 1951 (a "taxa do turismo"), além de ter feito o primeiro plano diretor de turismo do país em 1954. Em Lençóis também se criou um Conselho Municipal de Turismo (CMT) em 1961, no entanto a iniciativa não redundou em nenhuma transformação efetiva até 1972, quando a cidade passou a pleitear sua patrimonialização através da figura jurídica do CMT. 


\begin{abstract}
“A Pousada de Lençóis foi inaugurada em 20.02.79 com 18 apartamentos. Foi administrada pelo Governo do Estado durante 3,5 anos, sendo, posteriormente arrendada a um ex-diretor da Bahiatursa, em 01.10.82, que promoveu a ampliação de suas instalações de 18 para 36 apartamentos e tornou-se proprietário deste estabelecimento, sete anos depois.” (Brito, 2005:126-127)
\end{abstract}

Interessa notar que a construção da Pousada de Lençóis e o planejamento estadual do turismo na Bahia não são ações isoladas ou descontextualizadas. Estão inseridas no bojo de uma política nacional de planejamento econômico que tem a frente a Empresa Brasileira de Turismo (EMBRATUR), criada em 1966, como empresa pública vinculada ao Ministério da Indústria e do Comércio ${ }^{89}$. Tendo em vista este dado vale relembrar a caracterização do terciário brasileiro e seu lugar na industrialização do país em um período que praticamente toda ação de planejamento estava voltada para o desenvolvimento do secundário, sobre isso Francisco de Oliveira diz:

“A solução é encontrada fazendo os serviços crescerem horizontalmente,
sem quase nenhuma capitalização, à base de concurso quase único da força
de trabalho e do talento organizatório de milhares de pseudo-pequenos
proprietários, que na verdade não estão mais que vendendo sua força de
trabalho às unidades principais do sistema, mediadas por uma falsa
propriedade que consiste numa operação de pôr fora dos custos internos de
produção fabris a parcela correspondente aos serviços. É possível encontrar,
ao nível da prática das instituições que modelaram o processo de acumulação
no Brasil, transformadas em critérios de prioridades, as razões enunciadas:
não existe, em toda a legislação promocional do desenvolvimento, nem nos
critérios de atuação dos diversos organismos governamentais, nenhuma
disposição que contemple prioritariamente a concessão de créditos, a
isenção para importação de equipamentos, a concessão de incentivos fiscais,
as disposições de natureza tarifária, destinadas a elevar a capitalização dos

89 Sobre o tema da política nacional para o turismo Queiroz (2002) afirma: "Não se pode deixar de registrar que essas estratégias traçadas pelo governo do estado da Bahia para o turismo certamente foram reflexo das preocupações federais com a atividade no período. No ano de 1958, o presidente da República, Juscelino Kubitchek, havia sondado o governo norteamericano sobre a possibilidade de concessão de um empréstimo de US\$ 300 milhões para o Brasil. O então presidente dos EUA, Eisenhower, acreditando na importância do turismo como instrumento de paz e enriquecimento das nações, ao invés do empréstimo ofereceu uma ajuda técnica para que o Brasil organizasse e explorasse racionalmente o seu potencial turístico. Firmou-se assim um convênio entre a Confederação Nacional de Comércio (organismo incumbido pelo governo federal de conduzir o programa de cooperação) e a International Cooperation and Administration, de Washington, agência norte-americana responsável pelos programas de auxílio financeiro aos países com possibilidade de desenvolvimento turístico, $e$ constituiu-se uma Comissão Mista, que, na oportunidade, idealizou um projeto denominado Tourism Project for Brazil.” (Queiroz, 2002:53) 
serviços (com única exceção da Embratur, há pouco criada) [...]” (Oliveira, 2013:68)

A interpretação acima sugere um questionamento, que o calor do processo analisado (o texto em questão foi lançado por Francisco de Oliveira em 1972) certamente dificultava a formulação: quanto do caráter excepcional atribuído a criação da EMBRATUR em verdade não escondia o prenúncio das transformações do regime de acumulação do dito capitalismo tardio? Essa questão fica guardada por hora e o desenvolvimento da presente análise lidará com ela mais adiante. O fato é que não se tratava apenas de uma política econômica brasileira, na verdade o país buscava se adequar às possibilidades de internalização de capitais abertas em escala internacional:

"Já naquela época idealizava-se a constituição de um programa turístico para o Nordeste que contasse com o apoio dos EUA e financiamento do BID. Sabia-se que, desde 1968, o BID havia adotado uma política de atendimento de pedidos de empréstimos para projetos turísticos, especialmente daqueles mediados por planos oficiais e que se destinassem à infra-estrutura. Com essa visão, dirigentes das empresas de turismo dos estados da Bahia [...], Pernambuco e Ceará, reunidos com membros da SUDENE e do Banco do Nordeste, tomaram a decisão de realizar uma viagem aos EUA com o objetivo de ver de perto o que ali se fazia na área do turismo, no âmbito do programa Companheiros das Américas.” (Queiroz, 2002:113)

Já na esfera mais abrangente da economia nacional brasileira a crise inflacionária se estendeu até 1967. A crise só é estancada em 1968, com a adoção da política econômica anticíclica dos militares, de estímulo à produção, com aumento de gastos estatais na concessão de crédito ao empresariado, sobretudo para a indústria. Para Francisco de Oliveira tais créditos visavam remediar o descompasso entre departamento I e II da econômica brasileira, cuja indústria de bens de capitais se encontrava desestrutura, entre outros motivos por conta dos anos de recessão sem adequação técnica. A adequação produtiva empreendida se fez através da importação dos bens de capitais necessários a alavancagem da produção, o que para o autor, no entanto, representaria uma barreira ao pretenso crescimento internalizado do Brasil. O resultado disso foi o aumento da dependência das exportações, importantes na busca de equilibrar a balança comercial nacional, o que significava que a produção industrial nacional passava a concorrer internacionalmente com capitais mais produtivos, de modo que as taxas de lucro somente se mantiveram estáveis através de políticas de subsídio. 
"Esse subsídio, numa situação em que os preços internos crescem mais que os preços externos é, de certa forma, uma esterilização de capital, viabilizada pela chamada política de câmbio flexível. Essa esterilização de capital aparece na contabilidade das empresas como lucro, mas na contabilidade nacional é uma transferência da conta do Governo para a conta de capital das empresas, já que é renúncia a um imposto (no fundo ela é uma transferência da conta das famílias, intermediada pelo Governo.)” (Oliveira, 2013:104)

E,

“Com o subsídio, aumentam-se as exportações, buscando melhorar as reservas internacionais do país, a fim de melhorar a capacidade de barganha internacional; mas somente os ingênuos podem continuar acreditando que o comércio internacional é realmente multilateral: o que é multilateral é o sistema de pagamento desse comércio, mas, no fim das contas, os países que se abrem para as nossas exportações esperam tratamento idêntico de nossa parte para as suas.” (Oliveira, 2013:105)

O resultado dessas medidas foi o descompasso da balança comercial e o aumento ao recurso do crédito externo casado com a renúncia fiscal interna. O dito "milagre econômico" teria sido marcado por outra mudança importante: o ritmo da acumulação imposta pela indústria monopolista demanda uma fluidez monetária que é contradita pelo princípio da poupança, quer dizer, era preciso fazer circular o capital monetário retido em poupança para a manutenção desse padrão de acumulação. Esse intento só pode ser posto em prática através da organização e crescimento substantivos do mercado de capitais, porém tal mudança resultaria em

"Um complicado sistema montado, com a progressiva assunção ao primeiro plano dos bancos de investimento, que são a estruturação da expansão das empresas monopolísticas. Sem embargo, o mercado financeiro transformouse ele mesmo em ativo competidor dos fundos para a acumulação: a aplicação meramente financeira começou a produzir taxas de lucro muito mais altas que a aplicação produtiva e, de certo modo, a competir com a alocação dos recursos.”

[...]

“Em poucas palavras, um mecanismo circular que proporcionou o 'deslocamento' das órbitas financeira e real impede que a primeira sirva de fonte de acumulação para a segunda. O elemento de 'confiabilidade' dos papéis passa a ser estratégico nessa conjuntura, quando sua função seria meramente acessória.” (Oliveira, 2013:102) 
Está posta assim a contradição: como manter taxas de juros convidativas ao investidor sem com isso minar os investimentos na produção por conta do interesse nos investimentos no mercado financeiro? Entendida da maneira exposta acima a ascensão do mercado financeiro, que se sobrepõem a produção, parece questão de complicada solução, porém contornável por uma razão econômica planificadora, até mesmo de um ponto de vista dito socialista. É fundamental rever tal interpretação de modo a considerar os desdobramentos decisivos da terceira revolução industrial ${ }^{90}$ para o regime de acumulação do capitalismo mundial.

Para tanto é importante retomar, ainda que brevemente, os fundamentos da teoria do valor marxista, tendo a finalidade de explicitar a natureza das transformações que se operam definitivamente neste momento, qual seja, a desvinculação entre o dinheiro e sua substância social, o trabalho. Processo esse vinculado a lógica interna da acumulação capitalista, que Robert Kurz (2002) chamou ironicamente de “ascensão do dinheiro aos céus”. Esse processo tem a ver com a concorrência entre capitais e a luta entre capital e trabalho no interior das relações de produção, isso porque o sentido social que essas disputas tomam é o da busca sem limites por maior produtividade, já que somente deste modo um capital pode manter-se na concorrência ao mesmo tempo que ganha vantagem relativa na relação com as controvérsias da luta de classes. De modo geral, o incremento da produtividade se dá através do incremento técnico do processo produtivo, da racionalização do mesmo, redundando na expulsão de trabalho vivo. Em linguagem conceitual diz-se ser o aumento da composição orgânica do capital, ou seja, o aumento da razão do quantum de capital constante (trabalho morto) pelo quantum de capital variável (trabalho vivo) na composição do capital. A partir daí estamos diante da contradição imanente da forma da relação social capitalista: quanto mais produtivo o capital (e o sentido da reprodução social mediada pela mercadoria é que os capitais busquem maior produtividade para manterem-se na concorrência) tanto menos ele explora trabalho vivo, ou seja, tanto menor é sua taxa de lucro (razão do quantum de trabalho não pago ao trabalhador pelo total de investimentos do capital), ainda que sua taxa de mais-valia (razão do quantum de trabalho não pago aos trabalhadores pelos salários) tenda a continuar crescendo. Quer dizer, o capitalismo tem como imanência de sua contradição em processo a queda tendencial das taxas de lucro. Até aqui reproduzi uma das descobertas de Marx expostas no terceiro livro de O Capital. O que Robert Kurz sugere é que desde o entreguerras a reprodução do capitalismo mundial esbarra de modo definitivo nos limites impostos pela queda da taxa de lucro, isso porque

90 Chamada de "revolução da microeletrônica" por Robert Kurz (2002) ou de "revolução molecular-digital” por Francisco de Oliveira (2013). 


\begin{abstract}
"Tanto os custos preliminares de capital quanto os custos da infra-estrutura social necessária subiram a partir da Segunda Guerra Mundial a níveis tão astronômicos que se tornaram proibitivos para a esmagadora maioria dos países já no início dos anos 70. Portanto, em muitos casos a expansão fordista interrompeu-se no início ou a meio caminho. As importações de bens de investimento empresariais ou infra-estruturais deviam ser antecipadamente financiadas por créditos e os processos produtivos desenvolvidos não conseguiam sequer pagar os juros destes créditos. $\mathrm{O}$ resultado foi a famigerada crise das dívidas do Terceiro Mundo.” (Kurz, 2002:14)
\end{abstract}

Olhando bem o argumento de Kurz percebe-se que existe um processo histórico que vai do salto produtivo das guerras mundiais e tem seu ponto de viragem no início dos anos 1970. Nesse meio tempo a expansão territorial da relação capital por todo o globo parece ter viabilizado uma acumulação suficiente para estancar a sangria dos déficts impostos pelo desenvolvimento monstruoso da mais valia relativa. De alguma forma estamos diante do ajuste espacial proposto por David Harvey (2005). No entanto, Kurz aponta que a partir da revolução da microeletrônica isso deixa de fazer sentido. Os últimos suspiros produtivos do capitalismo em termos sociais gerais (quer dizer, não interessa aqui averiguar a produtividade de qualquer capital individual) são silenciados definitivamente. O gigantesco salto produtivo da terceira revolução industrial que, ultrapassando os padrões fordistas de acumulação, acaba também com qualquer possibilidade de valorização do valor, dando em uma crise qualitativamente distinta, uma crise de dessubstancialização (Kurz, 2002). Ainda assim, a crise insolúvel não significa o fim definitivo da forma social, que se mantém de maneira ficcionalizada:

“O limite absoluto não aparecerá sob a forma duma simples aceleração linear da "queda tendencial", de modo que o capitalismo seja abandonado com resignação pelo management, por falta de rentabilidade. Antes, atingido o limite absoluto, finda também a acumulação absoluta de "valor" em geral. Em termos substanciais: a taxa de lucro não "diminui", mas deixa totalmente de existir, com o desaparecimento de massas suplementares de valor. O conceito torna-se sem sentido. Ao mesmo tempo, o processo de acumulação continua ainda formalmente por um certo período (e assim são auferidos lucros em termos formais), mas já sem nenhum vínculo com a substância real do valor (em queda), guiado apenas pela agora incontrolada criação de "capital fictício" e de dinheiro sem substância, nas suas diversas formas fenomênicas.” (Kurz, 2002:15) 
Francisco de Oliveira, em seu ensaio O surgimento do antivalor de 1988, abordou a questão do descolamento do dinheiro de seu fundamento social demonstrando o papel do Estado keynesiano, a partir do uso do que chama de "fundo público", na gestão da crise de valorização (ainda que não trata da questão como crise de valorização, já que para ele há acumulação) ao operar a antecipação daquilo que seria o lucro:

"O que torna o fundo público estrutural e insubstituível no processo de acumulação de capital, atuando nas duas pontas de sua constituição, é que sua mediação é absolutamente necessária pelo fato de que, tendo desatado o capital de suas determinações autovalorizáveis, detonou um agigantamento das forças produtivas de tal forma que o lucro capitalista é absolutamente insuficiente para dar forma, concretizar, as novas possibilidades de progresso técnico abertas.” (Oliveira, 1988:16)

Os termos da luta de classes se recolocam então como disputa pelo fundo público, não mais pela valorização interna a produção propriamente dita, já que

“[...] no fundo, levado às últimas consequências, o padrão do financiamento público "implodiu" o valor como único pressuposto da reprodução ampliada do capital, desfazendo-o parcialmente enquanto medida da atividade econômica e da sociabilidade em geral.” (Oliveira, 1988:14)

O fundo público sustenta desta maneira a reprodução do capital e também da força de trabalho. Ao sustentar a reprodução do trabalhador, ainda que parcialmente, o fundo público o faz "como antimercadorias sociais, pois sua finalidade não é a de gerar lucros, nem mediante sua ação dá-se a extração da mais-valia” (Oliveira, 1988:15). Quer dizer, do ponto de vista do autor a reprodução da força de trabalho nesses termos seria uma negação da mercadoria como mediação social, no limite aparece em seu argumento como uma visada de horizonte que aponta para a superação do capitalismo:

"Quando todas as formas de utilização do fundo público estiverem demarcadas e submetidas a controles institucionais, que não é o equivalente ao Superior-Estado ou ao Estado Máximo, então o Estado realmente se transformará no Estado Mínimo. Trata-se da estrutura de um novo modo de produção em sentido amplo, de uma forma de produção do excedente que não tem mais o valor como estruturante. Mas os valores de cada grupo social, dialogando soberanamente. Na tradição clássica é a porta para o socialismo.” (Oliveira, 1988:28) 
A tomada de posição pelo estabelecimento dos "controles institucionais" de uma democracia, quer dizer, por uma “economia de mercado socialmente regulada”, está justificada no texto pelo desastre da opção por deixar a sociabilidade capitalista em crise largada a própria sorte, correndo o risco de "transformar-se numa tormenta selvagem na qual sucumbiriam juntos a democracia e o sentido de igualdade nela inscrito desde os tempos modernos” (Oliveira, 1988:27). De fato, a alerta já se fazia realidade no momento da publicação do artigo, o pêndulo político apontava para o desmanche do Estado de bem-estar social dos países centrais e da parca estrutura produtiva pública da periferia. Quer dizer, a disputa pelo fundo público estava sendo ganha pelo neoliberalismo, daí um posicionamento reativo e de defesa regulacionista da autonomia (na perspectiva assumida por essa pesquisa, autonomização) da política em relação a economia.

Para ser consequente teórico-praticamente, seria o caso de se perguntar: se o capital depende do fundo público (Estado) para acumular (ou para parecer que acumula) de que dinheiro é composto o fundo público? Ou melhor, o que é o dinheiro do fundo público? Neste particular Francisco de Oliveira se aproxima da crítica do dinheiro empreendida por Aglietta e Orléans ("A Violência da Moeda") ${ }^{91}$, ainda que no caso de sua interpretação tenha se dado como processo histórico de descolamento (uma "revolução copernicana”), enquanto no caso dos franceses parece que o dinheiro está entendido como espécie de signo puro, sem significante, separado de qualquer prática social que não sua própria troca. Isso implicaria na interpretação do valor como simples inverdade, o que não é exatamente o caso de Francisco de Oliveira, que entende a relação mercantil em perspectiva histórica:

\footnotetext{
"De fato, a desmercantilização da força de trabalho opera no sentido da anulação do fetiche: cada vez mais, a remuneração da força de trabalho é transparente, no sentido de que seus componentes são não apenas conhecidos, mas determinados politicamente. Tal é a natureza dos gastos sociais que compõem o salário indireto, e a luta política se trava para fazer corresponder a cada item do consumo uma partida correspondente dos gastos sociais. Não há fetiche, neste sentido: sabe-se agora exatamente do que é composta a reprodução social. Ou, em outras palavras, a fração do trabalho não-pago, fonte da mais-valia, se reduz, socialmente. Mas, pareceria ironia dizer que o mundo contemporâneo é completamente desfetichizado, pois a sociedade de massas parece a fetichização elevada à enésima potência. Pode-
}

91 “[...] a indiferença da moeda [...] do banco central é, no fundo, a única abrangência que cobre tanto o setor de economia de mercado quanto o setor hors marché (a economia pública de bens e serviços sociais); e cobre precisamente porque, em não sendo mais a moeda a expressão do tempo de trabalho socialmente necessário - erodida nessa função pelo anticapital e pela antimercadoria -, terminou por ser apenas a expressão monetária - mas não necessariamente de valor - de uma relação entre credores e devedores." (Oliveira, 1988:17) 
se, apenas, sugerir que no lugar do fetiche da mercadoria colocou-se um fetiche do Estado, que é finalmente o lugar onde se opera a viabilidade da continuação da exploração da força de trabalho, por um lado, e de sua desmercantilização, por outro, escondendo agora o fato de que o capital é completamente social.” (Oliveira, 1988:19)

Ainda assim, a passagem acima revela um posicionamento na compreensão teórica do conceito de fetiche importante de ser tencionada. A sobredeterminação da política faz com que o fetichismo da mercadoria seja compreendido como campo de manobra dos sujeitos da relação, campo no qual se nublaria a relação entre o trabalho como fundamento social do valor e o dinheiro como sua expressão. É o campo da negociação e da mentira do qual o capitalista de valeria na relação com o trabalhador para extrair a mais valia da força de trabalho e que estaria se desmanchando com a incapacidade do capital se autovalorizar e por sua dependência do fundo público. O que não se desmancha na interpretação a cima é o trabalho como contínuo trans-histórico, do contrário seria compreendida como contradição em termos a ideia da desmercantilização do mundo no qual se remunera força de trabalho. Somente entendendo o trabalho como ontológico pode-se esperar que, sendo conhecedora de sua "transparente" fonte de remuneração (o dinheiro impresso pelos bancos centrais) a força de trabalho continue se mobilizando cotidianamente para a produção concreta de sua sobrevivência ampliada como mercadorias desmercantilizadas! Que o Estado nacional seja uma estrutura fundamental da mistificação social não resta dúvida, mas imputar somente ao dito "fetiche de Estado" a manutenção da exploração do trabalho, salvaguardando este da crítica, revela o limite distributivista da mesma.

A sobreposição do mercado financeiro aos capitais produtivos e o volume crescente de crédito estatal injetado na economia deixam de ser uma questão de opção tecnocrática, política ou ideológica e passa a ser a forma de ser do capitalismo quando este já não pode mais repor seus fundamentos. Nesse sentido, a ascensão do “dinheiros aos céus” é a chave interpretativa também para a ascensão do turismo como atividade econômica no capitalismo do pós-guerra ${ }^{92}$, no limite trata-se de um instrumento para a disputa pela internalização dos

92 Interessa, mais uma vez, salientar a historicidade do turismo e criticar a busca de um fundamento ontológico para sua prática. Os textos de manual sobre o tema costumam repetir o mecanismo argumentativo, cada qual ao seu modo, da velha prática de buscar o idêntico na história: "o homem sempre viajou", gostam de repetir em suas introduções, reportando-se às formações sociais pré-modernas. Aqui o turismo é tratado como atividade econômica que tornase relevante no contexto da formação do Estado de bem-estar social, ou da sociedade de consumo, no pós-guerra. De qualquer forma, existem outros antecedentes mais estreitamente vinculados a formação social capitalista (Ouriques, 2005), como a prática do Grand Tour por parte das classes dominantes europeias para a formação de seus filhos. Ou das experiências pioneiras do turismo de massa do nazismo antes da segunda guerra mundial. 
excedentes monetários mundiais (sob diversas formas: por exemplo como empréstimos de bancos de desenvolvimento ou como salários poupudos de trabalhadores improdutivos bem remunerados gastos no gozo de suas férias), cada vez mais capitais fictícios. Neste sentido o turismo pode ser caracterizado como mais uma das formas de gestão de crise pelo Estado nacional, que no caso brasileiro passa a planificar seu desenvolvimento com maior intensidade justamente no momento em que a crise de dessubstancialização se consolidava como ponto sem volta na história do desenvolvimento do capitalismo mundial.

No caso do turismo em Lençóis, são reveladores os comentários de Mestre Osvaldo ${ }^{93}$ rememorados por Carlos de Almeida Toledo (2008) de sua pesquisa de campo. Como herdeiro de uma família de proprietários de terras na cidade, ele apontava como o turismo era interessante para os donos de imóveis pois, assim como o garimpeiro, as pessoas atraídas pelo turismo eram cheias de esperança e movimentavam o mercado imobiliário da cidade. A comparação entre a esperança do garimpeiro e a esperança dos empresários do turismo é um interessante indício do poder mobilizador do dinheiro, mas também pode esconder (ao fazer a aproximação) as importantes diferenças que se constituíam naquele momento. A prática social da esperança no caso do garimpeiro era o trabalho na serra, submetido as relações de trabalho aqui já tratadas; enquanto aqueles que chegam para trabalhar com o turismo manifestam socialmente sua esperança investindo dinheiro, quer dizer, querendo fazer de dinheiro mais dinheiro. De tais investidas no turismo, seria possível enumerar uma série de empreitadas frustradas, que mais não representaram que dissipação de poupanças familiares ou endividamento pessoal. Ainda que tenham vindo para se inserirem como trabalhadores, e não como empresários, normalmente estas pessoas já vivem plenamente monetarizadas, completamente dependentes do mercado para suprir suas necessidades, se comportam já como portadores do próprio “capital humano” - termo do vocabulário do empresariado e dos administradores locais, queixosos da falta da famigerada “mão-de-obra qualificada”. Para além disso, o comentário de Mestre Osvaldo revela um novo momento da autonomização das categorias do capital, momento da separação das personas que representam o proprietário da terra e o capitalista, seu discurso representa claramente o lugar de uma parte da classe

93 Como registra Liziane Peres Mangili, “"Mestre” Osvaldo, como é chamado entre a população, foi uma importante figura em Lençóis. Montou em sua própria casa um museu, aludindo à cidade e ao garimpo, e foi referência para todos os pesquisadores de Lençóis e da Chapada Diamantina, por seus depoimentos e do acervo que disponibilizava. Mestre Osvaldo faleceu em 2011." (Mangili, 2015:94) 
dominante local que congregava a personificação dessas duas formas de rendimento e que se autonomiza como proprietário da terra exclusivamente ${ }^{94}$.

Mas, se o Estado nacional já é em si o gestor das contradições imanentes da forma social capitalista, tanto pior quando produz contradições concretas dentro de sua própria estrutura administrativa, o que se explica por suas autonomizações internas. Em 1975 (um ano depois da BAHIATURSA ter enviado seu corpo técnico para a antiga área das Lavras Baianas a fim de avaliar sua potencialidade turística, e dois anos após a patrimonialização de Lençóis, ambos processos marcados também pelo destaque dos atributos naturais da área) a Secretaria de Minas e Energia do mesmo governo do estado da Bahia passa a desenvolver sondagens para projetos de mineração nas cidades de Rio de Contas, Andaraí e Lençóis (Mangili, 2015). Sobre isso Brito (2005) afirma:

"Enquanto fomentava o desenvolvimento da atividade turística, o governo do estado também promovia a implantação do garimpo mecanizado que entrou em operação na Chapada Diamantina, no início da década 80, com a chegada da Companhia Tijucana (de Diamantina - MG) a serviço da estatal Companhia Baiana de Pesquisa Mineral - CBPM, sendo responsável pela vinda à região de um significativo contingente de donos de máquinas e garimpeiros provenientes de Mato Grosso, Goiás, Minas Gerais e de outros estados.” (Brito, 2005:133-134)

O garimpo de draga (garimpo mecanizado) durou pouco menos de duas décadas na antiga área das Lavras Baianas (salvo exceções pontuais de garimpos pretensamente controlados ambientalmente, sobretudo na cidade de Andaraí) e teve desde seu início a anteposição dos movimentos ambientalistas que se constituíam na área, relacionados a uma parcela da classe média metropolitana recém-chegada. Fato é que o garimpo de draga se consubstanciou como uma das poucas alternativas possíveis de acesso a dinheiro para uma comunidade profundamente desmonetarizada em um momento que o país começava a colher os frutos podres do "milagre econômico" dos militares. Incapaz de internalizar a acumulação, mesmo porque em termos globais essa já se mostrava impossível como processo de valorização do valor, o país passa a amargar a crise econômica, fruto da impossibilidade de saldar suas dívidas externas. É a chamada “crise das dívidas” mencionada acima. Nesse período, que se caracteriza pelo processo inflacionário, se estende até os primeiros anos da

94 Brito (2005) menciona que parte da classe dominante da cidade, quando as primeiras ações do planejamento estatal do turismo começaram a serem implementadas, tiverem postura reativa e desacreditavam do potencial de atração de turistas daquele interior sem praia. 
década de 1990, as políticas de desenvolvimento do turismo, tanto em âmbito federal, quanto no estado da Bahia, passam por cortes de investimentos e paralisações.

O garimpo de draga atrai para a área investidores, quer dizer capital autonomizado da figura dos proprietários e dos comerciantes locais. Aparentemente ${ }^{95}$ como proprietários dos meios de produção, os donos de motores (dragas), implementaram uma reorganização da composição do capital garimpeiro, o que consequentemente alterou as relações de produção do garimpo na área. O maquinário utilizado nessa forma de garimpo representava custos em capital constante inéditos na antiga área das Lavras Baianas, o que de certo refletiu em mudanças nas relações de trabalho se comparados o garimpo mecânico e o garimpo manual.

Em entrevista, um garimpeiro que trabalhou em um dos maiores garimpos mecanizados de Lençóis durante os anos 1980 relatou sumariamente as relações de trabalho de então. Neste garimpo, que operava com 7 motores, trabalhavam cerca de 52 homens. Havia clara divisão interna do trabalho ${ }^{96}$, em cada máquina trabalhavam 7 garimpeiros, dos quais um era o gerente da máquina (aquele que coordenava o trabalho dos demais garimpeiros, inclusive podendo substituir um trabalhador se julgasse que este não estava trabalhando de acordo $^{97}$, mas que também trabalhava diretamente nas atividades do garimpo), enquanto os demais se dividiam em: bombeiro (ou draguista, aquele trabalhador que controlava o motor de sucção); mangoteiro (aquele garimpeiro que manejava a mangueira d’água pressurizada utilizada para desagregar o cascalho); pieiro (podiam se alternar nesta função os demais garimpeiros, o pieiro controlava a válvula e a posição do “chupão”, mangueira de sucção do cascalho já desagregado); os demais garimpeiros, servindo-se de ferramentas manuais, moviam os resíduos dentro da catra. Além desses trabalhadores, este garimpo contava com um gerente geral (representante do dono das máquinas, tratava apenas com os gerentes de máquina); um cozinheiro (que cuidava de toda alimentação da equipe) e um mecânico (responsável pela manutenção do maquinário). Próximo a catra, estavam instalados o escritório da gerência, a oficina e o barracão, onde os garimpeiros podiam dormir, de acordo com suas escolhas e necessidades. Eram seis dias de trabalho semanais, com expedientes que

95 Seria preciso empreender pesquisa de campo mais detalhada sobre o tema para verificar esta hipótese em seus pormenores.

96 Parte das informações aqui descritas foram acessadas também através da dissertação de Samadhi Gil C. Pimentel "O diamante é o piolho da terra: relações socioambientais no garimpo de draga da Chapada Diamantina, Bahia” (2014).

97 Vale destacar que a violência direta continuava sendo uma característica importante na forma das relações pessoais nesta forma de garimpo. A possibilidade de agredir ou ser agredido estava sempre considerada nas condutas pessoais. 
giravam em torno das $7 \mathrm{~h}$ as $17 \mathrm{~h}$, com poucas variações de acordo com o andamento do serviço. A remuneração de todos os trabalhadores era por porcentagem da produção, variando de acordo com a função desempenhada e feita quinzenalmente. Tanto a alimentação como o barracão eram oferecidos pelo proprietário sem descontos para os trabalhadores. Não existia contrato formal de trabalho. Durante cerca de três meses por ano, no período das chuvas quando o garimpo era alagado, o dono das dragas dispensava toda a equipe sem qualquer benefício, permanecendo apenas os "homens de confiança” (não mais que oito, geralmente os gerentes de máquina) que tinham apenas alimentação e abrigo custeado pelo patrão e iam "bater peneira em rabo de bica pra ver se conseguiam pegar algum mosquitinho", quer dizer, revolviam o material descartado do garimpo em busca de pequenos diamantes que tivessem passado despercebidos durante os trabalhos. Ao proprietário das terras o proprietário das máquinas pagava uma porcentagem da produção como renda da terra, do que é comum que se diga que eram sempre valores subestimados em favor do capitalista.

Sem esmiuçar a análise, é possível indicar algumas transformações sensíveis que a mecanização representou se comparada à extração manual do garimpo de serra ${ }^{98}$. A primeira delas, e mais óbvia, o tempo e o ritmo de trabalho passam a ser ditados pelo funcionamento da máquina, o capital imobilizado pelo dono da draga em capital constante força o expediente de controle da produtividade, personificada pelos gerentes que, diferente do jagunço do coronel, não zelam mais apenas pela propriedade do patrão (no caso dos coronéis suas terras), mas sobretudo pelo uso eficiente da mesma, as máquinas. A periodicidade da remuneração é preestabelecida, ainda que varie em quantidade correspondendo à produtividade, a escala de produção viabiliza uma circulação monetária mais frequente ${ }^{99}$. A alimentação e a moradia são internalizadas pela produção como custo, mas, além disso, geridas dentro da racionalidade produtiva do garimpo. Existia um posto de trabalho exclusivo para tanto, assim como horários para as refeições. O que essas informações sugerem é que o garimpo de draga, ao menos internamente à produção, representou a formação do tempo abstrato ${ }^{100}$.

98 O garimpo manual também é denominado garimpo de serra por oposição ao garimpo mecanizado que se desenvolveu quase exclusivamente no leito dos rios de fundo de vale, no caso de Lençóis notadamente ao longo do vale do rio São José.

99 Vale destacar a desconfiança que marca a relação também no garimpo de draga, o cálculo dos rendimentos feito pelo patrão são motivo de desconfiança justificada dos garimpeiros, assim como são comuns os relatos de roubo de diamantes por parte desses.

100 Seria importante desdobrar a pesquisa nesta questão, sobretudo analisando como o dinheiro acessado através do garimpo mecanizado foi vivenciado por esses trabalhadores. 
Mas, se por um lado o governo estadual da Bahia mantinha ações concomitantes e contraditórias, fomentando na mesma área as atividades do turismo e da mineração, o governo federal contribui para a complexificação do quadro através da criação em 1985 do Parque Nacional da Chapada Diamantina (PNCD) ${ }^{101}$, cuja área de preservação coincidia em partes com as áreas de garimpo mecânico e também do garimpo dito "tradicional”"102, o garimpo de serra manual. O PNCD resulta em escala local da militância dos ambientalistas da Chapada Diamantina, destaque dado ao terceiro voluntário do Peace Corps em Lençóis, Roy Funch, que havia chegado na cidade em 1978. Segundo Brito,

\begin{abstract}
“Traduzindo as mudanças ocorridas no Peace Corps (Corpo da Paz), que nos anos 70 passou a recrutar voluntários mais qualificados, Roy Funch chega a Lençóis com formação em bioquímica e especialização em fitofisiologia. Inicia seu trabalho, colocando em prática medidas voltadas para a proteção dos recursos naturais da região diante da ação dilapidadora em curso e também para dar vazão a um tipo de turismo que pressupõe a realização de caminhadas e, ao mesmo tempo, o respeito à natureza. Tudo começou quando numa das idas ao Capão, segundo ele 'vi o Vale e a beleza da região e pensei: se fosse nos EUA seria um parque, daí surgiu a ideia, porque não também aqui?”” (Brito, 2005:129)
\end{abstract}

Em entrevista a Brito, Funch afirma: "encontrei Lençóis e Mucugê mergulhadas numa pobreza absoluta com muita gente migrando, só ficando crianças e velhos. Devido à pobreza todo mundo tirava uma lasca da serra, seja caçando, retirando madeira ou diamante. Era tradição garimpeira, totalmente extrativista” (Brito, 2005:129). A parte o real estado de penúria ao qual as pessoas encontravam-se expostas, é importante entender a ideia de riqueza que subjaz na afirmação do ex-voluntário: o acesso direto aos recursos aparece como sinônimo de pobreza. O que se dá a entender deste ponto de vista é que a riqueza é maior quando maior a possibilidade de acesso às coisas mediado pelo dinheiro. Do que vale se perguntar: acessar os elementos de sua reprodução material como mercadorias resolve os

101 "O Parque Nacional da Chapada Diamantina (PNCD) situa-se no centro do Estado da Bahia (BA) e foi criado pelo Decreto Federal $N^{\circ}$. 91.655, de 17 de setembro de 1985, ocupando uma área de aproximadamente 152.400ha. Seu objetivo, segundo o Decreto de Criação, é proteger amostras representativas da serra do Sincorá, uma das feições que compõem a chapada Diamantina que, por sua vez, faz parte da serra do Espinhaço. Além disto, o Parque é uma área rica em nascentes, em uma região seca, e tem exuberante beleza cênica, tornando-o atraente para o turismo.” (Instituto Chico Mendes, 2007:2)

102 É notável a forma como o discurso que mobiliza a tradição como argumento se constitui como antagonismo ao caráter avassalador do avanço da modernização via garimpo mecanizado. $\mathrm{O}$ dualismo que o caracteriza, por mais bem-intencionado que seja, representa a perda da possibilidade de constituir um entendimento crítico da sociabilidade capitalista em processo. 
problemas do extrativismo? Uma análise simplória de nosso cotidiano de consumo evidencia, por exemplo, nossa total sujeição à cadeia produtiva da indústria monopolista do petróleo!

Não é por menos que o ex-voluntário do Peace Corps e primeiro diretor do PNCD entende que "foram os turistas que ensinaram os moradores de Lençóis a ver a serra"103 quando relatava como os garotos da cidade seguiam os primeiros grupos de turistas, sobretudo os tecnocratas baianos que se hospedavam na Pousada de Lençóis e os quais ele guiava para as cachoeiras do entorno. Segundo Funch, o encanto dos turistas pelas belezas naturais e o dinheiro que ele como guia amealhava educavam o olhar dos moradores locais. Em outros termos, é possível afirmar que é o olhar estrangeiro e urbano industrial, que primeiro enxerga o caráter turístico da Chapada Diamantina e seu potencial econômico ${ }^{104}$.

Se entre 1930 e o final dos anos 1960 a área estudada participou da modernização industrial brasileira como fornecedora de força de trabalho para as cidades, onde a acumulação se realizava (considerada aí também a reprodução ficcionalizada), ganhando assim a aparência de ter se estagnado no momento regional alguns atributos legados como estética advindos desse esquecimento, sobretudo no que diz respeito à arquitetura e a “natureza” (ainda que a primeira deteriorada pela desmonetarização e esvaziamento da cidade, e a segunda “intocada” apenas aos olhos dos desavisados, já que profundamente transformada por mais de um século de atividade garimpeira), tornam-se espécie de matériaprima para a inclusão da Chapada Diamantina nos planos de modernização turística do estado da Bahia. Em um exercício elucubrativo exagerado, não é difícil de imaginar que, se por algum motivo a Chapada Diamantina não tivesse passado pela dita regressão econômica, tais atributos certamente não existiriam mais, pois teriam sido solapados por uma "modernização positiva”, que na década de 1970 finalmente começava a chegar na forma do turismo.

Para encerrar este subitem é importante mencionar um ponto que deverá ser retomado mais adiante nesta dissertação. Em 1987 Francisco de Oliveira (2003) identificava que o frágil elo entre a classe trabalhadora baiana (que para ele se constituiu em Salvador e no Recôncavo a partir da instalação da Petrobras em 1950) e sua representação dava sinais de ser um "elo perdido”. De certo porque a promessa da proletarização em massa foi posta à deriva pela “crise do trabalho" (Kurz, 1992), ainda que o autor não argumente propriamente neste

103 Entrevista concedida em trabalho de campo durante o segundo semestre de 2016.

104 Durante a consolidação do turismo a mobilização do trabalho no ramo na Chapada Diamantina se firma como prática estatal através principalmente das instituições de ensino, desde a escola primária até os cursos de formação profissional para o ramo propriamente dito, como aqueles ofertados pelo Senac instalado em Lençóis. 
sentido. O mesmo está longe de ser uma verdade para a Chapada Diamantina, isso porque nela a "protoclasse" se transforma diretamente em "pós-classe”105. Nem mesmo os planejadores do turismo chegam a vislumbrar a formação do trabalho, nos termos de uma generalização do assalariamento, como possibilidade para a Chapada Diamantina. O que parece estar em questão é a monetarização das relações, a inclusão definitiva da área na sociabilidade de mercado, mesmo que seus moradores não tenham garantia alguma de que terão os meios para poder participar dela, pelo menos não sem ser como marginalizados. Para dizer em outros termos: são empurrados a tornarem-se consumidores num quadro geral de possibilidades e expectativas decrescentes de que possam se engajar no processo também como trabalhadores.

105 Falando sobre Salvador, Francisco de Oliveira descreve: "A trajetória da classe começou com uma protoclasse, atingiu seu auge nos dias do vigor da industrialização Petrobras+petroquímica, e transformou-se em pós-classe: virou pobreza. Na cada vez mais bela Salvador, fora dos olhares do turista, que vai do Aeroporto Dois de Julho/Luís Eduardo Magalhães pela orla magnífica, escondem-se favelas sem fim, onde moram os $27 \%$ de desemprego. [...] O desencanto mercantil reencanta-se no carnaval [...]. Para o observador mais arguto, a enganação dura pouco: logo se percebe que os blocos, trios elétricos, afoxés são compostos por brancos - mesmo que seja difícil definir quem é branco no Brasil, da mesma forma que é igualmente temerário definir quem é negro - e que o cordão de segurança é formado por negros. [...] A casa-grande se diverte, garantida pela senzala, e a nova síntese é Gilberto Freyre com Gilberto Gil.” (Oliveira, 2003:13-14). A formulação é oportuna pois explicita a pobreza como resultado do projeto modernizador fracassado, antes dele era outra coisa. 


\title{
FOTOGRAFIAS DO VOLUNTÁRIO DO PEACE CORPS STEVE HORMAN
}

Lençóis foi um dos municípios brasileiros que receberam voluntários do Peace Corps durante alguns dos anos em que a organização atuou no país, entre 1962 e 1980. Segundo Senilde Alcântara Guanaes, dos três jovens estadunidenses que residiram na cidade,

"Steve Horman (Estevão), natural de Marshall no Estado do Missouri (EUA), foi o segundo voluntário do Corpos da Paz em Lençóis, ele chegou à cidade por volta de 1970 e conseguiu realizar um trabalho significativo junto à população, provocando uma intensa mobilização entre os jovens e os diversos segmentos sociais da época através de um movimento chamado MCC - Movimento Criatividade Comunitária - que consistia na organização das diversas camadas populares com a finalidade de prestar serviços e benfeitorias à cidade com ações práticas e criativas.” (Guanaes, 2006:85)

Steve Horman tinha 22 anos quando chegou em Lençóis e segundo Liziane Peres Mangili

\begin{abstract}
"Preocupou-se em organizar a população, dentro da linha de 'desenvolvimento de comunidade’ pregada pelo Corpos da Paz. A ideia era pensar em soluções junto com a comunidade para reerguer a economia local e recuperar a cidade. Segundo Roy Funch, o grande mérito de Horman foi mobilizar a população: "Estevão era muito carismático, tinha muita energia, e botou aquela cidade para ferver. Ele formou o MCC, tomou um curso da Igreja Católica e colocou pra funcionar em Lençóis” [...] O Movimento Criatividade Comunitária (MCC) era um sistema de treinamento social que buscava orientar a população sobre formas de melhorar a condição de vida. O curso era promovido pela Igreja Católica, por meio de convênio com o Corpo da Paz.” (Mangili, 2015:94)
\end{abstract}

Já Heraldo Barbosa Filho afirma em entrevista à Guanaes que

““'Estevão é que descobriu esse método de criatividade comunitária (MCC), a ideia veio de um brasileiro chamado Eduardo Gregori, ele criou um método de dinâmica social que baseava-se em quatorze sistemas sociais. Ele dividiu o social em quatorze sistemas (tipo limpeza, saneamento, saúde, educação... não lembro todos) e o método era todo baseado na criatividade humana, a gente tinha que criar bastante para poder arranjar os recursos materiais para desenvolver os projetos, com apoio dos governos, sempre com o apoio dos governos, o governo federal, estadual, municipal, nunca subversivamente, sempre com a anuência dos poderes constituídos. Então, 
naturalmente que a cidade era muito carente, a prefeitura não tinha como varrer a rua, não tinha como colocar sanitário no colégio, não tinha como reformar um posto de puericultura, e nós fizemos tudo isso com esse grupo. E como é que a gente levantava os recursos? Levantava os recursos com criatividade, fazendo feira do cacareco, vendendo beiju na rua, o grupo vendia até serenata, fazíamos serenata e vendíamos músicas na serenata, com isso adquiríamos recursos para fazer esse tipo de coisa. Tudo era na base da criatividade" (Heraldo Barbosa, janeiro de 2004)." (Guanaes, 2006:85/86)

Em entrevista realizada em agosto de 2017 Heraldo Barbosa Filho relatou que a dinâmica de funcionamento das reuniões do MCC foram aprendidas por Horman no centro de treinamentos de líderes da Igreja na cidade de Ruy Barbosa, e que outros integrantes do movimento, como ele próprio, também frequentaram esse curso e repassavam os conteúdos para outras pessoas que participavam das reuniões. Ainda frisou que as reuniões do movimento congregavam figuras diversas da cidade, como o juiz, o promotor público, funcionários do Banco do Brasil, garimpeiros, estudantes, etc. Foi das atividades dos moradores organizados em torno do MCC que ganhou vulto a proposta de Steve Horman para o tombamento de Lençóis.

Um grupo de jovens integrantes do movimento realizou um levantamento histórico que veio a se desdobrar na produção do documento submetido ao Instituto do Patrimônio Histórico e Artístico Nacional (IPHAN) que pleiteava o tombamento da cidade, bem como a busca de amparo político em estâncias estaduais e nacionais ${ }^{106}$. Este mesmo grupo também produziu um material audiovisual a partir da pesquisa, o qual foi apresentado por eles no II Encontro de Governadores para a Preservação do Patrimônio Histórico, Artístico, Arqueológico e Natural do Brasil que se deu em Salvador no ano de 1971, e teve papel persuasório para que o grupo pudesse apresentar a proposta de tombamento para os então diretores da Embratur e da Bahiatursa durante a I Reunião Oficial de Turismo que ocorreu em

106 "Conseguir o apoio da mídia e de algumas personalidades influentes foi outra estratégia do grupo para alcançar o tombamento. Nesse sentido, articulara-se com Walfrido Moraes, pesquisador sobre a Chapada Diamantina e escritor de "Jagunços e Heróis", obra que narra a história do Coronel Horácio de Mattos, nascido em Lençóis. Walfrido escreveu um ofício ao então Ministro da Educação e Cultura, Jarbas Passarinho, que foi acompanhado da carta com o pedido de tombamento, assinada por Heraldo Barbosa Filho, e de uma declaração de apoio da Prefeitura de Lençóis. Talvez tenha sido através de Walfrido Moraes que conseguiram "contaminar algumas pessoas, como Pedro Calmon", relata Barbosa. Membro da Academia Brasileira de Letras, Pedro Calmon foi o conselheiro que escreveu o parecer sobre o tombamento da cidade." (Magili, 2013) 
Brasília no 1972. Os esforços do grupo culminaram no tombamento da cidade em 1973 como Conjunto Arquitetônico e Paisagístico pelo IPHAN.

O tombamento de Lençóis é o primeiro caso no Brasil cujo pedido não partiu de técnicos da área, mas sim dos próprios moradores da cidade, segundo Mangili

\begin{abstract}
"Era a primeira vez que uma proposta de tombamento de conjunto era feita por leigos e não técnicos, e também inédito que o dossiê de instrução do processo viesse, em grande parte, desses leigos: foi o material produzido pelos jovens do MCC [...]. Elaborado sem conhecimento técnico, o dossiê, assim como o processo de tombamento na íntegra, são importantes documentos que permitem identificar os valores que estavam sendo atribuídos ao que se então propunha como patrimônio, conjunto no qual a paisagem tinha valor fundamental e estava profundamente associada àquela sociedade.” (Mangili, 2014)
\end{abstract}

A autora entende ainda que "aquela cultura, em sua totalidade, era enaltecida, com todos seus componentes num só plano” (Mangili, 2014) ${ }^{107}$. É importante notar, no entanto, que um dos principais motivos para a mobilização do grupo MCC pelo tombamento de Lençóis foi a crença de que o reconhecimento do patrimônio da cidade poderia ser um forma de escape da decadência econômica e do esvaziamento populacional que ela passava. Desde o início, a proposta do tombamento estava atrelada a viabilização do turismo como atividade econômica ${ }^{108}$.

Steve Horman, o principal mentor do projeto, é formado em comunicação e fotógrafo profissional. Viveu em Lençóis como voluntário do Peace Corps entre 1970 e 1974, em seguida mudou-se para o Rio de Janeiro lugar em que trabalhou como fotógrafo para a EMBRATUR, retornando depois para os EUA, onde montou uma empresa de comunicação. No período em que morou em Lençóis, o então voluntário foi profícuo fotógrafo, tendo produzido boa quantidade de imagens da cidade e de seu entorno. Heraldo Barbosa Filho recorda que as fotografias eram reveladas em Salvador. Essa pesquisa acessou uma série de 52 fotografias ${ }^{109} \mathrm{P} \& \mathrm{~B}$ feitas por Horman, elas foram digitalizadas por Carlos de Almeida Toledo

107 Esse tema será retomado no próximo item desta dissertação.

108 Além disso, é de se notar que a própria vinda de Steve Horman para Lençóis como voluntário do Peace Corps dizia respeito à ação de um prefeito da cidade, Olympio Barbosa Filho (tio de Heraldo Barbosa Filho), que inscreveu a cidade no programa em busca de alternativas à decadência econômica.

109 As imagens encontram-se no Anexo E desta dissertação. 
a partir do acervo pessoal de Mestre Osvaldo. Outras 20 fotografias ${ }^{110}$ coloridas de autoria do voluntário estadunidense foram cedidas por Liziane Peres Mangili, que as digitalizou a partir do acervo pessoal de Heraldo Barbosa Filho, quem confirmou terem sido essas últimas as imagens utilizadas no material audiovisual do MCC.

Interessa notar que as imagens produzidas por Steve Horman, quem possuía conhecimentos sobre comunicação, talvez não tivessem como primeira finalidade a produção de uma peça publicitária, tampouco fizessem parte de um estudo sobre Lençóis. Possivelmente eram apenas registros pessoais. No entanto, acabaram sendo usadas no material elaborado pelo MCC, que foi uma espécie de síntese entre estudo e publicidade, cujo públicoalvo era o Estado nacional, na forma do IPHAN, da Bahiatursa, da Embratur e de políticos, com os quais tiveram que travar relações durante o processo.

Na análise dos dois conjuntos de imagens produzidas por Horman selecionadas estas podem ser claramente divididas em dois grupos. O primeiro deles vinculado com um "olhar de arquiteto”, possivelmente estimulado pelo projeto do tombamento, são sobretudo imagens de fachadas e possuem um tom austero, que é reforçado por serem P\&B. De alguma forma, essas imagens parecem retratar uma cidade-fantasma, dado que são poucas as pessoas registradas nessas fotografias, e mesmo estas estão distantes da objetiva do fotógrafo. No grupo de imagens coloridas, são representadas “paisagens de natureza”, registros sobre o trabalho no garimpo e pessoas em atividade de lazer. Em algumas dessas imagens as pessoas são o objeto de interesse do fotógrafo.

110 As imagens encontram-se no Anexo D desta dissertação. 


\section{FOTOGRAFIAS DO ARQUITETO FERNANDO M. LEAL EM PESQUISA PARA O IPHAN}

Parte das imagens produzidas pelo voluntário estadunidense Steve Horman apresentadas no item anterior foi usada para atrair a atenção do Estado nacional, na figura institucional do IPHAN, para a cidade de Lençóis após o pedido público de patrimonialização feito pelo grupo Movimento Criatividade Comunitária (MCC). Em 1972 será o próprio órgão que contratará o arquiteto Fernando Machado Leal para realização de um levantamento histórico e fotográfico que serviria de base para o processo de tombamento da cidade. Do trabalho do arquiteto resulta um relatório, que mais tarde viria ser publicado como artigo na “Revista do Patrimônio Histórico e Artístico Nacional”, número 18, de 1978, com o título de “A Antiga Comercial Vila dos Lençóis” e que está

\footnotetext{
“[...] composto por três partes, a primeira e segunda referem-se ao levantamento histórico (1.Introdução e 2. Resenha Histórica), e a terceira, sob título “A cidade”, aos diversos aspectos de Lençóis nos primeiros anos da década de 1970, quando foi feito o trabalho: 3.1 O sítio e o clima; 3.2 evolução urbana; 3.3 Mão de obra e técnica construtiva; 3.4 Arquitetura civil e religiosa; 3.5 Infraestrutura urbana; 3.6 Proposições iniciais para a preservação da cidade.” (Mangili, 2015:116)
}

Além do relatório, Leal apresenta ao IPHAN mais de 250 fotografias, das quais apenas 23 são publicadas como ilustrações do texto na revista da instituição ${ }^{111}$. Para se terem claras as circunstâncias da atividade do arquiteto na cidade e o entendimento que ele tinha do resultado de seu trabalho, vale destacar o seguinte trecho do relatório de Leal:

\footnotetext{
“A documentação fotográfica, anexa, fala melhor sobre o aspecto atual da cidade do que o resumido texto. Tanto a documentação aludida, quanto o texto visaram, justamente, fornecer subsídios para a apreciação da antiga Vila Comercial de Lençóis, por vezes enfatizando os aspectos negativos, no que diz respeito ao tombamento a que se destina o estudo, conforme se constata pelas fotografias. Se assim procedemos foi em virtude do assunto ser apreciado, em última instância, por técnicos que não visitaram Lençóis.” (Leal, 1978:141)
}

Este é o parágrafo de abertura do último item do relatório, "3.6 Proposições iniciais para a preservação da cidade”, do qual é importante salientar o fato da tomada de decisão a

111 Estas 23 imagens encontram-se no Anexo F desta dissertação. 
respeito do tombamento da cidade ser feita de forma remota, "por técnicos que não visitaram Lençóis”, dificuldade essa que Leal procura contornar, ou minorar, com uma documentação fotográfica, a qual segundo ele será de maior valia do que seu "resumido texto". Possivelmente, as fotografias feitas por Leal são as primeiras imagens que acompanham um estudo ou pesquisa sobre Lençóis que são entendidas pelo próprio pesquisador como melhores fontes explicativas que seu próprio texto. Tal afirmação pode ser questionada, já que o arquiteto se refere apenas ao "aspecto atual da cidade" ao apontar as fotografias como melhores fontes que o texto de seu relatório. De fato, o relatório, mesmo conciso, apresenta um panorama informativo sobre a formação da cidade em sua relação com o ciclo do garimpo de diamantes na Bahia a partir do século XIX. Mas o entendimento de que a documentação fotográfica "fala melhor" pode revelar a maneira como a cidade, enquanto fenômeno social, é compreendida pelo arquiteto. Quer dizer, não se tratou apenas de uma simples falta de pesquisa sobre a então história recente de Lençóis.

Outra passagem do relatório parece reveladora do entendimento que Leal fazia do que era a história da cidade e, por consequência, de sua própria atividade como técnico que a estuda para os fins da patrimonialização:

\footnotetext{
"Certamente, poderíamos citar outros dados relativos à vida da cidade, como, por exemplo, seus jornais, suas famílias mais importantes, suas associações, suas festas típicas, etc., entretanto, por julgarmos que esses elementos são de relativa importância para o objetivo maior do trabalho, o leitor interessado poderá ter notícias desses assuntos nas obras citadas, particularmente no Pequeno Álbum de Lençóis e na de Gonçalo de Athaíde Pereira. Se não nos detivemos em fatos recentes, como os referentes à atuação política e administrativa de Horácio de Matos, o grande chefe sertanejo, assim o fizemos por pertencerem à história contemporânea, sem influência decisiva na formação da cidade e sua arquitetura.” (Leal, 1978:125)
}

A partir do momento em que o processo social que se desdobra naquela área deixa de produzir novas construções (casas, ruas, igrejas, etc.) a história de Lençóis passa a não ter mais “influência decisiva na formação da cidade e sua arquitetura” segundo o pesquisador. Não é um exagero afirmar que a cidade é entendida por Leal como simples objeto, o que pode até soar estranho já que o próprio arquiteto sublinha em seu relatório a determinação comercial da formação de Lençóis, inclusive escolhendo nomeá-lo com o nome da antiga Comercial Vila de Lençóis ${ }^{112}$. No entanto, o arquiteto entende que

112 Do que vale lembrar que esta permaneceu como vila por menos de oito anos (entre 1856 e 1864), logo sendo elevada à categoria de cidade e chamada, simplesmente, Lençóis. 
“Como na área do ciclo do ouro, na do diamante foi também ao comerciante que se deveu a fixação do homem à terra e a formação de aglomerados urbanos. Os elementos populacionais [...] mostram discrepância acentuada com relação ao número inferior de garimpeiros, no caso de 1 para 4, o que é fácil de compreender-se, em virtude da psicologia deste tipo humano: aventureiro por excelência, sempre irrequieto, em busca de fortuna rápida. Conforme acentuou Gonçalo de Athaíde Pereira: "A cidade dos Lençóis foi sempre o centro importante de fortes operações comerciais, não só pelo seu desenvolvimento como por ser ali o lugar escolhido para residência de grandes comerciantes de pedras preciosas, alguns vindos de Santa Isabel, onde primitivamente se fazia tal comércio em grande monta.” (Leal, 1978:122)

O “expressivo” caráter comercial de Lençóis parece não implicar na consideração do comércio como relação social para Leal, do contrário as personas daquele processo não seriam entendidas como figuras autônomas como sugere o trecho acima. O que significa dizer que são aos comerciantes que se deve a formação dos aglomerados urbanos? Ou salientar que os grandes comerciantes de diamantes constroem suas residências, ao passo que os garimpeiros em busca de fortuna fácil, por sua psicologia, não se fixam?! Por essas afirmações logo se percebe o limite da compreensão do fenômeno urbano: a cidade é entendida como uma coisa pelo arquiteto, os comerciantes e grandes compradores de diamantes ao construírem suas casas e comércios formaram a cidade ${ }^{113}$.

Desse ponto de vista a história que interessa ser contada é a da construção da cidade como coisa. Quando as relações que sustentavam essa construção deixam de existir, ou não se acumulam em quantidade suficiente para a manutenção do processo, a história passa a não mais ter “influência decisiva na formação da cidade e sua arquitetura”. No entanto, ironia ou tragédia, lhe faltando a substância relacional abstraída no argumento do arquiteto, a coisa cidade passa também a ser tragada pelo tempo. Ora, é evidente na história de Lençóis (talvez hoje mais claramente do que na década de 1970) que o próprio processo de tombamento decorre da decadência da cidade, quer dizer, a razão pela qual Leal foi mobilizado como técnico para produzir sua pesquisa dizia respeito também à ruína da região das Lavras Baianas e não somente à formação da cidade no século XIX. Tendo isso em vista, é evidente que a história é mobilizada como justificativa discursiva de uma prática que estava posta

113 O que é curioso porque os grandes comerciantes de pedras preciosas e as notáveis personalidades lençoenses (cujos antigos imóveis são aqueles apontados como relevantes à patrimonialização pelo relatório do arquiteto) tampouco construíram suas próprias casas! Nem mesmo do ponto de vista da coisa física o argumento procede. 
aprioristicamente, a história interessa até o limite do conveniente para o exercício da patrimonialização, então personificada por Leal. Do ponto de vista dessa pesquisa, à uma historiografia da prática da patrimonialização caberia estabelecer criticamente os laços entre essa prática e a formação do Estado nacional brasileiro. Não somente como marcador histórico do momento de gênese institucional, mas também perguntando-se: O que está por trás da identificação e salvaguarda dos ditos patrimônios nacionais? Que história se conta sobre essa formação? E, talvez mais importante, qual o sentido do salvamento do nacional ${ }^{114}$ ?

As fotografias produzidas por Leal acompanham bem sua forma de entender a cidade, são imagens parecidas com as fotografias P\&B produzidas por Steve Horman pouco tempo antes. Registram fachadas de casas, ruas, detalhes construtivos e o interior de construções consideradas importantes, como a casa de lapidação e as igrejas. As pessoas que figuram nas imagens parecem fantasmas, estão distantes e as legendas sequer fazem menção a elas ${ }^{115}$.

Fato é que depois do relatório de Leal os “técnicos que não visitaram Lençóis” deram pareceres favoráveis ao tombamento da cidade, inclusive acatando a sugestão do tombamento do conjunto urbano de modo a extrapolar os nove itens apontados pelo arquiteto em seu relatório. É de se notar que, apesar de fazer menção a elementos como as tocas construídas por garimpeiros na serra ou as casas de "famílias de menor posse” localizadas em "ruas de importância secundária” em seu relatório, o arquiteto não as concebe como relevantes para a história nacional. Por isso parece importante retomar o ponto demarcado em nota de rodapé no item anterior, quando foi tematizado o pedido de tombamento da cidade por parte dos integrantes do grupo MCC. Sobre isso, Liziane Peres Mangili nos faz perceber um descompasso:

"[...] por parte dos proponentes do tombamento (comunidade de Lençóis, mais especificamente o grupo do MCC), o conjunto de bens destacados foi amplo: desde a paisagem natural até o casario, praças e ruas, ofícios e manifestações religiosa e cultural. Os valores a eles referenciados foram de ordem histórica, econômica, espiritual, memorial e social. Por parte dos técnicos do IPHAN, contudo, prevaleceram os valores estéticos, associados a uma parte do conjunto urbano. Ou seja, houve diferenças quantitativas e

114 Não é o caso de desdobrar o argumento neste momento, outros momentos desta dissertação lidam com este debate com maiores detalhes. De qualquer maneira não é demais apontar que o patrimônio nacional, antes de mais nada, conta a história da imposição violenta do trabalho.

115 Um contraponto interessante são as imagens contemporâneas produzidas por Rino Marconi em 1972, disponíveis no acervo digital do Museu da Imagem e do Som (MIS) e que serão abordadas no item 19. As fotografias autorais no tempo da circulação impressa desta dissertação. 
qualitativas no reconhecimento de bens patrimoniais e na atribuição de valores.” (Mangili, 2014)

Mangili (2013) demonstra também, como os pareceres técnicos de Pedro Calmon e Lygia Martins Costa buscam aproximar Lençóis do referencial arquitetônico das cidades coloniais já tombadas pelo IPHAN até a década de 1970, reafirmando o referencial estabelecido institucionalmente do que seria próprio da identidade nacional. Além disso, aponta que os técnicos estavam informados pelas referências do campo das artes, o que tornava certos caracteres, como "autenticidade” e “excepcionalidade”, atribuídos por um grupo de experts, centrais para os processos decisórios em torno da patrimonialização. No caso de Lençóis foi ignorada uma série de elementos indicados pelos moradores pleiteantes, sendo apenas o núcleo urbano construído considerado no processo de tombamento. Essa forma de proceder a patrimonialização tem ecos até os dias de hoje, mas a autora aponta para as mudanças das políticas públicas da área no Brasil:

"O campo patrimonial passou, nas últimas décadas, por expansões, mudanças e deslocamentos, devido ao avanço da globalização e à incorporação de outras disciplinas e campos de conhecimento, como a antropologia, a psicologia, geografia, linguística, economia e sociologia. A "noção tradicional de valor artístico é deslocada e/ou substituída pela noção mais ampla, de base antropológica, do valor cultural” (CASTRIOTA, 2009, p. 96). As Cartas Patrimoniais acompanharam essas mudanças e foram gradativamente acrescentando categorias de bens e valores em suas formulações. Uma das Cartas que coloca claramente a importância dos valores é a Carta de Burra, na qual a significância cultural é o que deve ser preservado e transmitido às gerações futuras, e não os bens em si.” (Mangili, 2013)

De fato, é notória a abertura do campo da patrimonialização para um espectro muito mais inclusivo, expandindo seu campo de ação para além da fronteira notadamente elitista que a limitava até não muitos anos atrás. Seria o caso, no entanto, de colocar em debate o conceito de cultura que organiza essa forma renovada de operar a patrimonialização, sobretudo a ideia de que se possa preservar uma manifestação cultural através de uma política pública, o que a rigor seria uma contradição em termos. Somente deslocando a cultura como esfera autônoma da totalidade social pode-se propor um projeto de conservação cultural, ainda mais como prática da tecnocracia estatal. Isso fica evidente quando se analisa o processo de tombamento de Lençóis: Mangili considera que no dossiê do MCC “aquela cultura, em sua totalidade, era enaltecida, com todos seus componentes num só plano”, essa totalidade seria então o objeto 
do tombamento ${ }^{116}$. No entanto, o próprio pedido de tombamento revela que os fundamentos sociais daquela totalidade estavam deixando de existir, o garimpo encontrava-se em decadência e a preservação era entendida como um caminho para algo completamente novo: o turismo. Somente entendendo a cultura como esfera cindida, que paira separada das relações sociais que a constitui, é possível realmente imaginar sua preservação nestes termos.

Do ponto de vista da crítica aqui esboçada, é particularmente importante a crítica da separação entre cultura e economia como esferas autônomas. Isso porque desta maneira fica sugerido que o trabalho e o dinheiro são formas de mediação social a-históricas, ou então, “aculturais”. Assim entendidas essas categorias ficam salvaguardadas da crítica e acabam sendo as verdadeiras formas culturais preservadas em todo o processo, ainda que na crise do trabalho permaneçam como ficção ${ }^{117}$.

Ainda assim, é de se notar que o ponto de vista que opera cindindo as esferas não o faz por simples erro analítico, isso porque ainda que se trate de uma abstração, tal separação se realiza como uma abstração real. Ou seja, ela tem sentido social e constitui lugares discursivos que se fazem e se realizam socialmente, inclusive de forma crescente, como é o caso da tecnocracia ${ }^{118}$.

116 É o caso de se questionar também o enaltecimento intransigente. Para o que nos serve a construção de uma memória sem crítica e autocrítica? Que se faz apenas como apologia?

117 Ver item 14. A descoberta da Chapada Diamantina e sua incorporação ao Estado nacional desta dissertação.

118 A qual também o executor desta pesquisa não deixa de personificar, como qualquer acadêmico. 


\title{
FOTOGRAFIAS DE ARISTIDES ALVES
}

PARA A BAHIATURSA

Aristides Alves é mineiro, radicado em Salvador desde 1972, onde cursou biologia na Universidade Federal da Bahia (UFBA). Em paralelo à faculdade mantinha a fotografia como hobby, principalmente registrando apresentações musicais e teatrais. Em 1975 foi convidado para ser fotógrafo da BAHIATURSA, de modo que a fotografia passou de hobby a trabalho. Criou a primeira agência de fotojornalismo da Bahia, a ASA, que se baseava na prática de agências paulistanas e cariocas que funcionavam autonomizadas dos jornais, quer dizer, seguiam suas próprias pautas ${ }^{119}$.

Em meados dos anos 1970 o planejamento do turismo do estado da Bahia começa a chegar na Chapada Diamantina. Como não podia deixar de ser, a fotografia foi um recurso técnico importante nos processos de pesquisa subsidiários desta transformação. Francisco Emanuel Matos Brito aponta que

\begin{abstract}
“A partir de 1974, verifica-se a primeira tentativa de ação planejada do Governo do Estado na região com o objetivo de interiorizar e promover o desenvolvimento do turismo ao deslocar para a Chapada Diamantina uma equipe técnica - da Coordenação de Fomento ao Turismo, ligada à Empresa de Turismo da Bahia (BAHIATURSA) - integrante do projeto "Identificação do Potencial Turístico do Estado” para realizar um diagnóstico dos municípios de Lençóis, Andaraí e Mucugê que resultou no documento Chapada Diamantina, uma avaliação prévia para a implantação do turismo nos municípios de Lençóis, Andaraí e Mucugê que, além de analisar as principais atividades econômicas dos referidos municípios, também efetua o levantamento fotográfico da área urbana, do artesanato, das manifestações culturais e dos principais casarões destas cidades.” (Brito, 2005:124)
\end{abstract}

Também no ano de 1976, o governo estadual baiano criou a EMTUR (Empreendimentos Turísticos da Bahia S.A.), órgão vinculado à Bahiatursa responsável pela construção de pousadas no interior do Estado (Brito, 2005). Lençóis foi uma das cidades escolhidas para integrar o programa. Nesse período Aristides Alves já era fotógrafo do órgão e integrava as equipes técnicas que trabalhavam na implementação do programa. Ele trabalhou cerca de vinte anos para a BAHIATURSA como funcionário assalariado, mas em paralelo manteve uma série de outros trabalhos como fotógrafo ou vinculados à fotografia. Contou ${ }^{120}$

119 A experiência não teve sequência pois a imprensa baiana não requeria uma produção de imagens a ponto de possibilitar a existência desse tipo de serviço.

120 Entrevista realizada em agosto de 2017. 
que a equipe que realizou a pesquisa preliminar para instalação da Pousada de Lençóis era composta, além dele como fotógrafo, por um redator, por uma pessoa ligada a área de projetos, e um "bucha” (um desenhista que produzia o projeto gráfico, os mapas e ilustrações necessários). Muitas vezes suas fotografias, sobretudo aquelas feitas propositalmente de pontos altos, serviam de subsídio para os desenhos e croquis do "bucha”. O próprio fotógrafo resumiu sua atividade na BAHIATURSA como a execução de uma "prospecção imagética" das potencialidades turísticas das localidades onde o órgão buscava desenvolver a atividade do turismo.

No entanto, Aristides Alves salientou também que suas atividades estavam longe de se encerrarem como pesquisa, desde o início as imagens eram feitas visando subsidiar a produção do material publicitário que a BAHIATURSA divulgava com o intuito de fomentar o turismo no estado baiano. Ele montou um laboratório de fotografia P\&B e um arquivo dentro da BAHIATURSA, e comentou que existia uma espécie de agência publicitária internalizada (não autonomizada) para produção dos materiais de divulgação. As fotografias produzidas durante a visita técnica para a construção da Pousada de Lençóis, além de comporem o material que subsidiou o trabalho de planejamento dos técnicos, foram usadas em publicações de divulgação na época, com panfletos, pôsteres, revistas, etc.

Infelizmente não foi possível acessar as fotografias originais. Mas, optou-se por manter esse conjunto entre as imagens selecionadas para essa pesquisa ${ }^{121}$, pelo entendimento de que ele representa um momento singular da estrutura de relações que estão por trás da produção da representação da área estudada. Entre as imagens selecionadas até este período estas são as primeiras remuneradas na forma salarial, a um técnico especializado e pelo Estado, portanto, como trabalho improdutivo do ponto de vista da reprodução capitalista.

121 Inclusive como registro para possíveis pesquisas futuras. 


\section{DIAMANTINA HIGHLANDS}

O livro mais antigo marcadamente “de fotografia” sobre a Chapada Diamantina encontrado durante esta pesquisa chama-se Chapada Diamantina = Diamantina Highlands. Tomar seu nome como anúncio premonitório da relação com o exterior (quase uma caricatura por conta do sinal de igualdade empregada da edição bilíngue), que viria se aprofundar em um futuro nada distante, além de valer como ensejo chistoso para o tema, tem também seu fundamento material. O livro foi publicado em 1988 pela AC\&M Assessoria de Comunicação e Marketing LTDA. Congrega as fotografias de Luiz Claudio Marigo, texto de introdução e legendas de Jorge Amado, textos sobre a ecologia da Chapada Diamantina de Roy Funch e sobre a história da região de Carlos Ribeiro. A publicação contou com verba angariada através da lei Sarney $n^{0}$ 7.505/86 (primeira lei de incentivo fiscal para cultura do Estado brasileiro, que vigorou entre os anos de 1986 e 1990, precedendo a lei $n^{\circ}$ 8.313/91, conhecida popularmente como lei Rouanet) junto a empresa CIBA-GEIGY Química S.A. Em resumo: o primeiro “livro de fotografias” da Chapada Diamantina tem como um dos públicos-alvo o estrangeiro e é produzido com dinheiro recolhido através de uma lei de incentivo à cultura, que funcionava através de renúncia fiscal do Estado, junto a uma indústria química multinacional. Certamente trata-se de uma estrutura econômica transformada, basta lembrar que em 1972 Francisco de Oliveira apontava a inexistência de legislação promocional do desenvolvimento do terciário, com exceção da EMBRATUR. A análise de tais mudanças é, entre outras coisas, o tema deste subitem.

Segundo Lúcia Aquino de Queiroz (2002), entre 1989 e 1990 dois estudos sobre o turismo na Bahia seriam publicados, tratam-se dos Turismo em Salvador ${ }^{122}$ e Salvador uma alternativa Pós-industrial ${ }^{123}$, estes textos, que serviram de subsídio à BAHIATURSA, têm em comum o diagnóstico da necessidade de internacionalização do turismo baiano. Ainda segundo a autora

“[...] o BID já havia apoiado iniciativas do Nordeste direcionadas para essa atividade [o turismo], a exemplo da viagem dos gestores turísticos nordestinos aos EUA em 1971, e participando da concepção do Plano de Turismo do Recôncavo. Contudo, a ideia inicial dessa nova parceria [que resultará no Prodetur/NE I] partiu do Estado de Sergipe e originou-se de uma consulta feita em 1990, pelo seu ex-governador, João Alves Filho, a Enrique Iglesias, então presidente do BID e seu amigo pessoal, sobre as possibilidades de esse organismo financiar um projeto turístico para o seu

122 BAHIA. Fundação CPE. Turismo em Salvador. Salvador: Fundação CPE, 1989.

123 SUAREZ, Marcus Alban. (coord.). Salvador, uma alternativa pós-industrial: cultura, turismo, alta tecnologia. Salvador: Governo do Estado-SICT/UFBA, 1990 
Estado, a custo estimado em US\$ 120 milhões. Iglesias, conforme relato de Alves, explicou-lhe que o banco não se interessaria por um projeto cujo montante de recursos era tão pouco expressivo para os seus padrões, sugerindo-lhe ampliá-lo, de modo a abarcar toda a região nordestina.” (Queiroz, 2002:145-146)

Quer dizer, para o banco o problema está longe de ser a existência de dinheiro, este se encontra superacumulado, mas sim como aplicá-lo de forma massiva. Neste particular, seria interessante questionar: qual o sentido de um banco de desenvolvimento fomentar justamente o turismo como via para o desenvolvimento? Ainda que esteja longe das intenções desta pesquisa apontar os melhores caminhos para o desenvolvimento, é de se considerar que seja mais ou menos reconhecida a fragilidade do turismo como atividade econômica, do que se pode derivar a coerência da acusação da finalidade do controle geopolítico desse tipo de financiamento. De qualquer forma a esfera do discurso também faz parte do planejamento como prática de Estado ou do empresário particular. A crise ecológica, ou a assim chamada questão ambiental, é um tema que passou a fazer parte das agendas de debate e logo o planejamento incorporou seu temário como embasamento propagandístico de suas propostas de política econômica. É justamente como política econômica que a questão ambiental ganha unidade, pois como questão concreta só pode conformar um ajuntamento de teorias e práticas inconciliáveis. Por isso mesmo, do ponto de vista aqui assumido, é apenas como parte de uma crítica da economia política que a questão ambiental guarda alguma relevância para o debate crítico. Como economia sustentável não ultrapassará o reformismo. Mas, no caso analisado, a liberação dos recursos estava atrelada à apresentação de um plano ${ }^{124}$ de desenvolvimento turístico por parte de cada um dos estados beneficiários. No caso baiano o plano já se encontrava pronto em $1992^{125}$,

“O Programa de Desenvolvimento Turístico da Bahia foi realizado pelas empresas Consultoria Turística Integrada (CTI) e SOLUÇÃO - Assessoria e Planejamento, contratadas pelo governo do Estado, sob responsabilidade da Bahiatursa. Esse programa tinha como objetivo 'captar recursos financeiros internacionais através de financiamentos do BID - Bando Interamericano de

124 A dependência estrutural do crédito quando o capital fictício passa a ser a forma hegemônica do capital em escala global conforma uma nova forma do acesso ao capital monetário adiantado, na qual os projetos e editais transformam-se na maneira renovada de "trabalhar para arranjar trabalho”. Coerentes ao seu tempo, são promessas de trabalho.

125 Vale destacar que no caso baiano o desenvolvimento do plano é especialmente célere. Parte dos outros estados participantes do acordo, por dificuldades financeiras e administrativas, somente cumprem tal exigência no final da década de 1990. 
Desenvolvimento, sendo o BNB - Banco do Nordeste do Brasil - o agente financeiro' (BAHIA, 1992b, p.3). [...] tinha como estratégia fundamental a criação de Centros Turísticos Integrados, que se constituiriam em instrumentos de promoção do desenvolvimento econômico da região litorânea e do interior do Estado, a serem implantados em áreas 'com maior potencial de recursos naturais, cujas qualidades cênicas apresentassem excepcional capacidade de atração para o turismo internacional' (ID., 1992b, p.3).” (Queiroz, 2002:148)

Neste primeiro projeto a Chapada Diamantina não foi incluída como área de investimento, mas em 1993 é feita uma revisão para um novo projeto e a BAHIATURSA lança o Relatório Prévio do Prodetur-BA à Missão de Orientação do BID, no qual são revistas as zonas turísticas do estado e a Chapada Diamantina passa a fazer parte do conjunto selecionado. Desse mesmo ano é o Plano de Desenvolvimento Turístico da Chapada Diamantina e a criação da Área de Preservação Ambiental APA Marimbus - Iraquara ${ }^{126}$, prevista neste mesmo texto. Em 1994 a parceria é consolidada, contando com a participação dos estados nordestinos, BID, BNB, SUDENE e EMBRATUR.

\begin{abstract}
"O programa na sua primeira fase, mais conhecida como Prodetur/NE I, iniciado em 1994, tinha como objetivo criar condições favoráveis à expansão e melhoria da qualidade da atividade turística e melhoria da qualidade de vida das populações dos municípios alcançados. O aporte de recursos de investimentos totalizou US\$ 670 milhões.

Na fase I foram privilegiadas: a infraestrutura de saneamento básico (água e esgoto) e de suporte ao turismo - instalação ou ampliação de aeroportos, urbanização de áreas turísticas, centros de convenções, recuperação do patrimônio histórico, bem como um aquecimento da economia das localidades turísticas.” (Paiva, 2010:204)
\end{abstract}

126 Segundo o próprio plano de manejo da APA Marimbus-Iraquara, produzido com verba do Prodetur/NE I em 1998, afirma que "A APA Marimbus-Iraquara, instituída através do Decreto Estadual n².216 de 14 de junho de 1993, em consonância com o PRODETUR - Programa de Desenvolvimento Turístico da Bahia, envolve uma área de $1.254 \mathrm{~km} 2$, na porção central da Chapada Diamantina, abrangendo terras dos municípios de Iraquara, Lençóis - inclusive suas sedes municipais - Andaraí, Palmeiras e Seabra. Dentro dos limites da APA coexistem ambientes singulares, bastante vulneráveis à degradação ambiental, que estavam a exigir um ordenamento criterioso das atividades econômicas, em particular, do turismo. Nesse contexto, é fora de dúvida que a APA é potencializadora da atividade turística, principalmente do ecoturismo." De uma só vez o governo do estado da Bahia criou outras oito APAs vinculadas às Zonas Turísticas da Bahia. 
Segundo Brito (2005) nesta primeira fase do programa, que se estende até $2005^{127}$, mais de $90 \%$ dos recursos previstos para a Chapada Diamantina ${ }^{128}$ foram destinados às obras de transporte $(54,3 \%)$, de saneamento $(28,3 \%)$ e de eletrificação $(10,2 \%)$, destaque dado à construção do aeroporto de Lençóis, concluído em 1998. Além disso se deu a liberação de crédito para iniciativa privada destinado à ampliação da hotelaria na área. Ainda como obra vinculada ao Prodetur/NE I entre 1996 e 1998 foram realizadas a restauração das fachadas do casario de Lençóis, denominada pelo projeto como "recuperação do centro histórico de Lençóis”, feita em parceria com o Instituto do Patrimônio Artístico e Cultural da Bahia (IPAC).

Em 2001, durante a vigência do Prodetur/NE I, Lençóis é incluída entre as cidades que receberam recursos do programa Monumenta, que

\begin{abstract}
“[...] foi um programa desenvolvido pelo Ministério da Cultura (MinC) e pelo BID, com parceria da UNESCO e do IPHAN, inspirado em ações anteriores de preservação deste último [sic] na cidade de Quito. De âmbito nacional, o programa atuou em 26 cidades brasileiras, tombadas pelo IPHAN ou detentoras de Conjuntos Urbanos tombados, entre 1999 e 2009." (Mangili, 2015:260)
\end{abstract}

Uma característica dos programas de desenvolvimento da Chapada Diamantina a partir dos anos 1990 é a incorporação de duas ideias que passam a organizar o discurso oficial, são elas a ideia de sustentabilidade, que, reveladoramente, é empregada tanto para se referir à questão ambiental como à gestão econômica; e a gestão participativa, que está mais para socialização dos conflitos e perdas. Na realidade não se trata de uma particularidade local, são diretrizes estabelecidas pelas instituições de fomento, que, ao que parece, ao socializar responsabilidades de gestão neutraliza as vozes dissonantes e críticas mais interessantes do processo. No caso do programa Monumenta esse viés se realizou através da Oficina de Planejamento Participativo, criticada por Liziane Peres Mangili (2015) por servir como ferramenta de gestão que reafirmava a posição dos técnicos envolvidos. Já no caso do

127 É de se atentar para não coincidência dos dados apresentados por Brito (2005) com os dados presentes no Plano de Desenvolvimento Integrado do Turismo Sustentável - Pólo Chapada Diamantina (2004).

128 A Zona Turística da Chapada Diamantina no Prodetur/NE I abarcava doze cidades, no Circuito do Diamante: Lençóis, Andaraí, Mucugê, Palmeiras, Iraquara, Seabra e Itaetê (com exceção de Seabra, maior cidade entre elas e centro econômico regional e Iraquara, as outras possuem áreas que compõem o PNCD); no Circuito do Ouro: Rio de Contas, Piatã, Érico Cardoso, Jussiape e Livramento do Brumado (Brito, 2005). 
Prodetur, em sua fase de implantação era prevista a formação de uma entidade gestora local, que se realizou na constituição do Conselho do Circuito do Diamante - CONCID.

A segunda fase do programa de desenvolvimento do turismo no Nordeste, Prodetur/NE II ${ }^{129}$, teve início em 2005 e previsão de término para 2020, segundo dados do governo do estado apenas $0,1 \%$ dos investimentos realizados pelo programa na Bahia até 2012 foram destinados ao Polo Turístico da Chapada Diamantina. Para além da contabilidade geral do programa, estéril para compreensão do processo nas suas implicações profundas, é importante ter claro que

“[...] 'o aumento de renda, de emprego e da qualidade de vida da sua população’ em geral, presente no discurso de (quase) toda intervenção pública e privada, também encerra uma conotação ideológica, pelo fato do empreendedor se apresentar como benfeitor universal, diluindo os reais beneficiários no bolo da população, ocultando assim o real sentido da intervenção, dirigida sobretudo, para beneficiar os agentes econômicos capazes de ter acesso às fontes de financiamentos, na forma de crédito, para ampliar e implantar seus empreendimentos turísticos. Quanto à inclusão dos demais, esta, além de não ocorrer para todos, está condicionada à capacidade de inserção de determinados trabalhadores no processo de desenvolvimento turístico, geralmente em atividades secundárias e de baixa remuneração.” (Brito, 2005:153)

Novamente o conceito de riqueza que organiza o argumento dos planejadores, também é reduzido a simples representação monetária. Mesmo assim, somente como malabarismo contábil a promessa de "qualidade de vida”, no caso um eufemismo para o poder de compra, poderá ser atendida como meta alcançada dos projetos. Para além de um pequeno grupo de beneficiados ${ }^{130}$, empresários da hotelaria, empreiteiras e agências de turismo (no caso da Chapada Diamantina boa parte deles pessoas vindas de fora, enquanto em outras áreas, como as zonas turísticas litorâneas, já se tratam dos grandes capitais internacionais do ramo) o turismo planificado não criou muito mais ${ }^{131}$ que postos de empregos precarizados e sazonais, além da pauperização relativa das populações das áreas de investimento, em decorrência da

129 O Polo Turístico da Chapada Diamantina no Prodetur/NE II passa a abarcar vinte e oito cidades, sendo acrescidas ao Circuito Diamante as cidades de Nova Redenção e Ibicoara e ao Circuito do Ouro as cidades de Paramirim, Rio do Píres e Abaíra; além da criação do Circuito da Chapada Norte, que inclui as cidades de Campo Formoso, Saúde, Caem, Jacobina, Ourolândia, Miguel Calmon, Morro do Chapéu, Piritiba, Bonito, Utinga e Wagner (Brito, 2005). O Prodetur/NE II também passa a abarcar parte do norte do estado de Minas Gerais e do estado do Espírito Santo.

130 Ainda aqui o sentido de beneficiamento pode ser contestado, já que parte desses "beneficiados" amargam a crise de seus negócios particulares e as dívidas do crédito acessado através dos programas ou por outras vias. 
inflação desmedida dos custos de reprodução das famílias e da especulação imobiliária. Quer dizer, ainda que redunde em maior oferta de empregos e volume de dinheiro circulando, as taxas de exploração desses trabalhadores achataram seus rendimentos ao limite de sua reprodução como força de trabalho, quando não abaixo disso.

Mas se “o trabalhador”, que é uma figura que personifica a produção, deve ser interpretado em perspectiva dentro do próprio capitalismo (o que os intérpretes do "sujeito histórico” positivo parecem perder de horizonte), não é diferente com “o consumidor” (escanteado como questão secundária pela crítica tradicional) o qual parece se autonomizar da figura do trabalhador. Se é possível pensar em um limite da reprodução da força de trabalho, é também necessário construir uma interpretação que consiga pensá-lo na sua dinâmica histórica. O limite da reprodução da força de trabalho socialmente definido (e aqui se tem em mente o caráter das necessidades humanas de que fala Marx em sua definição da mercadoria ${ }^{132}$ ) descreveria uma linha histórica ascendente se fosse o caso de expormos a questão de forma cartesiana. Mas isso não é bem o que interessa apontar aqui, parece mais importante voltar novamente à distinção entre riqueza efetiva e valor (Postone, 2014), e sugerir que o paradigma progressista do crescimento econômico já tenha se suprimido a si próprio como projeto viável. Para quem gosta de imagens pode-se dizer que não faltam indícios fenomênicos de que jogaram tanto fermento no bolo que ele cresceu demais, transbordou e está queimando de fora para dentro. O que não significa que a desigualdade tenha se resolvido, longe disso, tem muita gente sobrevivendo dos restos intragáveis desse bolo amorfo.

No planejamento econômico do estado da Bahia nos anos 1990, além do turismo já abordado, estavam previstas outras três frentes de ação (Brito, 2005): a expansão do Complexo Petroquímico de Camaçari; investimentos em dois grandes projetos de celulose; e a expansão das fronteiras agrícolas do estado através da agroindústria e de programas de agricultura irrigada. Nesta última frente a Chapada Diamantina também é afetada,

131 Se considerada a questão de um ponto de vista estritamente econômico, já que normalmente o turismo se faz com processo avassalador de transformação dos espaços, mas sobretudo das formas de sociabilidade dos lugares onde se instala.

132 "A mercadoria é, antes de tudo, um objeto externo, uma coisa, a qual pelas suas propriedades satisfaz necessidades humanas de qualquer espécie. A natureza dessas necessidades, se elas se originam do estômago ou da fantasia, não altera nada na coisa. Aqui também não se trata de como a coisa satisfaz a necessidade humana, se imediatamente, como meio de subsistência, isto é, objeto de consumo, ou se indiretamente, como meio de produção." (Marx, 1996:165). A indiferença quanto à origem da necessidade e a maneira de sua satisfação para a definição da coisa, a mercadoria, possivelmente tenha satisfeito os críticos que consideram a questão do consumo uma superficialidade. 
“[...] pelo fato desta região ser detentora da principal bacia hidrográfica do estado, representada pelo Rio de Contas e, principalmente, pelo Rio Paraguaçu, condição esta, que associada a outros fatores naturais e econômicos, despertou a atenção de grupos externos e da própria região para implantarem projetos irrigados constituindo assim o bipolo Mucugê/Ibicoara, ampliado na segunda metade dos anos 90 com a construção da Barragem do Apertado.” (Brito, 2005:132)

Neste particular, vale citar mais uma vez as contradições internas dos projetos de planificação econômica empenhados pelo estado baiano. A área mencionada (em transformação desde meados dos anos 1980, pelo reposicionamento das famílias da oligarquia local através de um projeto de modernização agrícola que contou com aporte de capitais internacionais do ramo) faz divisa com o PNCD, sendo motivo de litígios entre ambientalistas e as empresas ali instaladas, as quais fazem largo uso de fertilizantes e agrotóxicos.

Voltando novamente à escala do Estado nacional, os anos 1990 marcam o início do dito “ciclo neoliberal”. Para Francisco de Oliveira

\begin{abstract}
“O padrão da crise do desenvolvimento tornou-se, assim, o padrão normal do período neoliberal. Em termos de taxa per capita, a situação é ainda pior. Se tomarmos o referencial da década 1990-1999, quando o crescimento per capita acumulado ficou em apenas 1,6\%, levaremos 450 anos para dobrar a renda per capita dos brasileiros. Se considerarmos o período de 1990 a 2004, precisamos de "apenas" 150 anos para produzir o mesmo feito. E, contra toda história brasileira desde os anos 1930, trata-se de uma política econômica conservadora, medrosa, anti-intervencionista.” (Oliveira, 2018:68)
\end{abstract}

Em seguida o autor ressalva o caráter do anti-intervencionismo do neoliberalismo, que é o por abaixo dos direitos do trabalhador, enquanto por outro lado se governa para o capital financeiro, o que somente viria a ficar claro para a teoria social nos anos 2000. Aquilo que se realiza como política social durante o período de bonança do chamado "ciclo das commodities" não passou de "funcionalização da pobreza". Mais do que nunca o Estado se restringe à função de intermediário financeiro do capital fictício ${ }^{133}$, mesmo porque é um dos

133 Na Chapada Diamantina a comparação entre a ação do Estado no caso da construção da Pousada de Lençóis e do Hotel Portal de Lençóis é um exemplo claro dessa mudança: "Em meados dos anos 90, a implantação do Hotel Portal de Lençóis e a construção do aeroporto representaram um divisor de águas no desenvolvimento do turismo regional. Nesta segunda intervenção, o Governo do Estado, ao invés de construir diretamente, emprestou recursos para a edificação deste meio de hospedagem.” (Brito, 2005:266) 
entes sociais que pode transformar suas dívidas em papéis para alimentar o circuito virtuoso da ficcionalização, e de gestor da crise social, numa alternância e/ou mescla entre seus caráteres privatizante/policialesco ou assistencialista/humanista, as duas faces do mesmo processo que oscilam de acordo com as marés da política e dos fluxos de capitais financeiros internacionais. Por isso, parece interessante retomar o sentido dado ao subdesenvolvimento por Francisco de Oliveira (2003):

"Como a singularidade e não elo na cadeia do desenvolvimento, e pela 'consciência', o subdesenvolvimento não era, exatamente, uma evolução trancada, mas uma produção da dependência pela conjunção de lugar na divisão internacional do trabalho capitalista e articulação dos interesses internos. Por isso mesmo, havia uma abertura a partir da luta interna de classes, articulada com uma mudança na divisão internacional do trabalho capitalista.” (Oliveira, 2013:127)

Em 2003, quando o autor lança seu O Ornitorrinco, essa abertura já não parece mais uma possibilidade, a complexificação das relações com a economia internacional e a estrutura político econômica brasileira já a inviabilizava completamente. No entanto, a "abertura" ainda vislumbrada em 1972 (e, apesar da desilusão, aparentemente ainda desejada em 2003) não era outra coisa que o anseio desenvolvimentista que tem por base a naturalização do trabalho ${ }^{134}$ como mediação social, incorrendo na incorporação acrítica dos parâmetros de um capitalismo produtivo, compreendido de maneira positiva, ou seja, algo a ser restabelecido atualmente com a eliminação das “classes parasitárias" e a "luta pelos direitos”, ou revolucionado por um “Estado dos trabalhadores”. Daí a relevância dada para indicadores inócuos como o de crescimento econômico.

Mas quando os padrões de produtividade tornam-se barreiras definitivas para a reprodução do capitalismo enquanto valorização do valor, o que se pode enxergar dentro dos limites da sociabilidade da mercadoria e do Estado de direito será apenas gestão de crise. A partir de tal chave analítica pode-se, por exemplo, rever o papel do trabalho informal na reprodução do capital atualmente. Isso porque, ainda que "no fundo, só a plena validade da mais-valia relativa, isto é, de uma altíssima produtividade do capital, é que permite ao capital eliminar a jornada de trabalho como mensuração do valor da força de trabalho" (Oliveira, 2013:137), nada garante que por isso o capital passe a "utilizar o trabalho abstrato

134 "Esse exemplo do trabalho mostra com clareza como as próprias categorias mais abstratas, apesar de sua validade para todas as épocas - justamente por causa de sua abstração -, na determinabilidade dessa própria abstração, são igualmente produto de relações históricas e têm sua plena validade só para essas relações e no interior delas.” (Marx, 2011:83/84) 
dos trabalhadores 'informais’ como fonte de produção de mais-valor” (Oliveira, 2013:137), garantindo sua reprodução. Se por um lado parece relevante salientar a impossibilidade da manutenção dos atuais níveis de acumulação através da extração de mais-valia absoluta dos trabalhadores informais, por outro (e é o que parece mais importante discutir) a questão formulada desta maneira tende a encaminhar novamente o debate para uma espécie de vontade de retorno ao capitalismo produtivo, como se o retorno ao tempo da mais-valia relativa, do capital produtivo e da carteira de trabalho fosse o ponto que chegada da emancipação desejada ou, no melhor dos casos, caminho necessário para uma sociabilidade revolucionada.

Mas a economia se faz sob bases fictícias, dinheiro sem valor, promessa de trabalho futuro que toma forma de capital adiantado. Esse adiantamento impagável pode assumir múltiplas formas fenomênicas, que escamoteiam seu caráter ficcional. Nesse sentido, é importante mencionar, ainda que de modo ligeiro, algumas dessas formas aparentes que se fizeram ou fazem presentes na área pesquisada. Por princípio os gastos infraestruturais (aqui inclusos aqueles referentes aos programas de desenvolvimento do turismo, mas não só) empenhados pelo Estado, ainda que executados como programas de modernização planejada, são capitais empenhados de maneira improdutiva, assim como os "gastos sociais" - no que se destacam na área estudada a importância da aposentadoria rural ${ }^{135}$ e de programas de distribuição de renda como o Bolsa Família, que muitas vezes garantem a subsistência de três ou quatro gerações de algumas famílias. Inquerir a origem do dinheiro que move a economia do turismo, ou seja, quem são seus consumidores, não como crítica moral dessa ou daquela persona, mas buscando seus fundamentos econômicos, certamente apontarão também que boa parte dos turistas vivem de atividades improdutivas do ponto de vista da acumulação capitalista, ainda que alguns ostentem os signos do poder social, não passam de consumidores improdutivos $^{136}$.

135 "A Previdência Rural é menos uma previdência e mais um vigoroso programa de redistribuição de renda. Essa é hoje uma fonte importante de renda para muitos municípios pobres do Brasil." (Oliveira, 2018:65). Estando de acordo, é possível acrescentar, na mesma linha de raciocínio, que o crédito rural no Brasil é menos um sistema de incentivo à produção e mais um vigoroso programa de concentração de renda!

136 "Qual é então o critério econômico decisivo que permite determinar conceptualmente no plano do capital conjunto (isto é, depois de eliminar a distorção típica do capital singular), se um trabalho é produtivo ou não? A distinção entre a "verdadeira" criação de valor e a atividade de "simples mediação" (no sentido comercial, monetário ou jurídico) não é suficiente, pois ainda se apega à definição imediata de cada dispêndio de trabalho. Esta definição só pode indicar o motivo exterior pelo qual uma atividade é considerada um trabalho improdutivo, mas não chega a esclarecer o conceito econômico subjacente. Uma definição do trabalho produtivo, referida ao processo de mediação da reprodução capitalista no seu todo, só pode ser avançada 
Mas, mesmo que o capital fictício seja a mediação central de nossa sociabilidade, a reprodução das pessoas ainda se faz na concretude do cotidiano. Nesse sentido, o cotidiano se faz como representação concreta ("dispêndio de cérebro, músculos e nervos”) do trabalho produtivo $^{137}$. Esse seria um sentido profundo da ideia de sociedade do espetáculo proposta por Guy Debord (1997): ser simulação do capital produtivo operando. Do que se depreende que a matéria da compreensão superficial do conceito, como crítica da mídia e dos simulacros, são no máximo desdobramentos secundários do seu fundamento. Esse aprofundamento do conceito implicaria em não considerar o espetáculo como simples discurso falacioso desta ou daquela persona, mas sim como forma de ser da mediação da mercadoria quando já não repõem suas bases reprodutórias. Nessa chave os discursos das personas constituiriam momento necessário de seus posicionamentos na disputa por "dinheiro sem valor" (Kurz, 2014).

Retorna-se, então, novamente à questão da representação de classe apontada no final do item 14. A descoberta da Chapada Diamantina e sua incorporação ao Estado nacional. Francisco de Oliveira, em 2003, assim se referia ao problema no prefácio de $O$ elo perdido: “[...] se, na primeira vez que este trabalho veio à luz [1987], o elo estava perdido, desta vez pode ser que já não mais exista”. O elo era a consciência do trabalhador de sua subsunção ao capital, o elo entre sua condição de classe objetiva e a representação subjetiva que faz dessa condição. Elo que seria a condição para sua sublevação:

em última instância em termos de teoria da circulação. Quer dizer: em termos da teoria da circulação, só é produtivo de capital aquele trabalho cujos produtos (e também cujos custos de reprodução) refluem no processo de acumulação do capital; ou seja, aquele cujo consumo é recuperado de novo na reprodução ampliada. Só este consumo é um "consumo produtivo", não apenas imediatamente, mas também em referência à reprodução. Isso ocorre quando os bens de consumo são consumidos por trabalhadores que são por sua vez produtores de capital, cujo consumo não se esgota em si, mas retorna na forma de energia produtiva de capital, num novo ciclo de produção de mais-valia. Inversamente, todos os bens de consumo que são consumidos por trabalhadores improdutivos ou por não-trabalhadores (crianças, reformados, doentes etc.,) não retornam, como energia renovada, na criação de mais-valia: no plano do conjunto da sociedade, trata-se apenas de um consumo que desaparece sem deixar rastos e sem impulsionar a reprodução capitalista. O mesmo vale também para a produção de bens de investimento: em termos de teoria da circulação, este trabalho só é produtivo se o consumo de seus produtos se dá no contexto da criação de mais-valia, isto é, se retorna ao ciclo de produção da mais-valia. Pelo contrário, todos os bens de investimento cujo consumo ocorre fora da produção de maisvalia, integram, no plano do conjunto da sociedade, o mero consumo que "cai fora" da reprodução do capital global e do seu movimento de acumulação.” (Kurz, 2002)

137 Isso para não mencionar a violência direta. Quando a exceção é a regra, matar e morrer só fazem corresponder aos padrões de produtividade da sociabilidade em crise. No dia em que este trecho do texto está sendo escrito (30/10/2017) é impossível não se remeter ao novo recorde da barbárie nacional estampado como manchete por todos os jornais: o Anuário Brasileiro de Segurança Pública registra 61.619 homicídios em 2016, maior marca na história do país. 


\begin{abstract}
“Noutros termos, o operário para re-produzir-se deve vender sua força de trabalho e comprar os meios de sua subsistência; este é o momento objetivo de sua inserção na divisão social do trabalho. Mas não é senão quando ele reconhece o capitalista como aquele que, ilusoriamente - a "ilusão necessária” [Giannotti] -, lhe fornece dinheiro de que ele necessita para comprar os elementos de sua subsistência, que se fundam simultaneamente o operariado e a burguesia. Este é o momento da subjetividade ou da subjetivação da objetividade. A constituição das classes repousa sobre este movimento complexo da produção e da reprodução, e as representações das classes umas vi-à-vis das outras formam a trama insubstituível das mediações.” (Oliveira, 2003:18)
\end{abstract}

Mas, se hoje a mais-valia não é mais o centro motriz da reprodução capitalista (como argumentado acima e como o próprio autor de certa forma demonstra em $O$ surgimento do antivalor) como se dá essa "subjetivação da objetividade"138? Como sugestão de análise pode-se dizer que vivemos a exacerbação do polo do consumo na constituição da persona do trabalhador/consumidor. O diagnóstico histórico de que tendencialmente o consumidor vem ultrapassando o trabalhador na constituição da personalidade contemporânea não é nenhuma novidade, a sociedade de consumo é um tema já consagrado nas ciências sociais, o importante é entender seus nexos com a lógica reprodutiva do capital e colocá-la em perspectiva histórica para entender seus fundamentos. Nesse sentido, seria formando a subjetividade de consumidores que a objetividade da reprodução ficcionalizada do capital constitui um de seus principais dispositivos de mobilização atualmente.

É claro que o duplo não se desfez, um despossuído somente será consumidor sendo também trabalhador, ou trabalhador espetacular. Mas, ao mesmo tempo que arregimenta o trabalho, o processo parece se mover pela mobilização do consumidor, seja através da propaganda, seja negando-lhe o acesso (expropriação) à dita riqueza efetiva e alienando-o dos saberes que possibilitariam este acesso. Por isso à coerção do trabalhador imposta por um terceiro no processo produtivo se acrescenta a exacerbação de sua autodisciplina e

138 A formulação "subjetivação da objetividade” pode desdobrar debates importantes. Um deles não chega a ser um debate, mas a constatação de que a formulação é na realidade a explicitação da processualidade contida na ideia de personificação de Marx, quer dizer, subjetivação da objetividade é um sinônimo de personificação. Talvez o cariz claramente negativo desse processo na teoria de Marx force um desvio terminológico quando o assunto é a consciência de classe entendida em sinal positivo. Outro desdobramento possível, que se opera a partir de um desvio do sentido atribuído à objetividade na formulação acima (que seria a compreensão da objetividade para além da relação de classe, mas da forma da mediação social), seria a abertura do diálogo crítico com as teorias do sujeito e da subjetivação nos seus diversos matizes. Esse esforço demandaria uma historicização radical do conceito de sujeito. 
flexibilidade, coagido pelo terror de não ter os meios para participar das trocas mercantis. O que está longe de ser resolvido é o destino da massa crescente dos supérfluos ${ }^{139}$ (Scholz, 2016) que a produtividade monstruosa produz.

Se em 1930 tinha início a formação do Estado nacional brasileiro, o que em outros termos podemos entender como a internalização da metrópole no território nacional, esse processo se perpetua até os dias de hoje como ficção e espetáculo. O que se está sugerindo é que com o planejamento (incluído aí o planejamento do turismo) a metropolização alcançou a Chapada Diamantina. Porém, tal processo se dá já sobre as bases do capital fictício, expropriando e criando novas necessidades sem oferecer o meios de supri-las, quer dizer, a metropolização chega naquela área sobretudo formando consumidores, mas consumidores sem trabalho.

Os exemplos abrangem todo universo da vida cotidiana dos moradores da área, mas talvez um dos mais trágicos diga respeito a escalada da violência ligada ao narcotráfico. Durante os trabalhos de campo em Lençóis os assassinatos ocorridos na cidade foram tema cotidiano de conversas mantidas com alguns interlocutores, sobretudo no bairro do Alto da Estrela. O perfil dos mortos reproduz as estatísticas nacionais em escala local, normalmente são homens, jovens, negros ou pardos e de baixa escolaridade. Via de regra as mortes estão vinculadas às dívidas e disputas do tráfico de drogas, ao menos são sempre esses os motivos apontados.

Grosso modo, a interpretação corrente descamba para a culpabilização dos indivíduos, seriam eles que escolhem entrar na "vida errada" segundo o discurso mais frequente. Entre os moradores mais velhos, aqueles que viveram uma Lençóis “regional”, é comum o entendimento de que os jovens de hoje "querem tudo fácil”, "não gostam de trabalhar”, ou mais diretamente que "são vagabundos". Tal leitura emerge da comparação inevitável entre as condições atuais da vida material e aquelas de um período em que a fome ainda mobilizava trabalho. Do que é interessante notar que tal comparação raramente é feita em termos

139 "A superfluidade objectiva é a verdadeira categoria, a que é decisiva, não simplesmente a precariedade, que é o mero sentimento disso e que parece ser o subjetivamente verdadeiro, com a manutenção de uma atividade profissional seja de que tipo for, que deve ser mantida incondicionalmente, nem que seja na forma de um pós-moderno empresariado de si mesmo, tendo por fundo uma sociedade do trabalho concebida como ontológica. O medo de tornar-se supérfluo é tão grande que apenas consegue identificar-se a si mesmo teoricamente como o tornar-se precário, sendo assim tabu o chegar ao fim absoluto da sociedade do trabalho; este é o horror puro e simples para o precário, que se vê obrigado a posicionar-se no interior de relações em decadência para se poder manter a si mesmo como ser que se esforça ao máximo. Tudo isto tem de ser entendido no quadro de uma crítica geral da dissociação-valor, como crítica que a si mesma se afirma e simultaneamente se restringe." (Scholz, 2016) 
monetários, como renda per capita por exemplo, o que se dá pela simples impossibilidade de assim fazê-la pois o dinheiro era coisa muito mais marginal naquele período.

Por trás do conservadorismo, a opinião corrente revela a historicidade da pobreza, ou seja, não se trata de uma condição material estática, mas sim de uma objetividade relativa e socialmente constituída. Nos termos da riqueza efetiva (valor de uso) nos tornamos muito mais ricos como sociedade, essa é uma promessa basilar da modernização que verdadeiramente se realizou, senão a única. O falso é que seja o acesso à riqueza efetiva a finalidade dos esforços do trabalho e dos projetos de modernização, este é justamente o fetichismo da mercadoria operando como forma de consciência do processo social, talvez o elo que o mantenha. A necessidade dessa estrutura social de criar consumidores cada vez mais potentes (vide a importância da propaganda para entuchar-nos goela abaixo e acima, quer dizer, no estômago e na fantasia, novas necessidades) não é simples maquiavelismo da grande indústria, mas uma das resultantes dos esforços desesperados de salvar o trabalho como mediação social de sua crise.

O adiantamento da infraestrutura executado pelo planejamento estatal de fato retirou a Chapada Diamantina do relativo isolamento em relação a porção metropolizada do país, e a jogou definitivamente na condição de periferia. O Estado nacional chega como corpo repressivo, que criminaliza uma série de práticas de acesso direto aos recursos e também que reproduz a forma da violência policial característica dos grandes centros ${ }^{140}$. Chega também uma série de novas mercadorias do maravilhoso mercado global e seus consumidores arquetípicos exemplares na figura dos turistas, que reorganizam o padrão da desigualdade e os parâmetros da pobreza. Chega emprego também, não se pode negar, sobretudo na forma de postos precários e sazonais vinculados ao turismo, mas que estão longe de corresponder a um processo de valorização do valor. O descompasso entre o prometido e o acessado acaba constituindo motivo suficiente para os jovens, inexploráveis como trabalhadores e em busca de dinheiro, engrossarem as fileiras das facções, que também chegaram durante a última década em Lençóis, como brinde indesejado do pacote da modernização turística.

140 Como exemplo, ver relato no final do item 11. Ensaio II desta dissertação. 


\section{AS FOTOGRAFIAS AUTORAIS NO TEMPO DA CIRCULAÇÃO IMPRESSA}

Fotografia e turismo estão estreitamente relacionados. Conforme a Chapada Diamantina passa a ser reconhecida como área turística, além de receber turistas atrai também fotógrafos. Desde os anos 1970, mas principalmente a partir dos anos 1980, muitos fotógrafos profissionais $^{141}$ passaram a produzir imagens da área. Tratar de cada um desses fotógrafos e apresentar seus trabalhos de forma detalhada certamente resultaria em conteúdo suficiente para uma pesquisa a parte, até porque neste momento já parece possível apontar a superprodução de imagens como fenômeno relevante na área estudada, ainda que seja difícil apreender a produção e o consumo de imagens de forma objetiva. Por isso as fotografias que referenciam este item formam um grupo bastante heterogêneo, tanto como resultado do trabalho fotográfico, quanto com respeito às relações que caracterizam a produção de cada um deles. Portanto, a intenção aqui é extrair aquilo que as une como imagens produzidas num determinado momento da reprodução social na Chapada Diamantina, levando em conta suas relações com o Brasil e o mundo. Durante a pesquisa de campo foi possível entrevistar alguns desses fotógrafos, o que também informa esse item.

Mas antes de apresentar esse conjunto fotográfico parece importante fazer uma breve recapitulação das imagens apresentadas até aqui explicitando uma das perguntas que organizou a pesquisa com as fotografias: como dinheiro torna-se imagem, e como imagem torna-se dinheiro?

Rodolphe Lindemann era fotógrafo e pintor, aparentemente trabalhou para terceiros em Salvador quando chegou ao Brasil, para depois possuir em atelier próprio em sociedade com Guilherme Gaensly e em seguida sozinho. O negócio, do qual é possível encontrar anúncios frequentes nos jornais soteropolitanos da época (Alves, 2006; Santos, 2014; Kossoy, 2002), se mantinha da venda direta das imagens aos seus clientes. As condições específicas da produção dos postais da série “Lavras Diamantíferas Baianas” são desconhecidas, mas provavelmente não fogem desta característica, ressalvada a possibilidade aventada por Maria Guimarães Sampaio (Alves, 2006) de Lindemann haver tido algum tipo de contrato com fotógrafos do interior do estado para os quais fornecia os insumos e equipamentos para produção das imagens em regime de exclusividade e/ou com participação nos lucros.

Já Henry Furniss e Steve Horman são estadunidenses residentes provisoriamente na Bahia. O primeiro em Salvador e o segundo em Lençóis, mobilizados para o desempenho de

141 Não apenas profissionais, mas são estes que terão o interesse desta pesquisa neste item. 
atividades relativas aos interesses imperialistas dos EUA, o primeiro como cônsul entre os anos de 1898 e 1905, e o segundo como voluntário do Peace Corps entre os anos de 1970 e 1974. Ambos eram remunerados pelo Estado dos EUA para o desempenho de seus trabalhos no Brasil. Furniss era médico de formação, mas um entusiasta das ciências em geral, sendo a fotografia um de seus interesses particulares, o cônsul era um fotógrafo amador em um período em que a atividade estava longe de ser algo disseminado, sobretudo no Brasil. Já Horman era formado em comunicação e após o período como voluntário em Lençóis trabalhou profissionalmente como fotógrafo. As imagens que produziram sobre a área estudada foram aparentemente feitas por iniciativa e com recursos próprios em ambos os casos, ainda que a produção das imagens estivessem estreitamente relacionadas com as atividades que desempenhavam. As fotografias de Furniss possuem caráter mais documental e serviam para informar empresários e investidores estadunidenses sobre as possibilidades de se fazer dinheiro na Bahia, mas também transformaram-se em mercadoria cultural, ilustrando seu artigo em uma revista popular de ciências naquele país. Já as imagens de Horman, por mais que possuam caráter documental, foram utilizadas com fins claramente publicitários, tinham a intenção de justificar perante o Estado nacional o tombamento de Lençóis com vistas ao desenvolvimento do turismo como atividade econômica na cidade.

É difícil rastrear os nexos do dinheiro que estão por trás das imagens que ilustram o jornal $O$ Sertão, são muitas e não possuem referência de autoria. Mas de modo genérico é possível dizer que a quase totalidade delas são representações dos portadores do poder social, aquele que levam nos bolsos.

Fernando Machado Leal, por sua vez, foi contratado pelo IPHAN para produzir um relatório sobre Lençóis que contou com uma coleta de imagens da cidade. Enquanto arquiteto, produzir as fotografias fazia parte de seu trabalho, trata-se de mais um dos saberes que Leal dominava para a execução da pesquisa. Leal era um acadêmico, tinha titulação de arquiteto e foi professor na Universidade Federal da Bahia (UFBA). Já Aristides Alves foi funcionário da BAHIATURSA, assalariado e registrado como fotógrafo, ainda que tivesse formação universitária em biologia, condição em que se manteve por cerca de vinte anos. Durante este período produziu imagens de vários lugares da Bahia para o órgão de planejamento do turismo daquele estado. Ambos, enquanto fotógrafos, personificavam o Estado nacional quando produziram as imagens da Chapada Diamantina aqui selecionadas.

Todas as fotografias apresentadas até agora possuem uma característica em comum, foram produzidas como parte de finalidades que as extrapolam: fazer propaganda das lavras diamantinas da Bahia para possíveis investidores; informar empresários nos EUA ou ilustrar 
um artigo de revista; reforçar a autoridade dos "homens do poder"; persuadir os representantes do Estado pelo tombamento da cidade de Lençóis; compor um relatório técnico para IPHAN sobre o tombamento de Lençóis; servir de material para o planejamento do turismo pela BAHIATURSA na Chapada Diamantina ou ilustrar o material publicitário daquele órgão para divulgação da área como destino turístico. Já as fotografias das quais se passa a tratar agora, aparentemente tinham como finalidade as fotografias em si, a imagem era o fim último do processo em que o fotógrafo estava envolvido. Certamente esta afirmação é contestável do ponto de vista subjetivo de quem estava implicado no processo de produção das imagens, afinal, é claro que a mobilização dessas pessoas não se dá apenas pela fotografia como fim em si. O objeto da atenção de suas lentes muitas vezes são escolhas pessoais. Mais do que predileção por este ou aquele objeto, ou por este ou aquele tipo de fotografias, muitos fotógrafos também entendem seus trabalhos como engajamentos de ordem emocional ou político. Não é raro que alguns fotógrafos assumam a estratégia de executar trabalhos que não correspondem àquilo que enseiam para se reproduzirem e realizem os trabalhos que desejam de maneira paralela. No entanto, o que se quer explicitar aqui são as relações de produção dessas imagens, o que extrapola a esfera das motivações individuais.

Possivelmente as primeiras imagens com tal caráter, e que não sejam de um proprietário privado estrito senso, são as fotografias feitas pelo fotógrafo Rino Marconi e citadas em nota de rodapé no item que trata do relatório de Fernando Machado Leal. São mais de 560 imagens coloridas feitas em 1972 e hoje disponíveis no acervo digital ${ }^{142}$ do Museu da Imagem e do Som (MIS). Rino Marconi já conhecia a Chapada Diamantina desde 1969, quando esteve em Andaraí como fotojornalista a serviço do Jornal da Bahia, ele ressalta que nesse período, quando a BR-242 ainda era de terra, "no litoral ninguém sabia da Chapada, nem nunca tinha ouvido falar"143. A partir de então manteve-se frequentador da área, sobretudo da vila de Igatu:

\footnotetext{
"Igatu estava na maior miséria, fome, fome... pessoal vivia de catar sempreviva... E aí começou minha história de fotografia em Igatu, na Chapada. Chapada pra mim é praticamente Igatu e Mucugê. Fiz uma casa lá, tenho uma casa lá”. (entrevista, agosto de 2017)
}

142 É possível acessar o acervo via internet através do endereço: http://acervo.mis-sp.org.br/

143 Informações colhidas em entrevista realizada em agosto de 2017. 
Em Igatu ficou "fotografando muito, e era difícil, tinha pouco dinheiro, levava filme, dois filmes só”. Pelas dificuldades da época as fotografias do MIS chamam a atenção, são muitas e cobrem uma área extensa do interior baiano. O fotógrafo relatou as condições de produção dessas imagens:

"Rino Marconi: Foi uma viagem só. Aquilo ali foi um projeto maluco, o diretor do MIS nesse tempo era o Rudá de Andrade, tinha um sobrinho dele que morava aqui [Salvador], Tinho Andrade. A equipe era eu, o Tinho Andrade, o Rudá (que deu os filmes 35mm de cinema para eu rebobinar), Carlos Veiga (que era um maestro aqui de Salvador, conhecido) e outro amigo nosso, um diretor de teatro alemão e o diretor do Instituto Goethe aqui de Salvador...

Pesquisador: Nossa, um grupo!

Rino Marconi: A gente se meteu em uma kombi, começamos lá pelo fundo, Brumado.

Pesquisador: É, eu vi, vocês passam por um pedaço grande.

Rino Marconi: Era fazer aquele caminho todo e documentar o quanto podia. Em Lençóis chegou o Aloísio, cinegrafista, deve ter feito filme lá.

Pesquisador: E esse material de filme será que está no MIS também?

Rino Marconi: Deve estar no MIS, porque todo esse material eu mandei para eles.

Pesquisador: Além de financiar o material, vocês foram pagos para fazer...?

Rino Marconi: Não, que pago o quê!

Pesquisador: Você lembra quantos dias vocês ficaram viajando?

Rino Marconi: Rapaz, acho que uns 15 dias.

Não foram localizados os filmes mencionados pelo fotógrafo, mas no acervo digital do MIS encontram-se áudios gravados nesta mesma viagem. Como se percebe ela foi feita para se “documentar o quanto podia”, aparentemente não havia uma finalidade prévia além da própria captação das imagens e áudios. Ainda que não tenha sido remunerado pelo trabalho, sem o custeio dos filmes e da própria viagem provavelmente o fotógrafo não teria produzido tal material.

A suposição de que a finalidade da atividade de alguns fotógrafos passa a ser em si a própria produção de imagens é corroborada pelo fato de que vários desses trabalhos ganham a forma de livros de fotografias. São publicações cuja intenção é a exposição das imagens, ainda que muitos desses livros contenham algum tipo de texto. É de se notar que esse formato de publicação é particularmente custoso e possui um público consumidor restrito. Quer dizer, mesmo sendo mercadorias de preço elevado, muitos desses livros sequer se pagam através da venda de exemplares, quem dirá produzam algum tipo de rendimento. Os primeiros livros de fotografias sobre a Chapada Diamantina identificados nesta pesquisa são do final dos anos 
1980. Certamente a data está relacionada com o desenvolvimento do turismo naquela área, a qual ganha visibilidade externa para além da produção da mercadoria diamante, justamente por atributos que antes não eram considerados comercializáveis e que estão vinculados com as, por assim dizer, esferas da natureza e da cultura. Assim, os elementos que muitas vezes foram considerados como empecilhos à modernização, passam neste momento a poderem ser comercializados como mercadoria cultural fotográfica.

Mas, a data dessas primeiras publicações corresponde também ao advento da primeira lei de incentivo à cultura em escala nacional. Os dois primeiros livros de fotografias sobre a Chapada Diamantina localizados se valeram do mecanismo de financiamento da Lei 7.505. Baseada na renuncia fiscal do imposto de renda das empresas participantes, a lei que ficou conhecida como "Lei Sarney", foi criada em 1986 e vigorou até 1990, sendo em 1991 substituída pela Lei 8.313, conhecida com “Lei Rouanet”, que vigora até hoje. A publicação pioneira foi o livro Chapada Diamantina = Diamantina Highlands, lançado em 1988 e que conta com fotografias de Luiz Claudio Marigo, texto de introdução e legendas de Jorge Amado, textos sobre a ecologia da Chapada Diamantina de Roy Funch e sobre a história da região de Carlos Ribeiro. O livro foi financiado pela Ciba-Geigy Química S/A, na página de rosto do livro se encontra uma mensagem do diretor presidente da empresa Norbert Gmuer:

\footnotetext{
“Ao promover a edição desta magnífica obra, as empresas CIBA-GEIGY no Brasil atendem a dois propósitos fundamentais, coerentes com as tradições que sempre nortearam as suas atividades. De um lado, traduzir de forma concreta, por assim dizer, suas preocupações com a preservação do patrimônio natural e ecológico nas regiões que as acolheram. De outro lado, valorizar e divulgar importantes realizações do espírito humano, nas áreas científicas e artísticas.” (Amado, 1988)
}

Não é o caso de desdobrar muito tal questão, mas parece razoável problematizar os duvidosos “propósitos fundamentais”, “as tradições” e “preocupações” da Ciba-Geigy ao publicar um livro de fotografias sobre a Chapada Diamantina, para o que vale mencionar que após sucessivos processos de centralização de capital a empresa deu origem a duas multinacionais que são mais conhecidas do público contemporâneo: a Syngenta, gigante do agronegócio hoje incorporada pela estatal chinesa ChemChina, e a igualmente monopolista farmacêutica Novartis.

Já o livro de Zé Boni, Paisagens Mágicas, lançado em 1989, também foi financiado através da Lei Sarney pelo extinto Banco Econômico. Reconhecido por ser o banco privado mais antigo do Brasil, além de ser um dos bancos socorridos pelo Programa de Estímulo à 
Reestruturação e ao Fortalecimento do Sistema Financeiro Nacional (PROER) após o Plano Real, e também pela condenação de seu dono, Ângelo Camon Sá, por fraude bancária.

Mas não são apenas essas duas publicações, o Chapada Diamantina = Diamantina Highlands e o Paisagem Mágica: Fotografias da Chapada Diamantina, que contaram com financiamento estatal, a partir dos anos 1990 praticamente todos os outros livros de fotografias sobre a Chapada Diamantina se valeram de algum tipo de apoio estatal, além de alguns deles também contarem com patrocinadores privados diretos. Para além dos moralismos da origem do dinheiro, que antes deveria ser entendido como relação social totalizante e impessoal (ainda que submeta de maneira desigual os possuidores e despossuídos) e que se reproduz na forma de capital fictício, o que interessa perceber nesses casos é que a maior parte desses livros estão "realizados” como mercadorias antes mesmo de existirem como coisas físicas, a venda ou não dos livros é um detalhe marginal na maioria dos casos. Isso somente pôde acontecer, na escala que se deu, através da complexa estrutura estatal de gestão econômica da crise, que se faz, em grande medida, com o crescimento da autonomização dos agentes sociais em relação, e do mercado de futuros, no sentido amplo que esse conceito pode ter. O que obviamente não quer dizer que todos consigam se valer dessa estrutura, afinal, onde há concorrência e ganhadores, os perdedores são inevitáveis. Além daqueles que nem mesmo chegaram a publicar seus trabalhos autorais, outros o fizeram em grande parte por paixão obstinada, o que no mundo mediado pelo dinheiro deve significar mobilização em outras frentes de trabalho ou uma terceira fonte monetária qualquer.

É notável que de todas as imagens apresentadas até aqui nenhuma delas tenha sido produzida por um fotógrafo nascido na Chapada Diamantina (talvez algumas das imagens que ilustram o jornal $O$ Sertão sejam de autoria de um fotógrafo sertanejo da região, mas essa é informação não pôde ser confirmada). Tiãozinho, reconhecido em Lençóis como fotógrafo, por mais que tenha negado a identidade profissional quando indagado, explicou que não era possível viver somente da fotografia na cidade. Quando era jovem os equipamentos e insumos fotográfico eram mercadorias acessíveis apenas às famílias mais abastadas, aqueles que praticavam fotografia na cidade o faziam como hobby. São casos recentíssimos os de fotógrafos que nasceram naqueles municípios e conseguem se reproduzir a partir da fotografia, ainda assim com limitações evidentes.

Uma exceção, daquelas que confirma a regra, é o caso da fotógrafa Iêda Marques, que além de ser, até onde se pôde confirmar, a única fotógrafa nascida na Chapada Diamantina (em Boninal) que publicou um livro de fotografias, é também a primeira fotógrafa mulher 
mencionada nesta dissertação, e única nominalmente. Em $2012^{144}$ lançou o "Iêda Marques: lembranceiras, imaginário e realidade”, livro com registros realizados desde o começo dos anos 1980, quando voltou a morar em Boninal e passou a fazer fotografias, sobretudo como retratista. Aprendeu a fotografar em Salvador, onde morou durante a década de 1970 após retornar de São Paulo, para onde migrou com quinze anos. O livro de Iêda, em termos genéricos, trata dos mesmos temas de outros livros sobre a Chapada Diamantina, a natureza e a cultura, porém o faz, primeiramente de fora da área de influência imediata do PNCD, o que é uma excepcionalidade, mas mais do que isso, pode-se dizer que suas fotografias são produto de um ponto de vista interno da área retratada. São registros sensíveis do cotidiano, do íntimo de uma forma de vida sertaneja que vem se transformando radicalmente. Muitas das pessoas retratadas nas imagens de Iêda Marques são conhecidos da fotógrafa, pessoas do seu círculo de relações. Além disso, para essas pessoas tais fotografias possuíam sentido apenas dentro do âmbito privado ou comunitário. Ao serem publicadas como um livro, essas imagens, por mais sensíveis que sejam, não escapam de se transformarem em imagens de anônimos para consumidores abstratos. Quer dizer, sem que o conteúdo das fotografias mude, o sentido delas passa da esfera da pessoalidade para a impessoalidade.

Para encerrar este item e ensejar o próximo, uma pequena lembrança de Aristides Alves sobre a transformação imposta pela fotografia digital é reveladora ${ }^{145}$ :

"O caso de Calil Neto, que foi um fotógrafo que saiu de São Paulo e foi morar lá [Lençóis]. Eu estou citando ele porque teve uma época que ele sobreviveu em Lençóis fazendo foto preto e branco, ele montou um estúdio lá, um laboratório, e vendia essas fotos. E eu me lembro de uma vez que nós estávamos lá e chegou uma turista com um celular e ele tinha uma fotografia do... não me lembro o lugar, Pai Inácio provavelmente, e ela disse "eu fiz essa foto, está aqui”. Então, essa pessoa não compra mais essa foto, ela tem celular... Embora você tenha uma foto P\&B, papel, tamanho grande e tal...”146

144 Antes disso, entre os anos de 2004 e 2005, Iêda Marques assumiu a direção do Parque Nacional da Chapada Diamantina (PNCD).

145 Entrevista realizada em agosto de 2017.

146 Calil Neto publicou um livro de fotografias da Chapada Diamantina quando ainda morava em Lençóis em 2001, chamado "O Centro da Bahia: um testemunho sobre a Chapada Diamantina no século XXI”. 


\title{
A CHAPADA DIAMANTINA MAIS QUE DUPLICADA NA INTERNET
}

Em 2005 Francisco Emanuel de Brito observava que

\begin{abstract}
"A internet tem sido uma ferramenta muito utilizada pela maior parte dos turistas estrangeiros e muito pouco pelos brasileiros entrevistados. Alguns estrangeiros utilizam este serviço para enviar mensagens para familiares e amigos, dando notícias e muitas vezes já fazendo uma antecipação virtual e resumida do que eles dirão de viva voz quando regressarem para casa.” (Brito, 2005:360)
\end{abstract}

Cerca de nove anos depois, em 2014, Liziane Peres Mangili observou que

\begin{abstract}
“A Chapada Diamantina, na Bahia, é amplamente divulgada hoje como um paraíso ecoturístico. Basta fazer uma pesquisa em sites de busca que aparecerão inúmeras imagens de poços, rios, cachoeiras, grutas e lindas formações geológicas. Dentre elas, aparecerão também fotos da cidade de Lençóis. Da mesma maneira, se a busca for feita pelas palavras "Lençóis Bahia”, as mesmas imagens de formações geológicas, grutas e cachoeiras aparecerão, mesmo que estas maravilhas não estejam localizadas neste município.” (Mangili, 2014)
\end{abstract}

Aristides Alves ao comentar, em entrevista realizada em agosto de 2017, a relevância da revista Viver Bahia, produzida pela BAHIATURSA para divulgação dos destinos turísticos do estado, salientou a importância que possuía a fotografia impressa como única forma de conhecimento visual remoto de localidades como a Chapada Diamantina antes da circulação virtual de imagens através da internet e, antes disso, pela televisão ${ }^{147}$. Nos anos 1970, mesma década que Aristides Alves começou a trabalhar para a Bahiatursa como fotógrafo, Susan Sontag, nos EUA, avaliava que

147 Sobre o papel da televisão, Brito relata que "Um outro evento decorrente deste processo [turistificação da Chapada Diamantina] está relacionado à divulgação, com mais intensidade, da Chapada Diamantina em matérias veiculadas em diversos jornais, revistas especializadas na questão ambiental e em programas de televisão (Mais tarde na novela Pedra sobre Pedra), a exemplo de uma reportagem sobre a Cachoeira da Fumaça apresentada no Fantástico em agosto de 1987.

Esta reportagem acabou constituindo-se num dos eventos de descoberta de Lençóis para o turismo de natureza e cujos efeitos colaterais manifestam-se nos feriados seguintes como o de 7 de Setembro com a chegada inesperada de uma multidão de turistas de Salvador e demais municípios do interior numa cidade que àquela época dispunha de menos de 300 leitos e de comida insuficiente para suprir tamanha quantidade de pessoas.” (Brito, 2005:130) 
"A onipresença das fotos produz um efeito incalculável em nossa sensibilidade ética. Ao munir este mundo, já abarrotado, de uma duplicata do mundo feita de imagens, a fotografia nos faz sentir que o mundo é mais acessível do que é na realidade. [...] A necessidade de confirmar a realidade e de realçar a experiência por meio de fotos é um consumismo estético em que todos, hoje, estão viciados." (Sontag, 2004:34)

Em pouco mais de uma década, após o lançamento do livro de Brito (2005), o uso da internet como veículo de comunicação se difundiu amplamente na Chapada Diamantina, não sendo mais uma particularidade dos turistas estrangeiros, tampouco apenas de turistas. A internet é o principal meio contemporâneo de circulação de imagens, ela reorganizou em vários sentidos nossa relação com as fotografias. Uma das transformações mais evidentes é a viabilização da simultaneidade entre produção e veiculação da imagem: existe hoje a possibilidade do tempo zero da circulação, trata-se de uma realidade cada vez mais disseminada, o que era pouco verossímil há não muito tempo atrás.

Durante a coleta das fotografias para a presente pesquisa ficou claro que seria difícil acessar imagens produzidas como objetos de particulares, do âmbito da família, feitas como lembranças íntimas para e sobre os envolvidos diretos no evento registrado, congelamento imagético da vida privada das pessoas. Foi possível recolher algumas fotografias com este caráter, mas elas não chegaram a constituir um conjunto representativo que justificasse a inclusão na seleção final da pesquisa. Por isso todas as imagens apresentadas até aqui foram produzidas, ou ao menos utilizadas, como objetos dá e para a esfera pública.

Já parte significativa das imagens que circulam na internet, incluídas aí aquelas produzidas na Chapada Diamantina, possuem um caráter dúbio: a fronteira entre o público e o privado é pouco nítida nelas. Várias dessas fotografias não deixam de serem imagens que registram o cotidiano entre familiares e amigos. No entanto, elas extrapolam o circuito das relações pessoais de quem as produziu, dos envolvidos no evento registrado, estando disponíveis para a apreciação de qualquer pessoa, em qualquer parte do mundo, que disponha de acesso à internet. Os meios técnicos possibilitam a circulação praticamente imediata das imagens para a enorme rede de anônimos. Uma busca simples pelos principais pontos turísticos da Chapada Diamantina no site TripAdvisor ${ }^{148}$ possibilita que se visualize registros fotográficos das viagens de vários desconhecidos durante o desfrute do tempo livre que dispõem.

148 Um dos principais sites de compartilhamento e propaganda de informações sobre turismo do mundo. Versão brasileira: https://www.tripadvisor.com.br/ 
Mas, a interpretação das recentes transformações quantitativas e qualitativas da produção e uso das fotografias não se encerra como simples questão técnica, ou na constatação do barateamento e popularização desses meios, ainda que esse fato tenha importância central para constituição da superfluidade (Scholz, 2016) a que nos arremessa o processo. Retomar as questões levantadas por Theodor Adorno na conferência Tempo Livre (2009) proferida em maio de 1969 (em seguida publicada como ensaio), pouco menos de três meses antes de sua morte, permite encaminhar o debate para o tratamento da questão de forma mais frutífera de um ponto de vista crítico. Em linhas gerais o autor procura demonstrar as determinações sociais do dito tempo livre de modo a revelar a inconsistência da interpretação corrente de que este seria o tempo usado de forma autônoma pelas pessoas. Adorno expõem a relação elementar entre tempo livre e tempo de trabalho, evidenciando que a determinação do tempo em geral na sociedade mediada pela mercadoria é exercida pelo trabalho, “o tempo livre é acorrentado a seu oposto" (Adorno, 2009:62). Ainda que de acordo com a tese geral do ensaio, parece importante olhar mais de perto a abordagem de algumas questões, inquirindo os desdobramentos que esses detalhes implicam. No início de sua fala Adorno expõem a indagação que move seu argumento:

\footnotetext{
"Que ocorre com ele [tempo livre] com o aumento da produtividade no trabalho, mas persistindo as condições de não-liberdade, isto é, sob relações de produção em que as pessoas nascem inseridas e que, hoje como antes, lhes prescrevem as regras de sua existência?” (Adorno, 2009:62)
}

Está claro, a questão da produtividade não encerra o debate, não se trata apenas da liberação do tempo de trabalho pelo aumento da produtividade decorrente do desenvolvimento técnico, ela está considerada como momento das relações de produção. É importante que se demarque, o autor falava a partir de uma centralidade do mundo capitalista (a Alemanha) e em um período em que o Estado de bem-estar social podia parecer algo consolidado e perene. As contradições internas da reprodução capitalista como valorização do valor não estavam na pauta dos debates da teoria marxista, a qual dava destaque ao viés sociológico da questão da luta de classes, na qual foi alojada toda a compreensão da contradição e da dialética de Marx pela teoria. Adorno não lida com as contradições do aumento da produtividade nos termos da implicação que acarretam para a valorização do valor, mas tampouco dedica sua atenção crítica à desigualdade ou a luta de classes. O núcleo do seu interesse neste ensaio está situado na questão da autonomia. Quer dizer, o desenvolvimento das forças produtivas com a manutenção da "forma existente de relação 
social” (Kurz, 2002), na qual a exploração do trabalho é um fim em si, não corresponde a liberação que a ideologia informada pela razão instrumental propala. Em outras palavras, o trabalho tornar-se supérfluo não corresponde à superação de sua determinação na sociabilidade mediada por mercadorias, o tempo livre do trabalho que daí surge permanece intimamente relacionado com ele. Ainda que Adorno não trate a questão nestes termos, é possível entender a partir de seu ensaio que no tempo em que estão libertas de personificarem o trabalho, as pessoas são impelidas a personificarem o consumo, correspondente lógico do trabalho na tautologia posta pela sociabilidade da mercadoria. Trata-se de coação nos dois registros, coação para produção de mercadorias no tempo de trabalho, coação para a realização de mercadorias no tempo livre (e o contrário também).

Se aproximando um pouco mais do universo conceitual de Marx, não é exagero pensar que Adorno está tratando em seu ensaio do problema da autonomização, mas pensada para a esfera do consumo. Quer dizer, aquilo que é socialmente conexo ganha forma aparente de autonomia para os envolvidos na relação. No entanto, nos termos de Adorno a questão está tratada na chave teórica da oposição entre não-liberdade e liberdade real $^{149}$. O que o encaminha para a formulação de outro par dual, no qual diferencia, por um lado, o que parece ser um fundamento do humano e, por outro, a forma como as funções sociais constituem as pessoas como personificação, ainda que considere que "não se pode traçar uma divisão tão simples entre as pessoas em si e seus assim chamados papéis sociais” (Adorno, 2009:62). Ou seja, sua crítica está alicerçada na consideração do que as pessoas são em si, em um ideal positivo desse ser humano. Se olhamos as entrelinhas do argumento do autor, este pressuposto referido ao campo da liberdade conforma outra oposição: aquela entre criatividade e reificação. A sugestão de que exista um humano ideal organizando a crítica de Adorno ao tempo livre se revela também no trecho abaixo:

Em íntima relação com o tédio está o sentimento, justificado ou neurótico, de impotência: tédio é o desespero objetivo. Mas, ao mesmo tempo, também a expressão de deformações que a constituição global da sociedade produz nas pessoas. (Adorno, 2009:66)

Somente pode se deformar aquilo que possui forma. Qual seria a forma original deformada pela constituição global da sociedade? Curiosamente, Adorno remete-se a filosofia de Schopenhauer para dar início ao tratamento da questão do tédio, alertando que a teoria

149 É de se notar que na obra de Marx também existe essa dualidade organizando o argumento. 
daquele filósofo, que "ensinava que, ou as pessoas sofrem pelo apetite insatisfeito de sua cega vontade, ou se entediam tão pronto aquele esteja satisfeito” (Adorno, 2009:66),

“[...] não deve ser hipostasiada, nem ser considerada pura e simplesmente válida ou, porventura, ser encarada como condição original da espécie humana. O tédio existe em função da vida sob a coação do trabalho e sob a rigorosa divisão do trabalho.” (Adorno, 2009:66)

Ironicamente, também Adorno estrutura sua argumentação em uma hipóstase do humano. Seria o caso de buscar a hipóstase correta? Este não parece ser um caminho razoável para a crítica, sendo mais consequente buscar o negativo das contradições internas da forma social, do que estabelecer um pressuposto referencial positivo externo. Este referencial externo está identificado com a liberdade, o que como ideal abstrato pode parecer algo mais ou menos inócuo, um simples artifício retórico. Porém, logo a não-liberdade abstrata passa a revelar no argumento o referencial almejado, porque sem a liberdade é “estragada a alegria do trabalho" (Adorno, 2009:67) e, nas condições vigentes de não-liberdade

“[...] seria inoportuno e insensato esperar ou exigir das pessoas que realizem algo produtivo em seu tempo livre, uma vez que se destruiu nelas justamente a produtividade, a capacidade criativa.” (Adorno, 2009:67)

Produtividade (criatividade) e alegria no trabalho! Não são esses ideais próprios da modernidade? A rigor a crítica está voltada à sociedade de massas e à maneira como esta constitui as experiências subjetivas das pessoas. A consideração do trabalho, da mercadoria e do dinheiro, como mediação social alvo do interesse da crítica, é mantida até o ponto em que informa a crítica da razão instrumental. Pode-se dizer que a crítica caminha apenas até certo ponto na consideração dessas categorias. Essa característica se evidencia no ensaio quando Adorno adentra no plano das experiências e fixa seu próprio lugar social como contraexemplo positivo ante a autonomização entre tempo de trabalho e tempo livre presente na naturalização da prática dos “hobbies”. Depois de expor o modo como não faz distinção (entre trabalho e tempo livre) entre suas atividades cotidianas e como não se enfada com elas, considera que

"Sem dúvida, estou consciente de que estou falando como privilegiado, com a cota de casualidade e de culpa que isto comporta; como alguém que teve a rara chance de escolher e organizar seu trabalho essencialmente segundo as próprias intenções.” (Adorno, 2009:63) 
Aquilo que estava posto como uma questão da "situação geral da sociedade" (Adorno, 2009:62) parece se resolver por uma convicção subjetiva ${ }^{150}$ ! Afinal, do ponto de vista da mediação não há nada de substancialmente distinto (além dos privilégios e culpas mencionados pelo próprio autor) em ser a personificação do intelectual crítico, apenas mais um lugar na divisão social do trabalho. Marx (1996) já tratava da maneira como o corpo ou o conteúdo das mercadorias, enquanto frutos do trabalho das pessoas, importam apenas até o ponto em que são veículos do valor. A forma mercadoria é uma forma vazia na qual se adapta inclusive os conteúdos produzidos pela criatividade contestadora, a rigor não existe conteúdo em si anti-mercantil, a mercadoria diz respeito à mediação social. Daí Marx (1996) deriva o caráter fetichista da mercadoria, da cisão interna entre coisa útil e coisa de valor ${ }^{151}$. Adorno também se vale do conceito de fetiche na sua interpretação crítica do tempo livre:

\begin{abstract}
"Exemplar é o comportamento daqueles que se deixam queimar ao sol, só por amor ao bronzeado e, embora o estado de letargia a pleno sol não seja prazeroso de maneira nenhuma, e talvez desagradável fisicamente, o certo é que torna as pessoas espiritualmente inativas. O caráter fetichista da mercadoria se apodera, através do bronzeado da pele - que, de resto, pode ficar muito bem - das pessoas em si; elas se transformam em fetiches para si mesmas. [...] O fetichismo que medra no tempo livre está sujeito a controles sociais suplementares. Que a indústria dos cosméticos, com sua propaganda avassaladora e inevitável, contribua para isso é tão natural e evidente quanto o é que as pessoas condescendentes o reprimam.” (Adorno, 2009:65)
\end{abstract}

O trecho revela como o argumento do autor, por vezes, descamba para um juízo do gosto. A afirmação taxativa sobre o caráter não prazeroso da exposição ao sol é tão pueril, do ponto de vista de uma teoria crítica, quanto querer convencer racionalmente alguém que aprecia determinado alimento de que este alimento é ruim. Ao fazer a importante crítica do açambarcamento total do tempo para a reprodução do capital e da constituição de estigmas sociais que moldam coercitivamente as práticas, Adorno revela seus gostos e preconceitos

150 "Não significa menos do que, mesmo onde o encantamento se atenua e as pessoas estão ao menos subjetivamente convictas de que agem por vontade própria essa vontade é modelada por aquilo de que desejam estar livres [...]” (Adorno, 2009:62).

151 "Esse caráter fetichista do mundo das mercadorias provém, como a análise precedente já demonstrou, do caráter social peculiar do trabalho que produz mercadorias" (Marx, 1996:199). Seria o caso de mencionar que na década de 1960 uma pretensa autonomia do fazer intelectual e acadêmico fosse mais "plausível", ainda que falsa. Esse encantamento somente com muito esforço pode ser mantido hoje diante das transformações sofridas pela universidade de lá para cá. 
pessoais alçando-os ao lugar de verdades incontestes, sendo falsa consciência tudo aquilo que está para fora desse limite. Certamente os gostos do autor, que identificam em seu argumento o humano ideal, foram constituídos como a identidade social própria da persona do intelectual, não por acaso o ideal de liberdade que organiza o argumento do ensaio é autorreferenciado na figura do acadêmico ${ }^{152}$.

Parece problemática também a ideia de que as pessoas tornem-se fetiches para si mesmas. Que a reificação conforme nossa existência corpórea e espiritual na sociedade mediada pela mercadoria não resta dúvidas, desde nossa existência como portadores da mercadoria força de trabalho, até nossa aparência, considerados aí além dos objetos de consumo como signos, também os estigmas raciais, étnicos e de gênero que constituem violentamente nossa sociabilidade. No entanto, considerar que o fetichismo da mercadoria se apodera das pessoas em si mesmas não é o mesmo que elas sejam fetiche para si mesmas. Trata-se de uma incoerência, o fetichismo, ao menos o fetichismo da mercadoria, é uma característica que diz respeito à relação. A rigor o fetiche não pode ser para si ${ }^{153}$. Também é uma característica da relação a própria liberdade do sujeito, aquela realmente existente, quer dizer, a dupla liberdade do trabalhador: livre dos meios de produção e livre para vender sua força de trabalho (liberdade negativa). Ou seja, a liberdade como forma de consciência é ela própria um idealismo característico da sociedade mediada pelo trabalho e pelo dinheiro, na qual as pessoas estão autonomizadas e se entendem como indivíduos.

Ainda assim, apesar das diferenças, interessa apreender o argumento central do ensaio de Adorno, o tempo livre é incorporado pela lógica mercantil, redundando justamente em um esfumaçamento dos limites entre este e o tempo de trabalho. O tempo livre é o tempo da fuga do trabalho e também o tempo de sua reposição como mediação social. Daí emerge a máxima do "Do it yoursef”, a sua encarnação social, o "self made man", é aquele que se entende volitiva e praticamente autônomo, mesmo que subsumido à mediação social da mercadoria, do trabalho e do dinheiro. O "Do it yourself" corresponde àquilo que Adorno chama de pseudo-atividade ${ }^{154}$, e que se diferencia do hobby por ser a ideologia da quebra da separação,

152 "Caso um dia o tempo livre se transformasse efetivamente naquela situação em que aquilo que antes fora privilégio agora se tornasse benefício de todos - e algo disso alcançou a sociedade burguesa, em comparação com a feudal -, eu imaginaria este tempo livre segundo o modelo que observei em mim mesmo, embora esse modelo, em circunstâncias diferentes, ficasse, por sua vez, modificado.” (Adorno, 2009:63)

153 É de se notar que antes de suspender sua agonia diante do espelho, o alferes de Machado de Assis (1994) foi bastante bajulado por amigos e familiares!

154 Tanto quando falsa liberdade e liberdade real, a oposição pressuposta na ideia de pseudoatividade denota a existência de uma atividade verdadeiramente humana, algo questionável no 
ou seja, que propõem da unidade entre os tempos de trabalho e livre. É uma das formas bemacabadas do indivíduo.

No campo específico da fotografia, o advento da produção e circulação virtual das imagens representou a possibilidade da popularização massiva dessa prática. Na base do "Do it yourself”, um exército global de fotógrafos e “selfie makers” alimenta o fluxo incessante de imagens que circulam na internet. Não poucos são aqueles que almejam algum dia serem remunerados para tanto, mas como, do ponto de vista dos custos, a unidade da imagem cada vez mais tende a zero, enquanto alimentam suas esperanças, alimentam também uma imensa coleção de duplicatas do mundo.

Mais do que isso, de forma crescente novas parcelas do mundo são pensadas de forma quase exclusiva como elementos para a experiência visual. O turismo e a produção de imagens estão intimamente relacionados com esta forma de apreensão do mundo a partir de uma visualidade ensimesmada. Como forma de experiência sensória a visão também se autonomiza como forma de dar sentido ao mundo.

Sem exageros, seria possível produzir um inventário volumoso de historietas sobre a Chapada Diamantina concernentes a esse diagnóstico. Alguns desses casos são mais do que anedotas casuais, revelam mesmo aquilo que anima tomadas de decisões importantes. Roy Funch $^{155}$, um dos responsáveis pela criação do PNCD, conta como foi seu insight pessoal com relação ao parque:

\footnotetext{
"Em um desses passeios pela serra, eu estava sozinho indo pro Capão, eu virei a "esquina" da serra e abriu a visão do vale, os morros dos dois lados... tinha acabado de chover, tinha cascatas em todo canto, eu olhei para esse lugar e pensei ali mesmo, se isso fosse nos EUA, na Europa, seria um parque nacional...” (Roy Funch, janeiro de 2004, apud Guanaes, 2006:90).
}

Se já é revelador que tenha sido a "visão do vale" o que animou o biólogo estadunidense a se mobilizar para a criação do PNCD, ainda mais é seu relato sobre a maneira como os técnicos do então Instituto Brasileiro de Desenvolvimento Florestal (IBDF) decidiram estender a área do parque na direção sul:

argumento do autor.

155 Apresentado nesta dissertação no item 14. A descoberta da Chapada Diamantina e sua incorporação ao Estado nacional. 
“Só para mostrar como o processo era meio doido, eles chegaram aqui e se basearam na proposta do meu livro, que era realmente da BR até em Mucugê, área do Parque que eu conhecia bem (que acabou ficando no decreto do Parque), eu andava muito nesse trecho, era uma área mais ou menos bem definida pelas estradas de serras, aí a gente passou uma semana aqui indo para vários pontos e no último dia da vistoria deles alugamos um avião para ver por cima, para checar os limites e as áreas por cima, então a gente voou para cima e para baixo do Parque e todo mundo ficou satisfeito e a gente disse para o piloto: vamos voltar para o aeroporto, e o piloto naquele momento disse: vocês querem ver mais umas cachoeiras? Eles (os técnicos) disseram: por que não.... Então voamos ao sul do Mucugê, tinha umas 3 ou 4 cachoeiras lindas lá e em questão de 15 minutos o Parque quase dobrou de tamanho, simplesmente porque os técnicos adoraram as cachoeiras e (para incluí-las) fizeram um novo limite do Parque que passava por Mucugê e incluía áreas quase até o município de Ibicoara. Então, o processo de criação do Parque foi medonho, não tinha realmente embasamento técnico nenhum, era só ver que estava bonito, preservado, e muito em função das serras (quantidade de montanhas) e dos recursos hídricos, e vamos preservar isso, preservar...” (Roy Funch, janeiro de 2004, apud Guanaes, 2006:93).

A culpabilização dos técnicos ou da desorganização institucional acaba encobrindo que o processo decisório da criação das áreas de preservação, como observa Senilde Alcântara Guanaes, “[...] passa não apenas pela preocupação com os nichos de biodiversidade mas também e principalmente pela importância estética e paisagística desses nichos para o usufruto da sociedade urbana industrializada” (Guanaes, 2006:95). A afirmação da importância estética como o principal fator para a demarcação de áreas de preservação certamente é um exagero, as determinações são muitas e variam consideravelmente de caso em caso, e normalmente possuem como pano de fundo, atreladas a questão ambiental, argumentos condizentes à viabilização de projetos de desenvolvimento econômico. O que no caso do PNCD é evidente, o parque está intimamente vinculado ao desenvolvimento do turismo.

No caso de outra área de preservação contígua ao PNCD, a Área de Preservação Ambiental - APA Marimbus-Iraquara ${ }^{156}$, a visualidade também é isolada como determinação do planejamento técnico. O zoneamento da APA Marimbus-Iraquara, firmado em 1997 em seu Plano de Manejo, divide sua área em quinze zonas que, por sua vez, se enquadram em três categorias (Preservação, Conservação e Uso Sustentável). Dentre as quinze zonas estabelecidas pelo Plano de Manejo, duas Zonas de Conservação se destacam pela centralidade atribuída à visualidade: a Zona de Controle da Paisagem (ZCP) e a Zona de

156 Ver item 18. Diamantina Highlands desta dissertação. 
Proteção Visual (ZPV). Juntas essas duas zonas totalizam 208 quilômetros quadrados, correspondendo a quase $17 \%$ da área total da APA. É notável que a ZPV corresponda àquilo que se pode ver no trajeto de carro entre o aeroporto de Lençóis e a sede da cidade, além do próprio entorno visível a partir da referida sede.

Além do planejamento, a própria prática do turismo está profundamente marcada pela mediação visual autonomizada. Os passeios ofertados pelas agências de turismo são vendidos sempre através de um "cardápio” fotográfico de "atrativos”, assim chamadas as localidades visitadas. A própria ideia de que os lugares visitados sejam "atrativos" corresponde à experiência visual que oferecem. Alguns dos passeios realizados em trabalho de campo confirmaram o diagnóstico de Susan Sontag:

"Assim como as fotos dão às pessoas a posse imaginária de um passado irreal, também as ajudam a tomar posse de um espaço em que se acham inseguras. Assim, a fotografia desenvolve-se na esteira de uma das atividades modernas mais típicas: o turismo. Pela primeira vez na história, pessoas viajam regularmente, em grande número, para fora de seu ambiente habitual, durante breves períodos. Parece decididamente anormal viajar por prazer sem levar uma câmera. As fotos oferecerão provas incontestáveis de que a viagem se realizou, de que a programação foi cumprida, de que houve diversão. As fotos documentam sequências de consumo realizadas longe dos olhos da família, dos amigos, dos vizinhos. [...] Um modo de atestar a experiência, tirar fotos é também uma forma de recusá-la - ao limitar a experiência a uma busca do fotogênico, ao converter a experiência em uma imagem, um suvenir. Viajar se torna uma estratégia de acumular fotos. A própria atividade de tirar fotos é tranquilizante e mitiga sentimentos gerais de desorientação que podem ser exacerbados pela viagem. Os turistas, em sua maioria, sentem-se compelidos a pôr a câmera entre si mesmos e tudo de notável que encontram. Inseguros sobre suas reações, tiram uma foto. Isso dá forma à experiência: pare, tire uma foto e vá em frente. O método atrai especialmente pessoas submetidas a uma ética cruel de trabalho - alemães, japoneses e americanos. Usar uma câmera atenua a angústia que pessoas submetidas ao imperativo do trabalho sentem por não trabalhar enquanto estão de férias, ocasião em que deveriam divertir-se. Elas têm algo a fazer que é uma imitação amigável do trabalho: podem tirar fotos." (Sontag, 2004:19)

Durante os trabalhos de campo no ano de 2016 subi duas vezes o Morro do Pai Inácio, um dos principais pontos turísticos da Chapada Diamantina. Todos os dias ascende grande número de turistas ao seu cume, cujo acesso é relativamente simples se comparado a outros “atrativos” da área. O pôr do sol é o momento mais aguardado pelos visitantes que sobem o morro. A primeira vez que fiz o passeio estava acompanhado de um amigo e uma amiga, 
saímos já no meio da tarde de Lençóis, trata-se de um trajeto curto de carro (aproximadamente 29 quilômetros), mas acabamos ficando parados em um engarrafamento inesperado na BR-242, de modo que a trilha para subir o morro também encontrava-se engarrafada de turistas, grande parte deles clientes das agências que normalmente reservam o final do dia de alguns tours para o afamado pôr do sol. Os atrasos no percurso fizeram com que chegássemos ao topo faltando poucos minutos para o sol sumir no horizonte, a atmosfera de euforia e urgência entre os turistas era patente: tinham poucos minutos para fazer suas fotografias. Dividindo minha máquina fotográfica com minha amiga, fiz uma pequena série de imagens da ação dos turistas ${ }^{157}$, para depois deixar que ela fizesse também nossas fotografias do pôr do sol.

A segunda visita fez parte de um tour de um dia que comprei em uma agência de turismo de Lençóis. A princípio acabaríamos o passeio justamente subindo o Morro do Pai Inácio para assistir ao pôr do sol, mas como o dia amanheceu chuvoso a guia que nos acompanhava achou por bem reorganizar a ordem em que visitaríamos os “atrativos”, de modo que adiantamos a subida ao morro e não esperamos o pôr do sol, mesmo porque o tempo encoberto o inviabilizava. Ainda assim a produção de imagens foi a prática que deu sentido para o passeio, aliás, este tour inteiro teve a fotografia como marcador espaçotemporal determinante. Em síntese: se desloque ao local, tire fotografias nele e se encaminhe para o próximo “atrativo", o tempo era contado com rigor e os deslocamentos necessariamente feitos de carro. No topo os guias que nos acompanhavam sugeriram duas atividades: que tirássemos uma fotografia ao lado de uma pedra em formato de coração, e que tirássemos uma fotografia deitados sobre outra pedra destacada na beira do morro, simulando que planávamos no ar. Nos dois momentos formou-se uma pequena fila de espera para o clique desejado.

Ao chegar em São Paulo e rever as fotografias das duas visitas em meu computador imaginei a possibilidade de ver as fotografias produzidas pelos turistas no Morro do Pai Inácio. Ato contínuo e irrefletido passei a buscar imagens sobre o tema na internet. Nesta breve pesquisa logo pude perceber um padrão nas imagens encontradas, alguns ângulos se repetem, um deles exaustivamente: a vista do Morro dos Três Irmãos, por vezes enquadrando parte do Morro do Camelo, por vezes privilegiando o chão onde é possível enxergar a pedra em formato de coração. Detalhe curioso, o terreno permite um giro de $360^{\circ}$ percorrendo o perímetro do cume do morro, muitos outros enquadramentos seriam possíveis. Desta forma, pude fazer uma seleção de imagens de terceiros que compõem uma espécie de complemento

157 Ver Anexo G desta dissertação. 
daquela pequena série que havia produzido em minha primeira visita ao morro. Mas, para além do padrão, o relato desse exercício me interessa pela facilidade de sua execução. Em aproximadamente meia hora pude juntar na minha casa, em São Paulo, mais de 150 fotografias feitas do mesmo ângulo no Morro do Pai Inácio, produzidas por pessoas diferentes e desconhecidas.

Sontag faleceu em 2004 e pôde ver apenas os primeiros resultados da popularização massiva da fotografia digital e da circulação das imagens via internet. Na década de 1970, quando a tecnologia de transmissão remota de imagens difundida como consumo de massa ainda era a televisão e as fotografias circulavam majoritariamente na forma impressa, a filósofa identificava uma duplicata do mundo feita em fotografias. Se no tempo da circulação impressa das imagens fotográficas já era possível diagnosticar um comportamento compulsivo de consumo de imagens, o que dizer dos dias que correm?!

Tendo isso em mente é possível, fazendo um pequeno desdobramento a partir da leitura de Sontag, reposicionar a interpretação da questão tendo a forma da mediação social como núcleo da crítica. Quer dizer, o problema da interpretação da mediação social deve passar pela questão da propriedade, mas que não se encerra aí. Mais do que na "posse imaginária” ou a falsa acessibilidade do mundo através das imagens fotográficas, a questão está situada na própria reificação, ou seja, na relação mediada por coisas produzidas como coágulos de tempo de trabalho (Marx, 1996). Neste sentido, o caráter metafísico atribuído às fotografias é antes fundamento do próprio mundo mediado pelo capital como relação social. A falsidade ou o sentido imaginário, atribuídos pela autora ao mundo das duplicatas fotográficas, talvez seja um dos indícios fenomênicos da ficcionalização ${ }^{158}$ dessa relação.

158 Ver item 14. A descoberta da Chapada Diamantina e sua incorporação ao Estado nacional desta dissertação. 
ENSAIO III

A fotografia abaixo (Figura 18) foi produzida por Furniss ${ }^{159}$. É difícil distinguir detalhes nela, sua qualidade é um impeditivo. No terreno pedregoso em declive, é possível ver duas mulheres negras e vestidas de branco sentadas em frente de uma toca, da qual podemos divisar uma parede feita de pedras sobrepostas, uma porta e um pequeno telhado de palha. Ao redor alguns materiais frutos de coleta, como o que parece ser uma pilha de varas de madeira do lado esquerdo da parede de pedras. A legenda atribuída pelo cônsul estadunidense é objetiva: “Casa de garimpeiro construída em saliência mineirada".

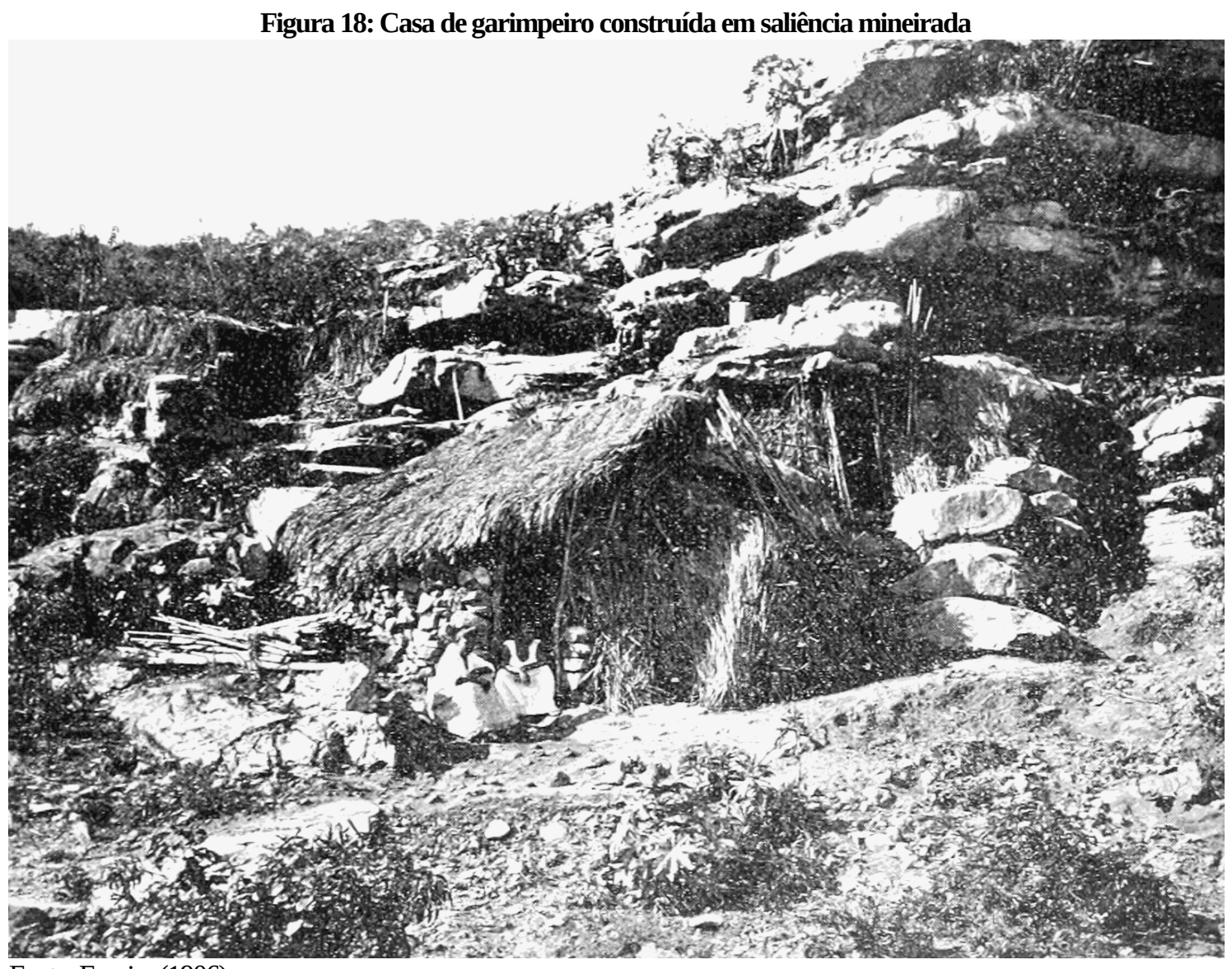

Fonte: Furniss (1906)

É importante notar que esta forma de habitação estreitamente relacionada à atividade econômica que identifica a área não foi registrada por Steve Horman para compor o material audiovisual $^{160}$ que buscava atrair a atenção governamental para a patrimonialização de

159 Ver item 7. Fotografias do cônsul estadunidense Henry Watson Furniss desta dissertação.

160 Ver item 15. Fotografias do voluntário do Peace Corps Steve Hormann desta dissertação. 
Lençóis. Já Fernando Machado Leal ${ }^{161}$ chegou a produzir imagens de uma "loca de garimpeiro no Serrano", em Lençóis, durante sua visita técnica a serviço do IPHAN, no entanto, nenhuma dessas imagens (Figuras 19, 20, 21 e 22) estão presentes no artigo publicado na Revista do Patrimônio Histórico e Artístico Nacional, tampouco parecem ter influído o processo de patrimonialização, já que as tocas garimpeiras não foram consideradas.

Figura 19: Loca de garimpeiro no Serrano, vista externa. Lençóis - Bahia

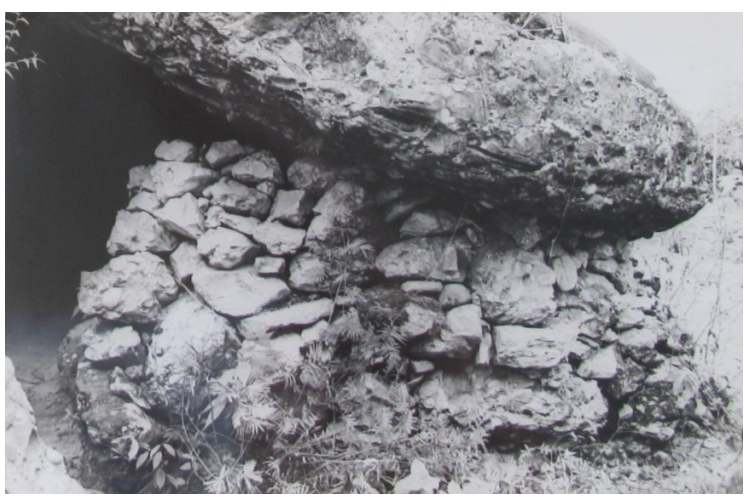

Figura 21: Entrada de loca no Serrano. Lençóis - Bahia

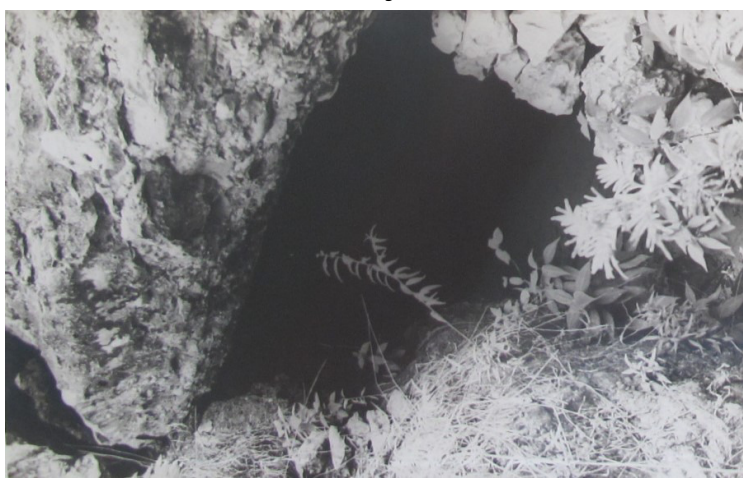

Fonte: Arquivo Iphan.
Figura 20: Loca de garimpeiro, vista interna. Lençóis - Bahia

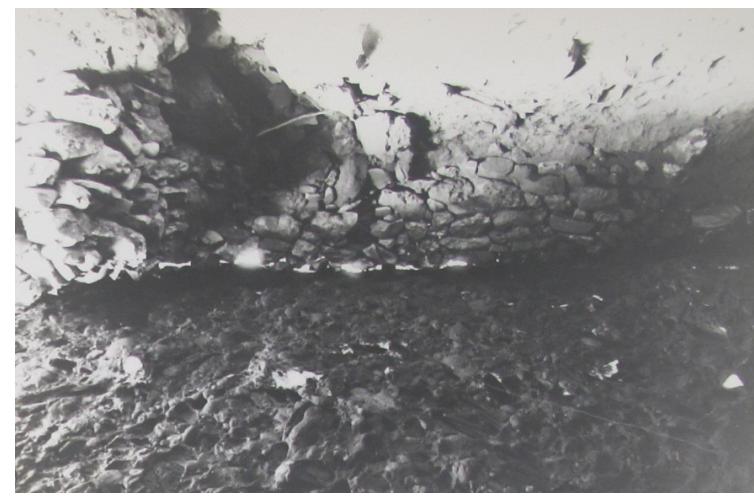

Figura 22: Loca de garimpeiro, vista interna. Lençóis - Bahia

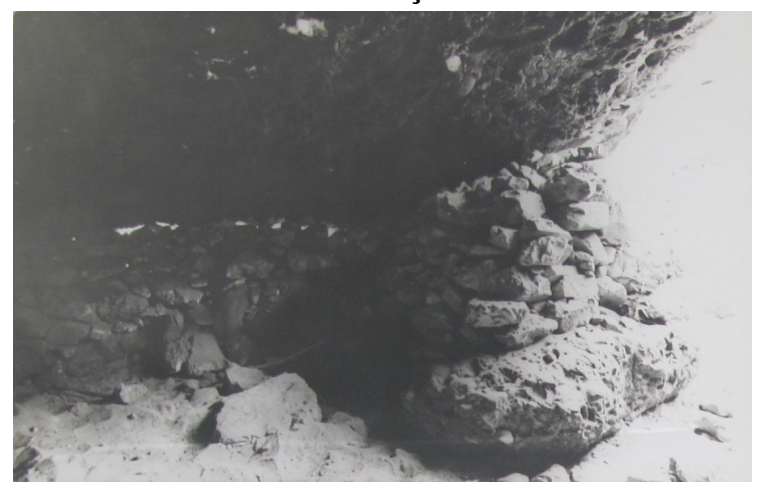

Outra fotografia (Figura 23) que compõem o material que Leal produziu durante sua pesquisa pode ser considerada como um indício do motivo pelo qual as tocas não foram consideradas patrimônio arquitetônico, ou seja, que este fato não é mera casualidade.

Em segundo plano, do lado direito de uma cruz erguida sobre o lajedo, é possível identificar o que parecem ser quatro construções. A mais próxima é a estrutura de madeira de uma casa, as colunas sustentam a trama do telhado que já está praticamente pronta para receber a cobertura. Acima desta, outra estrutura de casa já possui cobertura de palha e uma porta, além de ter uma trama de varas de madeira que provavelmente servirão de sustentação

161 Ver item 16. Fotografias do arquiteto Fernando M. Leal em pesquisa para o IPHAN desta dissertação. 
para paredes de enchimento. Ainda mais acima, outra casa em construção possui fundação feita de pedra, a estrutura das paredes e telhado de madeira, o telhado encontra-se parcialmente coberto de palha e as paredes em construção são feitas de adobe, possui porta e janela frontais. Por fim, a quarta construção talvez sejam duas casas que se valem da mesma estrutura, visto que possui duas portas frontais, além de três janelas, também é construída sobre fundação de pedra e possui paredes de adobe, a cobertura do telhado é de telha de cerâmica e a parede da frente parece estar rebocada e pintada. A legenda da fotografia indica: “Construção primitiva no bairro Tomba Surrão, Lençois - Bahia”.

Figura 23: Construção primitiva no bairro Tomba Surrão, Lençois - Bahia

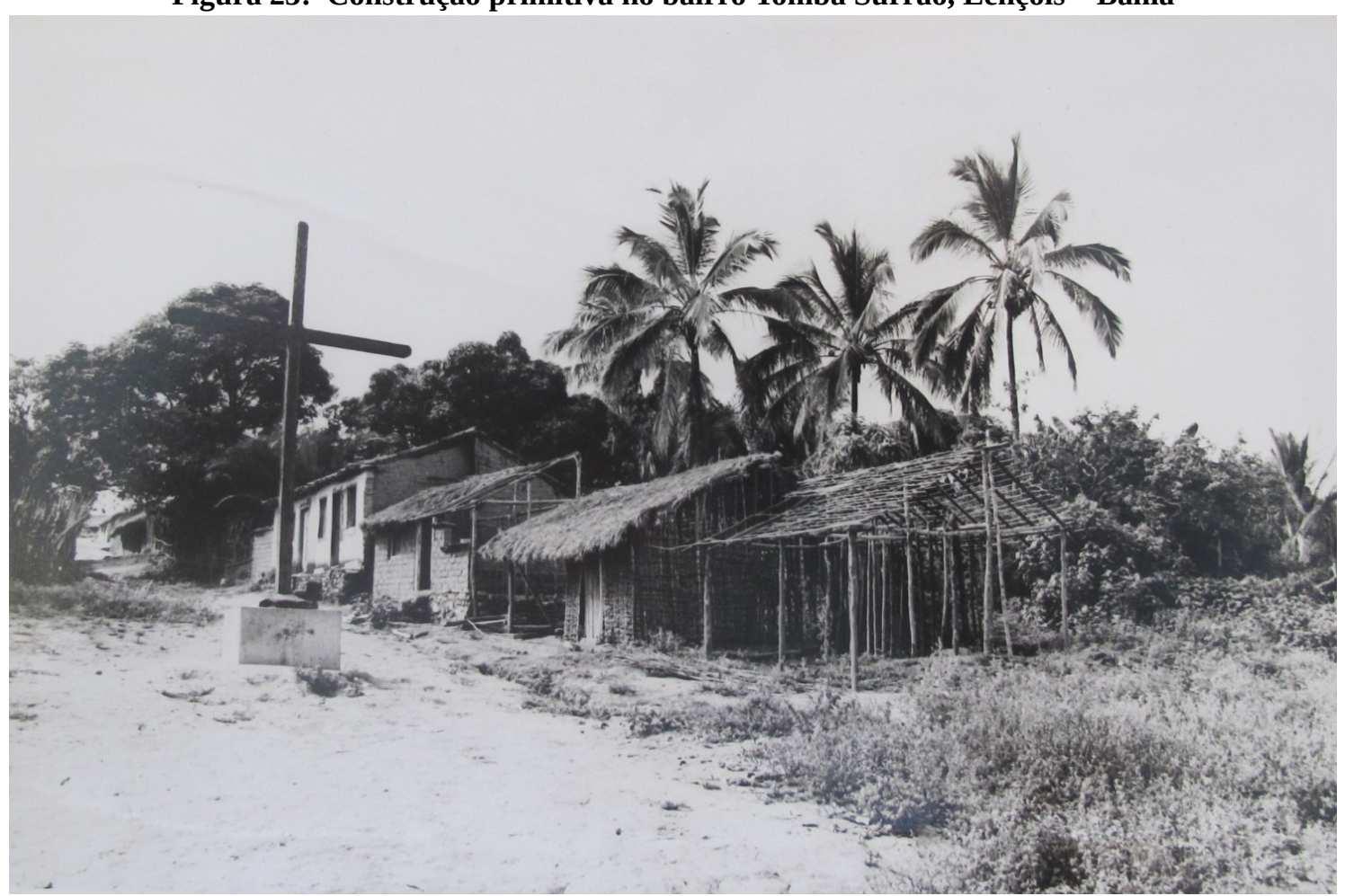

Fonte: Leal (1978).

Vale destacar que as legendas atribuídas por Leal às fotografias de seu estudo sobre Lençóis, em sua quase totalidade, fazem menção apenas aos logradouros e aos proprietários dos imóveis registrados. Algumas delas possuem indicações sobre o estado de conservação das edificações, o uso nalgum evento histórico considerado revelante, detalhes estruturais ou intervenções que o arquiteto julgou descaracterizantes. Mas a imagem acima é a única para a qual o arquiteto se vale de uma caraterização abstrata: é uma "construção primitiva”. Nas fotografias sobre a toca do Serrano, talvez o simples fato de ter indicado que se tratava de uma “loca de garimpeiros” tenha sido suficiente para o arquiteto, não sendo preciso apontar que também esta era considerada por ele primitiva. 
A partir deste singelo detalhe nas escolhas de Leal para legendar as imagens de sua pesquisa é possível apenas sugerir que a leitura da história que organizava o que deveria ser considerado como patrimônio histórico nacional pelo arquiteto estava informada pelo dualismo que separa, dentro de uma mesma comunidade, o primitivo de seu oposto. Permanecer no campo da imagem fotográfica e de seu correlato categorial na geografia, a paisagem, implica em uma limitação à interpretação do processo social. Quer dizer, mais do que a pretensa representação da materialidade em si, interessa que uma fonte de pesquisa comporte sobretudo os discurso das personas envolvidas no processo social analisado. Em resumo: através da fotografia a aproximação àquilo que se pensa sobre o processo é superficial.

Por isso também, o trabalho de campo como procedimento de pesquisa interessa não apenas na aproximação que possibilita ver como foi produzida a materialidade, mas também como se estabelecem os discursos sobre o processo analisado. O que não significa dizer que a pesquisa de campo seja uma busca pelos discursos verdadeiros sobre o processo social analisado, pelo contrário, seu momento mais frutífero é a revelação da contradição entre os discursos.

Nesse sentido, a análise do filme Diamante Bruto de Orlando Senna, gravado em Lençóis e lançado em 1977, se apresenta como material de análise mais fértil que as fotografias para o debate em torno da oposição entre o tradicional e o moderno. Sobre o filme o diretor comenta no documentário Brilhante gravado e dirigido por Conceição Senna em 2004:

"Fomos pra Lençóis, eu e a minha mulher, Conceição, e mais uns amigos pra pensar o que poderíamos fazer ali, que filme poderíamos fazer nesse lugar. $\mathrm{E}$ esse impulso, esse tipo de cinema que a gente fazia na época, sempre me fazia relacioná-lo com um filme que fosse realmente comunitário, que pudesse fazer com toda a população do lugar, evidentemente era um lugar pequeno. E claro, eu pensava sempre na minha terra, em Lençóis, onde eu nasci, onde eu vivi minha infância e de onde, na verdade, pelo menos espiritualmente, eu nunca tinha saído. A gente perguntou a eles que tipo de história a gente devia contar de Lençóis. Bom, apareceram ideias, falou-se em Horácio de Matos, falou-se em João Requizado, mas, na verdade, o que as pessoas queriam mesmo fazer era uma história de amor, como eles diziam, a partir de um livro, uma história muito conhecida, também de um autor local, de Afrânio Peixoto, Bugrinha, que conta a história de uma pessoa rica, branca, bem sucedida, e de uma negra, pobre...” (Brilhante, 2004) 
Na realidade, no romance de Afrânio Peixoto, lançado em 1922, Bugrinha, a personagem que dá nome à obra, não é negra e sim descrita como morena ${ }^{162}$. O próprio diretor relata em sua biografia como a decisão de transformar a personagem em uma mulher negra no filme surgiu por conta do processo de produção comunitária, que no caso em questão contou com o posicionamento dos estudantes de Lençóis estimulados por um professor:

\begin{abstract}
"Essa compreensão dos habitantes de que iríamos contar essencialmente essa história mas não íamos reproduzir fielmente o romance, de que iríamos contá-la à nossa maneira e espelhando a atualidade, ficou clara quando os estudantes sugeriram uma moça negra para fazer o papel de Bugrinha. Não uma morena, como está no romance. O argumento era que a população da cidade tinha (acho que ainda tem) 80\% de afro-descendentes. Lembro-me de um professor dizendo que Afrânio Peixoto tinha adoçado a pílula ao definir a personagem como morena, que o conflito que o escritor propunha era mais verossímil entre um branco e uma negra, tanto no passado como no presente.” (Leal, 2008:240/241)
\end{abstract}

Mais do que "adoçar a pílula” a opção de Afrânio Peixoto pela personagem morena correspondia diretamente a sua convicção nacionalista racista, o que fica claro tanto em sua obra científica, como na sua participação política. Em 1923, um ano depois do lançamento de Bugrinha, assim se posicionava na Câmara dos Deputados sobre a possível vinda de negros estadunidenses para o Brasil:

“É nesse momento que a América pretende desembaraçar-se do seu núcleo de 15 milhões de negros no Brasil (...) Quantos séculos serão precisos para depurar-se todo esse mascavo humano? Teremos albumina bastante para refinar toda essa escória? Quanto tempo ainda para redenção de Caim (...)” (Peixoto, apud Cruz, 2004:89)

O médico lençoense, entusiasta da eugenia no Brasil, em seu ensaio Clima e Saúde de 1938 reafirma seu posicionamento favorável ao branqueamento da raça como elemento da formação nacional:

162 É de se notar que o uso da palavra "bugre”, para designação, desde os povos indígenas que habitavam a área que conformaria o território nacional até o mestiço interiorano, esteve sempre carregada de sentido pejorativo. "A denominação de bugres dada pelos portugueses aos indígenas do Brasil em geral e a uma tribo de São Paulo em particular talvez exprimisse o horror teológico de cristãos, mal saídos da Idade Média, ao pecado nefando, por eles associado sempre ao grande, ao máximo de incredulidade ou heresia. Já para os hebreus o termo gentio implicava idéia de sodomia; para o cristão medieval foi o termo bugre que ficou impregnado da mesma idéia pegajosa do pecado imundo. Quem fosse herege era logo havido por sodomita; como se uma danação arrastasse inevitavelmente à outra” (Freyre, 1963:178, apud Guisard, 1999:92). 
"Se os antropólogos e sociólogos mais sisudos estabelecem que não há raça pura, senão no sentimentalismo político, isto é patente no nosso tempo e à nossa vista. Um exemplo, o que ocorre no Brasil. O sangue autóctone dos índios, assimilado pelos brancos ao norte; o negro importado por toda a parte. O selvagem desapareceu e o negro não vem mais; o branco vem sempre, e se reproduz. Em 1869 Gobineau, no Brasil, vaticinava: "as crianças morrem, tal quantidade, que em número de anos pouco considerável, não haverá mais brasileiros”. “Em menos de duzentos anos ver-se-á o fim da posteridade dos companheiros de Costa Cabral (sic) e dos imigrantes que o seguiram". Não só o Brasil cresce, e enormemente, de população; em 72, perto de Gobineau, éramos 10 milhões, meio século após já 47 milhões..., como as misturas raciais se fazem rapidamente. A albumina branca depura o mascavo nacional... Negros puros já não há; mestiços, por fraqueza somática, sensualidade, nervosidade, sensibilidade à tuberculose, ou desaparecem pela morte precoce, ou se cruzam, sempre com elementos mais brancos: a raça se aclara. Em duzentos anos, longe de se extinguirem no Brasil os descendentes do povo de Cabral, terá passado inteiramente o eclipse negro, desses quatro séculos de mestiçagem.” (Peixoto, 1975:15/16, apud, Seyferth, (?): 30/31).

No próprio romance a mesma tese é apresentada, expressa na opinião do velho Sobral, um personagem secundário na trama e tido como "maluco" por outros personagens por ser abolicionista, republicano e comunista em um contexto ainda pré-abolição. Segue o diálogo entre Sobral e o médico Gonzaga:

“João Sobral tomou de novo o braço de Gonzaga, e se afastou para outro canto, pretextando fumar.

- Você vê? Louvores à terra... censuras à gente... Imprevidência eterna, constante confiança em amanhã... Significativo... não lhe disse que Lençóis é o Brasil? Desconfiado e humilde consigo, vaidoso e enfático de seu torrão, sempre em crise, nunca precavido... Há mais de trezentos anos isso... e continuará, nessa maravilha, miragem, ou obsessão... a natureza que não cansamos de louvar...

- Parece que temos orgulho ou vaidade, por Deus... que a criou...

- Orgulho aliás injusto, ou vaidade com as dos outros, de pouco siso, porque a terra, se é boa, e nem sempre é boa, não é nem única, nem, ainda menos, é a melhor... Mas, não importa, nossos brasões, são esses imensos Brasis...

- O Amazonas, o maior rio; Paulo Afonso, a maior cachoeira; terra a mais não acabar; a baía de Todos os Santos, o mais vasto ancoradouro; o Rio de Janeiro, a mais bela cidade; jazidas por toda parte; montanhas de ferro em Minas Gerais; os diamantes mais puros na Chapada; o açúcar mais doce em Pernambuco; matas de café em São Paulo; rebanhos sem fim no Rio Grande... 
- Entretanto, quando passam da terra à gente, a injustiça continua, invertida... É uma lástima, somos descendentes de pretos escravos, caboclos selvagens, e os Portugueses... foram degradados. Não há mal que não digam desses aventureiros, os mais nobres ricos-homens, a princípio, depois os mais esforçados rapazes do reino, cujo único defeito foi faltarem à Pátria que deixaram, e vieram felicitar a outra que procuravam para ingratos filhos e espúrios descendentes, os quais insistem na calúnia dos degredados, ontem, e hoje nos marotos, pés-de-chumbo... Dos selvagens, alguns assimilados e por isso desapareceram da vista: depomos que os matamos a álcool, doenças e trabalhos forçados... Dos negros, tão pacientes e servis, que nos ajudaram a fazer isto, pretendemos que, minoria íntima e misturada, seja totalidade da raça, e a execrada mestiçagem, diminuta fração, são todos os Brasileiros...

- Você tem razão... somos povo modesto... A nossa humildade de nacionais contrasta com nossa ênfase de proprietários. Temos o ar de dizer sempre ao estrangeiro: - Não merecemos, os Brasileiros, a terra que possuímos: ela grandiosa, nós miseráveis...

- E, entretanto, não há povo no mundo que tenha, como o nosso, ascendência mais nobre e mais ilustre: ajudamos a restauração da fé contra os Infiéis, e o triunfo da Civilização Cristã na Península e nas Índias, forçando o refluxo, da Europa, para as nascentes ameaçadas do Islamismo; descobrimos o mundo, todos os mares e terras, e demos, por oceanos desconhecidos, a volta à mesma Terra; com o nosso fausto enriquecemos a Igreja, a Europa, o mundo; o nosso cruzado foi mais valioso e universal do que é hoje a libra. Nun’Álvares, Gama, Frei Bartolomeu dos Mártires, Fernão Magalhães, Camões, Antônio Vieira, Pombal... honrariam qualquer maior povo da História... Descendemos deles... e entretanto lhes chamamos degredados; misturamo-los com alguns índios bravos e negros boçais e, parece que nos honra isso mais, provirmos destes mestiços...

- Você tem razão... também aqui os mineiros de Lençóis são os mais determinados dos sertanejos da Bahia e de Minas; há uma epopeia sem dúvida neste esforço heroico e insubmisso contra a terra, que esconde nas entranhas os seus tesouros, donde o amor cobiçoso do homem os vai arrancar, nas grotas, nos barrancos, nos emburrados, nos lancheios... e só vemos, para este empenho, o resíduo de gente, mendigos, parasitas, comborças, como se não fosse natural, e inevitável, que só as árvores grandes suportem no tronco e sob a ramaria todas as lianas e fetos, plantas rasteiras e grimpantes, que tiram das outras sombra e proteção, as razões mesmas da vida...” (Peixoto, 197- :18/19)

O trecho acima não é o único do romance em que o personagem de João Sobral, personificação de uma inteligência extemporânea na trama ${ }^{163}$, expressa a tese de que Lençóis é

163 Segundo o próprio autor, comentando o universo retratado no livro: "Sobral, a quem até o nome conservei, e está na memória de todos em Lençóis e foi velho e impenitente sonhador, lá daquele desertão, há trinta anos e mais, de ideias e utopias, que ainda não são criadas nem recebidas pelas gentes cultas das capitais e do litoral, às vezes presumidas e atrasadas, um bandeirante, também de ideias utópicas...” (Peixoto, 197-:103) 
como o Brasil. Deste modo, a superação do caráter regional com a crítica da "nossa ênfase de proprietários” é um caminho necessário para se estabelecer como “nacionais”. O otimismo de Afrânio Peixoto quanto a formação do nacional estava assentado no branqueamento da raça.

É notável como no filme de Orlando Senna, produzido pouco mais de meio século depois do livro de Afrânio Peixoto e feito “espelhando a atualidade” de então, esse paralelo entre Lençóis e o Brasil já não é mais possível, a região não pode ser mais entendida como síntese da nação. Em outros termos, é possível dizer que o filme ao refletir a atualidade da cidade, reflete também a internalização do dualismo como forma de compreensão do processo social nacional territorializado.

Ainda que o turismo já fosse um projeto para a cidade quando o filme foi gravado vale lembrar que Lençóis já havia se tornado patrimônio arquitetônico em 1973, que a BAHIATURSA já havia desenvolvido seus estudos na área em 1974 e que o próprio filme cita a construção da Pousada de Lençóis, que viria a ser inaugurada em 1979 - são as atividades agropastoris $^{164}$ que representam a figura do moderno no filme, em anteposição às relações de produção “tradicionais” que caraterizavam o garimpo e a moral antieconômica e religiosa da população da cidade. Vale mencionar que o próprio diretor, de família de proprietários de terras, tentou montar uma granja junto com a esposa em Lençóis antes de se engajar definitivamente na produção do filme:

"Um tempo feliz em Lençóis, há quase vinte anos não curtia a cidade, tinha
feito poucas e rápidas visitas por motivos familiares. [...] A cidade estava
encolhendo, muita gente indo embora, a produção de diamantes baixíssima,
e havia tentativas por parte de algumas pessoas de criar novas fontes de
trabalho para os garimpeiros, novos veios econômicos: café e outras
agriculturas, criação de gado. Nessa perspectiva, nossas iniciativas (a granja
e as produções de nossos amigos) eram bem-vindas e contaram com a
simpatia da comunidade. Nos associamos a um senhor de Feira de Santana
que tinha um carro-frigorífico e que dizia entender do negócio e que passou
a gerenciar a empresa. O plano era simples: como a granja operaria apenas
com o carro-frigorífico, sem um frigorífico fixo, os abates seriam
coordenados com os compradores, a cada encomenda se faria o abate e a
entrega imediata. Tracei um raio de ação de 50 quilômetros, alcançando
várias comunidades além de Lençóis, que nos indicaram os dias que as
entregas deviam ser feitas, geralmente coincidentes com os dias de feira de

164 A sequência inicial do filme: logo após passarem os letreiros sobre imagens aéreas das serras, se vê uma tomada aérea da cidade, e depois a câmera acaba focalizando um avião no céu, antes do corte para a cena seguinte a câmera deixa de acompanhar a aeronave e desce ao chão focalizando duas grandes placas, uma que anuncia investimentos da Sudene a um empreendimento, provavelmente à Bahema Agropecuária S.A, tema da segunda placa. 
cada uma delas. Fizemos alguns testes, o carro-frigorífico levou alguns lotes às comunidades vizinhas, os frangos chegavam congelados, nos conformes. Quando estava próxima a data em que a granja iria começar a funcionar, a fornecer frangos regularmente aos compradores, dois acontecimentos derrubaram o projeto, ambos ligados ao nosso gerente. Primeiro descobriu-se que ele estava tuberculoso, tivemos de afastá-lo dos frangos e fazer exame médico em duas mil aves. Não havia contaminação. Contratamos outra pessoa para operar o carro-frigorífico e veio o segundo golpe: o tal carro pifou. [...] Tentamos alugar outro carro-frigorífico, não havia muitos à disposição e eram caros para o nosso periclitante capital inicial. E o tempo passando e os frangos crescendo além do período previsto, entupindo a granja e comendo cada vez mais. Decidimos fazer o abate geral, duzentos frangos por dia, e distribuir para a população. Aí aconteceu o drama sentimental da Conceição, que tinha acompanhado a evolução de seus lindos pintinhos dourados de penugem macia, dia a dia, até vê-los adultos e prontos para serem sacrificados. Causava sofrimento, ela não aguentava isso. Nem eu. Não era nossa praia, não sabíamos lidar com aquilo. A granja foi fechada, o grande galpão que construí ficou com meu pai e existiu por muitos anos, servindo a outros fins, até ceder lugar para um hotel.” (Leal, 2008:236-238)

Quer dizer, antes de iniciar a produção de Diamante Bruto Orlando e Conceição fazem uma tentativa frustrada de engajarem-se justamente na atividade que no filme representa o pólo do desenvolvimento. O fracasso da granja parece, para além dos problemas técnicos, comportar também elementos que dizem respeito à personalidade do diretor e de sua esposa, personalidade esta certamente formada e informada pelo universo metropolitano.

O filme não assume para si o discurso de nenhum dos pólos do dualismo que apresenta ao espectador. Na transposição do romance regionalista para a linguagem audiovisual boa parte da caracterização da comunidade é feita na forma documental, na fala direta das personas representadas. O próprio personagem Jorge de Castro - o rapaz branco e de família rica que retorna para a cidade e revive um romance de infância com Bugrinha, e que é um dos três personagens do filme representados por atores profissionais ${ }^{165}$, no caso por José Wilker -, que no livro vai estudar em uma cidade grande e volta quatro anos depois para Lençóis usando um “capacete de engenheiro”, na adaptação de Orlando Senna vira José de Castro,

165 Além de José Wilker, o seu pai na história, Dr. Zézinho, é interpretado por Wilson Mello, que no documentário "Brilhante" (2004) conta que se inspirou no pai de Orlando Senna, Esmeraldo Senna, para compor o personagem. E a esposa de Orlando Senna, Conceição Senna, interpreta Rita, uma mulher "de fora” casada com Tibúrcio, o jagunço da fazenda da Encantada, propriedade da família Castro. 
um famoso ator de novela que retorna para a cidade depois de vinte anos fora ${ }^{166}$. Aí também se misturam a figura do personagem e do ator.

O filme apresenta o embate entre o discurso da modernização e o discurso da tradição dando margem para o questionamento e para o posicionamento das partes em relação. Sem superar o dualismo, o filme o apresenta de forma aberta. Em uma cena que se passa no curral da fazenda da Bonita, na qual o proprietário executa “um projeto” que José Castro estava curioso pra conhecer; ele, seu pai Dr. Zézinho, também fazendeiro, e o proprietário ${ }^{167}$ da fazenda em questão conversam sobre a "pecuária moderna”. Se dá o seguinte diálogo:

Dr. Zézinho: O prefeito me pediu pra aproveitar mais de 300 homens aqui, mas não deu não, você sabe como é né? Eu tive que despedir eles todos, semana passada despedi mais de 200, poxa, porque não dá, não tem condição. A gente quer ter boa vontade, mas você sabe é impraticável, impraticável... esse pessoal não quer mesmo esse tipo de trabalho.

Fazendeiro: Ele pediu pra por aqui na Bonita cem homens, eu botei. Apenas para atender. E não deu certo, tive que mandar tudo embora.

José de Castro: Esse pessoal do garimpo não se adapta por quê?

Fazendeiro: São os vícios que vem da época do auge do garimpo, entendeu? Viciaram trabalhar só com aquilo, só aprenderam aquilo. E sabe, não há escolas técnicas, não tem aqui escolas técnicas. Então, o que eles vão aprender no seu garimpo? Nada. E com essa falta agora, com essa dificuldade, eles estão com um desemprego muito grande. Compreendeu? Esse é o problema. Por que o senhor não passa aqui uns dias para tomar umas aulas?

José: O que eu vou fazer com o boi?

Dr. Zézinho: Você que estava curioso pra ver!

José: Ver é uma coisa, mexer nele... (risos).

Dr. Zézinho: Você aprende, é prática.

Fazendeiro: Não é mexer com boi não, é mexer com vaca” (Filme “Diamante Bruto")

166 Mesmo período que o próprio Orlando Senna declara ter ficado afastado da cidade, fazendo apenas visitas pontuais por motivos familiares.

167 Orlando Senna conta em sua biografia que no dia da primeira projeção pública do filme em Lençóis, com muita gente reunida, o projetor queimou no começo do filme, justamente no momento seguinte da cena em questão: "Acontece que a projeção do filme havia parado exatamente depois de um fazendeiro, um boiadeiro, esculhambar os garimpeiros, dizer que garimpeiro é preguiçoso. Uma hora depois, estou em casa lamentando a estreia fracassada e aparece um grupo de garimpeiros, muito chateados com o que o fazendeiro dissera no filme, esses forasteiros vêm pra nossa terra, não conhecem nosso trabalho e ainda ofendem a gente. Estavam decididos a dar umas pancadas no fazendeiro, um corretivo, e tinham vindo me informar sobre essa decisão. Eu disse que não precisavam fazer isso, que eles respondiam essa ofensa no próprio filme, e muito bem respondida, que esperassem a exibição completa no dia seguinte. E foi o que aconteceu, eles ficaram satisfeitos com a resposta que dão na tela." (Leal, 2008:246/247). 
Até este momento o diálogo se dá enquanto o fazendeiro trabalha no curral, ele está fazendo um procedimento na vagina de uma vaca confinada, com a mão e o antebraço dentro do corpo do animal, o que causa certo ruído visual com o discurso sobre a pecuária moderna. Nesse momento a cena é cortada e ele aparece mexendo em um cilindro refrigerado. $\mathrm{O}$ diálogo continua:

Dr. Zézinho: Pessoal aqui só quer saber mesmo do garimpo.

Fazendeiro: Eles nasceram nisso, viveram isso ...

José: Porque, acho, que o trabalho no garimpo é mais à vontade, trabalha quando quer, e esse é um trabalho mais disciplinado.

Fazendeiro: Porque obedece horário. Garimpeiro vai, ele chega lá, lava um pouquinho a terra, o cascalho. Depois ele vai dormir um pouquinho, depois vai fumar um cigarro, depois vai tirar um soninho. Lá pelas três horas da tarde ele lava mais um cascalhozinho e volta pra casa.

José: Quer dizer, acaba dando a impressão de que é preguiçoso.

Fazendeiro: Mas é o que ele é, por vício natural de origem.

José: Trazer um inglês (risos).

Fazendeiro: (risos) seria o ideal. Mas a libra está muito alta, nos temos que ir com brasileiro mesmo, que já tem gente muito boa.

Nesta cena é apresentado o ponto de vista do proprietário agrícola moderno, o qual entende os garimpeiros como preguiçosos, personas não acostumadas ao trabalho que exige a obediência de horários. O arremedo irônico da cena, no qual José de Castro sugere em tom de piada para o fazendeiro que contrate ingleses, revela um limite daquele empreendimento moderno: o fazendeiro não conseguiria comprar a força de trabalho sugerida pelo ator, segundo ele porque “a libra está muito alta”. Já em outra cena, que não conta com nenhum personagem ficcional, três garimpeiros estão em pleno trabalho e externam suas opiniões sobre as dificuldades que envolvem o garimpo naquele momento. Começam falando do garimpo mecanizado:

Garimpeiro 1: A draga é negócio de companhia, é negócio fino, que eu trabalho na draga e conheço mais ou menos. Agora, dizem eles que o garimpo acabou e o garimpo não acabou. O garimpo é a situação da fraqueza dos garimpeiros, que não podem trabalhar de jeito nenhum. E só vai se Deus mandar do céu um filho de Deus pra botar um armazém para os pobres dos garimpeiros comer um pouquinho, pra aguentar a trabalhar e tocar o garimpo da Lavra. Se não vir, a Lavra vai acabar, como está acabando, por falta de um auxílio dos homens para os fracos.

Garimpeiro 2: Então o causo vai ser esse, por esse motivo que digo que o garimpo não vai pra frente. Os homens que ajudavam o garimpo foram aqueles velhos que já morreram. Então, como dizem, fica essa turma moderna, essa turma moderna diz que não tem fé em garimpo. Então, volto a 
dizer, o garimpo não vai para frente. A não ser que venha uma ajuda diferente, né? Quisera, o governo poderá ajudar a gente, né?

Garimpeiro 1: Quando pega o diamante o patrão diz: 'é, é corado, é jaçado ${ }^{168}$, tem um ponto, é quebrado, um pião torto. Esse tem uma mosca mesmo no meio!' Ora, se eu acho o diamante bonito, uma beleza para mim e meus olhos, mas ele pra me engolir, engolir os pobres garimpeiros, ele diz: ‘é jaçado, olha, olha aí um ponto no meio do diamante’. Ele ali “lépe” [gesto de lambida na mão] e o pobre do garimpeiro, coitado, ficou burro, ignorante. Ele pode quebrar pedra, ele não sabe qual é o valor do diamante, ele não sabe o que vale nada. Finalmente, ele só pode viver sempre na [?], coitado, sofrendo. Porque quando ele dá, os comilão "lépe" [gesto de lambida da mão], ele fica com o gesto, com a cara pra cima, levar pão da testa. É como deve ser o mundo para os pobres dos garimpeiros.

Garimpeiro 3: Quem fica rico são os donos de terra e os capangueiro. Porque os garimpeiros não têm a possibilidade de ficar rico, porque os lobos não deixam nenhuma chance de melhora para o pobre garimpeiro. O capangueiro é quem sabe o preço do diamante porque tem a tabela dada pelos escritórios, garimpeiro não tem tabela, por isso não sabe o preço de diamante.

Essa cena explicita a opinião dos garimpeiros sobre a decadência da atividade e sobre as relações de trabalho e comerciais nas quais estão envolvidos. Em um primeiro momento um dos garimpeiros se posiciona a respeito do garimpo mecanizado ${ }^{169}$, o garimpo de draga, entendido como "negócio fino, negócio de companhia", o que pelo tom da fala parece não incluir eles garimpeiros, porque logo ele emenda dizendo que o garimpo não acabou, que o que está faltando são proprietários que acreditem na atividade e reestabeleçam a relação de trabalho de fornecimento ${ }^{170}$, para os “pobres dos garimpeiros comer um pouquinho" e poderem trabalhar. O segundo garimpeiro reafirma a opinião do companheiro, o garimpo dependia dos homens que "ajudavam”, sem eles o garimpo não vai para frente. No entanto, ele aventa outra possibilidade para o garimpo não acabar, talvez “o governo poderá ajudar”. Na sequência da cena o mesmo garimpeiro, que começou ponderando que é a falta de um homem que estabeleça um armazém para os garimpeiros poderem comer que faz as Lavras estarem em decadência, passa a contar como o "patrão" rouba o garimpeiro na compra dos diamantes, que por sua vez é "ignorante" e não sabe quanto vale o diamante. Ou seja, a mesma figura que faz falta ao garimpo em decadência é a razão da pobreza dos garimpeiros. Já o terceiro garimpeiro reafirma a posição anterior e é mais explícito na definição de quem ganha na relação: “quem fica rico são os donos de terra e os capangueiros”. Segundo ele, o

168 “Jaçado: adj. que tem jaça ou mancha: diamante jaçado.” (Borba, 2004)

169 Ver trecho dessa dissertação a partir da página 116.

170 Ver item 5. Crise: novas relações e uma outra região desta dissertação. 
garimpeiro não ganha porque “os lobos” não deixam, são os capangueiros que têm as informações sobre os preços pagos pelos compradores internacionais, por isso os garimpeiros são enganados.

Em outra cena José de Castro conversa com Manuel Alves, o pai de Bugrinha (o Garimpeiro 1 da cena mencionada anteriormente). Os dois conversam sobre o preço dos diamantes, a diferença entre o preço praticado nas Lavras, para o pagamento dos garimpeiros, e o preço pago pelos mesmos diamantes no exterior:

José de Castro: Me diga uma coisa, quanto que sai um diamante de um quilate para um garimpeiro aqui?

Manuel Alves: Um diamante de um quilate aqui para um garimpeiro, é assim a base de um milhão de cruzeiro.

José: Você sabe porque quanto é vendido um diamante desse em Nova Iorque, no estrangeiro?

Manuel: Sei sim senhor...

José: Cento e cinquenta mil.

Manuel: Cento e cinquenta mil...

José: Quer dizer, alguém ganha cento e quarenta e nove.

Manuel: Veja o que é né. Agora, é esse motivo que os pobre dos garimpeiros aqui não pode arranjar nada, nem fazer nada. Porque nós nossos ignorante, não sabemos o preço do diamante. [?] no garimpo, vende aqui como se vende abóbora.

José: Eu sou da teoria que a gente tem mais é que aprender. No meu trabalho também me enganam, mas eu vou aprendendo. Quer dizer, eles vão me enganar cada vez menos, eu começo sendo enganado muito, sendo enganado muito e vou continuando, algum dia eu vou saber tanto quanto quem está mandando em mim e eu duvido que ele me engane com facilidade. Ele pode me enganar, eu acho, mas com facilidade não, porque eu vou reclamar bastante. A gente tem que espernear, eu acho.

Manuel: Pode enganar não, engana. Porque atrás do sabido tem outro mais. José: É, isso eu acho também.

Manuel: Porque até hoje muitos ainda enganam o senhor, às vezes muitos mais sabidos que o senhor. Porque eu sou sabido, o senhor é sabido, né? Mas tem outro mais sabido do que eu, mais sabido e mais sabido. E você é um moço prático, moço sabido, moço andado, mas vão ver tem outros mais do que o senhor.

José: É, mas algum dia o sabido demais se atrapalha.

Manuel: Se atrapalha?

José: É. Eu sempre escuto por aí dizer que o pessoal que trabalha no garimpo é meio preguiçoso, que não quer nada, quer mais é ficar bebendo...

Manuel: Preguiçoso? Preguiçoso? É menos verdade, eu contesto e detesto! Não há homem pra fazer o que o garimpeiro faz, eu não acredito que há. Porque se nós levar, nós garimpeiros, qualquer um dentro de uma gruna dessa, ele morre sufocado sem saber por onde sair. E a gente entra com um 
candieiro na mão e viajamos um quilômetro embaixo do chão atrás do diamante. O garimpeiro [?] não é preguiçoso.

José: Se o trabalho no garimpo é uma coisa tão cansativa, porque o senhor não arranja um trabalho nas fazendas que estão por aí?

Manuel: Na fazenda? Será possível que essa mãozinha velha, já nessa idade, 68 anos, vai pra fazenda trabalhar pra enriquecer branco? Dá não, branco já não precisa de nada, branco já é rico, como o senhor é rico e outros da sua são igual. Você é rico, sabe que você ganha na sombra, ganha sentado, toda graça que você fazer, dinheiro tá saindo. Agora quer que um pobre como eu vai pra fazenda bater foice, bater machado, bater enxada, plantar capim pra eles engordar vaca. Pra comer o leite, me dão uma xícara, né? Acha que tá bom? Não vou não, prefiro ir pro meu garimpo relar meu cascalhinho e sofrer andando.

José: Você diz que na fazenda é duro, no garimpo é duro, então não tem jeito de trabalhar...

Manuel: Garimpo é um jogo, mas nesse jogo vivemos sempre na esperança e diversos tem bamburrado e tem salvado a situação. No garimpo vive infusado, trabalhando, sofrendo e padecendo, mas esperando. Quando pensa que não, Deus manda um diamante bom, especial e por aí ele tem um dinheiro.

José: É um jogo meio doido né, porque mesmo que você ganhe algum dia, você ganha mil, sabendo que o diamante está valendo cento e cinquenta mil, cento e setenta mil lá fora. Mesmo que você ganhe você está perdendo. Não é um jogo doido esse?

Manuel: É doido, mas todo garimpeiro é doido mesmo, nós queremos viver em cima do serviço.” (Filme "Diamante Bruto”)

Nesse diálogo fica expressa a opinião de um garimpeiro tanto sobre o trabalho no garimpo, como nas fazendas. Ele tem ciência de sua posição na relação com as outras personas nos dois contextos, que o preço do diamante é subestimado abusivamente pelos compradores nas Lavras, e que nas fazendas vai “trabalhar pra enriquecer branco". Quando José de Castro observa que, se para o garimpeiro tanto o garimpo, como o serviço das fazendas são duros, não haveria trabalho para ele, Manuel Alves responde que o "garimpo é um jogo”. Na sequência, quando o ator coloca em questão a racionalidade desse jogo, "no qual mesmo que você ganhe você está perdendo", tem como resposta que "todo garimpeiro é doido mesmo”. Quer dizer, o garimpo não é simplesmente um trabalho, ele tem algo de jogo que mobiliza o garimpeiro para além dos rendimentos, e faz o garimpeiro doido. O garimpo tem um feitiço diferente, não pode ser equiparado com o fetichismo da mercadoria ${ }^{171}$, talvez o seja em processo de formação.

171 Ver a Conclusão desta dissertação. 
Mas, além disso, Manuel Alves entende também que "toda graça” que o ator José de Castro/José Wilker fizer, “dinheiro tá saindo”. É possível afirmar, talvez com certa dose de exagero, que o filme sugere indiretamente uma segunda linha de modernização para além da agropecuária. Essa sugestão não está proposta claramente no enredo do filme, ainda que o personagem de José Wilker represente um ator de televisão, mas a forma como o filme é produzido, com a participação da comunidade em todos os seus momentos, inclusive como atores, parece indicar que Lençóis e seus moradores, particularizados pelo exotismo e pela tradição, estavam fadados a serem transformados em produtos culturais. Desta maneira, o filme em si está posto como possibilidade por essa outra via de modernização, que existe baseada em uma estrutura econômica nacional transformada, basta lembrar que sua produção contou com financiamento da Embrafilmes.

Para além das cenas descritas acima, que são exemplos mais claros do interesse do diretor no debate sobre a economia local e nas contradições dos discursos sobre as relações de produção, o filme incorpora no enredo uma série de elementos do universo cultural e religioso de Lençóis, explicitando a importância desses elementos da reprodução daquela comunidade para além da reprodução estritamente econômica. Esse lugar está personificado no filme por $\mathrm{Janu}^{172}$, um homem negro que toca uma flauta e tem poderes mágicos. Em sua primeira aparição ele está sentado diante de uma cobra, ambos estão estáticos, como se se encarassem. Em outra cena Bugrinha escuta a melodia melancólica da flauta de Janu que se aproxima do local onde ela e José de Castro se encontravam, o ator não se lembra dele, e Bugrinha lhe explica que "ele conversa com os bichos, com as plantas. O povo diz que na serra ele pega diamante e joga fora, não vende”. Na sequência Janu sai andando pelo terreno pedregoso, sem deixar de tocar sua flauta, e encontra uma mulher que bate com um pedaço de madeira no lajedo, ela está sinalizando a saída de uma gruna para o marido garimpeiro que está perdido embaixo da terra. A mulher reclama que eles estão infusados, há três meses sem pegar diamante, e diz que pretende ir à casa de um curador para ver o que está atrapalhando a vida dela e do marido. Nesse momento Janu se abaixa junto à mulher, a qual para de bater com a madeira na pedra e se agacha também, e diz "oh Senhor dos Passos, siga os passos dele Senhor dos Passos”, Janu, por sua vez, evoca Zangpuguê ${ }^{173}$ e logo em seguida aponta: “olha ele lá, lá vem ele saindo, lá vem ele”. Depois que o garimpeiro saí de debaixo do chão, os

172 No romance de Afrânio Peixoto também existe um personagem apelidado de Janu, é Januário, amigo de infância de Bugrinha e Jorge de Castro. O rapaz possui deficiência intelectual, é um "inocente". A manutenção do mesmo nome para personagens distintos é estranha.

173 “Mas como diz o dono da casa, "acima de tudo paira Deus, Nosso Pai Celeste ou Zangpuguê"”” (Senna, 1998). 
dois homens estão tomando café feito pela mulher enquanto fumam, o garimpeiro diz: "pois não é que o zabumba é bom para asma, bronquite, tudo isso...” esperando a confirmação de Janu, que assente: “ótimo, ótimo...”.

Janu aparece pela última vez no filme quando Bugrinha explicava sua forma de amor a José de Castro, que parece impaciente com aquela maneira de amar que não compreende. Nesse momento se ouve o som da flauta de Janu e se dá o seguinte diálogo:

"Bugrinha: Olha o Janu de novo! Vamos conversar com ele! José de Castro: Não chama esse cara aqui não vai...

Bugrinha: Por que? Talvez você me entenda melhor, o que [?] a gente. (Bugrinha se levanta) Venha Janu, vem cá meu nêgo!” (Filme “Diamante Bruto")

Após este diálogo, Janu acaba de tocar a música em sua flauta e passa a conversar com José de Castro:

"Janu: Pronto meu [?], vou lhe falar sobre o diamante. O diamante tem os donos e tem os dias. O diamante mete choque, faz medo e faz até matar. Lhe digo com certeza que tem, o senhor não duvide não, que tem mesmo viu! O senhor duvida que aí onde o senhor está sentado passar um canal de ter o diamante aí?

José de Castro: Eu acho que eu duvido.

Janu: Pois não duvide não que tem mesmo.

José de Castro: É? Como você sabe que tem?

Janu: Sei que tem porque conheço pelo cascalho, a gente conhece onde está o diamante. É conhecido pelo cascalho, porque tem as informações. Sabe? E a gente chega, trabalha e pega mesmo.

José de Castro: Mas como é que você sabe a informação?

Janu: Informação eu sei é trabalhando o serviço, fazendo o cascalho, né? Agora, informação é as pedras que tem que é a informação do diamante. Tem a ferragem, tem uma pedra por nome Cabo Roque, tem o pingo d'água, tem o cristal, tem o feijão e... tem a ferragem. A informação do diamante é isso. Tanto faz o diamante como o carbonato.

José de Castro: E porque as pessoas não acham, tendo muito sinal?

Janu: Acha! Depende da sorte, é porque tem os donos. Acontece que o senhor vem, trabalha aqui e não pega o diamante, eu venho, trabalho e pego. O senhor deixa o diamante feito pra mim.

José de Castro: Quer dizer que além do sinal só quem pode achar é quem for o dono?

Janu: É, quem é o dono. O senhor não sendo o dono, o senhor põe ele na mão e ele torna a ir embora outra vez. Agora, o dono sou eu, chego e pego. José de Castro: Então não precisa do sinal?!

Janu: Precisa sim, porque não tendo o sinal não tem informação.

José de Castro: Mas não tem o dono? 
Janu: Tem o dono! Pois é! O dono é quem tem que apanhar ele.

José de Castro: E quem que dá?

Janu: Quem que dá o diamante?

José de Castro: O dono.

Janu: Quem que dá o dono? Quem que dá o dono é o esforço que a gente faz, de trabalhar e bater em cima dele. Quer dizer, Deus é primeiro quem dá, né? Acontece que a pessoa faz o esforço e vai bater em cima. Tanto que o garimpeiro que não tem coragem não trabalha diamante, não trabalha $o$ garimpo para pegar o diamante. Você se atrapalha e larga mesmo. E tem com toda a certeza.

José de Castro: Mas ele fica com medo do quê?

Janu: Fica com medo da livusia que ele faz pra pessoa. Livusia é tanta que se o sujeito não tiver coragem ele larga.

José de Castro: E como é que é?

Janu: Como é que é? Como é que é que mete medo mesmo. Agora, a pessoa corajosa quando vê um negócio desse diz logo "é um diamante que tem aqui”, e trabalha e pega ele mesmo. A visagem que ele faz é aparecer pra gente meia noite, representa mó de uma pessoa numa estrada, em cima da serra o senhor vê luz, a mó de farol de carro... Ali é o diamante. Quando ele está avexado pra sair, pra vir pegar ele, ele faz tudo isso. Faz essa livusia toda na serra. Tem garimpeiro que corre, larga [?] de cascalho, com medo. Uns diz que é feitiço que gente tá fazendo pra eles, outros diz que é gente morta que veio meter medo, assombrar... mas não é. É o encanto do diamante que é forte e faz tudo isso. E o senhor pode acreditar que tem mesmo. Pode procurar qualquer um garimpeiro.” (Filme “Diamante Bruto”)

Na sequência desse diálogo são sobrepostos pequenos relatos de uma série de garimpeiros sobre histórias pessoais de livusias de diamante. Em seguida reaparece Janu, que fala de uma visagem de diamante que vem em forma de mulher, com um longo vestido e segurando um candieiro de gruna na mão, se a mulher é branca trata-se de um diamante, se negra de um carbonato. Nesse momento a câmera fecha no rosto de José de Castro, ele fica quieto e pensativo, em dois momentos anteriores do filme esta visagem havia aparecido para ele.

Assim, o filme apresenta essas explicações, tidas como fantasiosas por um olhar externo àquela comunidade, na maneira como operavam a sociabilidade representada. Faz isso sem estabelecer uma hierarquia entre as ditas esferas da economia e da cultura, ou propor uma conciliação entre elas - talvez apenas como produto-filme. O próprio desfecho trágico do romance entre Bugrinha e José de Castro, preservado do livro na adaptação fílmica, pode ser interpretado como resultante do choque entre os dois mundos que eles representam. Desse choque sai mortalmente ferida a personagem que simboliza o feminino, o não-branco e a tradição, em oposição ao personagem que simboliza o masculino, o branco e a razão, o qual 
acaba o filme vivo e constrangido pelo desdobramento não desejado que suas ações produziram, sujando suas mãos e sua camisa branquíssima com o sangue da outra. Não há síntese positiva, tampouco um lugar social preservado da contradição, a síntese é a morte e o constrangimento. A última cena do filme, após a revelação do assassinato de Bugrinha à José de Castro, é a imagem do caminhar lento dos devotos de Nosso Senhor dos Passos, que carregam a imagem do padroeiro dos garimpeiros, aos poucos o canto de devoção é encoberto pela melancólica melodia que Janu tocava em sua flauta.

Essa é uma interpretação possível do filme produzido por Orlando Senna. Certamente não é aquela que está majoritariamente presente no documentário Brilhante, realizado por Conceição Senna em 2004. O documentário é construído a partir de fragmentos de uma série de entrevistas realizadas com moradores de Lençóis, algumas pessoas que possuem relação com a cidade e a equipe que participou de Diamante Bruto. Mescla a história da cidade com a história da produção do filme e da repercussão que ele teve nas transformações ocorridas a partir da implementação do turismo. Além disso, trata das contradições resultantes do desenvolvimento do turismo, sobretudo da criminalização do garimpo. Uma das perguntas centrais que organiza o documentário é se um filme, no caso o Diamante Bruto, pode mudar a realidade de uma cidade, Lençóis. Quer dizer, aquela segunda via de modernização “escondida” em Diamante Bruto é o tema explícito do documentário ${ }^{174}$. Uma das opiniões expressas em Brilhante é que o filme foi o motivador das transformações econômicas que o sucederam, o que o próprio diretor nega, para ele "os filmes não produzem esse tipo de resultado" ${ }^{\text {175 }}$. Certamente as transformações que se deram em Lençóis advém de um processo

174 Outro material audiovisual que trata do tema a partir do caso de Lençóis é o curta-metragem "Jardim de Plástico" de Delmar Alves de Araújo.

175 No depoimento de sua biografia essa apreensão aparece mais nuançada: "A relação dessa comunidade com esse filme vai além dos aspectos psicoculturais, já que ela acredita que Diamante Bruto foi a ignição para uma nova economia, a do turismo, que começou a se desenvolver no início dos anos 1980 e deu nova vida a Lençóis. O documentário Brilhante, realizado pela Conceição e lançado em 2006, conta essa história e os seus surpreendentes desdobramentos, para o bem e para o mal. Um filme pode mudar uma pessoa? Pode. Um filme pode mudar uma comunidade? Não é normal que isso aconteça, mas pode, a depender das circunstâncias. E devendo levar em conta que qualquer mudança provoca consequências inesperadas e às vezes indesejadas, além das consequências esperadas. Essa conexão do cinema com Lençóis se desenvolveu através de outras pessoas, de jovens cineastas que acamparam por lá nos anos 1980, organizaram um cineclube, incensaram a mitologia local de Diamante Bruto, fizeram filmes - Moisés Augusto, Jorge Felippi, José Araripe, Póla Ribeiro que fez A Lenda do Pai Inácio, e outros. Jovens nativos se envolveram com o cinema e hoje são profissionais, como a produtora Solange Lima. Brilhante trata exatamente das várias facetas dessa relação, tanto que foi anunciado pela distribuidora como um caso de amor entre uma cidade e um filme." (Leal, 2008:248/249) 
do qual o próprio filme também é resultante ${ }^{176}$, mas Orlando Senna e outros entrevistados chamam a atenção para a forma como a produção do filme e o próprio produto agiram na “recuperação da autoestima” da comunidade, que pôde se entender sobre outra ótica, para além da decadência do garimpo, ela tinha uma cultura a ser valorizada.

De certo, essa valorização está entendida de uma perspectiva simbólica e cultural, porque do ponto de vista econômico somente se sustenta sobre um entendimento superficial do que seria um processo de valorização. No entanto, é importante notar que estas esferas somente se separam como abstração analítica, a comunidade se transformou como totalidade. O documentário expressa isso no caso particular do garimpo, que depois da constituição do PNCD e do crescimento do turismo passou a ser entendido como atividade predatória e foi criminalizado. Ou seja, aquele processo que teve início internamente como reconhecimento dos valores culturais locais se desdobrou como impedimento daquela forma de reprodução social, senão como produto cultural. Nesse sentido é exemplar o comentário de José Wilker sobre o processo:

\footnotetext{
"É impossível você impedir... bloquear o futuro, impedir que a cidades, que as pessoas, evoluam. Mas eu gostaria que houvesse uma mágica que fizesse que as cidades evoluíssem e paralela a essa evolução se preservasse o que a gente tem de melhor. Tudo aquilo que faz da gente o povo que a gente é.” (Documentário Brilhante)
}

A mágica desejada por José Wilker não ocorreu, a cidade se transformou como totalidade ${ }^{177}$. Porém, através da fotografia a paisagem pôde ser outras vezes mais entendida como mágica, ainda que de maneira completamente distinta. O livro Paisagens Mágicas, publicado em 1989 pelo fotógrafo paulistano Zé de Boni, é um exemplo disso. Entre as belas fotografias P\&B do livro uma imagem (Figura 24) se destaca por ser das pouquíssimas em que está registrada uma pessoa.

176 Para mais informações ver item 14. A descoberta da Chapada Diamantina e sua incorporação ao Estado nacional desta dissertação.

177 Em outro trecho do documentário o ator diz que a Lençóis de hoje (começo dos anos 2000) é uma metrópole se comparada com a cidade que conhecerá em meados dos anos 1970: "Pra mim foi uma surpresa fantástica, eu fiquei muito tempo sem voltar a Lençóis, eu ouvia falar de Lençóis. E as pessoas diziam: "tem que ir lá, tem que ir lá, tem que ir lá.", muita gente que nem sabia que eu teria um dia ido lá, "você precisa conhecer Lençóis, precisa visitar aquele lugar". E eu voltei para Lençóis uns três anos atrás e me deparei com..., comparado com o que Lençóis era quando a gente filmou, uma metrópole. Cara, que impressionante, como é que isso aconteceu?” (Documentário "Brilhante”). 


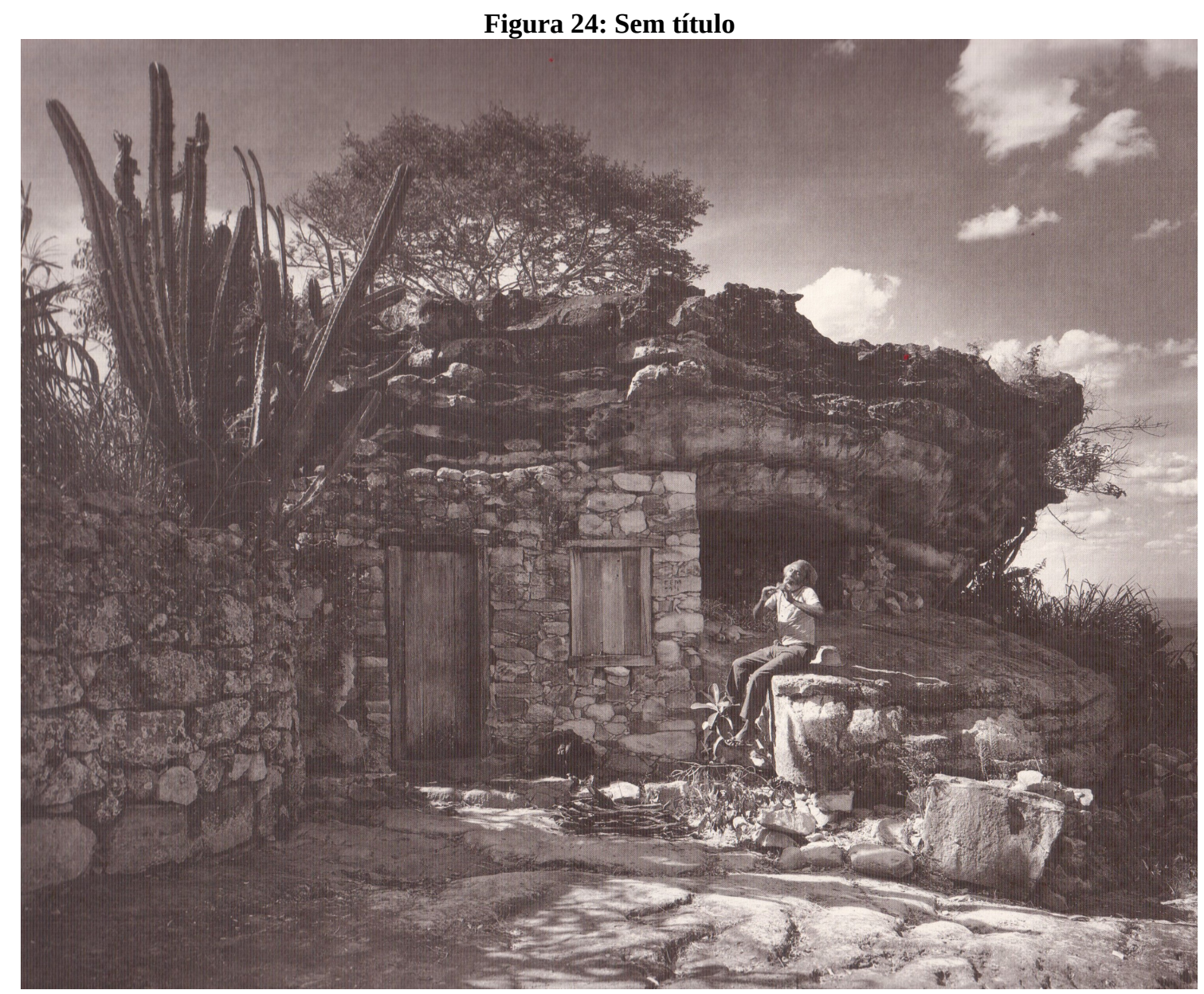

Fonte: Boni (1989)

A legenda que a acompanha é a seguinte:

"Um duende? A loca sob a pedra que parece um cogumelo é sua casa. O velho Joaquim passa suas tardes ali tirando os sons mais exóticos com uma flauta doce ou de bambu. Para o visitante que chega ele improvisa versos com uma rapidez que nosso raciocínio tem dificuldade em acompanhar. Ou então pega a sanfona para alegrar o encontro lembrando o que ele fazia quando percorria a Chapada, animando festas e forrós. Igatu já teve mais de trinta mil habitantes e hoje é quase só ruína. No fim do que restou da vila, solitário, Joaquim Riachão, "o cantador do sertão", sobrevive, como que recusando a aceitar que os dias de glória do garimpo de diamante já passaram.” (Boni, 1989)

A escolha completamente fora de contexto da figura mítica europeia do duende é reforçada pela comparação da toca de Joaquim com um cogumelo, mas também ensejada pelo texto de Walfrido de Moraes presente no livro, que retoma a história da cidade perdida na Serra do Sincorá, aquela que teria origem escandinava e pré-colonial. Tal cidade foi objeto da pesquisa de campo do Cônego Benigno José de Carvalho e Cunha entre as décadas de 1830 e 1840, vinculada ao Instituto Histórico e Geográfico Brasileiro e em parte financiada pelo 
orçamento da Província. Ainda que ridicularizada mais tarde, naquele momento a empreitada do Cônego ${ }^{178}$ tinha sentido como

\begin{abstract}
"Arqueologia Nobiliárquica. Seu papel foi o de elaborar discursos históricos de origem onde as elites e as classes dominantes do país - os nobres pudessem se reconhecer. O projeto da arqueologia nobiliárquica de postular um lugar "nobre” para as sociedades indígenas na identidade da Nação, não se concretizou. Não foi possível fundar "empiricamente” este discurso. Ele só foi possível na ficção, através das metáforas e eufemismos do Romantismo. O espelho científico da "cultura branca", destarte, espatifouse.” (Lúcio Menezes Ferreira, 1999: item 3, apud Toledo, 2008)
\end{abstract}

Se aquela era a intenção do Cônego, Walfrido de Moraes retoma a história da cidade perdida, um século e meio depois das pesquisas do religioso, não por nenhuma pretensão científica, e sim porque ela lhe serve para construir o universo mágico que o livro de fotografias quer sugerir. Ou seja, tanto quanto as imagens do fotógrafo que vê duendes, o uso da história está posta justamente no registro do ficcional. O que do ponto de vista que não distingue autonomia e autonomização pode ser visto como algo indiferente ${ }^{179}$. Do ponto de vista dessa dissertação, pelo contrário, parece ser essa a verdadeira mágica que se opera na frente de modernização encabeçada pela indústria cultural: os discursos que recalcam as contradições do processo social tornam-se eles mesmos mercadorias para a economia também ficcionalizada, ou seja, o capital se reproduzindo como capital fictício ${ }^{180}$.

178 Para mais detalhes ver o item "As lentes do IHGB e o relatório do presidente da Província" da tese de Carlos de Almeida Toledo (2008).

179 O notável como o escritor que se notabilizou como cronista das glórias da "civilização do diamante" adere ao discurso ambientalista de forma conciliatória. A narrativa sobre a cidade perdida se encerra da seguinte maneira: "De nossa parte, não nos consideramos com o direito de perturbar essa ilusão, esse sonho ou esse delírio. Ao contrário, cumpre-nos alimentá-lo com a certeza de que, em realidade, não existe apenas uma cidade encantada ou perdida, envolta pelas brumas e por entre os azuis daquela paisagem mágica, mas certamente um paraíso, com todas as suas deliciosas bem-aventuranças!...” (Boni, 1989).

180 Ver item 14. A descoberta da Chapada Diamantina e sua incorporação ao Estado nacional desta dissertação. 


\title{
CONCLUSÃO: PAISAGEM, FOTOGRAFIA
}

E FETICHISMO

Partir do diálogo crítico com um artigo de Pierre Monbeig, publicado em 1954 no “Boletim Carioca de geografia” e intitulado "Papel e Valor do Ensino da Geografia e de sua Pesquisa” pode ser um bom ensejo para o que se quer reforçar nesta conclusão. O texto endereçado aos geógrafos engajados no magistério secundário e na pesquisa de base para a planificação estatal, ainda que não diga respeito diretamente ao temário aqui desenvolvido, aborda de forma concisa dois pontos que animaram esta pesquisa.

O primeiro deles, e o mais simples, diz respeito a uma aproximação que o autor faz entre o conceito de paisagem para a pesquisa em geografia e a prática da fotografia. Afirma no artigo que o complexo geográfico ${ }^{181}$

\begin{abstract}
“[...] se exprime antes de tudo na paisagem, a qual, formada una e indissoluvelmente pelos elementos naturais e pelos trabalhos dos homens, é a representação concreta do complexo geográfico. Por esta razão, o estudo da paisagem constitui a essência da pesquisa geográfica. Mas é absolutamente indispensável que o geógrafo não se limite à análise do cenário, à apreensão do concreto. A paisagem não exterioriza todos os elementos constituintes do complexo. Nem sempre nela se encontrarão expressos com clareza os modos de pensar, as estruturas financeiras que são, entretanto, parcelas apreciáveis do complexo geográfico. Outro perigo - a limitação do campo de estudo geográfico à paisagem arrisca a levar o pesquisador à única estrada da descrição. Ele olha, observa minuciosamente e com perfeito espírito científico, mas tende a esquecer o essencial: a explicação. Satisfaz-se em ser excelente máquina fotográfica e, nesse jogo atraente, prende-se menos à análise dos processos do que à sua descrição. Passa ao lado dos problemas pois, submerso pela massa dos fatos observados, já não pode distingui-los com clareza. A paisagem é um ponto de partida, mas não um fim. Resulta do complexo geográfico, sem confundir-se com ele.” (Monbeig, 1956:12)
\end{abstract}

181 Monbeig se antepõem a prática do ensino de geografia como simples exercício mnemônico dos fatos geográficos, por isso define o objeto da disciplina como complexo geográfico: "A pesquisa geográfica trata dos complexos de fatos e são esses complexos que, por sua localização no globo, são verdadeiros “fatos” geográficos. Cabe ao geógrafo explicar esta localização, procurar-lhe as consequências, examinando as relações, ações e interações que unem uns aos outros os elementos constitutivos do complexo geográfico. Complexo geográfico, sim, porque se localiza e porque implica em ações recíprocas mutáveis do meio natural e do meio humano. A variedade dos componentes do complexo geográfico é tanto maior quanto mais elevado é o grau de civilização técnica atingido pelo grupo humano, instalado há séculos, senão milênios, e muito numeroso.” (Monbeig, 1956:10) 
Quer dizer, tanto a paisagem como a fotografia ocupam a mesma posição: são o resultado de um processo social e o ponto de partida da investigação. Mas apenas o ponto de partida, por que a pesquisa reduzida à mobilização exclusiva da paisagem está fadada a permanecer na esfera da descrição, não evoluindo para o campo da explicação. Por ora ficam guardadas essas ideias, elas interessam, mas devem ser submetidas a uma elaboração teórica mais rigorosa.

O segundo ponto que vale fazer emergir do texto de Monbeig é sua apreciação acerca da relação da qual é fruto o complexo geográfico, portanto a relação que interessaria ao geógrafo estudar. Do ponto de vista de Monbeig o processo permanente de constituição do complexo geográfico poderia ser definido abstratamente como a transformação dos elementos naturais pelos trabalhos dos homens, ou seja, a conjunção dos sucessivos e concomitantes resultados da relação entre sociedade e natureza. É fundamental que se diga que não se trata de uma concepção datada ou ultrapassada, a relação sujeito-objeto (ou homem-natureza) permanece como fundamento científico praticamente inconteste da geografia. Sobre ele variam matizes de pensamento que se diferenciam quanto ao polo de determinação da relação, ou então que se atentam às formas socialmente constituídas de distribuição dos produtos dessa relação entendida como fundamental, ainda assim ela permanece intocada, como fundamento ontológico do humano e do próprio espaço geográfico.

Sobre a dinamicidade dessa relação Monbeig afirma "que nada é mais mutável que o comportamento das sociedades humanas diante do meio natural” (Monbeig, 1956:13) e na sequência complementa que

\footnotetext{
"Vivemos mesmo esta grande experiência que é o domínio cada dia mais completo do meio por nossa ciência, por nossos técnicos, por nossos meios de produção. Esta revolução nas relações das sociedades humanas e dos meios naturais é muito recente, e diante de nossos olhos, adquire proporções inéditas." (Monbeig, 1956:13)
}

Parece importante colocar em destaque a natureza dessa recente "revolução nas relações” entre as sociedades humanas e os meios naturais. Salvo engano, a revolução das relações de que fala Monbeig é compreendida por ele como uma transformação que diz respeito à técnica. A técnica ${ }^{182}$ evolui e revoluciona a relação, ou a técnica é revolucionada

182 A maneira como isso se volta para a forma de conhecer o real salta aos olhos quando o autor compara o complexo geográfico a um motor desconhecido: "É necessário desmontar as peças que as peças que compõem o motor, tendo, porém o cuidado de identificar cada elemento, de ver como se ajusta o outro, de desconhecer-lhe a função e avaliar-lhe a importância do conjunto. Este trabalho de desmontagem do motor é a explicação do complexo geográfico. 
(por exemplo com o advento dos combustíveis fósseis, da fotografia ou da bomba atômica) e a relação sujeito-objeto consequentemente.

A revolução das relações das sociedades humanas e dos meios naturais inclusive operaram uma transformação interna dentro da própria ciência geográfica segundo Monbeig. Para ele

\begin{abstract}
"Se, desde então, todos os conhecimentos científicos e suas aplicações técnicas progrediam bem além do que seria de esperar, nossa inquietação cresceu terrivelmente. Guerras, revoluções, fome, desemprego, vida em campos de concentração aniquilaram toda tranquilidade, são como as Erynnias, a compensação do "progresso". Se já não duvidamos do poder sobre a natureza que nos confere a ciência, o homem torna-se o centro de nossa preocupação. Por um paradoxo apenas aparente, quanto mais se desenvolvem ciências e técnicas, mais duvidamos do futuro de nossas sociedades. Os geógrafos são arrastados para o movimento do pensamento da época atual [...]. Automaticamente, o homem ocupa o centro das pesquisas. Em lugar de partir das condições ambientais para ir até os grupos humanos, a geografia tende cada vez mais a tomar estes últimos como ponto de partida.” (Monbeig, 1956:14)
\end{abstract}

Como o progresso técnico paira no fundo em branco de uma relação trans-histórica entre homem e natureza, sem questionamento sobre sua forma socio-histórica de mediação, diante da contradição entre desenvolvimento técnico e escalada dos "problemas humanos”, o argumento do autor se desloca do árido rigor científico para a região nebulosa da mitologia. Não há espaço para contradição interna no pensamento positivo. Esse limite é uma vez mais recoberto pelo dualismo, o “progresso” é “compensado” por uma externalidade difusa e indefinida. O que é contradição interna da modernização acaba entendida como "paradoxo apenas aparente". Moishe Postone (2014) fornece um gancho fundamental para o desenvolvimento deste debate quando salienta em sua crítica do marxismo tradicional que

“[...] Marx altera os termos do problema epistemológico. Ele desvia a atenção do problema do conhecimento do sujeito individual (ou supraindividual) cognoscente e sua relação com um mundo exterior (ou externalizado) para as formas de relações sociais, vistas como determinações de subjetividade bem como de objetividade sociais. O problema do

Depois de identificadas, todas as peças, numeradas, classificadas, nosso mecânico se encontra melhor preparado para conhecer de que modo a união delas constitui um motor e como funciona este. Ele compreende porque pode, segundo a análise, aprender as relações dos diferentes elementos entre si e graças a esse primeiro trabalho, descobrir como cada um contribui para a boa marcha do conjunto.” (Monbeig, 1956:15/16) 
conhecimento torna-se agora uma questão da relação entre formas de mediação social e formas de pensamento.” (Postone, 2014:98, grifos meus)

Por isso Marx se debruça na compreensão da forma lógica da mercadoria, a forma de mediação socio-histórica elementar da sociedade capitalista, ela diz respeito também a nossa forma de pensar. Nesse sentido, à mediação social da mercadoria corresponde a forma do pensamento que naturaliza a relação como sendo relação sujeito-objeto, ou seja, a forma de pensamento da relação sujeito-objeto não é a expressão de um princípio trans-histórico, nem tampouco uma simples irrealidade, ela corresponde à abstração realmente existente da mediação social da mercadoria. Quer dizer

“A reflexão sobre as formas de vida humana, e, portanto também sua análise científica, segue sobretudo um caminho oposto ao desenvolvimento real. Começa post festum e, por isso, com os resultados definitivos do processo de desenvolvimento. As formas que certificam os produtos do trabalho como mercadorias e, portanto, são pressupostos da circulação de mercadorias, já possuem a estabilidade de formas naturais da vida social, antes que os homens procurem dar-se conta não sobre o caráter histórico desses formas, que eles antes já consideram imutáveis, mas sobre seu conteúdo.” (Marx, 1996:201)

Neste sentido, é a incompreensão do caráter histórico da mercadoria como forma elementar da mediação social do capitalismo que Marx crítica ao ironizar as robinsonadas da economia política:

"Como a Economia Política gosta de robinsonadas, aparece primeiro Robinson em sua ilha. Moderado por origem, ele precisa satisfazer, entretanto, a várias necessidades e, por isso, tem de executar trabalhos úteis de diferentes espécies, fazer ferramentas, fabricar móveis, domesticar lhamas, pescar, caçar etc. Não falamos aqui das orações e coisas semelhantes, porque nosso Robinson se compraz nelas e considera tais atividades recreio. Apesar da diversidade de suas funções produtivas ele sabe que elas são apenas diferentes formas da atividade do mesmo Robinson, portanto, somente modos diferentes de trabalho humano. A própria necessidade o obriga a distribuir seu tempo minuciosamente entre suas diferentes funções. Se uma ocupa mais, outra menos espaço na sua atividade total depende da maior ou menor dificuldade que se tem de vencer para conseguir o efeito útil pretendido. A experiência lhe ensina isso, e nosso Robinson, que salvou do naufrágio o relógio, o livro razão, tinta e caneta, começa, como bom inglês, logo a escriturar a si mesmo. Seu inventário contém uma relação dos objetos de uso que ele possui, das diversas operações requeridas para sua produção e, finalmente, do tempo de trabalho 
que em média lhe custam determinadas quantidades desses diferentes produtos. Todas as relações entre Robinson e as coisas que formam sua riqueza, por ele mesmo criada, são aqui tão simples e transparentes [...]. E todavia já contém todas as características essenciais do valor.” (Marx, 1996:202)

O artifício de tomar o presente para desvelar o passado à compreensão pode tornar-se o velar da incompreensão de ambos. O “método da economia política” é justamente essa projeção anacrônica das categorias sociais próprias de uma formação social (sociedade capitalista) para outras como categorias de um humano a-histórico (“humano a-histórico” é uma redundância, a ideia de humano guarda em si uma essencialidade trans-histórica). A categoria trabalho é desta maneira empregada pela economia política (e não somente por ela, como se viu logo acima) como mediação indeterminada da relação entre homem e natureza, no entanto a indiferença quanto ao "trabalho", ou o "trabalho em geral”, ou ainda o "trabalho puro e simples” como atividade humana somente passa a se formar historicamente com a modernização. Daí também a ironia de Marx com a figura de Robinson Crusoe, que mesmo isolado produz os elementos de suas necessidades sob a métrica do tempo abstrato, como coisas de valor, embora o valor seja uma determinação mercantil, uma forma de relação social.

Ora, se o "trabalho" como "forma de mediação social” entre homem e natureza, e entre os homens em sociedade, corresponde exclusivamente à realidade da formação social capitalista, a forma de conhecer que se pensa como relação sujeito-objeto (considerados aí os diversos sistemas filosóficos) constitui a correspondente "forma de pensamento" daquela formação social. Ou seja, tanto quanto o “trabalho” o indivíduo ${ }^{183}$ cognoscente cartesiano também se forma na modernidade como realidade sócio-histórica.

A caracterização da forma da mediação social através da mercadoria decupada por Marx no primeiro capítulo de “O Capital” revelará ainda outros elementos sobre o indivíduo moderno (outra redundância talvez desnecessária). Marx explicita a natureza dupla na mercadoria, como “valor de uso" e “valor”, e expõem o desdobramento lógico da “forma

183 Do que vale observar que "paisagem [...] é ligada a um observador individual, que procura mediar entre ele e a natureza e desaparece sem esta função mediadora. Agora resta-nos a tarefa de melhor e de modo mais preciso, determinar este observador, este indivíduo, este sujeito da paisagem, e determiná-lo historicamente. O termo "indivíduo" já diz como este é constitutivo para a paisagem. A palavra latina "individuum" é composta de 'in' que significa ao mesmo tempo "um" e 'sem ou a' $e$ "dividuus" que significa "divisível” e ou "dividido" $e$ que, por sua vez, é derivado de "dividire", verbo derivado de "videre" o que significa "ver". "Indivíduo", portanto significa: "um dividido pelo ver" e "um que divide pelo ver"." (Eberle, 1980) 
valor" até a "forma dinheiro". No último item do capítulo, "O caráter fetichista da mercadoria e seu segredo", anuncia que "analisando-a [a mercadoria], vê-se que ela é uma coisa muito complicada, cheia de sutileza metafísica e manhas teológicas”. Isso decorre justamente de sua dupla natureza:

"O misterioso da forma mercadoria consiste, portanto, simplesmente no fato de que ela reflete aos homens as características sociais do seu próprio trabalho como características objetivas dos próprios produtos de trabalho, como propriedades naturais sociais dessas coisas e, por isso, também reflete a relação social dos produtores com o trabalho total como uma relação social existente fora deles, entre objetos.” (Marx, 1996:198)

Na sociedade onde a mercadoria é a forma da mediação, o dinheiro (que é a forma realmente existente mais desenvolvida da “forma equivalente”) é o "que objetivamente vela, em vez de revelar, o caráter social dos trabalhos privados e, portanto, as relações sociais entre os produtores privados” (Marx, 1996:201). Portanto o caráter fetichista que Marx atribui à mercadoria decorre justamente do trabalho como forma da mediação social. Sociabilizados que somos pela mediação da mercadoria e pelo trabalho (a substância do valor) temos como indivíduos inescapavelmente uma apreensão fetichizada da realidade social na qual estamos inseridos.

A esta altura o leitor atento possivelmente se lembre do primeiro excerto de Monbeig aqui transcrito, nele o geógrafo afirma que “a paisagem não exterioriza todos os elementos constituintes do complexo. Nem sempre nela se encontrarão expressos com clareza os modos de pensar, as estruturas financeiras que são, entretanto, parcelas apreciáveis do complexo geográfico” (Monbeig, 1956:12, grifos meus). Nesse ponto é preciso retomar o ponto deixado em aberto no início. Uma possível aproximação deste trecho do texto de Monbeig com a análise de Marx sobre a mercadoria será necessariamente superficial. O fetichismo da mercadoria não se confunde com “falta de clareza”, não se está apenas diante de um resultado de interações sociais que não revelam por completo todas as determinações do processo. Permanecer no campo da análise da mercadoria como coisa física, mais do que correr o risco de ser apenas descritivo, é estar enfeitiçado por um fantasma que nada tem a dizer sobre as reais determinações desse processo:

“A impressão luminosa de uma coisa sobre o nervo ótico não se apresenta como uma excitação subjetiva do próprio nervo, mas como forma objetiva de uma coisa fora do olho. Mas, no ato de ver, a luz se projeta realmente a partir de uma coisa, objeto externo, para outra, o olho. É uma relação física 
entre coisas físicas. Porém, a forma mercadoria e a relação de valor dos produtos de trabalho, na qual ele se representa, não têm que ver absolutamente nada com sua natureza física e com as relações materiais que daí se originam. Não é mais nada que determinada relação social entre os próprios homens que para eles aqui assume a forma fantasmagórica de uma relação entre coisas.” (Marx, 1996:198)

Mais do que não serem claras quanto às suas determinações sociais, as mercadorias as escondem completamente, o valor como forma da riqueza social capitalista em nada está presente no corpo físico das mercadorias, ainda que as formas concretas do mundo sob a mediação da mercadoria e do trabalho estejam irremediavelmente vinculadas à valorização do valor (ainda que fictícia) como processo social.

Portanto, as imagens estudadas nesta pesquisa não são entendidas como representações suficientes do tempo e espaço que registram. Elas estão compreendidas como representações que escondem tanto as determinações sociais daquilo que buscam registrar, como de suas próprias condições de imagens produzidas no mundo das mercadorias. Como coisas físicas, imagens que congelam as formas fenomênicas de um espaço num tempo passado, elas não passam de uma redundância do fetichismo. Por isso a intenção por detrás da coleta e análise das fotografias foi a coleta dos discursos sobre elas e das relações que as cercam como produtos sociais. A intenção foi que as contradições entre esses discursos, e deles com as próprias imagens, pudessem emergir da superfície silente das fotografias indicando caminhos para a interpretação do processo social nublado por elas. Sunsan Sontag escreveu que

\footnotetext{
"A fotografia dá a entender que conhecemos o mundo se o aceitamos tal como a câmera o registra. Mas isso é o contrário de compreender, que parte de não aceitar o mundo tal como ele aparenta ser. Toda possibilidade de compreensão está enraizada na capacidade de dizer não. Estritamente falando, nunca se compreende nada a partir de uma foto. [...] a representação da realidade pela câmera deve sempre ocultar mais do que revela. Em contraste com a relação amorosa, que se baseia na aparência, a compreensão se baseia no funcionamento. E o funcionamento se dá no tempo e deve ser explicado no tempo. Só o que narra pode levar-nos a compreender." (Sontag, 2004:33/34)
}

A narrativa dá a chance de entender a história para além do desdobramento (ou desenvolvimento) temporal da humanidade. Em certo sentido, a forma como Marx se dispõem a ler a história é de olhar para outras formações sociais dizendo “não”. Não é possível entendê-las com as lentes do presente, tampouco vestir as lentes do passado, estas já não 
existem mais. A narrativa não nos revela o que fomos em sí, mas pode dar indícios do que somos como formação sócio-histórica. Tendo em conta a contradição em processo (Scholz, 2016) que caracteriza a história interna da modernização e parafraseando Sontag, essa pesquisa propôs que foram as narrativas do que não funciona, ou melhor, do que funciona se destruindo, o que suscitou alguma compreensão materializada na dissertação aqui encerrada. 


\section{REFERÊNCIAS}

\section{Bibliografia:}

Adorno, Theodor W. Indústria cultural e sociedade. São Paulo: Paz e Terra, 2009. Sobre sujeito e objeto. http://antivalor.vilabol.uol.com.br/ (acesso em 10/03/2012)

Aguiar, Durval Vieira de. Descrições práticas da Província da Bahia. Rio de Janeiro: Cátedra, 1979.

Amado, Jorge. Chapada Diamantina: Diamantina Highlands. Rio de Janeiro: A\&CMAssessoria de Comunicação e Marketing, 1988.

Alcântara, Araquém. Chapada Diamantina. São Paulo: TERRABRASIL, 2007.

Alfredo, Anselmo. Formação nacional negativa e a condição energética na periferia brasileira. In: II Simpósio Internacional: Eletrificação e Modernização Social. A expansão da energia elétrica para a periferia do capitalismo. São Paulo: Universidade de São Paulo e Universidad de Barcelona/Geocrítica, 2015.

. Cítica à economia política do desenvolvimento e do espaço. São Paulo: Annablume, 2013.

Alves, Aristides. Chapada Diamantina. (fotografias) Salvador: Seplantec Seagri, 1997.

. Garimpo de Imagens. (fotografias) Salvador: Asa Foto Ltda, 2008.

- A fotografia na Bahia (1839-2006). Salvador: Secretaria da Cultura e Turismo; Funcultura; Asa Foto, 2006.

Andrade, Oswald. Manifesto Antropofágico. Rio de Janeiro: Revista Periferia v. III, n. I, 2011.

Assis, Machado. O espelho. In: Obra completa. Rio de Janeiro: Nova Aguilar, v. II, 1994.

Babinski, Henri. Rapport sur une visite aux Lavras Diamantinas. Paris: IMPRIMERIE ET LIBRAIRIE CENTRALES DES CHEMINS DE FER, 1897.

Bahiatursa. Plano de Manejo: Área de Proteção Ambiental Marimbus - Iraquara. 1998.

Bannagi, Gabriel. Agitação e Placidez, os muitos movimentos do Jarê contemporâneo, Áltera - Revista de Antropologia, João Pessoa, v. 2, n. 3, p. 97-122, jul./dez. 2016.

Benjamin, Walter. Magia e técnica, arte e política: ensaios sobre literatura e história da cultura. São Paulo: Brasiliense, 1994.

Besse, Jean-Marc. Ver a Terra: seis ensaios sobre a paisagem e a geografia. São Paulo: Perspectiva, 2006. 
Borba, Francisco da Silva (org.). Dicionário UNESP do português contemporâneo. São Paulo: UNESP, 2004.

Brito, Francisco Emanuel Matos. Os ecos contraditórios do turismo na Chapada Diamantina. Salvador: UFBA, 2006.

Boni, José de; Moraes, Walfrido. Paisagens mágicas: fotografias da Chapada Diamantina. São Paulo: Empresa das Artes, 1989.

Centro Cultural Chic Chic. Inventário Patrimonial de Igatu. Andaraí: Centro Cultural Chic Chic, 2009.

Chagas, Américo. O chefe Horácio de Matos. Salvador: EGBA, 1996. . Montalvão. Salvador: Secretaria da Cultura e Turismo, EGBA, 1998.

Challoner, Jack (ed.). 1001 invenções que mudaram o mundo. Rio de Janeiro: Sextante, 2010.

Cruz, Natalia dos Reis. O integralismo e a questão racial. A intolerância como princípio. Tese de doutorado História/UFF, Niterói, 2004.

Cruz, Rita de Cássia. Políticas de turismo e (re)ordenamento de territórios no litoral do Nordeste do Brasil. Tese de doutorado FFLCH/USP, 1999.

Dedord, Guy. A sociedade do espetáculo. Rio de Janeiro: Contraponto, 1997.

Derby, Orville. The Serra do Espinhaço, Brazil, Journal of Geology vol. XIV, número 5, 1906.

- The Geology of the Diamond and Carbonado Washings of Bahia, Brazil, Annual Report of the Smithsonian Institution, 1906, Washington DC: Government Printing Office, 1907.

Diegues, Antonio Carlos. O Mito Moderno da Natureza Intocada. São Paulo: Hucitec, 2001.

Eberle, Matthias. Das Individuum als Konstitutiver Faktor der Landschaft. In: Individuum und Landschaft. Giessen, Anabas-Verlag, 1980. (Mimeo da livre tradução do Prof. Dr. Augustin Wernet juntamente com Evanice Hudson para o seminário “A expedição de Langsdorff ao Brasil”)

Ermakoff, George. O negro na fotografia brasileira do século XIX. Rio de Janeiro: George Ermakoff Casa Editorial, 2004

Falcón, Gustavo Aryocara de O. \& Dultra, Célia Maria M. Diamante. (In) A inserção da Bahia na evolução nacional $1^{\circ}$ etapa: 1850-1889. Salvador: Governo do Estado da Bahia; Secretaria do Planejamento, Ciência e Tecnologia (CPE), 1978.

Ferreira, Francisco Ignacio. Diccionário Geographico das Minas do Brazil, Rio de Janeiro: Imprensa Nacional, 1885. 
Ferrez, Gilberto. A Fotografia no Brasil: 1840-1900. Rio de Janeiro: FUNARTE, 1985.

Funch, Roy. Um guia para a Chapada Diamantina. Cruz das Almas: Gráfica e Editora Nova Civilização, 2002.

Furniss, Henry Watson. Diamonds and Carbons in Brazil. In: Popular Science Monthly (69), Setembro1906.https://en.wikisource.org/wiki/Popular_Science_Monthly/Volume_69/Septem ber_1906/Diamonds_and_Carbons_in_Brazil (acesso em 10/5/2016

Furtado, Celso. Formação econômica do Brasil. São Paulo: Nacional, 1979.

Gaudemar, Jean-Paul de. Mobilidade do trabalho e acumulação do capital. Lisboa: Estampa, 1977.

Guanaes, Senilde Alcântara. Meu quintal não é parque! Tese de doutorado, IFCH/UNICAMP, 2006.

Guisard, Luís Augusto de Mola. O Bugre, um João-Ninguém: um personagem brasileiro. São Paulo: Em Perspectiva, 13(4), 1999.

Harvey, David. O ajuste espacial, In: A produção capitalista do espaço. São Paulo: Annablume, 2005.

Heidemann, Heinz Dieter. Os migrantes e a crise da sociedade do trabalho: humilhação secundária, resistência e emancipação. In: Migrações: descriminação e alternativas. São Paulo: Paulinas, 2004.

Heidemann, Heinz Dieter; Toledo, Carlos de Almeida; Boechat, Cássio Arruda. $O$ trabalho no Brasil: traçado interpretativo de sua história de formação e de sua crítica. São Paulo: Revista de Estudos Avançados 28 (81), 2014.

Herald, Marc W. A Half-century monopoly (1880-1930s): the black diamonds (carbonados) of Bahia and Jewish Merchants. Fortaleza: Rev. Ciênc. Admin. v. 17, n. 1, p. 13-54, jan./abr. 2011. Instituto Chico Mendes. Plano de Manejo do Parque Nacional da Chapada Diamantina. Brasília, 2007.

Jappe, Anselm. Guy Debord. Petrópolis: Vozes, 1999.

Kossoy, Boris. Fotografia \& história. São Paulo: Ateliê Editorial, 2001. . Realidades e ficções na Trama Fotográfica. São Paulo: Ateliê Editorial, 2002.

. Hercule Florence: A descoberta isolada da fotografia no Brasil. São Paulo: Edusp, 2006.

- Dicionário histórico-fotográfico brasileiro: fotógrafos e ofício da fotografia no Brasil (1833-1910). São Paulo: Instituto Moreira Sales, 2002.

Kurz, Robert. O colapso da modernização. Rio de Janeiro: Paz e Terra, 1992.

- Ascensão do dinheiro aos céus. 2002. http://obeco.planetaclix.pt (acesso em 10/03/2012) 
- A substância do capital. 2004/2005. http://obeco.planetaclix.pt (acesso em 10/03/2012)

. A expropriação do tempo. In: Folha de São Paulo, edição de 3 de janeiro de 1999.

. Dinheiro sem valor. Lisboa: Antígona, 2014.

. O estouro da Modernidade com canhões e tostões. 2002b. http://obeco.planetaclix.pt (acesso em 15/05/2016)

- A falta de autonomia do Estado e os limites da política: quatro teses sobre a crise da regulação política. 1994 http://obeco.planetaclix.pt (acesso em 10/10/2017)

Leal, Fernando Machado. A antiga Comercial Vila dos Lençóis. In: Revista do Patrimônio Histórico e Artístico Nacional (18), Rio de Janeiro, p 115-160, 1978.

Leal, Hermes. Orlando Senna: o homem da montanha. São Paulo: Imprensa Oficial, 2008.

Lefebvre, Henri. Vida Cotidiana no Mundo Moderno. São Paulo: Ática, 1991.

Leite, Ana Carolina Gonçalves. Acumulação de capital, mobilização regional do trabalho

e coronelismo no Brasil. Bogotá: Cuadernos de Geografía / Revista Colombiana de Geografía, Vol. 23, n. ${ }^{\circ}$ 1, 2014.

Linsker, Roberto. Chapada Diamantina: Águas do Sertão. São Paulo: Terra Virgem, 2005.

Lima, Carlos César Uchôa de. Lençóis, uma ponte entre a geologia e o homem. Feira de Santana: Universidade Estadual de Feira de Santana, Departamento de Ciências Exatas, 1997.

Losh, Paul S. Dr. Henry W. Furniss, Cônsul afro-americano na Bahia, 1898-1905. Revista Afro-Ásia, 40 (2009), 223-258.

Mangili, Liziane Peres. Anseios, dissonâncias, enfrentamentos: o lugar e a trajetória da preservação em Lençóis (Bahia). Tese de Doutorado, FAU/USP, 2015.

- A ressignificação da paisagem cultural na Cidade de Lençóis (BA). Belo Horizonte: Terceiro Colóquio Ibero-Americano Paisagem Cultural, Patrimônio e Projeto, 2014.

- O processo de tombamento da cidade de Lençóis/BA: valores, envolvidos e seus discursos sobre patrimônio. Salvador: Encontro Internacional Arquimemória 4, maio de 2013. Marques, Iêda. Lembranceiras, imaginário e realidades. Lauro de Freitas: Solisluna: 2012.

Martins, José de Souza. Sociologia da fotografia e da imagem. São Paulo: Contexto, 2009.

Marx, Karl. O Capital. São Paulo: Abril Cultural, 1996.

- Grundrisse : manuscritos econômicos de 1857-1858 : esboços da crítica da economia política. São Paulo: Boitempo, Rio de Janeiro: Editora UFRJ, 2011.

Mendes, Ricardo. Gaensly na Bahia: a terra e o homem, 2014 (http://www.fotoplus.com/ download/gaensly-na-bahia-2014.pdf) 
Meneses, Ulpiano T. Bezerra de. A paisagem como fato cultural. In: YÁZIGI, Eduardo (org.). Turismo e Paisagem. São Paulo: Hucitec, 2002.

Ministério do Interior - Superintendência do Desenvolvimento do Nordeste. Parque Nacional da Chapada Diamantina (mapa). Sétima edição, 2015.

Ministério do Turismo. Destino Referência em Turismo - Lençóis, Chapada Diamantina BA. Goiânia: Instituto Casa Brasil de Cultura, 2010.

Monbeig, Pierre. Papel e valor do ensino da geografia e de sua pesquisa. Conselho Nacional de Geografia / IBGE, 1956.

Moraes, Walfrido. Jagunços e Heróis. Bahia: Empresa Gráfica da Bahia / Assembleia Legislativa, 1997.

Musse, Ricardo. A administração do tempo livre. São Paulo: Lua Nova, n. 99, 107-134, 2016.

Neto, Calil. O Centro da Bahia: Testemunho sobre a Chapada Diamantina. Editora Maianga, 2001.

Novaes, Adauto (org.). O olhar. São Paulo: Companhia das Letras, 1988.

Novais, Fernando A. Portugal e Brasil na crise do antigo sistema colonial (1777-1808). São Paulo: Hucitec, 1995.

Ouriques, Helton Ricardo. A produção do turismo: fetichismo e dependência. Campinas: Editora Alínea, 2005.

Oliveira, Francisco de. O elo perdido: classe e identidade de classe na Bahia. São Paulo: Editora Fundação Perseu Abramo, 2003. - Elegia para uma re(li)gião: Sudene, Nordeste. Planejamento e conflitos de classes. São Paulo: Boitempo, 2008. . Crítica da Razão Dualista / O Ornitorrinco. São Paulo: Boitempo: 2013

- O Surgimento do Antivalor - Capital, Força de Trabalho e Fundo Público, Revista Novos Estudos, número 22, 1988.

. Brasil: uma biografia não autorizada / Francisco de Oliveira. São Paulo: Boitempo, 2018.

Paiva, Maria das Graças de Menezes Venâncio. Análise do Programa de Desenvolvimento do Nordeste (Prodetur/NE) na perspectiva do planejamento estratégico. RAP-FGV, Rio de Janeiro 44 (2), p.197-213, 2010.

Pedreira, Pedro Tomás. Os Quilombos Baianos. (In) Revista Brasileira de Geografia, ano $X X I V, n^{\circ}$ 4. Rio de Janeiro: IBGE, 1962.

Peixoto, Afrânio. Bugrinha. Rio de Janeiro: Ediouro, 197-. 
Pimentel, Samadhi Gil C. O diamante é o piolho da terra: relações socioambientais no garimpo de draga da Chapada Diamantina, Bahia. Dissertação de Mestrado, PPGM/UEFS, Feira de Santana, 2014.

Postone, Moishe. Tempo, trabalho e dominação social. São Paulo: Boitempo, 2014.

Prado Júnior, Caio. Formação do Brasil Contemporâneo: Colônia. São Paulo: Brasiliense, 1977.

Puntoni, Pedro. A Guerra dos Bárbaros: Povos Indígenas e a Colonização do Sertão Nordeste do Brasil, 1650-1720. São Paulo: Edusp, Fapesp, 2002.

Queiroz, Lúcia Aquino de. Turismo na Bahia: estratégias para o desenvolvimento. Salvador: Secretaria da Cultura e Turismo, 2002.

Raffestin, Claude. Por uma geografia do poder. São Paulo: Ática, 1993.

Rezende, Rui. Chapada Diamantina: um paraíso desconhecido, Editora P55, 2012

Rocha, Lindolfo. Maria Dusá. Rio de Janeiro: Instituto Nacional do Livro, 1969.

Sales, Herberto. Cascalho. Rio de Janeiro: Edições 'O Cruzeiro', 1951.

. Garimpos da Bahia. Rio de Janeiro: Ministério da Agricultura, 1955. . Além dos Marimbus. Rio de Janeiro: Grupo Aché, 1961.

Sampaio, Teodoro. O Rio São Francisco e a Chapada Diamantina. São Paulo: Revista Santa Cruz, 1905.

Santana, Maria da Ajuda Santos. Imagens Valiosas. http://www.revistadehistoria. com.br/secao/perspectiva/ imagens-valiosas, 01/02/2013. (acesso em 20/01/2015)

Santos, Isis Freitas dos. “Gosta dessa baiana?”Crioulas e outras baianas nos cartões postais de Lindemann (1880-1920). Dissertação de mestrado, Universidade Federal da Bahia, Faculdade de Filosofia e Ciências Humanas, Salvador, 2014.

Seabra, Manoel; Goldenstein, Léa. Divisão territorial do trabalho e nova regionalização. In: Revista do Departamento de Geografia (USP). São Paulo, 1982. Págs. 21-47.

Senna, Ronaldo de Salles. Lençóis: um estudo diagnóstico. Feira de Santana: UEFS \& Prefeitura de Lençóis, 1996.

_. Jarê - uma face do candomblé; manifestação religiosa na Chapada Diamantina. Feira de Santana: UEFS, 1998.

Serrer, Pedro Benetazzo. Pensando o turismo e o patrimônio cultural da reprodução crítica do capital e o caso de Paranapiacaba. Trabalho de Graduação Individual/USP (TGI), 2013.

Seyferth, Giralda. Colonização, imigração e questão racial no Brasil. (?)

Scholz, Roswitha. Cristóvão Colômbo Forever?, 2016. http://www.obecoonline.org/roswitha_scholz24.htm (acesso em 10/11/2017) 
Silva, Wagner Souza e. Foto 0/Foto1. São Paulo: Edusp, 2016.

Simmel, Georg. A filosofia da paisagem. Covilhã: Universidade da Beira Interior, 2009.

Sontag, Susan. Na caverna de Platão. In: Sobre Fotografia, São Paulo: Companhia das Letras, pgs. 11-37, 2004.

Sticker, Erico J. Siriuba. Uma pequena biblioteca particular - subsídios para o estudo da iconografia do Brasil. São Paulo: Edusp / Imprensa oficial do Estado de São Paulo, 2004.

STC-Bahia. Plano de Desenvolvimento Sustentável Integrado do Turismo Sustentável ChapadaDiamantina,2004.https://edisciplinas.usp.br/pluginfile.php/1710994/

mod_resource/content/1/PDITS\%20Chapada\%20Diamantina.pdf

Thomaz, Tatiana dos Santos. Geografia e fotografia: relação entre paisagem, espaço e imagem. In: Espaço \& Geografia, vol. 15, n. 2, 2012, pgs. 517-549.

Toledo, Carlos Almeida. A região das Lavras Baianas. Tese de doutorado FFLCH/USP. São Paulo, 2008.

Toledo, Carlos de Almeida \& Boechat, Cassio de Arruda. Mobilização do trabalho e estudo da região. Boletim Campineiro de Geografia, v. 2, n. 3, Campinas, 2013.

. Modernização, Contradições Espaciais e Relação Agrário-Urbana no Brasil.2008.

Trigo, Luiz Gonzaga Godoi. A sociedade pós-industrial e o profissional em turismo. Campinas: Papirus, 1998.

Urry, John. O olhar do turista: lazer e viagens nas sociedades contemporâneas, São Paulo: Studio Nobel/SESC, 2001.

Vasquez, Pedro Karp. Fotógrafos alemães no Brasil do século XIX. São Paulo: Meta Livro, 2000.

Yázigi, Eduardo; Carlos, Ana Fani Alessandri; Cruz, Rita de Cássia Ariza (orgs.). Turismo: espaço, paisagem e cultura. São Paulo: Hucitec, 1996.

Zacariades, Marcos. Cenários da memória diamantina. Governo da Bahia, 2016.

\section{Audiovisual:}

A Lenda do Pai Inácio. Direção: Pola Ribeiro, 1987, 18 min.

Brazil: The Troubled Land. Direção: Helen Jean Rogers, 1964, 25 min.

Brilhante. Direção: Conceição Senna, 2005, 75 min.

Cascalho. Direção: Tuna Espinheira, 2004, 104 min.

Comento de Mão. Direção: Rodrigo Moraes, (?), 9 min. 
Cortadores de Pedra. Direção: Paula Zannardi, 2017, 30 min.

Diamante Bruto. Direção: Orlando Senna, 1977, 100 min.

Em Nome da América. Direção: Fernando Weller, 2017, 96 min.

Jardim de Plástico. Direção: Delmar Alves de Araujo, 2008, 16 min.

Lençóis. Direção: Pola Ribeiro, (?), 19 min.

Três Chapadas e um balão - Diamantina. Direção: Maurício Dias, 1997, 52 min. 


\section{ANEXO A - Postais da série "Lavras Diamantíferas Baianas" de Rodolphe Lindemann}

Série de vinte e quatro cartões-postais datados de 1900. São registros da cidade de Lençóis e áreas de garimpo de diamantes nos seus arredores. Ainda que controversa, a autoria é atribuída ao fotógrafo Fréderic François Rodolphe Lindemann, cuja nacionalidade, também incerta, provavelmente seja francesa. Para mais detalhes sobre as imagens e o fotógrafo consultar: A fotografia na Bahia (1839-2006) (Alves, 2006); O negro na fotografia brasileira do século XIX (Ermakoff, 2004); A Fotografia no Brasil: 1840-1900 (Ferrez, 1985); Dicionário histórico-fotográfico brasileiro: fotógrafos e oficio da fotografia no Brasil (1833-1910) (Kossoy, 2002); Gaensly na Bahia: a terra e o homem (Mendes, 2014); Imagens Valiosas (Santana, 2013); "Gosta dessa baiana?" Crioulas e outras baianas nos cartões postais de Lindemann (1880-1920) (Santos, 2014); Fotógrafos alemães no Brasil do século $X I X$ (Vasquez, 2000). As imagens foram digitalizadas por Carlos de Almeida Toledo a partir do arquivo pessoal de Mestre Osvaldo. 
Figura 25 - A praça da Cidade de Lençóes em dia de feira. Bahia - Brazil

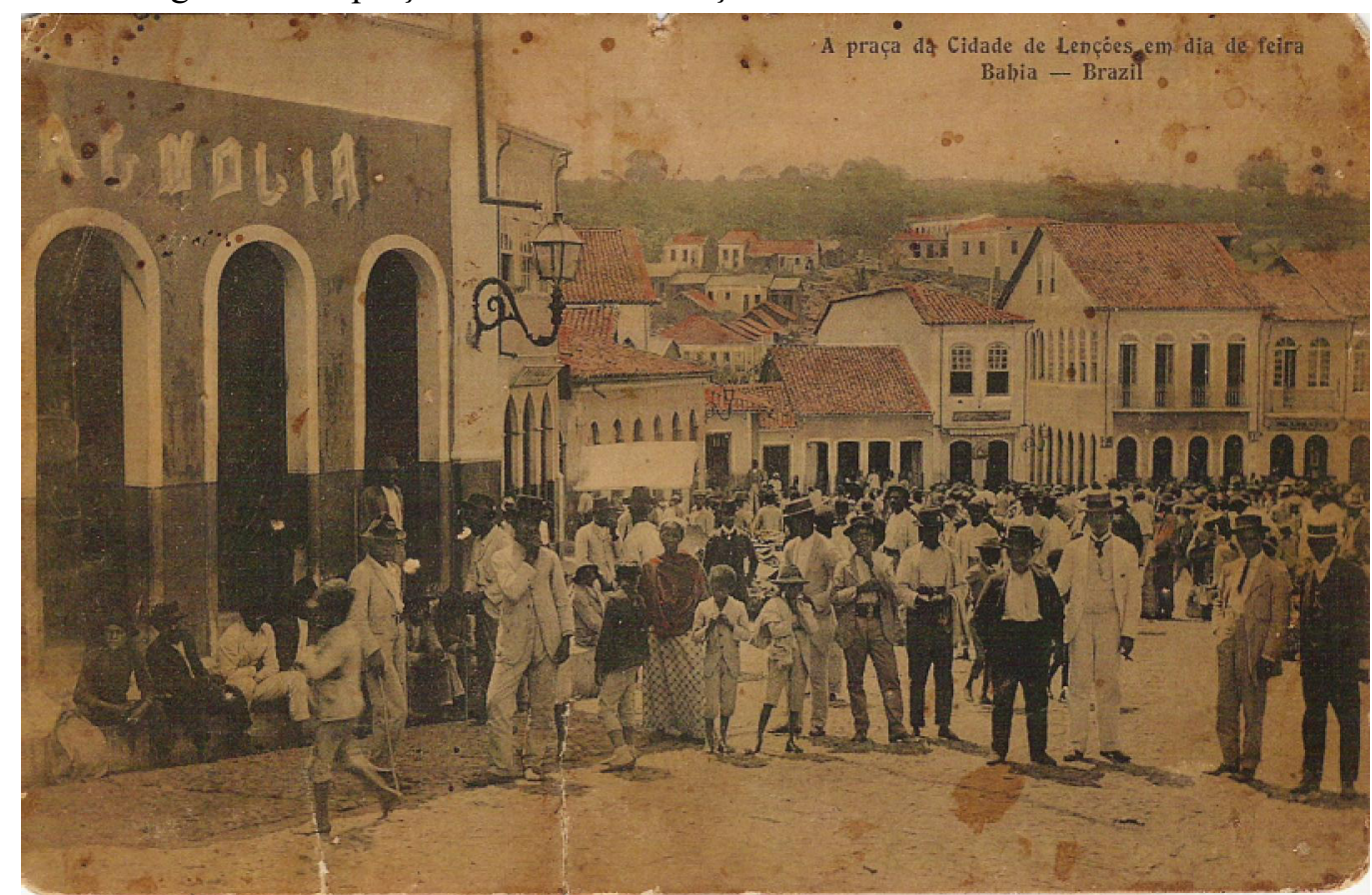

Fonte: Arquivo pessoal de Mestre Osvaldo.

Figura 26 - Feira na praça do Mercado. Lençóes - Bahia

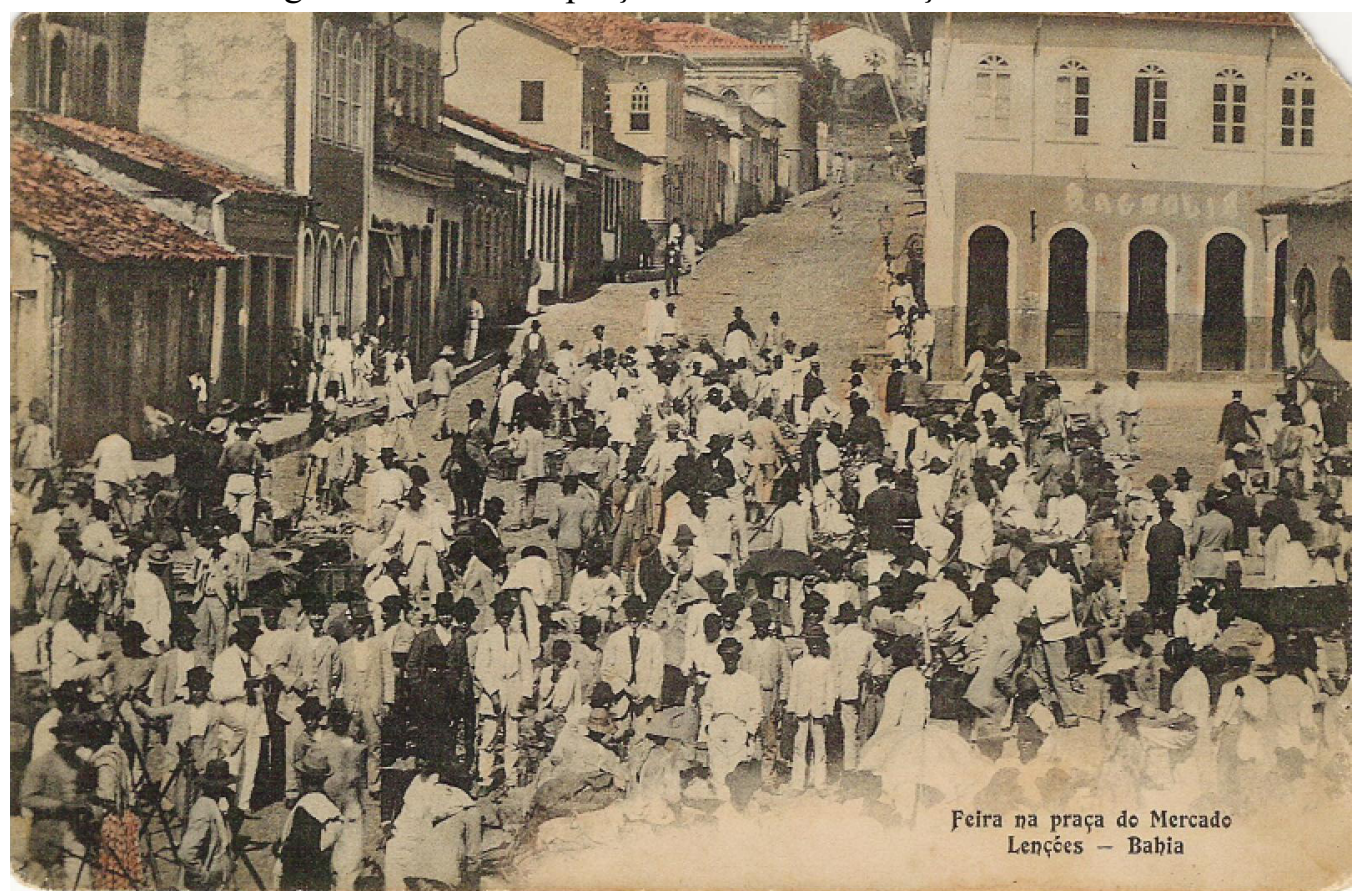

Fonte: Arquivo pessoal de Mestre Osvaldo. 
Figura 27 - Procissão do S.S C. Jesus. Lençóes - Bahia

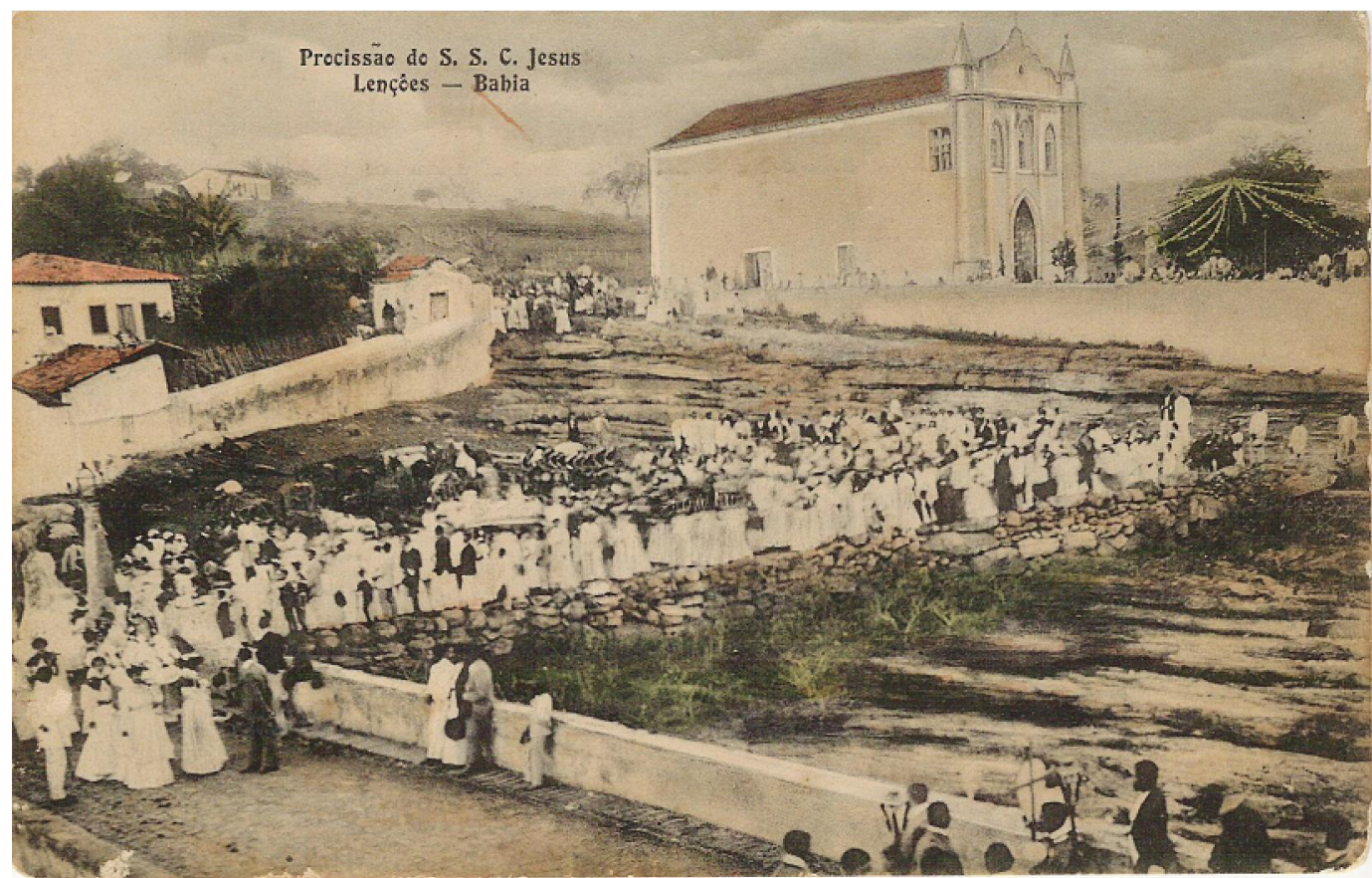

Fonte: Arquivo pessoal de Mestre Osvaldo.

Figura 28 - Paço do Concelho e Loja Magnólia. Lençóes - Bahia

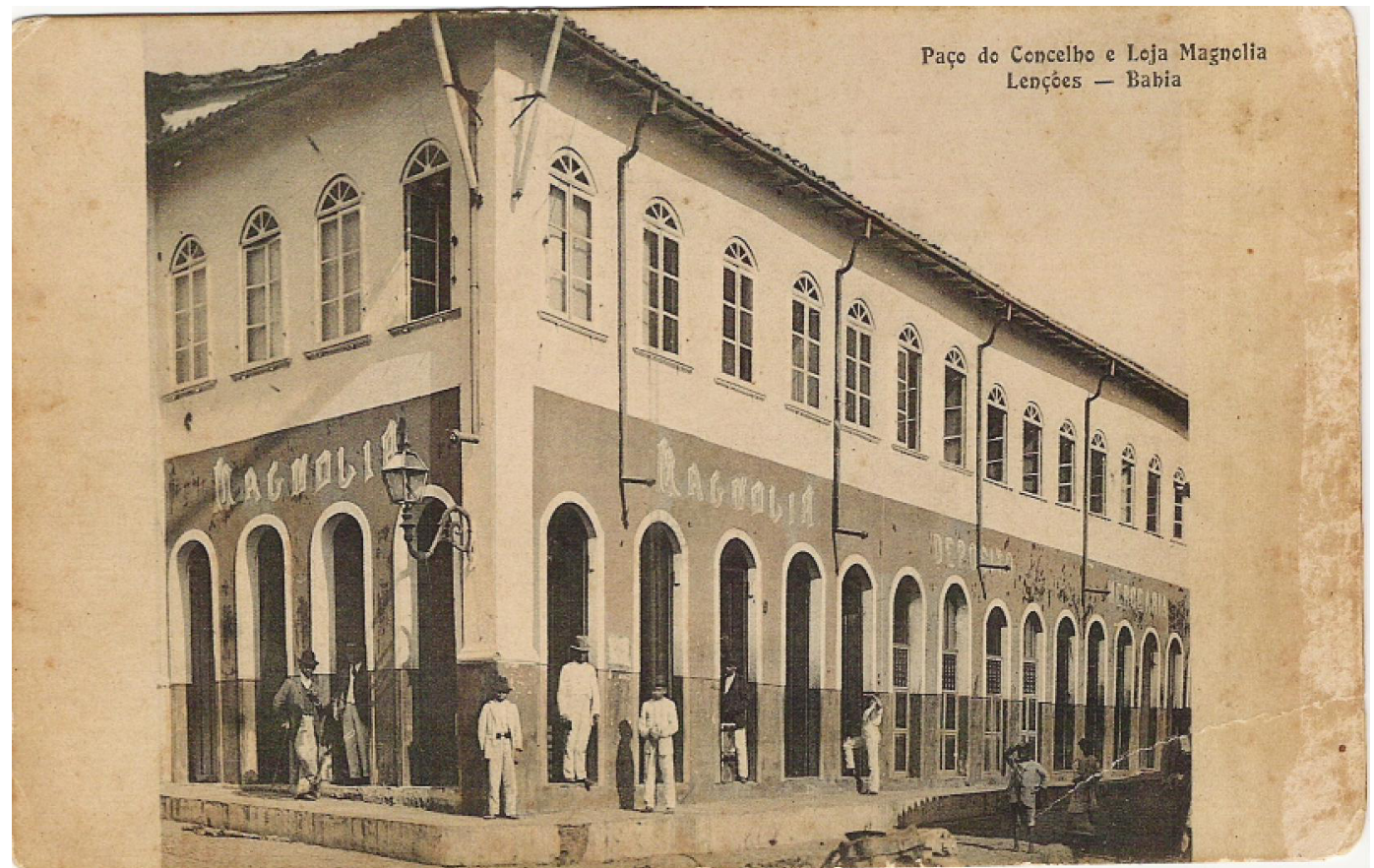

Fonte: Arquivo pessoal de Mestre Osvaldo. 
Figura 29 - Chacara Eugenio Alcantara. Lençóes - Bahia

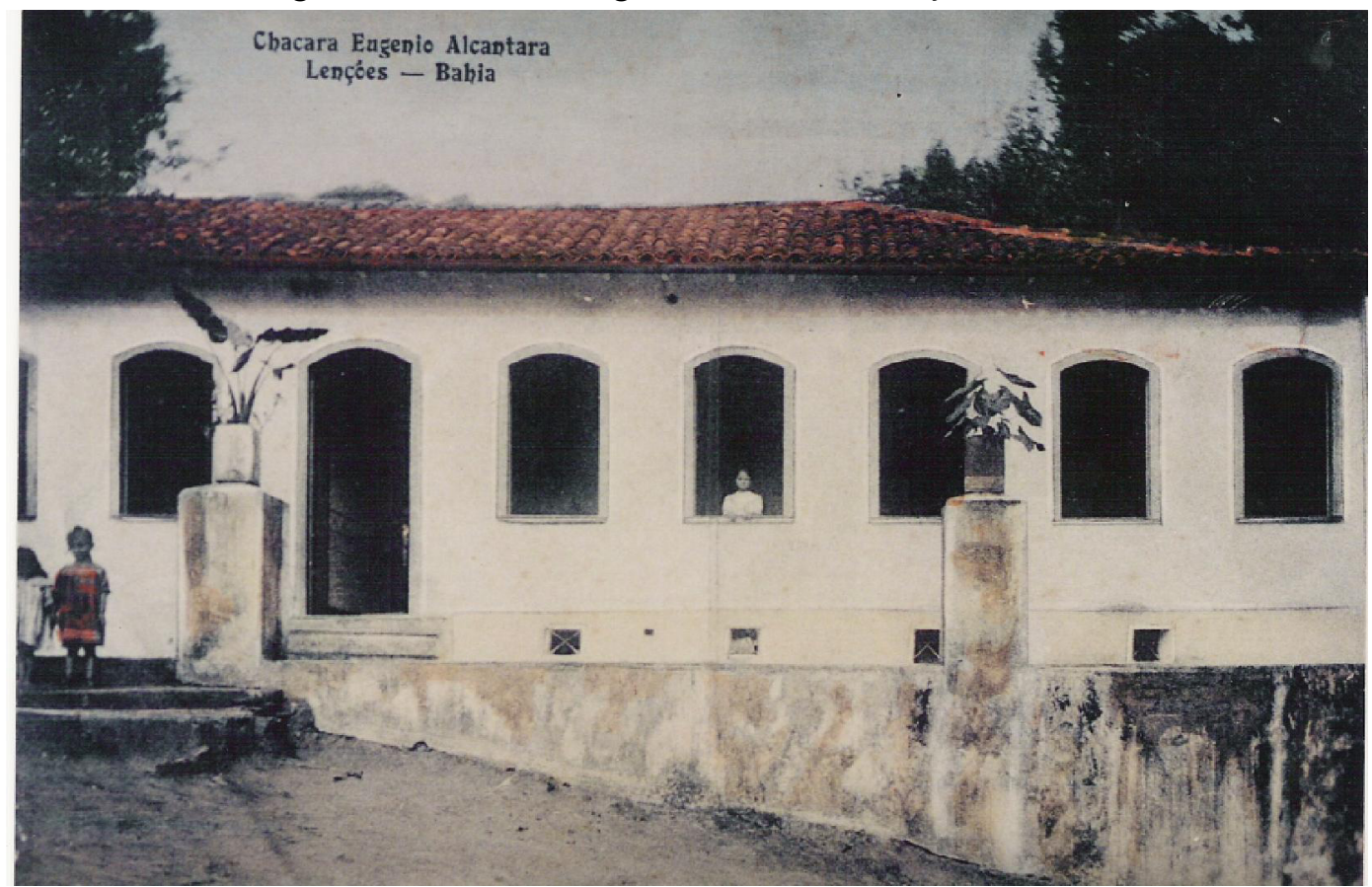

Fonte: Arquivo pessoal de Mestre Osvaldo.

Figura 30 - Um trecho da Cidade Lençóes. Bahia - Brazil

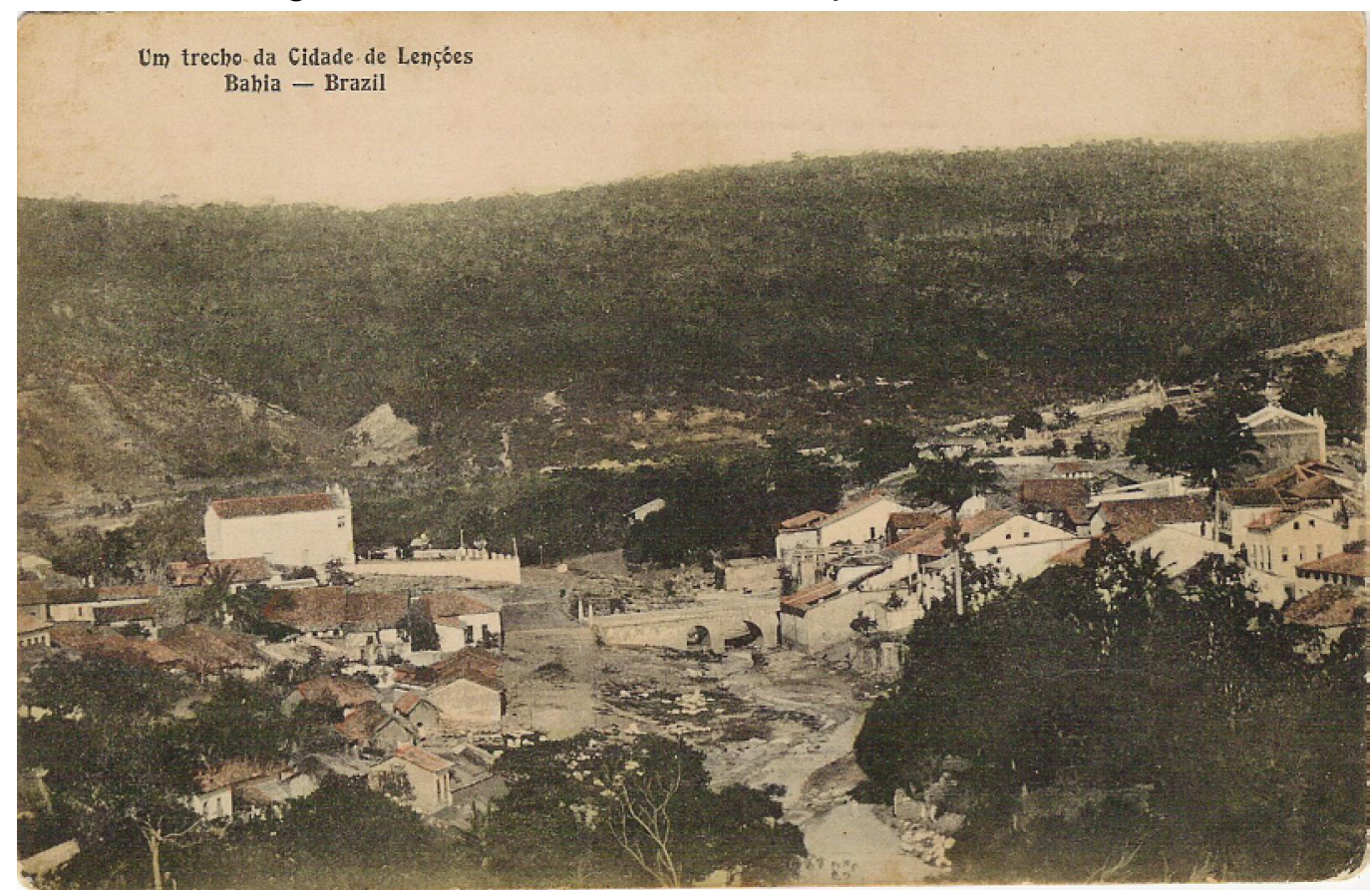

Fonte: Arquivo pessoal de Mestre Osvaldo. 
Figura 31 - Um trecho da Cidade de Lençóes. Estado da Bahia - Brazil

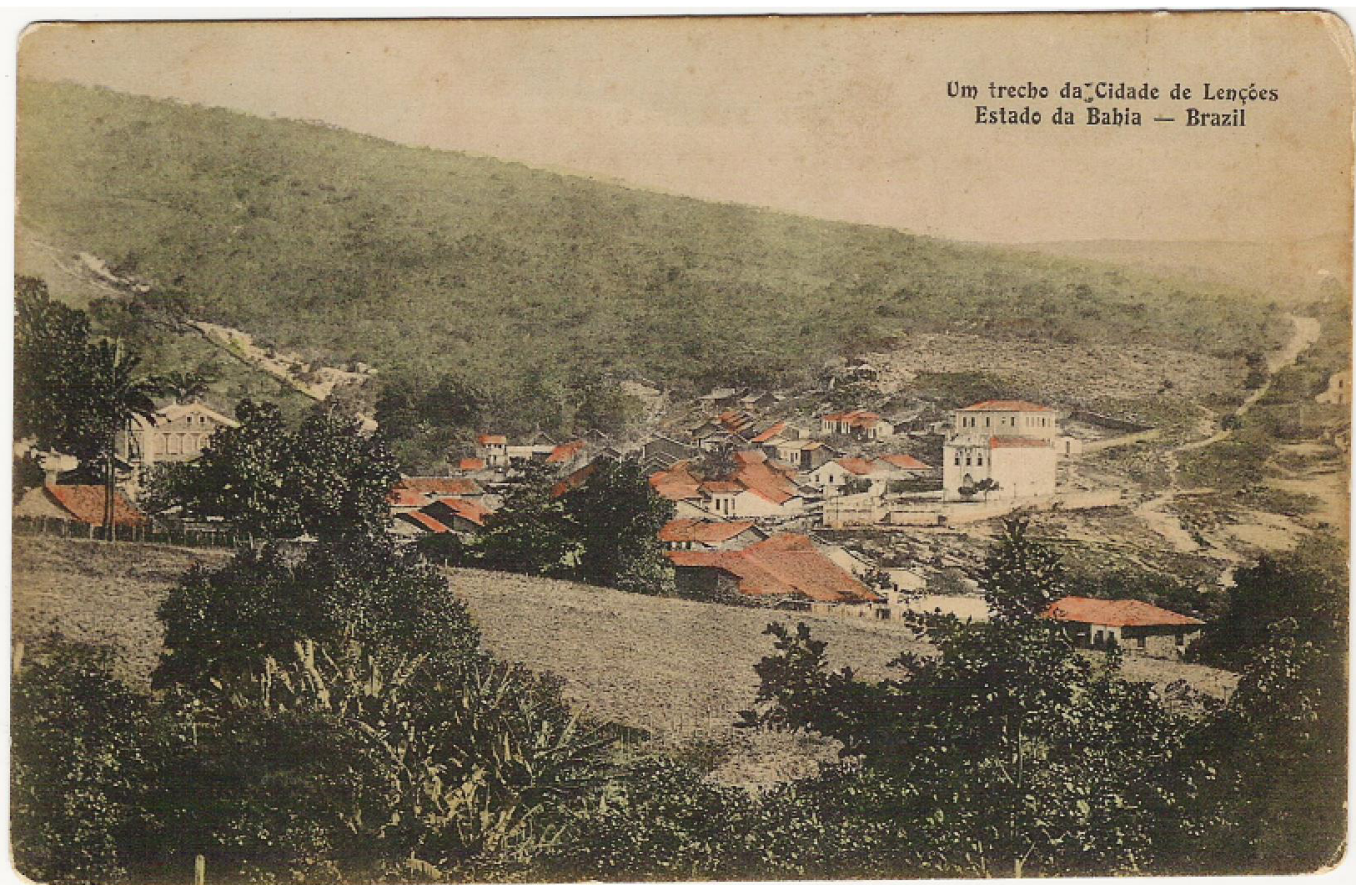

Fonte: Arquivo pessoal de Mestre Osvaldo.

Figura 32 - Um trecho da Cidade de Lençóes vista do alto. Bahia - Brazil

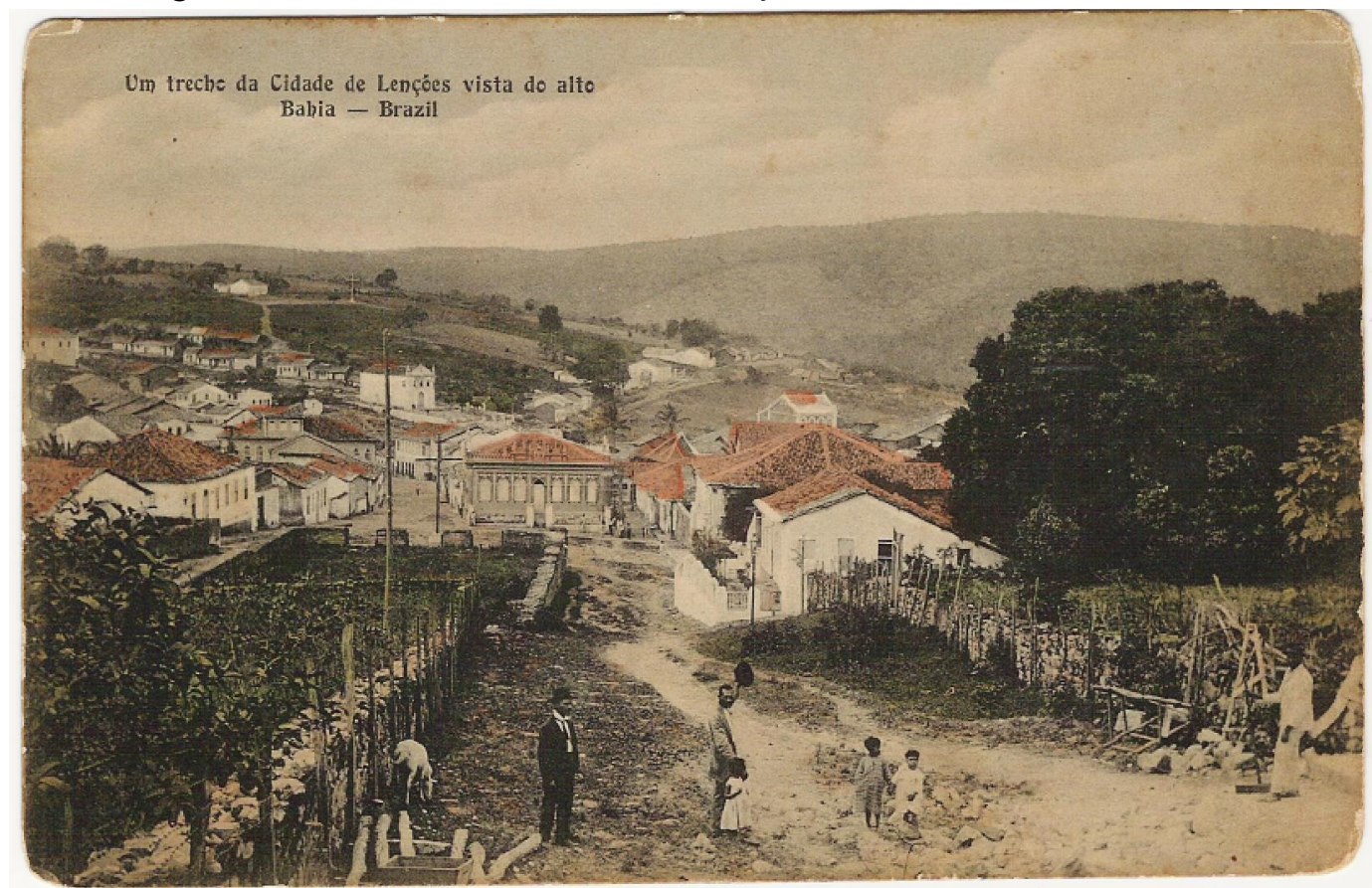

Fonte: Arquivo pessoal de Mestre Osvaldo. 
Figura 33 - Alto da Estrella. Lençóes - Bahia

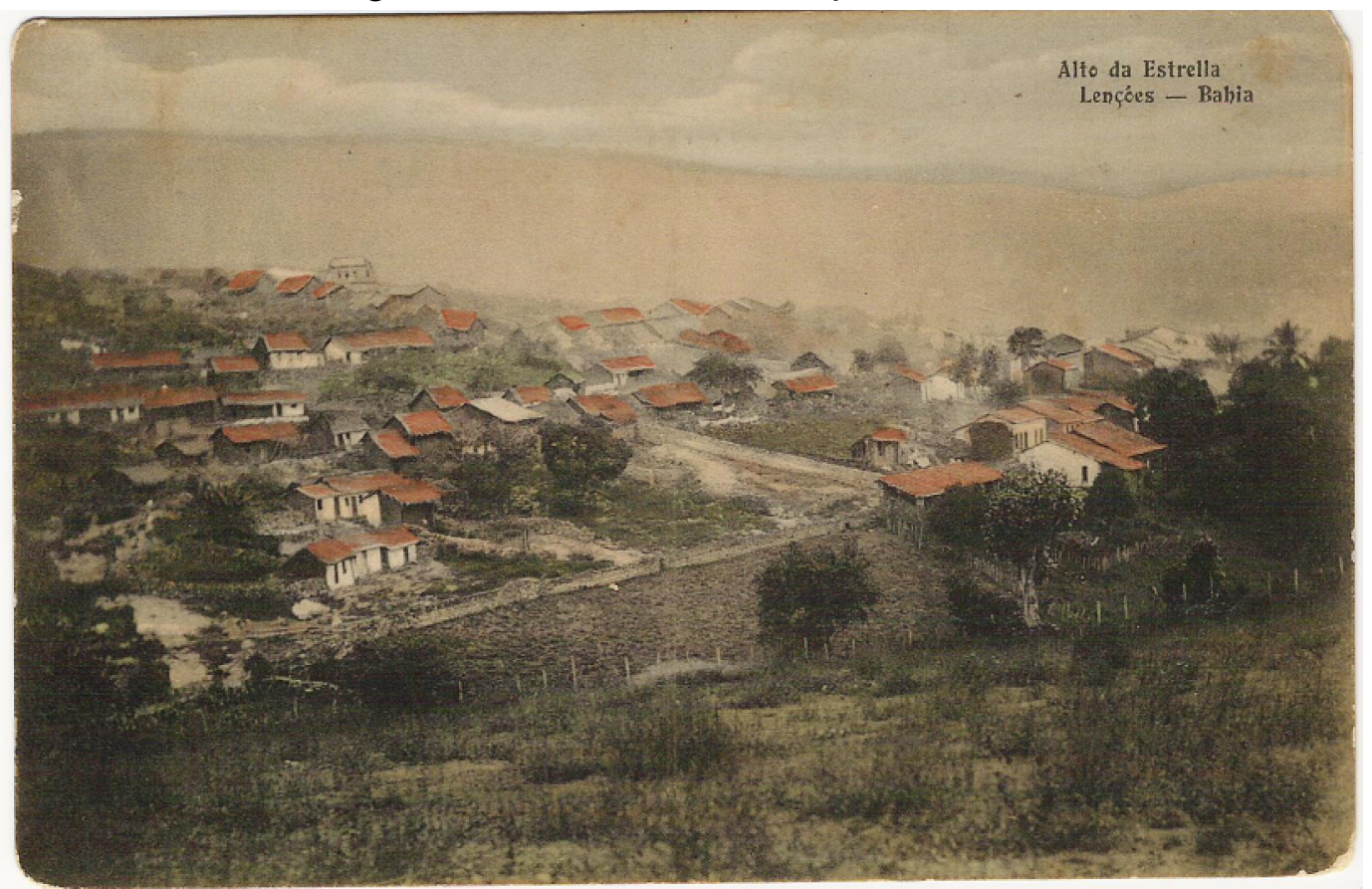

Fonte: Arquivo pessoal de Mestre Osvaldo.

Figura 34 - Rua do Lava-Pés. Lençóes -Bahia

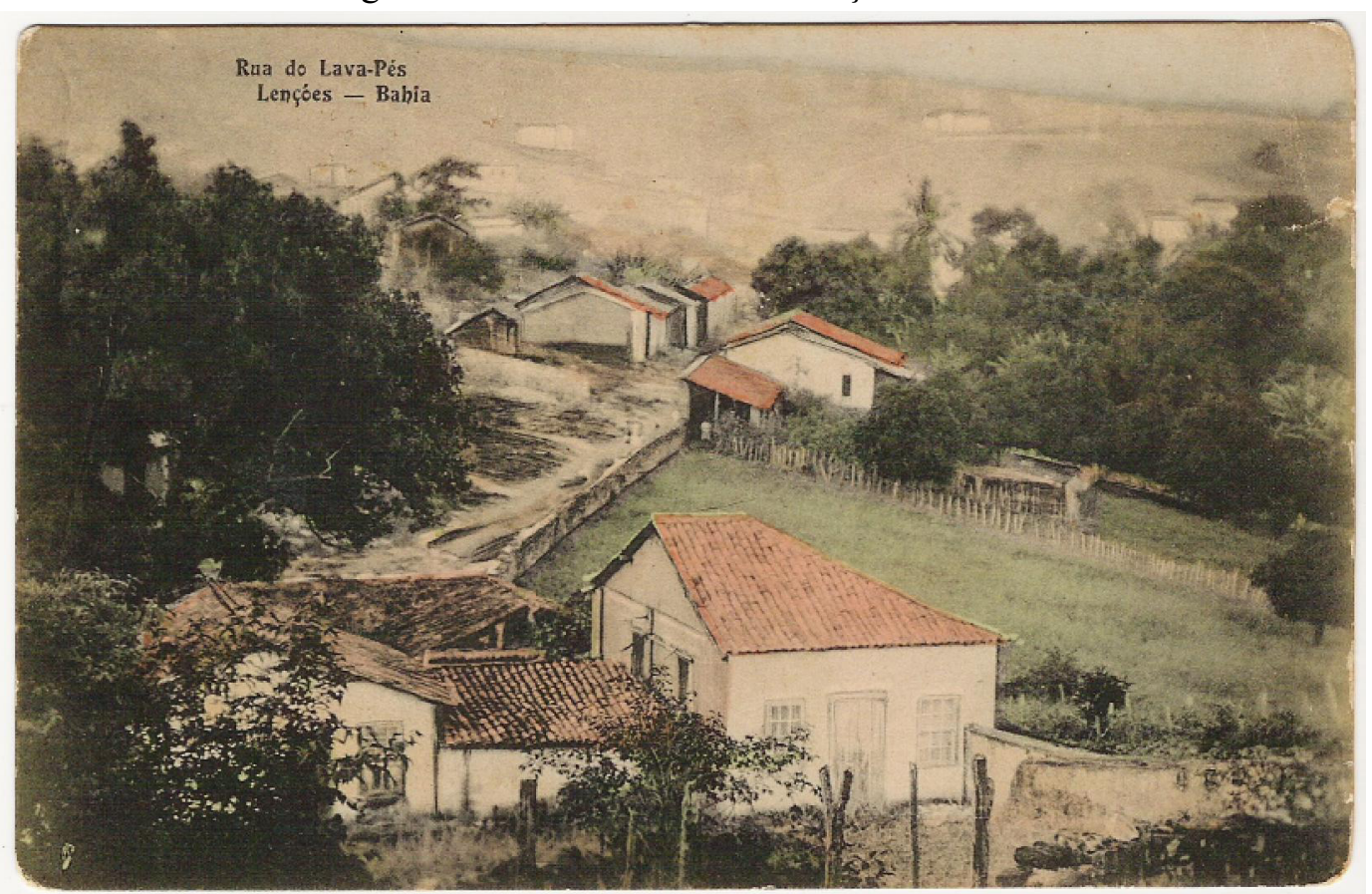

Fonte: Arquivo pessoal de Mestre Osvaldo. 
Figura 35 - Rua do Lava-Pés. Lençóes -Bahia

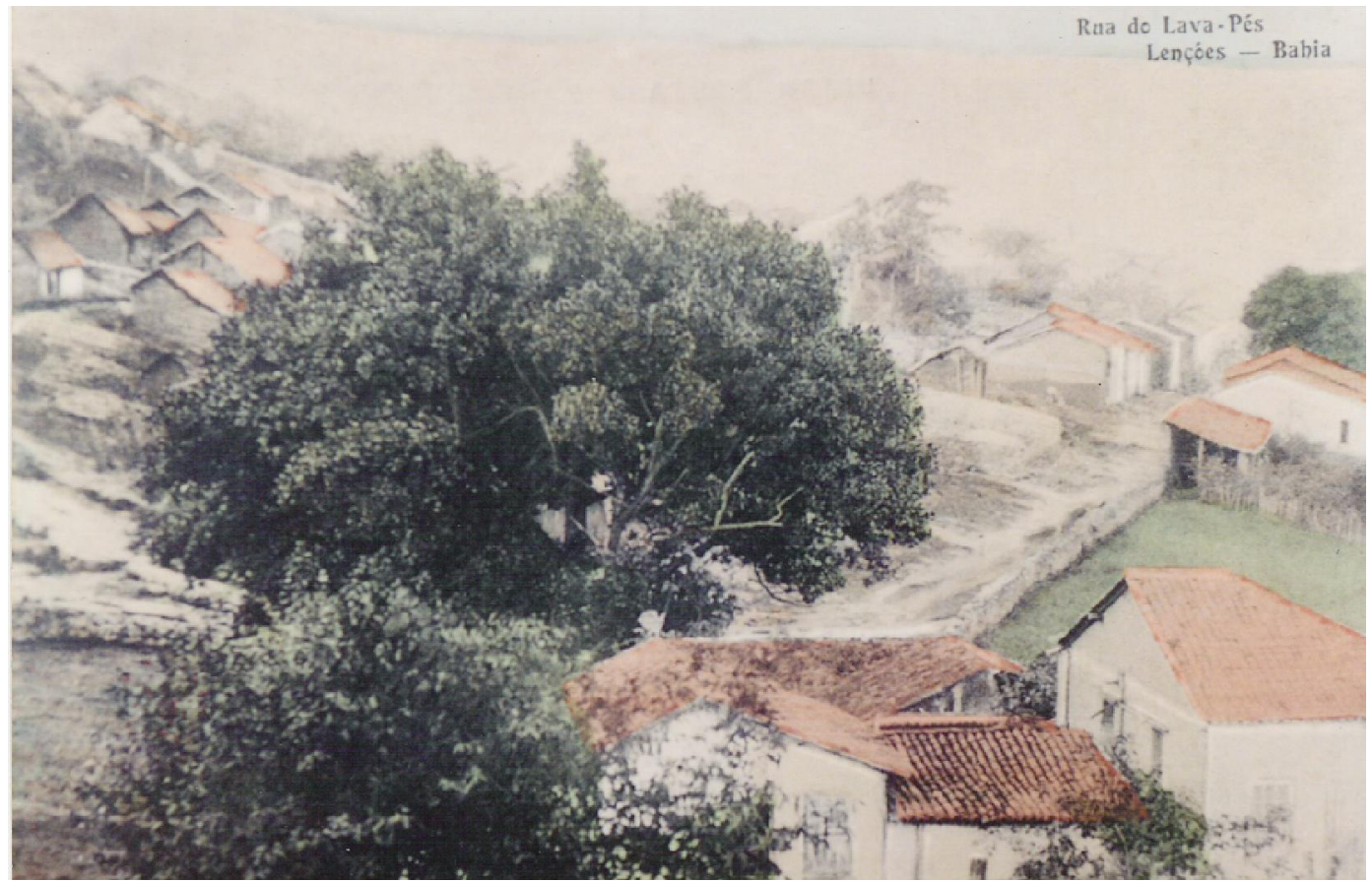

Fonte: Arquivo pessoal de Mestre Osvaldo.

Figura 36 - Pedras no Garimpo Estrella do Céo. Lençóes - Bahia

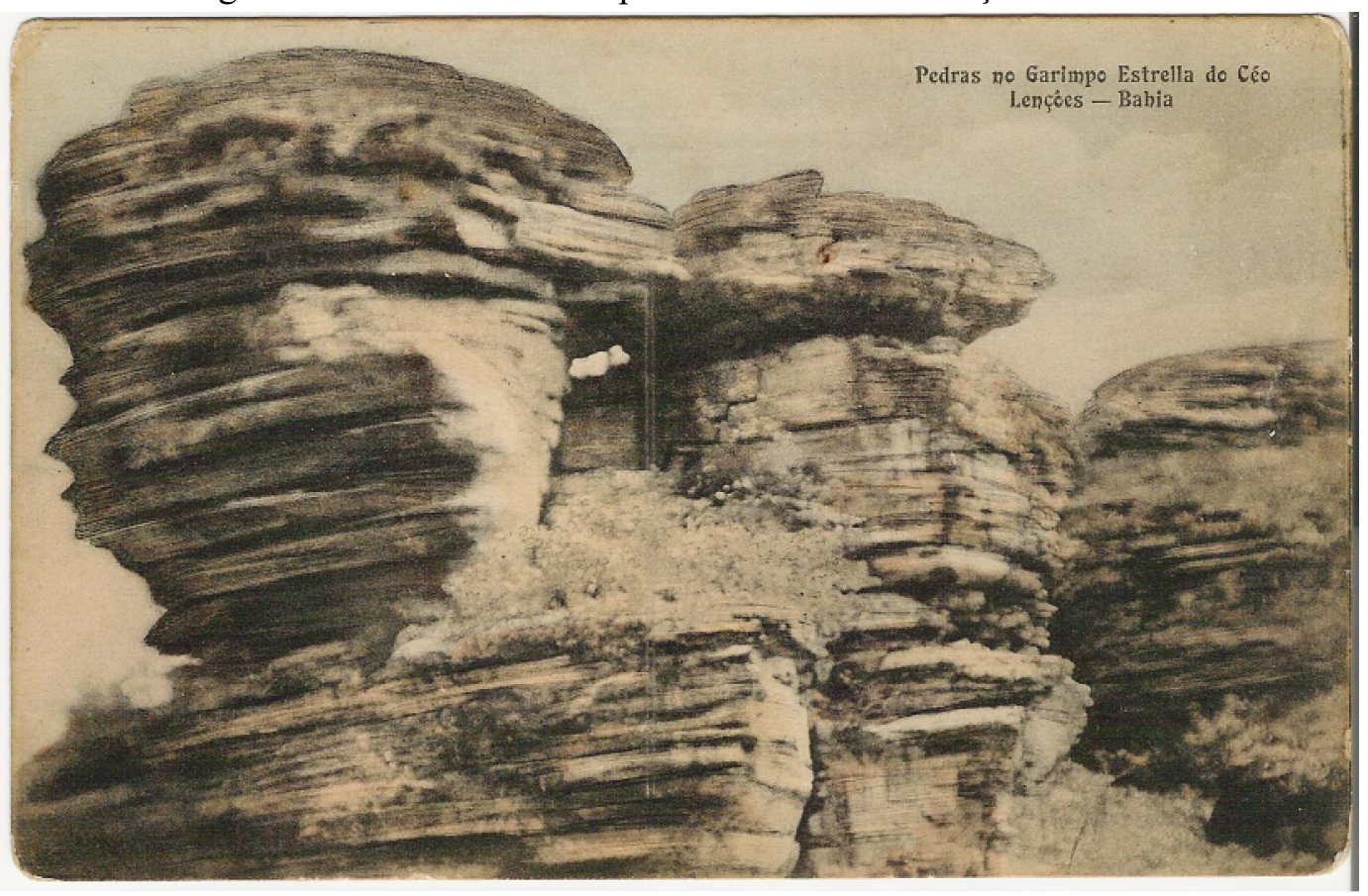

Fonte: Arquivo pessoal de Mestre Osvaldo. 
Figura 37 - Garimpeiros em trabalho. Lençóes - Bahia

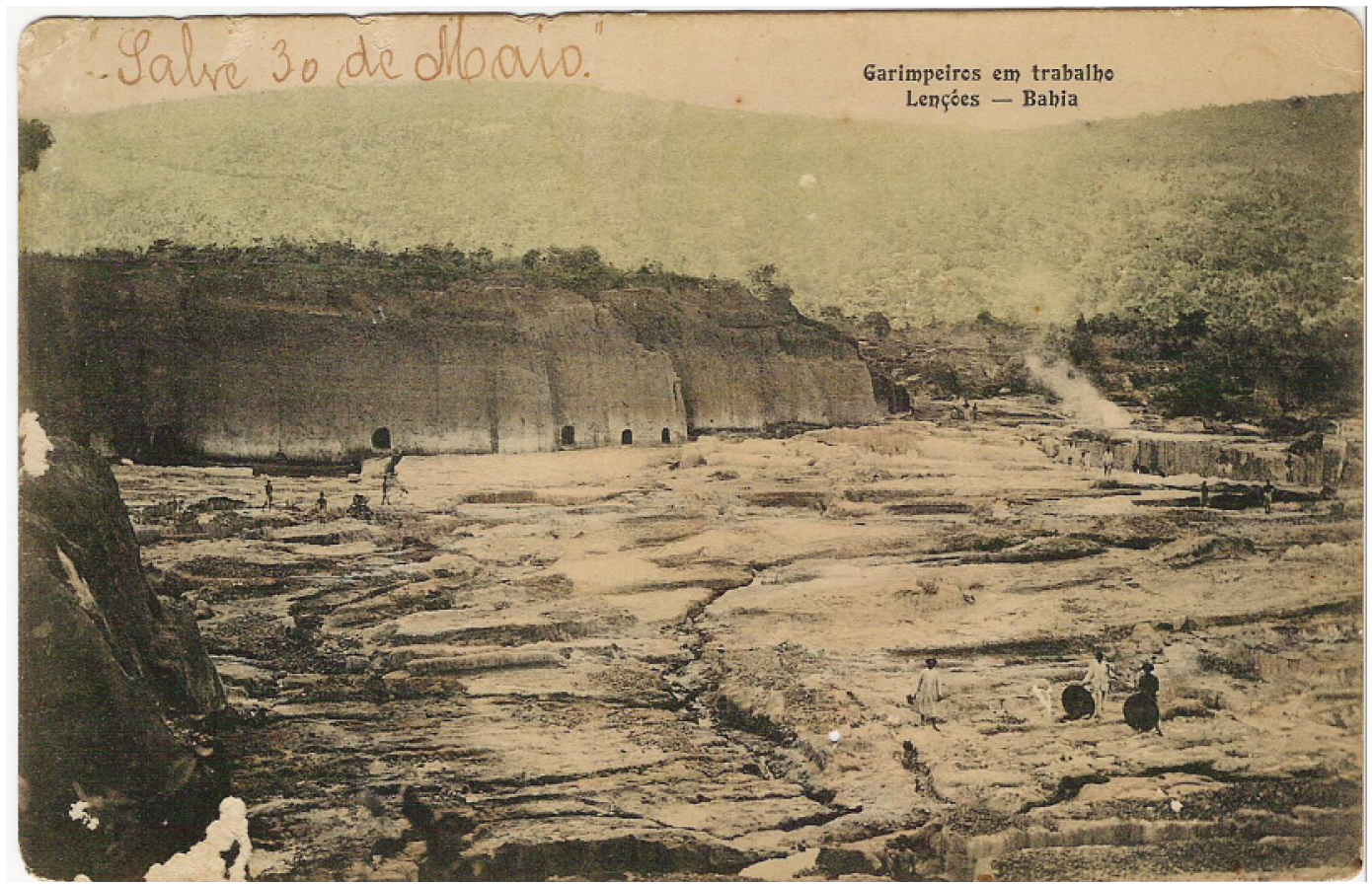

Fonte: Arquivo pessoal de Mestre Osvaldo.

Figura 38 - Sem título.

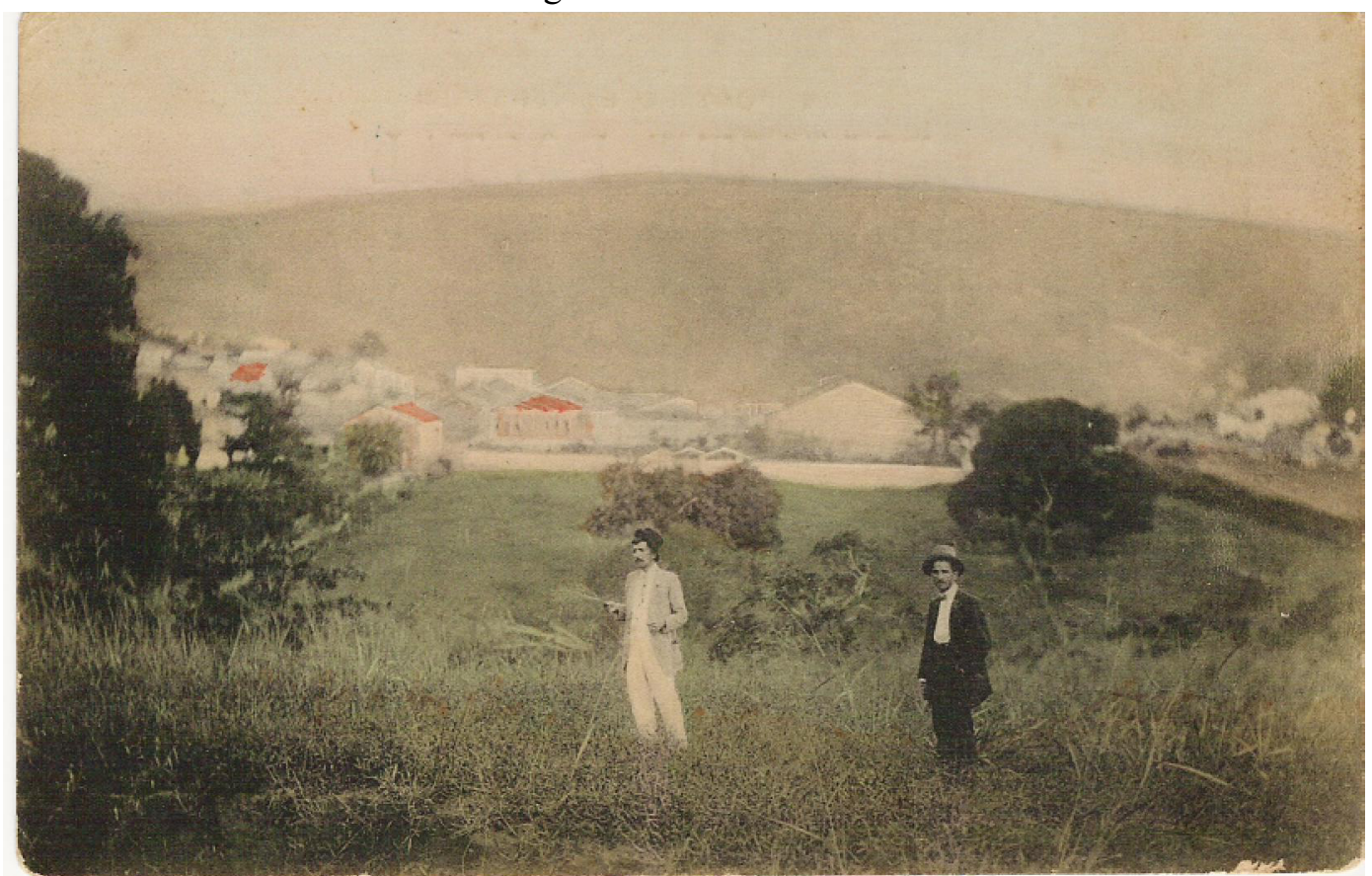

Fonte: Arquivo pessoal de Mestre Osvaldo. 
Figura 39 - Excursão do garimpo Breguinho. Lençóes Bahia

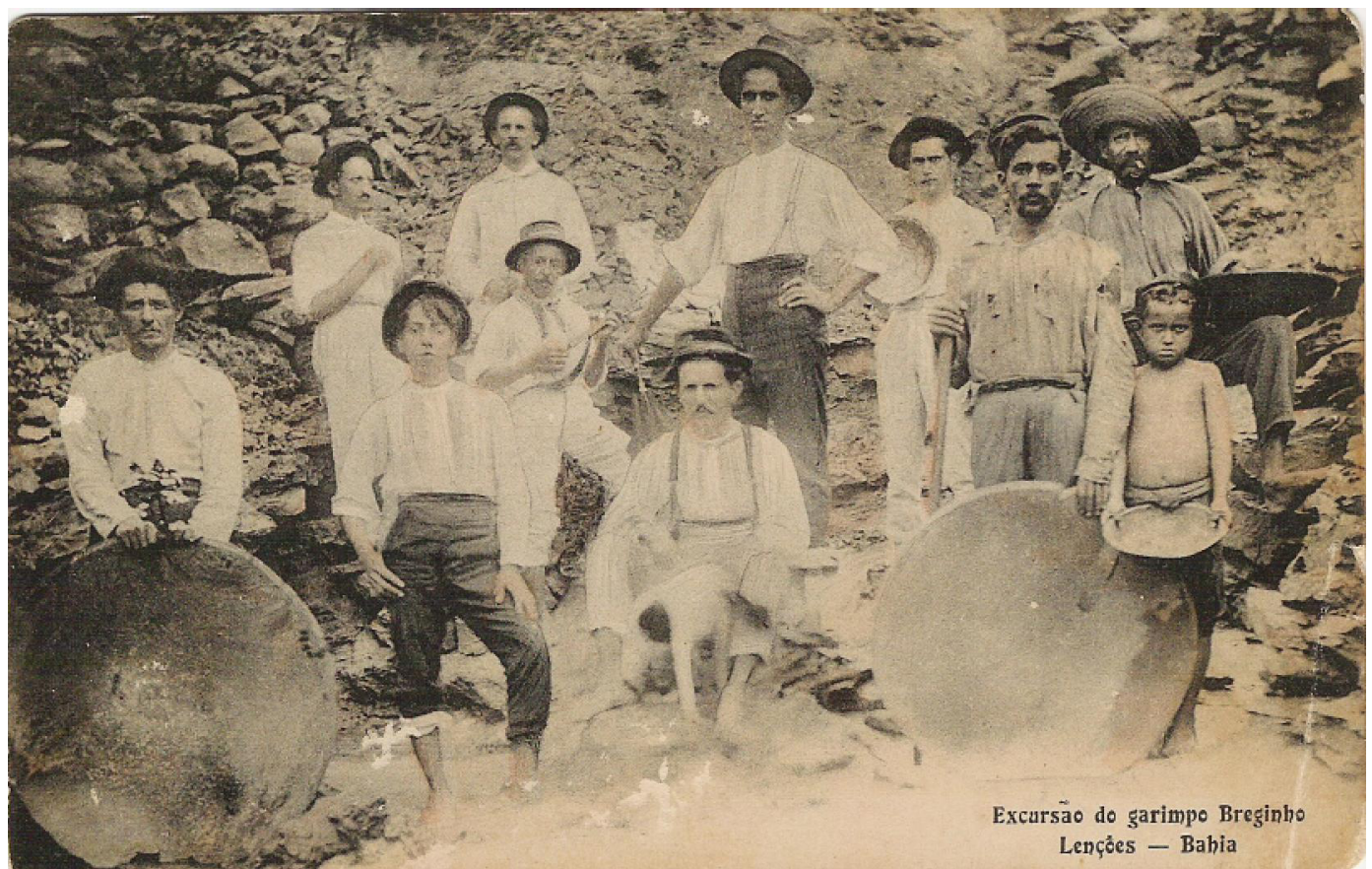

Fonte: Arquivo pessoal de Mestre Osvaldo.

Figura 40 - Garimpo Estrella do Céo. Lençóes - Bahia

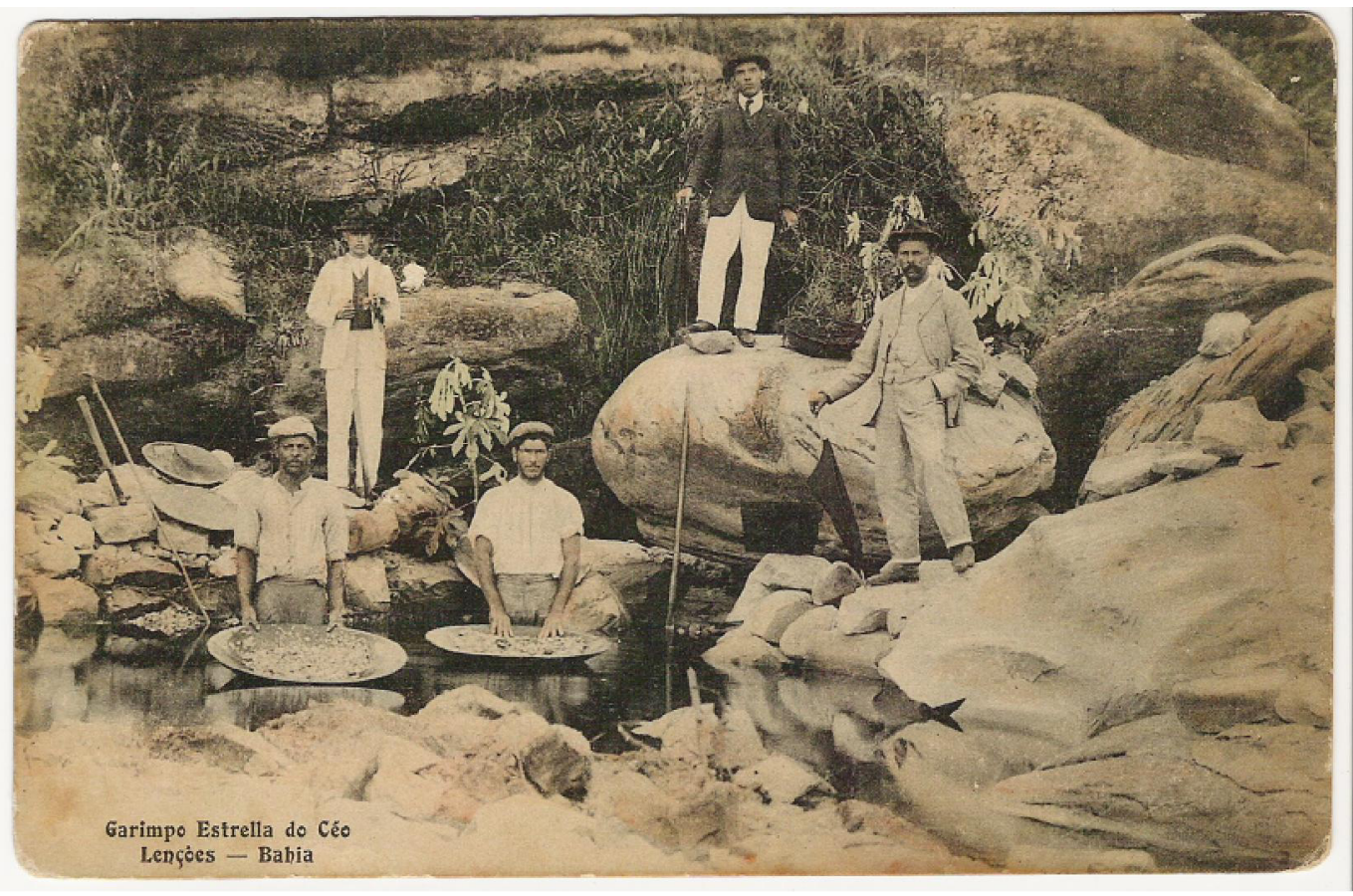

Fonte: Arquivo pessoal de Mestre Osvaldo. 
Figura 41 - Em busca de fortuna. Lençóes - Bahia

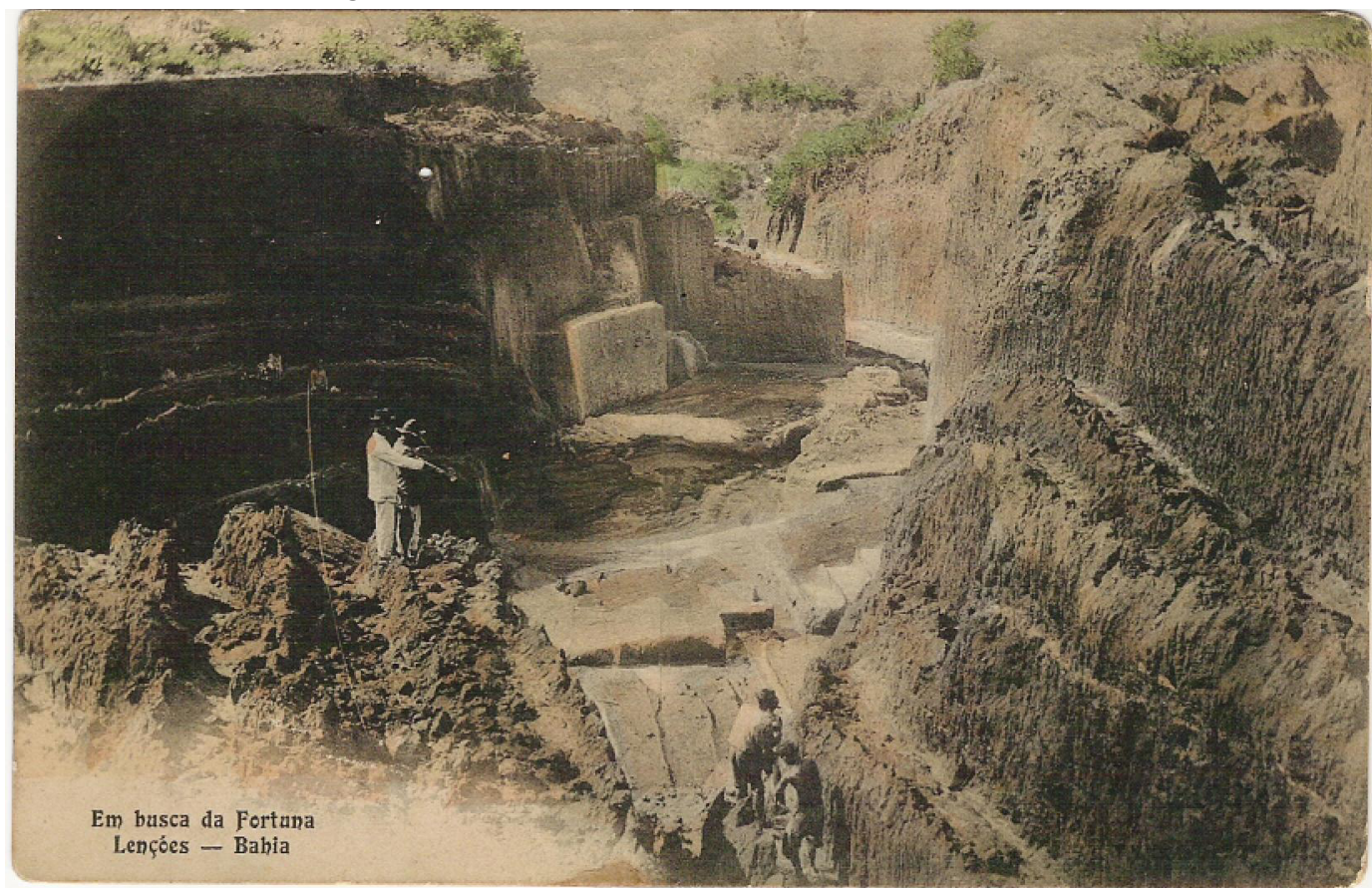

Fonte: Arquivo pessoal de Mestre Osvaldo.

Figura 42 - Sem título

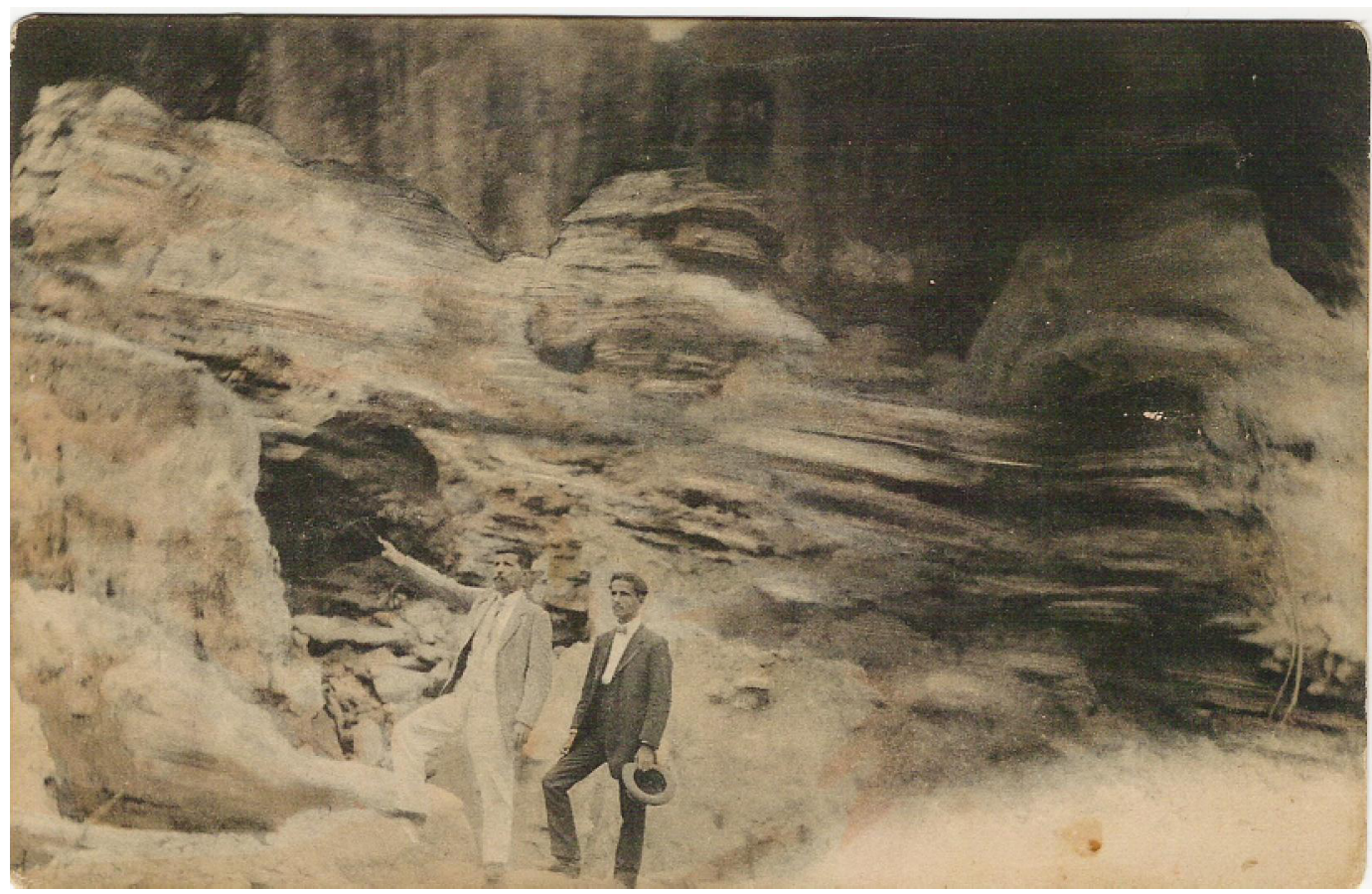

Fonte: Arquivo pessoal de Mestre Osvaldo. 
Figura 43 - Garimpeiros trabalhando. Lençóes - Bahia

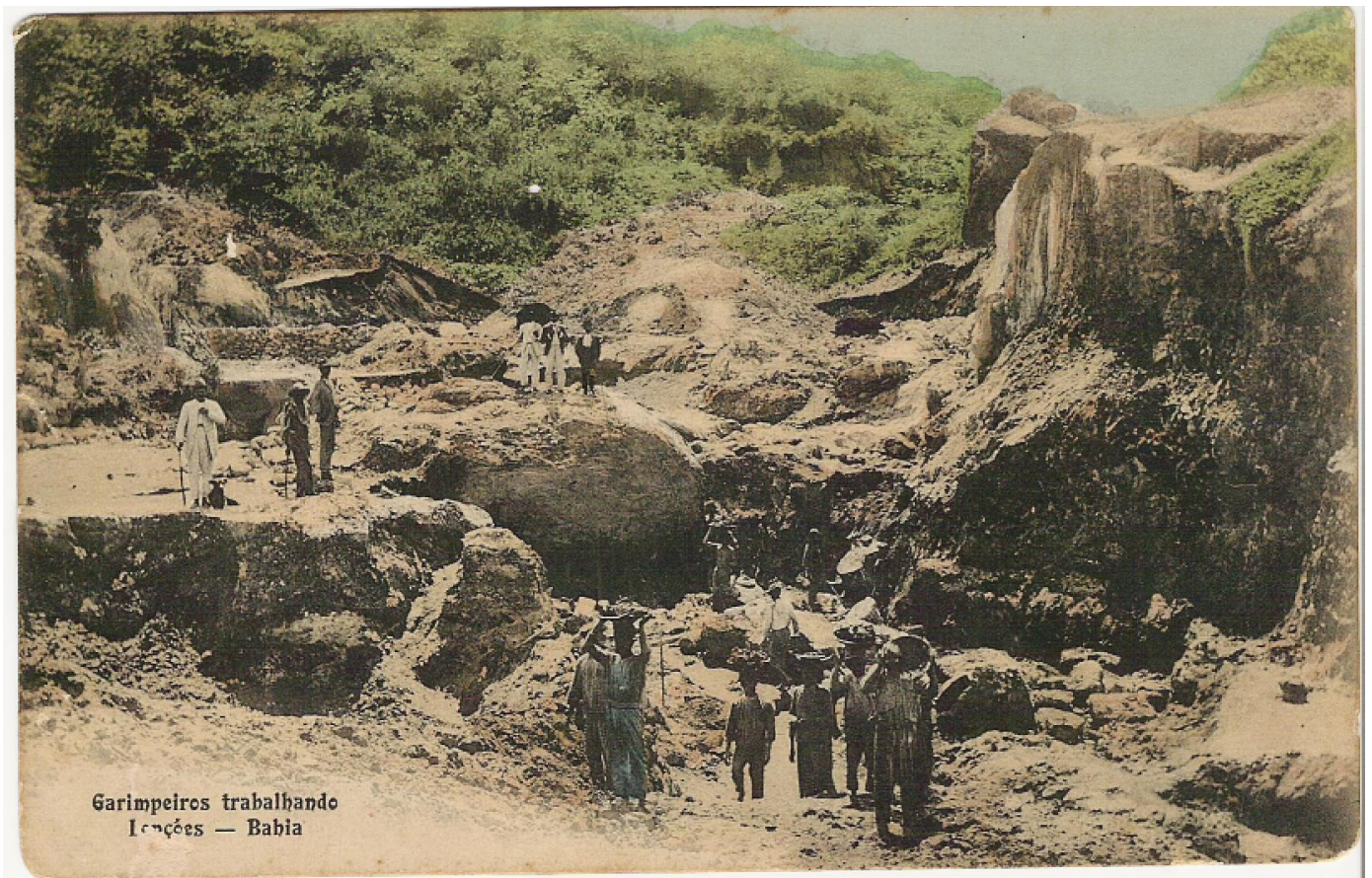

Fonte: Arquivo pessoal de Mestre Osvaldo.

Figura 44 - Em visita a garimpos. Lençóes - Bahia

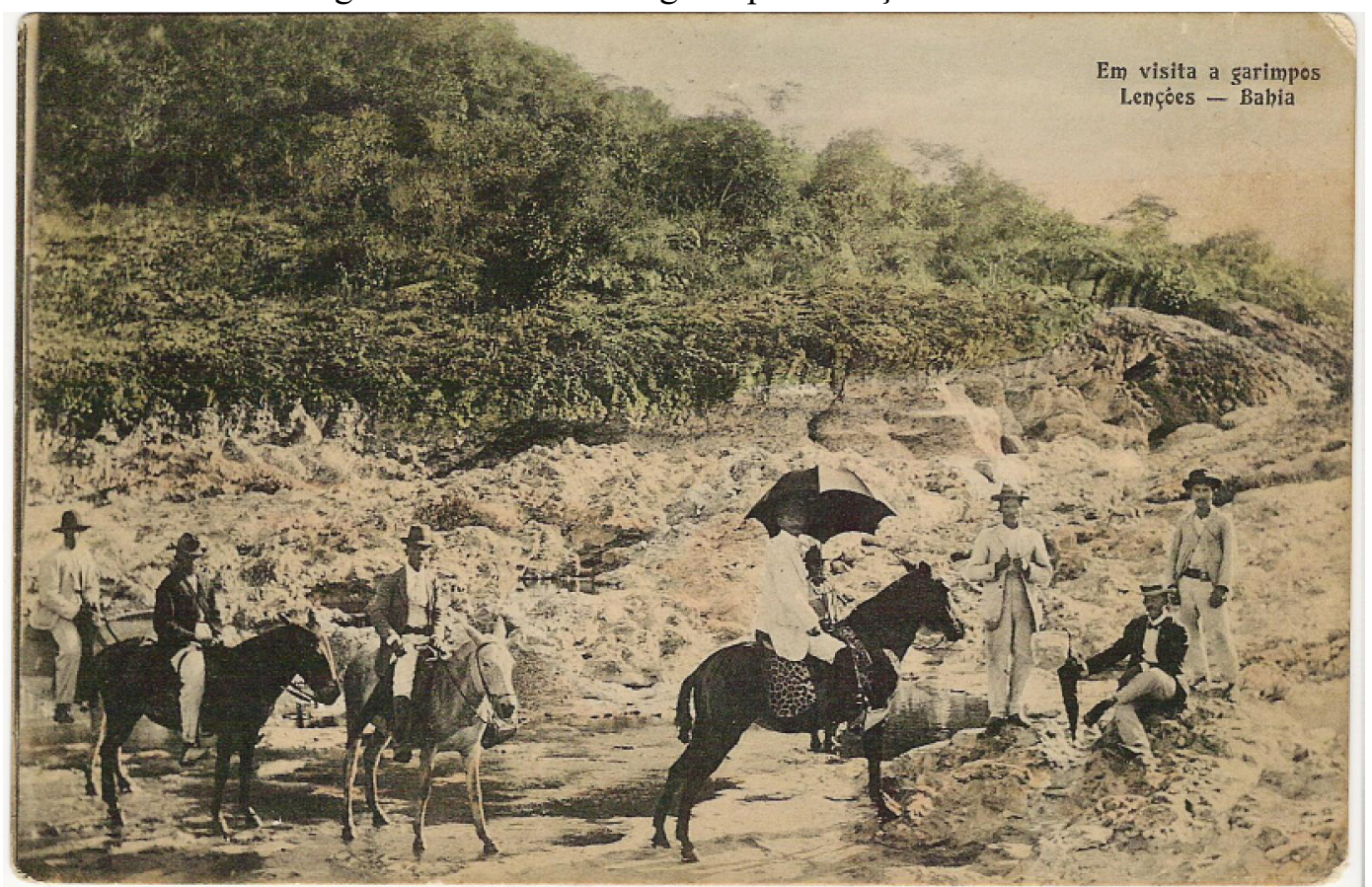

Fonte: Arquivo pessoal de Mestre Osvaldo. 
Figura 45 - Um admirador da natureza Lençóes - Bahia

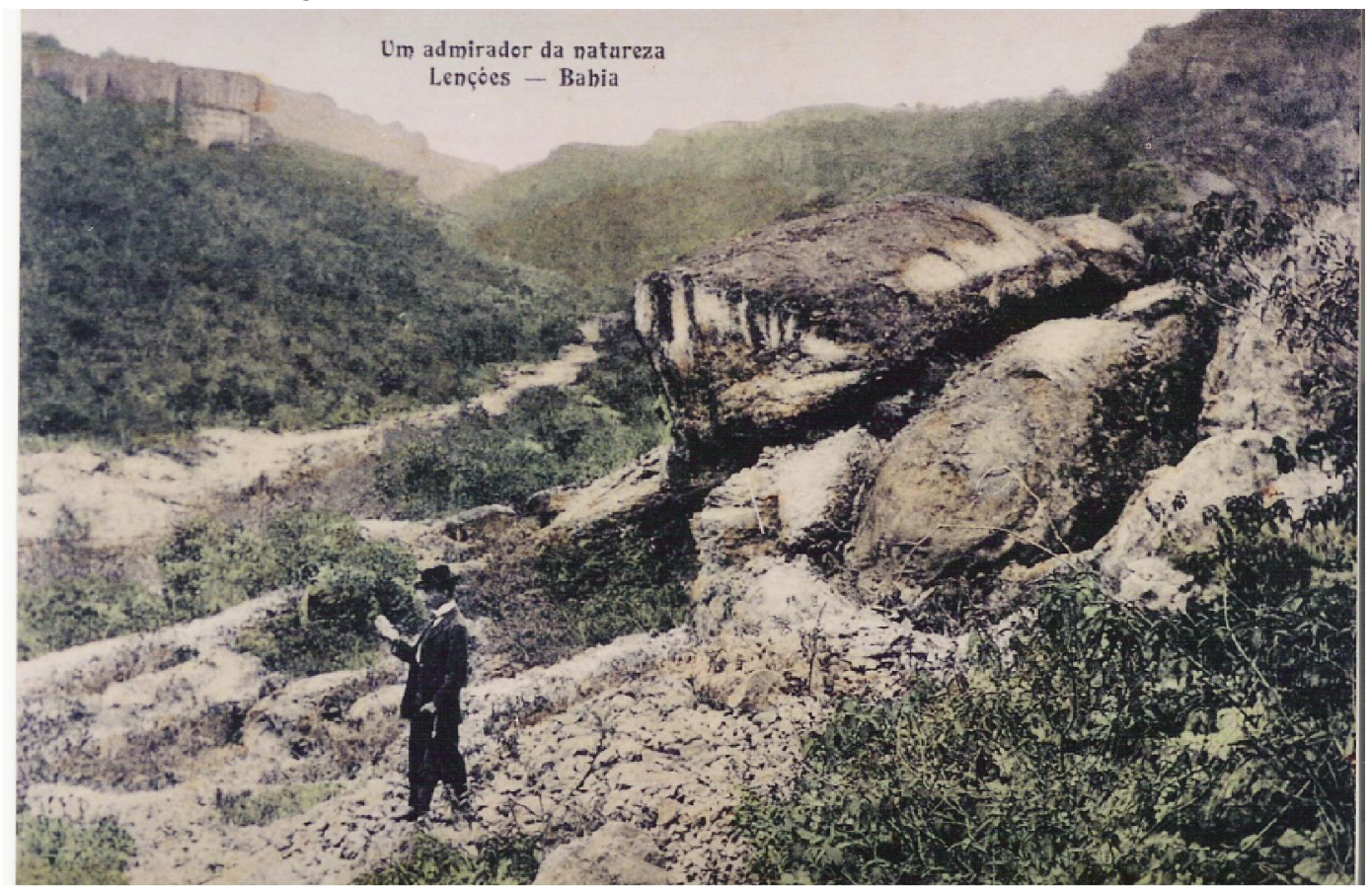

Fonte: Arquivo pessoal de Mestre Osvaldo.

Figura 46 - Veneno-Garimpo de diamantes e carbonatos. Lençóes - Bahia

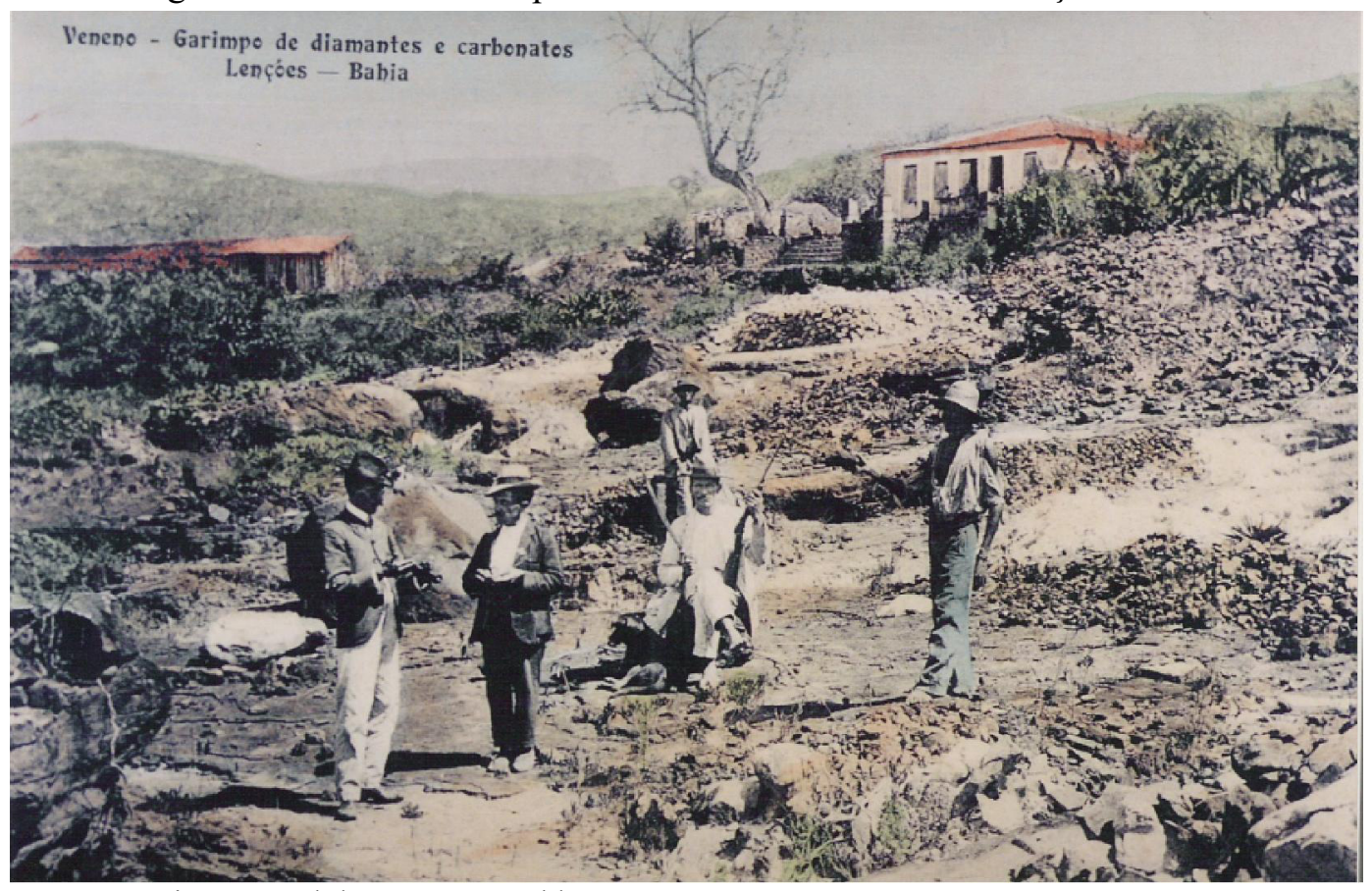

Fonte: Arquivo pessoal de Mestre Osvaldo. 
Figura 47 - Garimpeiros em trabalho. Lençóes - Bahia

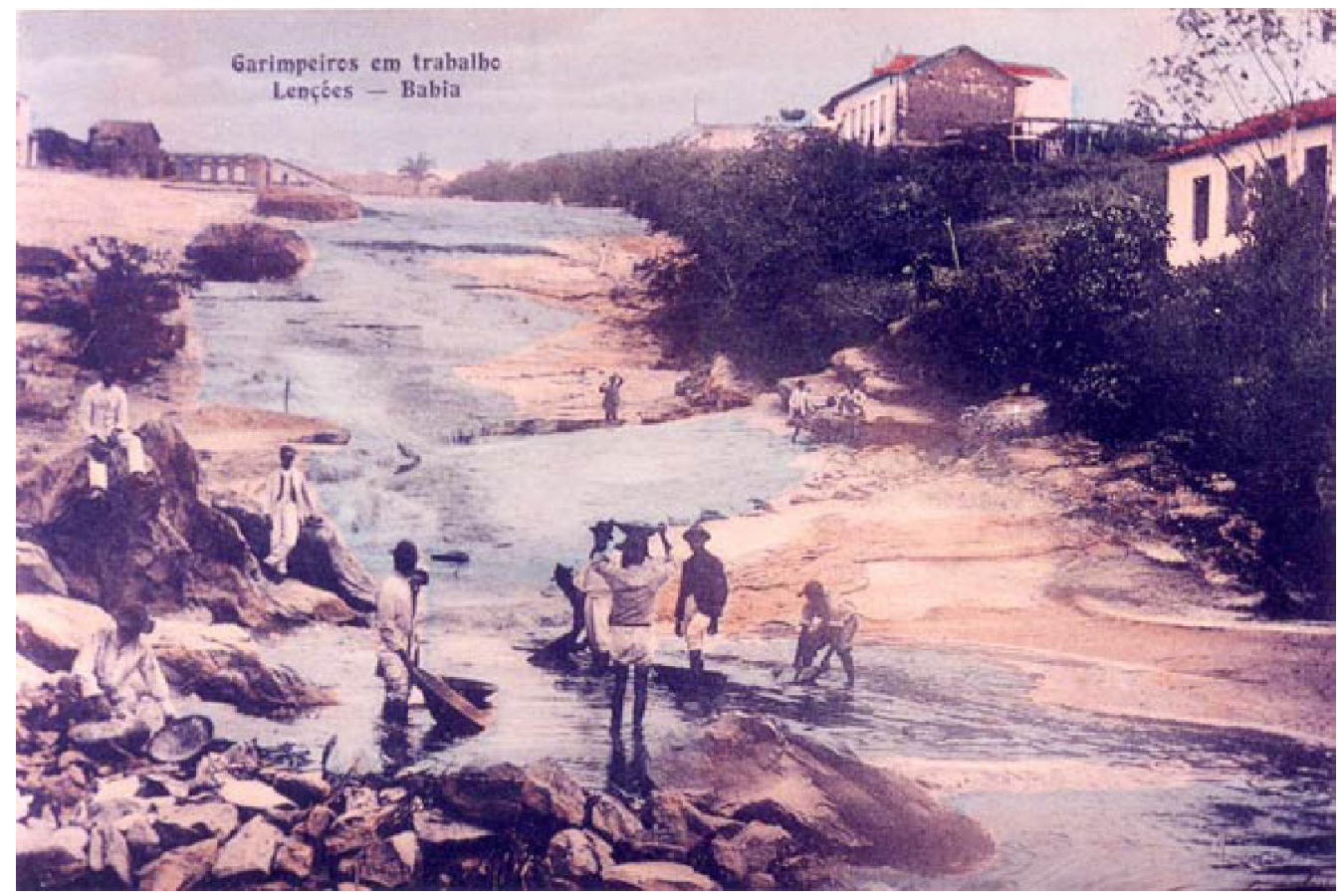

Fonte: Arquivo pessoal de Mestre Osvaldo.

Figura 48 - Um trecho da Cidade de Lençóes. Bahia - Brazil

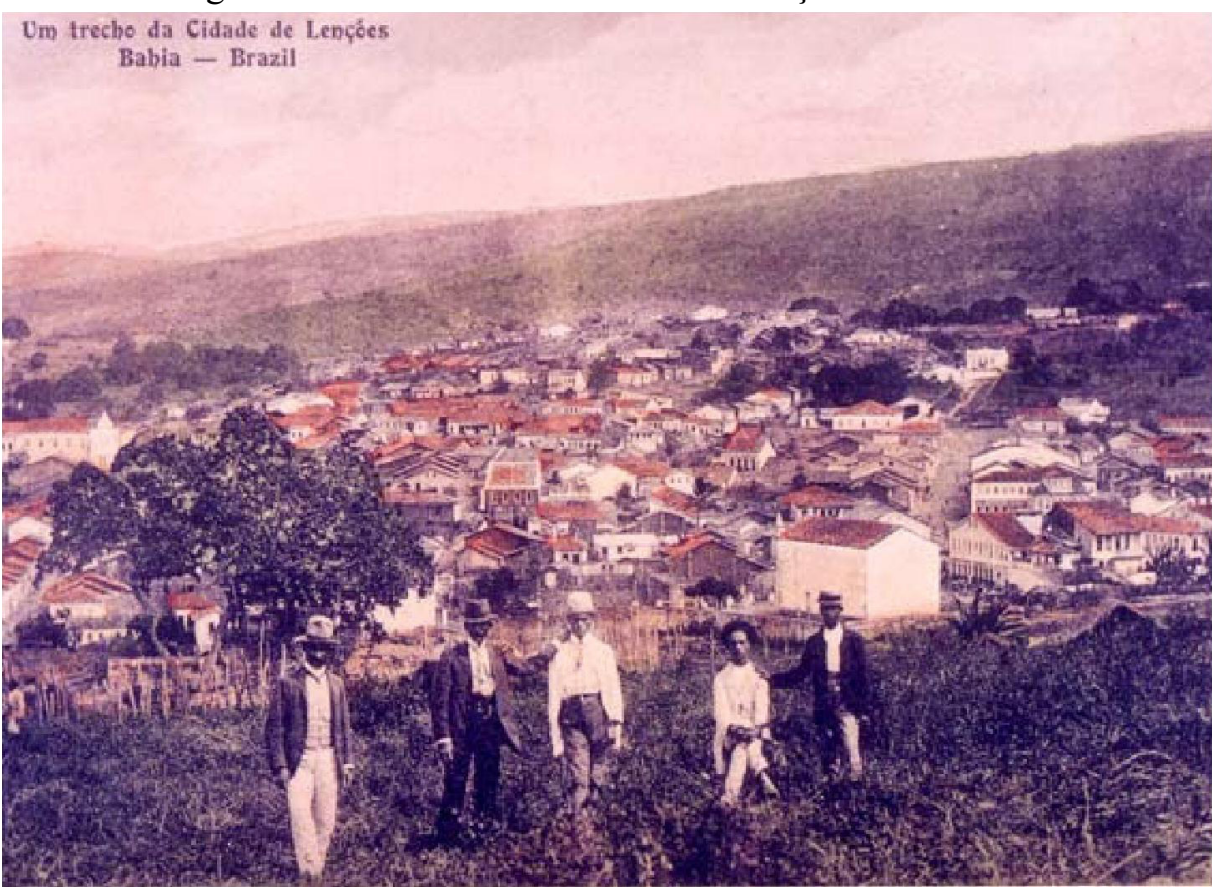

Fonte: Arquivo pessoal de Mestre Osvaldo. 


\section{ANEXO B - Fotografias do cônsul estadunidense Henry Watson Furniss}

Imagens produzidas pelo cônsul estadunidense Henry Watson Furniss. O médico negro desempenhou a função diplomática em Salvador entre os anos de 1898 e 1905, período durante o qual fez uma série de excursões ao interior do estado. As imagens da região das Lavras Baianas aqui agrupadas ilustraram o artigo "Diamonds and Carbons in Brazil", de autoria do próprio cônsul e publicado no número 69 da revista "Рориlar Science" de 1906. Além de ilustrarem também dois artigos do geólogo Orville Derby: The Serra do Espinhaço, Brazil, Journal of Geology (Derby, 1906); The Geology of the Diamond and Carbonado Washings of Bahia, Brazil (Derby, 1907). Para mais informações sobre o fotógrafo consultar: Dr. Henry W. Furniss, Cônsul afro-americano na Bahia, 1898-1905 (Losh, 2009). 
Figura 49 - O maior carbonato encontrado.

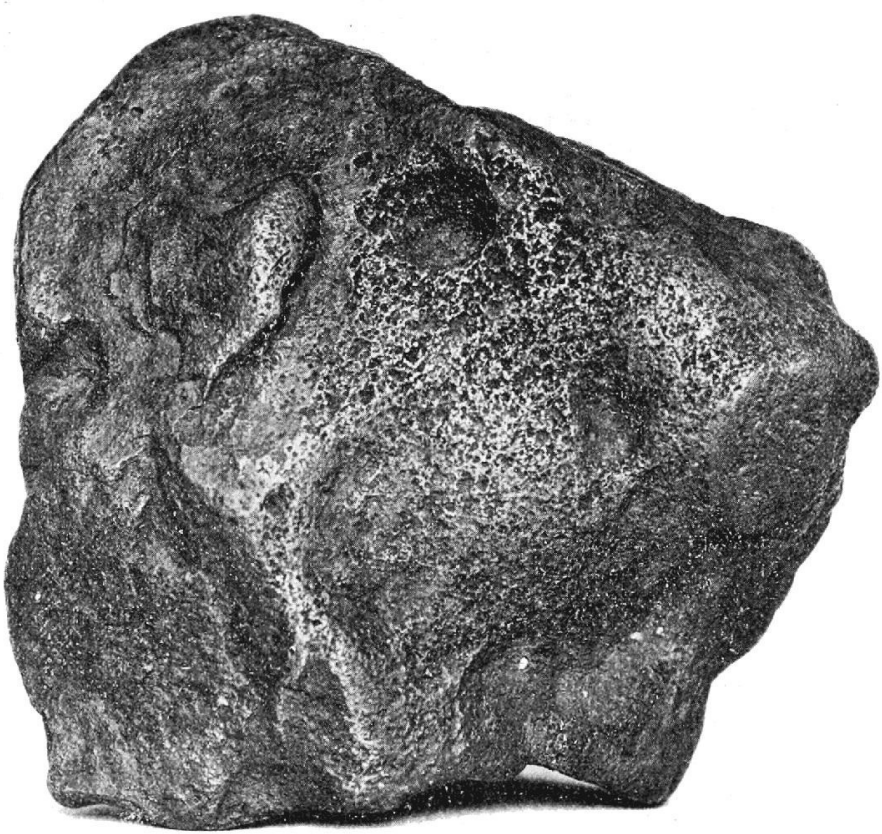

Fonte: Revista "Popular Science" n 69, 1906

Figura 50 - Casa de um rico proprietário de mina.

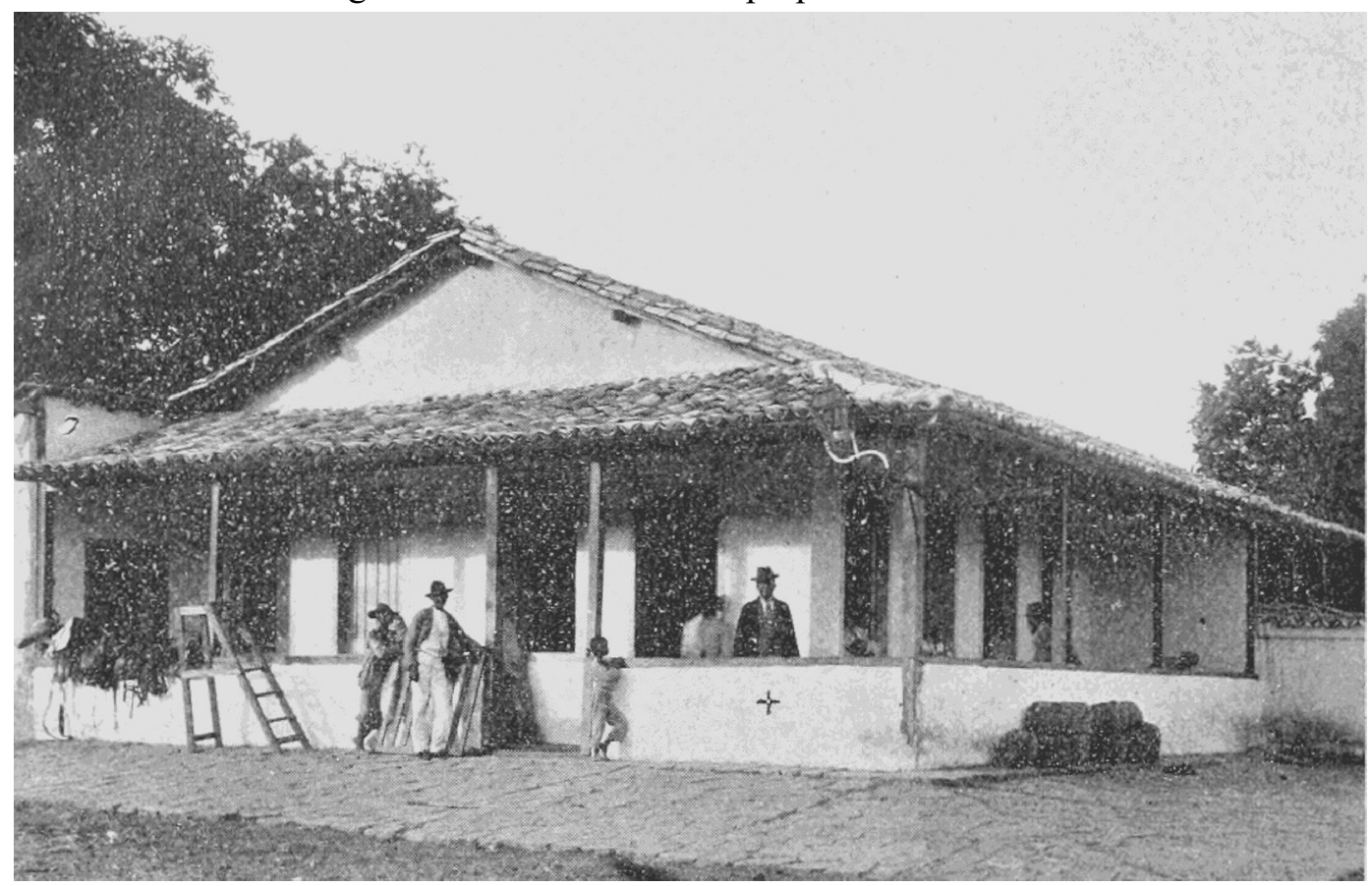

Fonte: Revista "Popular Science" n 69, 1906 
Figura 51 - Casa de garimpeiro construída em saliência mineirada.

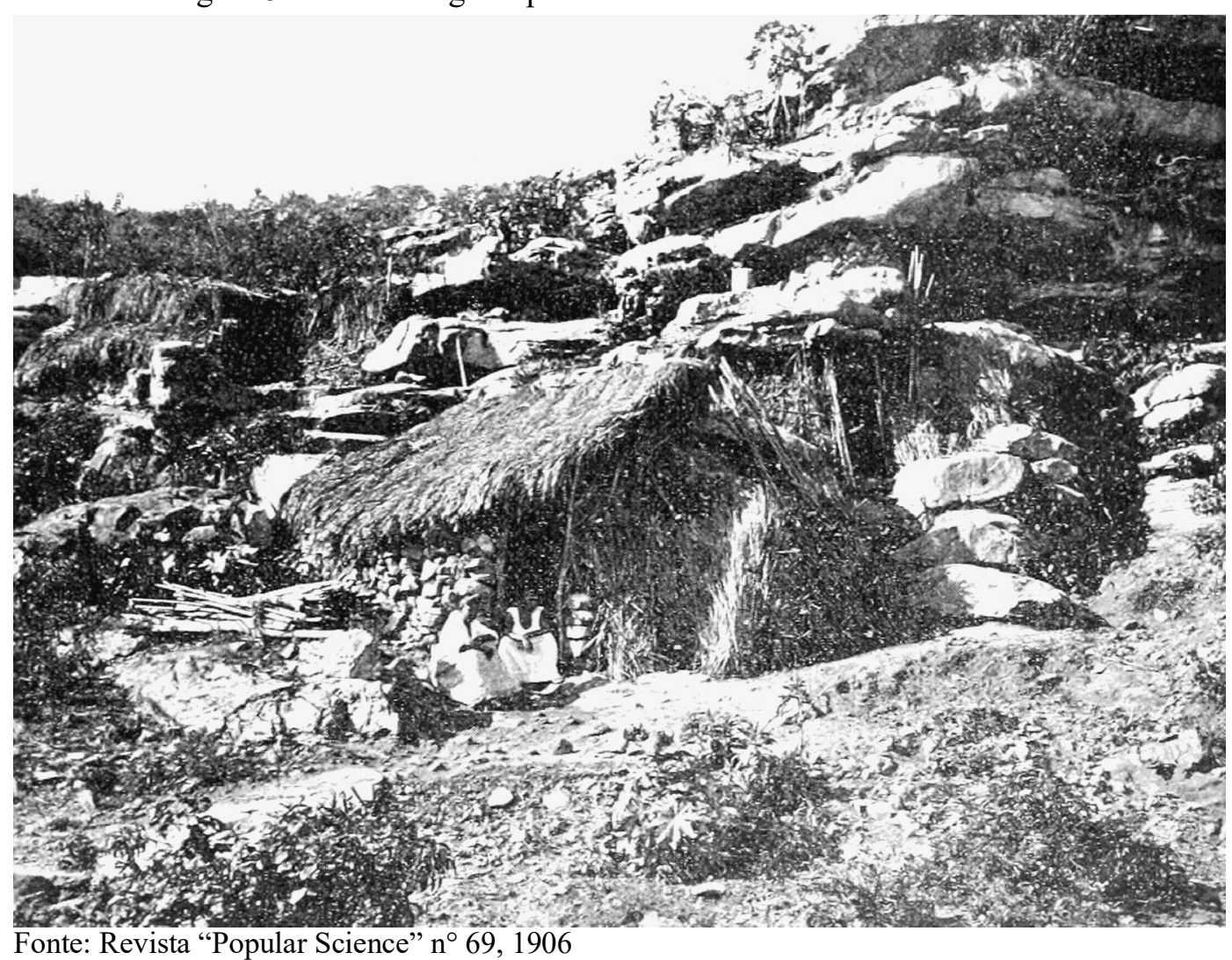

Figura 52 - Método garimpeiro de remoção de subsolo para expor o cascalho.

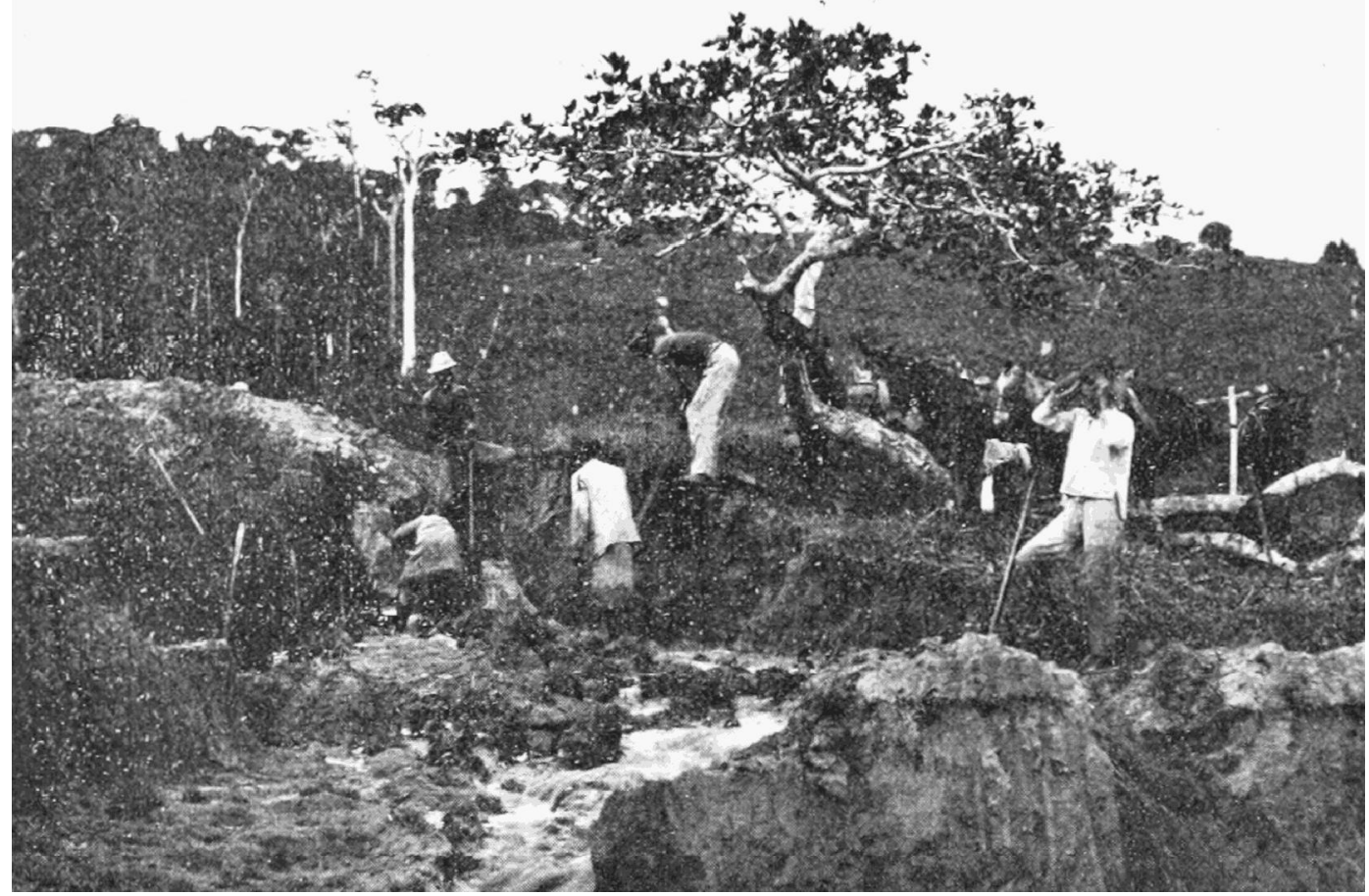

Fonte: Revista "Popular Science" n 69, 1906 
Figura 53 - Concentração final e lavagem em batéias.

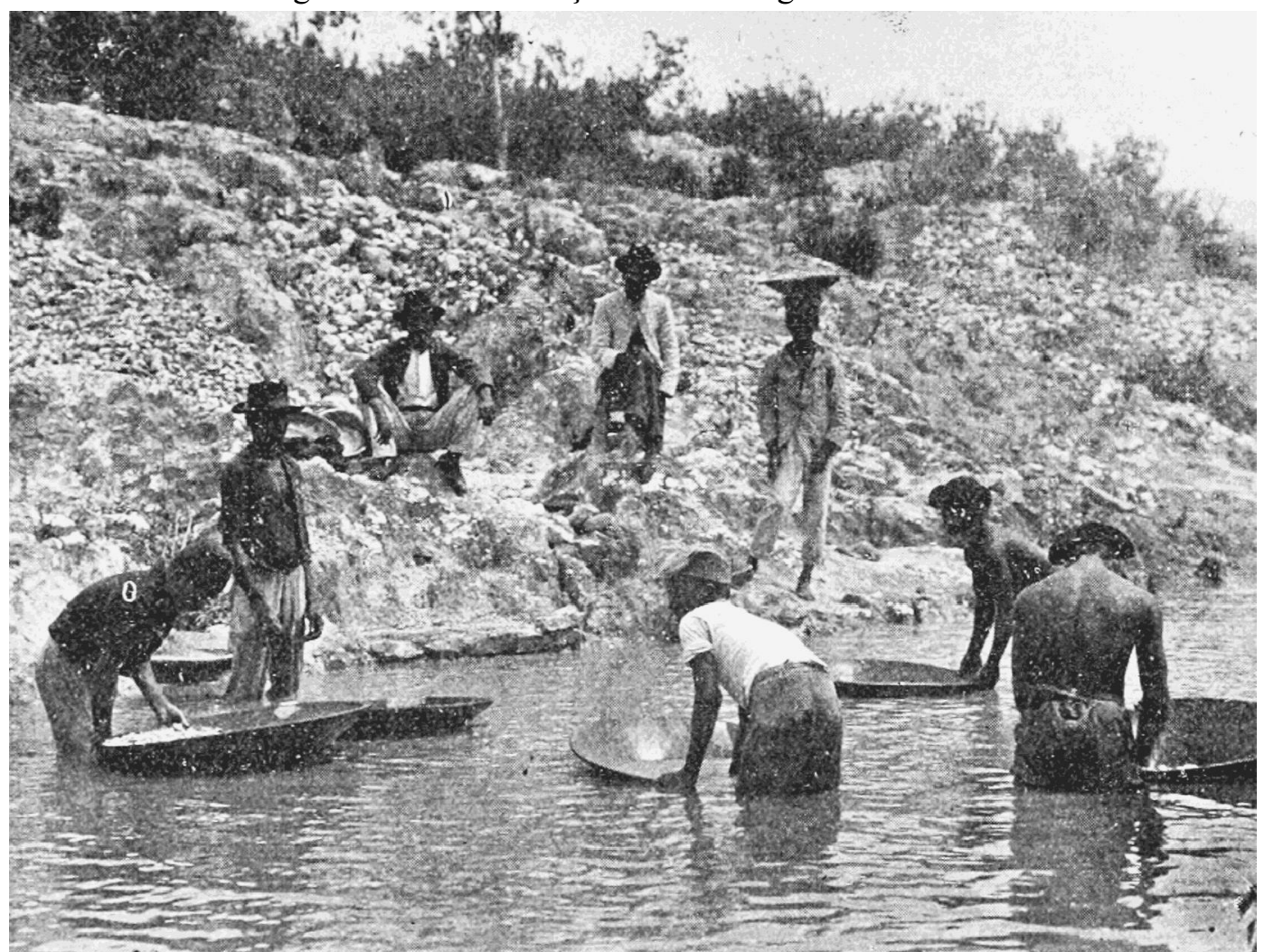

Fonte: Revista "Popular Science" n 69, 1906

Figura 54 - Garimpeiros escoando água para coletar cascalho.

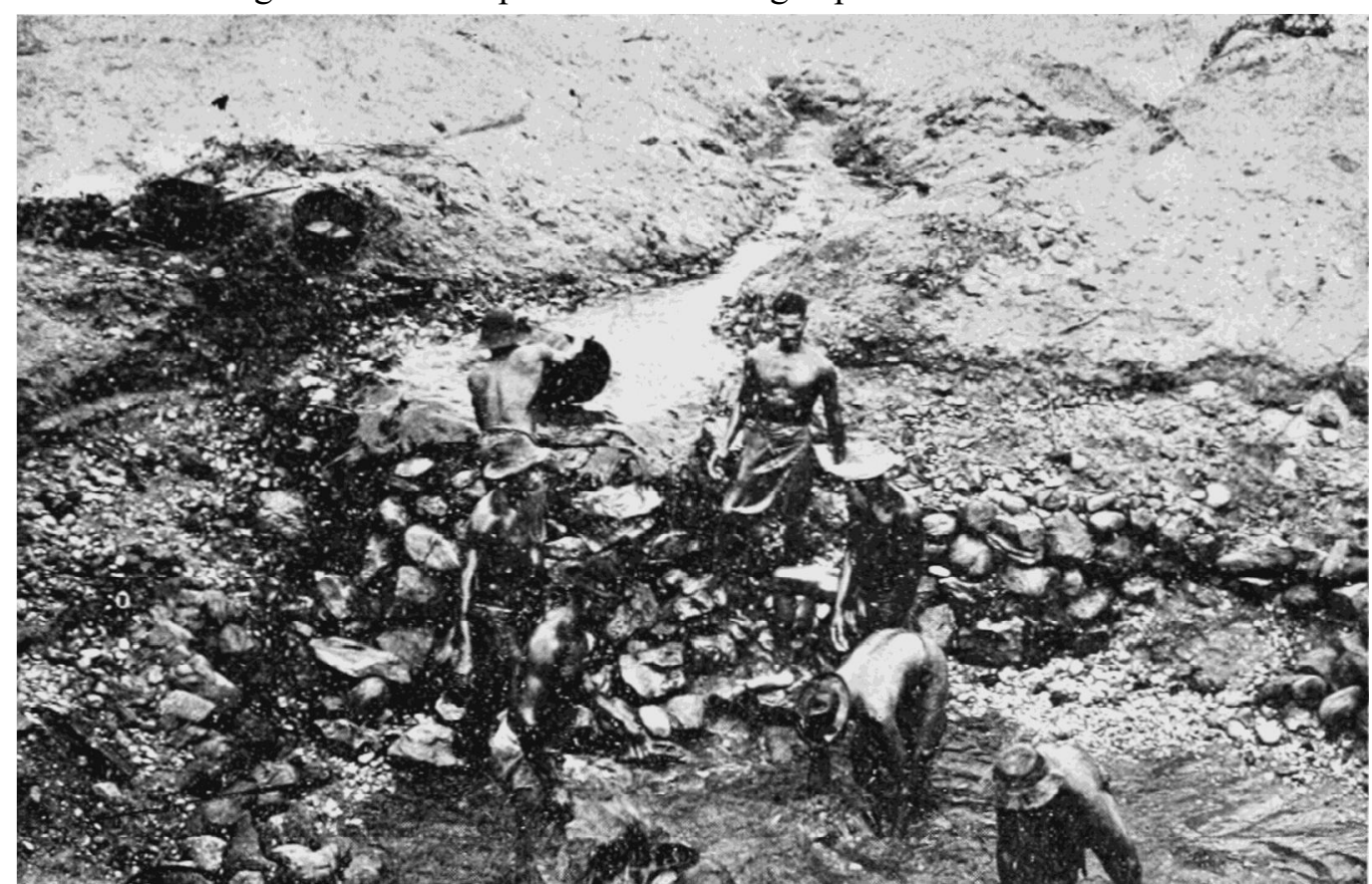

Fonte: Revista "Popular Science" nº 69, 1906. 
Figura 55 - Vista de Santa Isabel do Paraguassu.

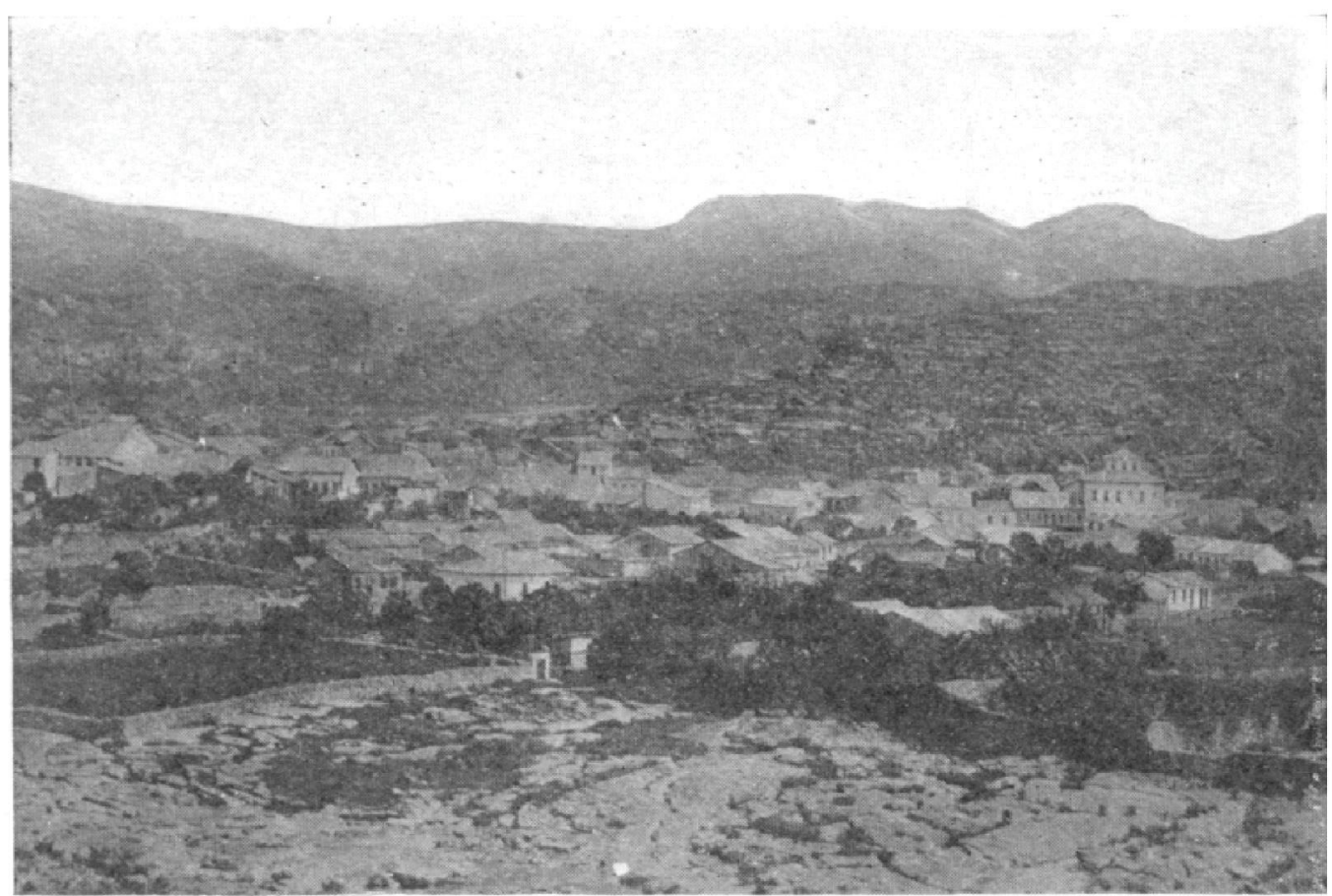

Fonte: The Serra do Espinhaço, Brazil”, Journal of Geology vol. XIV, número 5 (1906).

Figura 56 - Lençóis, construída no solo de rolamento de diamantes.

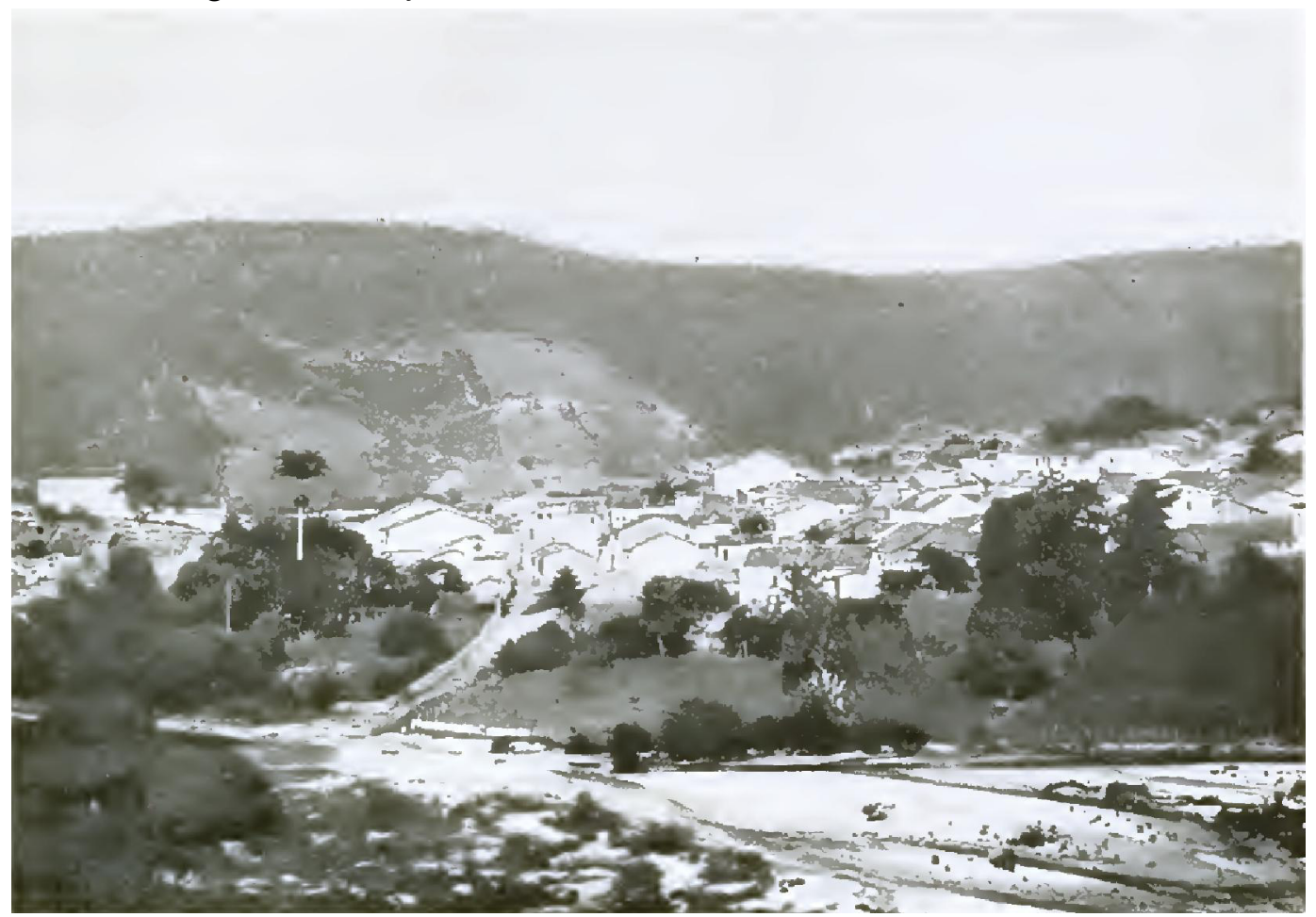

Fonte: The Geology of the Diamond and Carbonado Washings of Bahia, Brazil" Annual Report of the Smithsonian Institution, 1906, Washington DC: Government Printing Office, 1907. 
Figura 57 - Um mergulhador nativo nu se preparando para ir para baixo, suspenso na corda é um tubo de transporte de ar para um homem em traje de mergulho já no fundo.

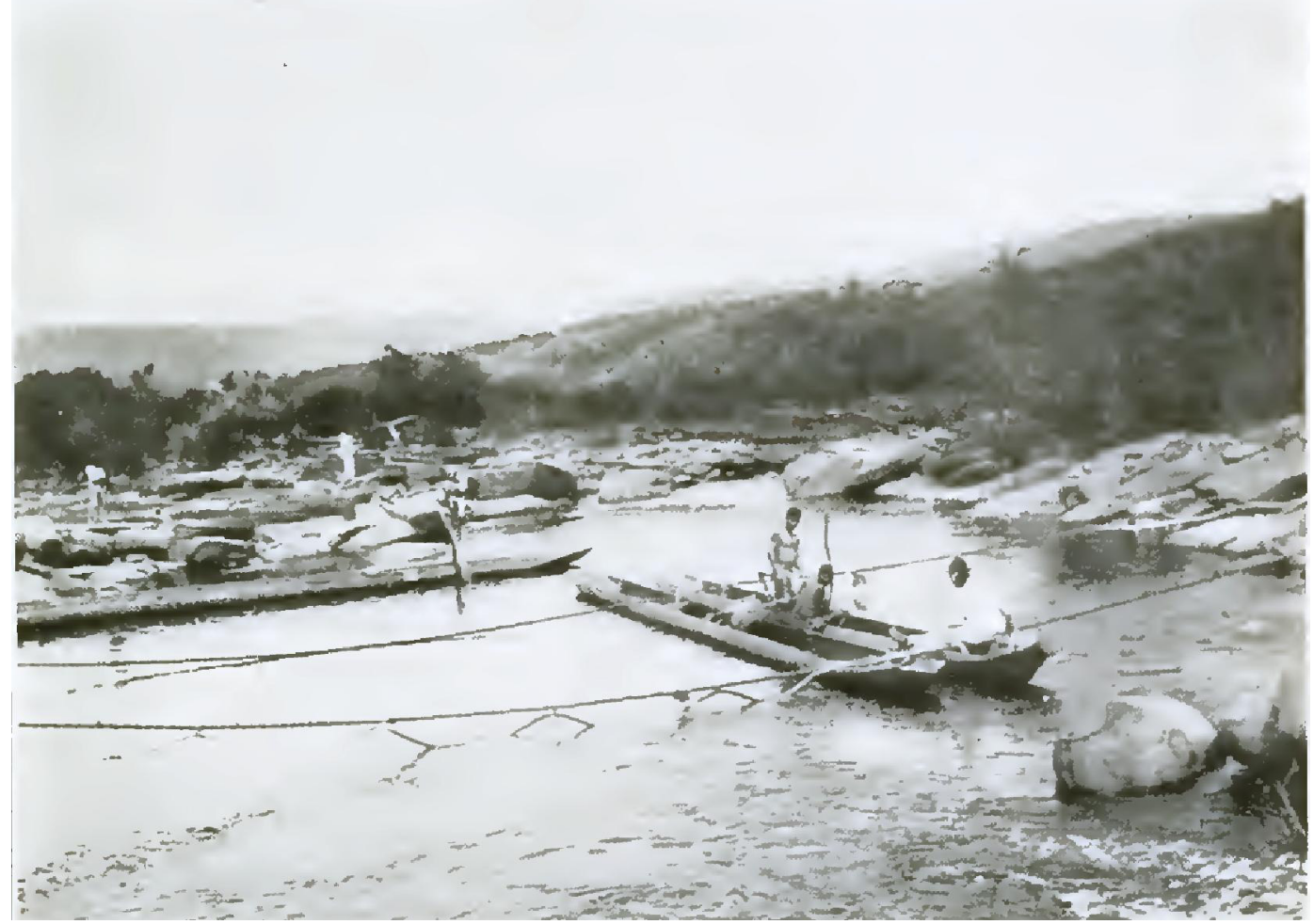

Fonte: The Geology of the Diamond and Carbonado Washings of Bahia, Brazil” Annual Report of the Smithsonian Institution, 1906, Washington DC: Government Printing Office, 1907.

Figura 58 - Garimpeiros concentrando cascalho com enxadas em valas de água.

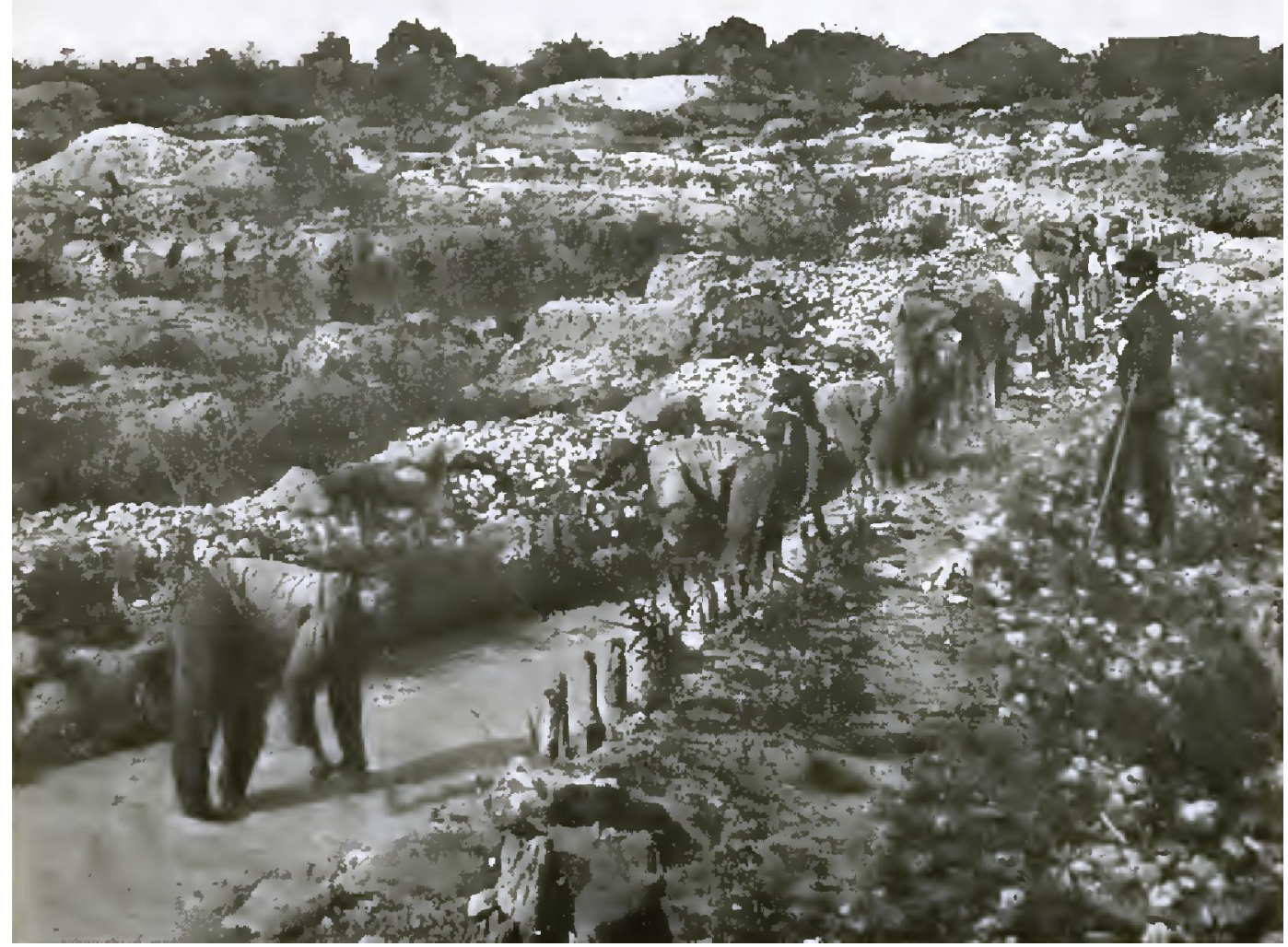

Fonte: The Geology of the Diamond and Carbonado Washings of Bahia, Brazil" Annual Report of the Smithsonian Institution, 1906, Washington DC: Government Printing Office, 1907. 


\section{ANEXO C - Fotografias do jornal "O Sertão"}

Esta é uma pequena amostra de páginas ilustradas por fotografias do jornal "O Sertão”, que foi criado em Lençóis em 1921 pelo Cel. Horácio de Queiroz Matos, existiu, com períodos de inoperância, até 1950. Foi propriedade de outros donos após o assassinado do famoso coronel em 1931. Para maiores informações bibliográficas sobre Horácio de Matos ver: O chefe Horácio de Matos (Chagas, 1996) e Jagunços e Heróis (Moraes, 1997). Esta pesquisa teve acesso a uma parte significativa dos exemplares de " $O$ Sertão" a partir do material digitalizado dos originais do acervo pessoal de Heraldo Barbosa Filho pela pesquisadora Liziane Peres Mangili, que gentilmente os cedeu. 
Figura 59 - Página do jornal O Sertão do dia 31 de julho de 1921.

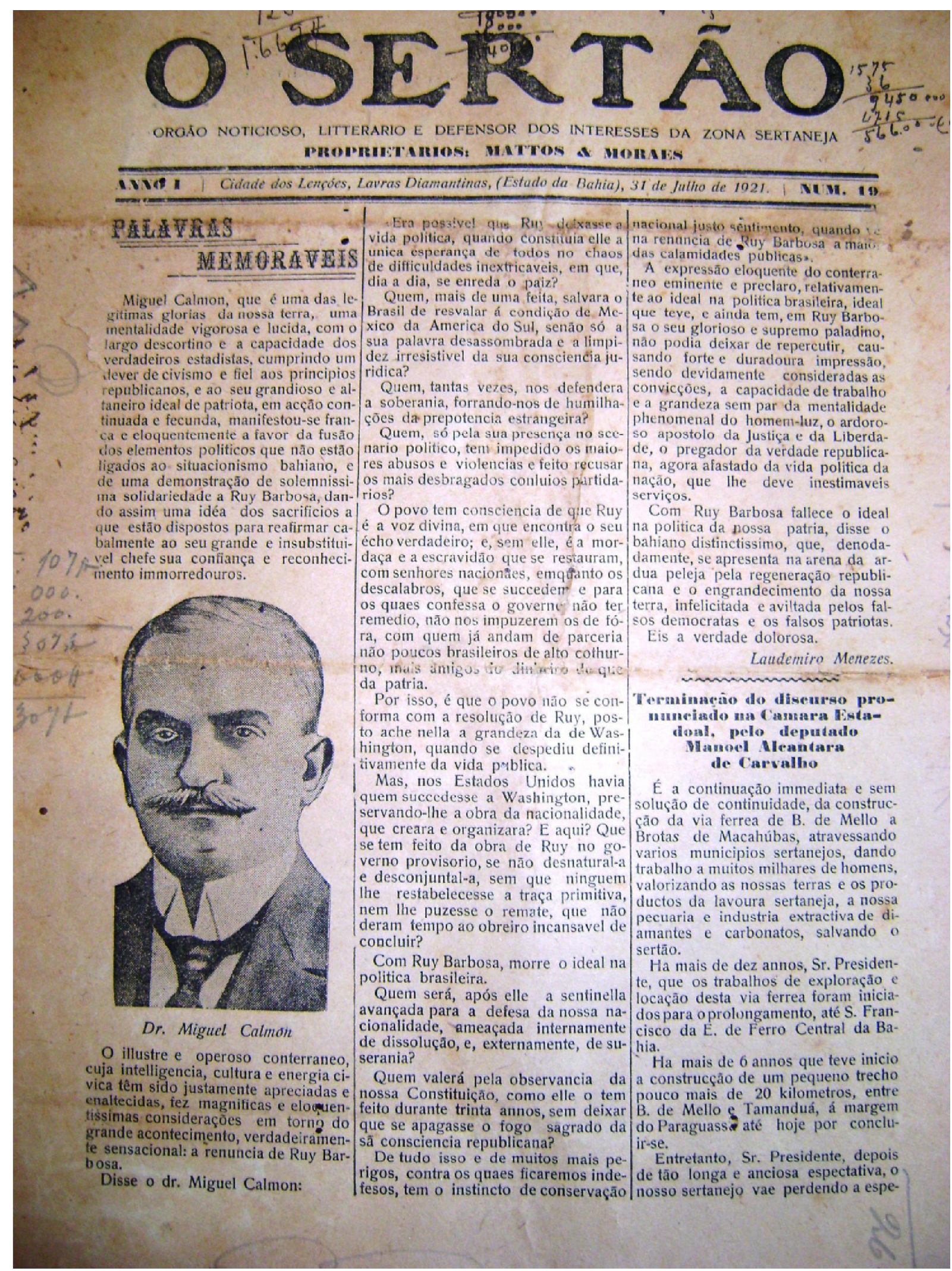

Fonte: Arquivo pessoal de Heraldo Barbosa Filho. 
Figura 60 - Página do jornal O Sertão do dia 13 de novembro de 1921.

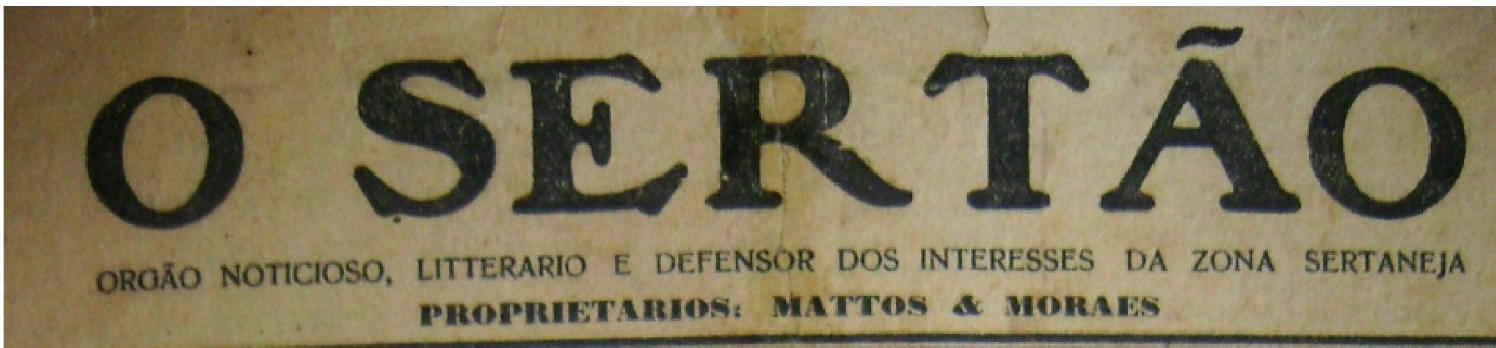

Qvo I I Cidade dos Lençóes, Lavras Diamantinas, (Estado da Bahia), 13 de Novembro de 1921. I NuM. a33

\section{A. PATRIA}

A Patria nắo ế ninguem: são todos, - cada qual tem no seio della o mesmo direito á vida, á palavra, á associaçăo.

Á Patria não é um systema, nem um monopolio, nem uma forma de governo; é o céo, o sol, o povo a tradiçẫo, a consciencia, o lar, o berço dos fithos e o tumulo dos antepassados, a communhão da lei, da lingua e da liberdade.

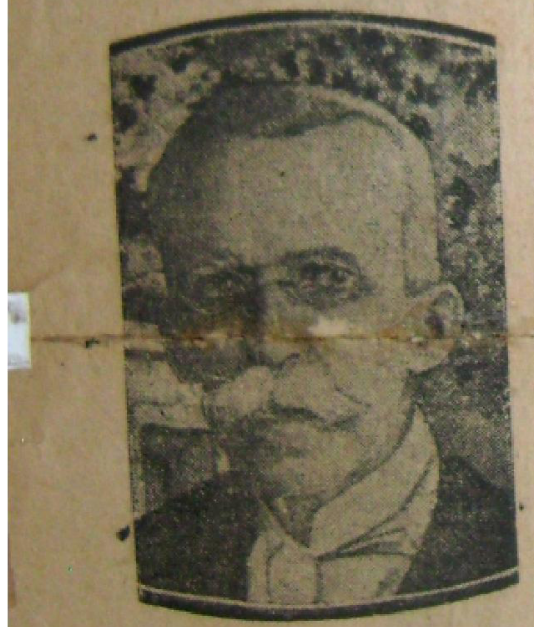

Cons. Ray Barbosa

\section{A Asso-iangè̃o \\ Commercial}

\section{AO GOMMRRCIO}

-A Associaçăo Commercial năo se a poupado a esforços encaminhados no sentido de evitar ao commercio os grandes vexames e inconvenientes, que the resultarão do imposto dos lucros commerciaes.

Assim é que, nestes ultimos dias, se tem ella entendido, através de constantes e numerosos teiegrammas, com as suas dcmais congeneres, dirigindo-se igualment providencias, ao exm. ${ }^{\circ}$ sr. Presidente da Republica e a personalidades representativas do paiz, capazes de beneficamente influirem a favor de uma justa soluç̃̃o ao caso.

Mas a Associação da Bahia, como

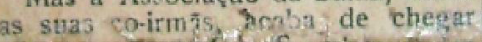
a convruço velute- Engoina twaus os recursos ao seu alcance, sem obter o desejado desenlace das suas nobres pretençōes, que são em ultima analyse, as do proprio commercio.

Da Associação Commercial de Porto Alegre tivemos a communicaça de que é alli opinião geral adoptarse a defesa judiciaria do commercio através de um mandado prohibitorio, com a recusa á apresentação de balanços.

Tambem da Associação Commercial do Rio de Janeiro, como do sr Os que a servem são os que năo Affonso Vizeu, recebemos despachos

invejam, os que nấo infamam, os que telegraphicos, avisando-nos que a alinvejam, os que tho intaman, os que não sublevam, os que não desalentam os que não imnudecem, os que não acobardam, mas resiste, mas esforçam
mas pacificam a justiça, a administra cho pacilicain a justic 0 enthusiasmo.

Porque todos os sentimentos s. porque todos os sentimentos săb benig

No proprio patriotismo armado,

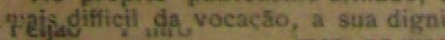
eija dain
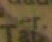
to esta no matar, 1 natc pode; ludida Associação, após ter-se valido rou não apresentar balanços e acon-

selhar ao commercio recorrer ao poder judiciario, por intermedio igualmente do interdicto prohibitorio, para o que já contractou advogado, que a seu proprio eonsultor juridico, dr. James Darcy. A Associaçá Comnercial da Bahia vê-se na conti gencia congeneres, a que deliberou hoje, em reuniăo extrordinaria da suls Directoria. Assim, pois, e em conclusáo: a Asaciaça Commercial toma a liberade de aconselhar á praça que se L3 submetta á exigencia da apresennáb de balanços, devendo valer-se, quanto á cobrança do imposto sobre os lucros de 1920, da mesma providencia do interdicto prohibitorio, para a que se poderá o Commercio entender com o advogado da Associaçāo, sr. dr. Homero Pires .

Bahia, 25 de Outubro de 1921. Rodolpho de Souza Martins, Presidente.

José da Costa Magalhães, Secretario.

PARA

INTENDENTE DE LENÇÓES

Armando Spinola Pereira

Ao eleitorado des-

\section{te Municipio}

O Directorio politico Lençoense, tendo conhecimento de atse fol o cel.

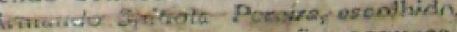
$\mathrm{m}$ á reuniào para esse fim corivoca da eque teve logar no dia 9 do findante, em casa do cel. Horacio de Mattos, Delegado Regional, para it:Matos, Delegado Regional, para ir la sua maioria, apoiar a referida can de confiado ao referido Cidadão o governo deste Municipio, terāo os seus habjtantes de gosar de uma epoca de paz e fruir os beneficos effeitos do progresso, pois o referido Cidadäo dispõe de todos os requisitos necesdispoe de todos os raracter impollut. sarios, já pelo seu caracter impollum nais ainda pelo seu espirito de ordem e progresso alliados ao munto co.

$\mathrm{Na}$ convição absoluta de que : ua espectativa nảo será mallograda, pede e espera do digno eleitorado o seu votó na eleição a realizar-se
13 de Novembro p. futuro.

O Directorio agradecido. Manoel Alcantara de Carvalho P. Dr. Zecarlos Barretto-V. P. Prof. Antonio C. de Assis-1 $1^{\circ} \mathrm{S}$. Exuperio Martins Andrade - 2. S. Nelson Alcantara de Carvallo. Faustino Castra.

Aljredo Gomes de Azevedo. 
Figura 61 - Página do jornal O Sertão do dia 18 de dezembro de 1921

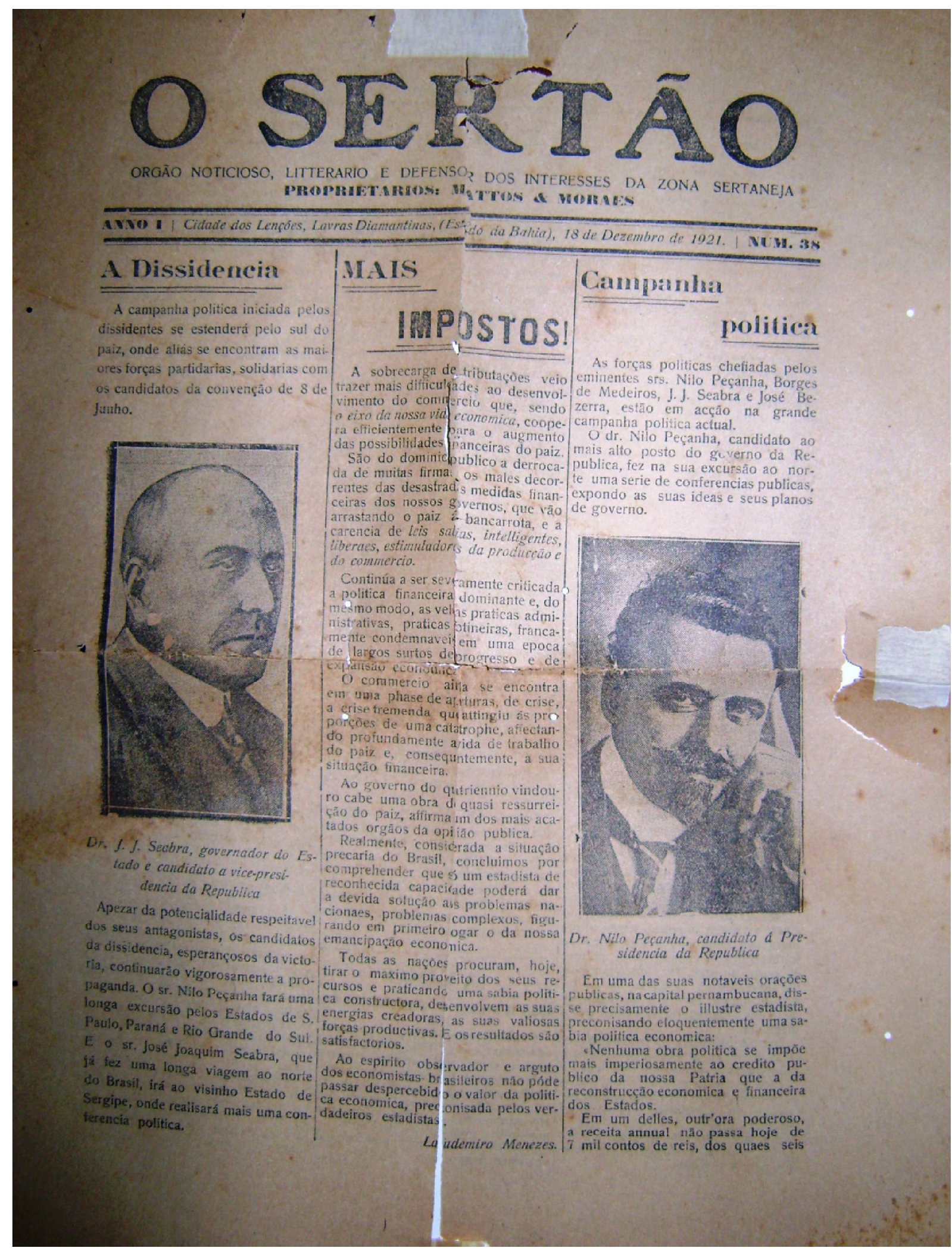

Fonte: Arquivo pessoal de Heraldo Barbosa Filho. 
Figura 62 - Página do jornal O Sertão do dia 29 de outubro de 1922.

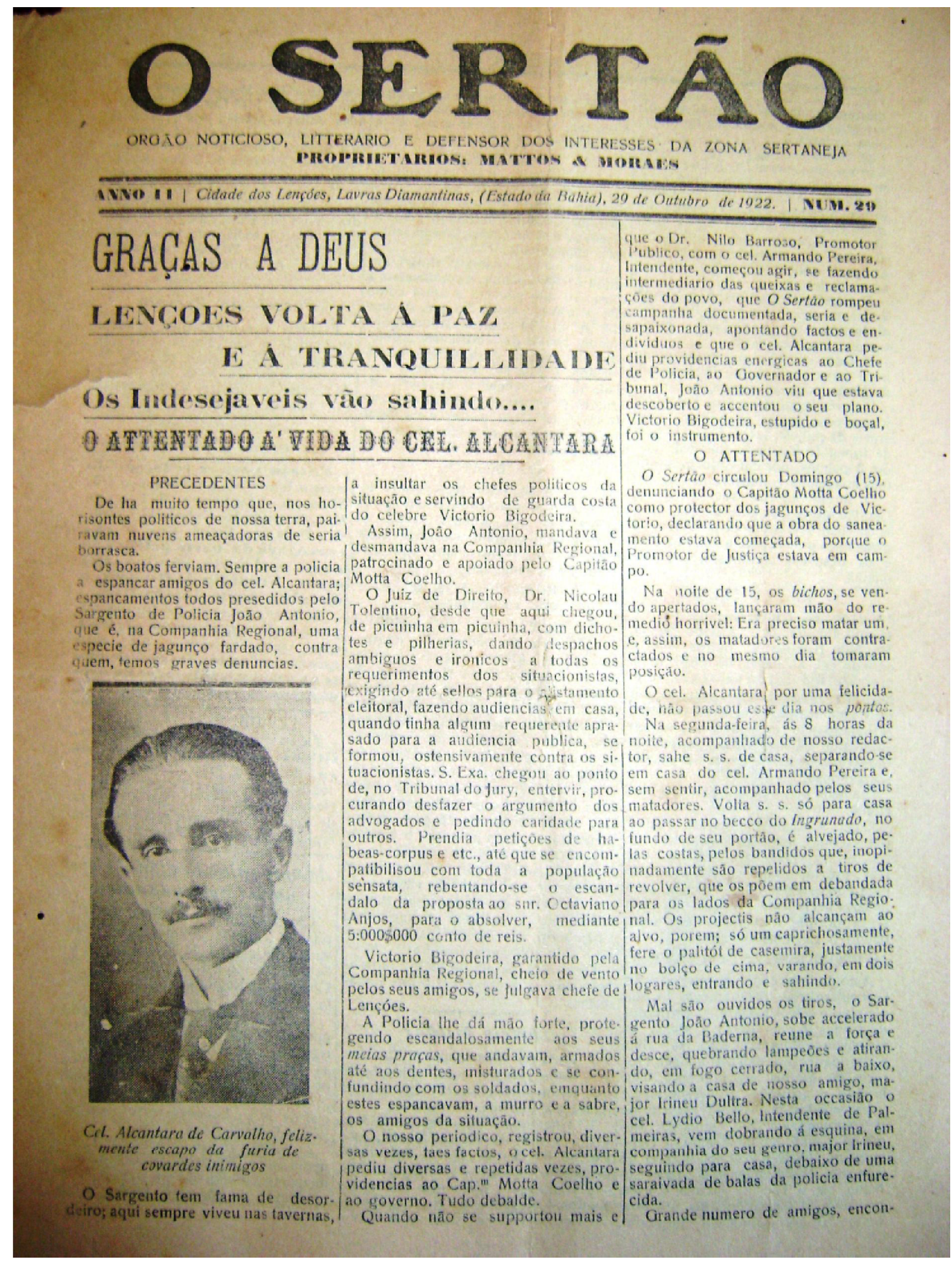

Fonte: Arquivo pessoal de Heraldo Barbosa Filho. 
Figura 63 - Página do jornal O Sertão do dia 24 de maio de 1931.

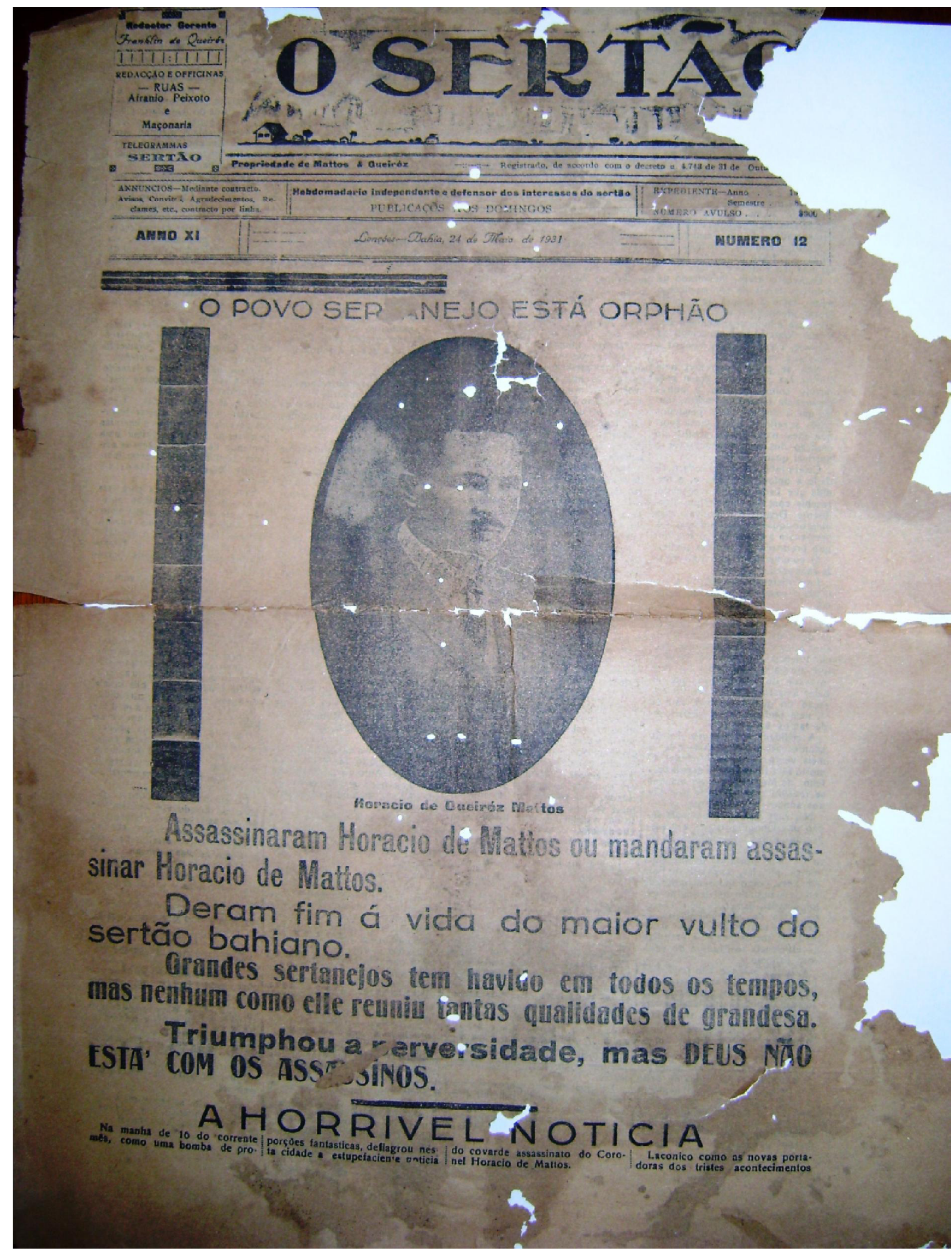

Fonte: Arquivo pessoal de Heraldo Barbosa Filho. 
Figura 64 - Página do jornal O Sertão do dia 15 de maio de 1932.

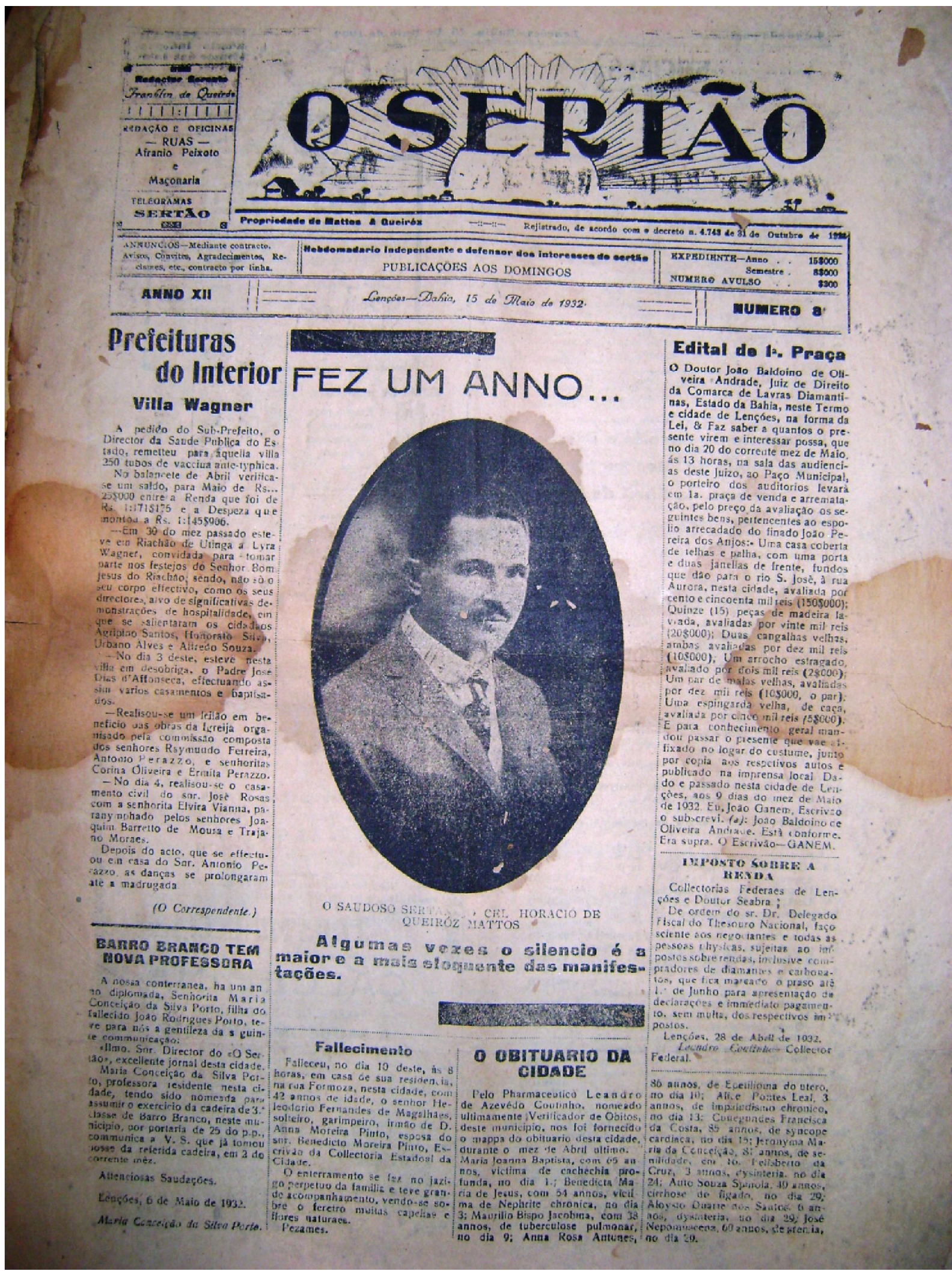

Fonte: Arquivo pessoal de Heraldo Barbosa Filho. 
Figura 65 - Página do jornal O Sertão do dia 5 de agosto de 1934

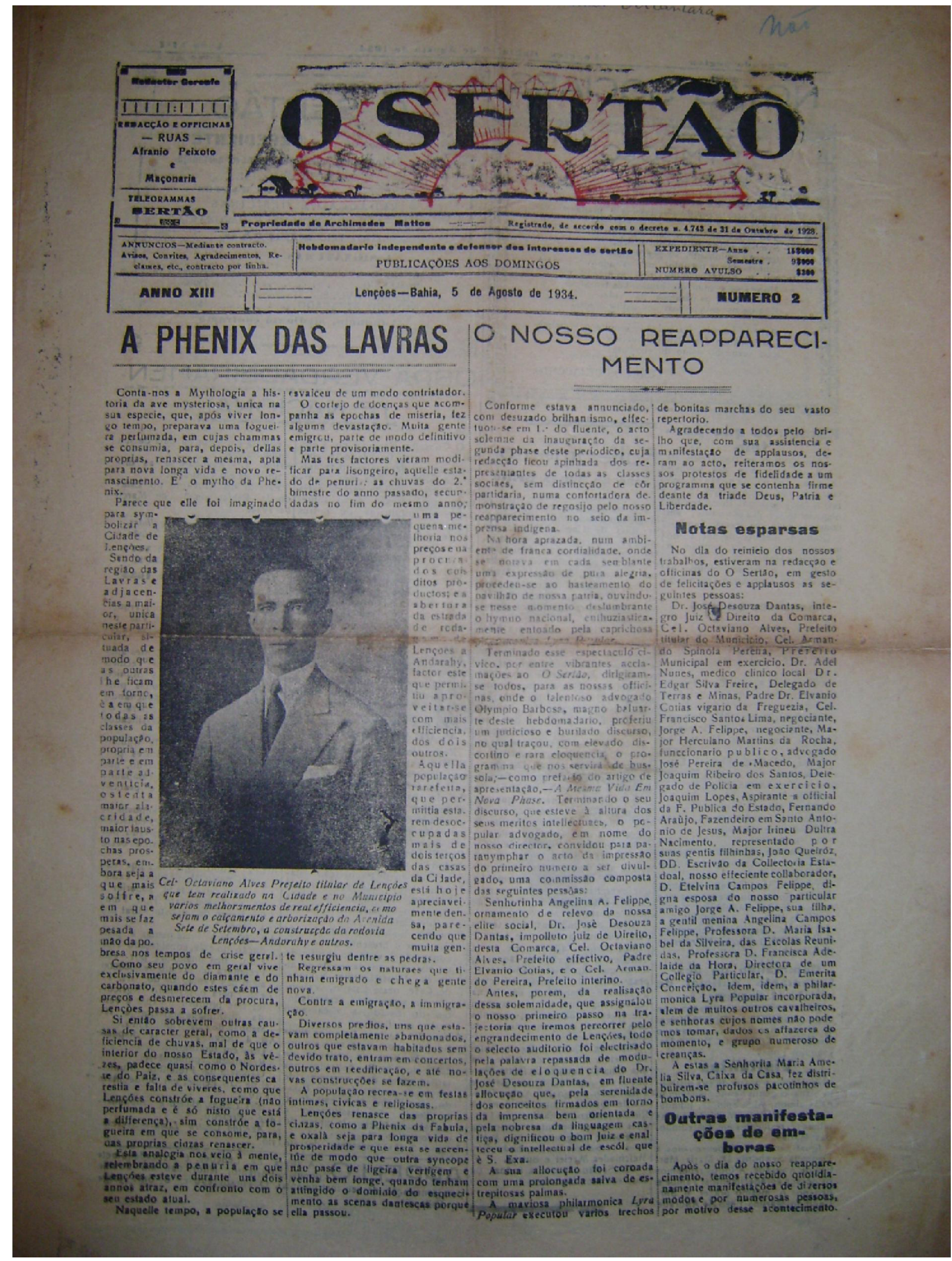

Fonte: Arquivo pessoal de Heraldo Barbosa Filho. 
Figura 66 - Página do jornal O Sertão do dia 28 de abril de 1935.

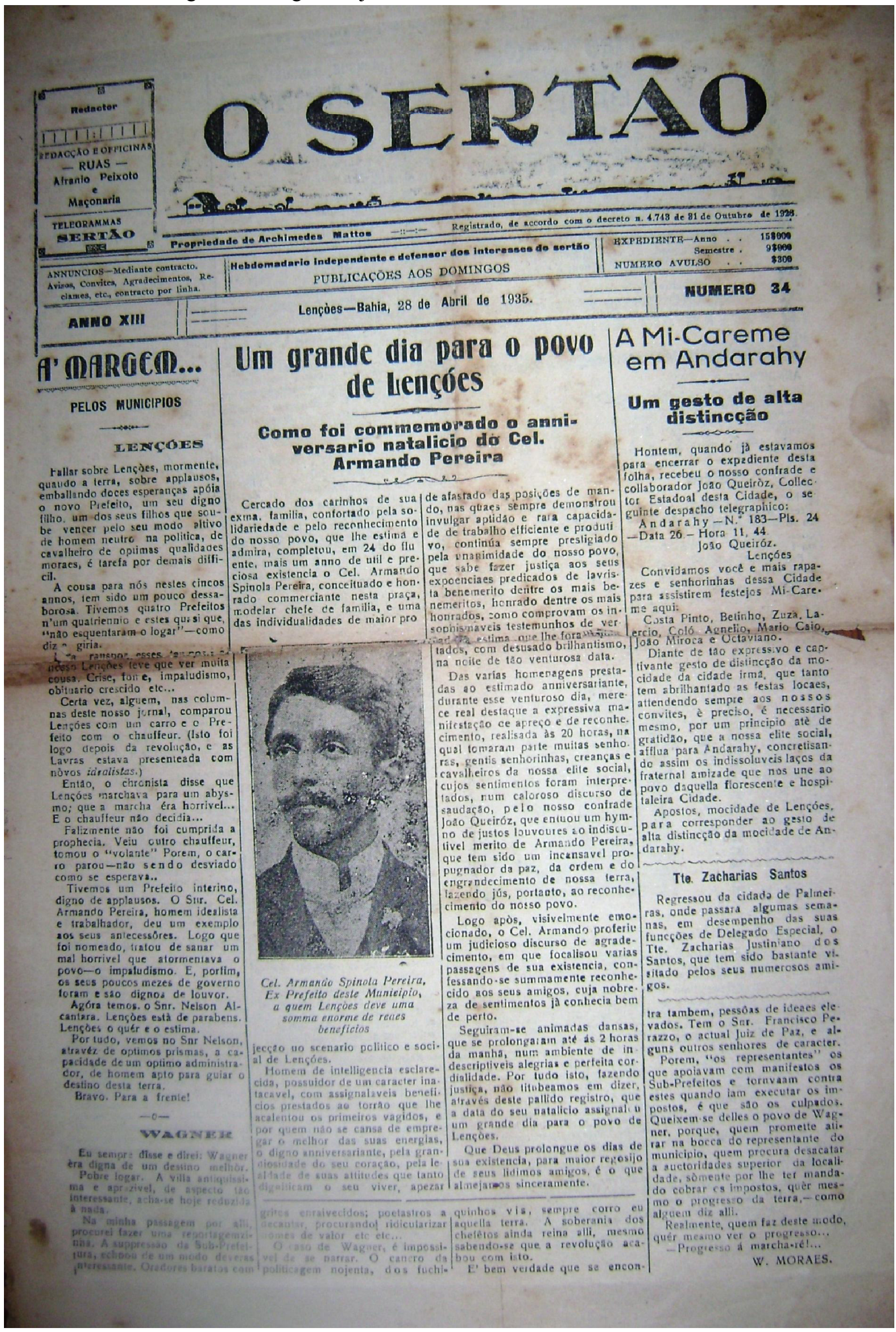

Fonte: Arquivo pessoal de Heraldo Barbosa Filho. 
Figura 67 - Página do jornal O Sertão do dia 7 de setembro de 1940.

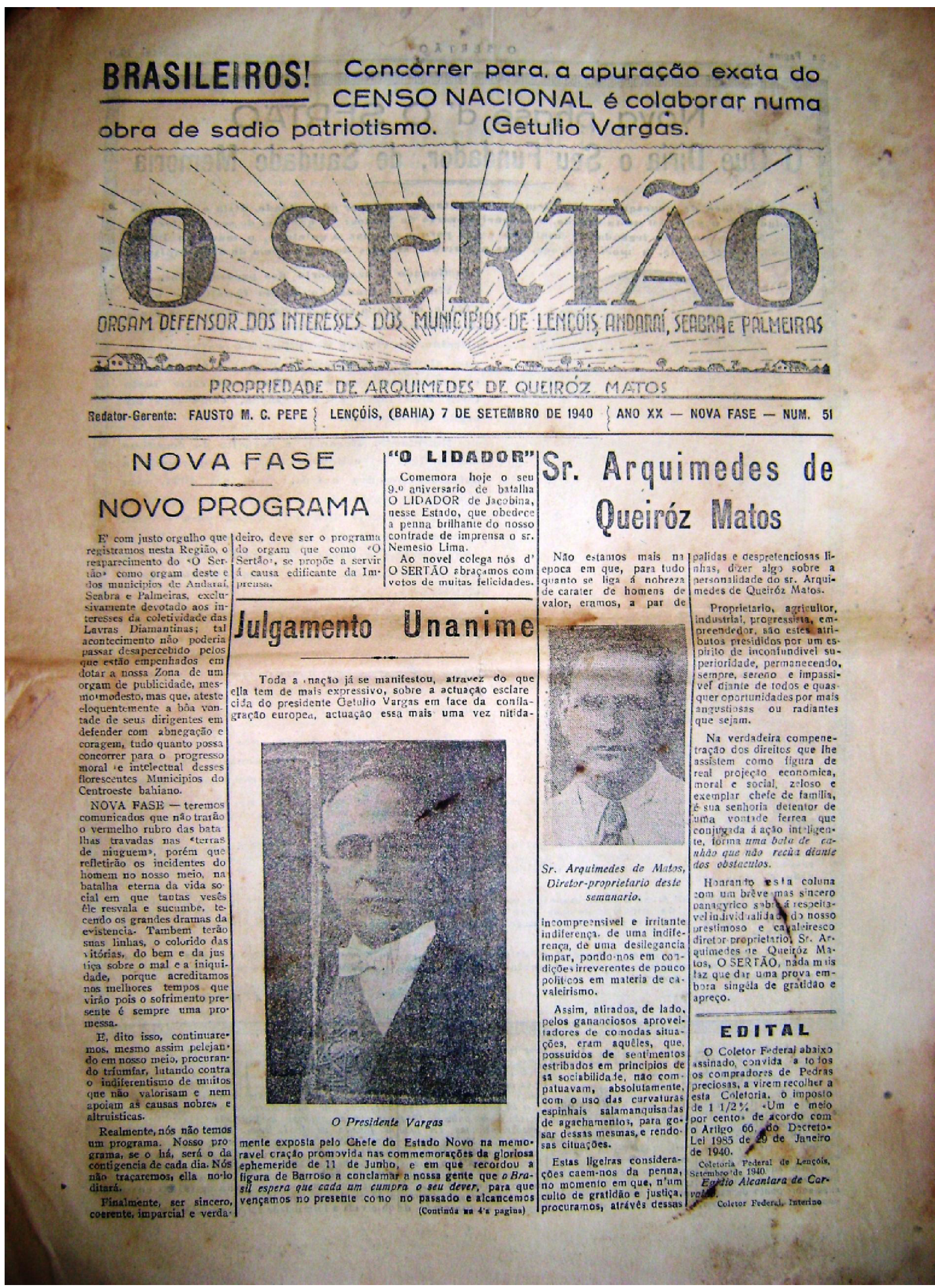

Fonte: Arquivo pessoal de Heraldo Barbosa Filho. 
Figura 68 - Página do jornal O Sertão do dia 22 de setembro de 1940.

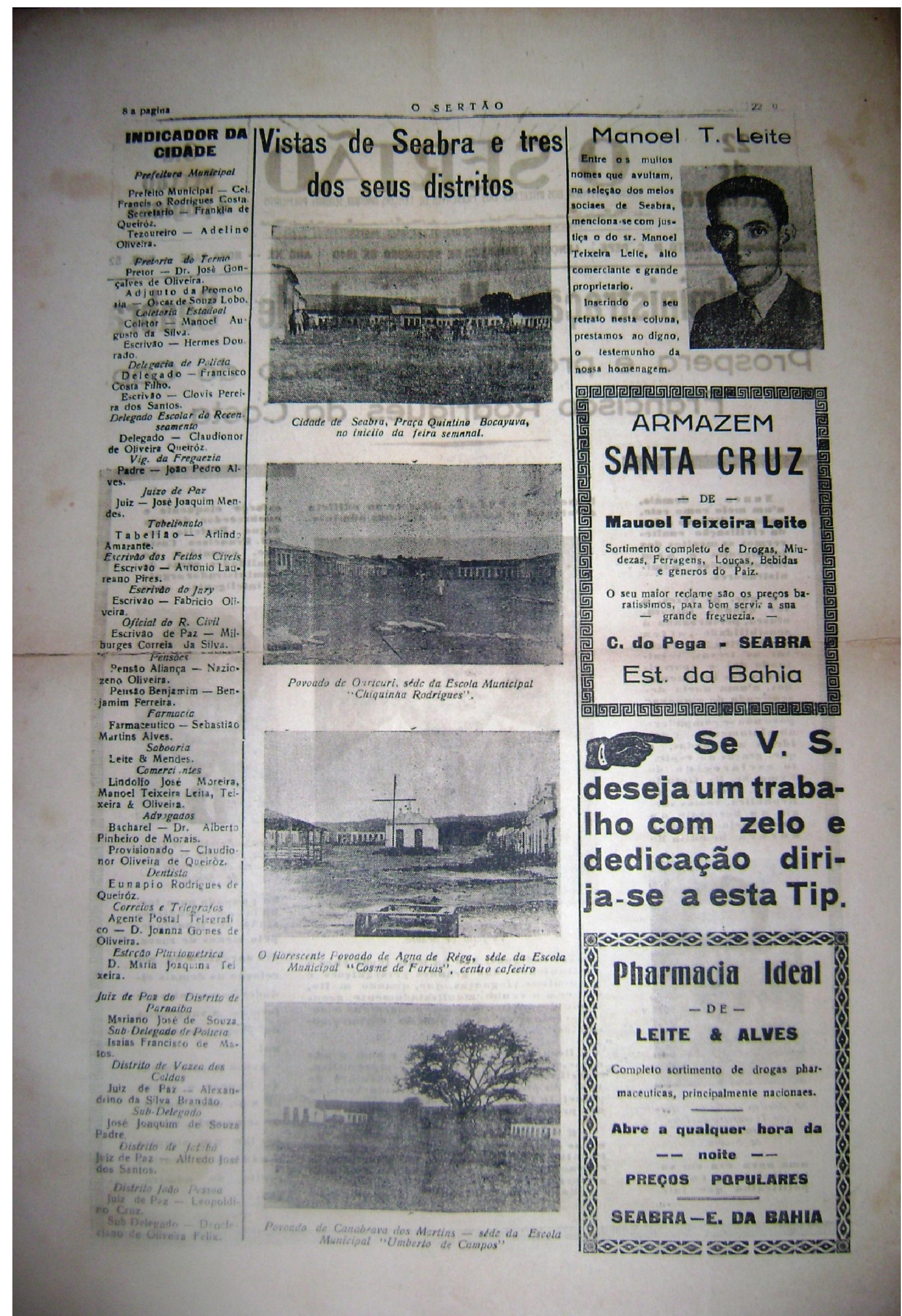

Fonte: Arquivo pessoal de Heraldo Barbosa Filho. 
Figura 69 - Página do jornal O Sertão do dia 22 de setembro de 1940.

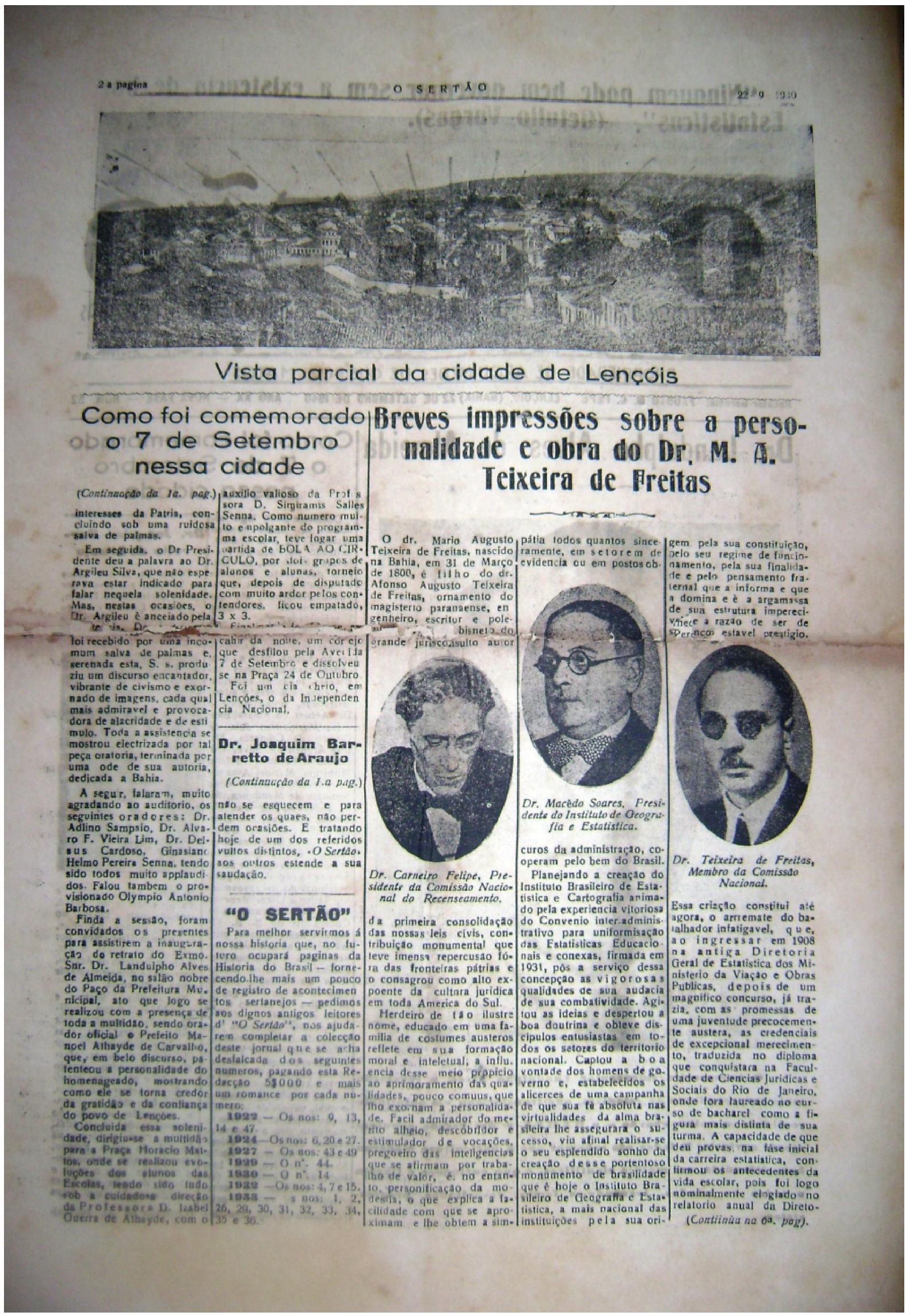

Fonte: Arquivo pessoal de Heraldo Barbosa Filho. 
Figura 70 - Página do jornal O Sertão do dia 30 de março de 1941.

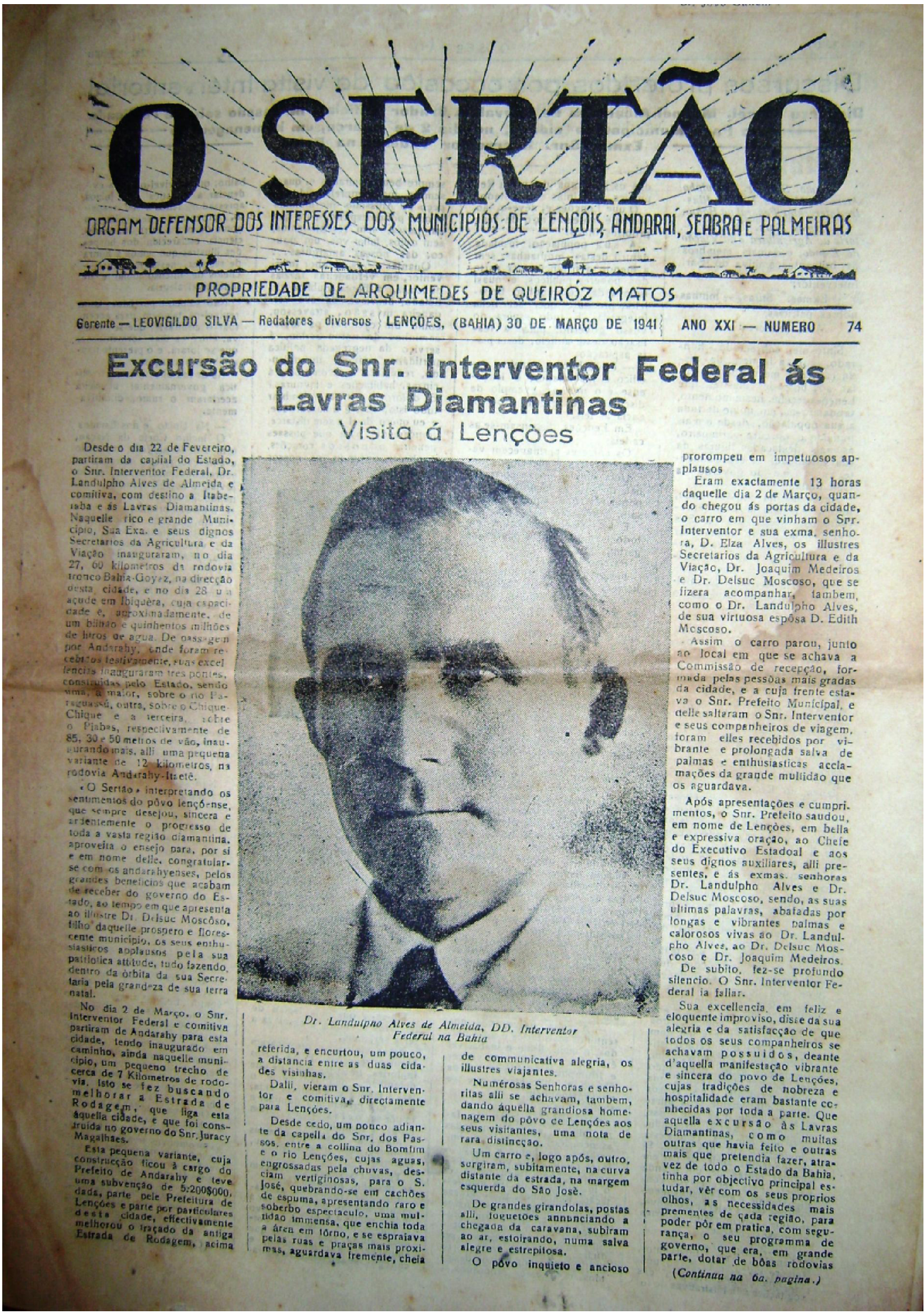

Fonte: Arquivo pessoal de Heraldo Barbosa Filho. 
Figura 71 - Página do jornal O Sertão do dia 14 de dezembro de 1941.

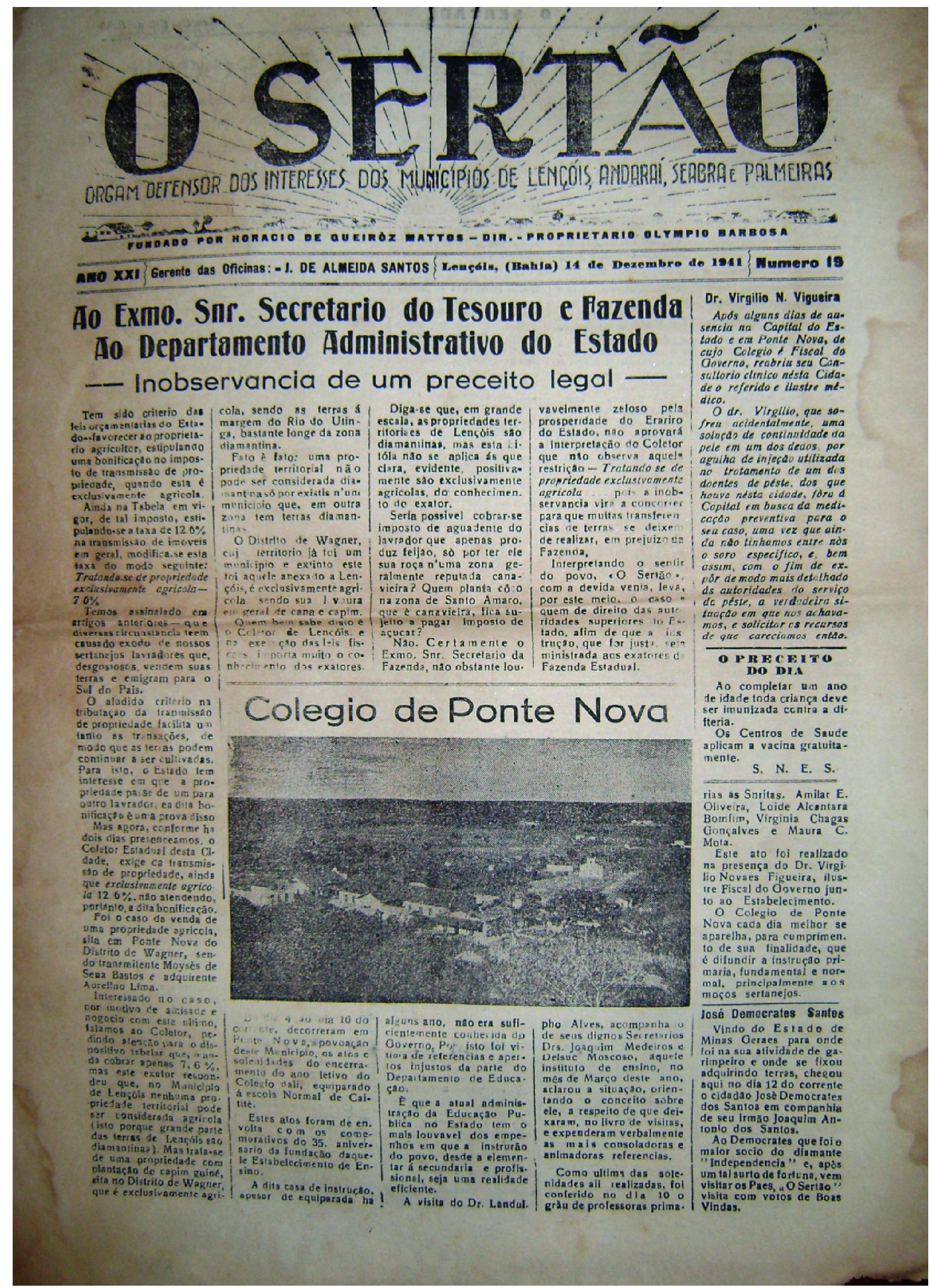

Fonte: Arquivo pessoal de Heraldo Barbosa Filho. 
Figura 72 - Página do jornal O Sertão do dia 26 de abril de 1942.

\section{JUSTA E PATRIOTICA HOMENAOEM D' "O SERTÃO" ao Eminente Chefe Nacio- nal, Presidente Dr. GETULIO VARGAS, por ocasião do seu aniversario natalicio}

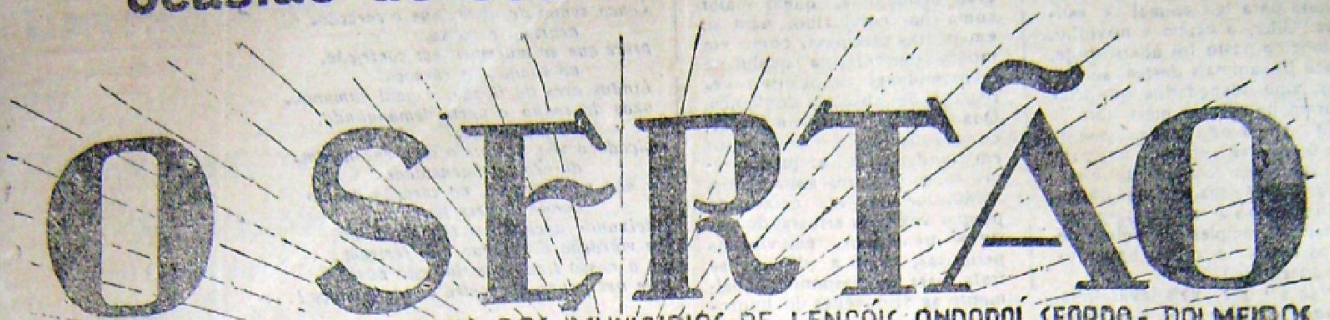

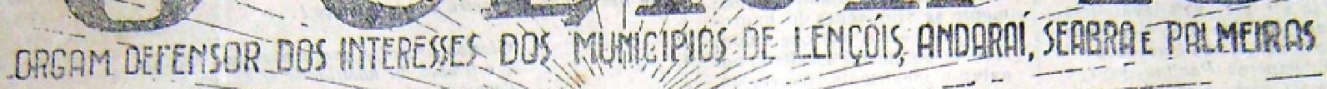

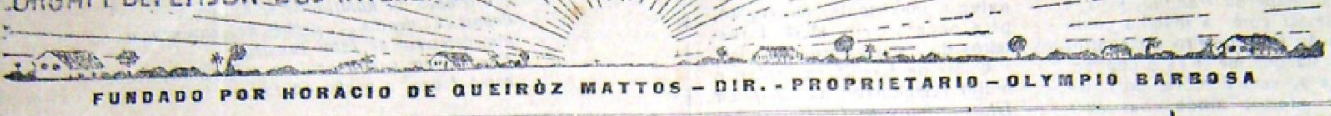

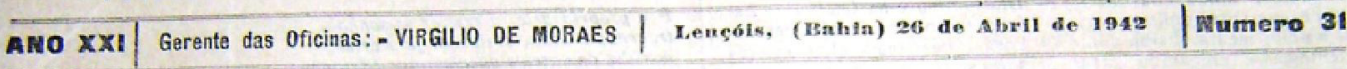

As comemorações, em Lençòes, por ocasião do Aniversario do Presidente VARGAS

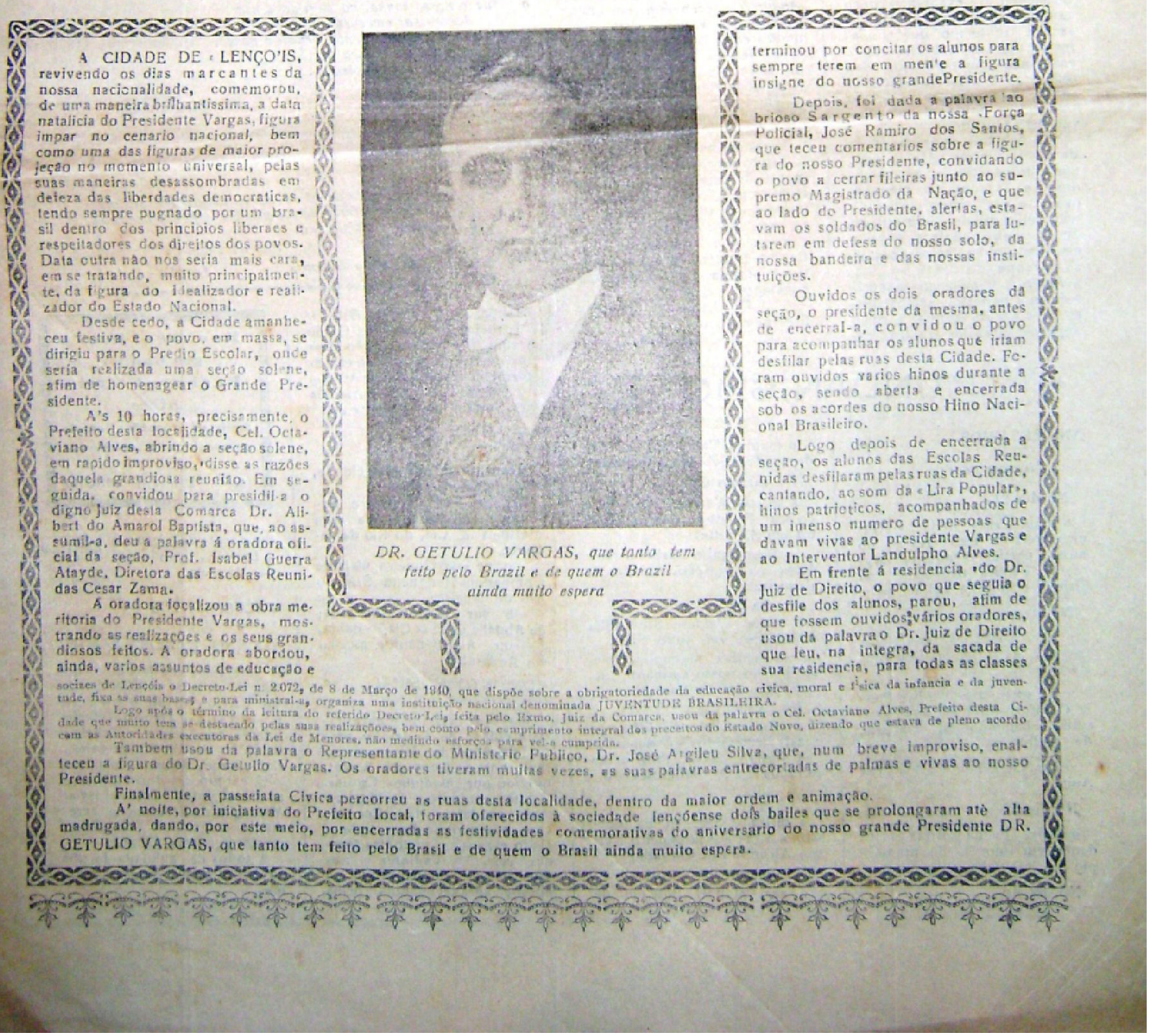

Fonte: Arquivo pessoal de Heraldo Barbosa Filho. 
Figura 73 - Página do jornal O Sertão do dia 9 de maio de 1943.

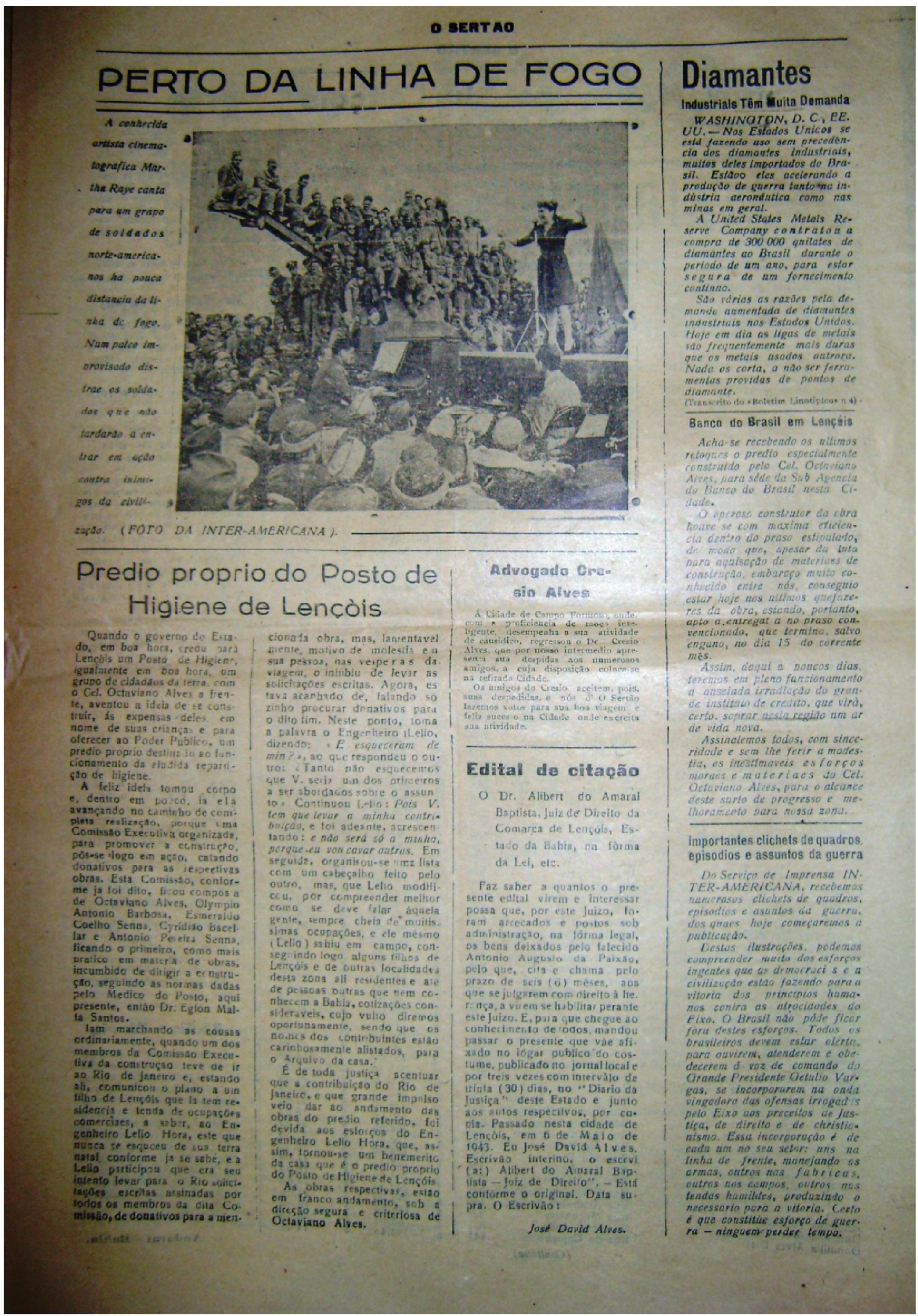

Fonte: Arquivo pessoal de Heraldo Barbosa Filho. 
Figura 74- Página do jornal O Sertão do dia 26 de setembro de 1943.

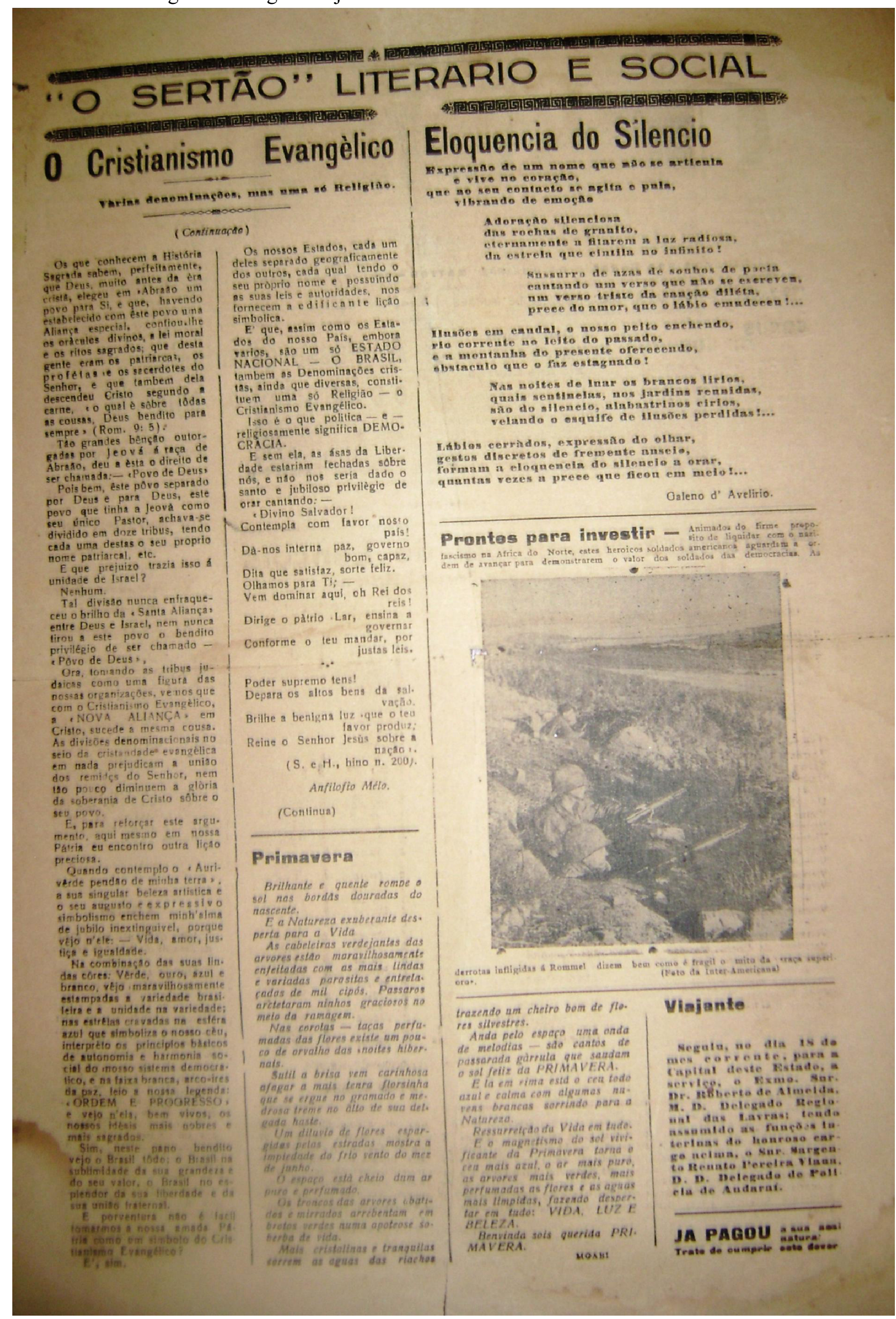

Fonte: Arquivo pessoal de Heraldo Barbosa Filho. 
Figura 75 - Página do jornal O Sertão do dia 4 de dezembro de 1946.

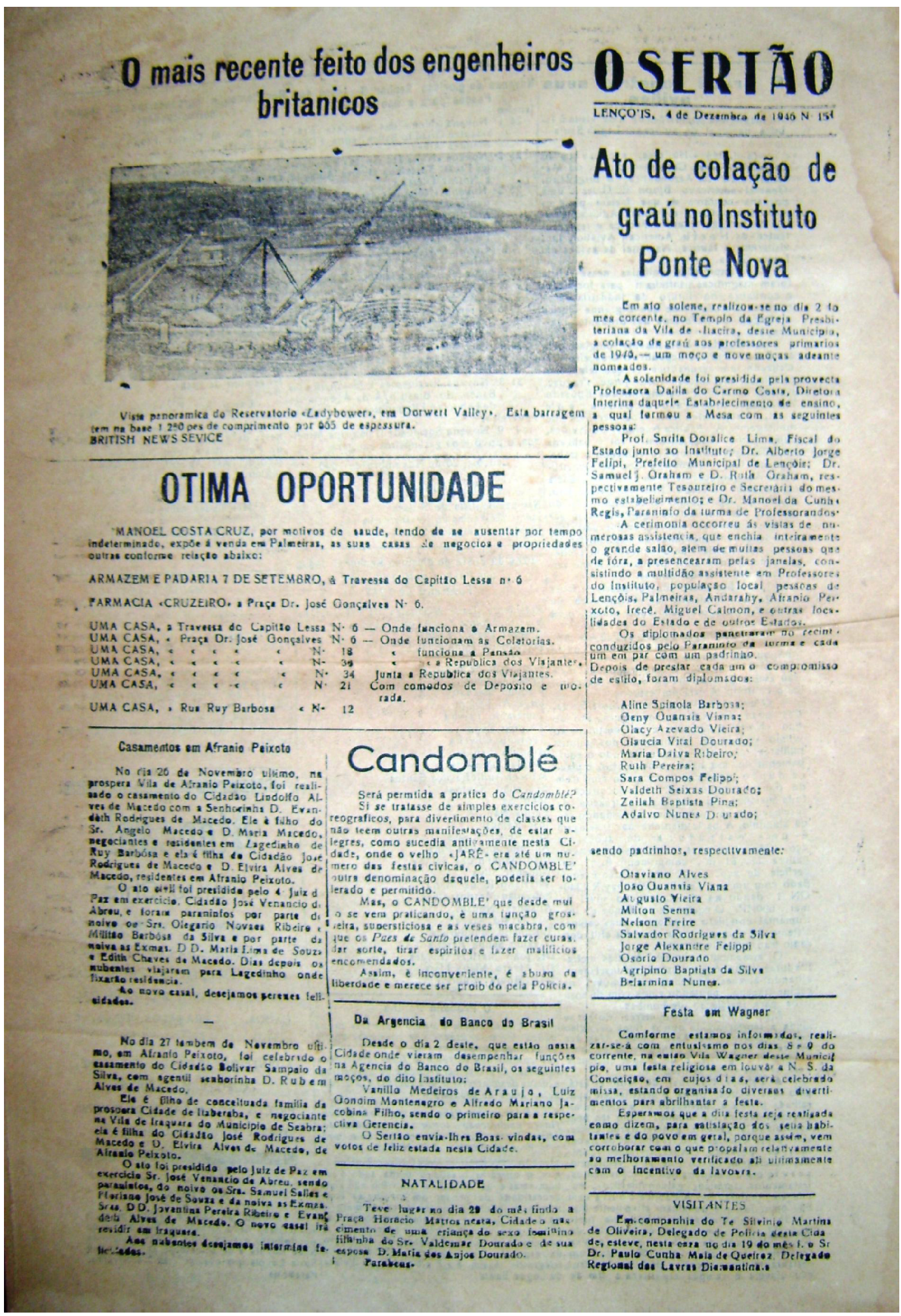

Fonte: Arquivo pessoal de Heraldo Barbosa Filho. 
Figura 76 - Página do jornal O Sertão do dia 14 de março de 1948.

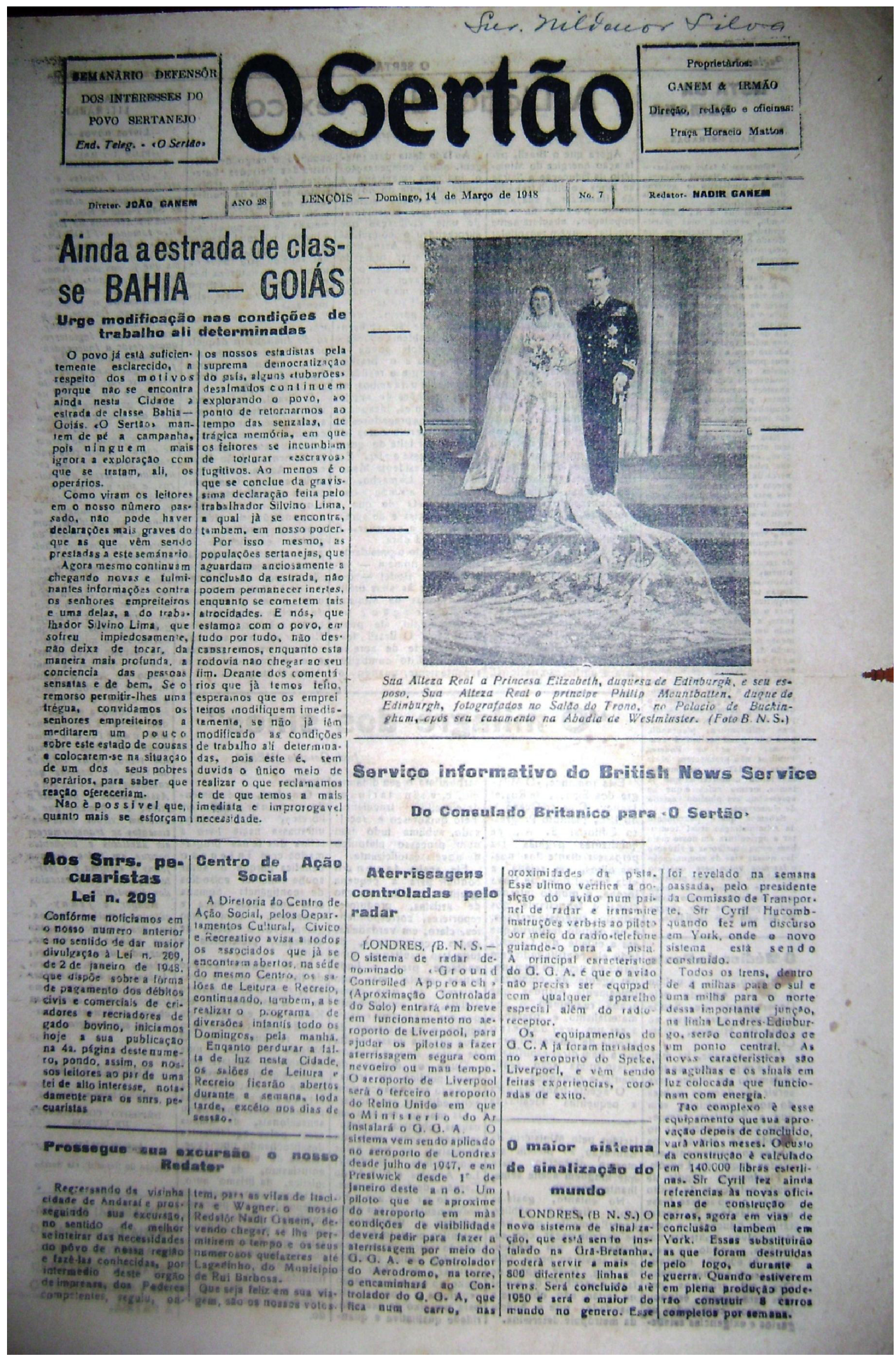

Fonte: Arquivo pessoal de Heraldo Barbosa Filho. 
Figura 77 - Página do jornal O Sertão do dia 6 de março de 1949.

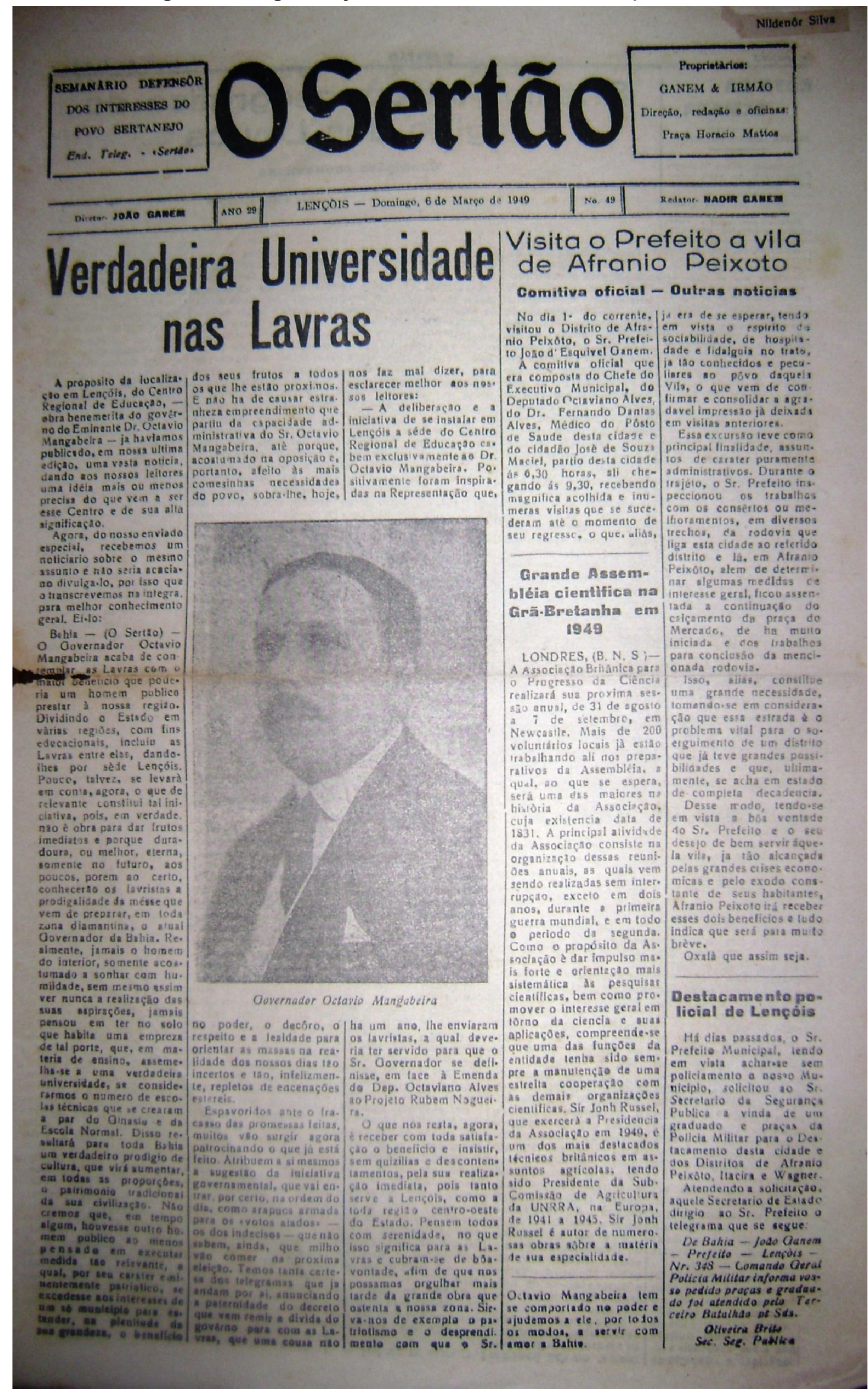

Fonte: Arquivo pessoal de Heraldo Barbosa Filho. 
Figura 78 - Página do jornal O Sertão do dia 30 de setembro de 1950.

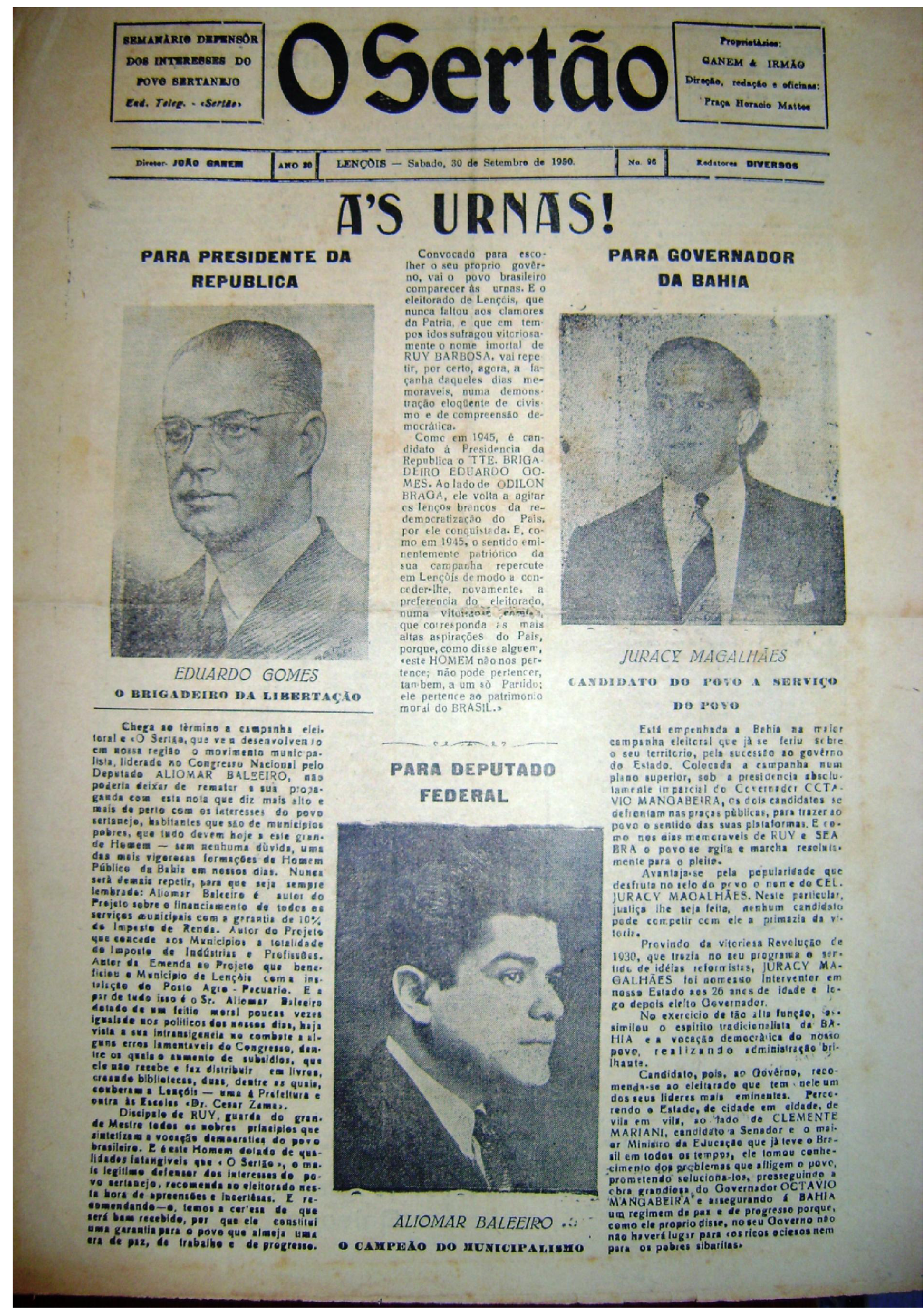

Fonte: Arquivo pessoal de Heraldo Barbosa Filho. 


\section{ANEXO D - Fotografias do Voluntário do Peace Corps Steve Hormann (coloridas)}

Essas imagens foram produzidas em 1971 por Steve Horman, voluntário estadunidense do Peace Corps então em atividade em Lençóis. Elas foram utilizadas pelo grupo organizado por Horman, o MCC (Movimento Criatividade Comunitária), na produção do material audiovisual que foi apresentado no Primeiro Encontro de Governadores (Salvador, 1971), na Primeira Reunião de Turismo (Brasília, 1972) e ao IPHAN, visando o tombamento da cidade. Para maiores informações sobre a atividade do grupo MCC e sobre a atividade de Steve Horman ver: Os ecos contraditórios do turismo na Chapada Diamantina (Brito, 2006) e Anseios, dissonâncias, enfrentamentos: o lugar e a trajetória da preservação em Lençóis (Bahia) (Mangili, 2015). As imagens foram cedidas por Liziane Peres Mangili e digitalizadas a partir do arquivo pessoal de Heraldo Barbosa Filho. 
Figura 79

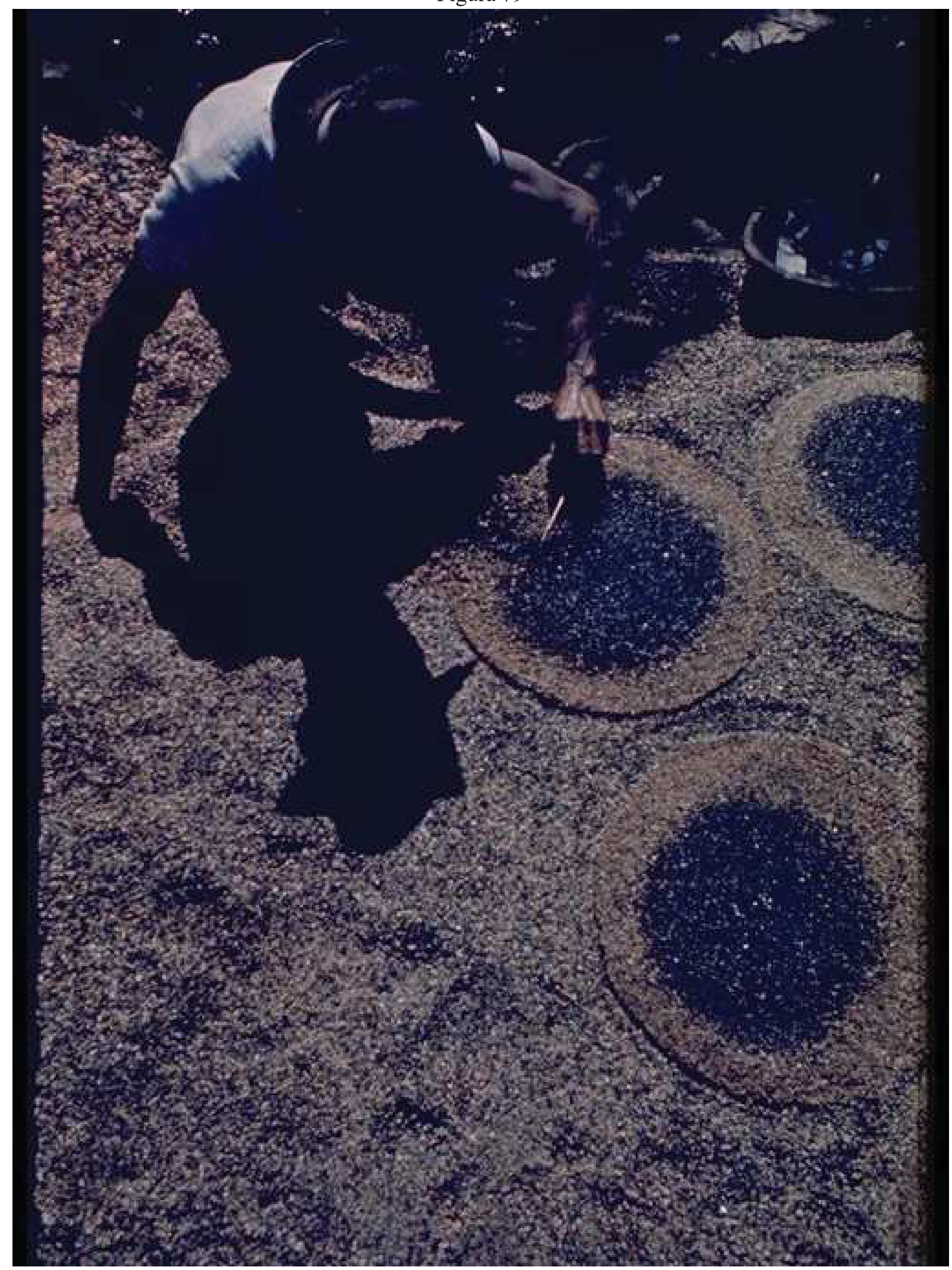

Fonte: Arquivo pessoal de Heraldo Barbosa Filho. 
Figura 80

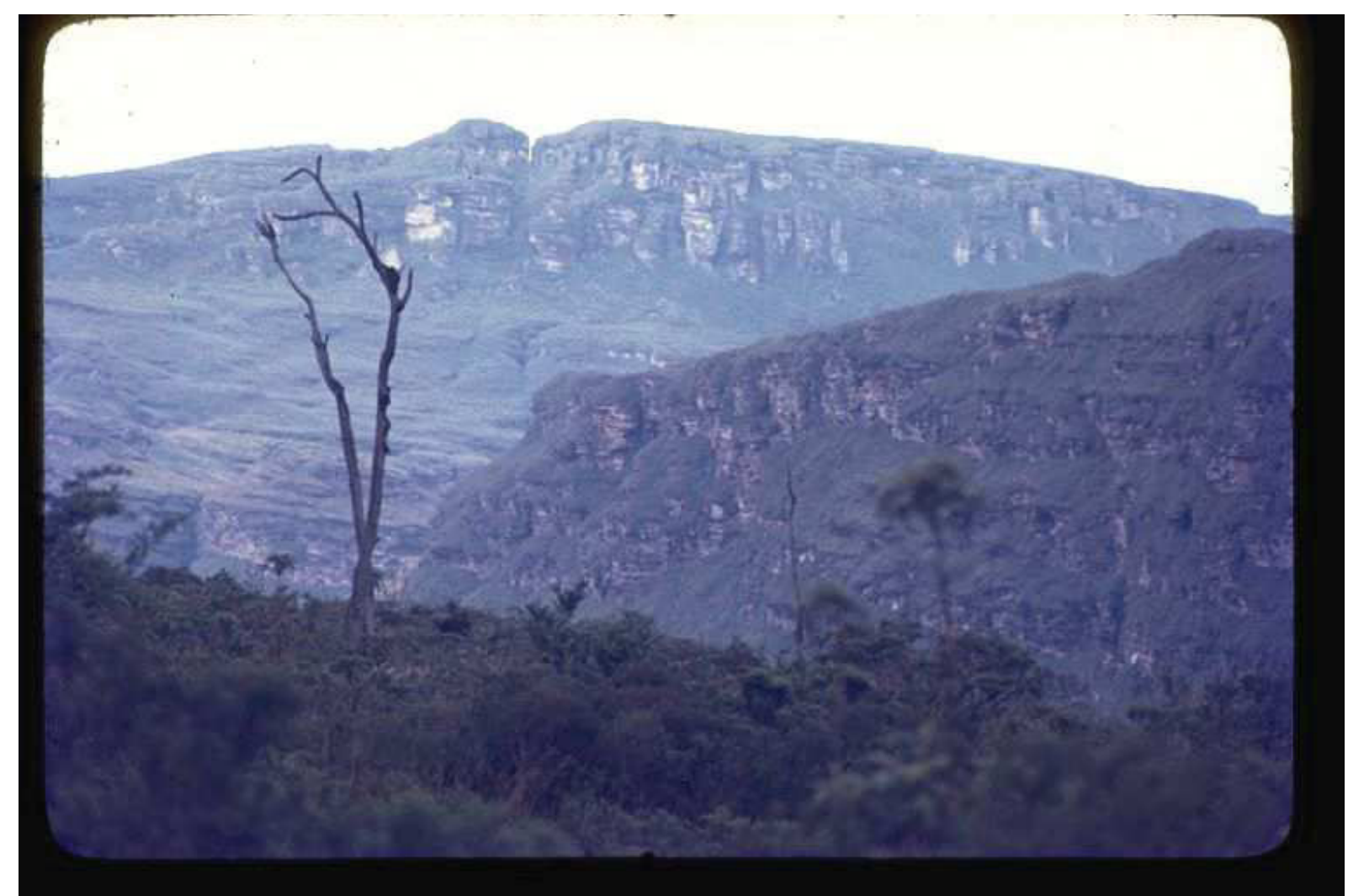

Fonte: Arquivo pessoal de Heraldo Barbosa Filho.

Figura 81

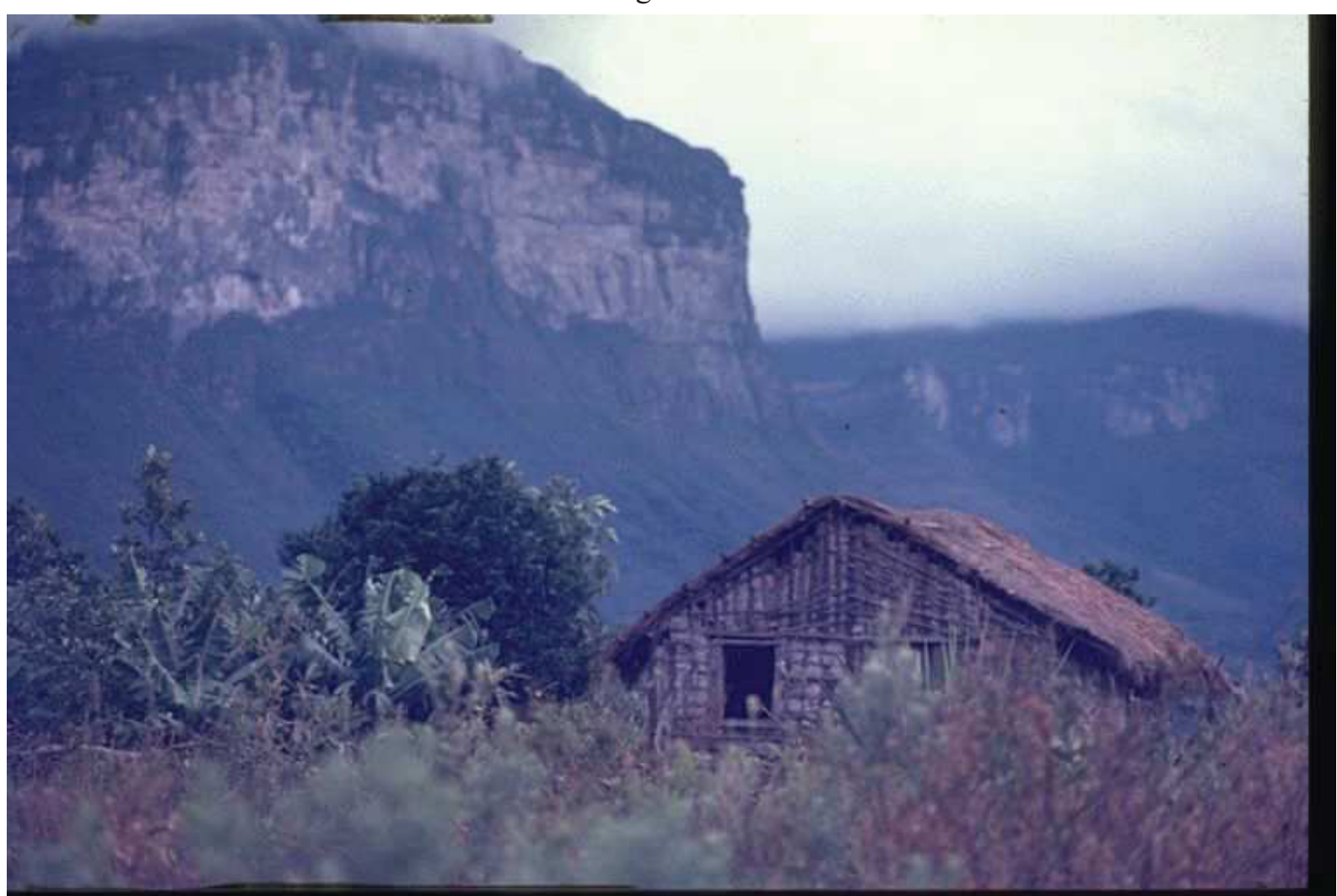

Fonte: Arquivo pessoal de Heraldo Barbosa Filho. 
Figura 82

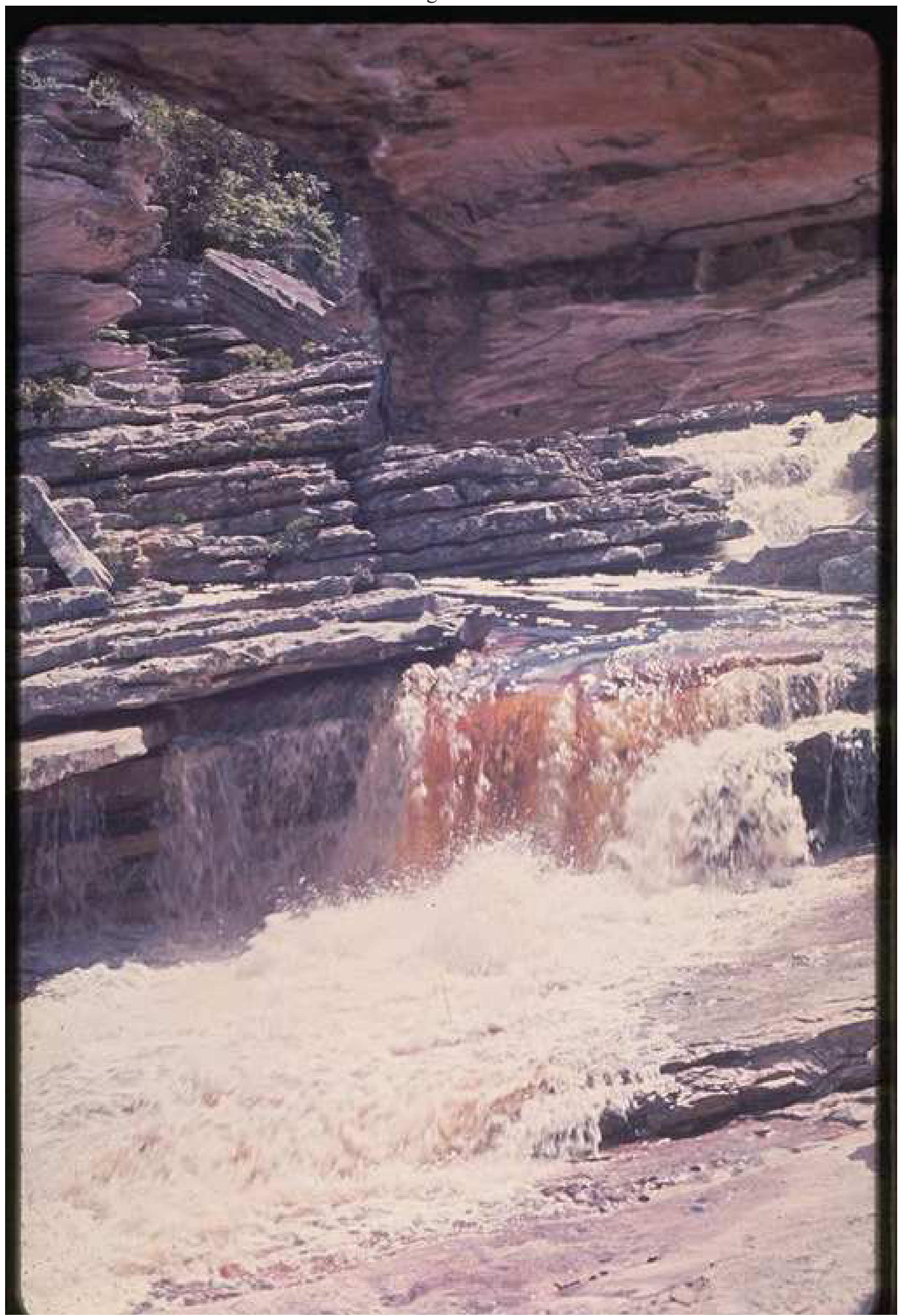

Fonte: Arquivo pessoal de Heraldo Barbosa Filho. 
Figura 83

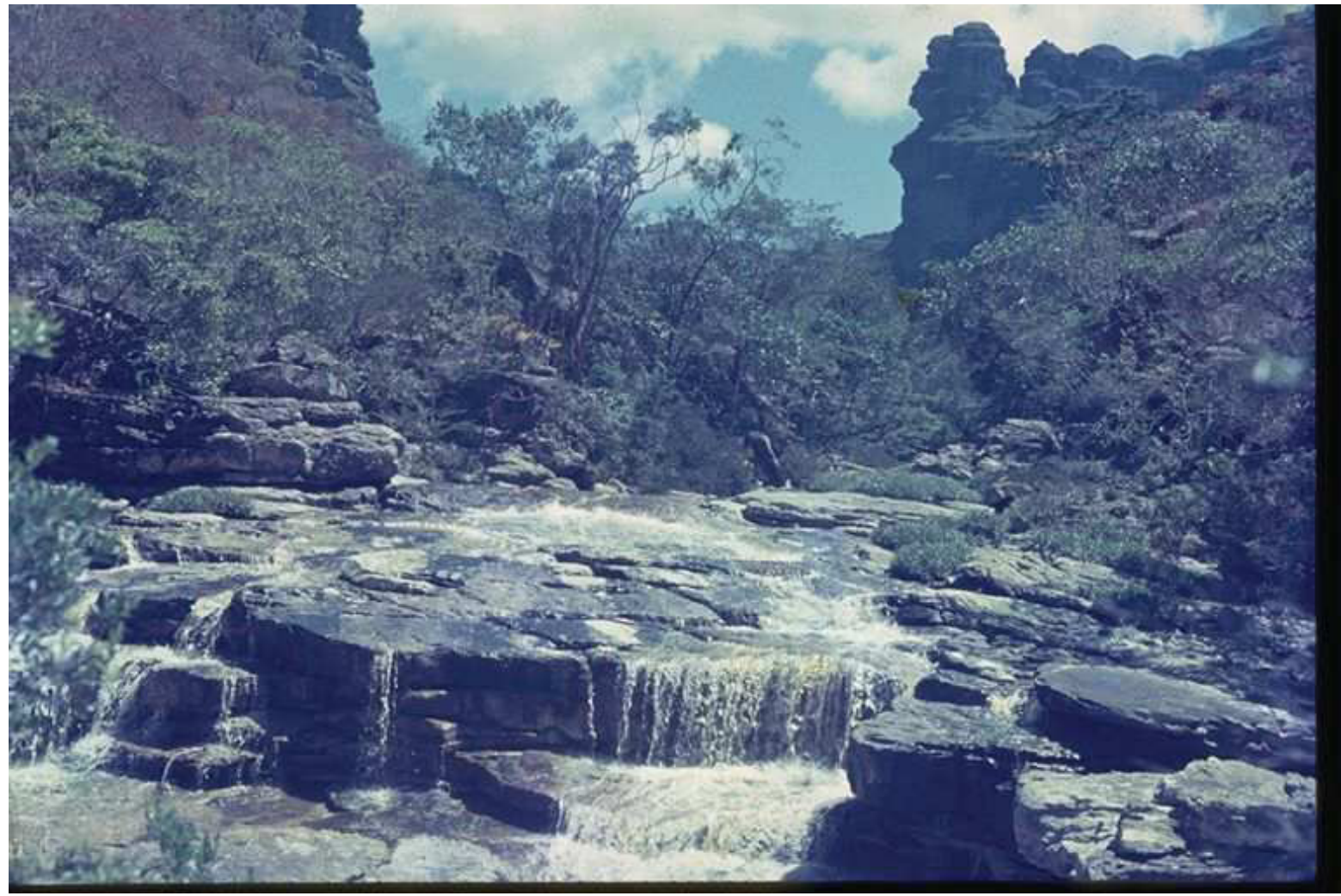

Fonte: Arquivo pessoal de Heraldo Barbosa Filho.

Figura 84

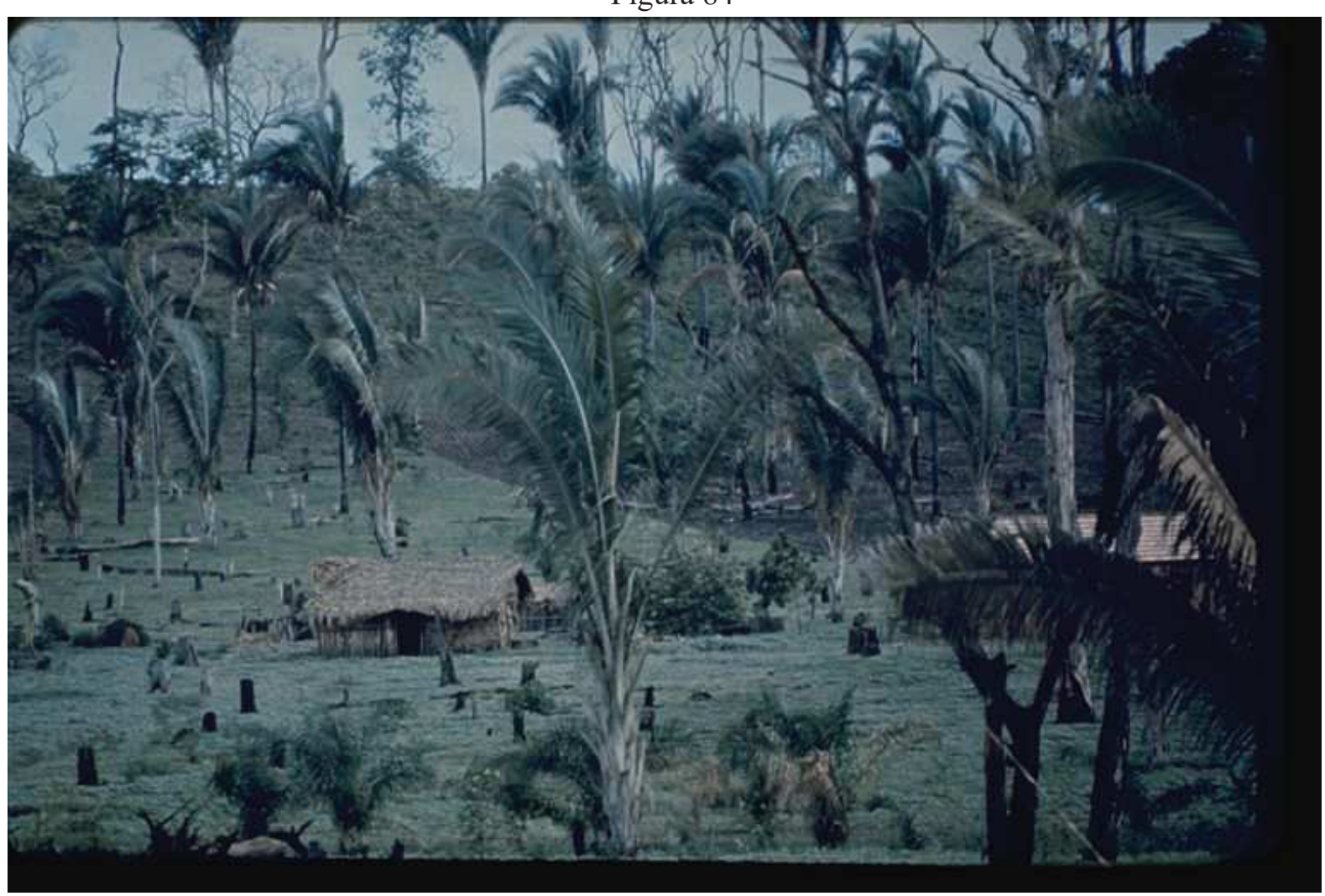

Fonte: Arquivo pessoal de Heraldo Barbosa Filho. 


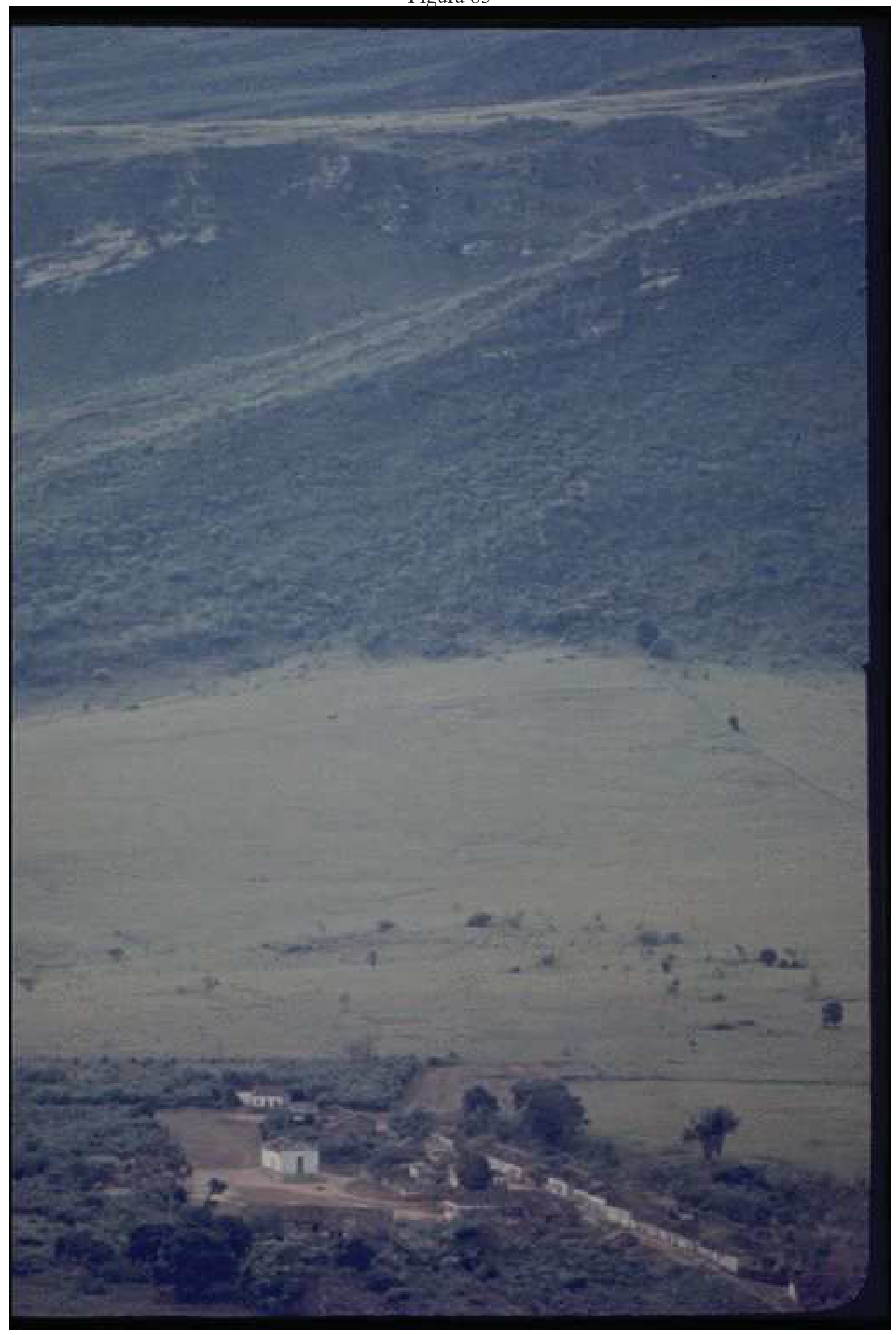

Fonte: Arquivo pessoal de Heraldo Barbosa Filho. 
Figura 86

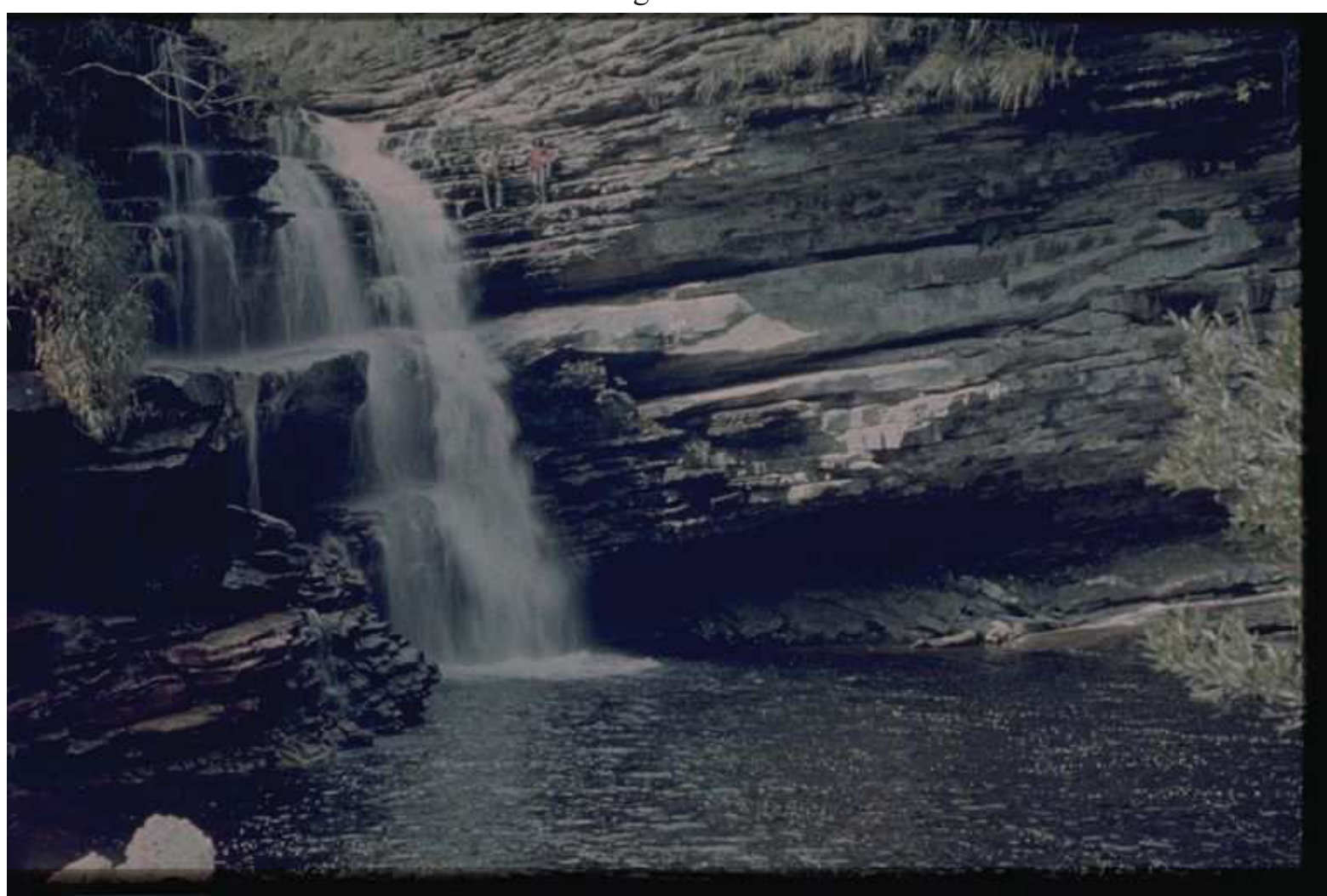

Fonte: Arquivo pessoal de Heraldo Barbosa Filho.

Figura 87

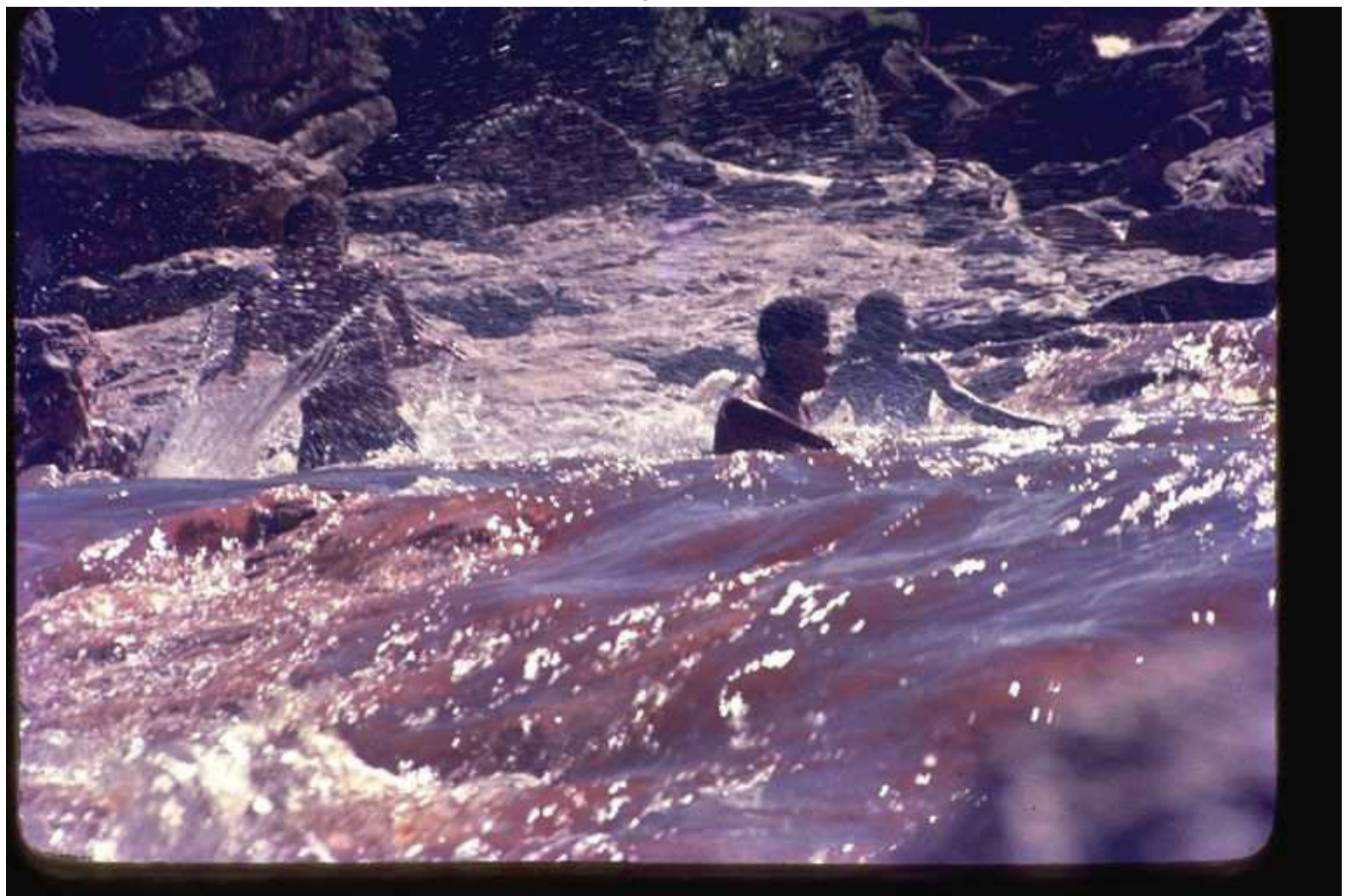

Fonte: Arquivo pessoal de Heraldo Barbosa Filho. 
Figura 88

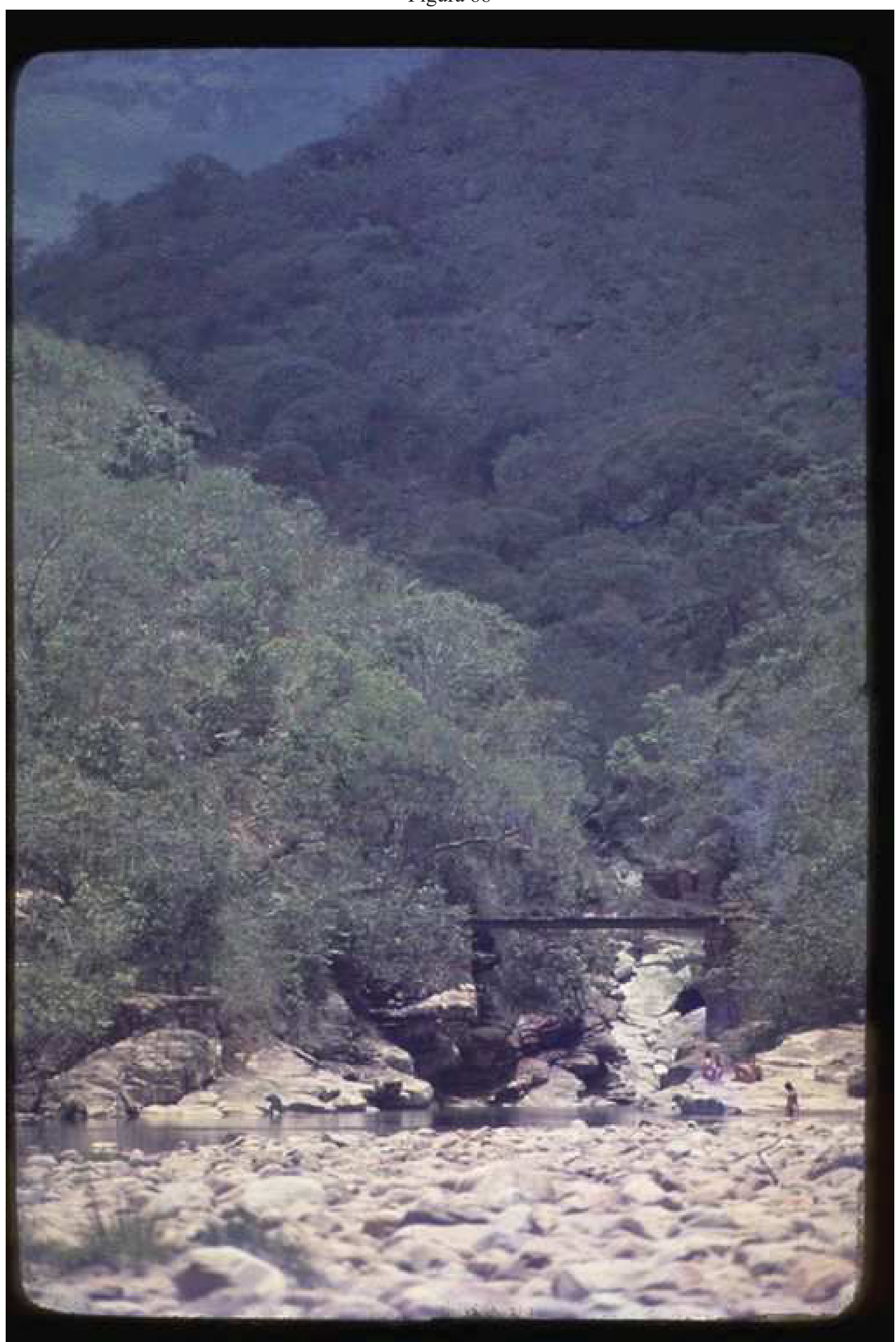

Fonte: Arquivo pessoal de Heraldo Barbosa Filho. 
Figura 89

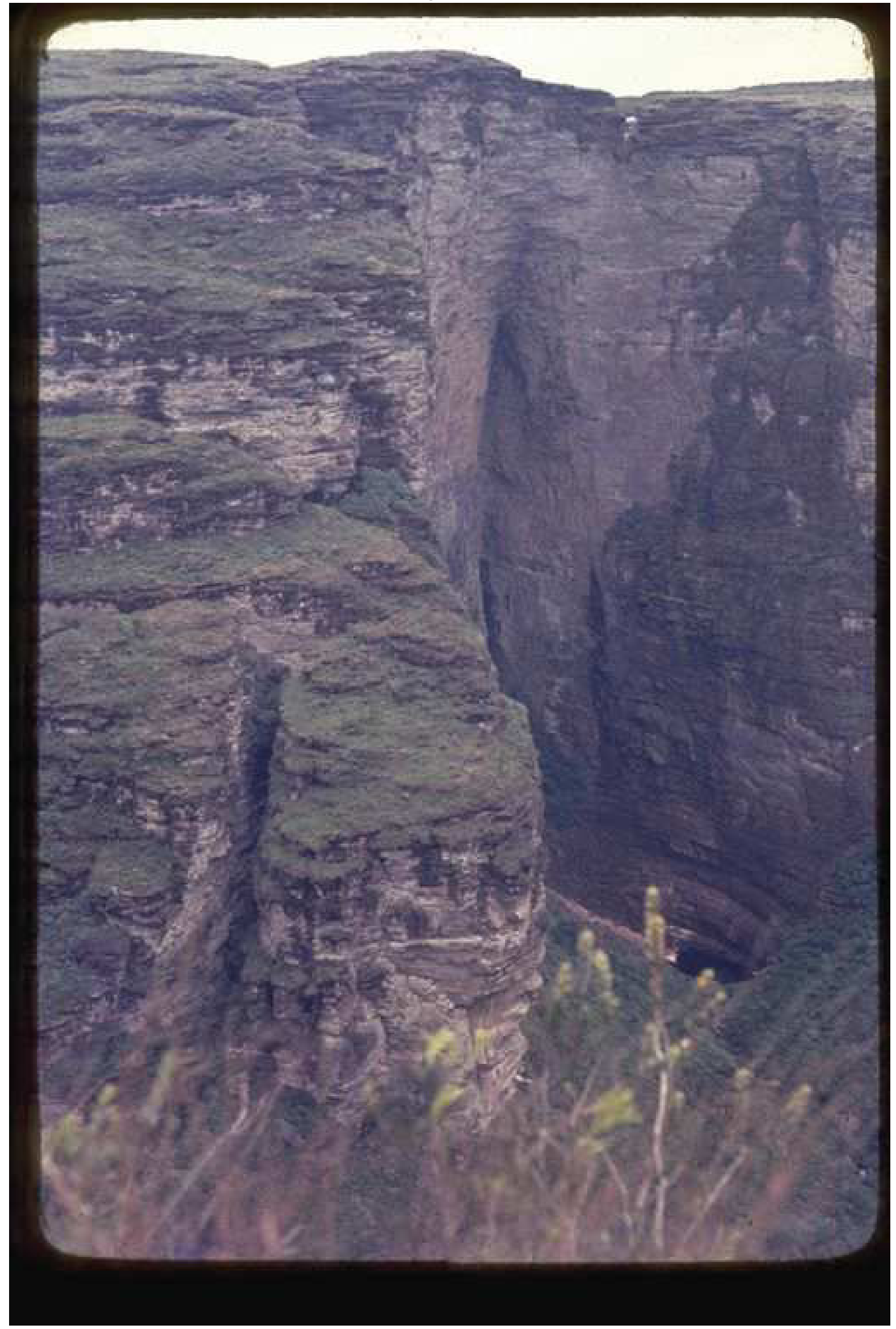

Fonte: Arquivo pessoal de Heraldo Barbosa Filho. 
Figura 90

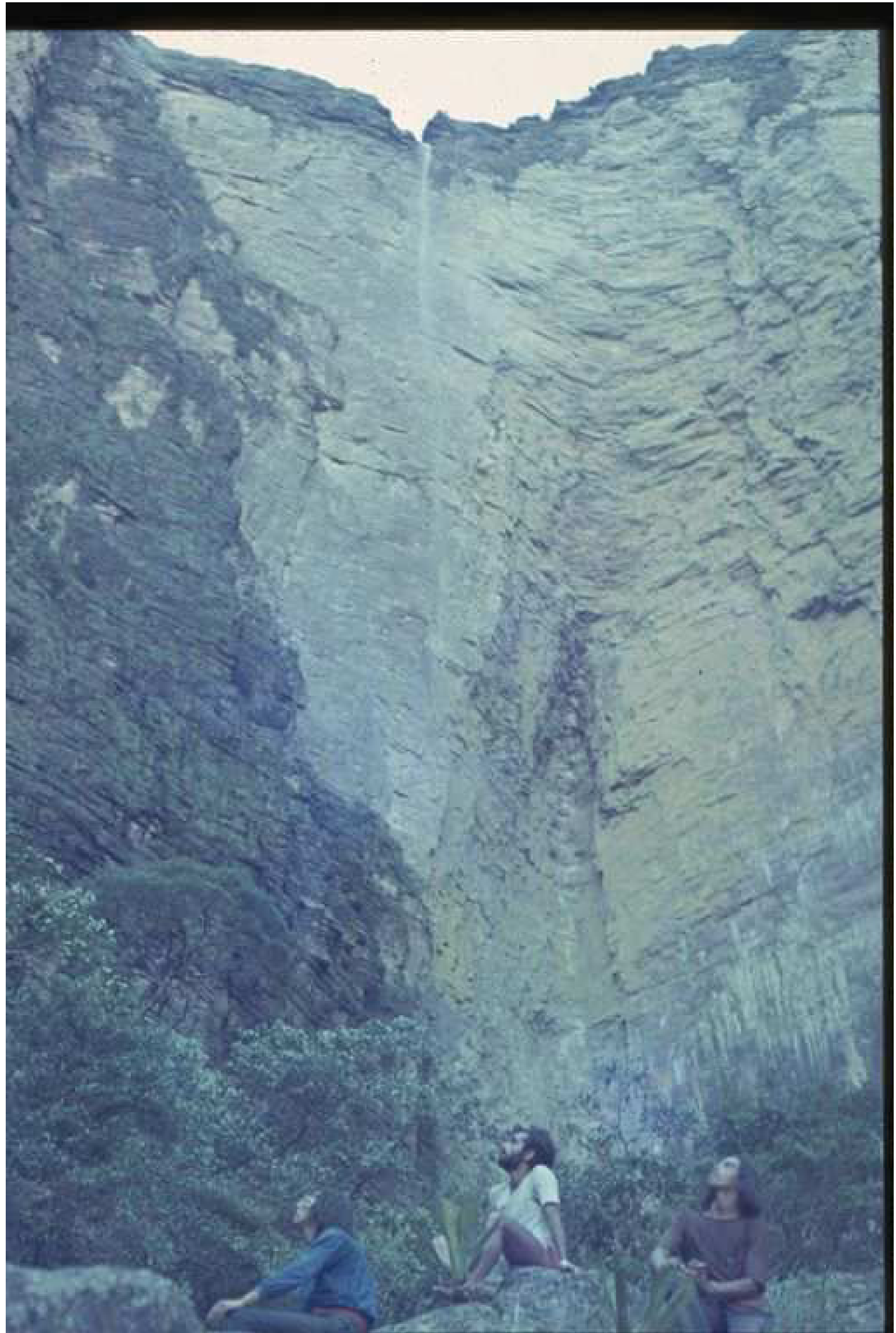

Fonte: Arquivo pessoal de Heraldo Barbosa Filho. 
Figura 91

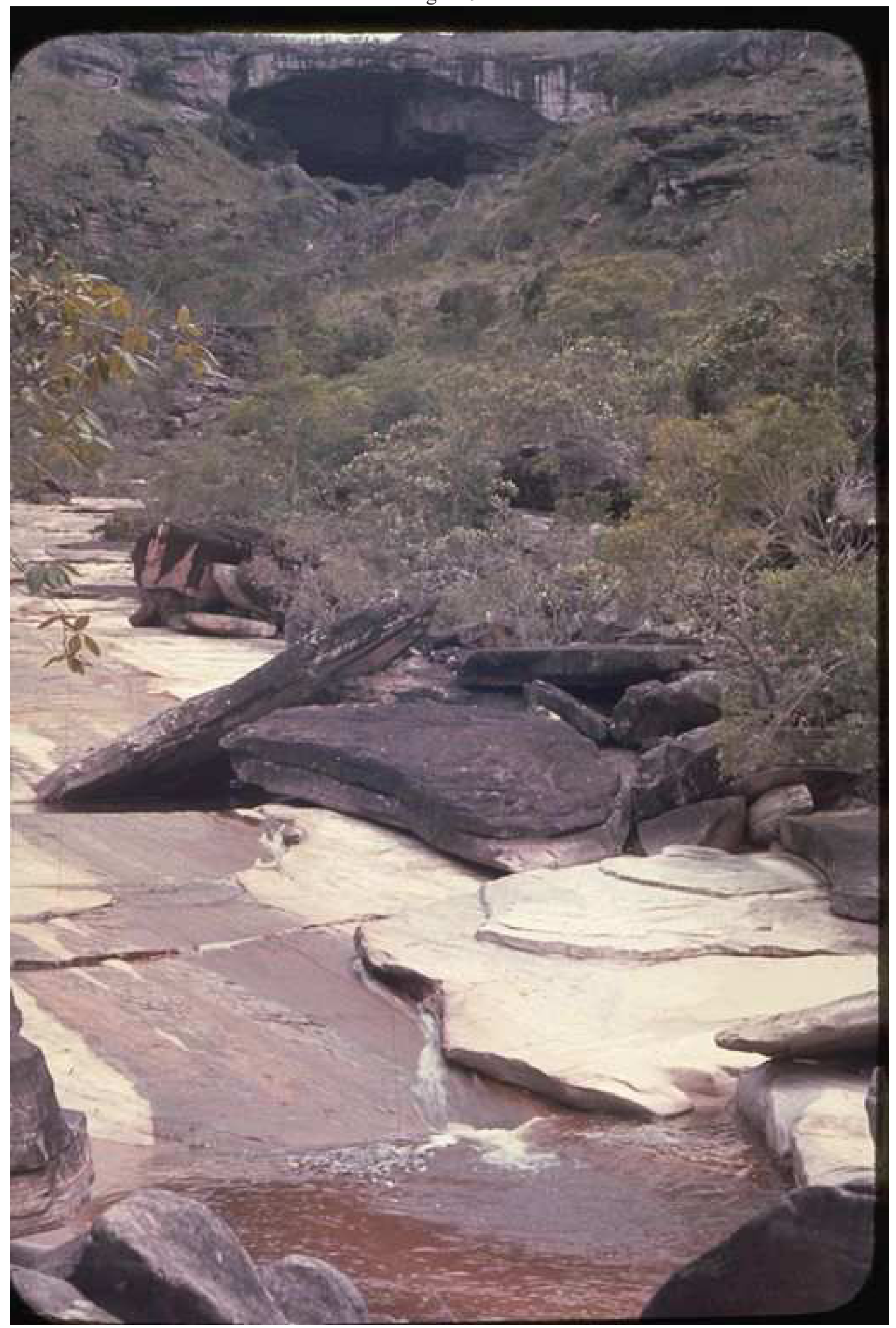

Fonte: Arquivo pessoal de Heraldo Barbosa Filho. 
Figura 92

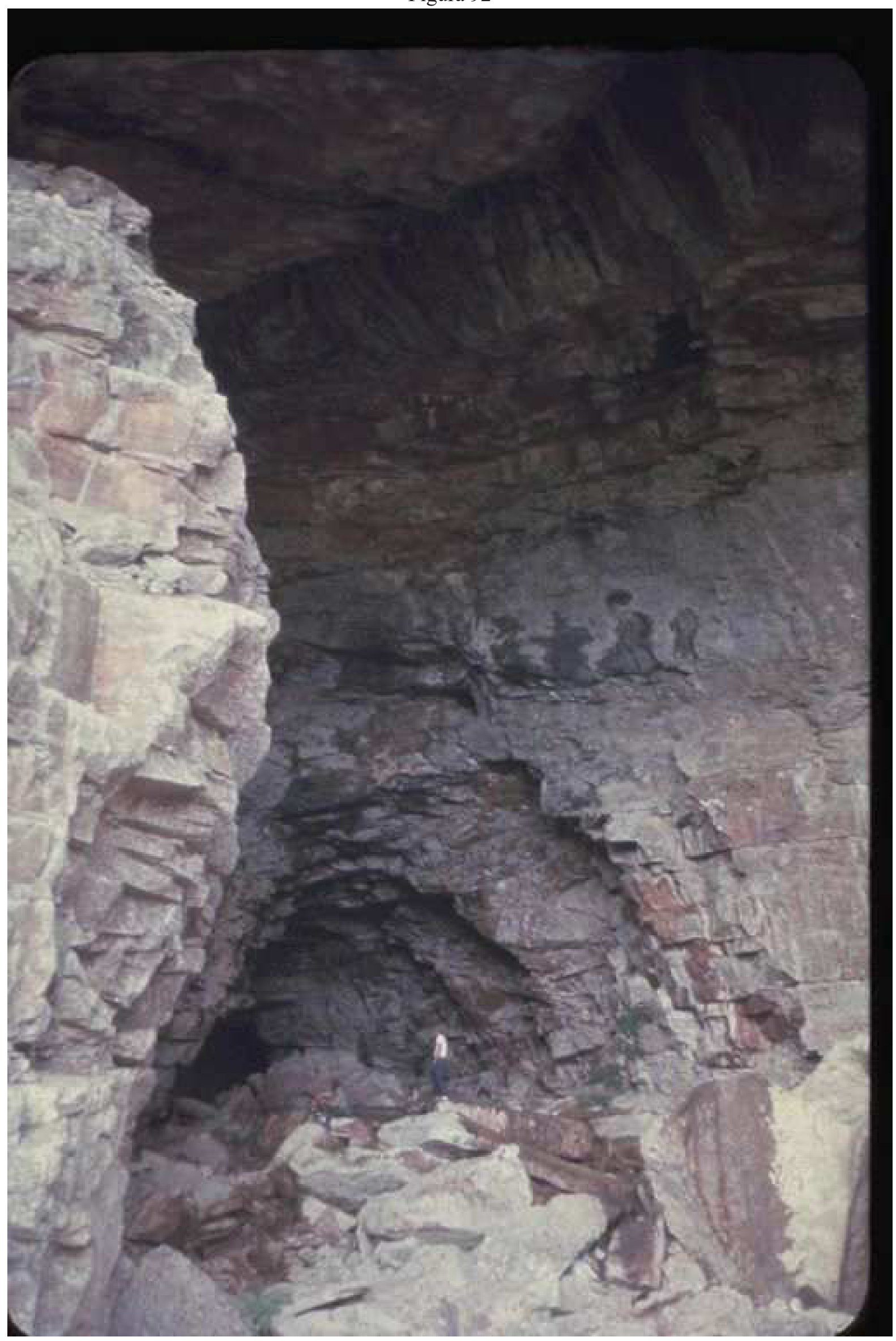

Fonte: Arquivo pessoal de Heraldo Barbosa Filho. 
Figura 93

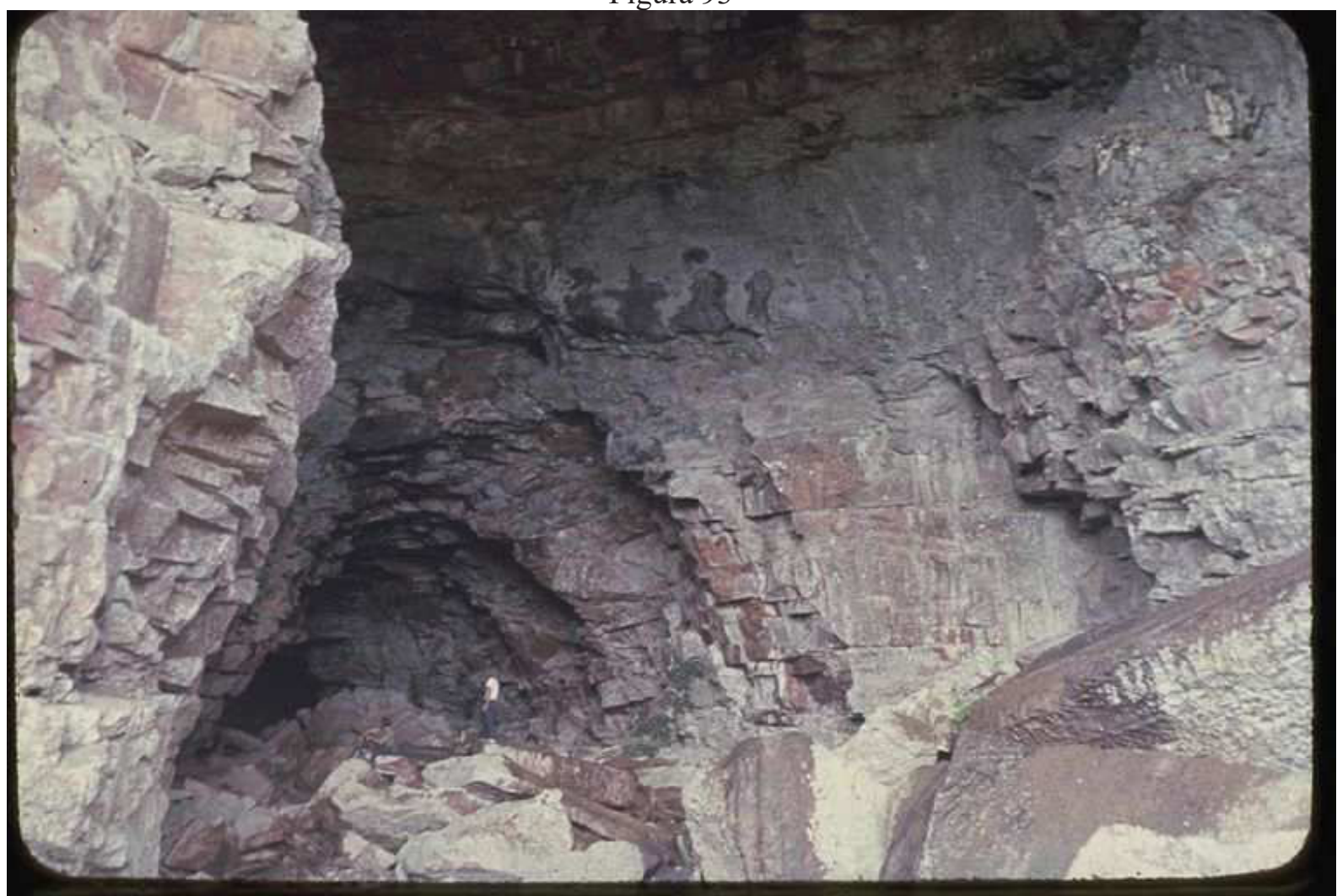

Fonte: Arquivo pessoal de Heraldo Barbosa Filho.

Figura 94

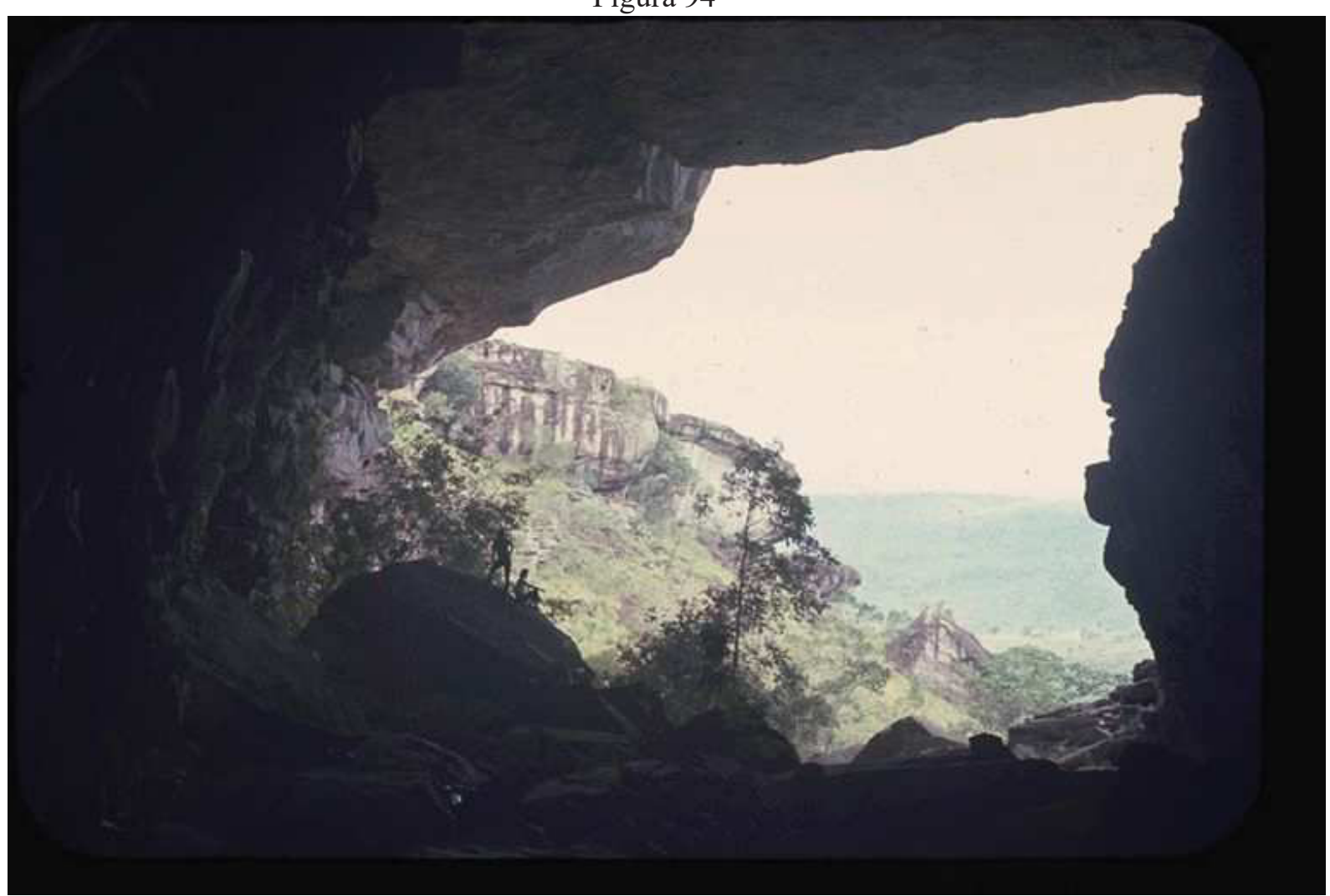

Fonte: Arquivo pessoal de Heraldo Barbosa Filho. 
Figura 95

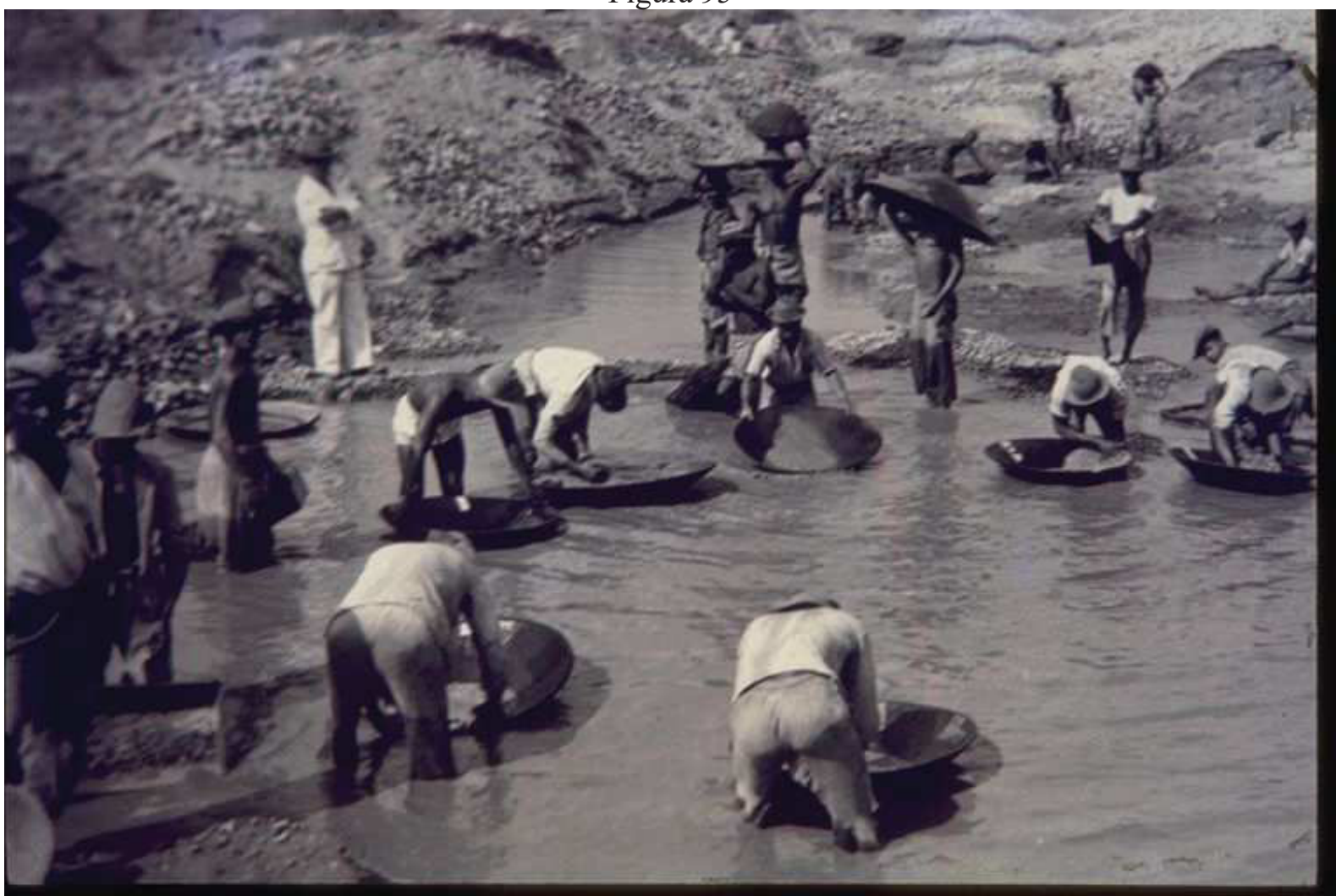

Fonte: Arquivo pessoal de Heraldo Barbosa Filho.

Figura 96

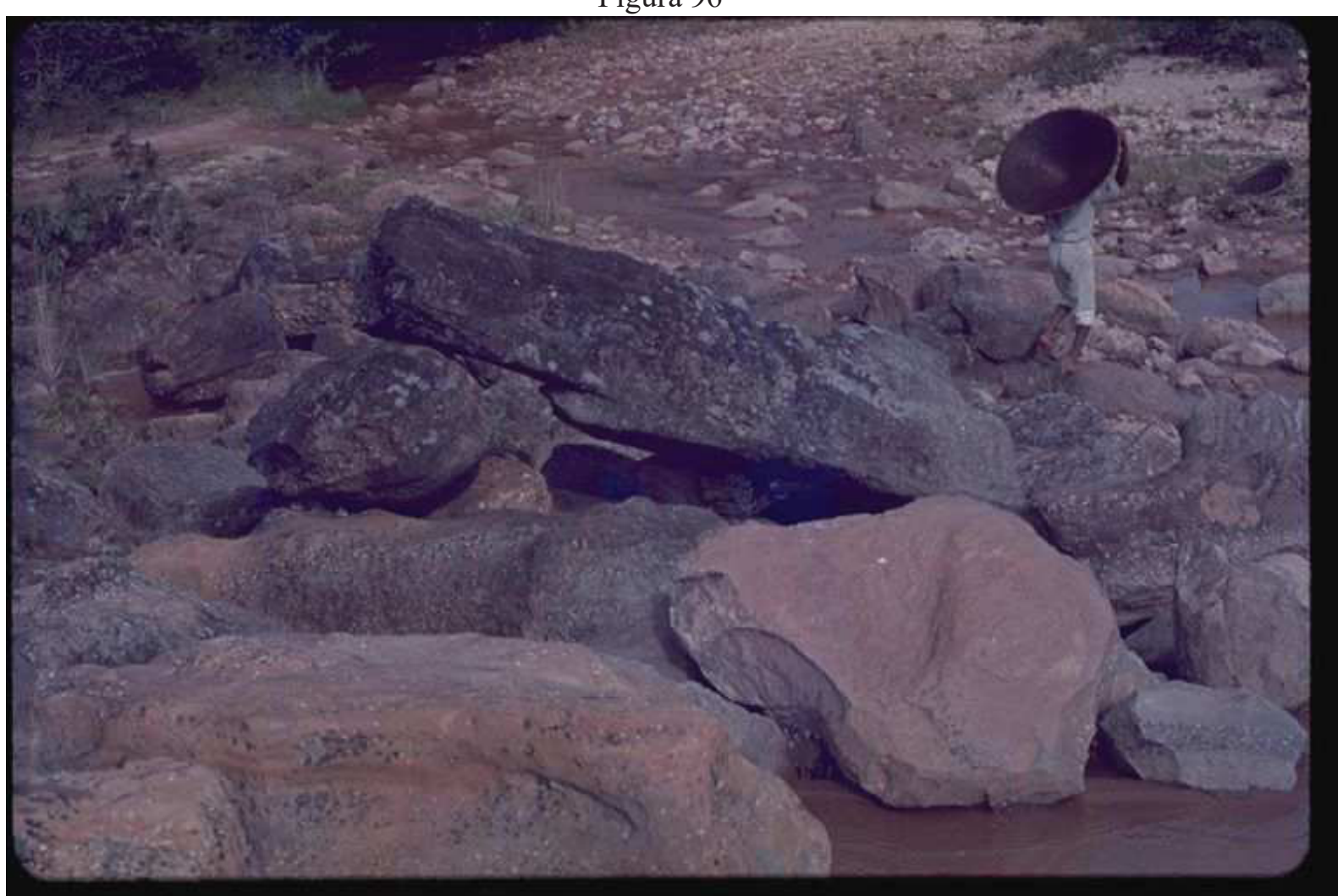

Fonte: Arquivo pessoal de Heraldo Barbosa Filho. 
Figura 97

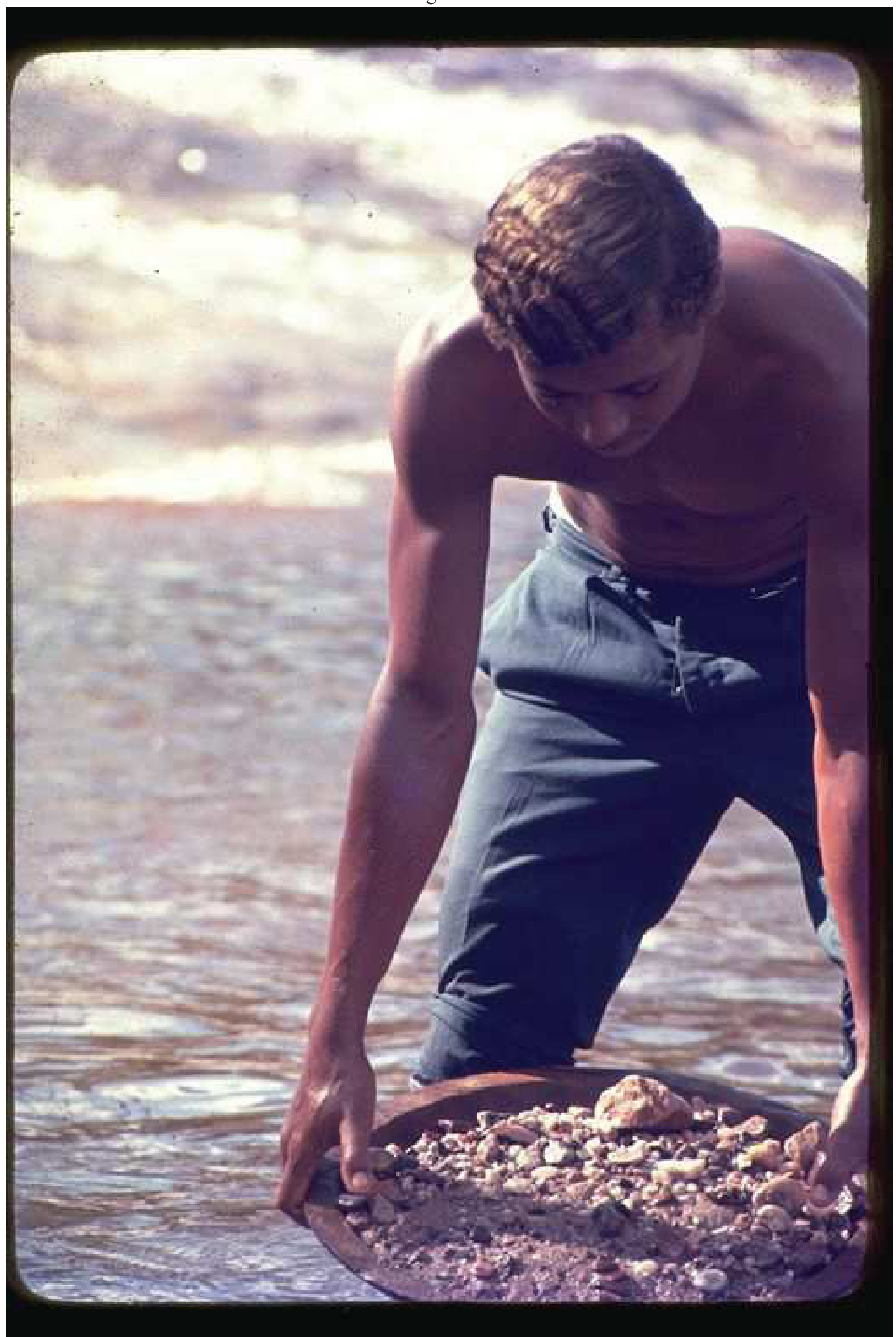

Fonte: Arquivo pessoal de Heraldo Barbosa Filho. 
Figura 98

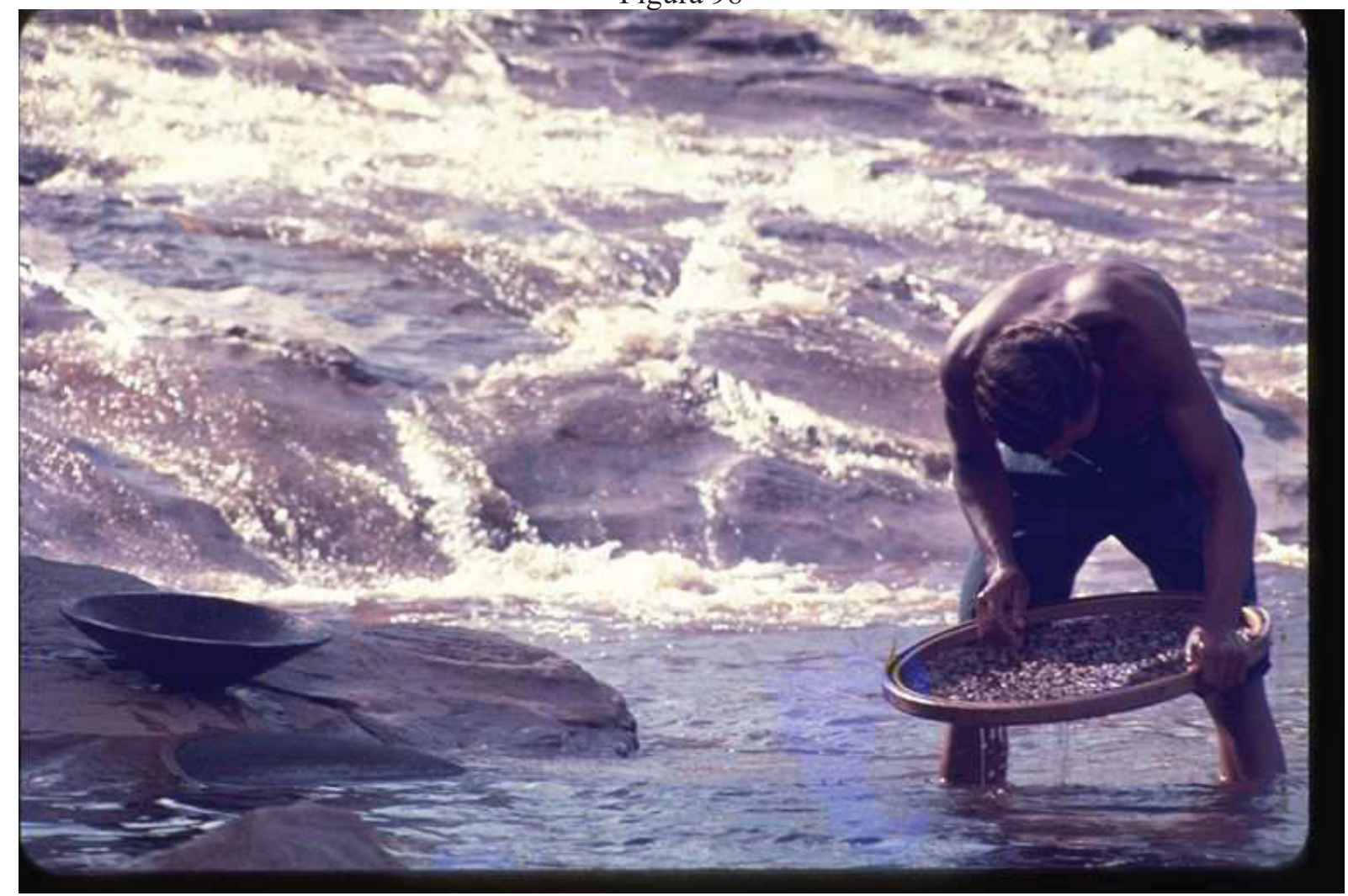

Fonte: Arquivo pessoal de Heraldo Barbosa Filho. 


\section{ANEXO E - Fotografias do Voluntário do Peace Corps Steve Hormann (P\&B)}

Essas também são imagens produzidas pelo voluntário estadunidense Steve Horman na sua passagem pela cidade de Lençóis no início dos anos 1970. Foram digitalizadas por Carlos de Almeida Toledo a partir do acervo pessoal de Mestre Osvaldo. 
Figura 99

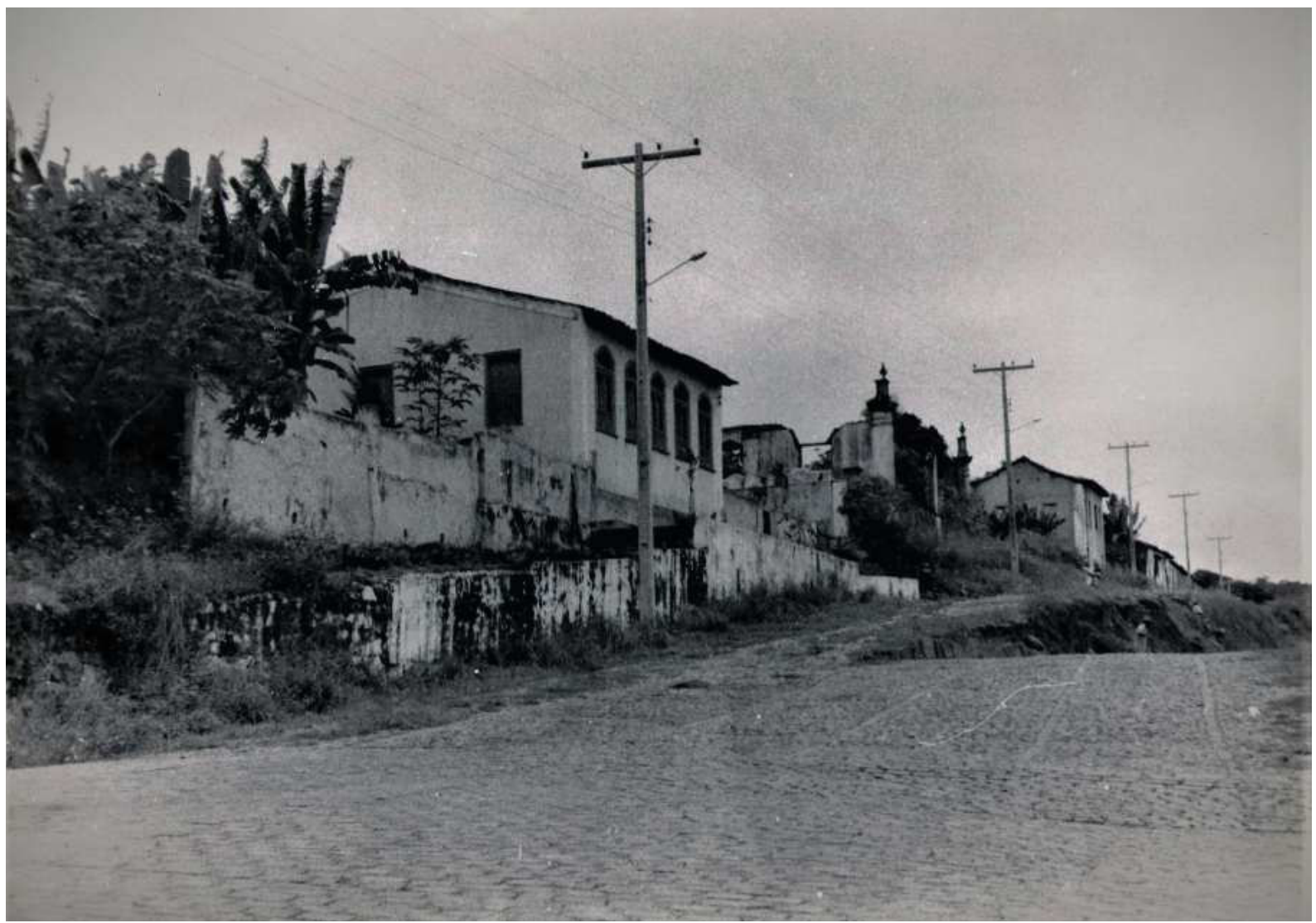

Fonte: Arquivo pessoal de Mestre Osvaldo

Figura 100

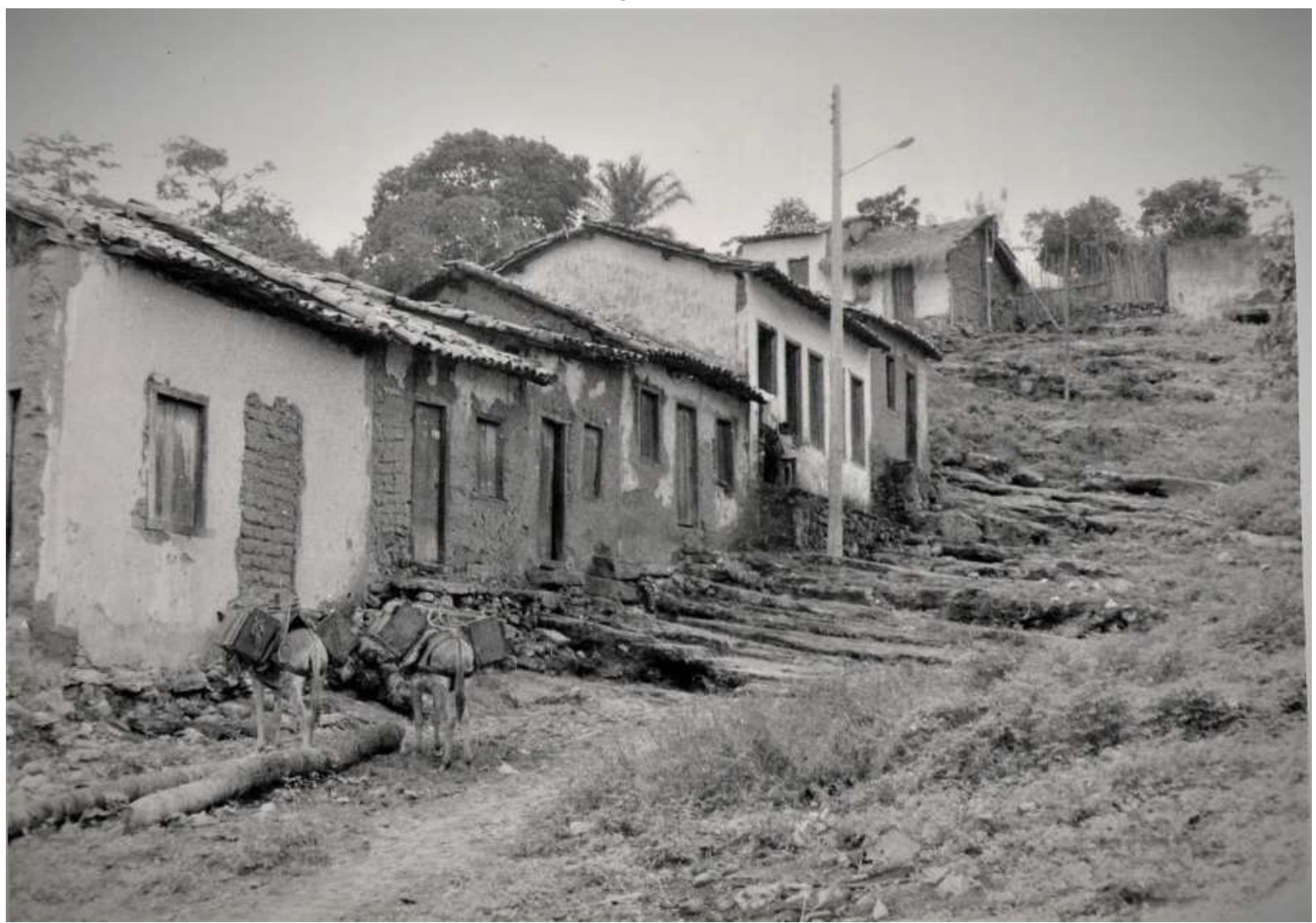

Fonte: Arquivo pessoal de Mestre Osvaldo 
Figura 101

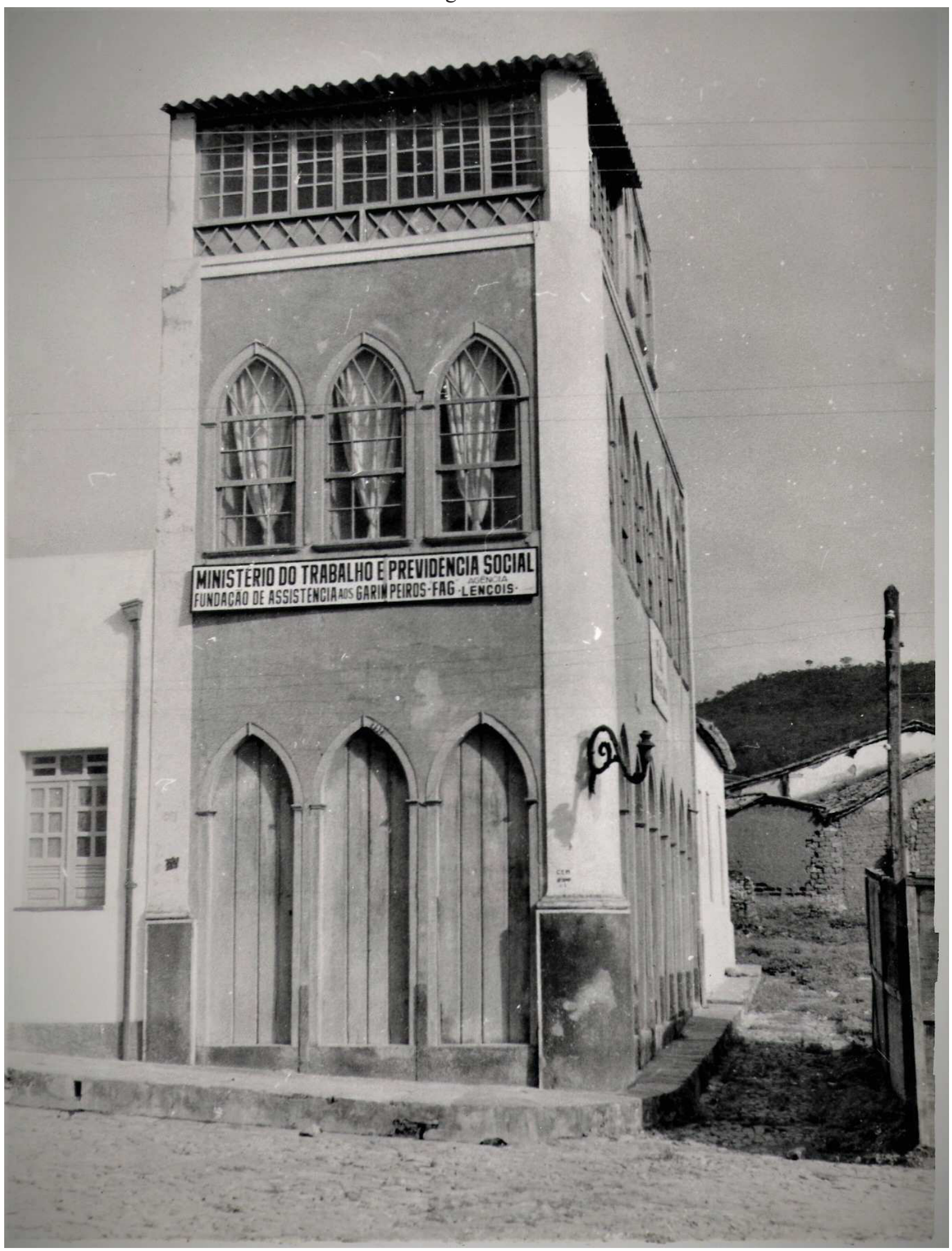

Fonte: Arquivo pessoal de Mestre Osvaldo 
Figura 102

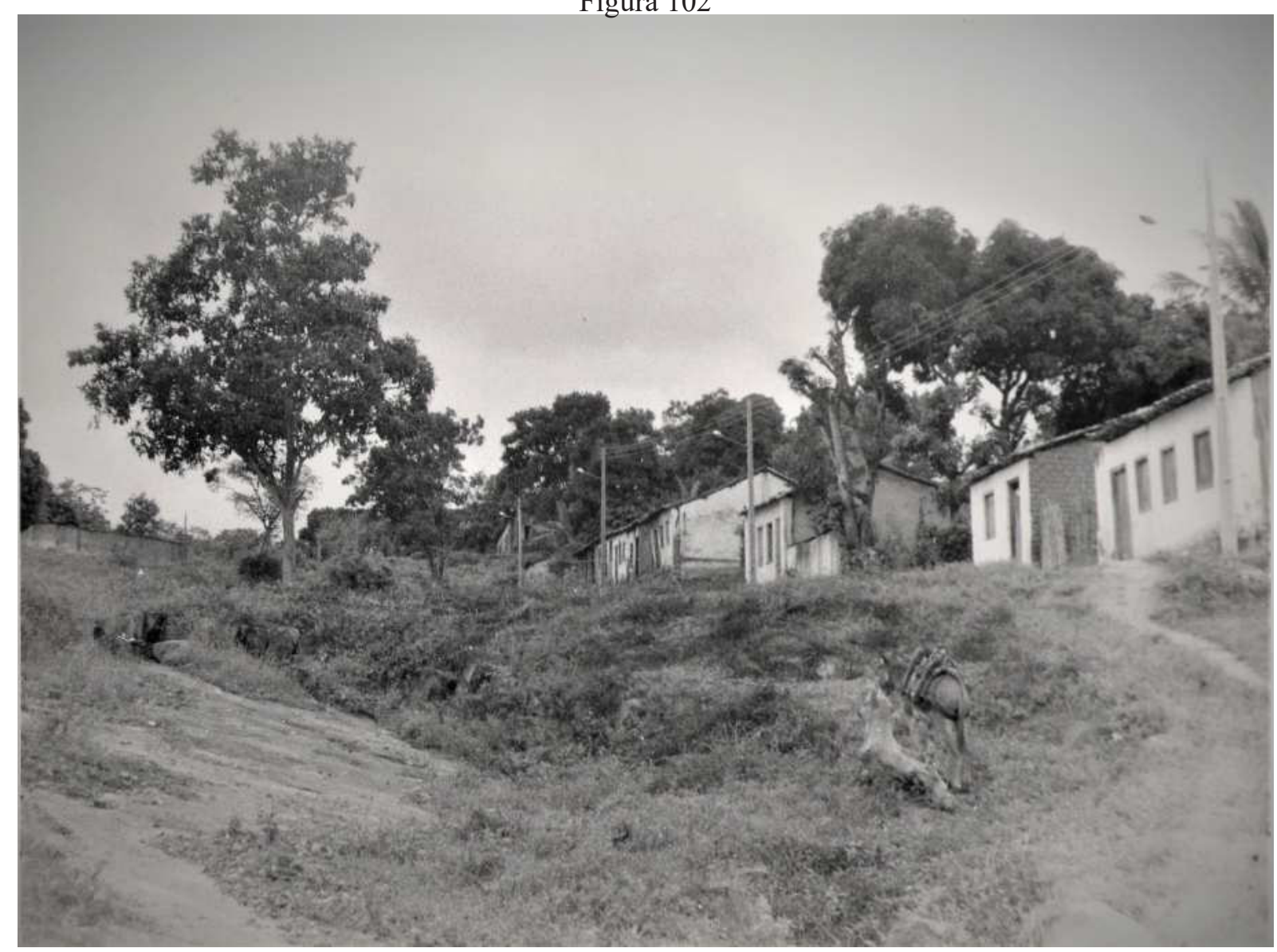

Fonte: Arquivo pessoal de Mestre Osvaldo 
Figura 103

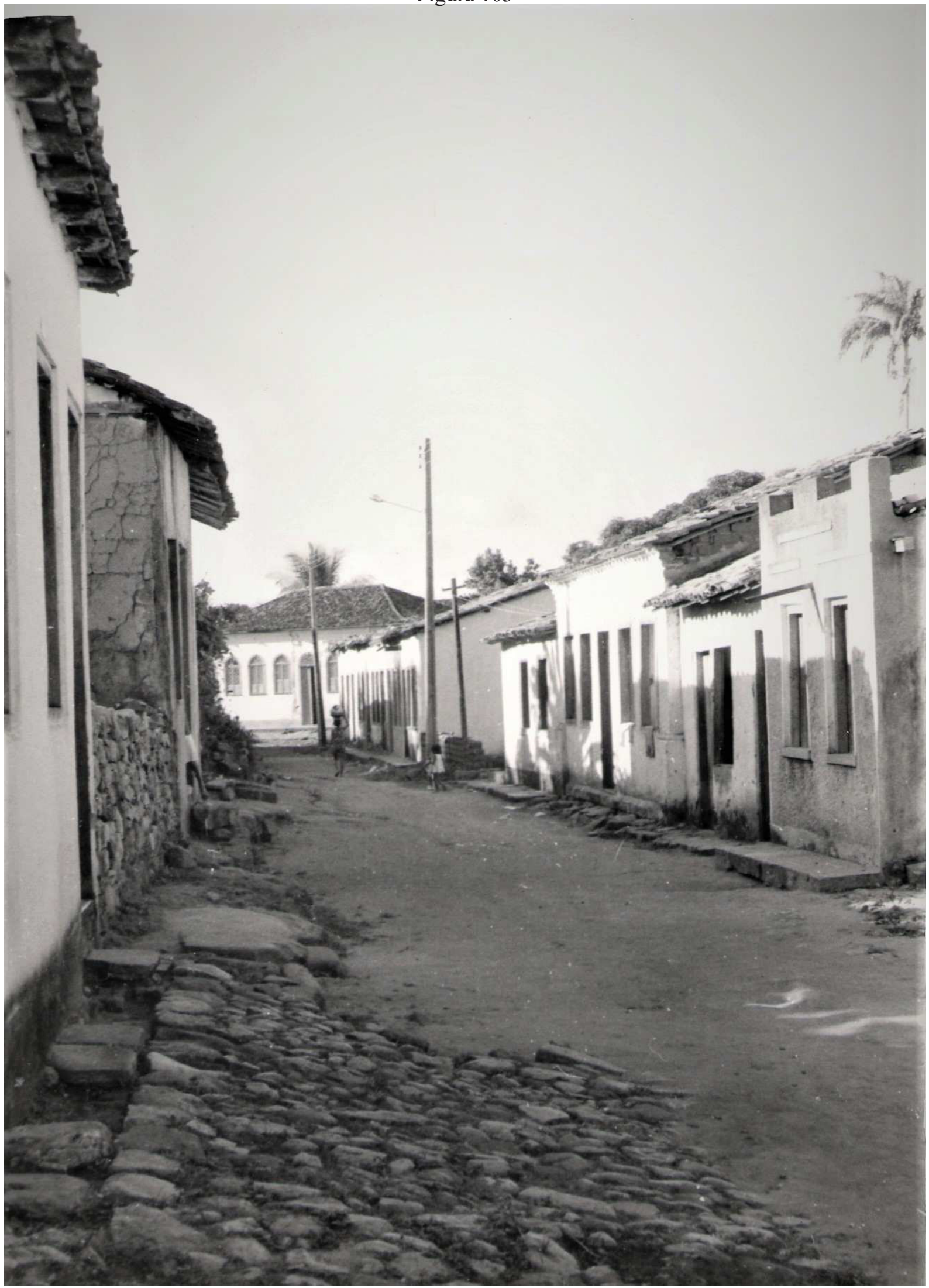

Fonte: Arquivo pessoal de Mestre Osvaldo 
Figura 104

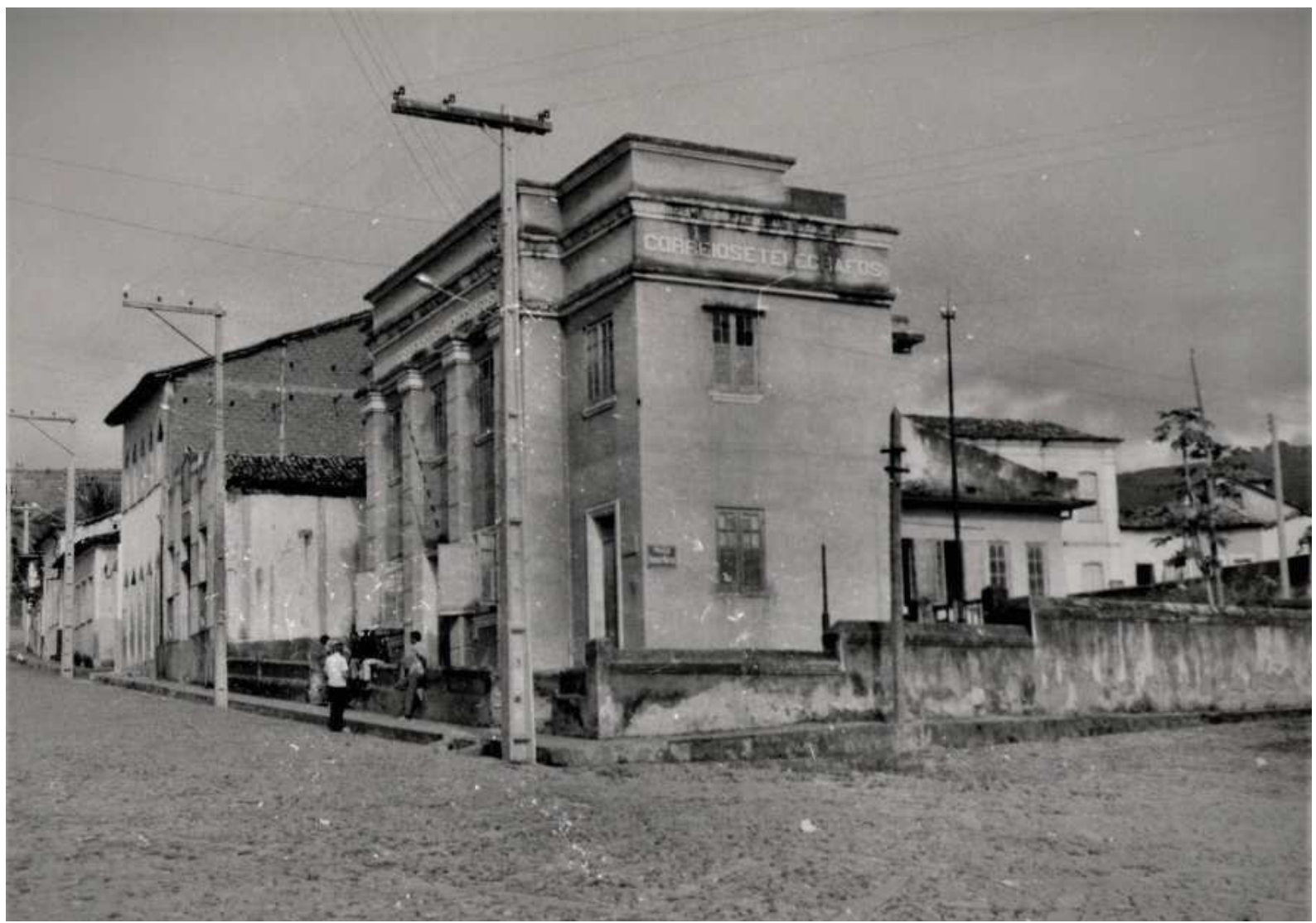

Fonte: Arquivo pessoal de Mestre Osvaldo

Figura 105

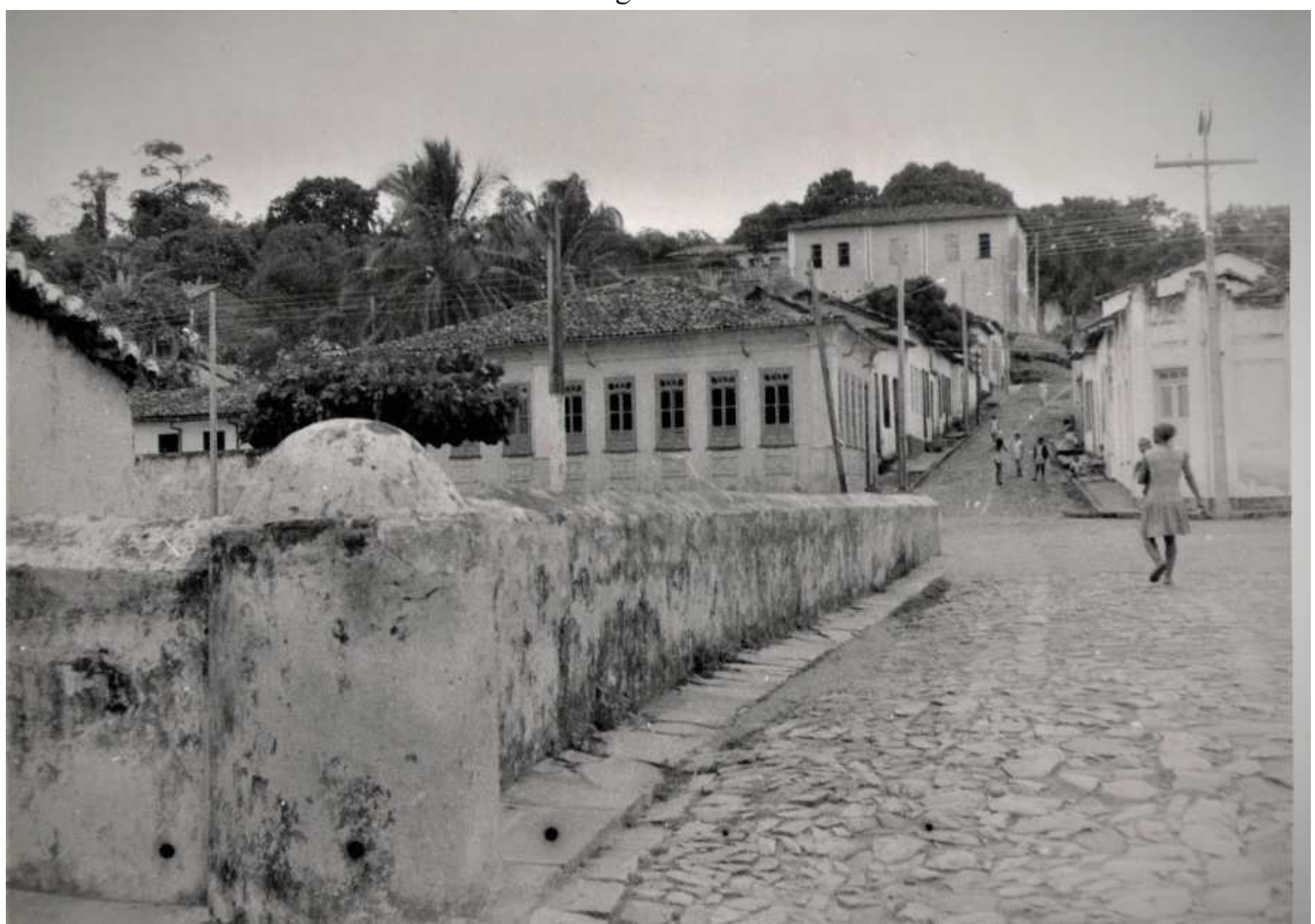

Fonte: Arquivo pessoal de Mestre Osvaldo 
Figura 106

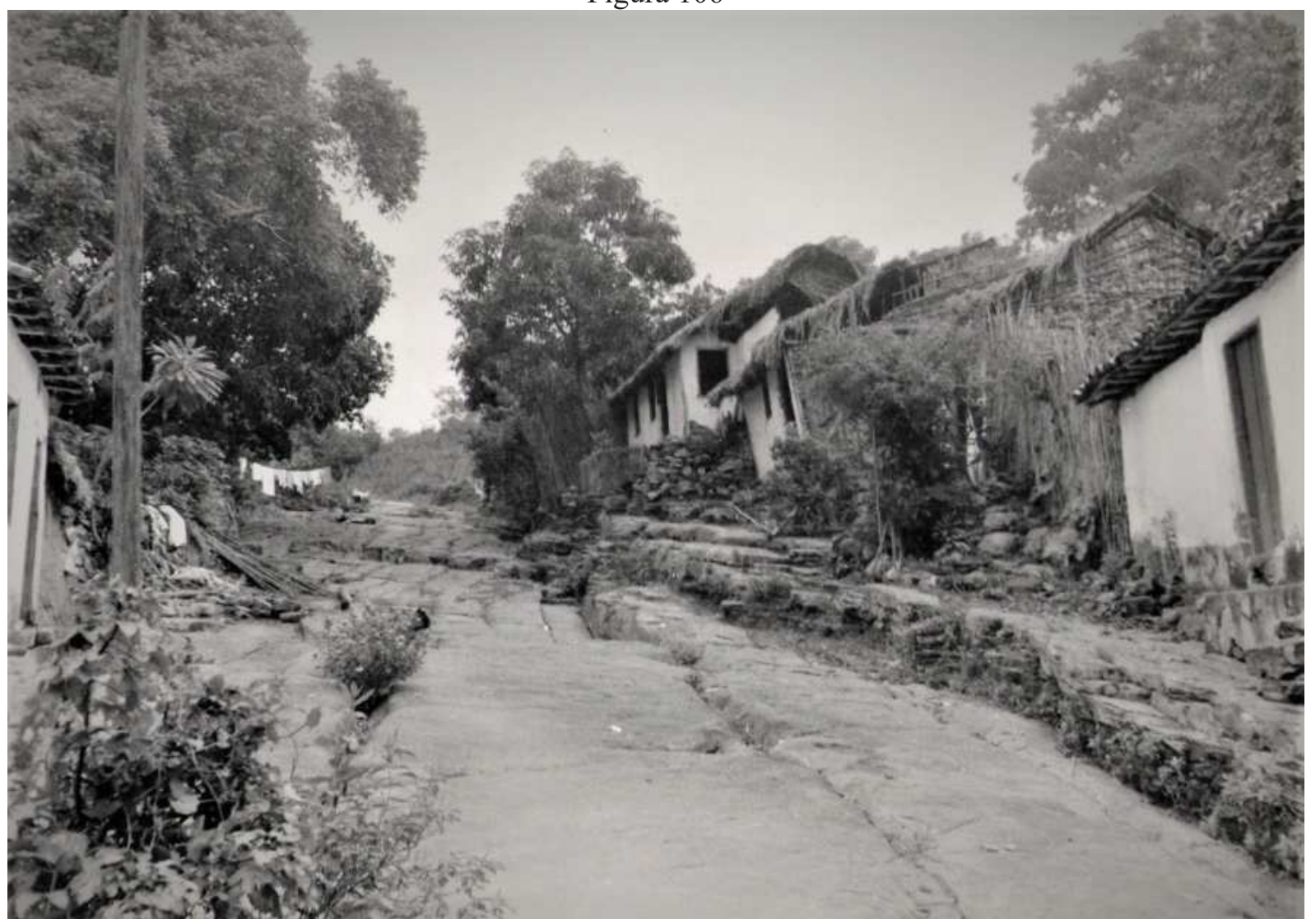

Fonte: Arquivo pessoal de Mestre Osvaldo

Figura 107

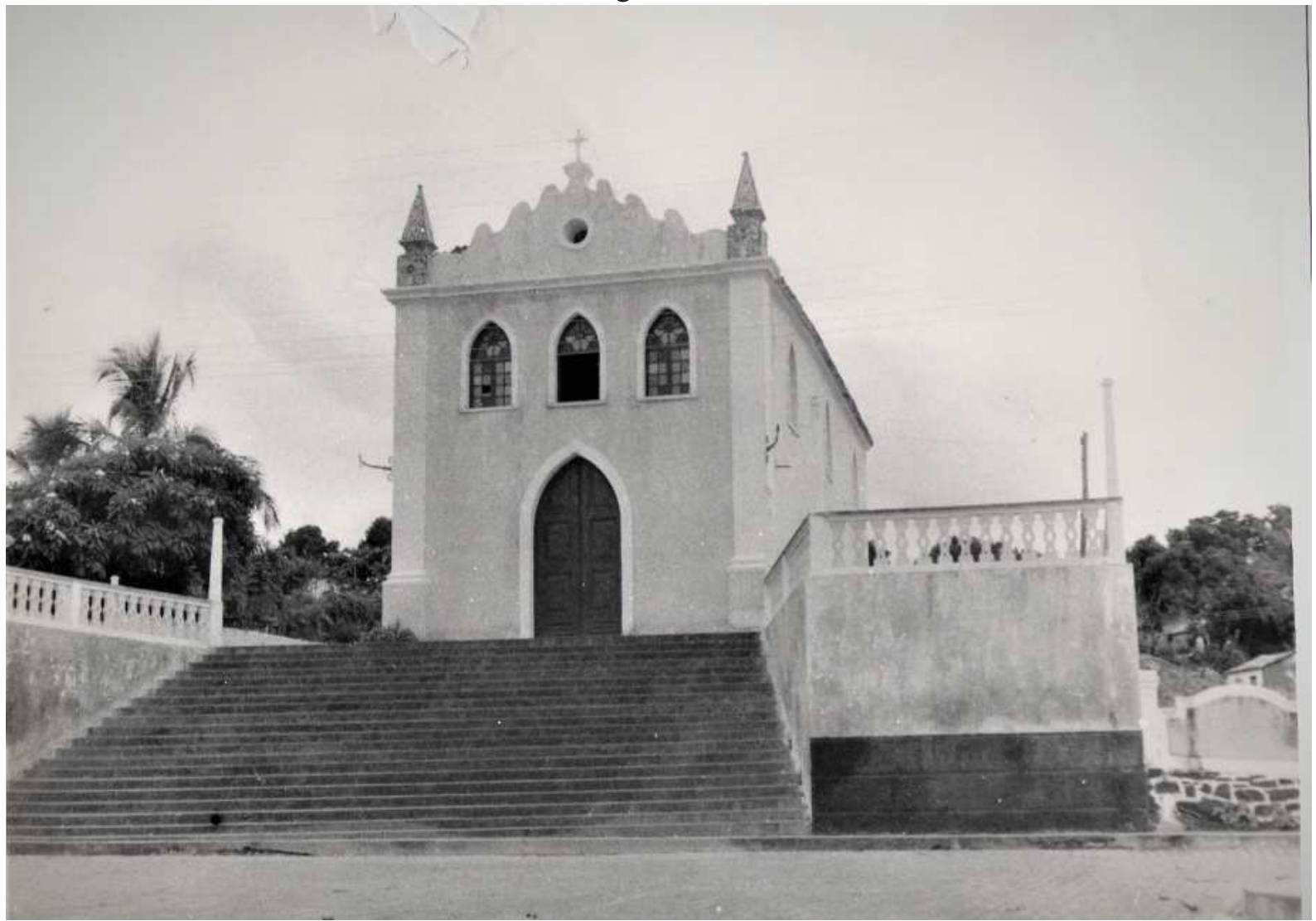

Fonte: Arquivo pessoal de Mestre Osvaldo 
Figura 108

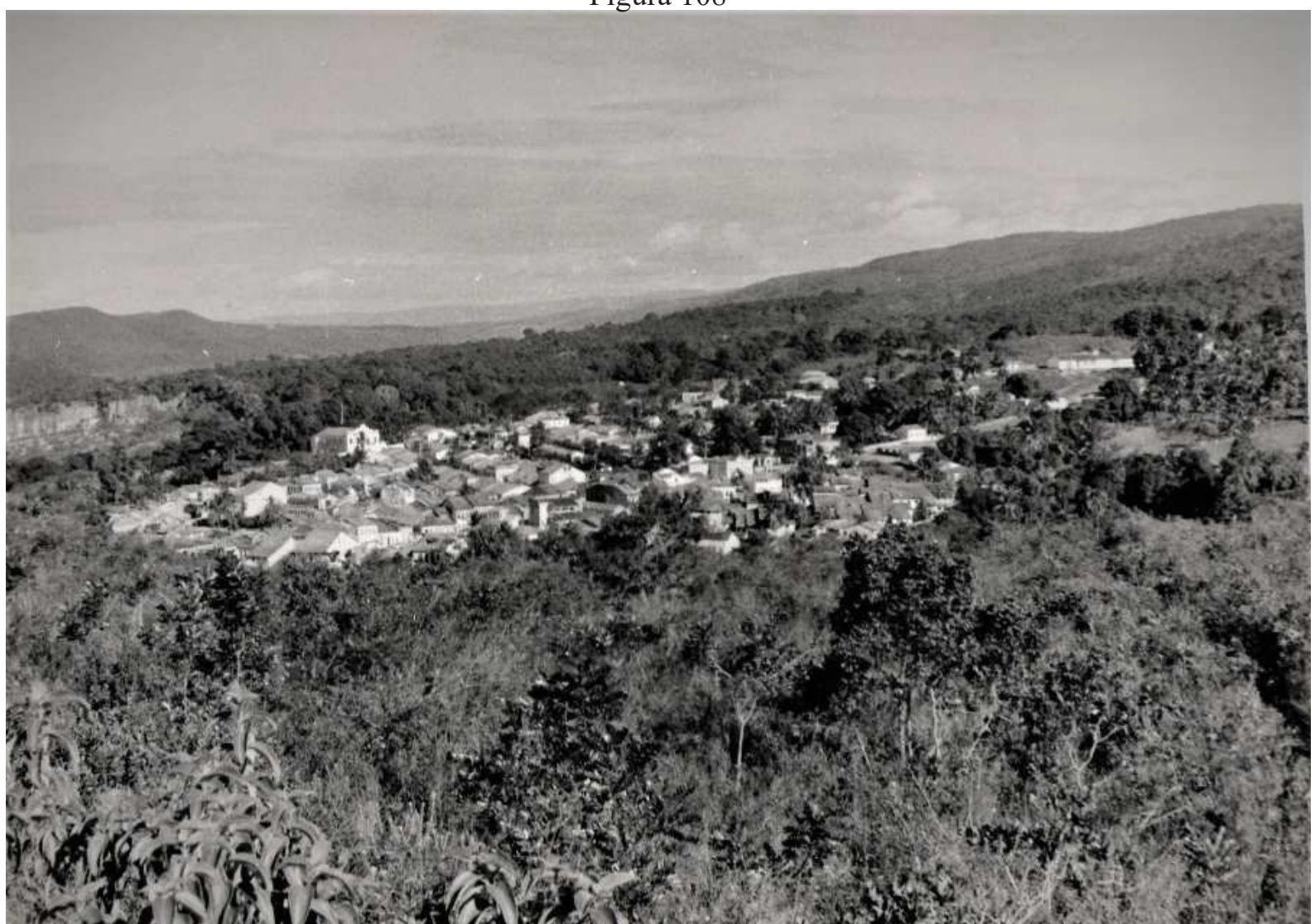

Fonte: Arquivo pessoal de Mestre Osvaldo

Figura 109

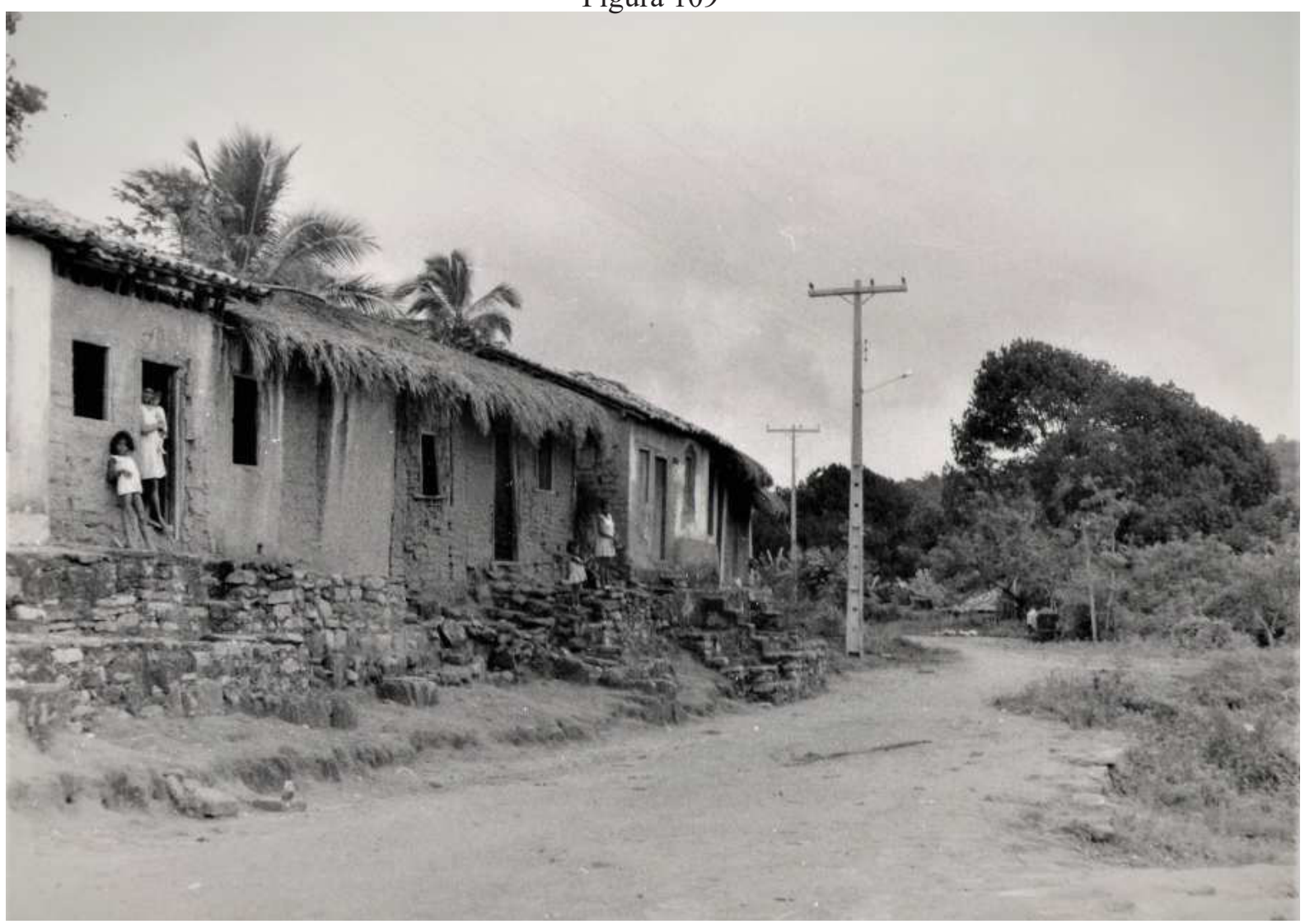

Fonte: Arquivo pessoal de Mestre Osvaldo 
Figura 110

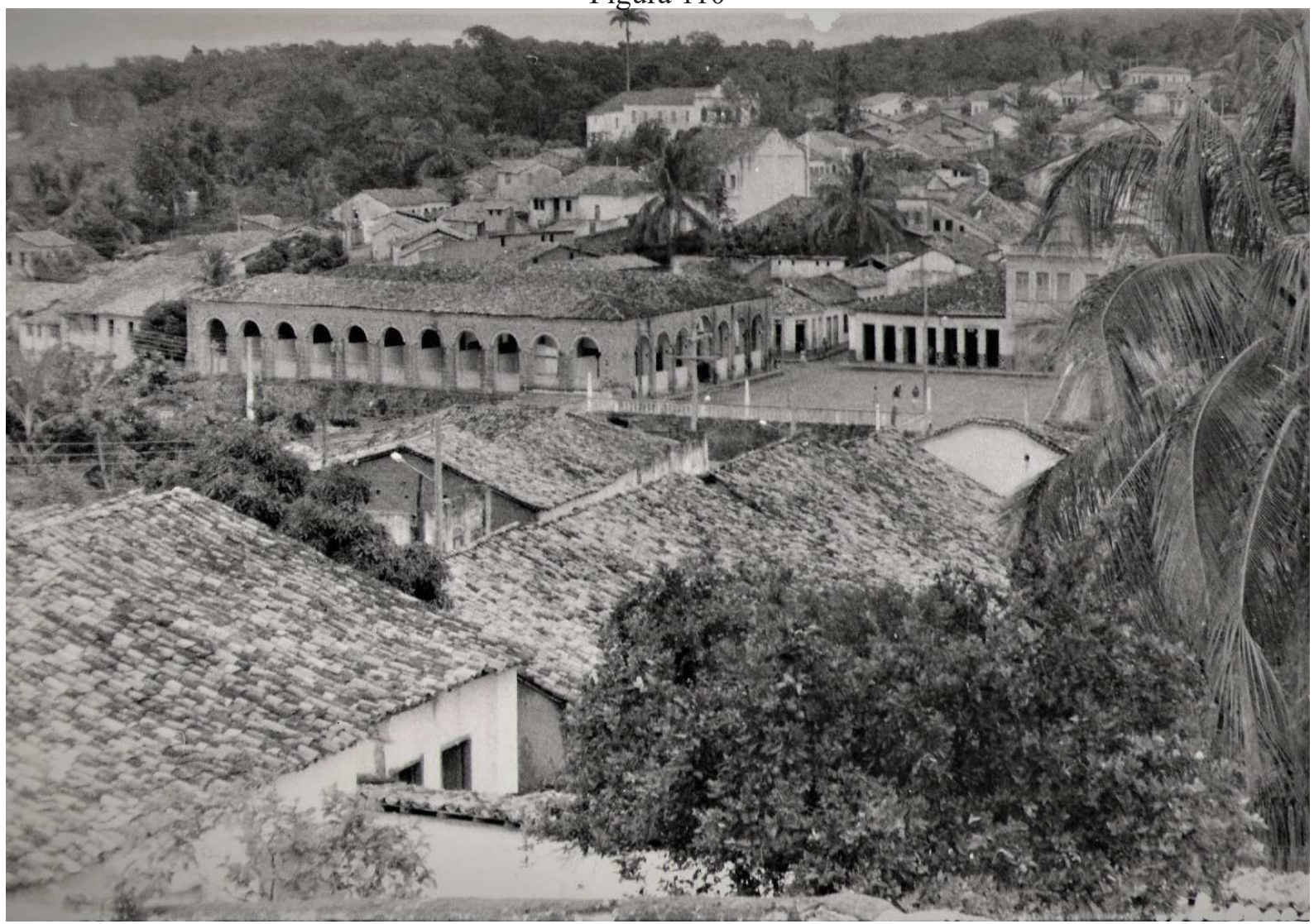

Fonte: Arquivo pessoal de Mestre Osvaldo

Figura 111

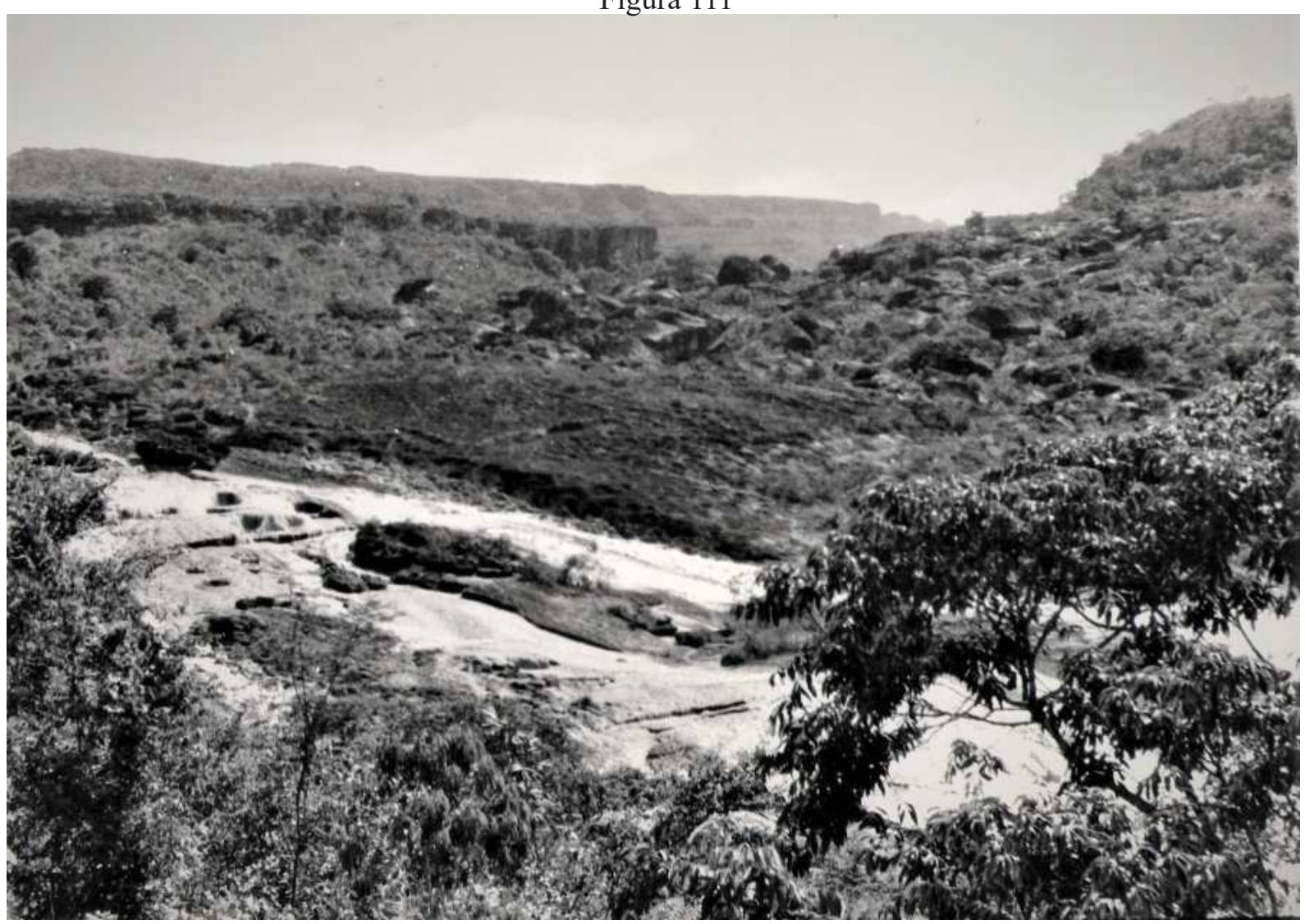

Fonte: Arquivo pessoal de Mestre Osvaldo 
Figura 112

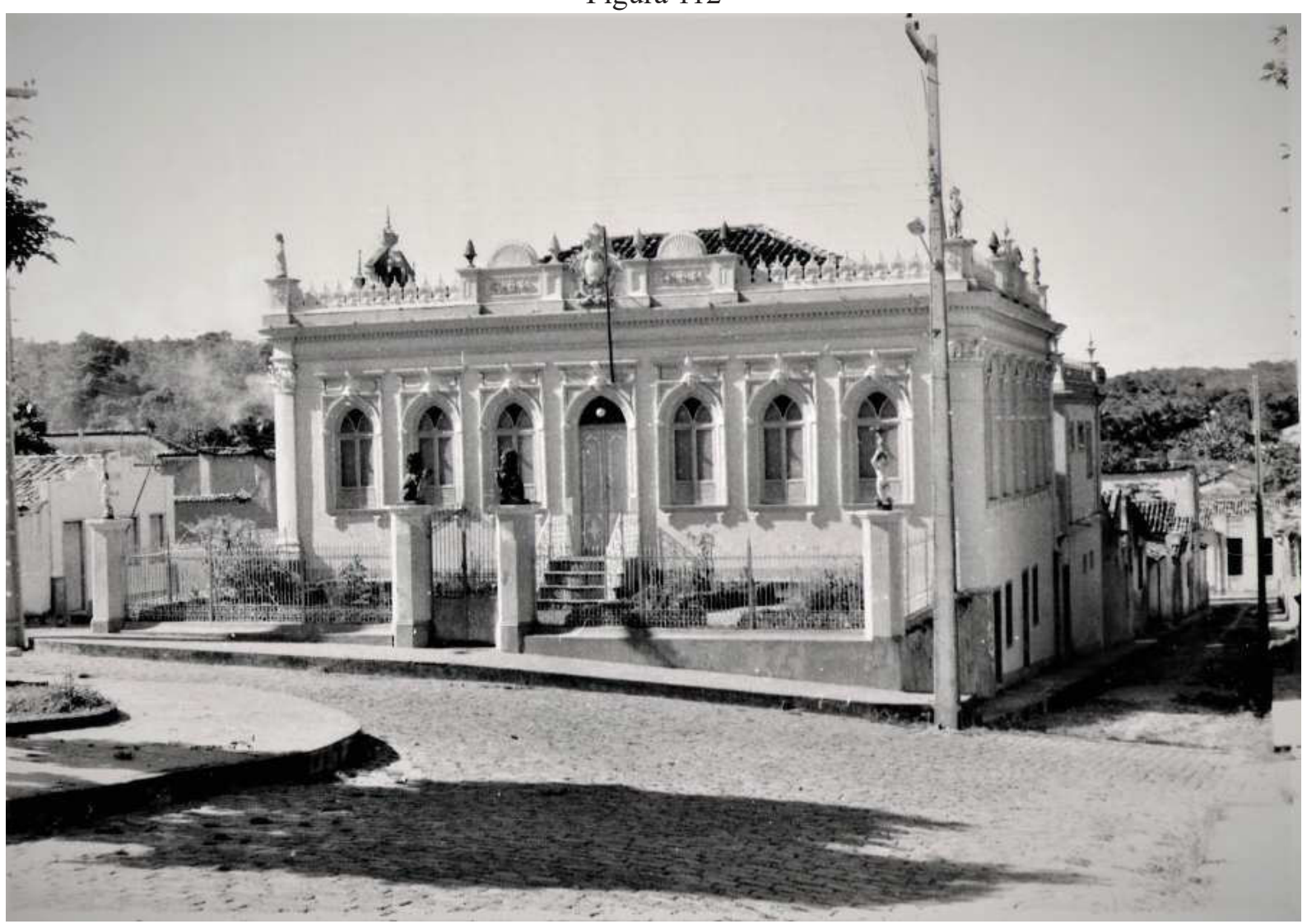

Fonte: Arquivo pessoal de Mestre Osvaldo

Figura 113

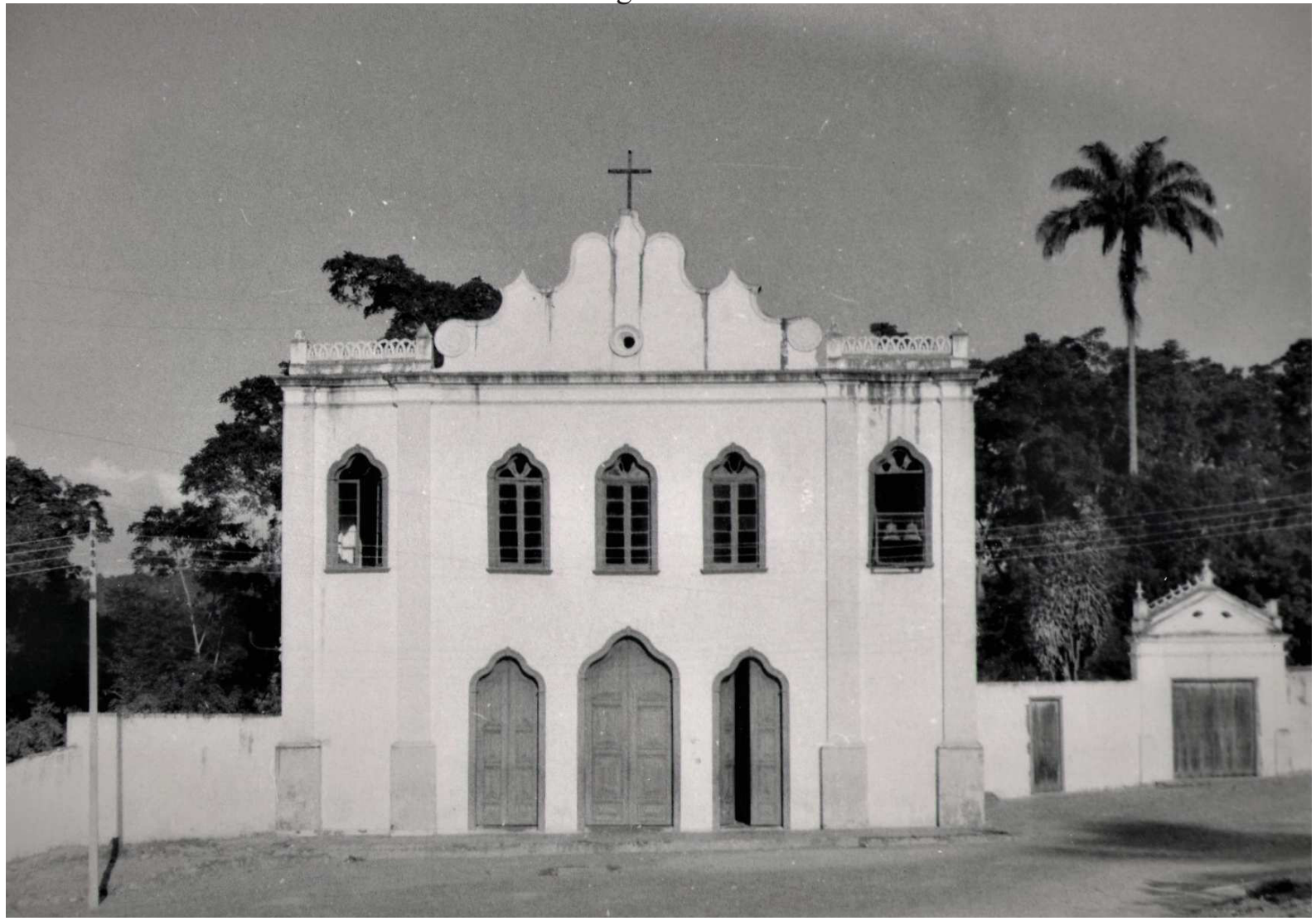

Fonte: Arquivo pessoal de Mestre Osvaldo 
Figura 114

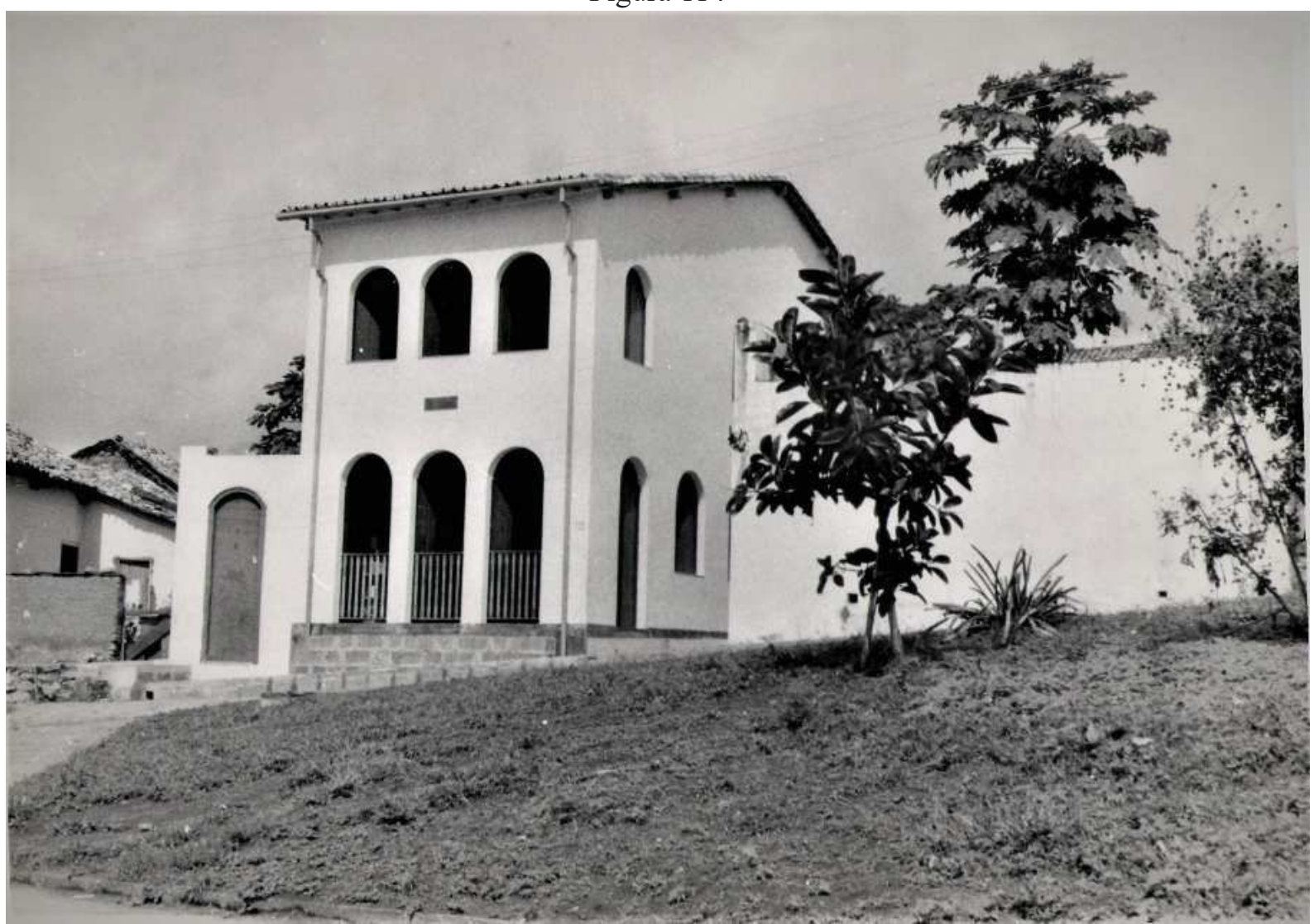

Fonte: Arquivo pessoal de Mestre Osvaldo

Figura 115

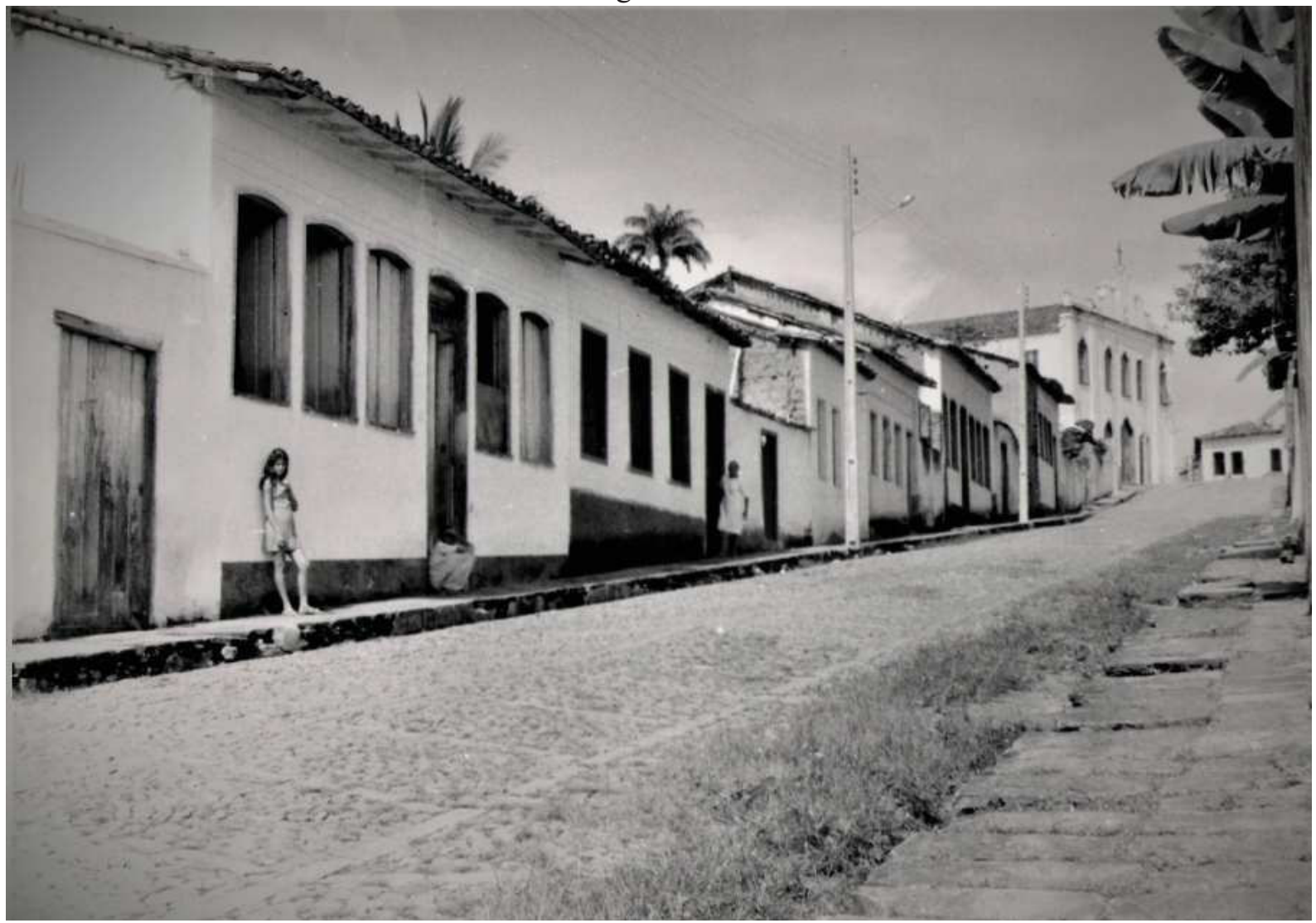

Fonte: Arquivo pessoal de Mestre Osvaldo 
Figura 116

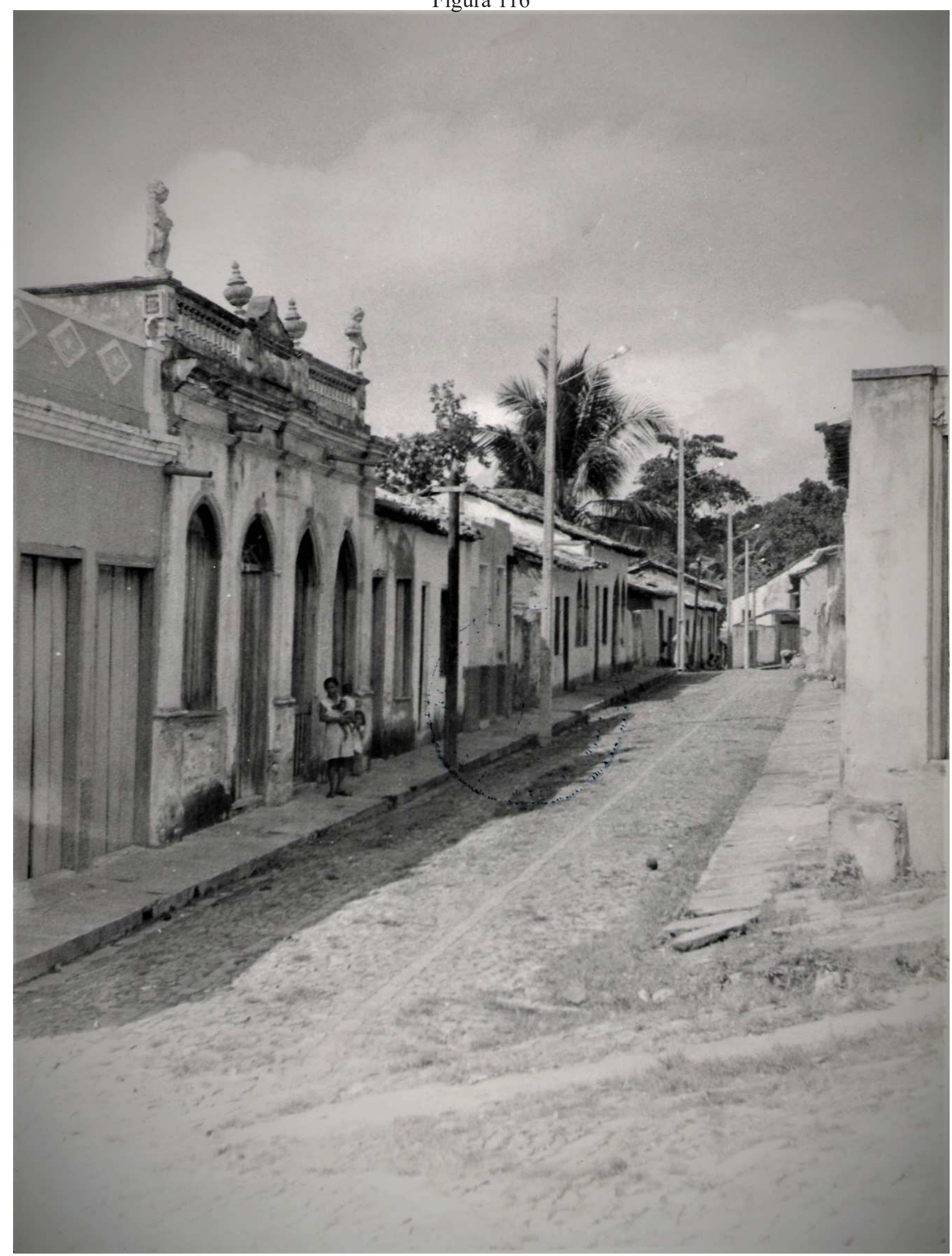

Fonte: Arquivo pessoal de Mestre Osvaldo 
Figura 117

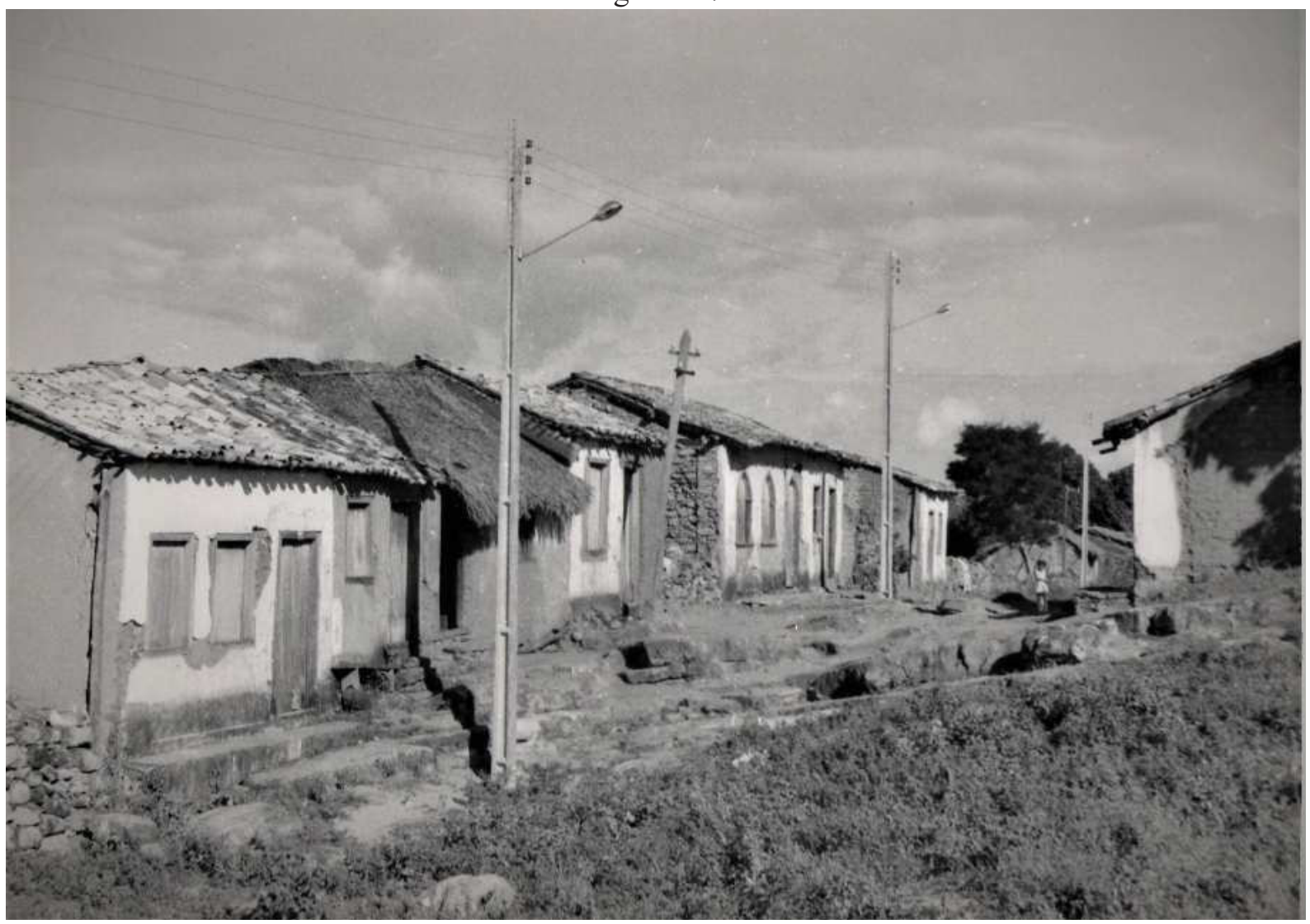

Fonte: Arquivo pessoal de Mestre Osvaldo

Figura 118

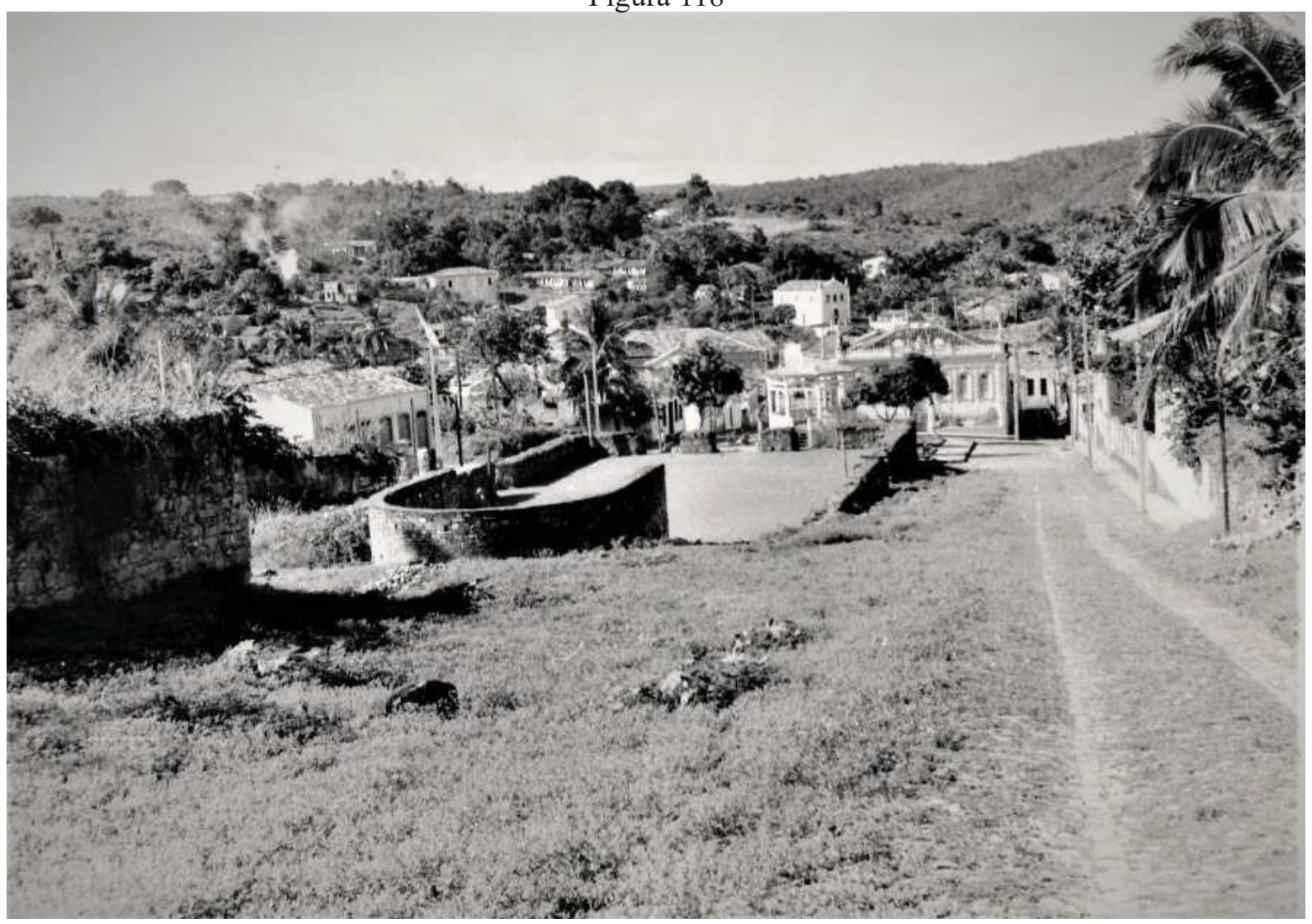

Fonte: Arquivo pessoal de Mestre Osvaldo 
Figura 119

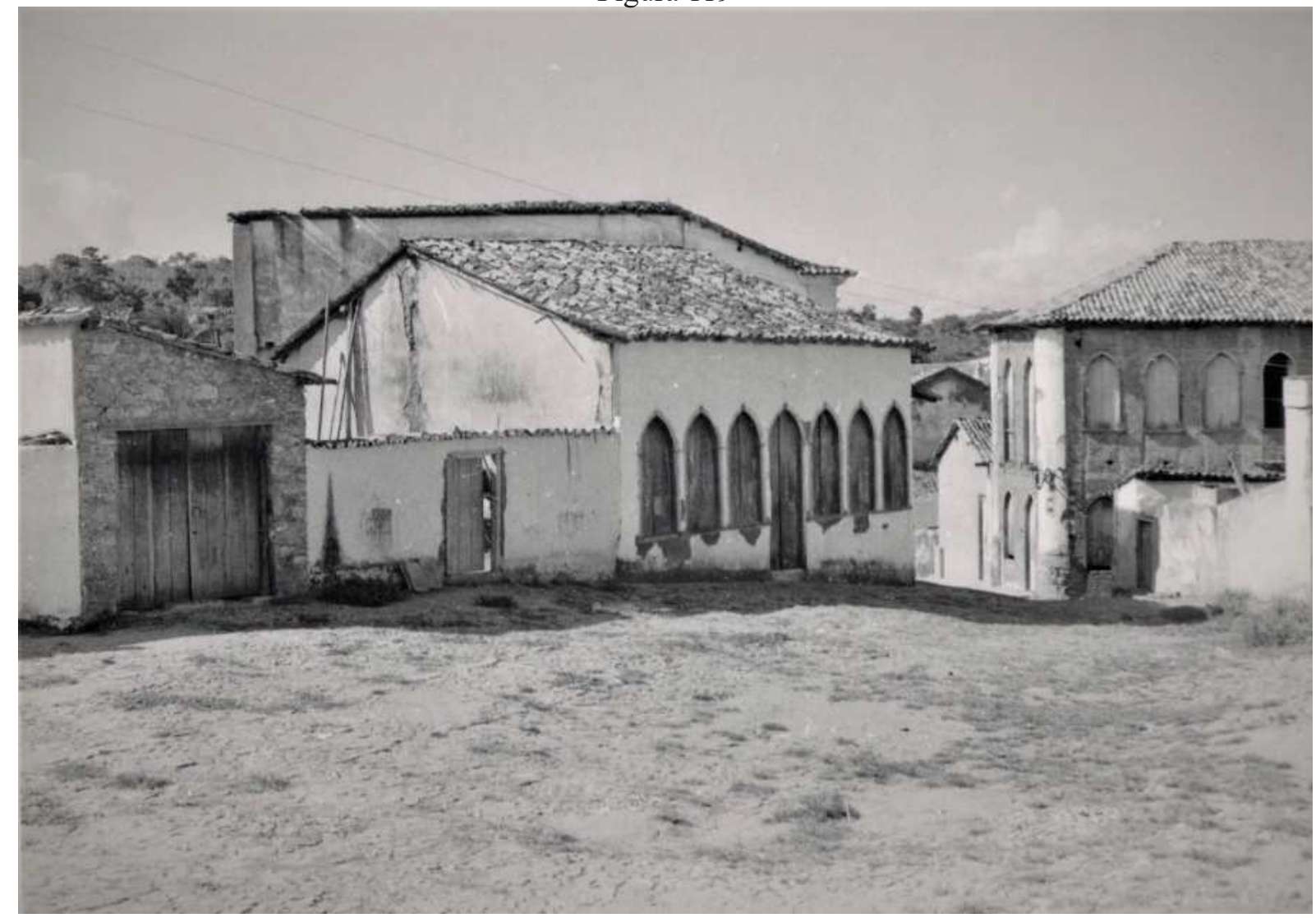

Fonte: Arquivo pessoal de Mestre Osvaldo

Figura 120

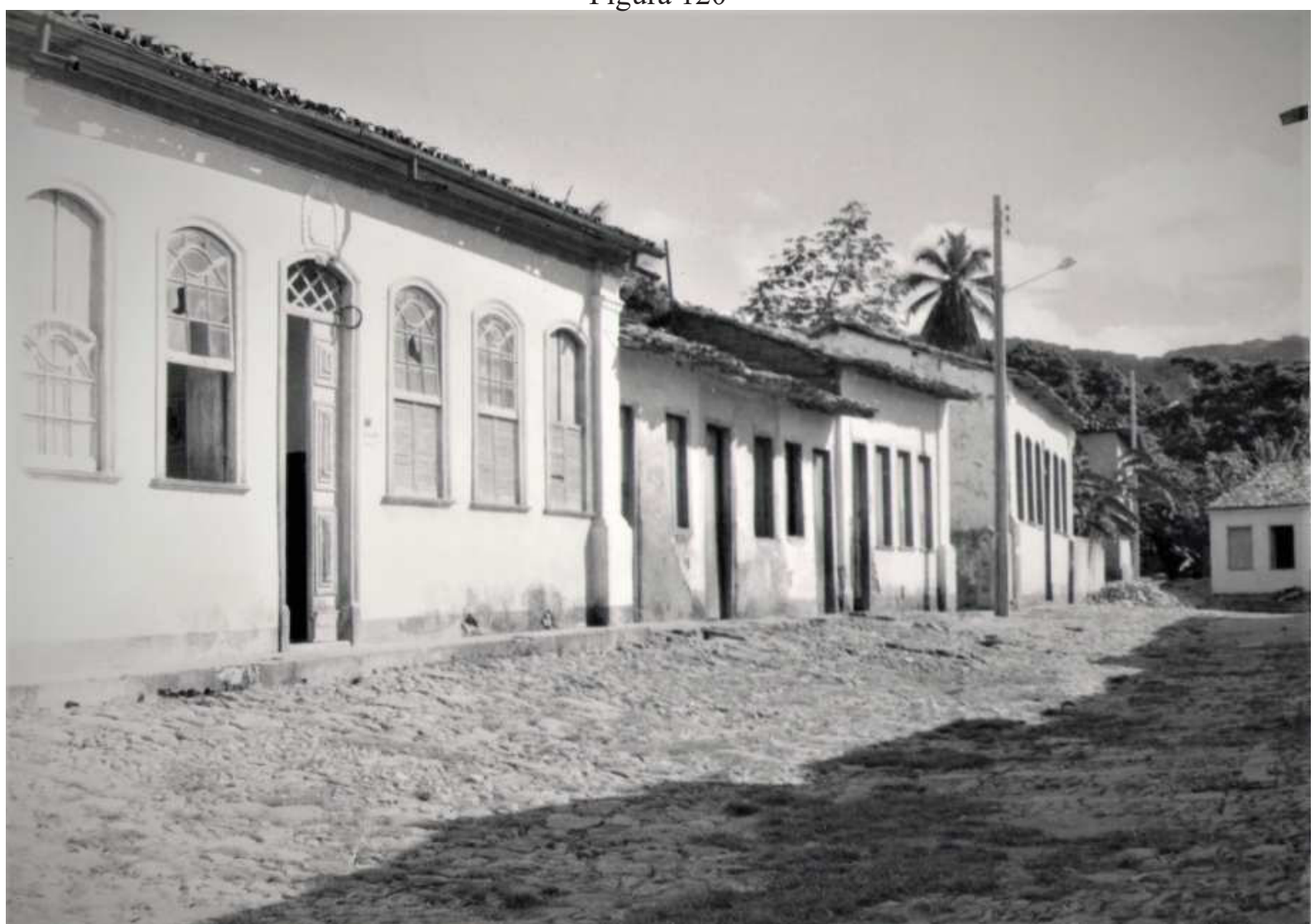

Fonte: Arquivo pessoal de Mestre Osvaldo 
Figura 121

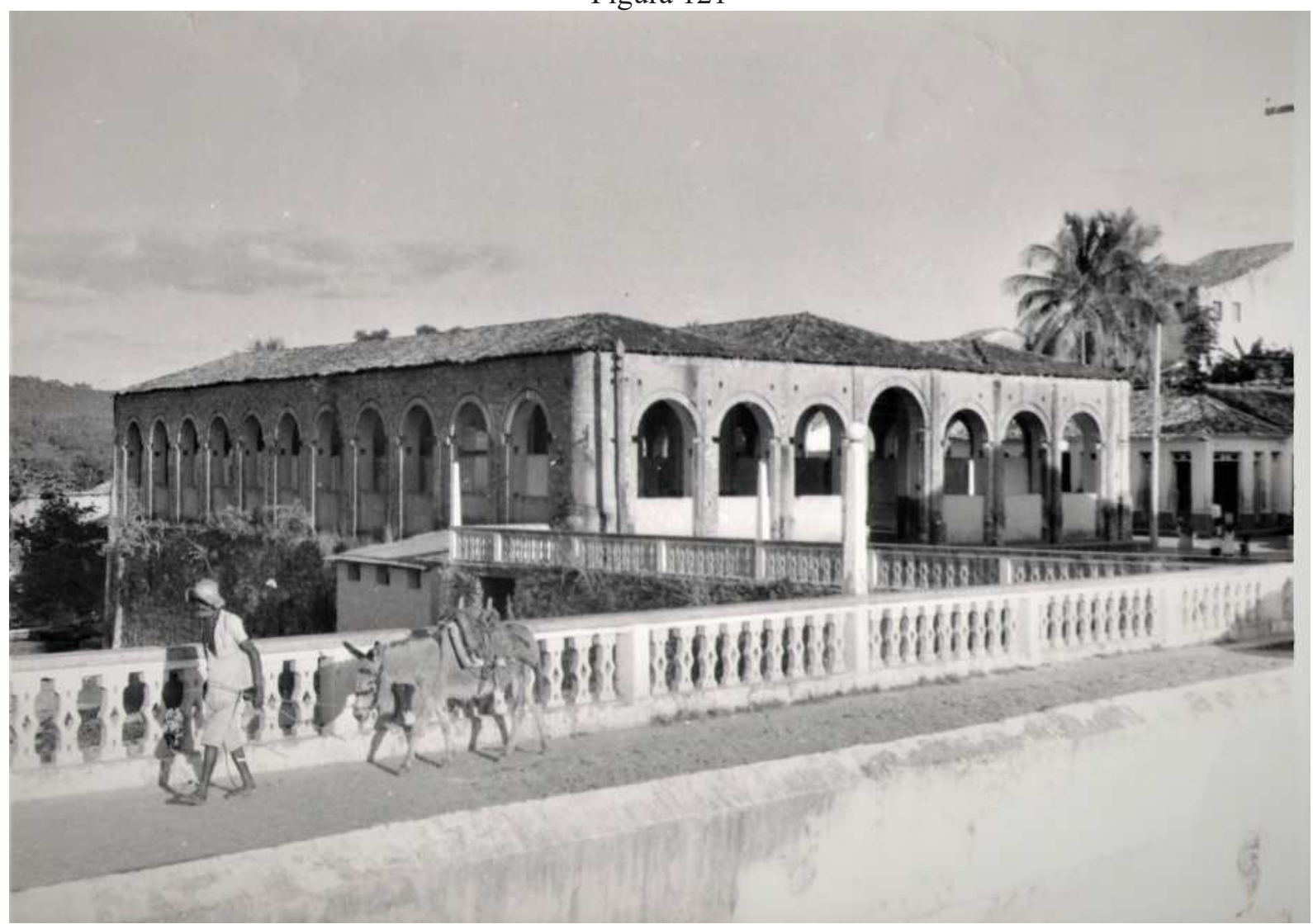

Fonte: Arquivo pessoal de Mestre Osvaldo

Figura 122

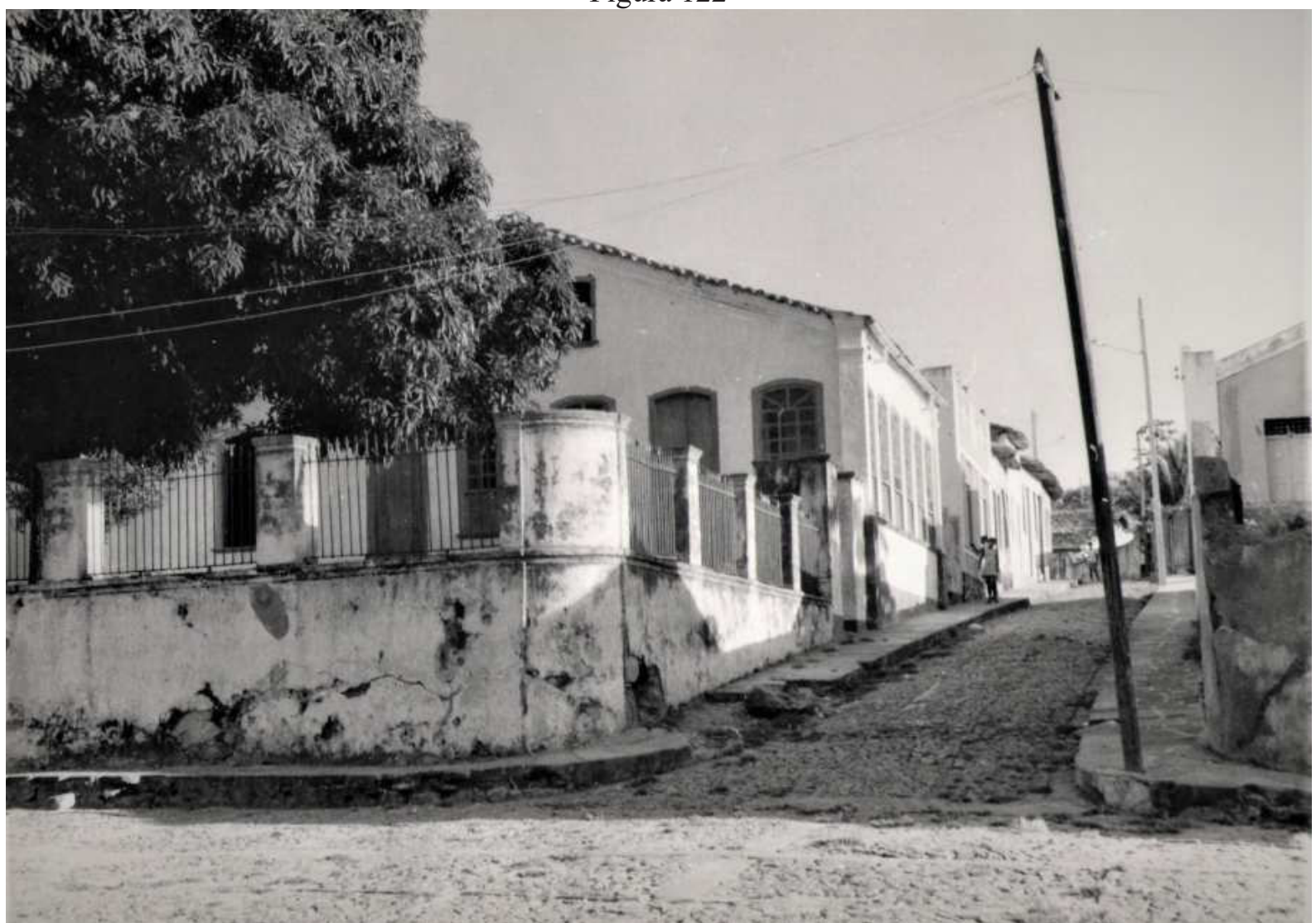

Fonte: Arquivo pessoal de Mestre Osvaldo 
Figura 123

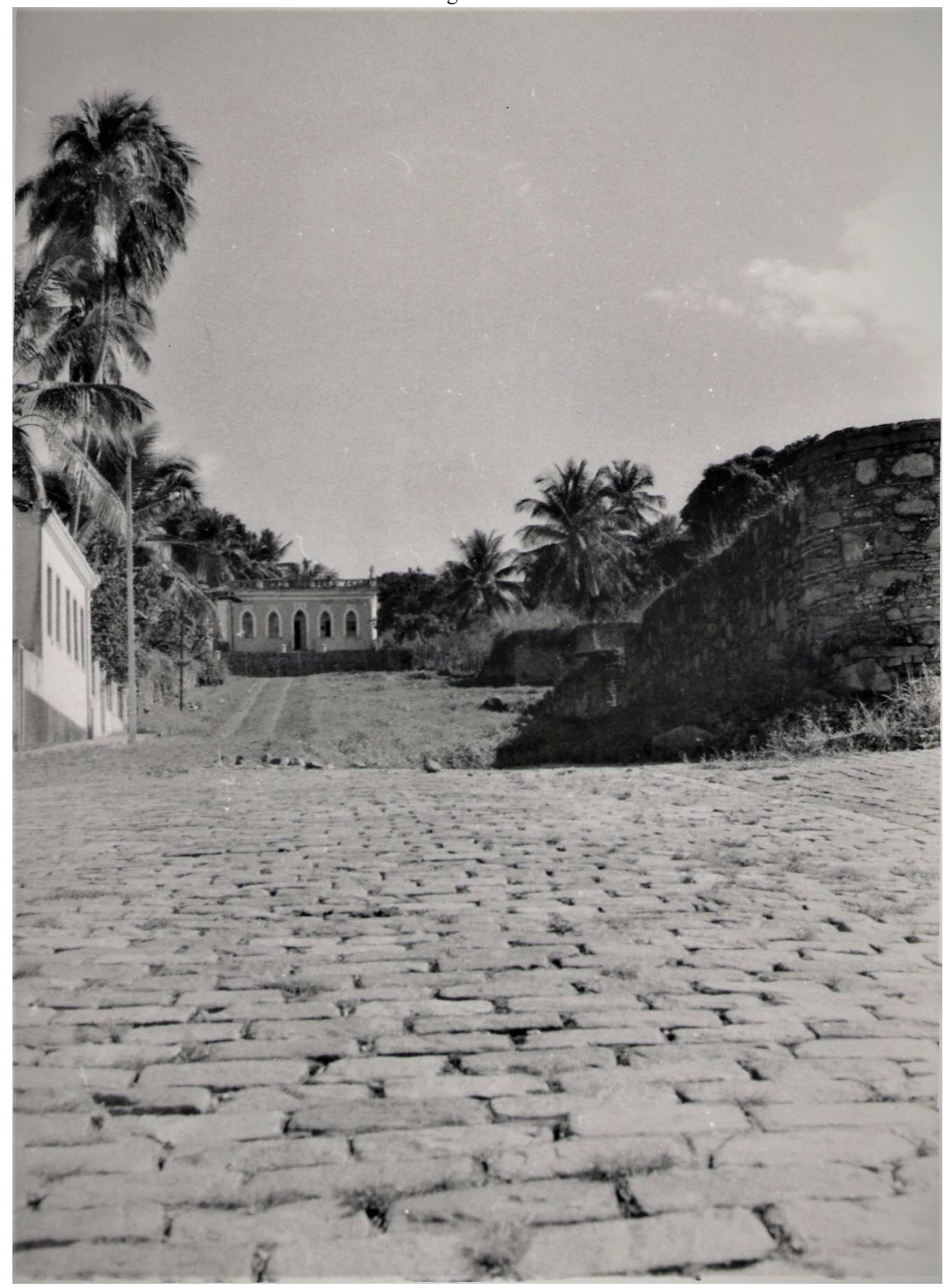

Fonte: Arquivo pessoal de Mestre Osvaldo 
Figura 124

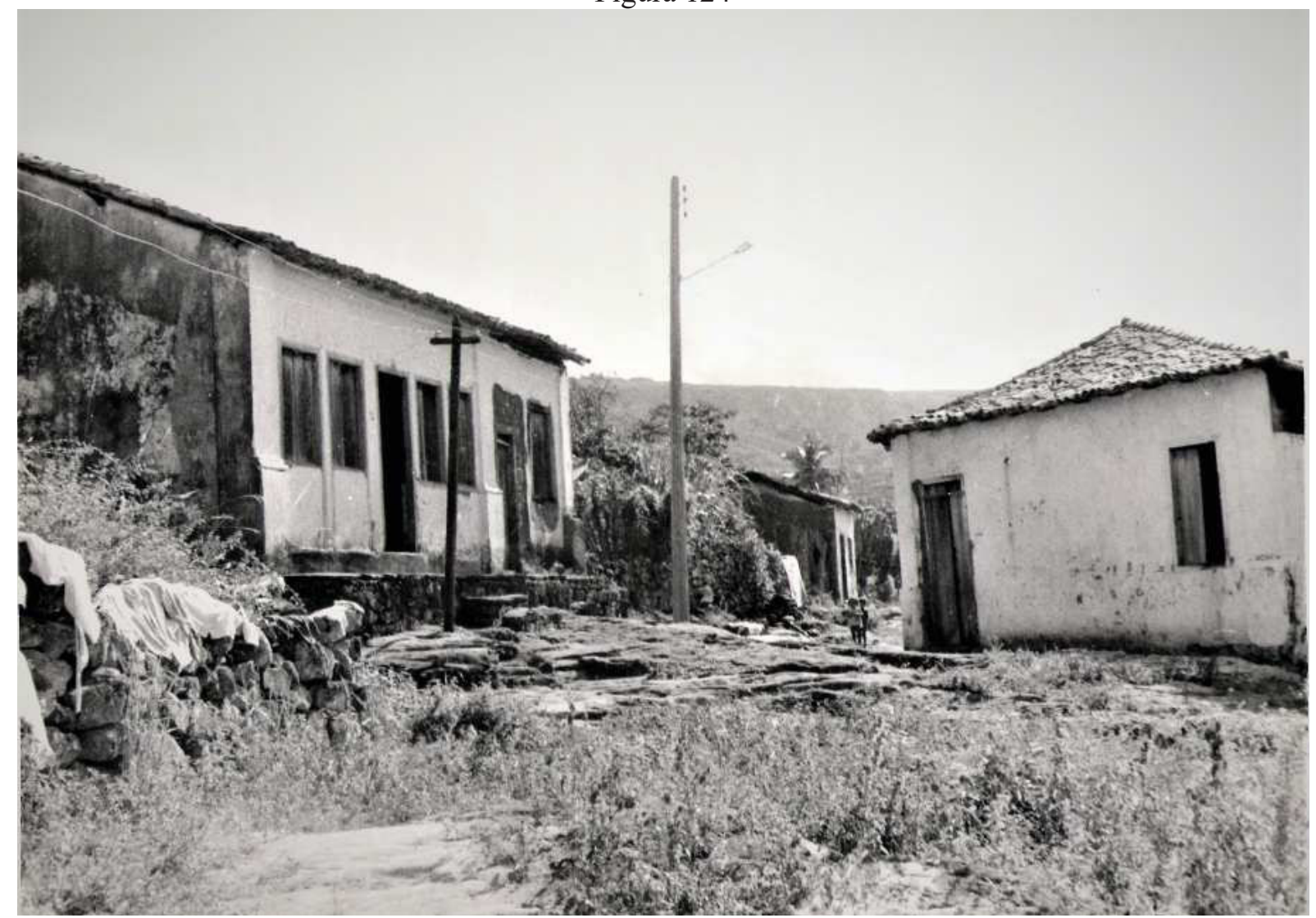

Fonte: Arquivo pessoal de Mestre Osvaldo

Figura 125

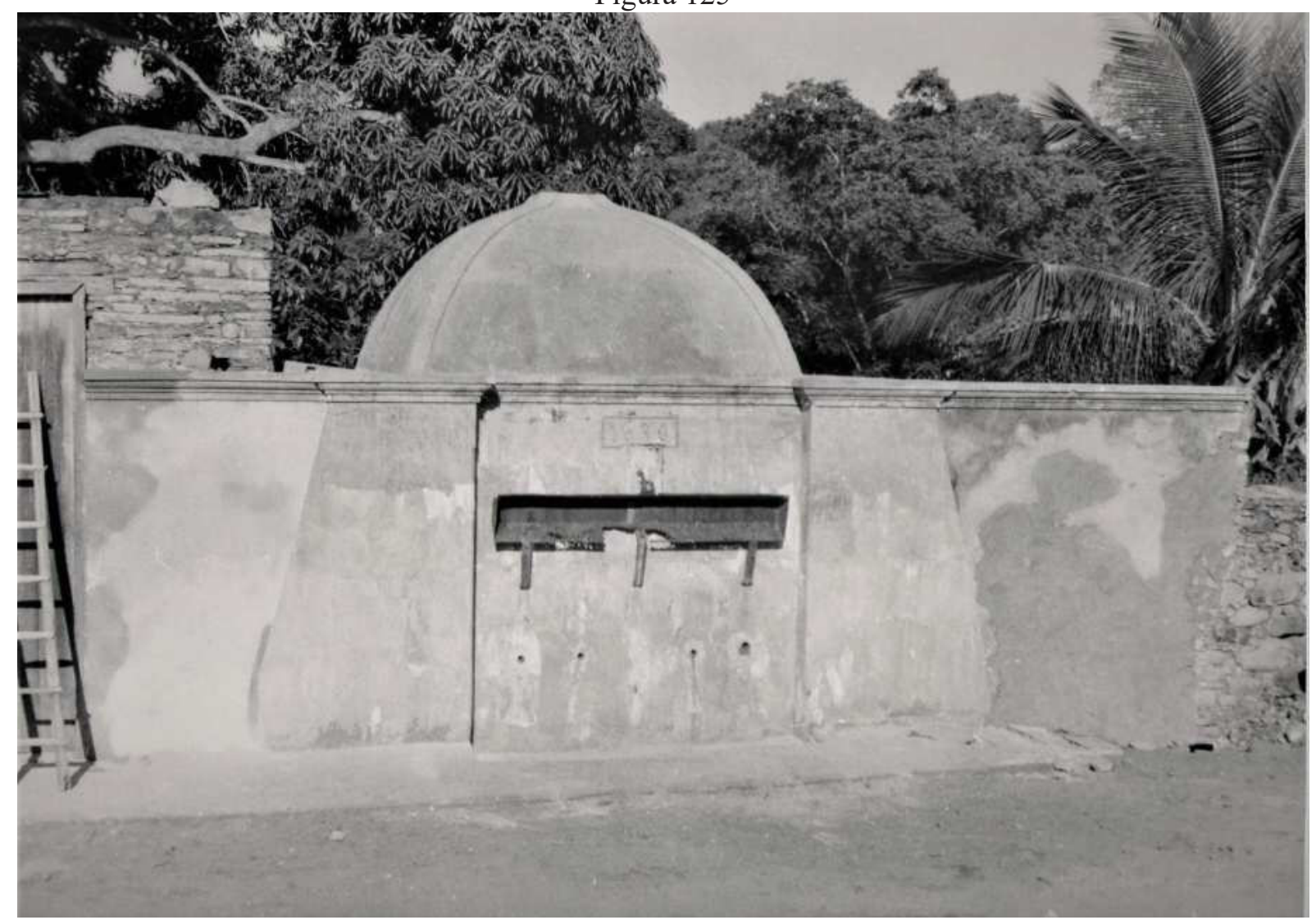

Fonte: Arquivo pessoal de Mestre Osvaldo 
Figura 126

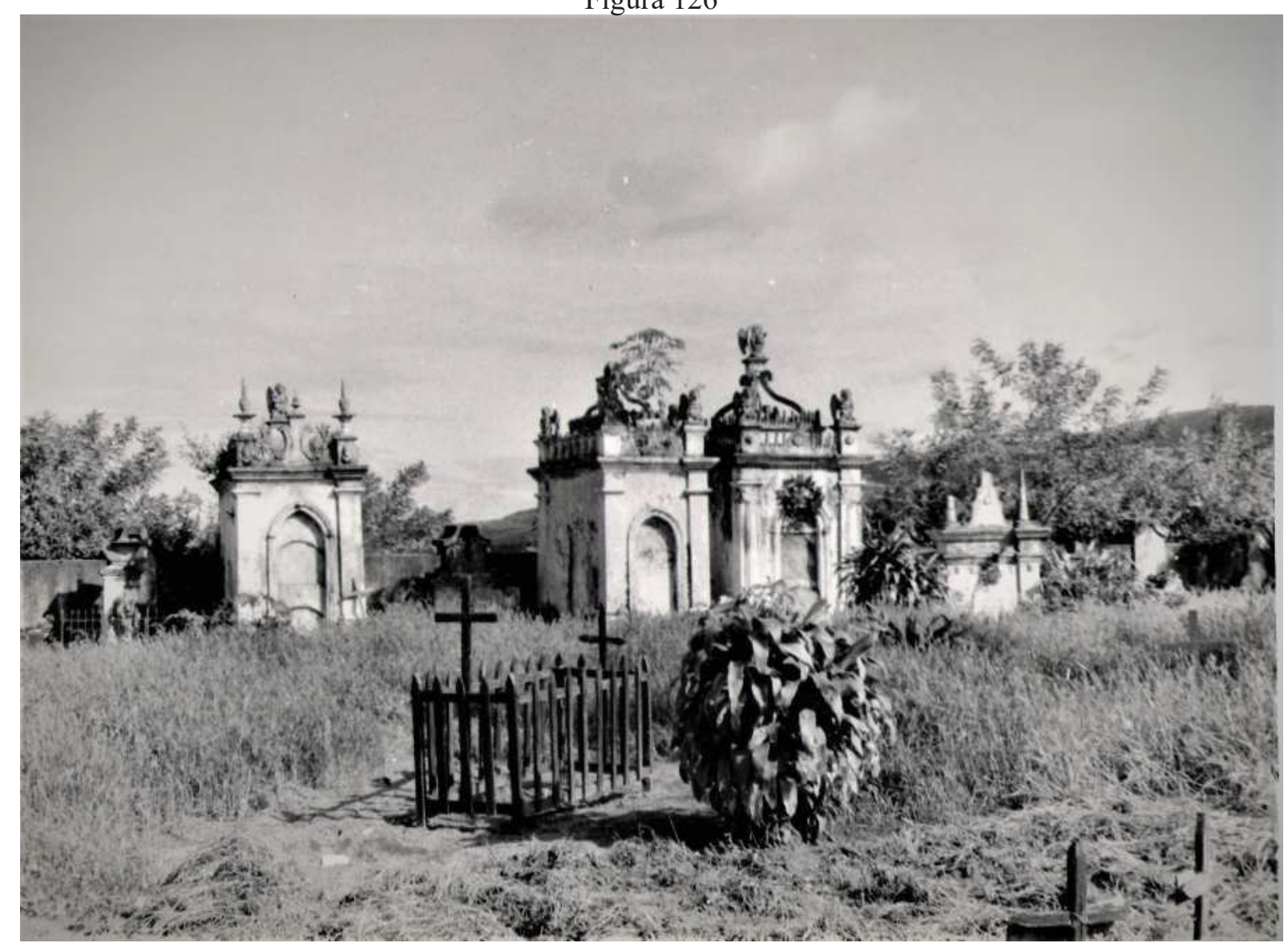

Fonte: Arquivo pessoal de Mestre Osvaldo 
Figura 127

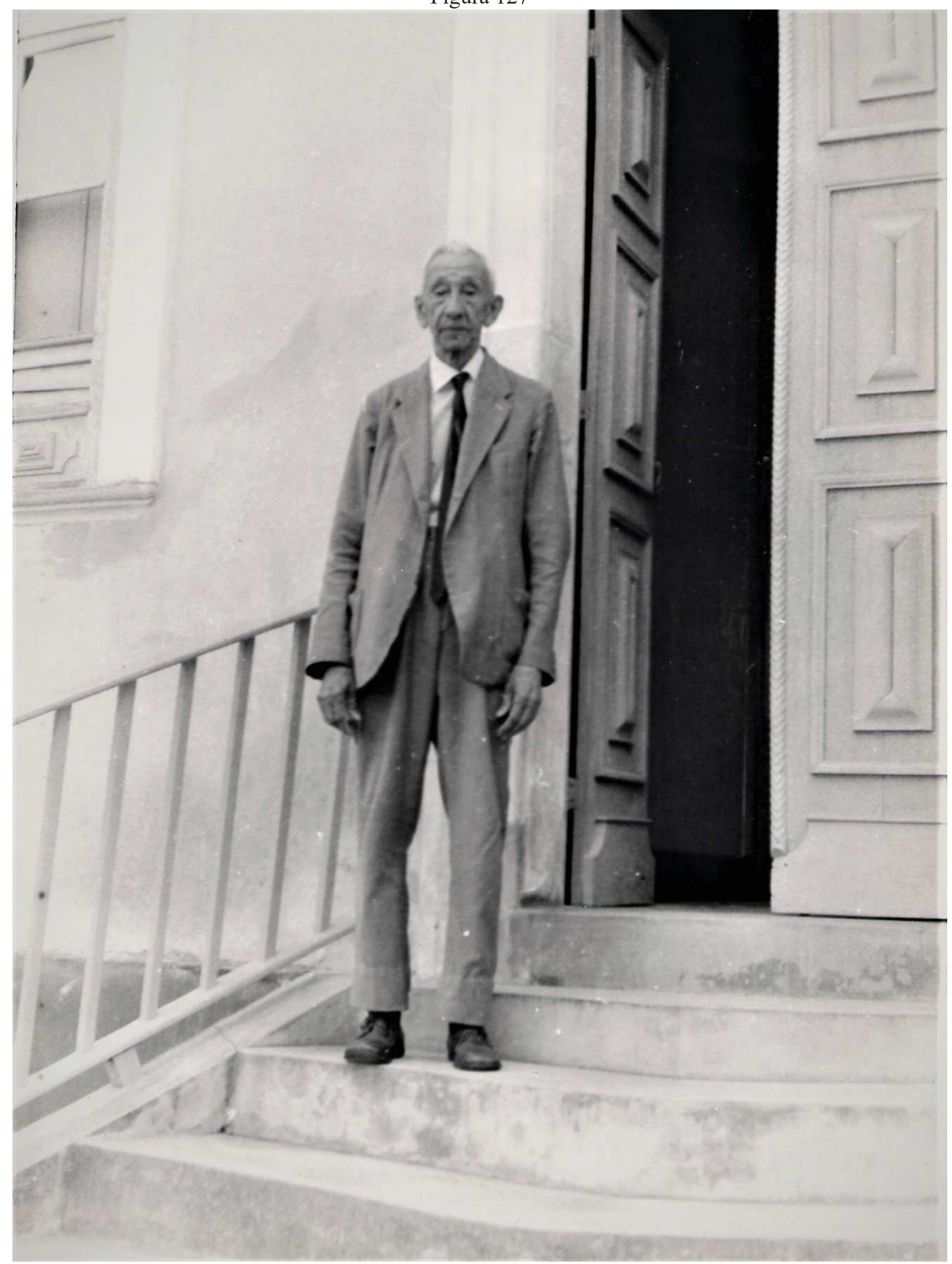

Fonte: Arquivo pessoal de Mestre Osvaldo 
Figura 128

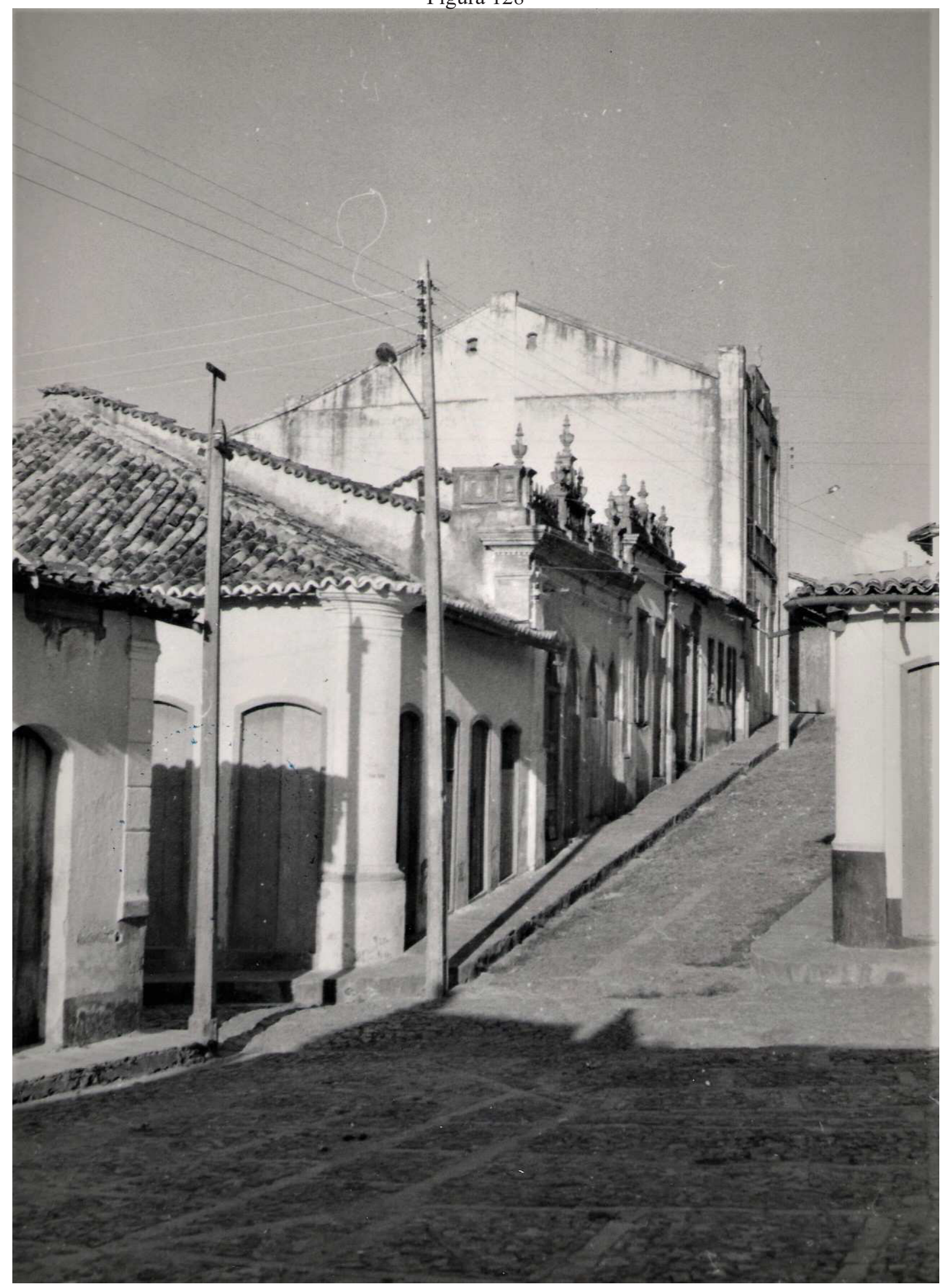

Fonte: Arquivo pessoal de Mestre Osvaldo 
Figura 129

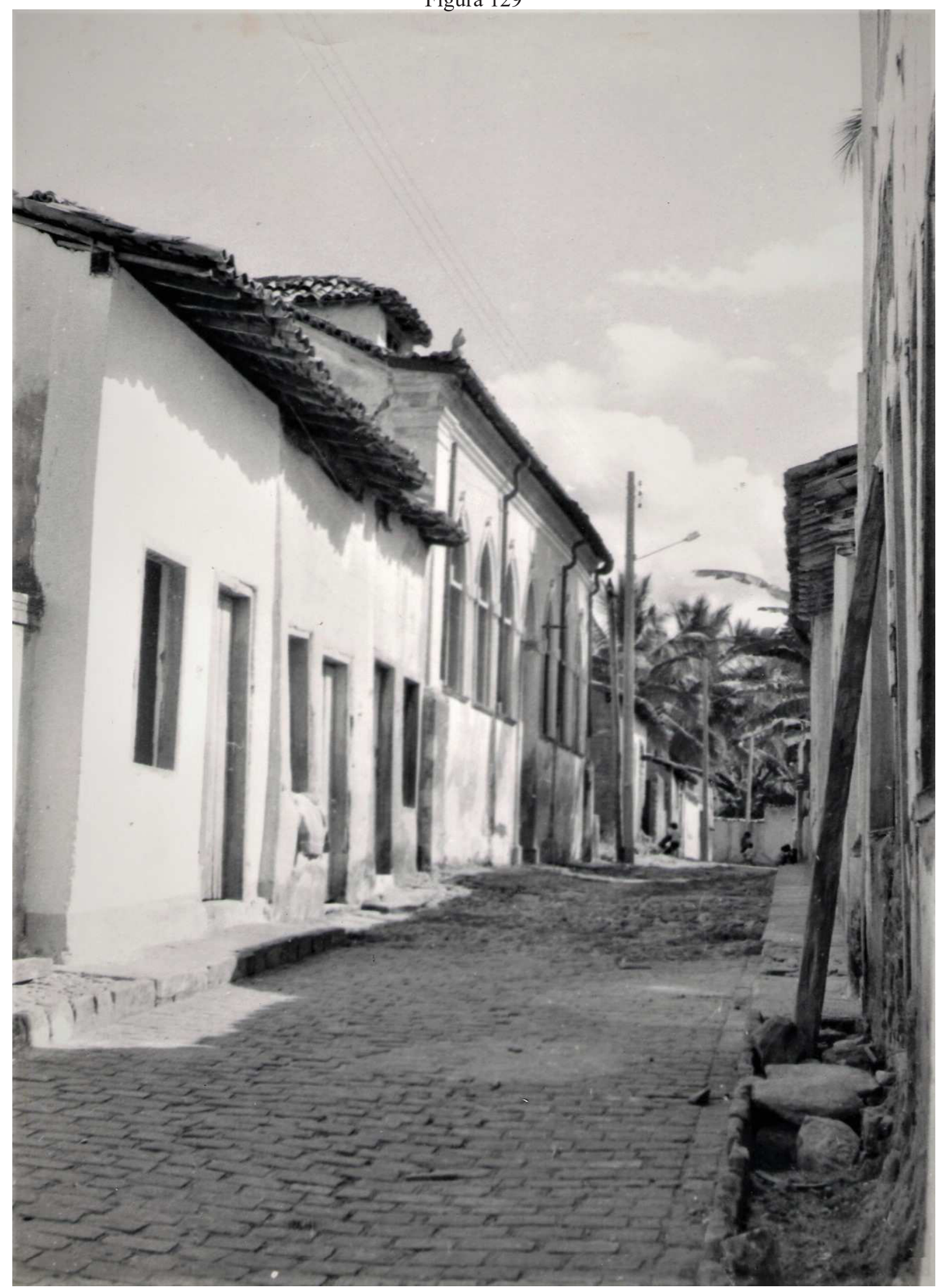

Fonte: Arquivo pessoal de Mestre Osvaldo 
Figura 130

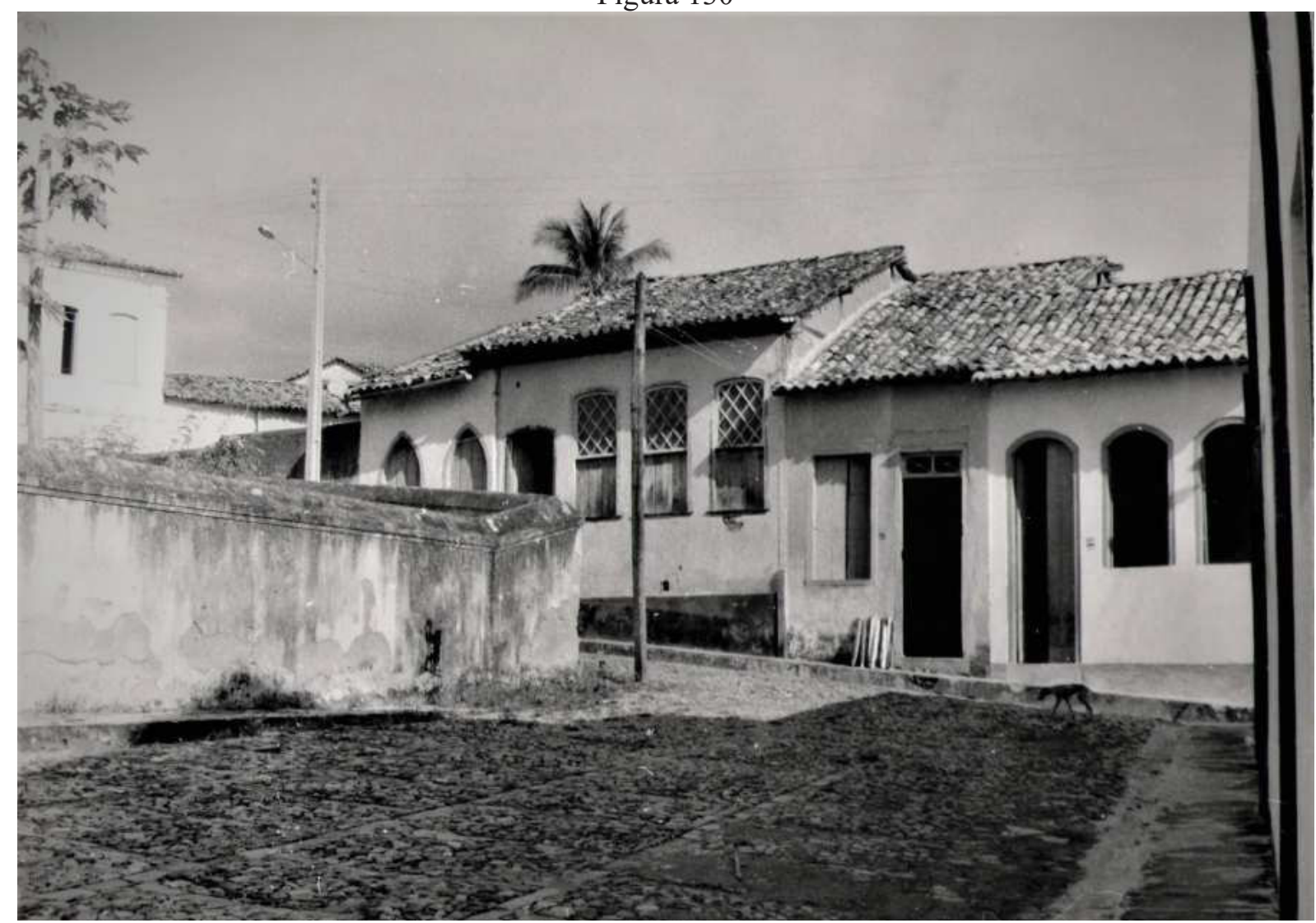

Fonte: Arquivo pessoal de Mestre Osvaldo

Figura 131

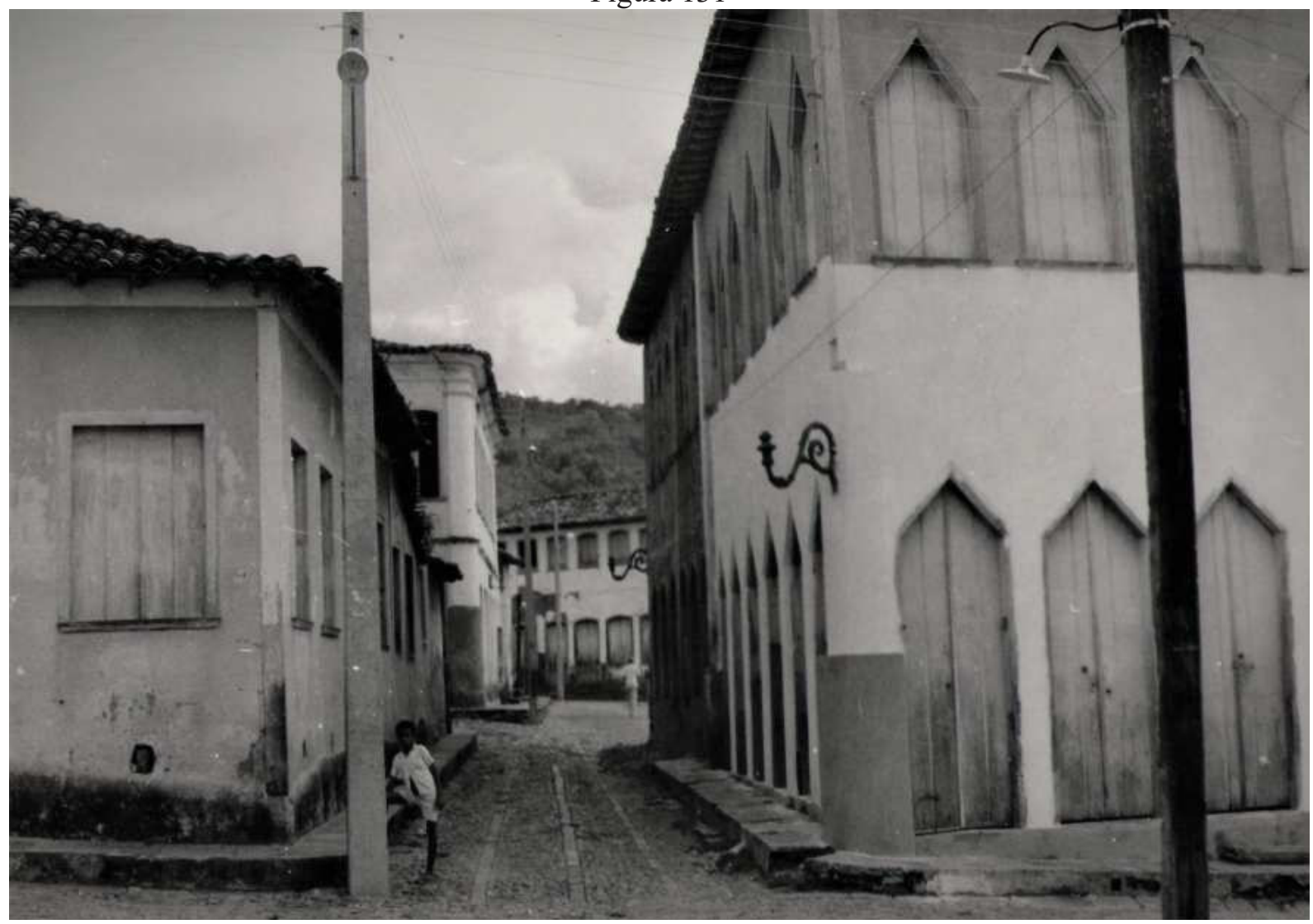

Fonte: Arquivo pessoal de Mestre Osvaldo 
Figura 132

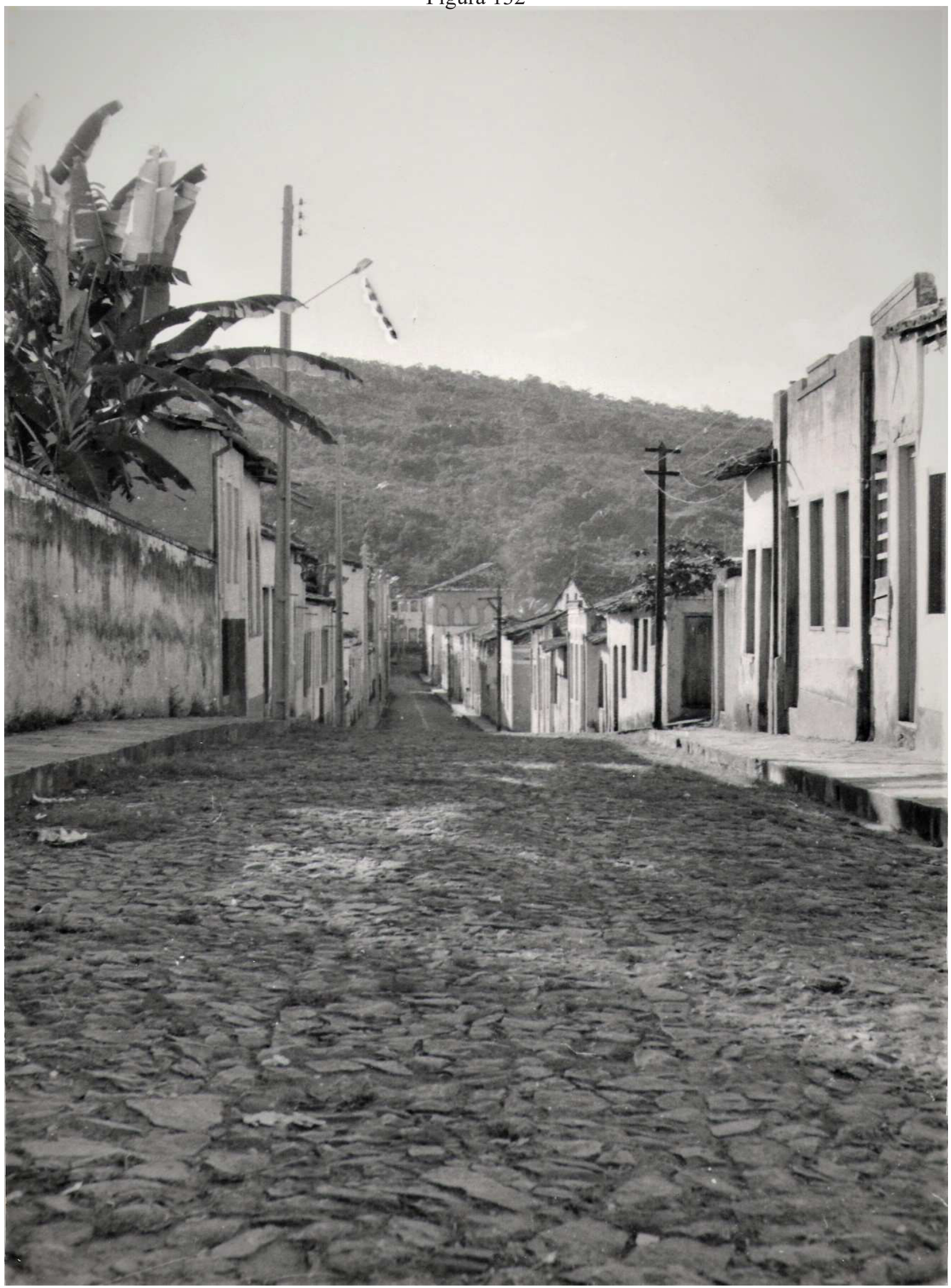

Fonte: Arquivo pessoal de Mestre Osvaldo 
Figura 133

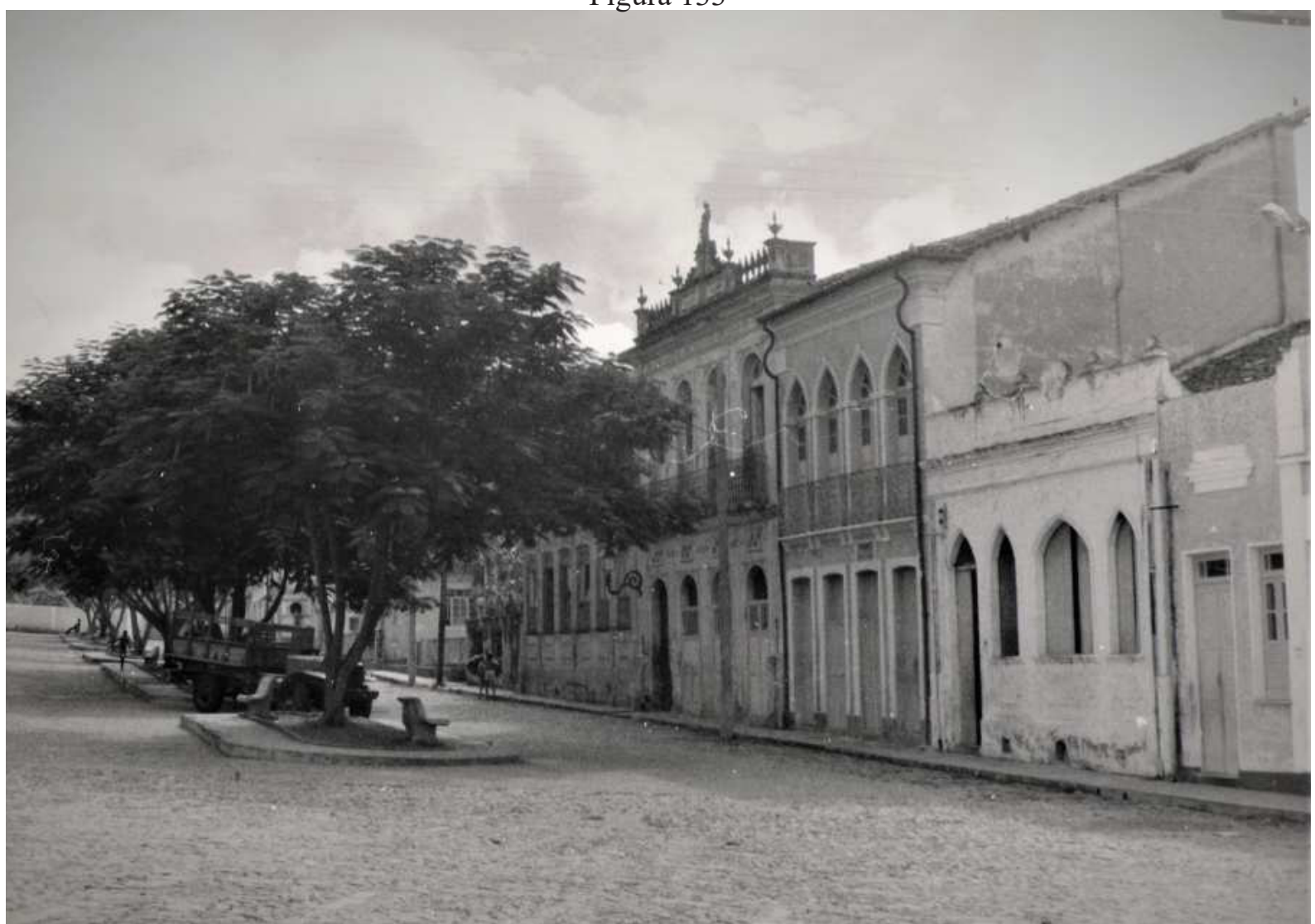

Fonte: Arquivo pessoal de Mestre Osvaldo

Figura 134

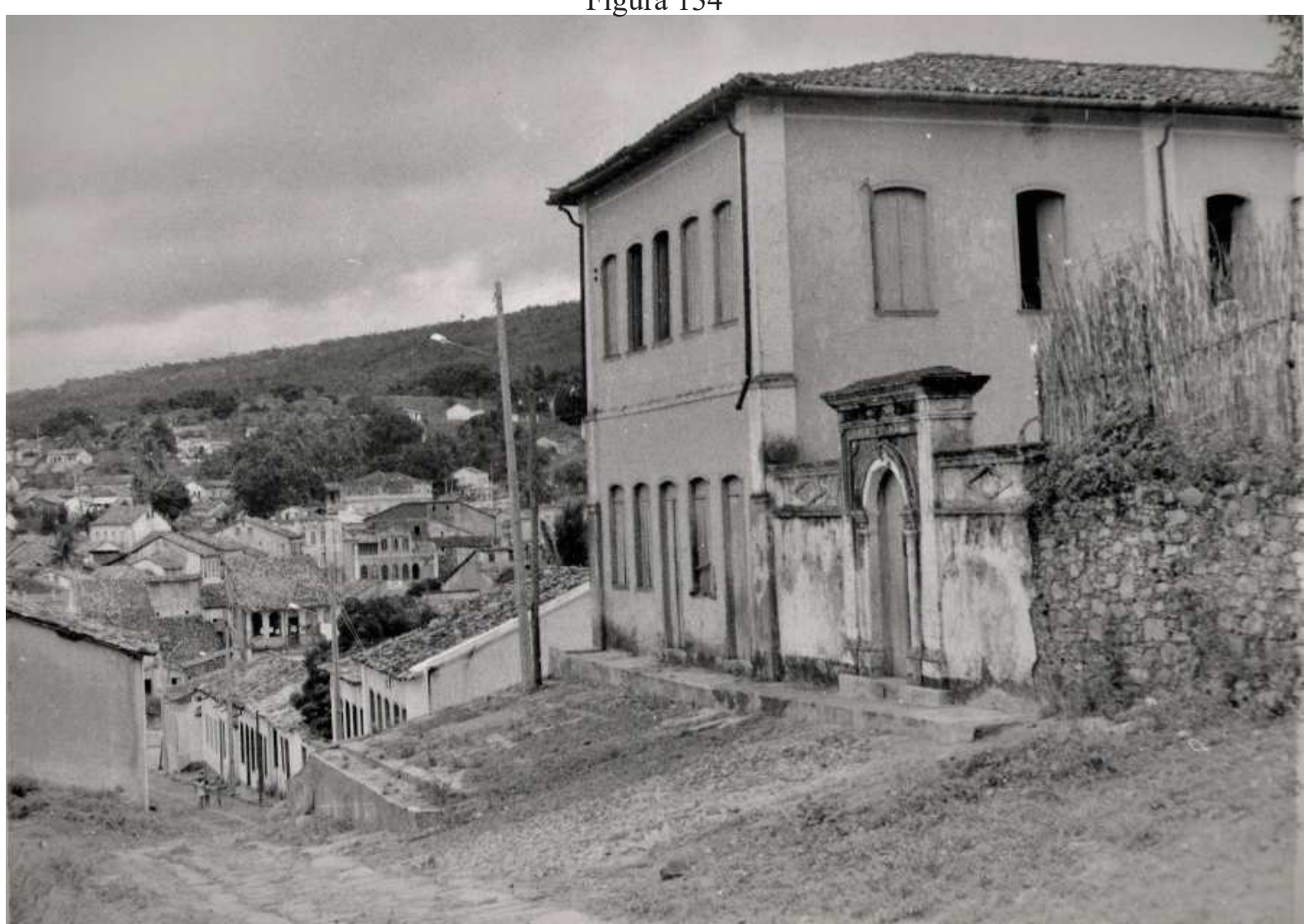

Fonte: Arquivo pessoal de Mestre Osvaldo 
Figura 135

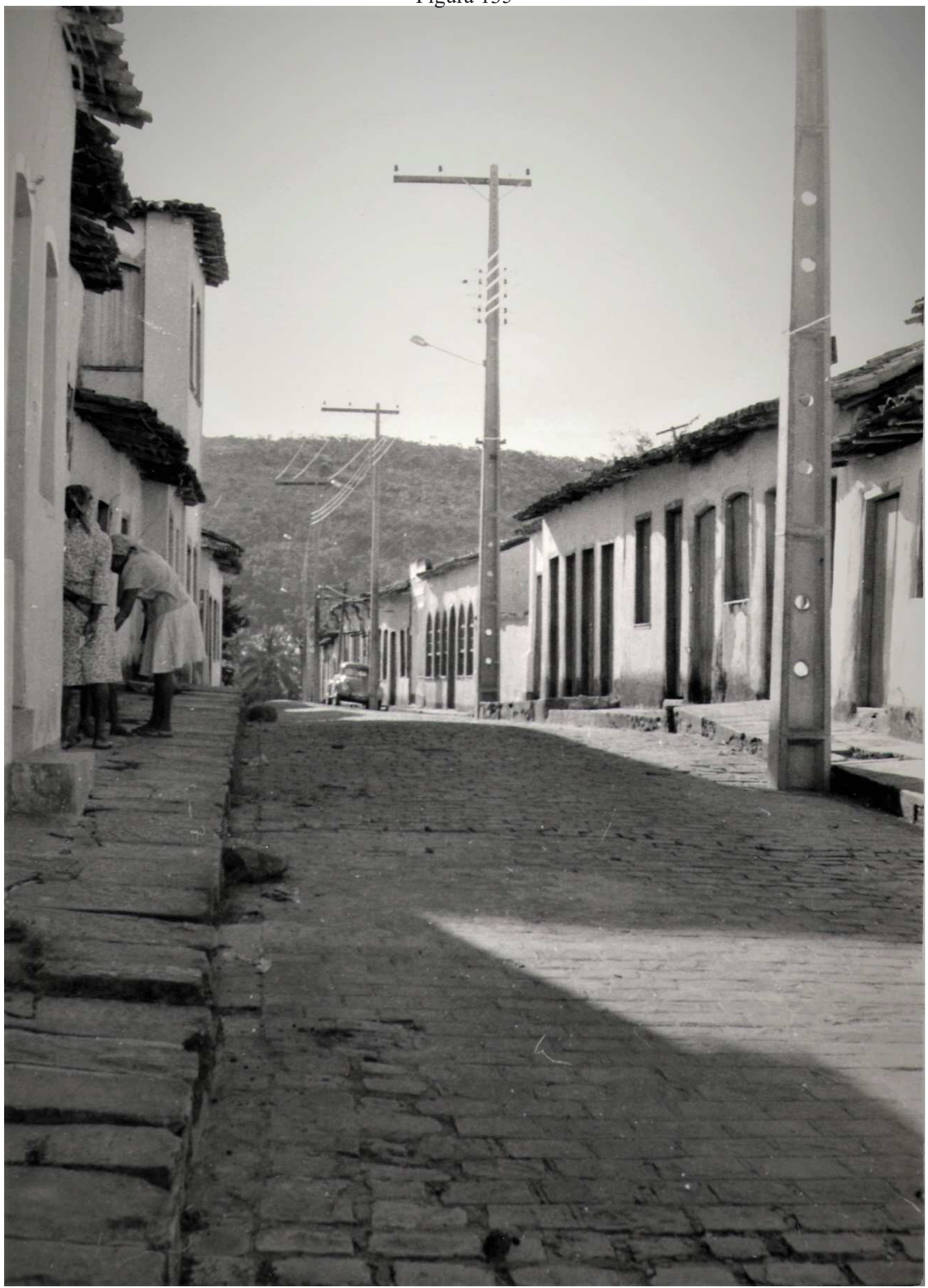

Fonte: Arquivo pessoal de Mestre Osvaldo 
Figura 136

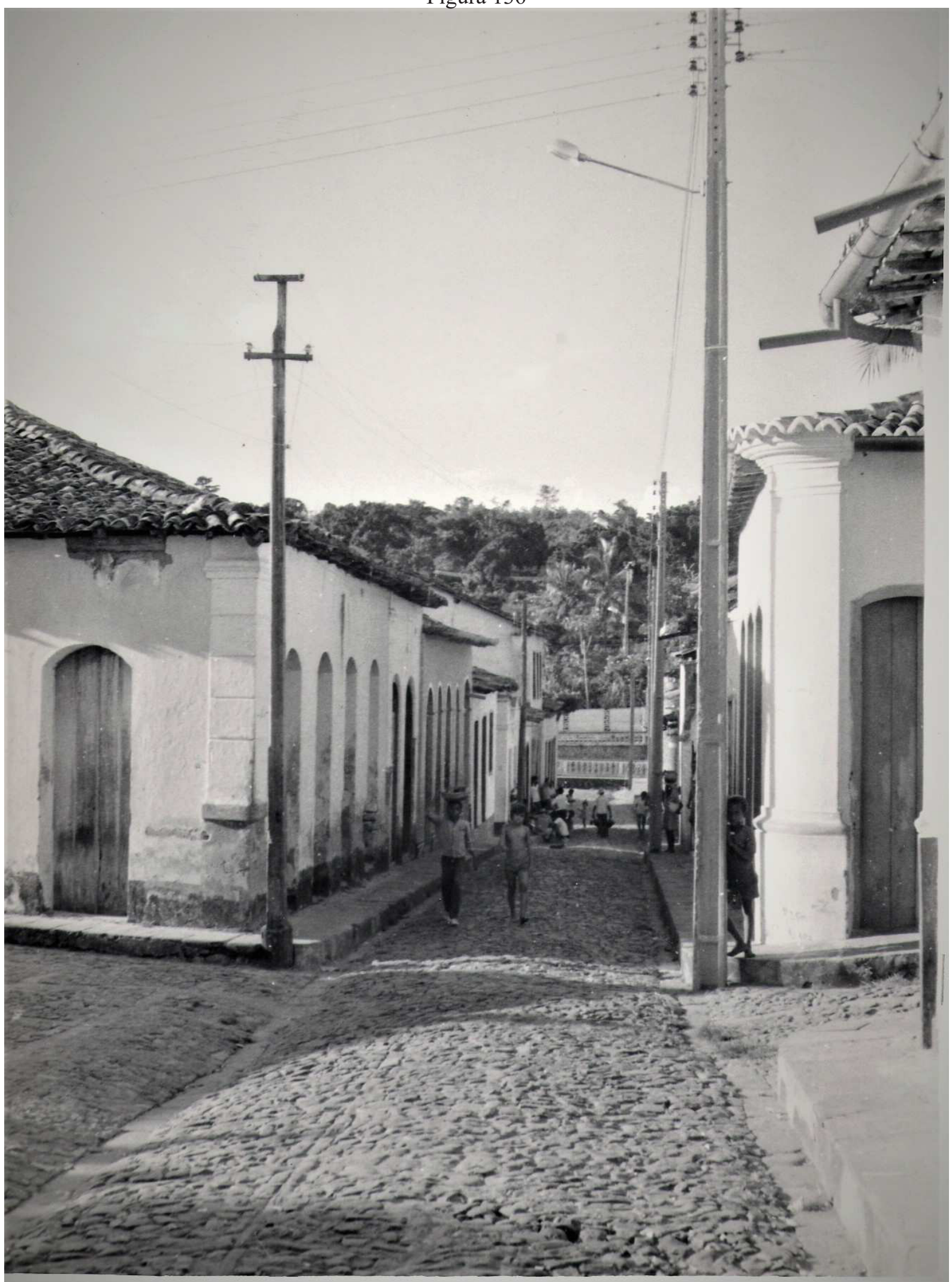

Fonte: Arquivo pessoal de Mestre Osvaldo 
Figura 137

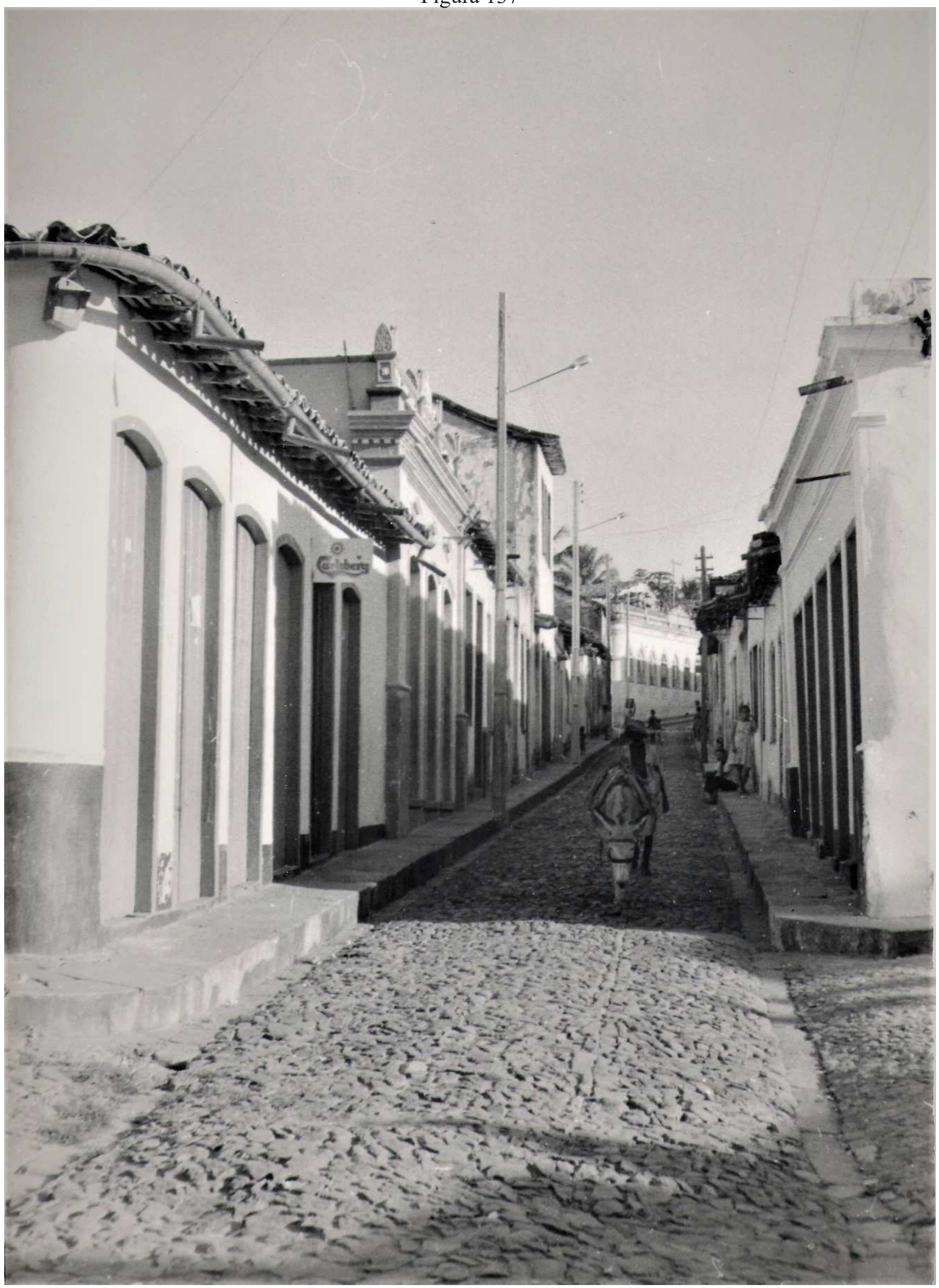

Fonte: Arquivo pessoal de Mestre Osvaldo 


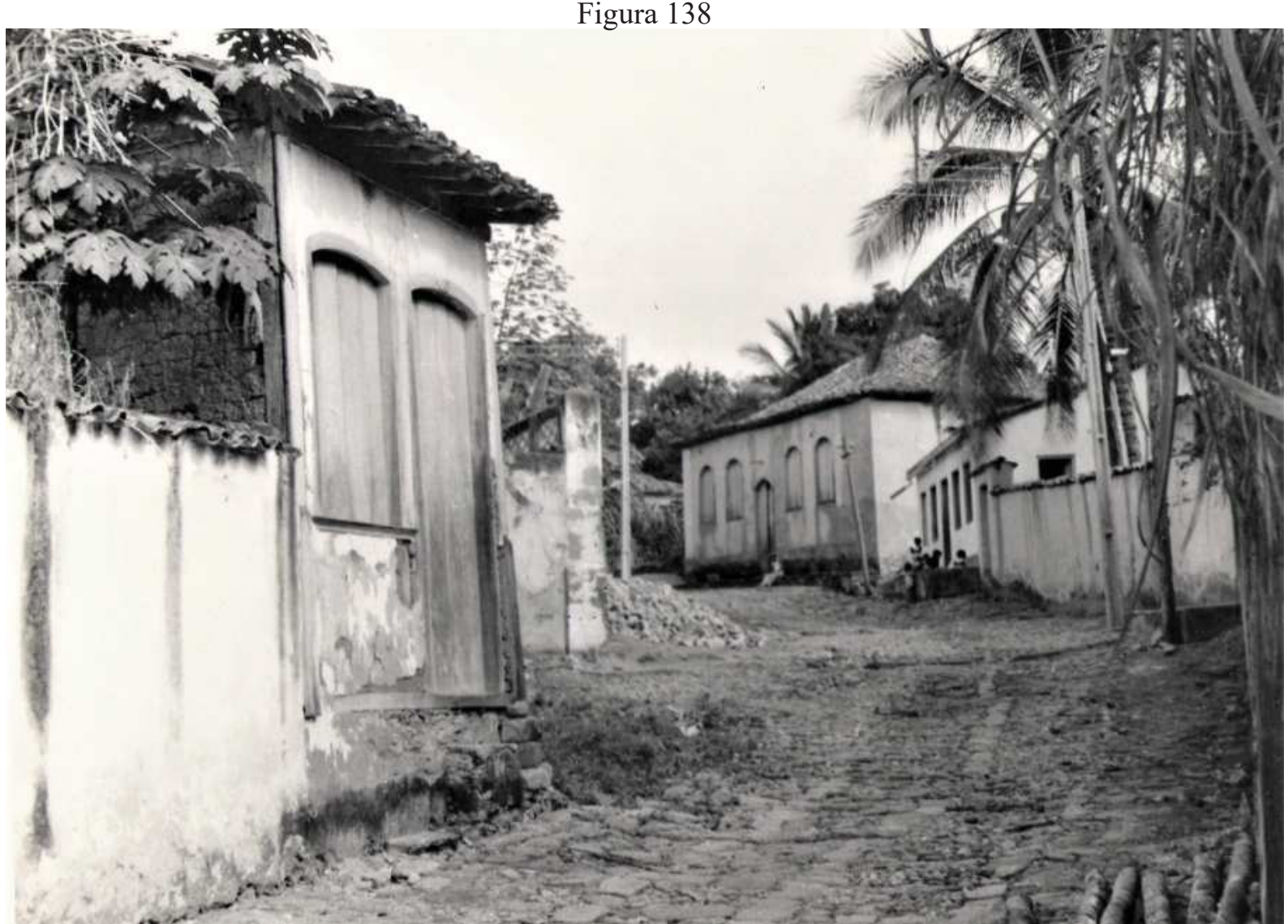

Fonte: Arquivo pessoal de Mestre Osvaldo

Figura 139

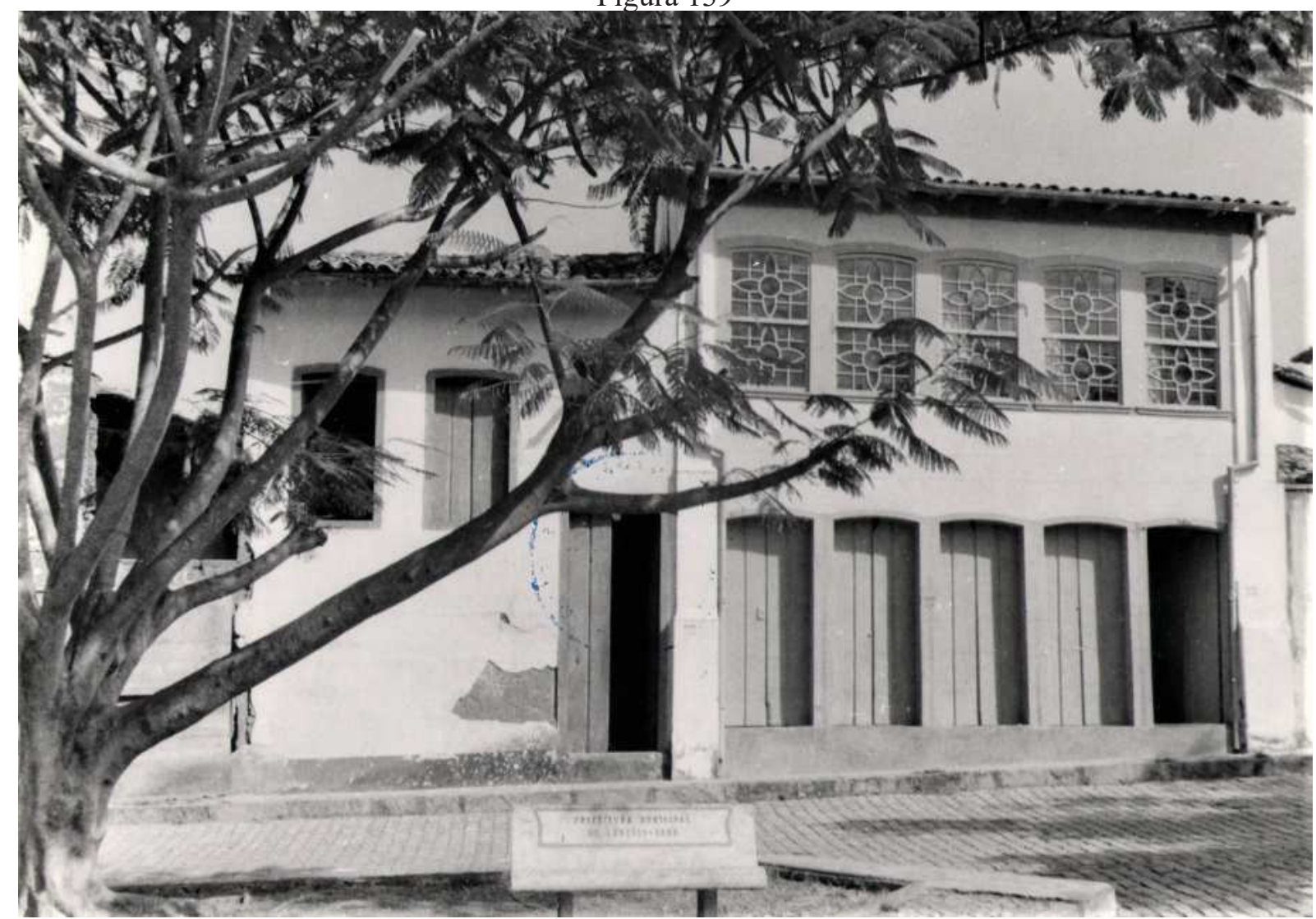

Fonte: Arquivo pessoal de Mestre Osvaldo 
Figura 140

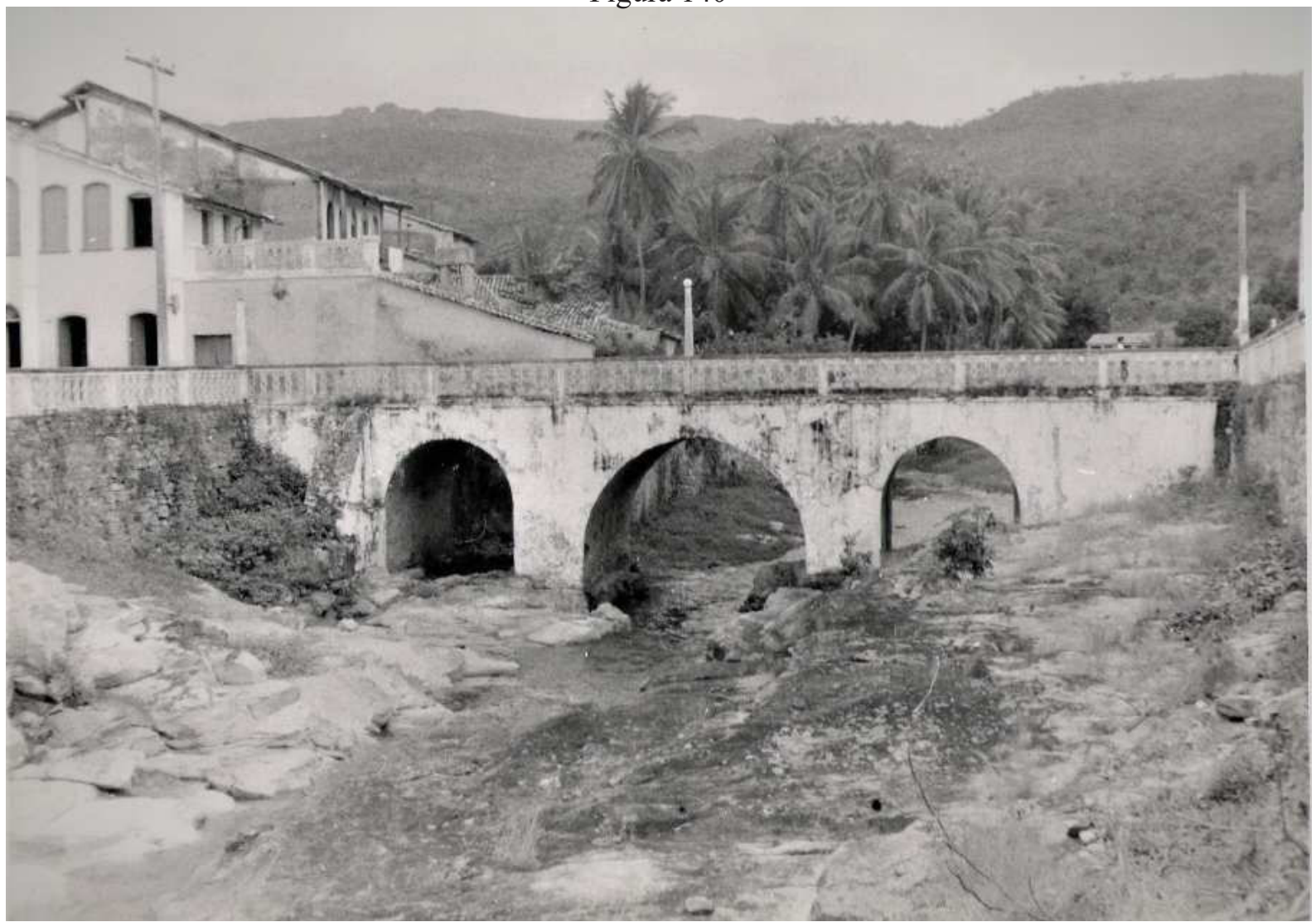

Fonte: Arquivo pessoal de Mestre Osvaldo

Figura 141

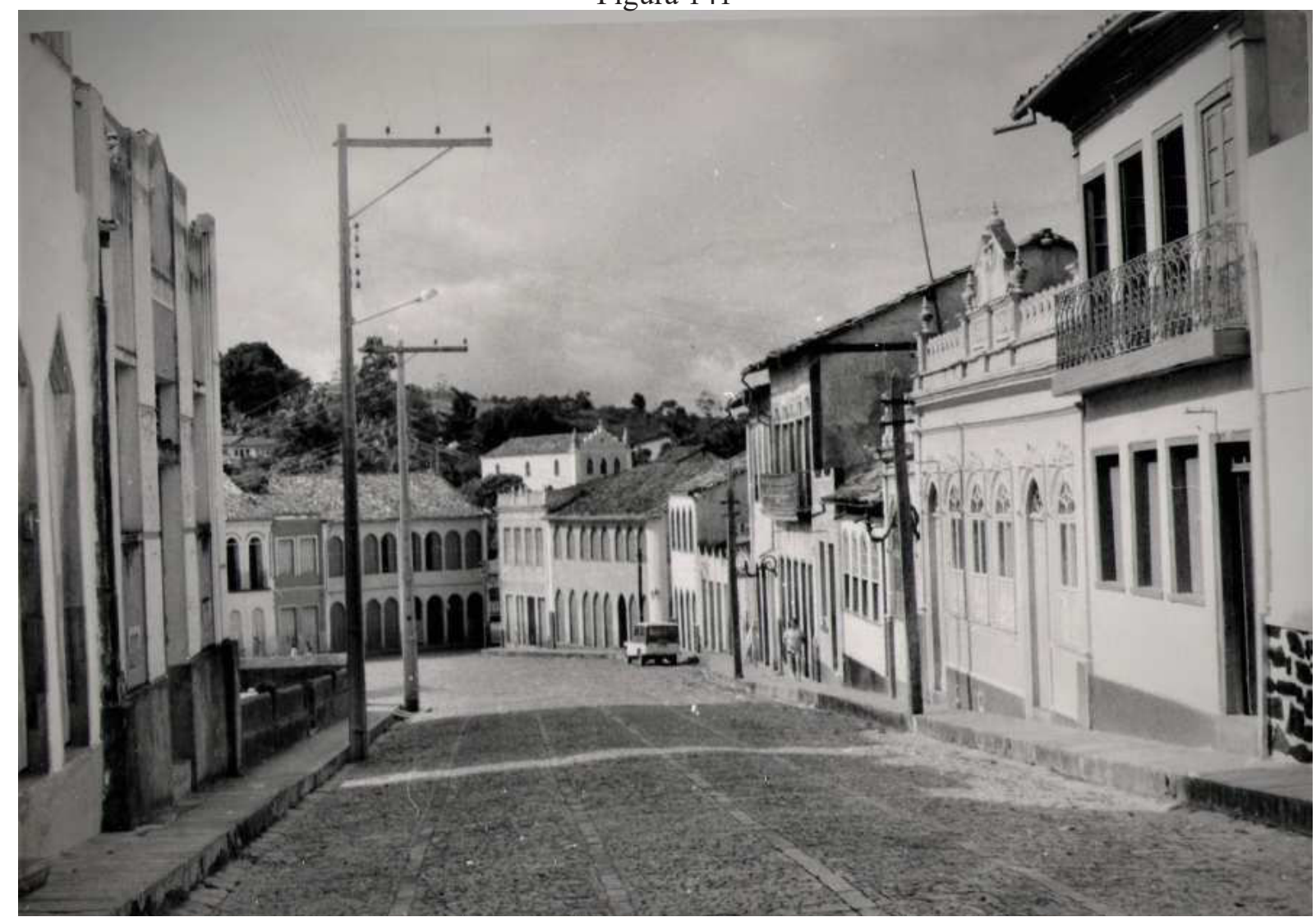

Fonte: Arquivo pessoal de Mestre Osvaldo 
Figura 142

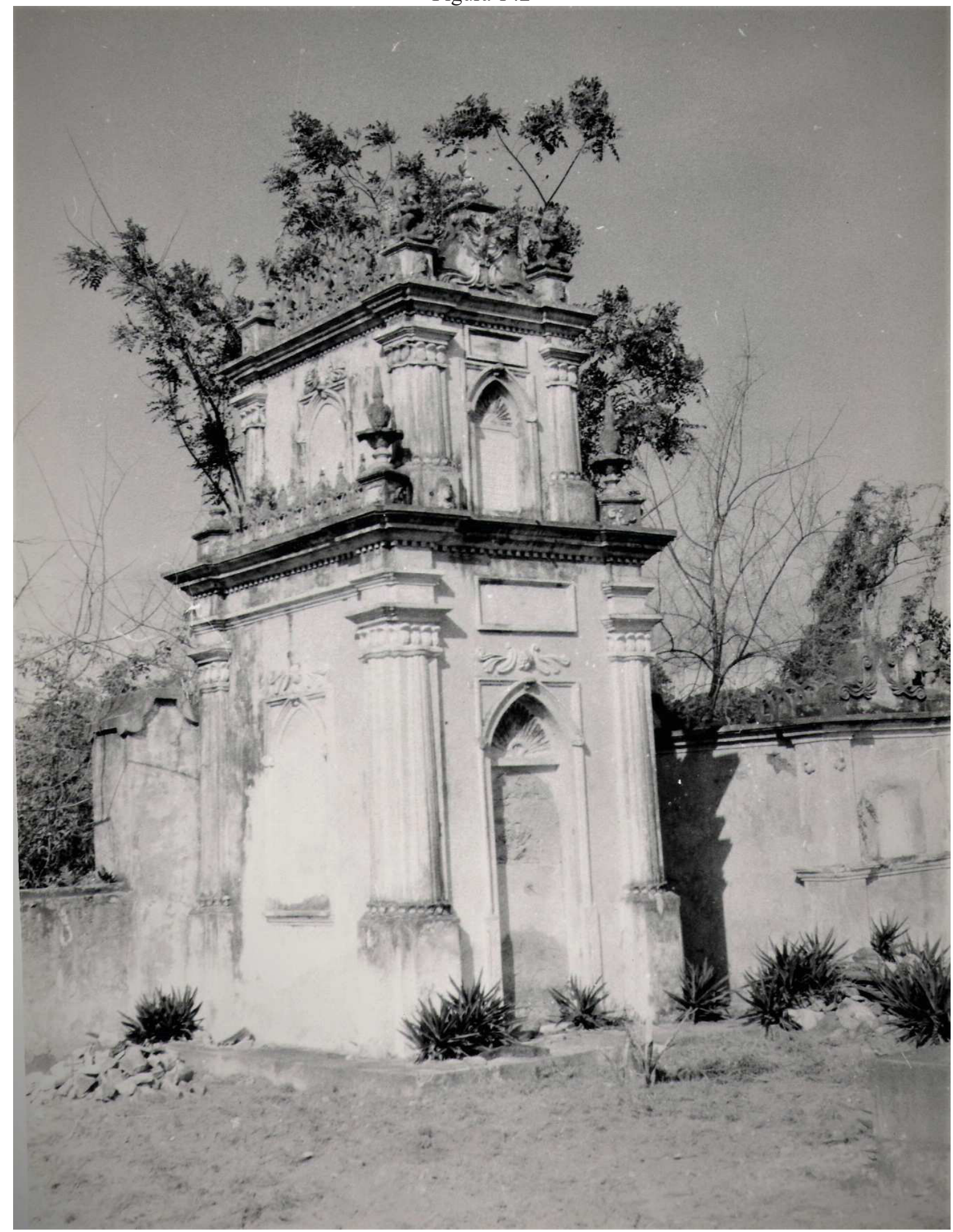

Fonte: Arquivo pessoal de Mestre Osvaldo 
Figura 143

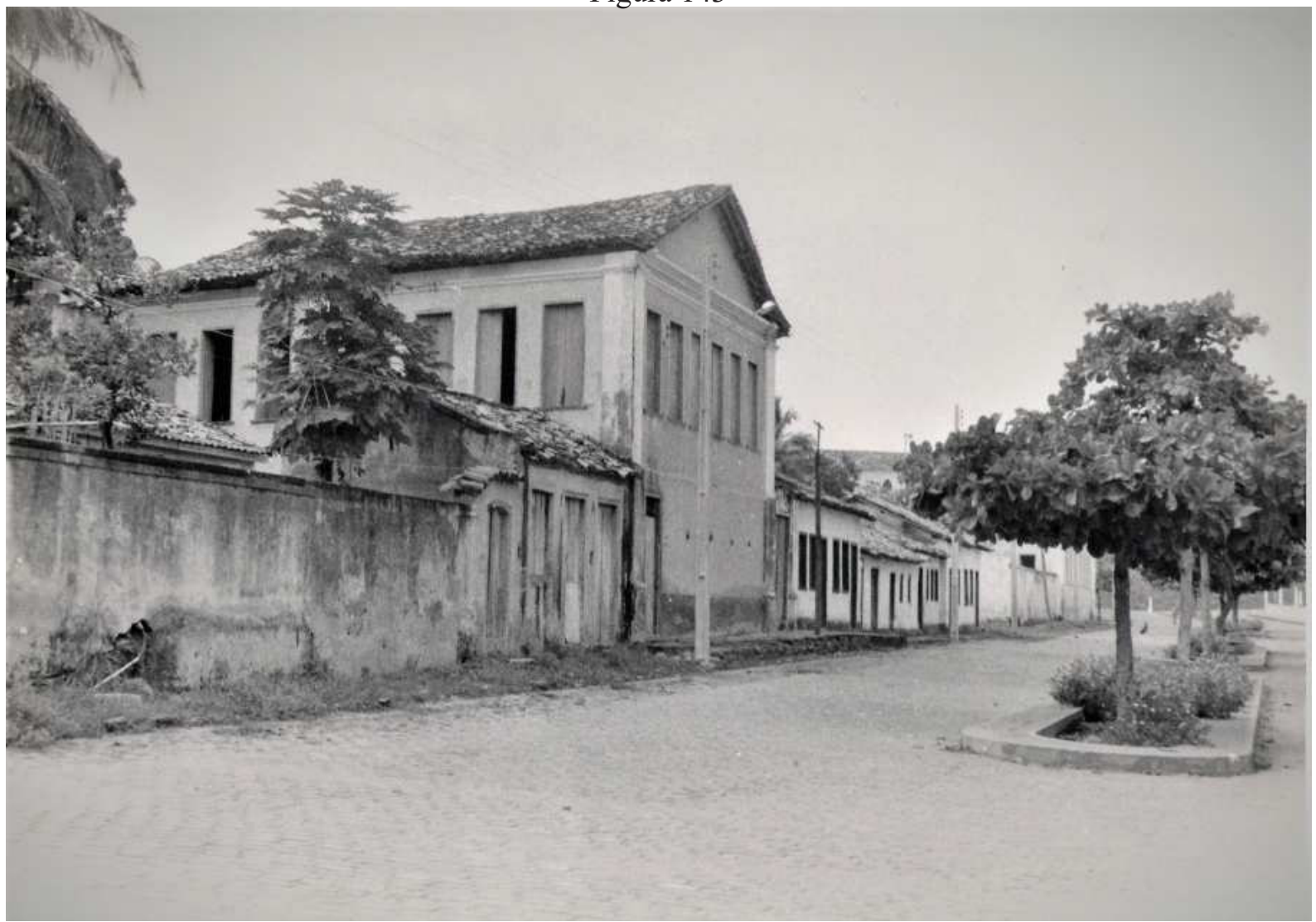

Fonte: Arquivo pessoal de Mestre Osvaldo

Figura 144

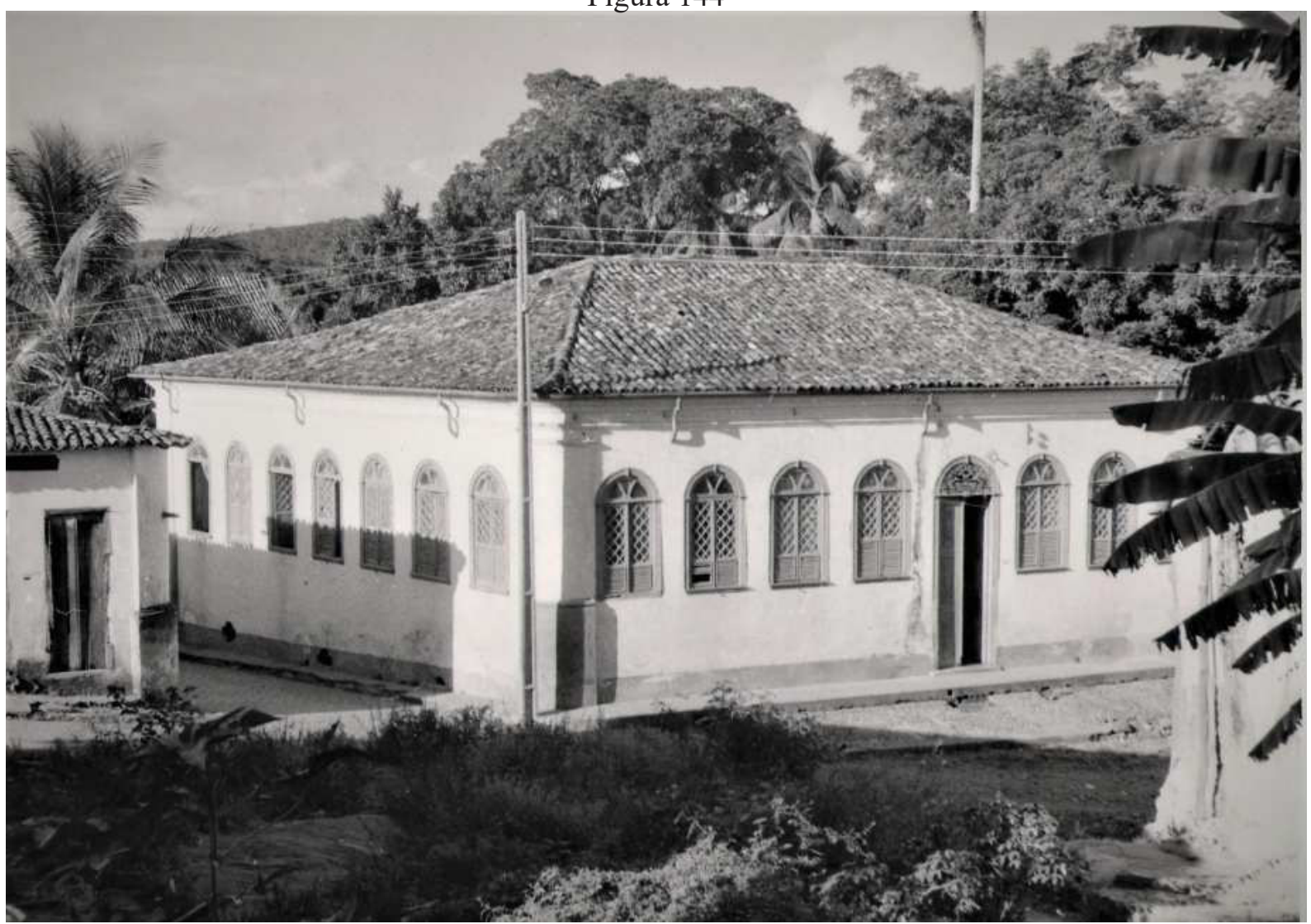

Fonte: Arquivo pessoal de Mestre Osvaldo 
Figura 145

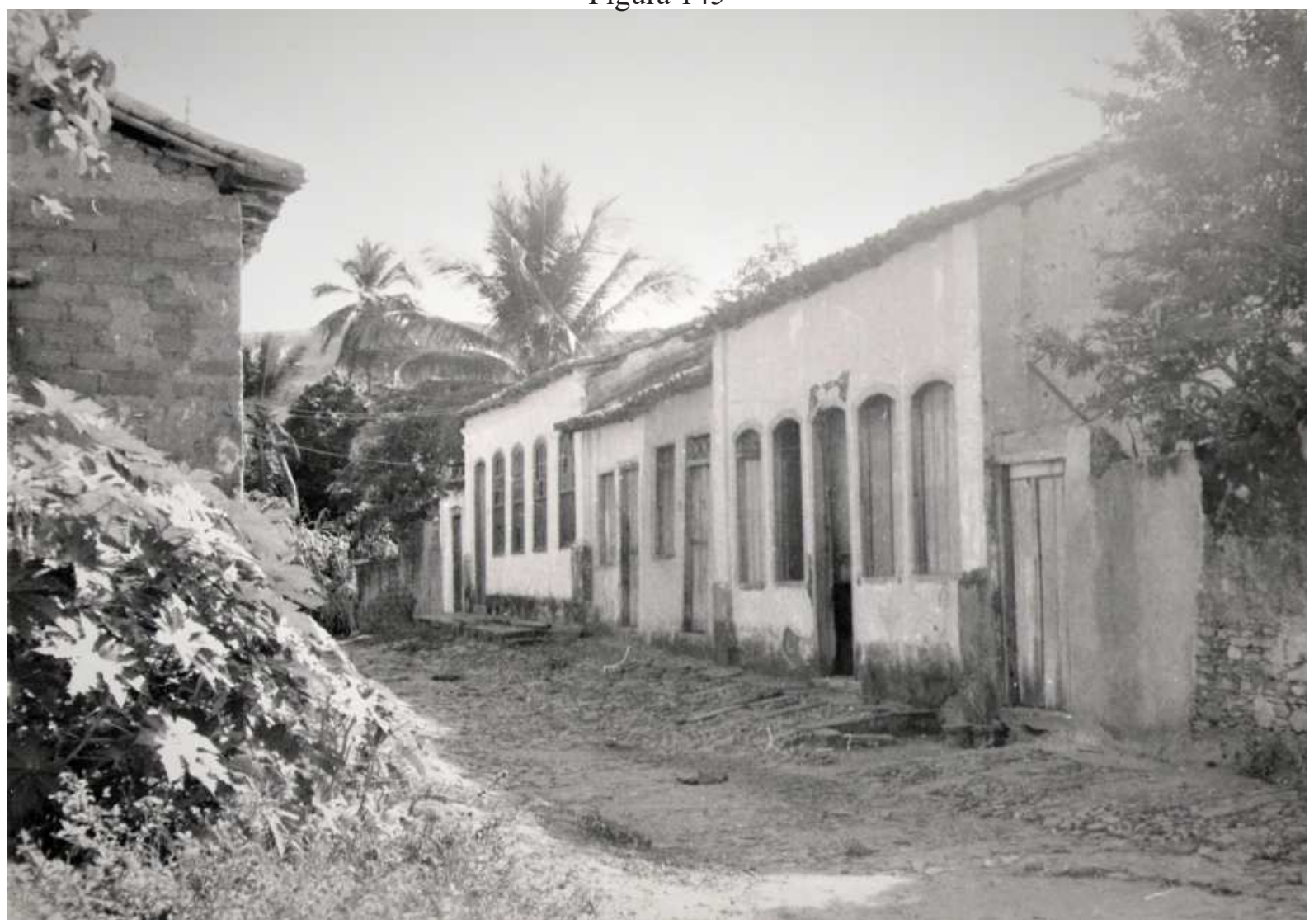

Fonte: Arquivo pessoal de Mestre Osvaldo

Figura 146

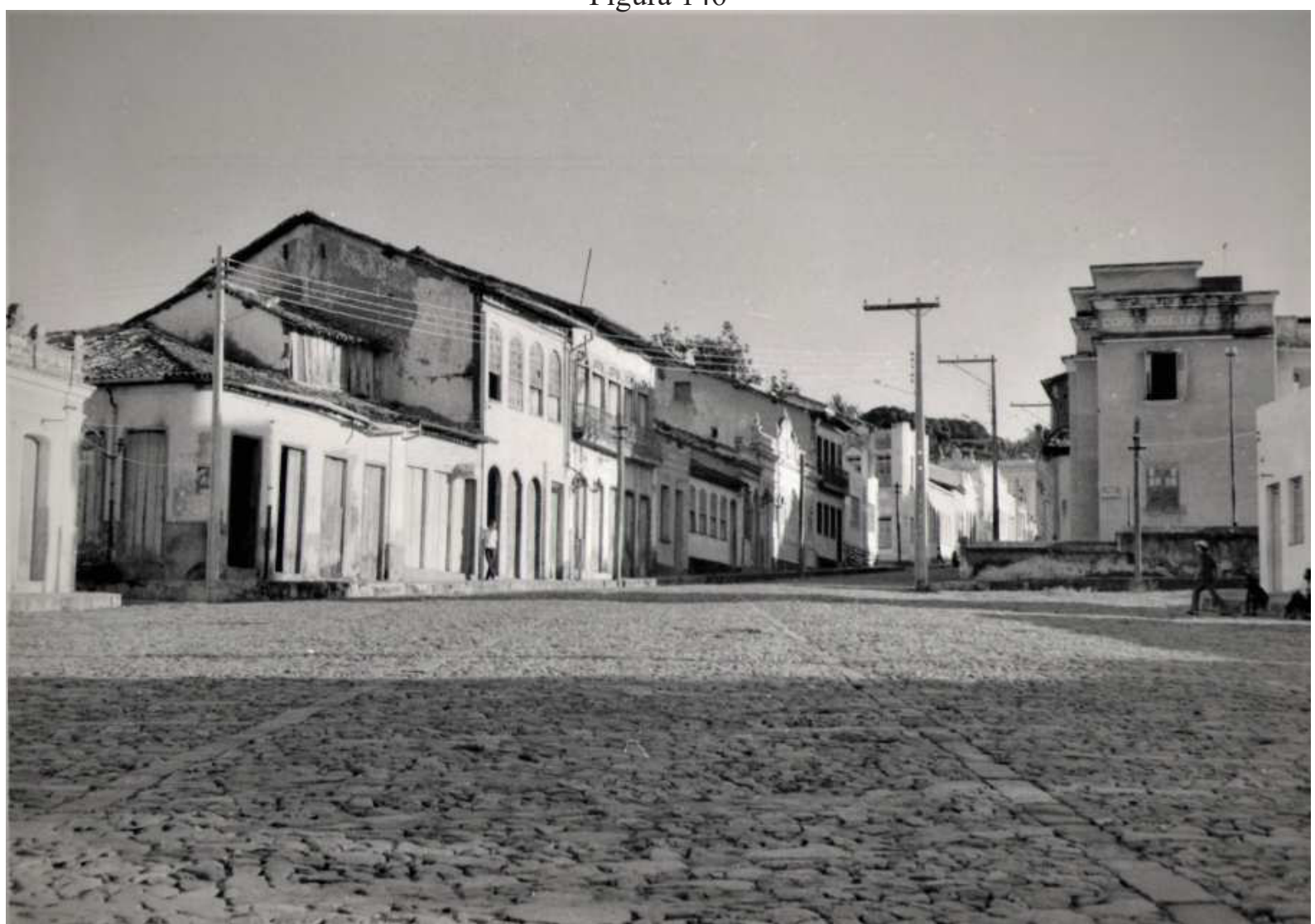

Fonte: Arquivo pessoal de Mestre Osvaldo 
Figura 147

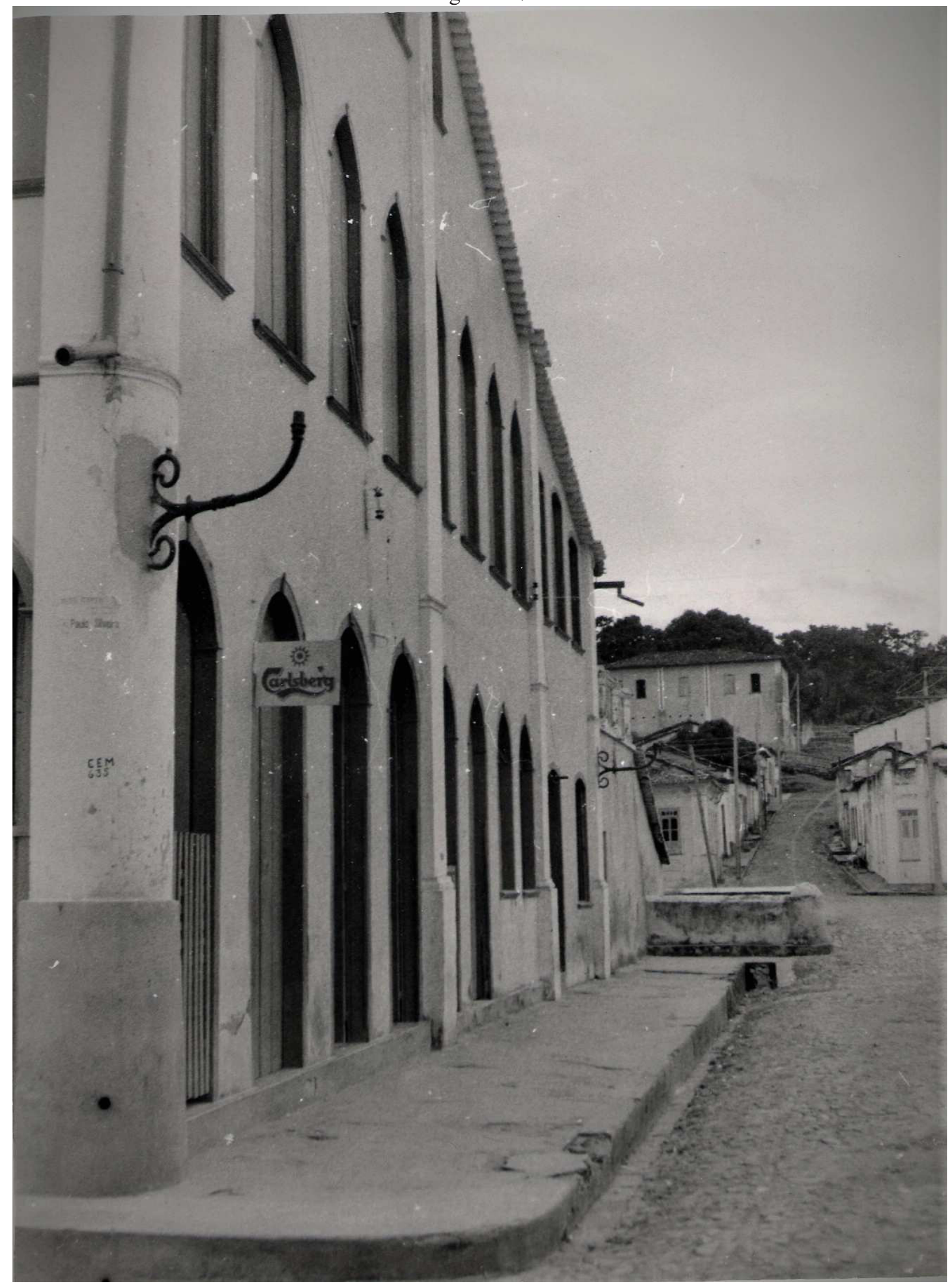

Fonte: Arquivo pessoal de Mestre Osvaldo 


\section{ANEXO F- Fotografias do arquiteto Fernando $M$. Leal em pesquisa para o IPHAN}

Fernando Machado Leal produziu mais de 250 fotografias sobre a cidade de Lençóis em 1972, as quais incorporaram o relatório de seu estudo encomendado pelo IPHAN para o tombamento daquela cidade. As 23 imagens deste anexo foram aquelas selecionadas para ilustrar o relatório publicado em forma de artigo na "Revista do Patrimônio Histórico e Artístico Nacional (18)" em 1978 com o nome de "A antiga Comercial Vila dos Lençóis”. Além do próprio relatório, é possível ter mais informações sobre o processo na tese de Liziane Peres Mangili, "Anseios, dissonâncias, enfrentamentos: o lugar e a trajetória da preservação em Lençóis (Bahia)” (2015). 
Figura 148 - Rua Abelardo Andrea, esquina com o fim da rua Urbano Duarte (Boa Vista)

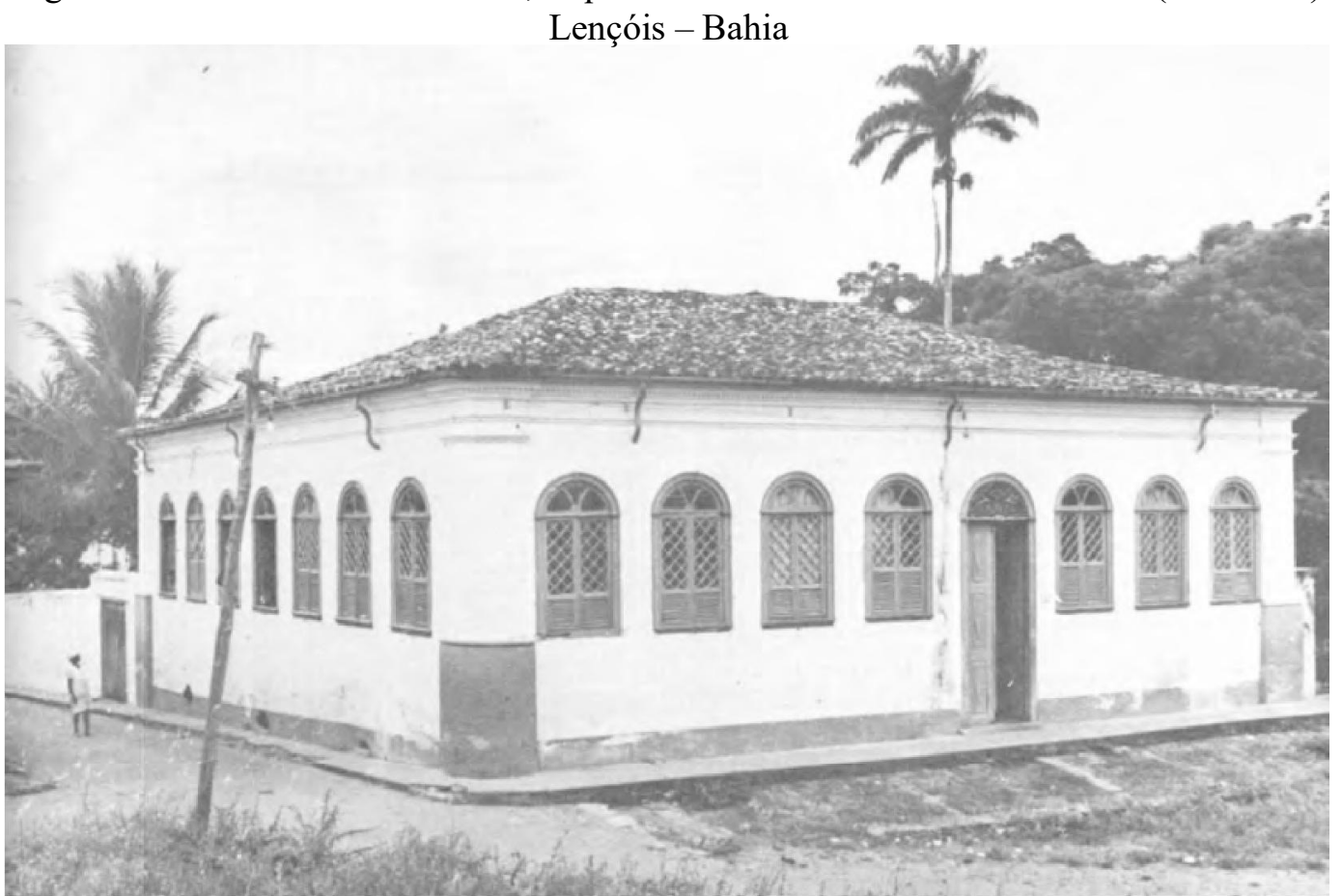

Fonte: Revista do Patrimônio Histórico e Artístico Nacional (18), 1978.

Figura 149 - Rua dos Patriotas, esquina com Alfrânio Peixoto - Detalhe Lençóis - Bahia
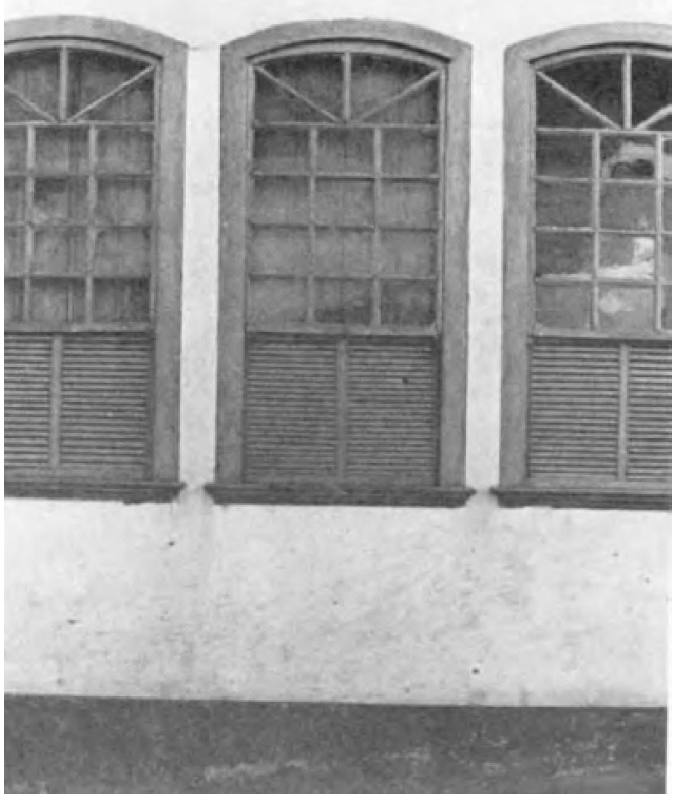

Fonte: Revista do Patrimônio Histórico e Artístico Nacional (18), 1978. 
Figura 150 - Praça do Rosário, vendo-se a Casa de Cultura Afrânio Peixoto e a Igreja Matriz Lençóis - Bahia

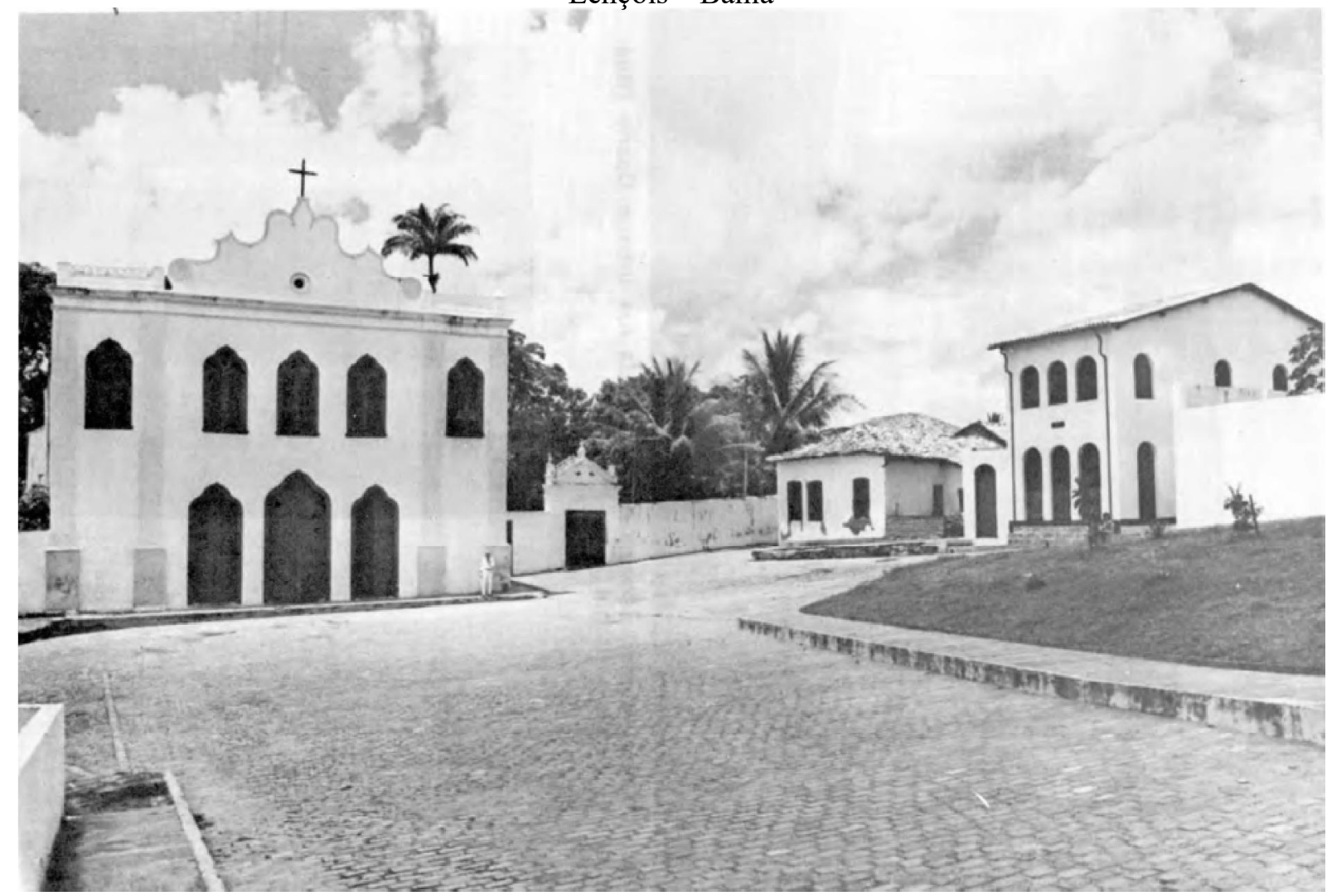

Fonte: Revista do Patrimônio Histórico e Artístico Nacional (18), 1978.

Figura 151 - Rua Rui Barbosa - Lençóis - Bahia

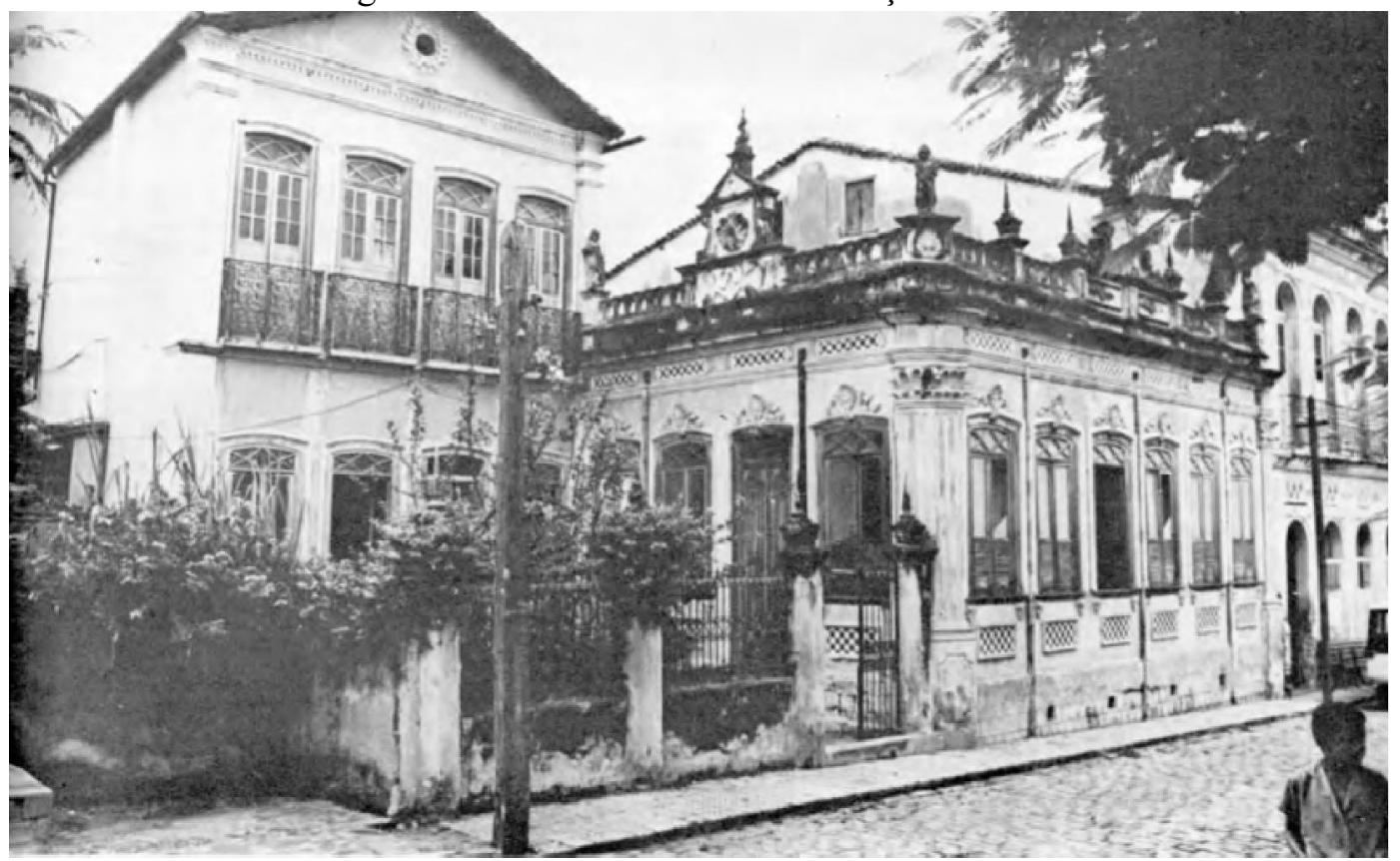

Fonte: Revista do Patrimônio Histórico e Artístico Nacional (18), 1978. 
Figura 152 - Rua Rui Barbosa, sobrado antigo - Lençóis - Bahia

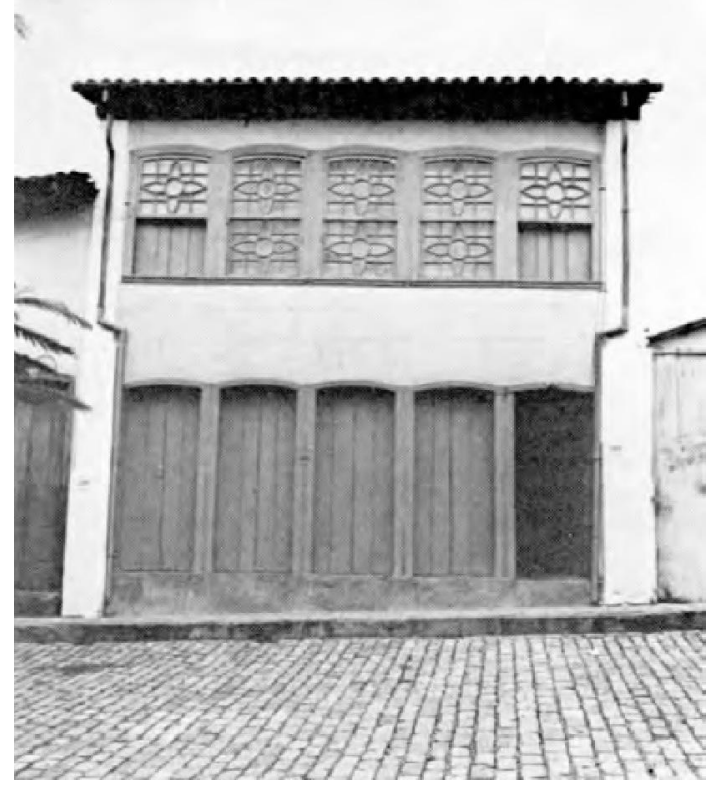

Fonte: Revista do Patrimônio Histórico e Artístico Nacional (18), 1978.

Figura 153 - Av. 7 de Setembro: Casa natal de Urbano Duarte, atual sede da Biblioteca Urbano Duarte Lençóis - Bahia

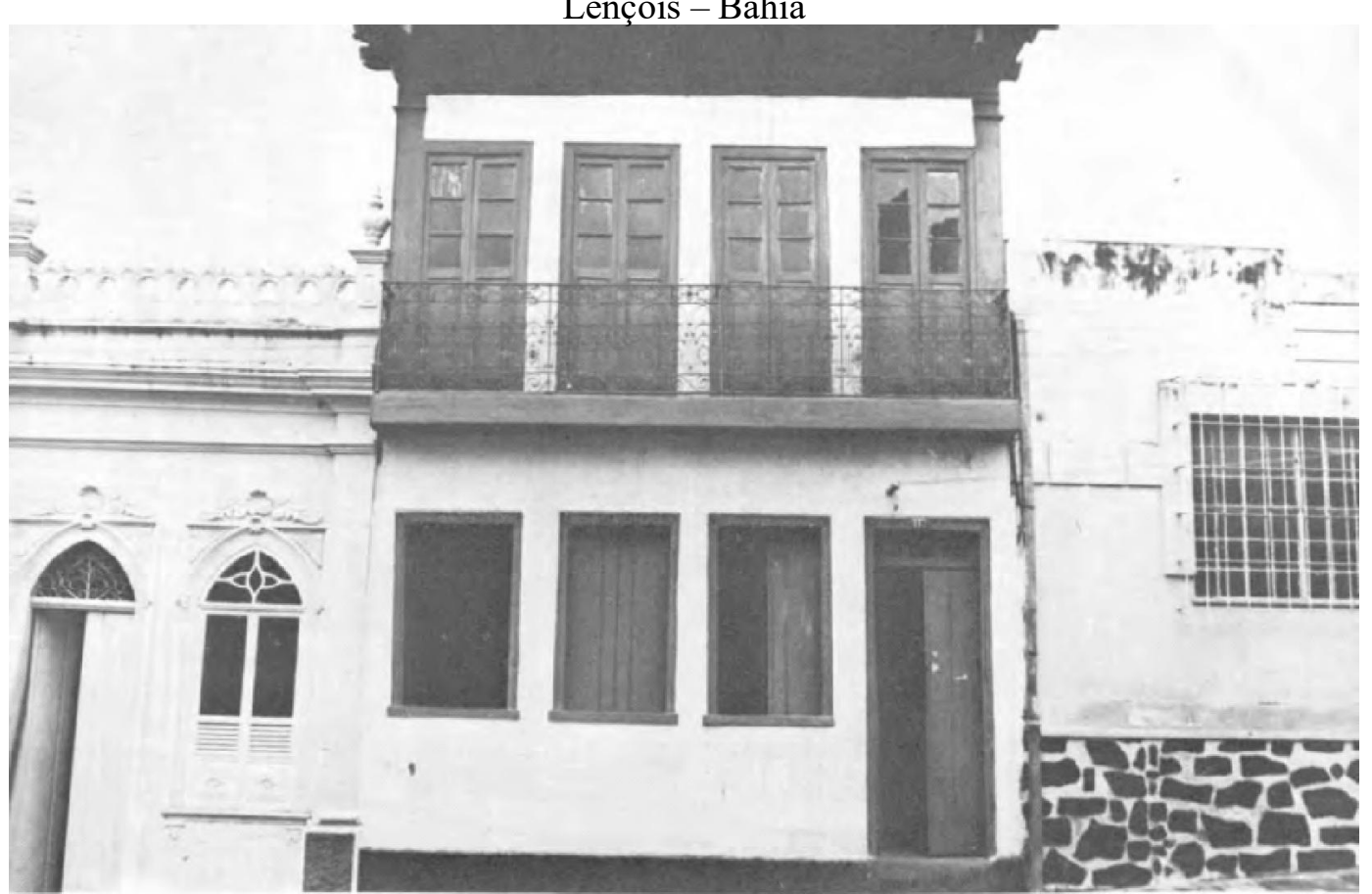

Fonte: Revista do Patrimônio Histórico e Artístico Nacional (18), 1978. 
Figura 154 - Av. 7 de setembro, antiga residencia de César Sá, atual sede da Prefeitura Municipal Lençóis - Bahia (atual sede do Iphan)

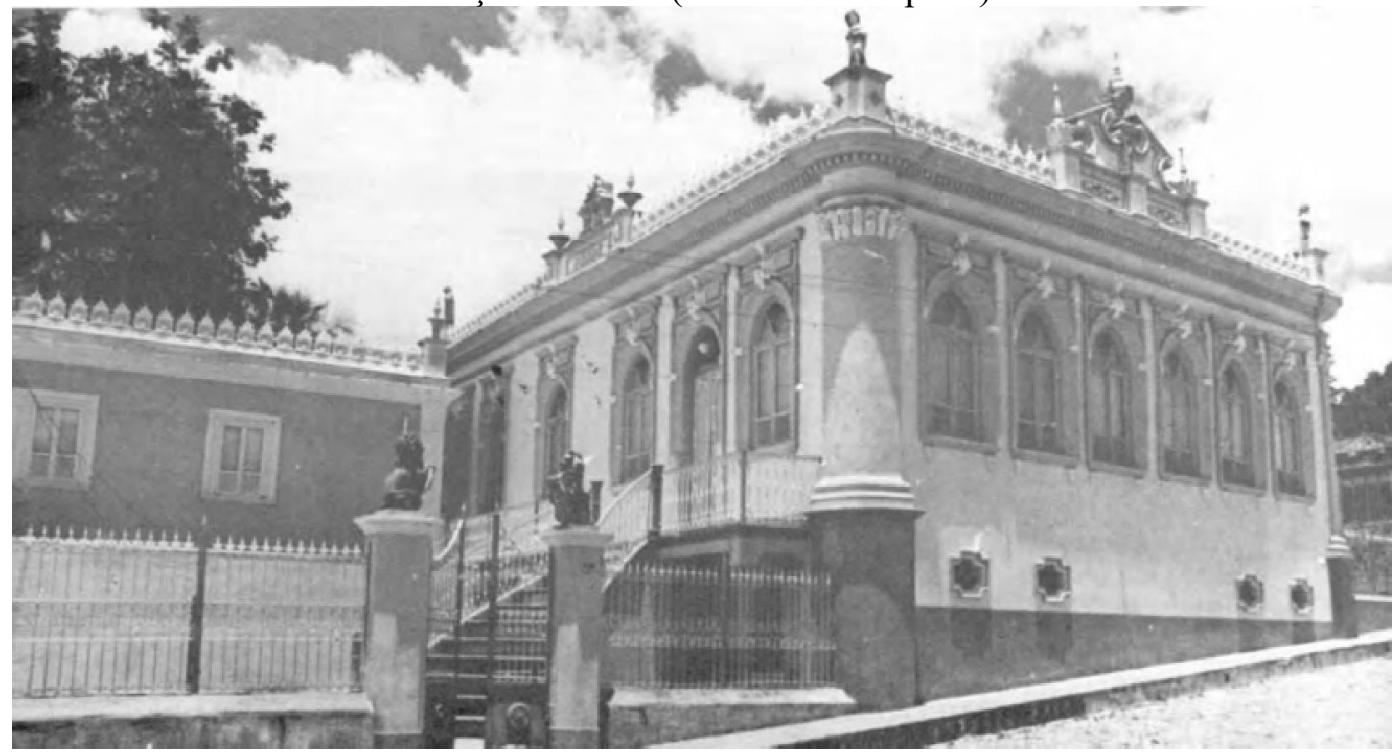

Fonte: Revista do Patrimônio Histórico e Artístico Nacional (18), 1978.

Figura 155 - Praça Otaviano Alves, vendo-se a antiga casa de residência da Família César Sá, atual sede da Prefeitura Municipal de Lençóis - Bahia (atual sede do Iphan)

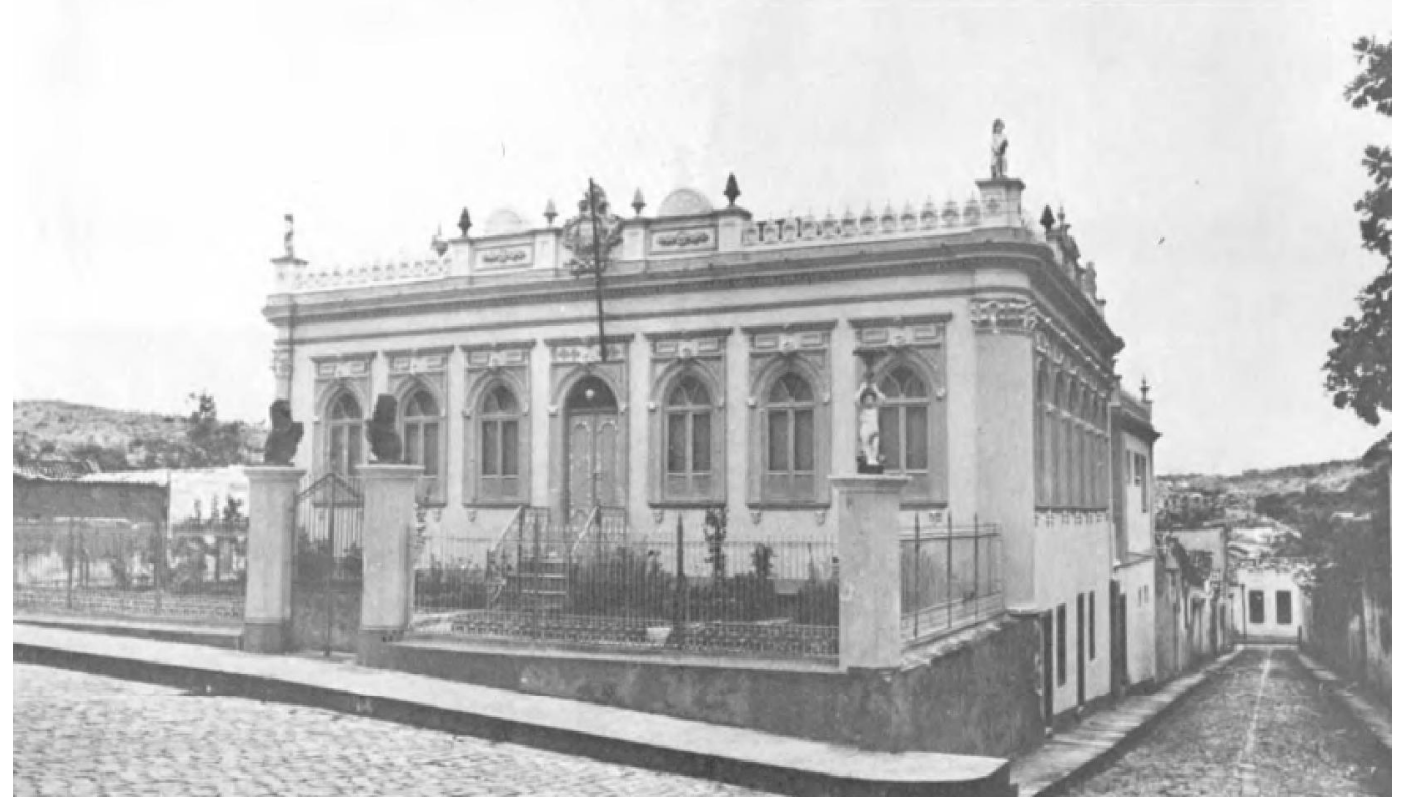

Fonte: Revista do Patrimônio Histórico e Artístico Nacional (18), 1978. 
Figura 156 - Ponte sobre o rio Lençóis - Lençóis - Bahia

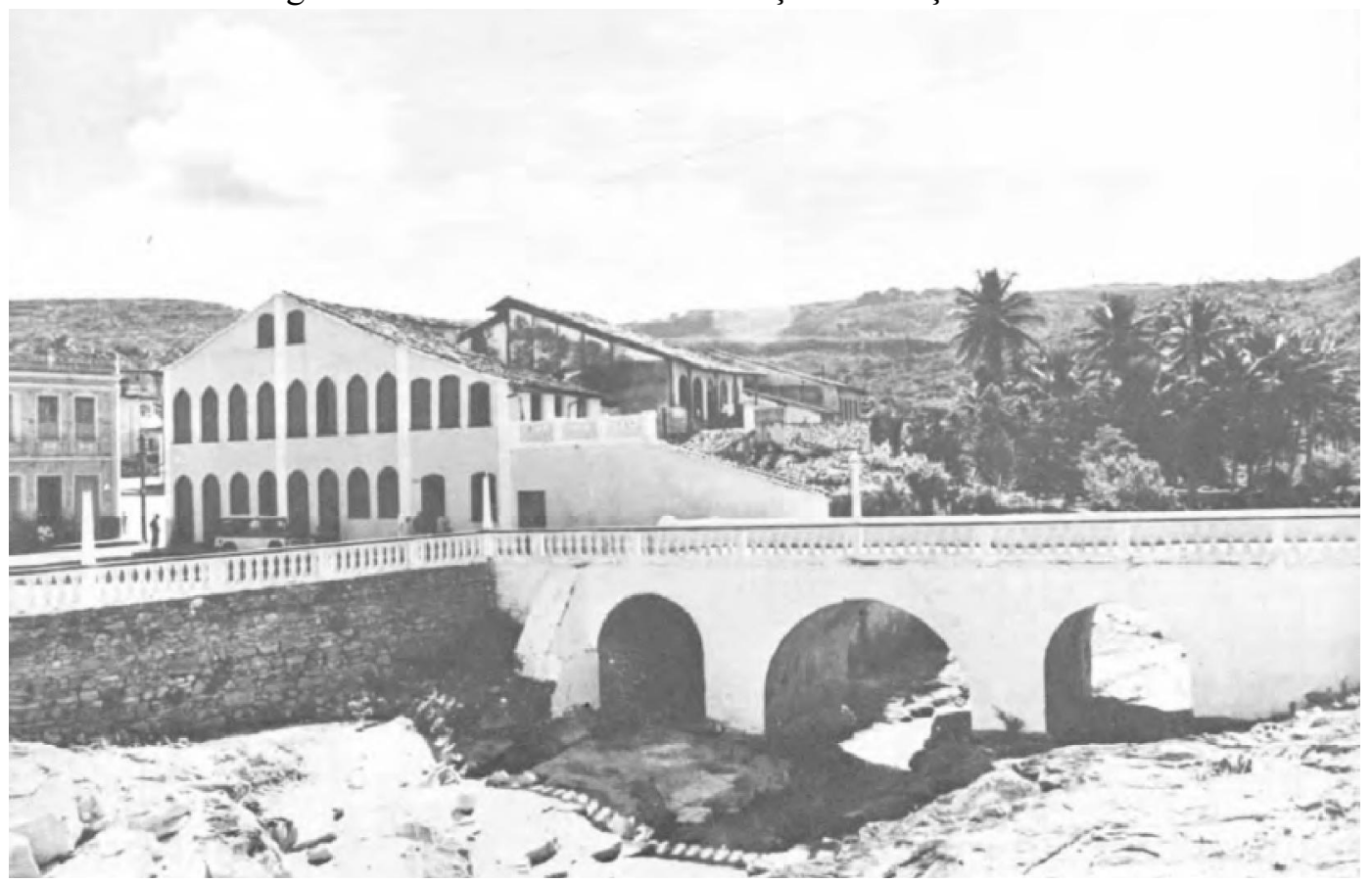

Fonte: Revista do Patrimônio Histórico e Artístico Nacional (18), 1978.

Figura 157 - Ponte sobre o rio Lençóis - Lençóis - Bahia

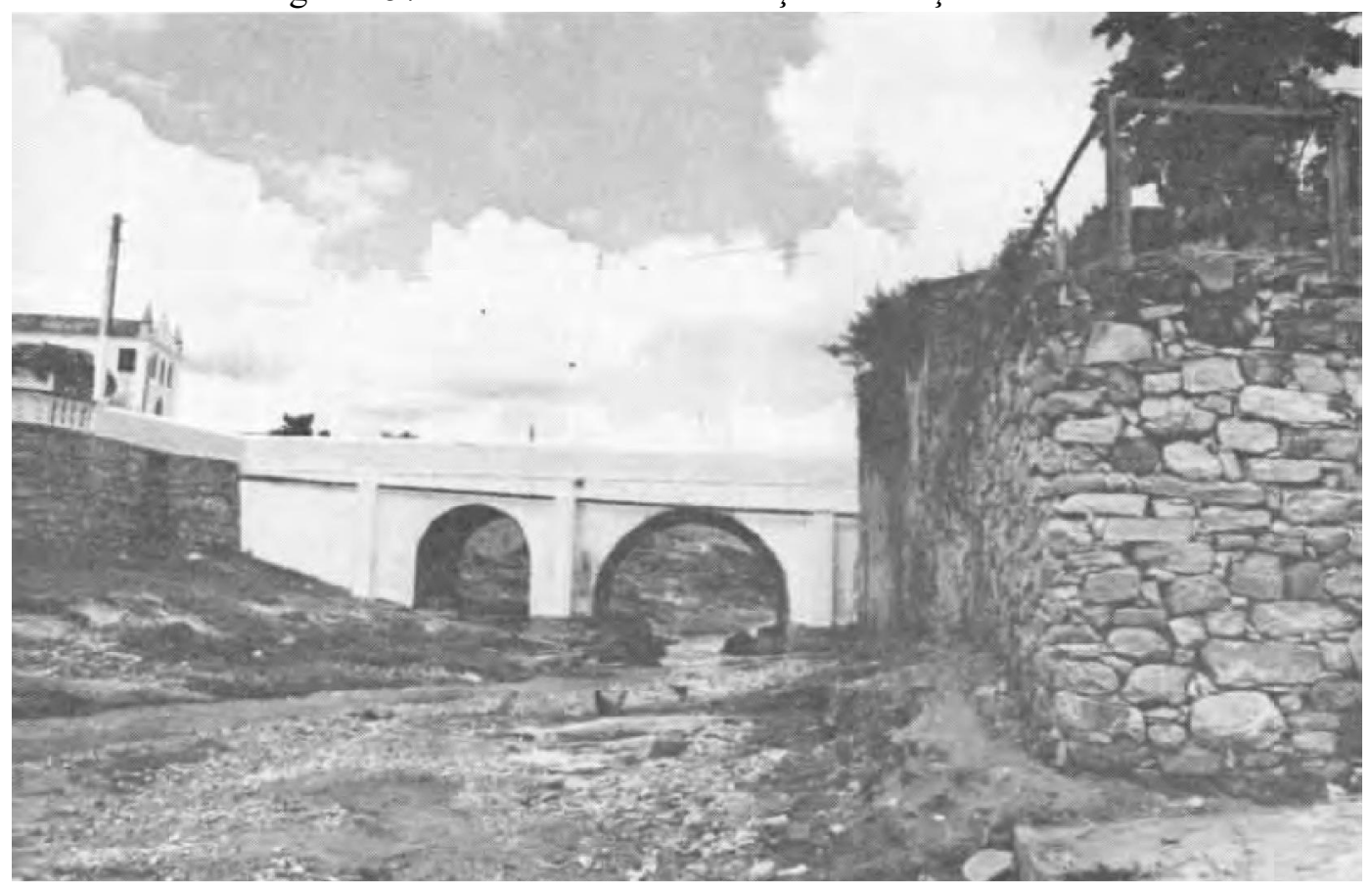

Fonte: Revista do Patrimônio Histórico e Artístico Nacional (18), 1978. 
Figura 158 - Praça Horácio de Matos - Lençóis - Bahia

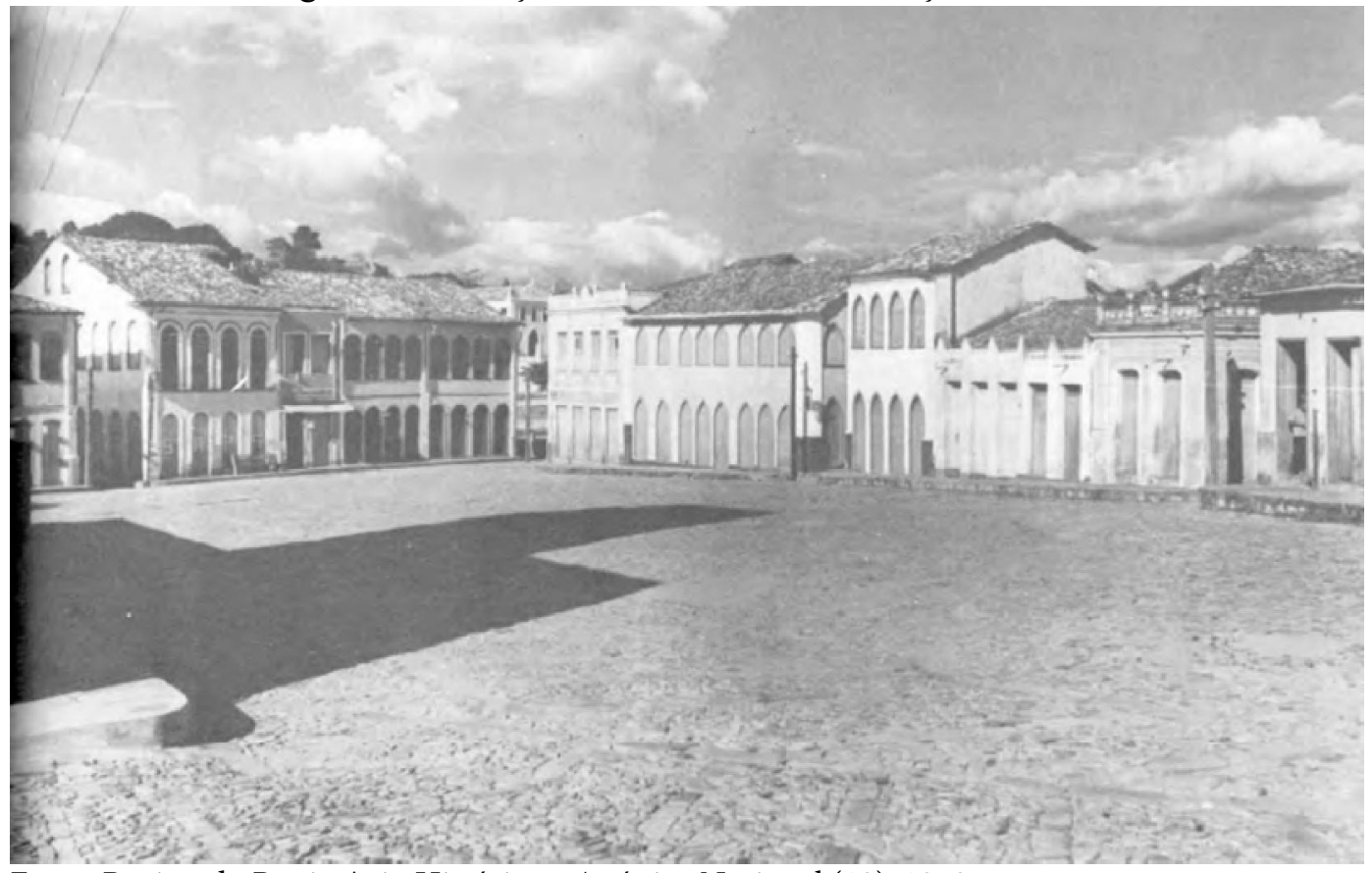

Fonte: Revista do Patrimônio Histórico e Artístico Nacional (18), 1978.

Figura 159 - Praça Horácio de Matos - Lençóis - Bahia

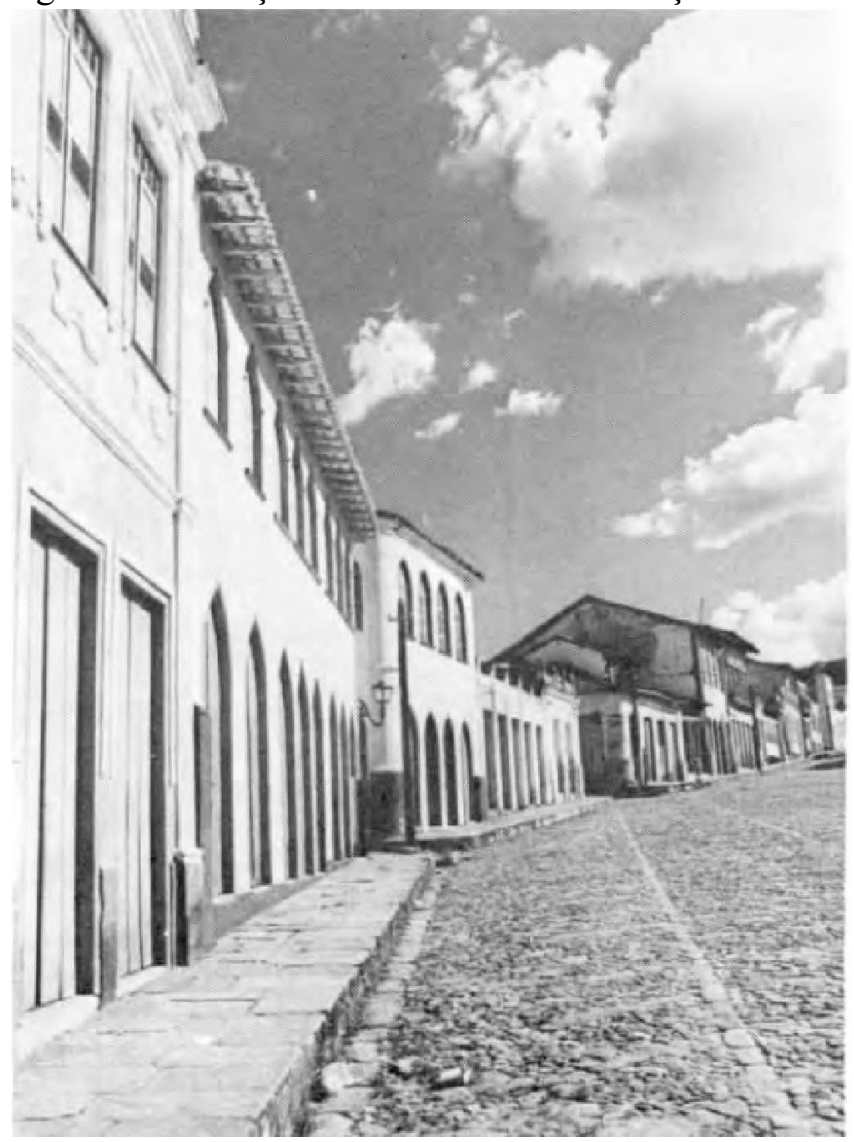

Fonte: Revista do Patrimônio Histórico e Artístico Nacional (18), 1978. 
Figura 160 - Rua dos Mineiros - Lençóis - Bahia

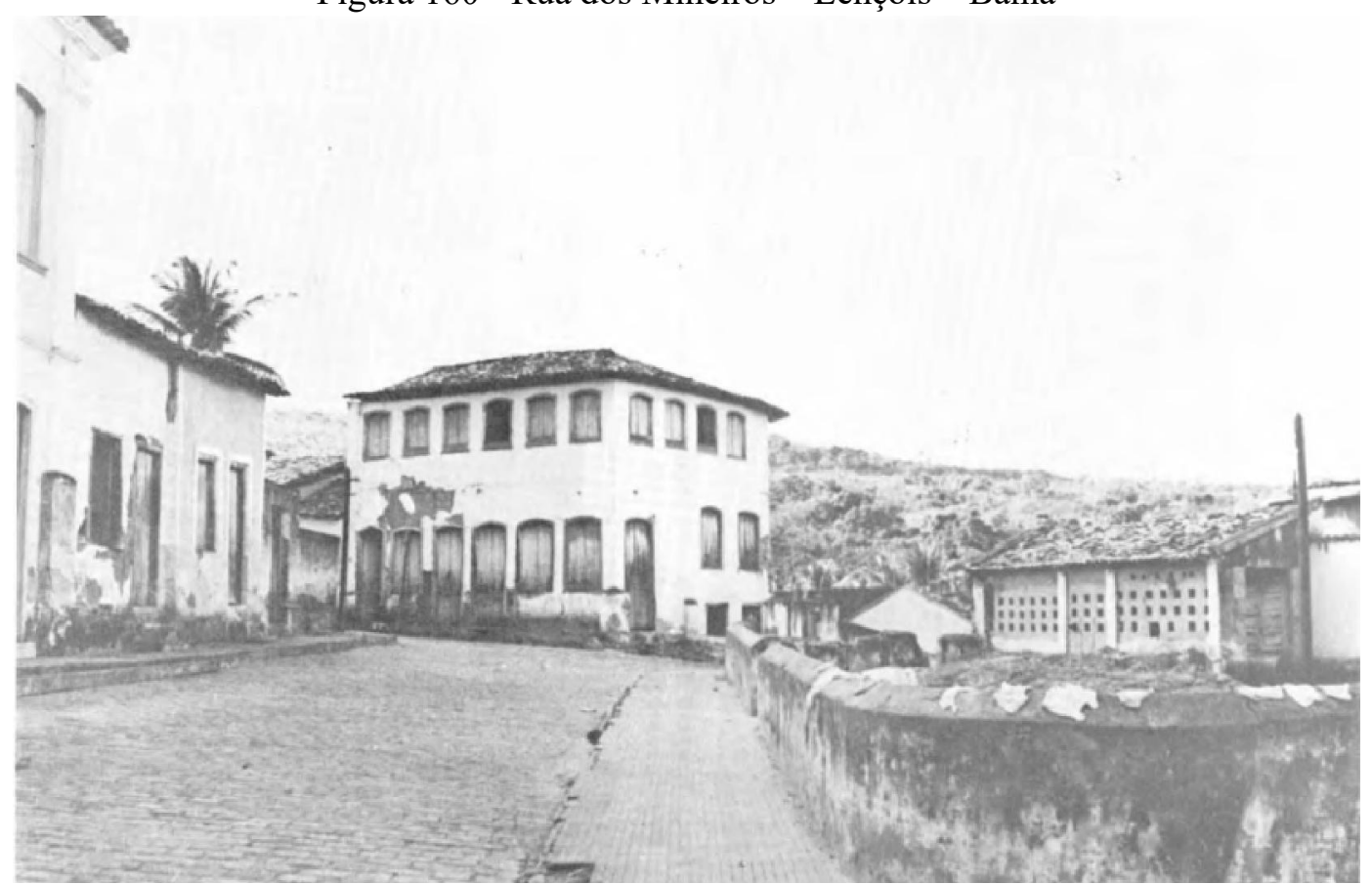

Fonte: Revista do Patrimônio Histórico e Artístico Nacional (18), 1978.

Figura 161 - Praça Aureliano Sá, esquina com a Praça Horácio de Matos - Lençóis - Bahia

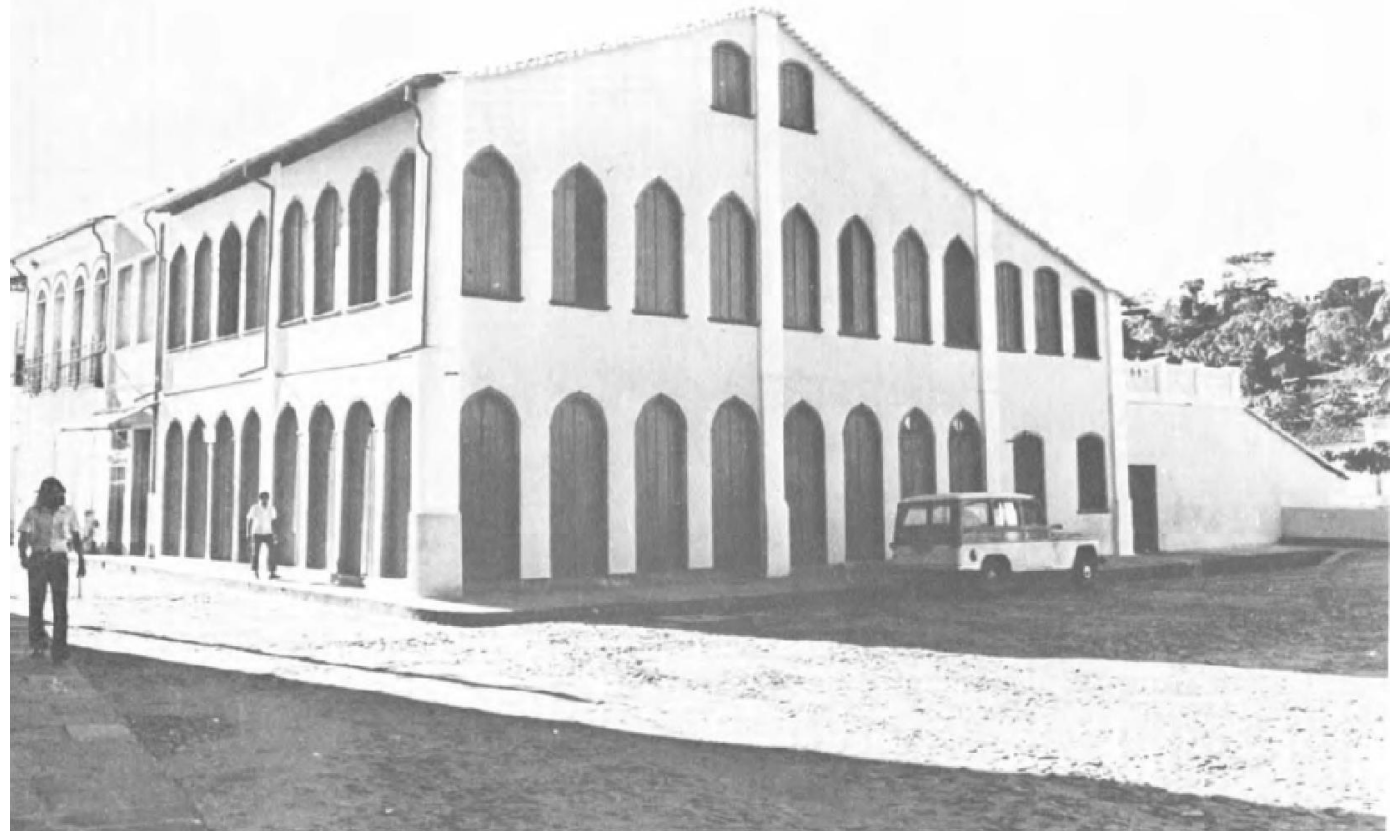

Fonte: Revista do Patrimônio Histórico e Artístico Nacional (18), 1978. 
Figura 162 - Rua Tiradentes - Lençóis - Bahia

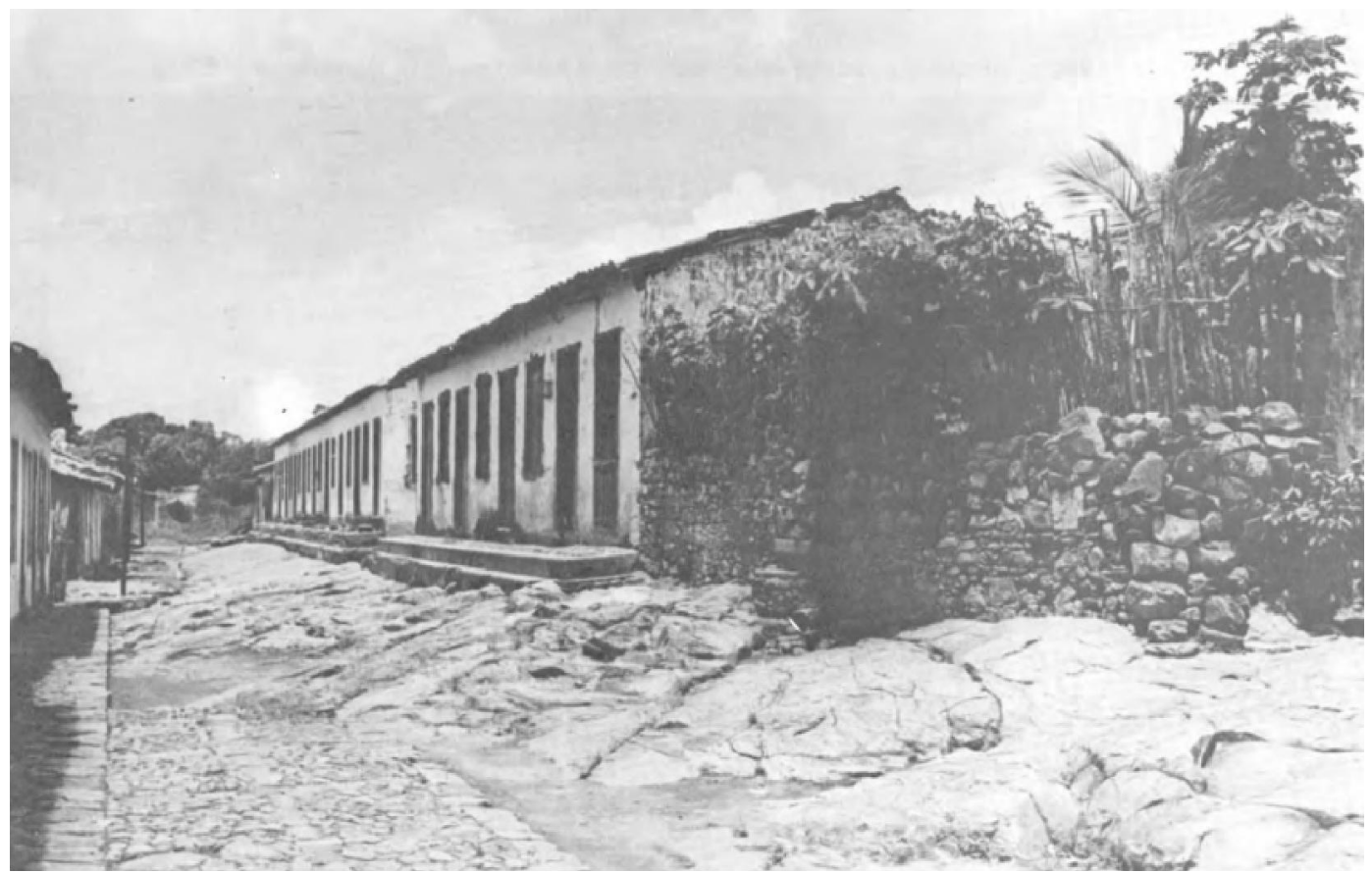

Fonte: Revista do Patrimônio Histórico e Artístico Nacional (18), 1978.

Figura 163 - Rua Silva Jardim: prédio do antigo Quartel, segundo informação de Heraldo Barbosa Filho Lençóis - Bahia

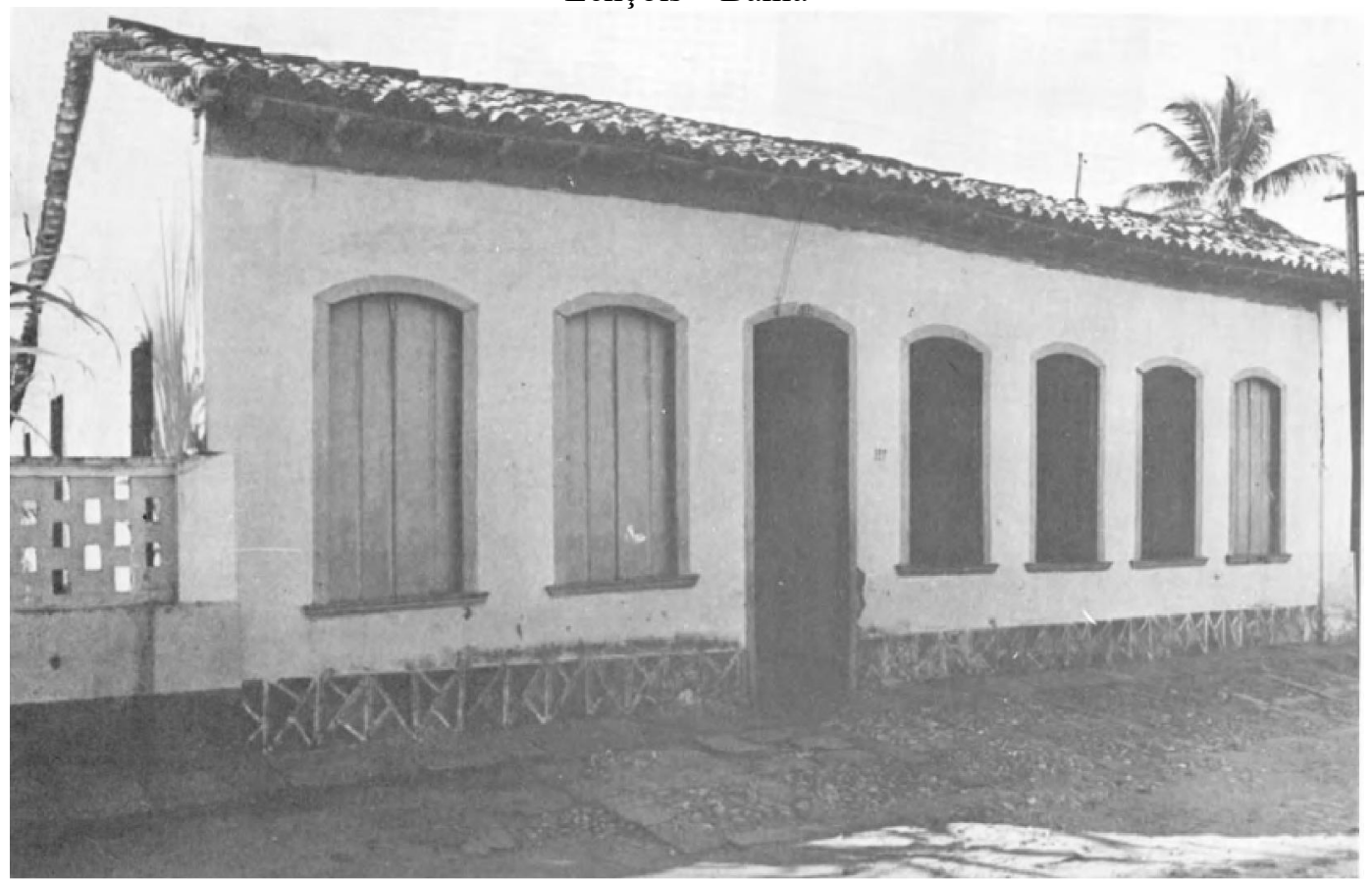

Fonte: Revista do Patrimônio Histórico e Artístico Nacional (18), 1978. 
Figura 164 - Beco de chegada à Rua Urbano Duarte (Boa Vista) - Lençóis - Bahia

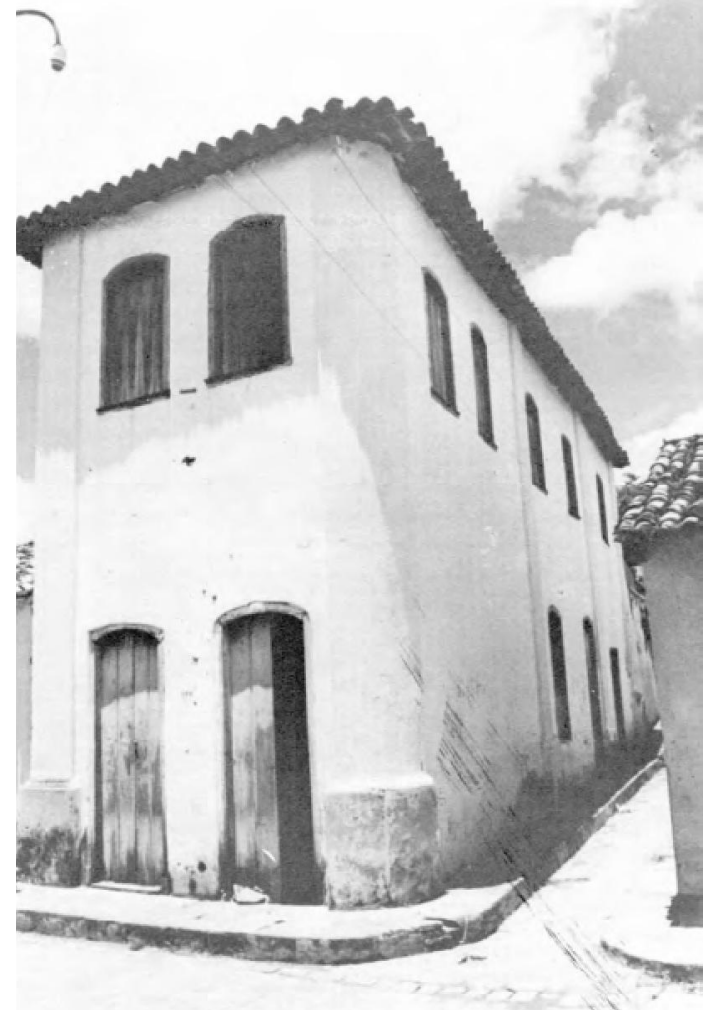

Fonte: Revista do Patrimônio Histórico e Artístico Nacional (18), 1978.

Figura 165 - Rua Urbano Duarte (Boa Vista) - Lençóis - Bahia

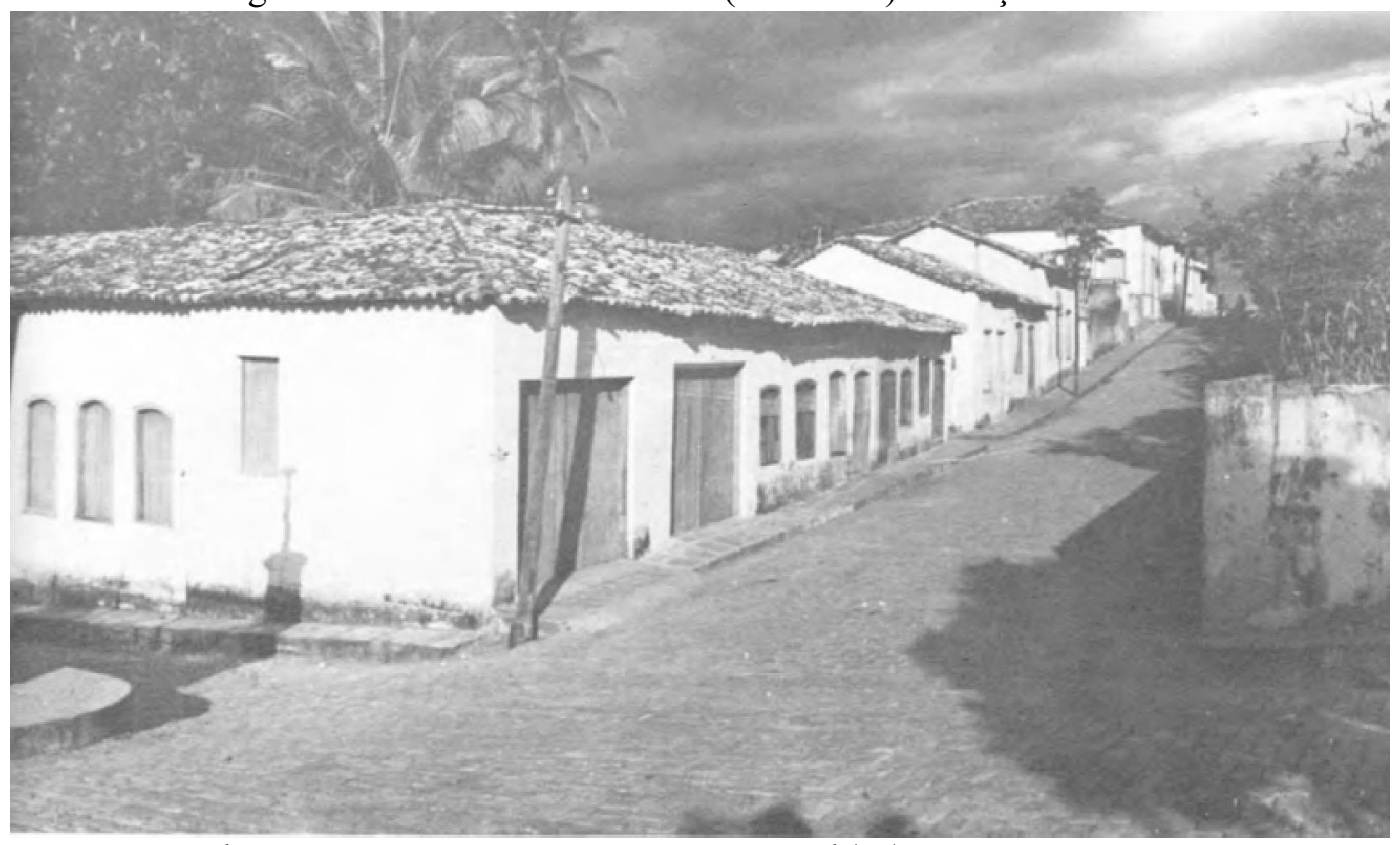

Fonte: Revista do Patrimônio Histórico e Artístico Nacional (18), 1978. 
Figura 166 - Rua Urbano Duarte (Boa Vista) - Lençóis - Bahia

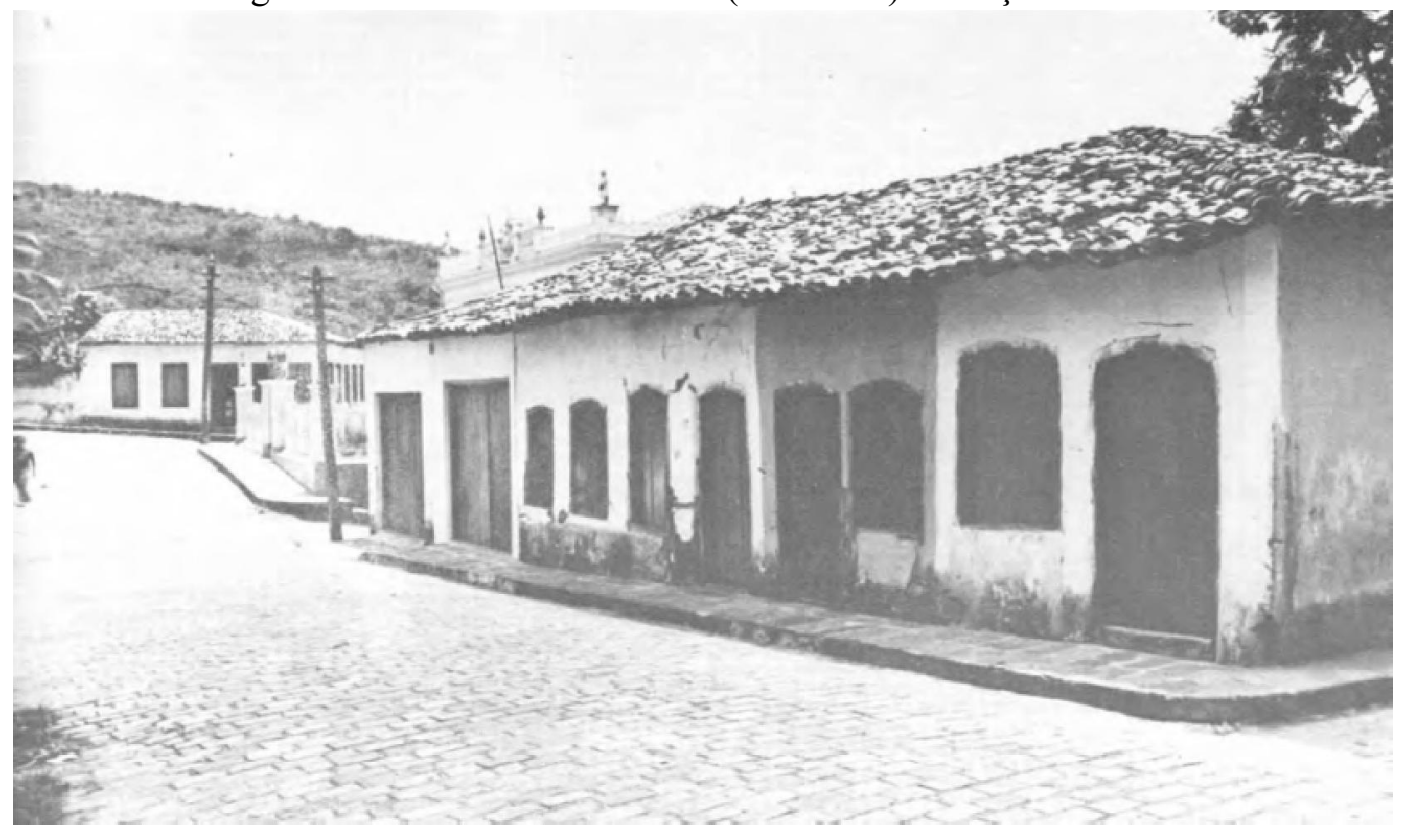

Fonte: Revista do Patrimônio Histórico e Artístico Nacional (18), 1978.

Figura 167 - Bica em forma de cabeça de animal colocada em condutor de águas pluviais

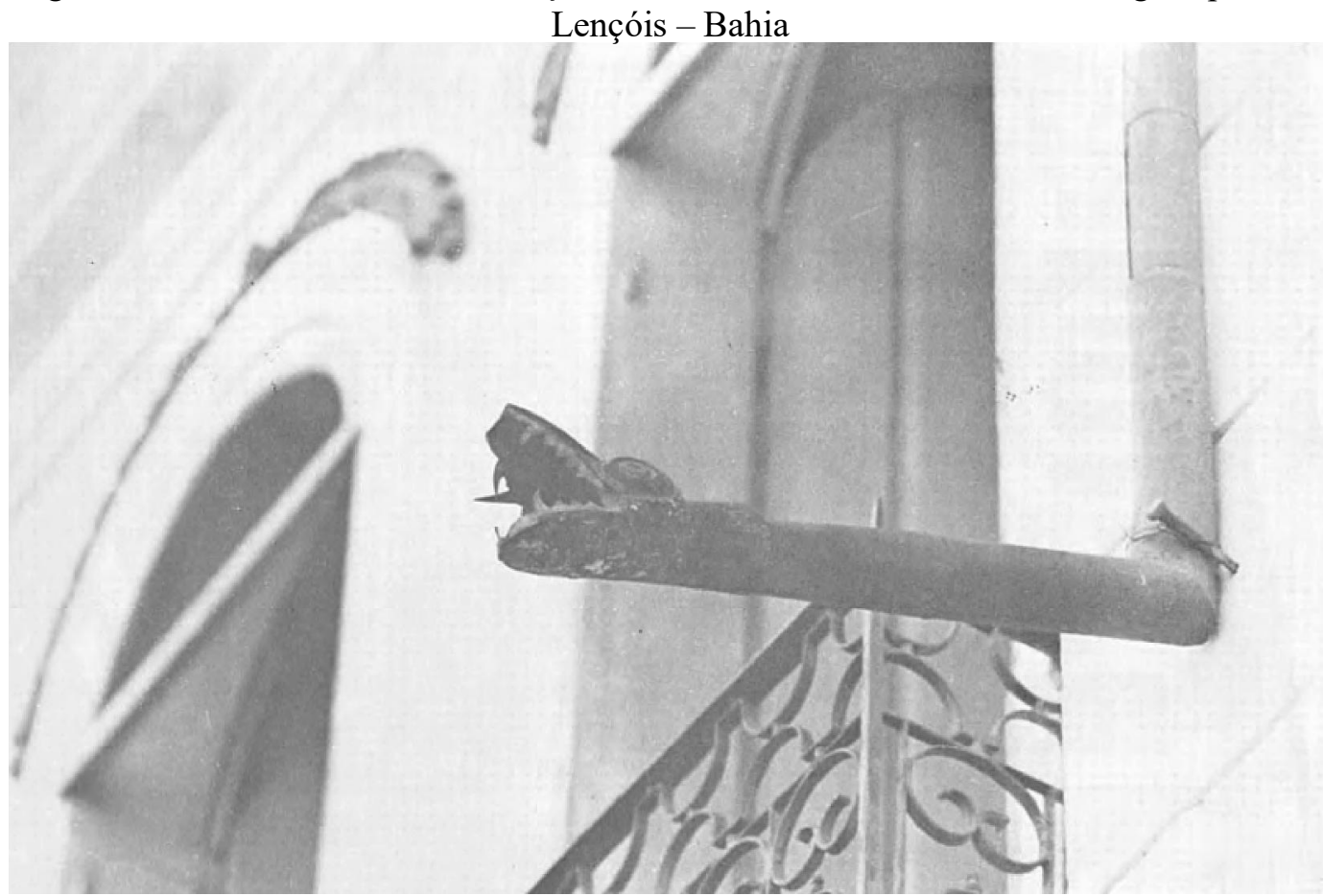

Fonte: Revista do Patrimônio Histórico e Artístico Nacional (18), 1978. 
Figura 168 - Casa de lapidação, vendo-se em primeiro plano roda d'água que movimenta a maquinaria

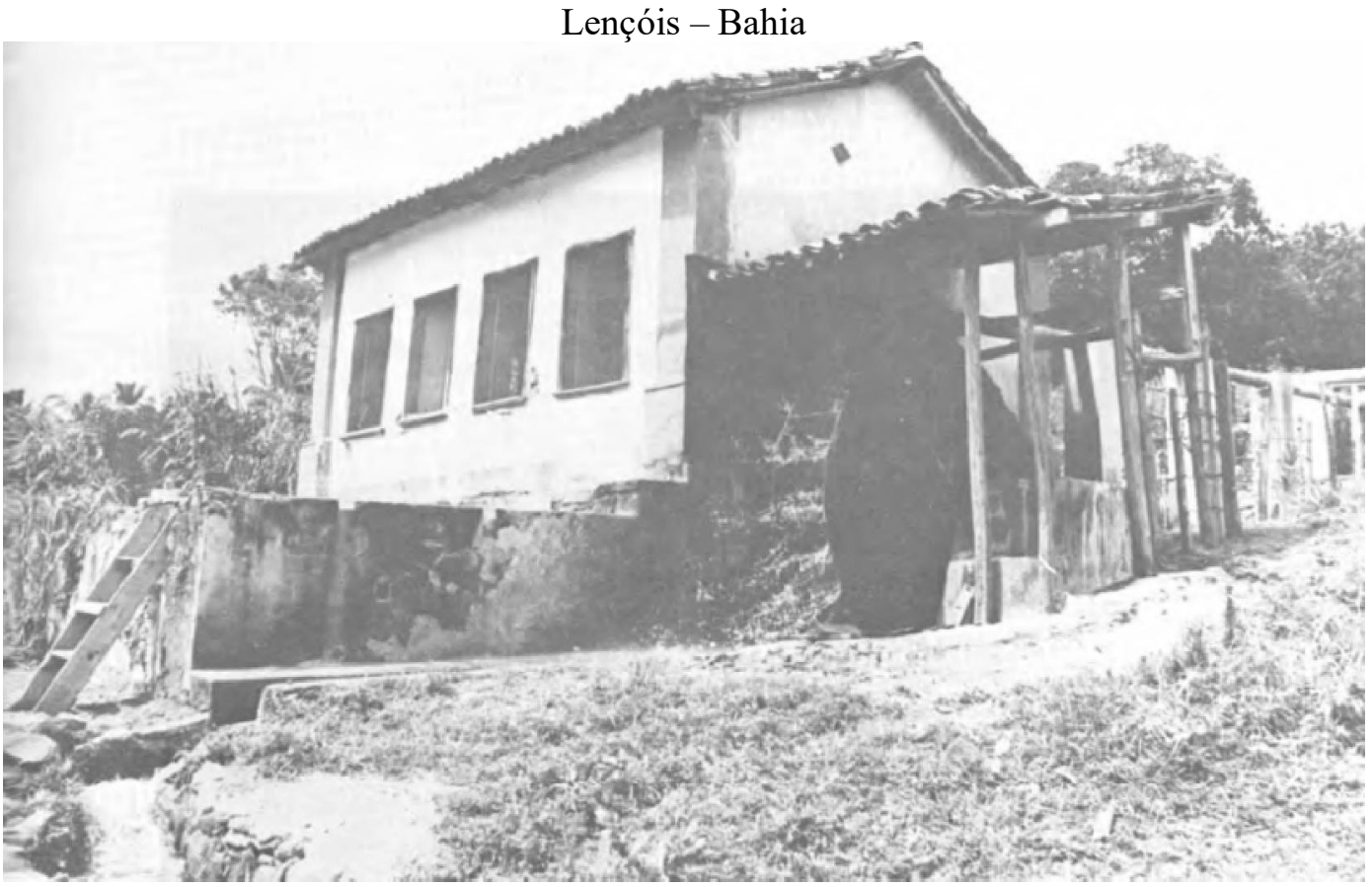

Fonte: Revista do Patrimônio Histórico e Artístico Nacional (18), 1978.

Figura 169 - Casa de Lapidação - Vista da Maquinaria - Lençóis - Bahia

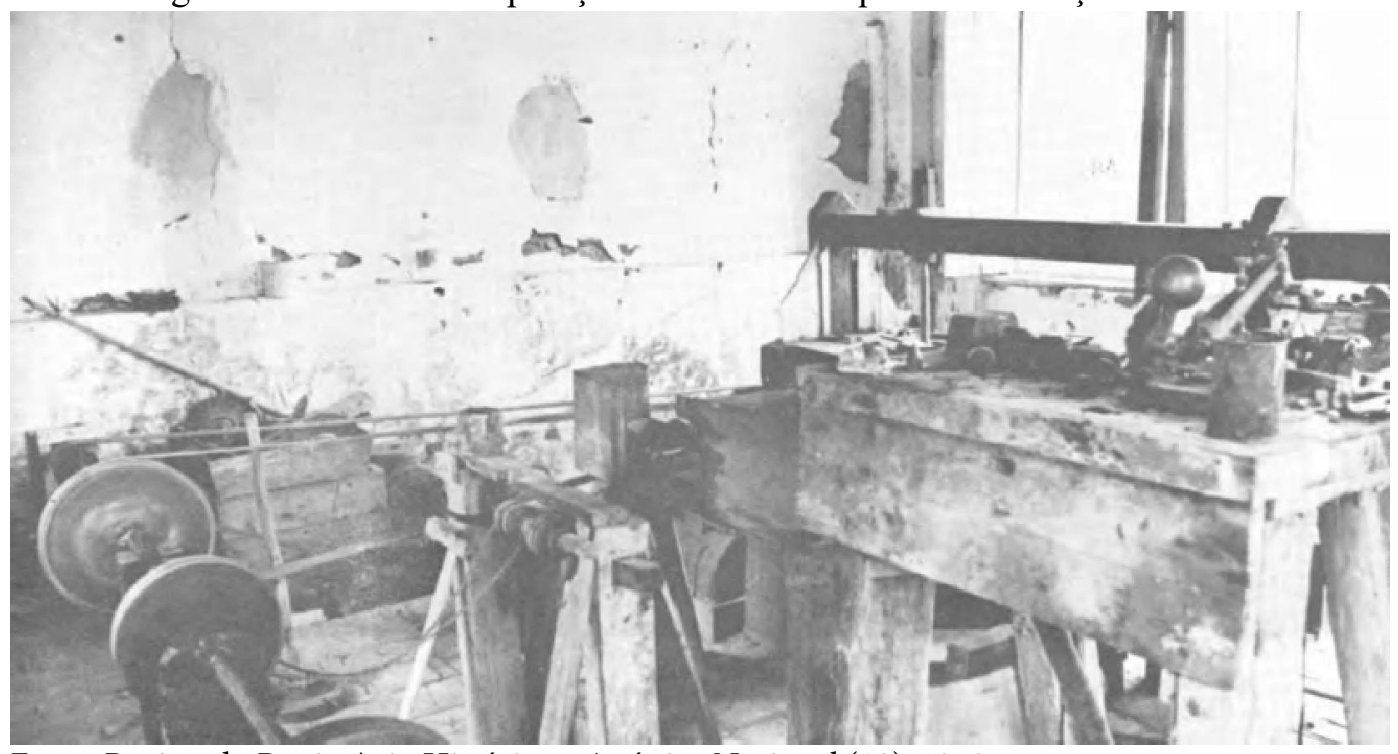

Fonte: Revista do Patrimônio Histórico e Artístico Nacional (18), 1978 
Figura 170 - Rua Voluntários da Pátria - Lençóis - Bahia

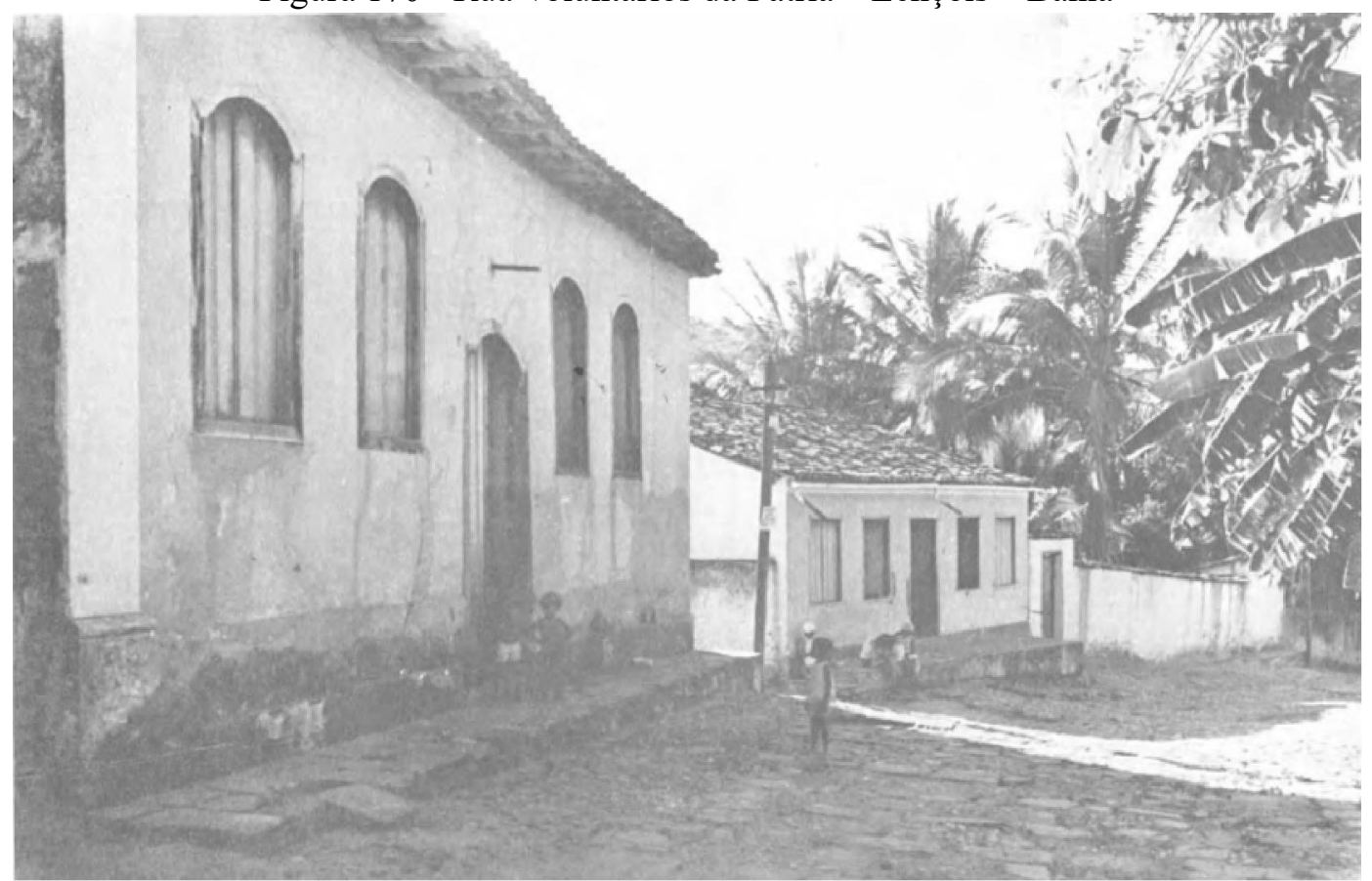

Fonte: Revista do Patrimônio Histórico e Artístico Nacional (18), 1978. 


\section{ANEXO G - Fotógrafos do Pôr do Sol no Morro do Pai Inácio}

Este pequeno ensaio fotográfico foi produzido em trabalho de campo no ano de 2016. São turistas durante os minutos do pôr do sol visto do alto do Morro do Pai Inácio, um dos mais visitados atrativos da Chapada Diamantina, localizado no município de Palmeiras. 
Figura 171

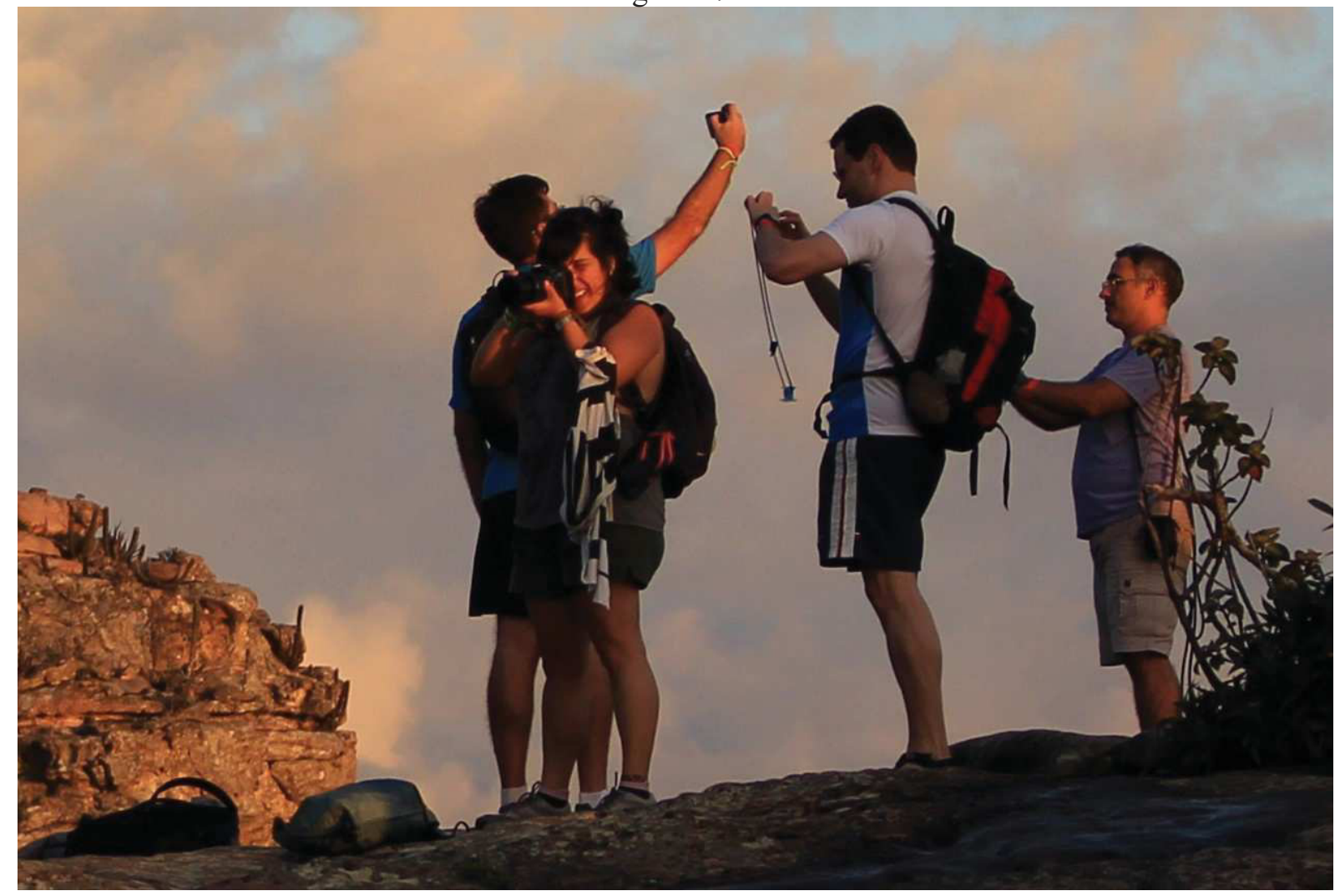

Fonte: Arquivo pessoal do Autor 
Figura 172

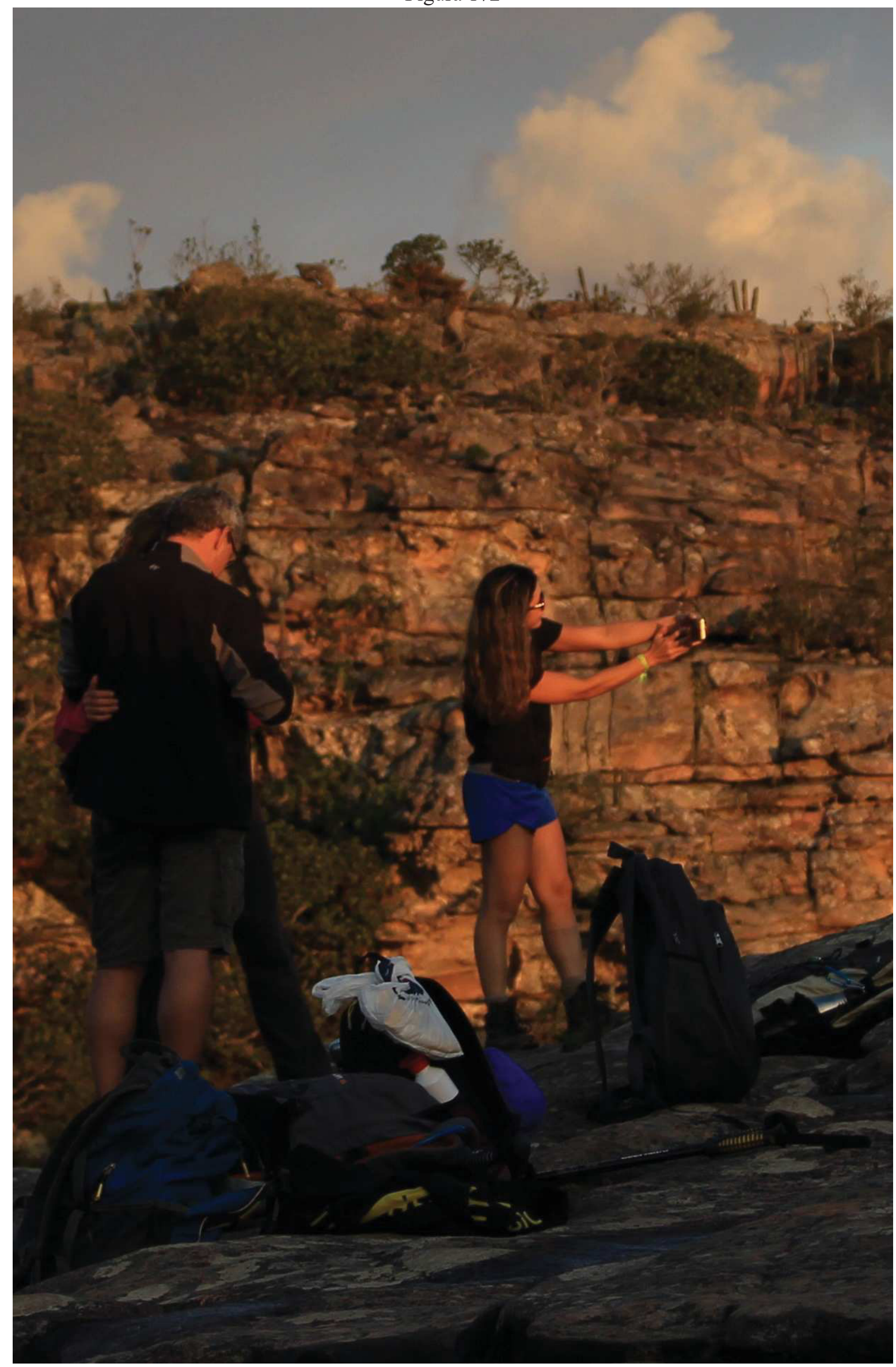


Figura 173

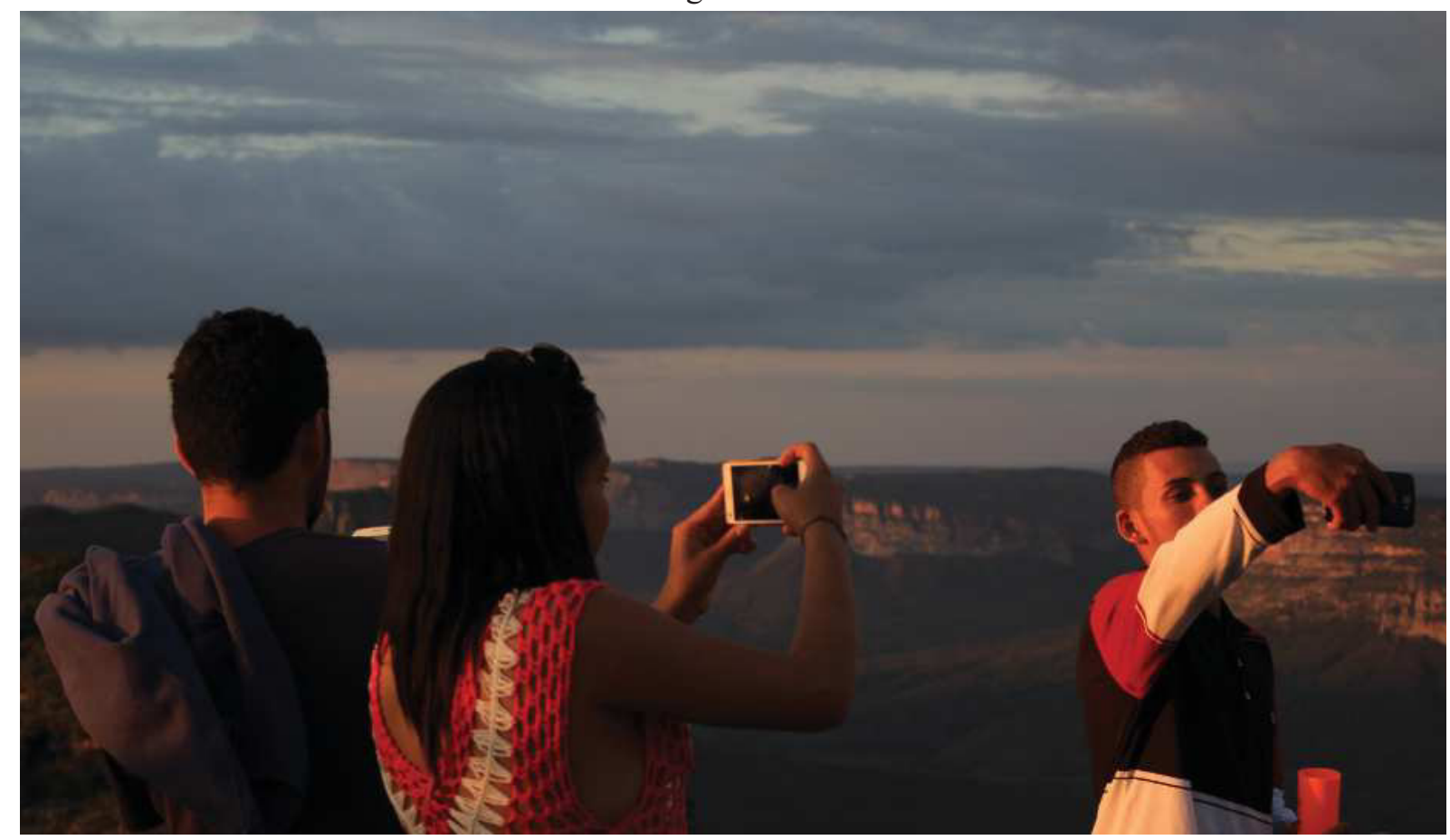

Fonte: Arquivo pessoal do Autor 
Figura 174

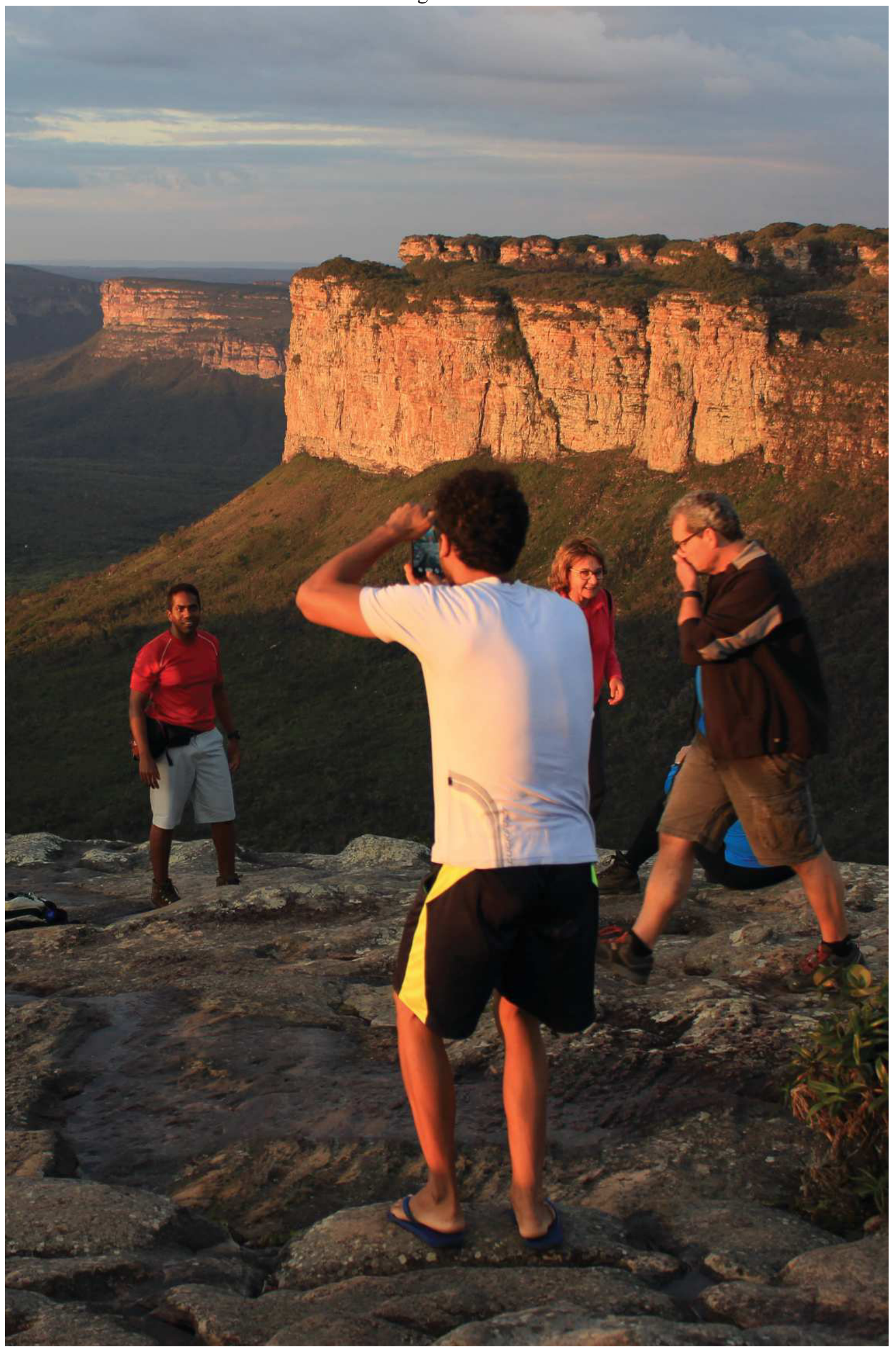


Figura 175

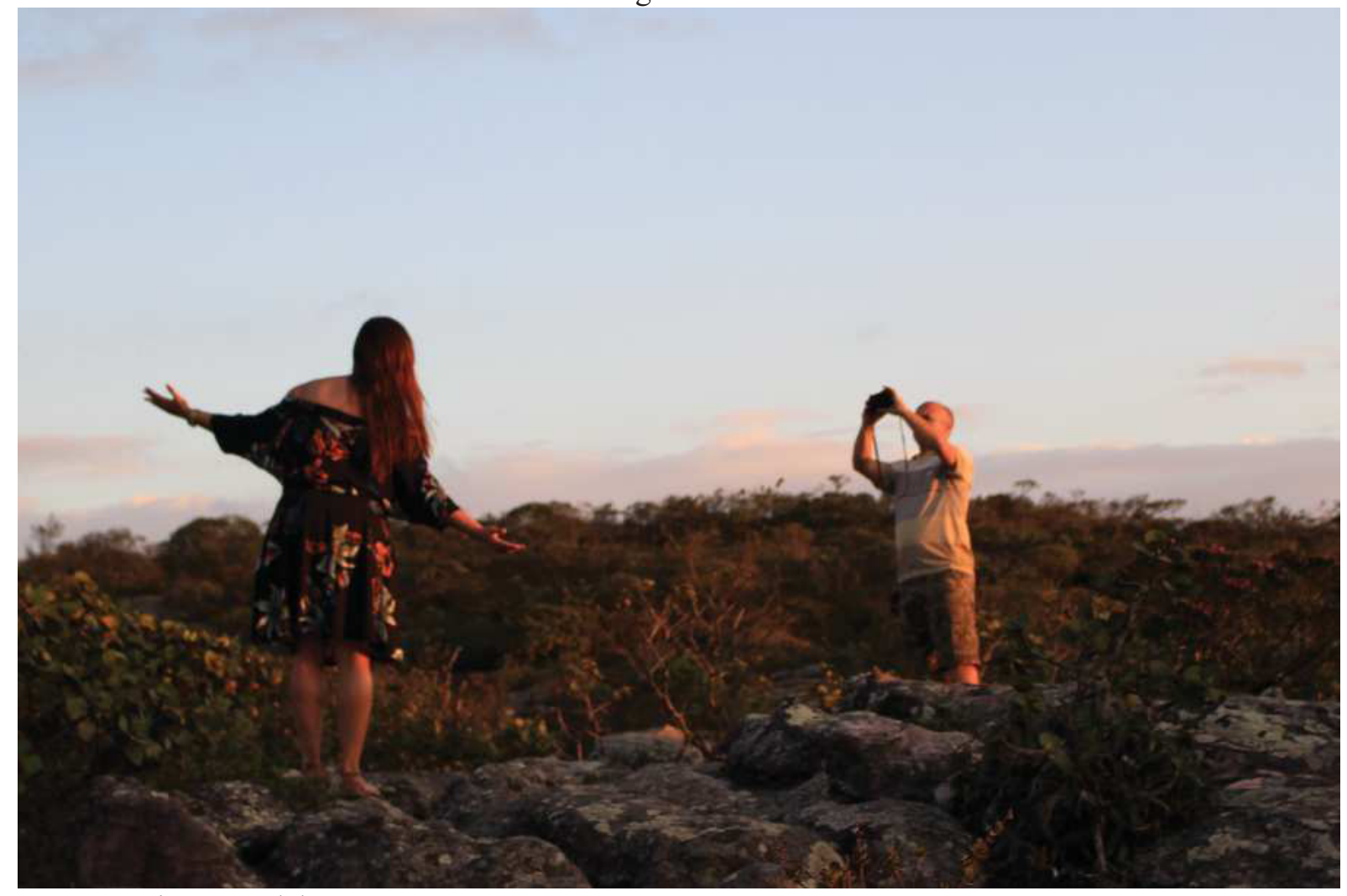

Fonte: Arquivo pessoal do Autor 
Figura 176

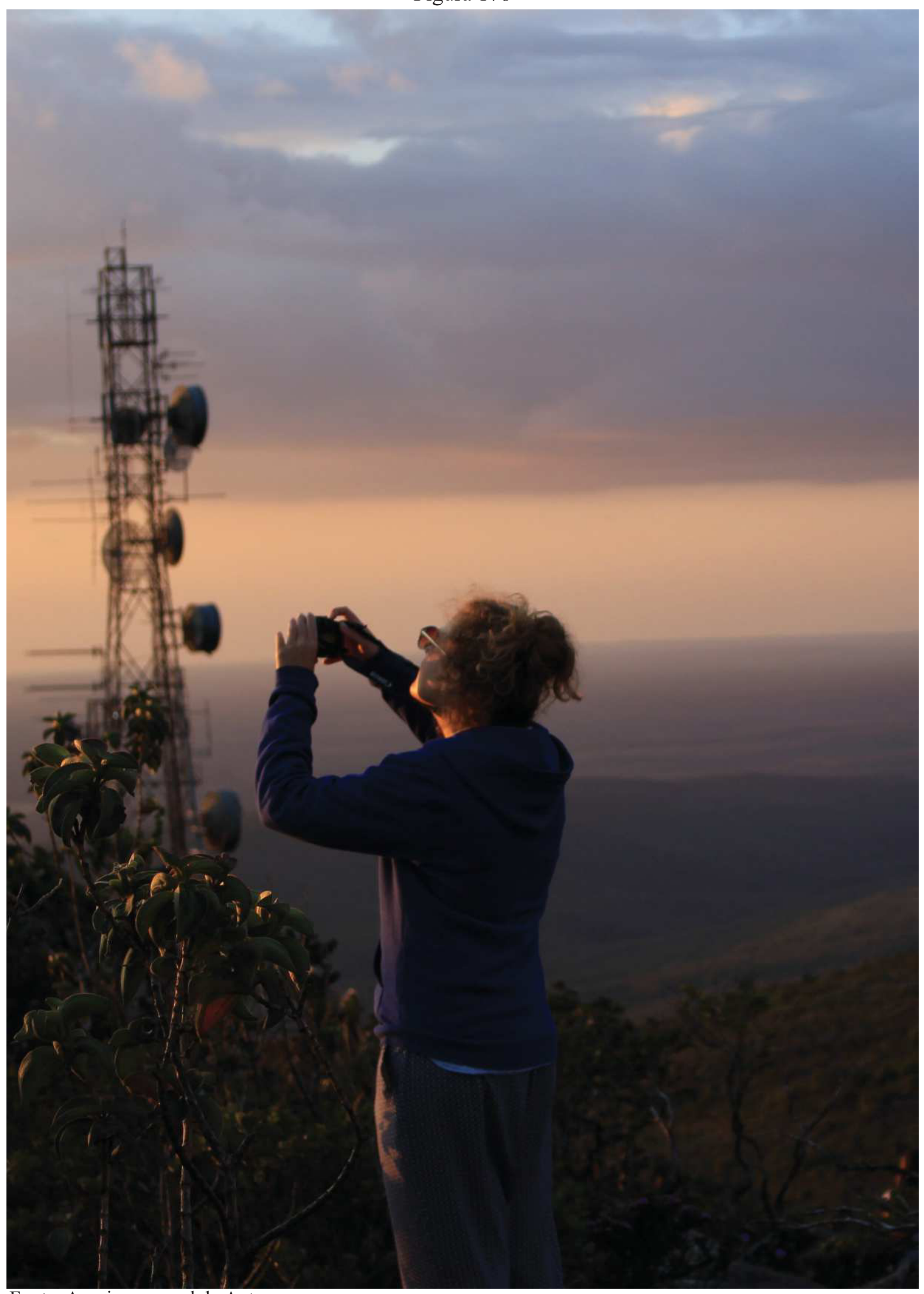

Fonte: Arquivo pessoal do Autor 
Figura 177

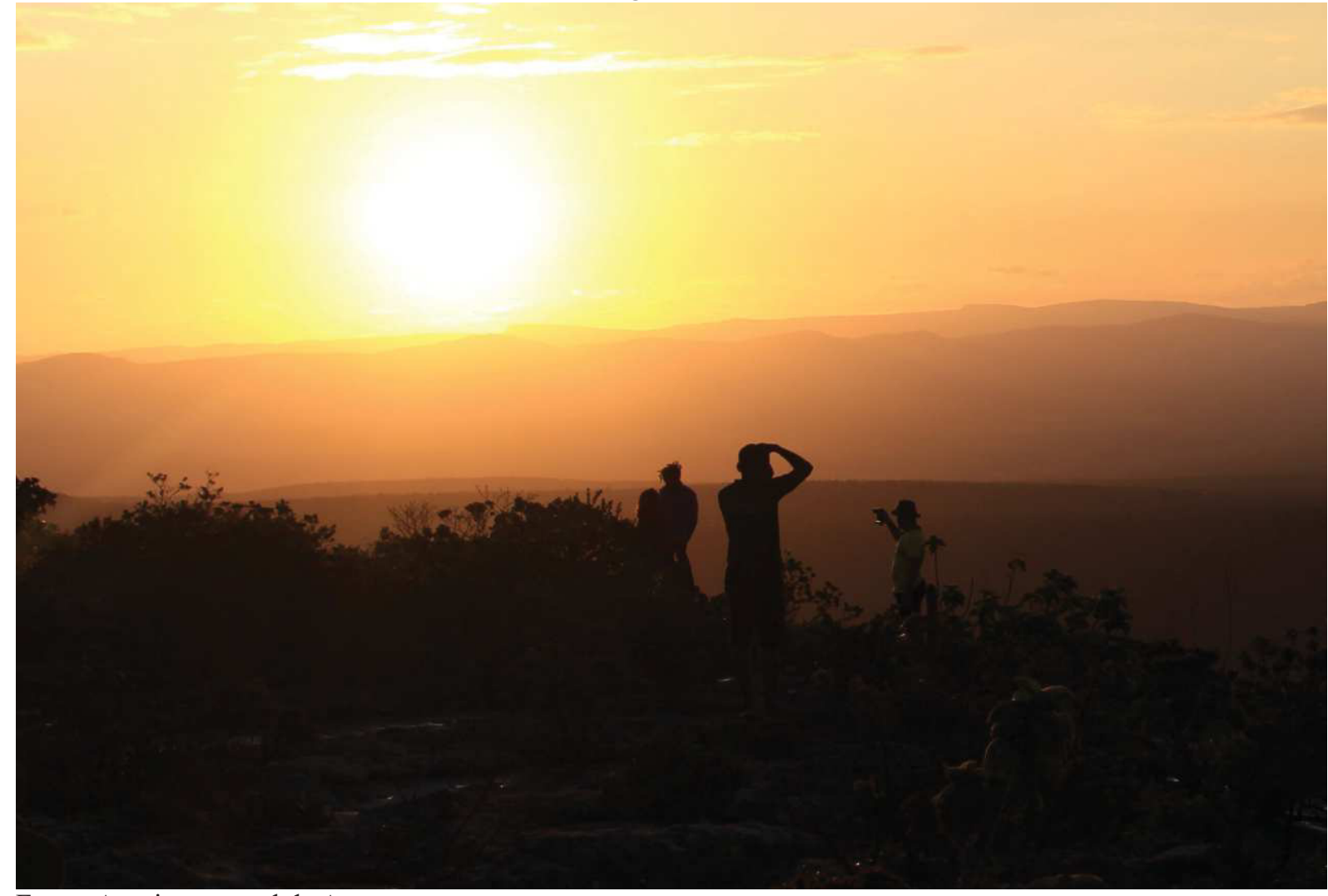

Fonte: Arquivo pessoal do Autor 
Figura 178

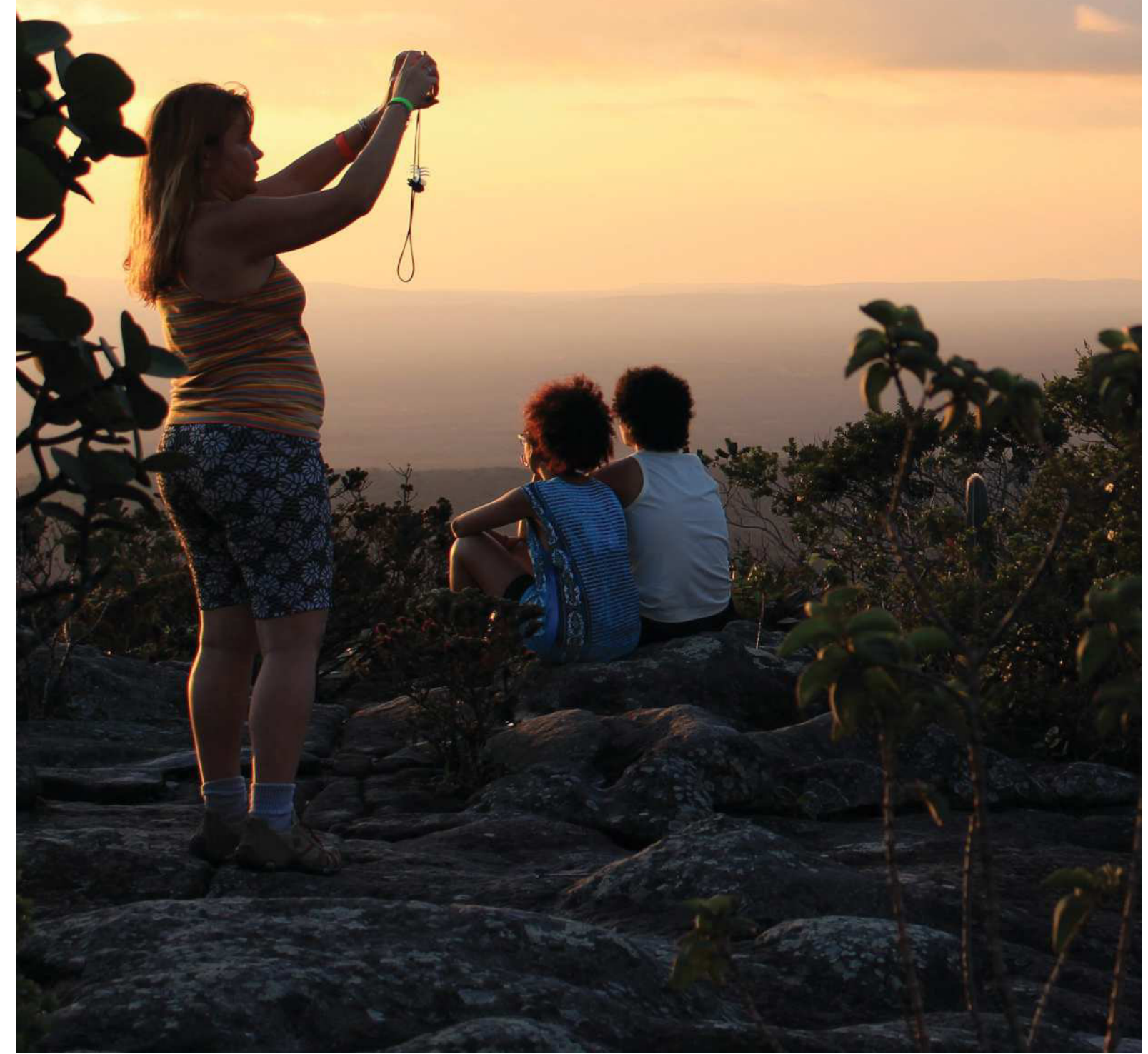

Fonte: Arquivo pessoal do Autor 
Figura 179

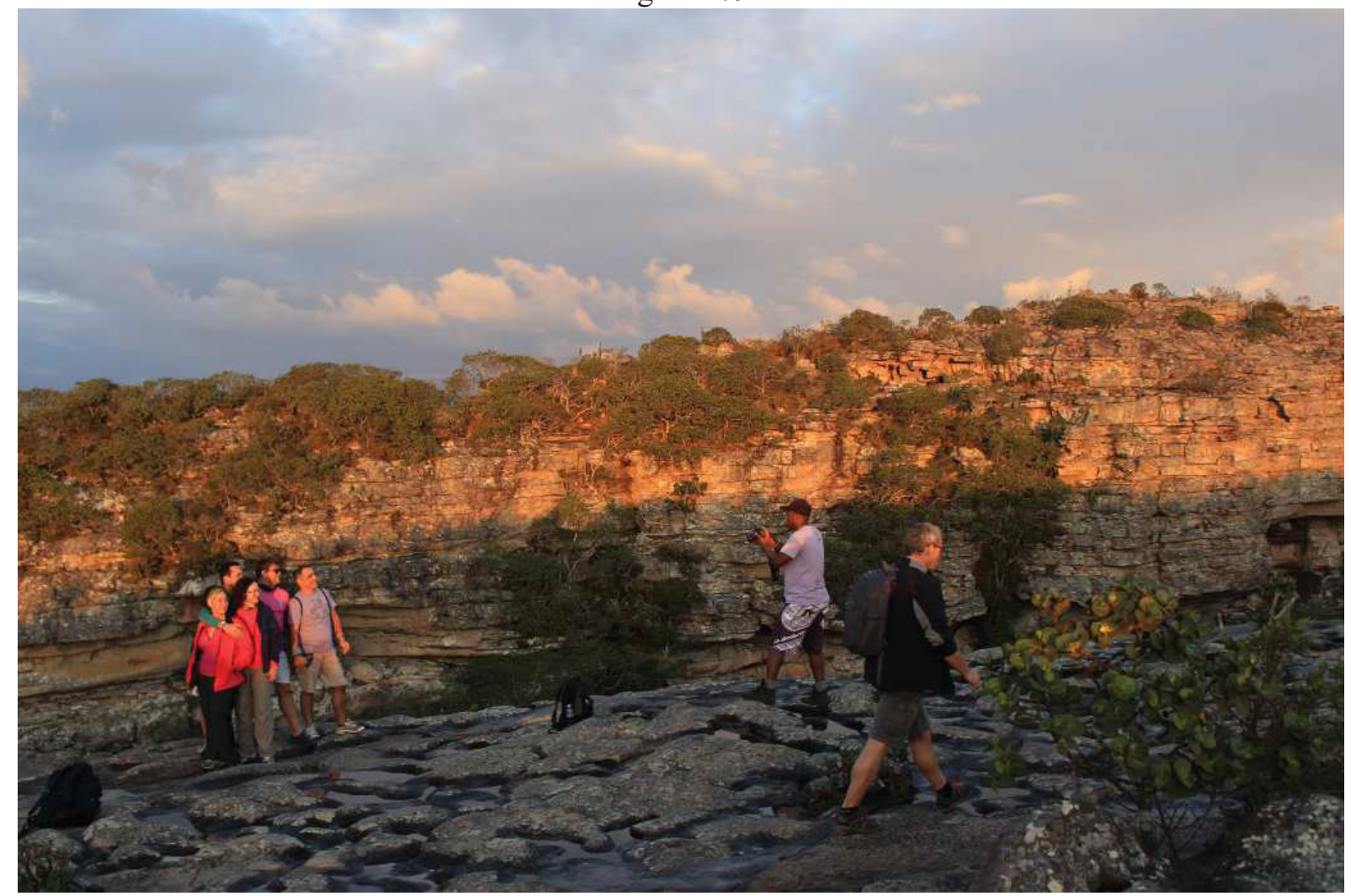

Fonte: Arquivo pessoal do Autor 
Figura 180

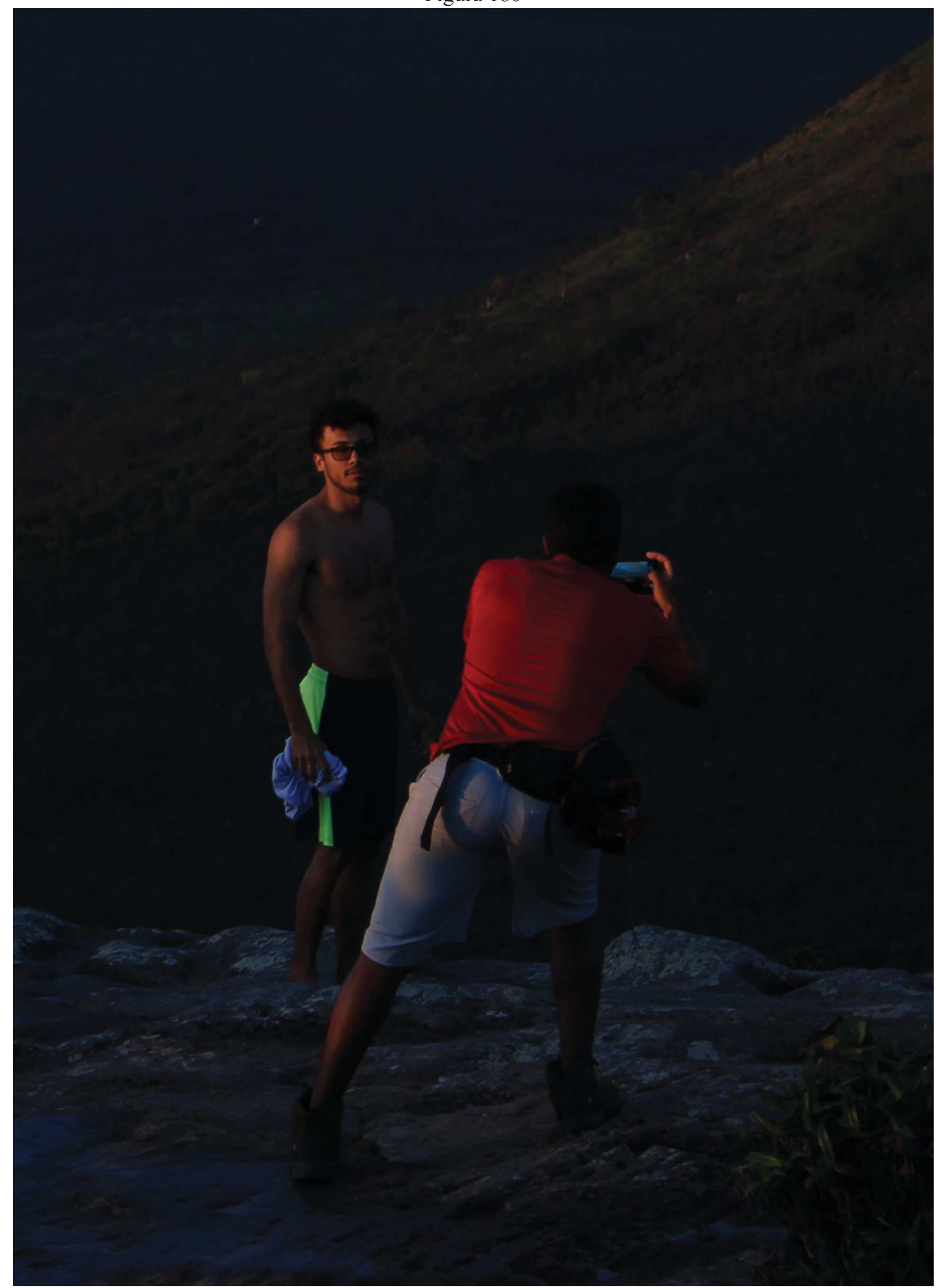

Fonte: Arquivo pessoal do Autor 
Figura 181

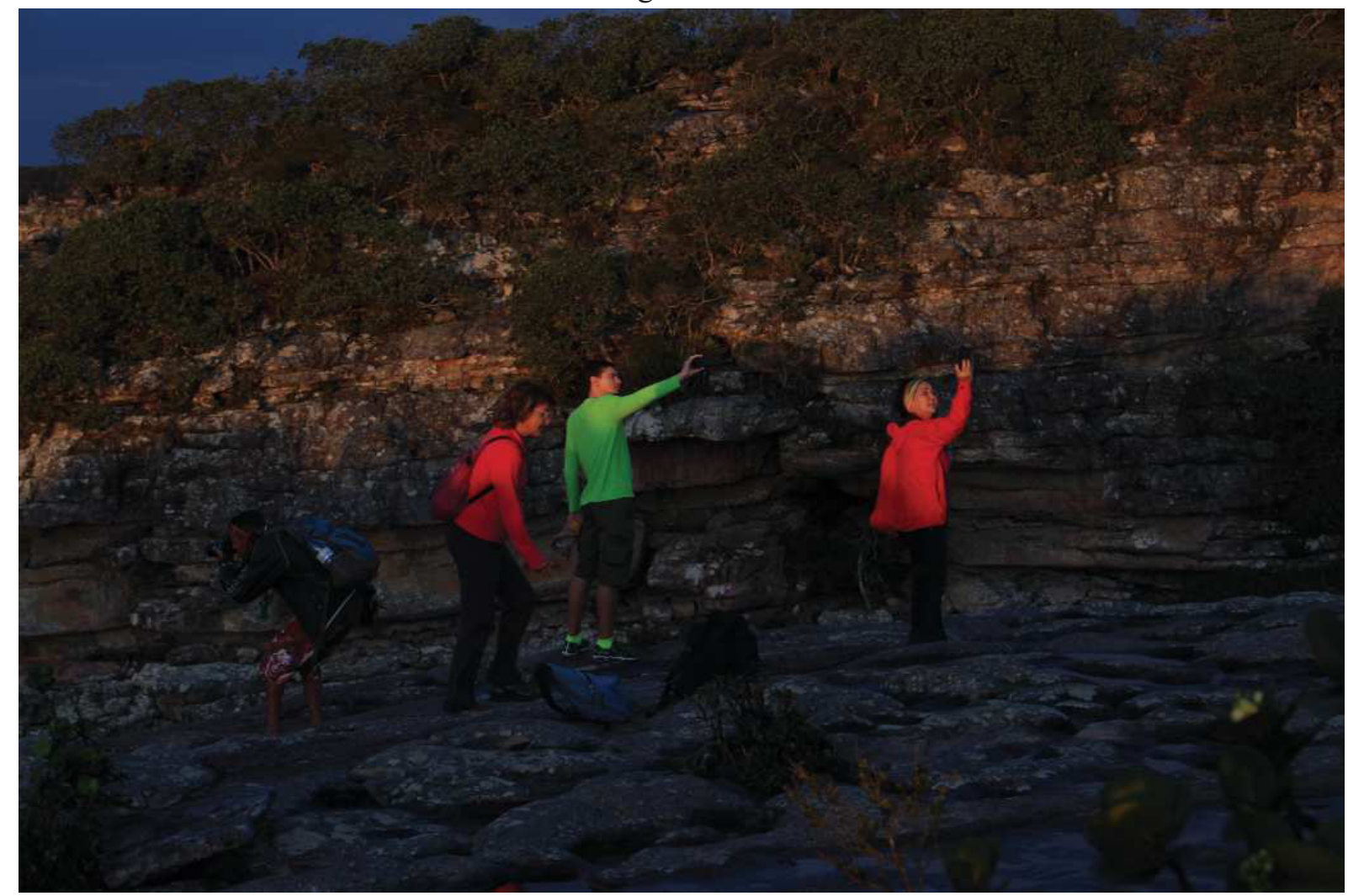

Fonte: Arquivo pessoal do Autor 
Figura 182

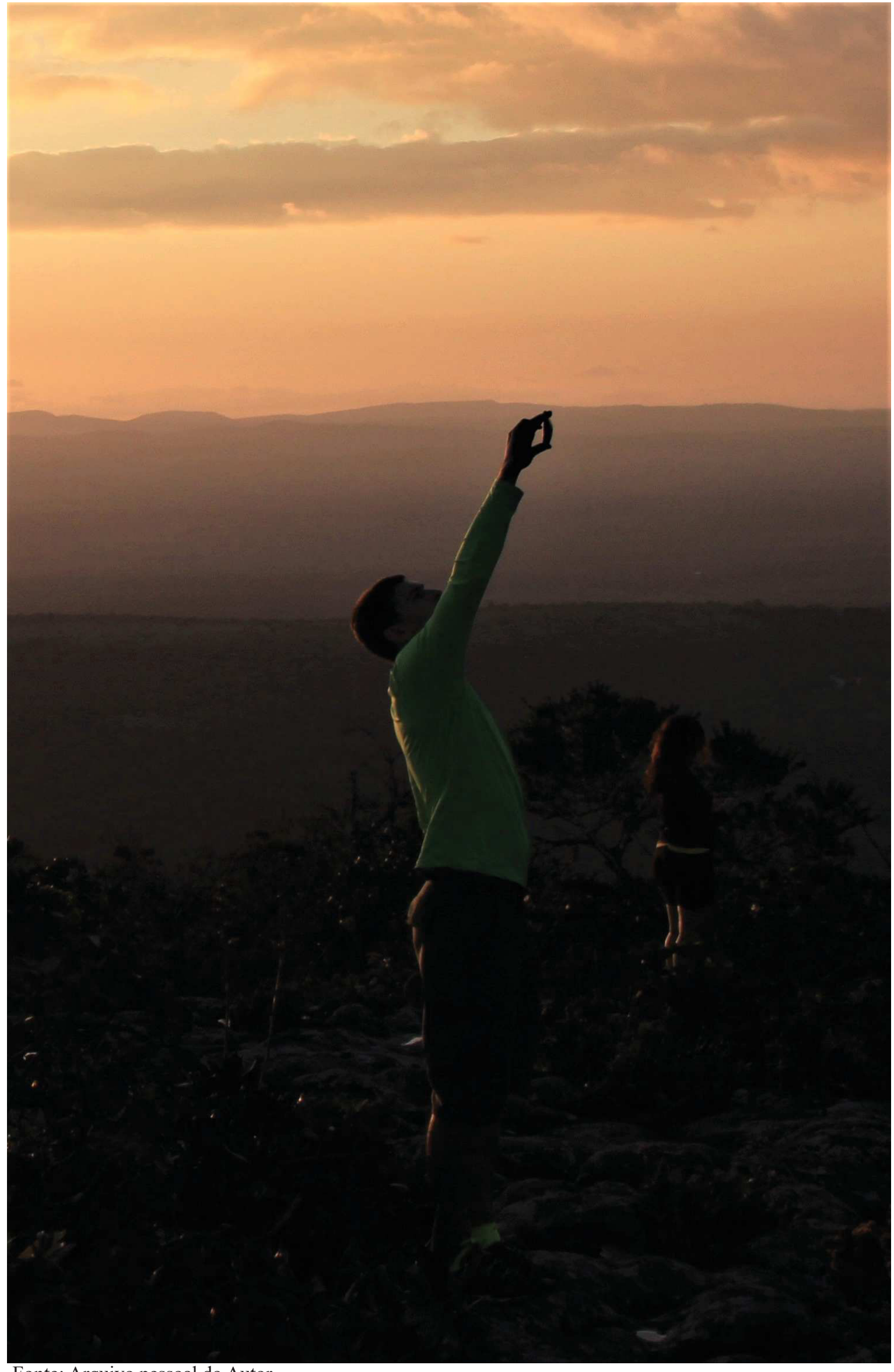


Figura 183

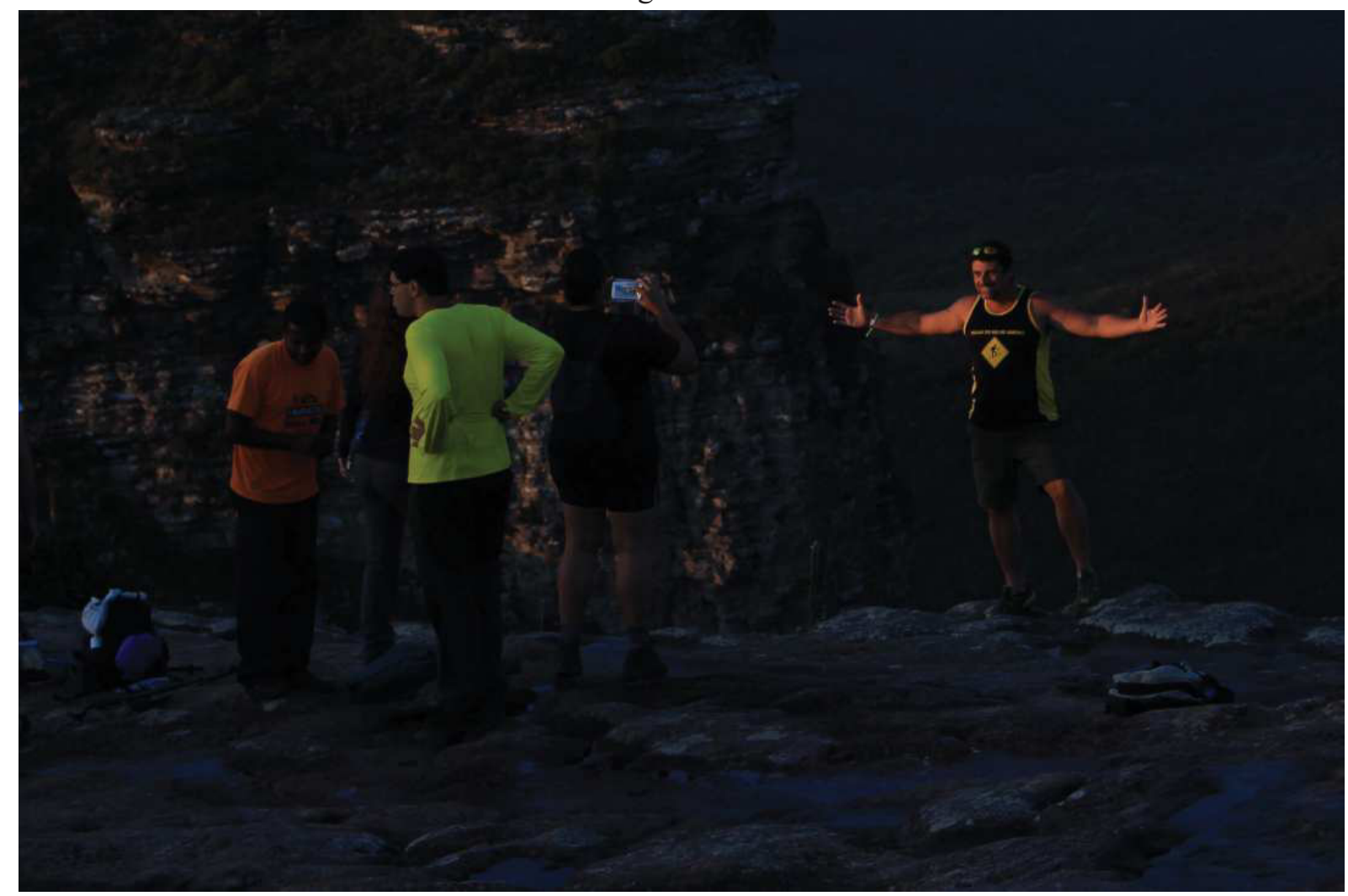

Fonte: Arquivo pessoal do Autor 